\title{
26. CRETACEOUS AND CENOZOIC SEDIMENTS FROM THE ATLANTIC OCEAN
}

\author{
Wolfgang H. Berger, Geologisch-Palaeontologisches Institut der Universität Kiel, Germany \\ and Scripps Institution of Oceanography, La Jolla, California \\ and \\ Ulrich von Rad, Bundesanstalt für Bodenforschung, Hannover, Germany
}

\begin{abstract}
Leg 14 of the Deep Sea Drilling Project completed 9 holes; 7 were located off NW Africa, 1 in Ceara Abyssal Plain, and 1 on Demerara Rise. Quaternary and Pliocene sediments consist of nanno chalk oozes and brown clay. The facies boundary (CCD) is near 5000 meters. Sedimentation rates are between 10 and 30 meters/million years (m/My) for chalk ooze and 2 to $4 \mathrm{~m} / \mathrm{My}$ for pelagic clay. Redeposition off the Amazon produces terrigenous and bioclastic turbidite sequences with rates increasing, on the average, from 50 to $150 \mathrm{~m} / \mathrm{My}$. During the Miocene the CCD is shallow, with restricted calcareous ooze and extended brown clay domain. Terrigenous and siliceous deposits are abundant off NW Africa. The Oligocene is characterized by a major hiatus; where present (Demerara Rise, foot of continental rise), it appears similar to the Miocene. Off NW Africa, Eocene sediments consist of brown clays, in part zeolitic, and greenish clays which, though rich in quartz and siliceous fossils, are less rich than Miocene sediments. Chert is rare. On Demerara Rise, the Eocene is represented by siliceous foram-nanno chalk. The Paleocene rests unconformably on Maestrichtian at Site 144, where the Cretaceous-Tertiary boundary was cored. Off NW Africa, brown and green pelagic clay and dolomite-clay (chert) cycles apparently belong to this period. The major sediment types of the Post-Cenomanian Cretaceous are zeolitic radiolarian, brown clay, black shale, limestone beds and chert layers. Redeposition is thought to play a major role in the origin of limestones and cherts. Cenomanian carbonates consist mainly of nanno marl ooze, presumably deposited on an ancestral Mid-Atlantic Ridge. Calcareous carbonaceous sediments intercalated with limestone beds occur on Demerara Rise. Below the CCD, black shales, limestones and chert accumulated off NW Africa. Near the presumed boundary of ancestral ridge flank and continental rise, cyclic sequences of black shale and dolomite silts (in part ankerite) were deposited. Aptian and Albian sediments consist of black nanno marl off NW Africa and of shelly and quartzose calcarenite, and carbonaceous clay on Demerara Rise.

The changing sediment patterns are related to changes in topography (continental drift, sea-floor spreading, sea-floor subsidence, orogenic activity including compressional buckling at the Gibraltar Fracture Zone) and changes in deep-sea circulation (carbonate under-saturation, oxygenation, nutrient concentration, bottom current strength), upper water circulation (from trans-Atlantic to intra-Atlantic currents, variations in upwelling, fertility), and redeposition processes.
\end{abstract}

\section{LIST OF CONTENTS}

\section{INTRODUCTION}

General

Data Sources and Acknowledgments

788

788

788

OVERVIEW OF RESULTS

Time Scale

Site Summaries

General/Site 135/Site 136/... Site 144

Regional Patterns

DISTRIBUTION OF COMPONENTS AND ASPECTS OF

\section{SEDIMENTS}

Major Biogenous Components (Silt and Sand)

Coccolithophorids / Foraminifera / Other Calcareous Fossils/ Siliceous Fossils/Other Noncalcareous Fossils

Terrigenous Components (Silt and Sand) General/Quartz/Mica/Other Terrigenous Components

Clay Minerals General/Detrital Minerals/Alteration and Authigenic Minerals

Authigenic Minerals (Silt and Sand)

General/Oxides and Hydroxides/Sulfides/"Glauconite" and other Greenish Minerals/Heavy Metals in Manganese Concretions, Sulfides and "Glauconite"/Phosphates/Sulfates/Carbonates/Zeolites

Volcanogenic Components (Silt and Sand)

Color

General/Red/Brown/Yellow/Green/Black

Sediment Structures

Primary Structures/Grading and Spacing/Bioturbation
FACIES TYPES AND ASSOCIATIONS Classification $\quad 827$ Facies Cored $\quad 827$

Pelagic Clays (Pelites) $\quad 827$ Occurrence/Main Types/Texture/Composition

Calcareous Sediments

827 Occurrence, Percent Carbonate/Main Types, Oxidation/Texture of Calcareous Oozes/Composition of Calcareous Oozes Distribution and Composition of Unconsolidated Calcareous Muds/Lithified Calcareous Sediment

Siliceous Oozes and Muds $\quad 846$

Cherts 846

Occurrence, Age and Depth of Burial/Types and Composition/Mineralogy of Silica Modifications/Origin and Diagenesis

Terrigenous Sediments $\quad 854$ Occurrence and Main Types/Texture, Composition, and Origin

Volcanogenic Sediments Occurrence/Texture/Composition/Sedimentary Structures

Carbonaceous Sediments, Dolomite-Pelite Cycles $\quad 865$ Occurrence and Main Types/Composition/Dolomite-Pelite Cycles

SUMMARY AND PALEOENVIRONMENT 871

Stratigraphic Patterns $\quad 871$

Sedimentation Rate Patterns $\quad 871$

Paleogeography $\quad 874$

Paleobathymetry $\quad 874$

Facies domains $\quad 881$ 


\section{INTRODUCTION}

\section{General}

This paper provides a summary of sedimentologic information generated by Leg 14 of the Deep Sea Drilling Project. The Glomar Challenger departed from Lisbon, Portugal, on October 9, 1970. The first part of the cruise was spent in drilling and coring seven holes off NW Africa (Sites 135 to 141, see Figure 1). After crossing the Atlantic, three more sites were occupied off South America, one near the foot of Ceara Rise, about $700 \mathrm{~km}$ northeast of the Amazon Shelf, and the other two on the Demerara Rise (Sites 142, 143 and 144). Site 143, on the flank of Demerara Rise, was occupied without success. In all, 5042 meters were penetrated; of these 747 meters were cored and 406 meters were recovered.

\section{Data Sources and Acknowledgments}

Sampling of the sedimentary record (distribution of cores related to geologic time) is summarized in two fence diagrams off Africa, one parallel to the coast roughly along the border of the "magnetic quiet zone" (Heirtzler and Hayes, 1967), and the other one perpendicular to the coast (Figure 2). The fence diagram parallel to the coast should not be interpreted as a geologic profile since each site represents a special local situation. Sites 142 and 144 are presented as single columns. To drill the number of holes scheduled in the time allotted, spot coring had to be employed. The length of stratigraphic record that one core must represent is therefore correspondingly great (Table 1).

TABLE 1

Sample Representation

\begin{tabular}{cc}
\hline Cores (per cent) & Representation $(\mathrm{m})$ \\
\hline 17 & $<11$ \\
16 & $11-20$ \\
15 & $21-40$ \\
30 & $41-80$ \\
22 & $81-160$ \\
1 & $>160$ \\
100 (=98 cores) & $40-50$ (median) \\
\hline
\end{tabular}

As is readily seen from the table, one core typically represents about 50 meters of sedimentary sequence; that is, ten times its own length. The distribution of core lengths is as follows: less than 1 meter, 24 per cent, 1 to 2 meters, 13 per cent, greater than 2 meters, 62 per cent. In cores with poor recovery, the lithology may be biased toward firm material (indurated clay, chert, limestone, etc.) and against loose material such as sand. These sampling deficiencies, as well as bias in site locations (drilling on hills, uneven geographic distribution), must be kept in mind when interpreting the record. We state the weaknesses of our data here in order to point out the disadvantages associated with spot coring and to avoid repetitive use of qualifying statements throughout this paper.

The single most important data source for the present account is the shipboard sedimentology report prepared with W. E. Benson and P. R. Supko during the Leg 14 cruise. Much additional material comes from post-cruise laboratory work in Kiel and Hannover (see Appendix).
DSDP laboratories contributed grain size analyses and most carbonate determinations. All X-ray data were taken from von Rad and Rösch, this volume. Thanks are due several other persons who contributed to the present work. Throughout this report we rely on revised age determinations by P. H. Roth and J. P. Beckmann. Roth also contributed information on nannofossil preservation, and Beckmann gave valuable advice in the identification of shallow-water carbonates. H. J. Schrader (Kiel) reexamined the smear slides for siliceous fossils and made identifications and photographs. C. Samtleben gave generously of his time to provide expert assistance at the SEM in Kiel. F. W. Haake (Kiel) also kindly assisted at this instrument. Mrs. Scheuermann (Hannover) provided excellent TEM and SEM photomicrographs from cherts and limestones. H. Hufnagel, H. Jacob, and H. Wehner (Hannover) contributed detailed analyses of carbonaceous sediments. W. R. Riedel identified radiolarians on SEM photographs. J. Gieskes gave advice on matters of geochemistry. Mrs. K. Berger and Mrs. A. von $\mathrm{Rad}$ helped with data reduction and tabulation of results. Miss J. Meyer (S.I.O.) did most of the drafting. J. Connelly (DSDP) also assisted, especially with preparation of the plates. A. Kaneps and F. L. Parker graciously checked the manuscript for style and logic.

We are especially grateful to Professor E. Seibold (Geologisch-Palaeontologisches Institut, Kiel) and to Professor W. Schott and Dr. U. von Stackelberg (marine geology division of the Bundesanstalt) for making it possible for us to participate in this program.

\section{OVERVIEW OF RESULTS}

\section{Time Scale}

Unless otherwise stated, ages are bio-ages determined by J. P. Beckmann, P. H. Roth, M. G. Petrushevskaya and G. E. Kozlova on the basis of foraminifera, coccolithophorids and radiolarians. Berggren's (1972) scale for the Tertiary and an unofficial scale for the Cretaceous, developed by consultation with various stratigraphers and checked against a recent unpublished compilation of radiometric ages by the late Edwin Allison (San Diego), were used for conversion of bio-ages to years (Figure 3). Except for Cenomanian and earlier time, this scale closely parallels that of Bandy (1967). Bandy assumed 20 million years (My) duration for the Cenomanian, and $10 \mathrm{My}$ for the Albian. The corresponding sedimentation rates at Site 137 for ridge and upper flank facies appear somewhat too low when using this scale $(8 \mathrm{~m} / \mathrm{My})$, although it is not known what a "normal" rate would be.

The sample ages used for lithostratigraphy are of varying quality (Figure 4). For example, 141-8 and 141.9 are based on sedimentation rates and some sparse information on fish teeth (Helms and Riedel, 1971; P. Helms, personal communication). Others are based on interpolation and facies correlation; for example 138,3 to $5 .^{1}$ Many cores do have calcareous or siliceous fossils, however, allowing reliable dating.

\footnotetext{
${ }^{1}$ Read "Site 138, Cores 3 to 5."
} 


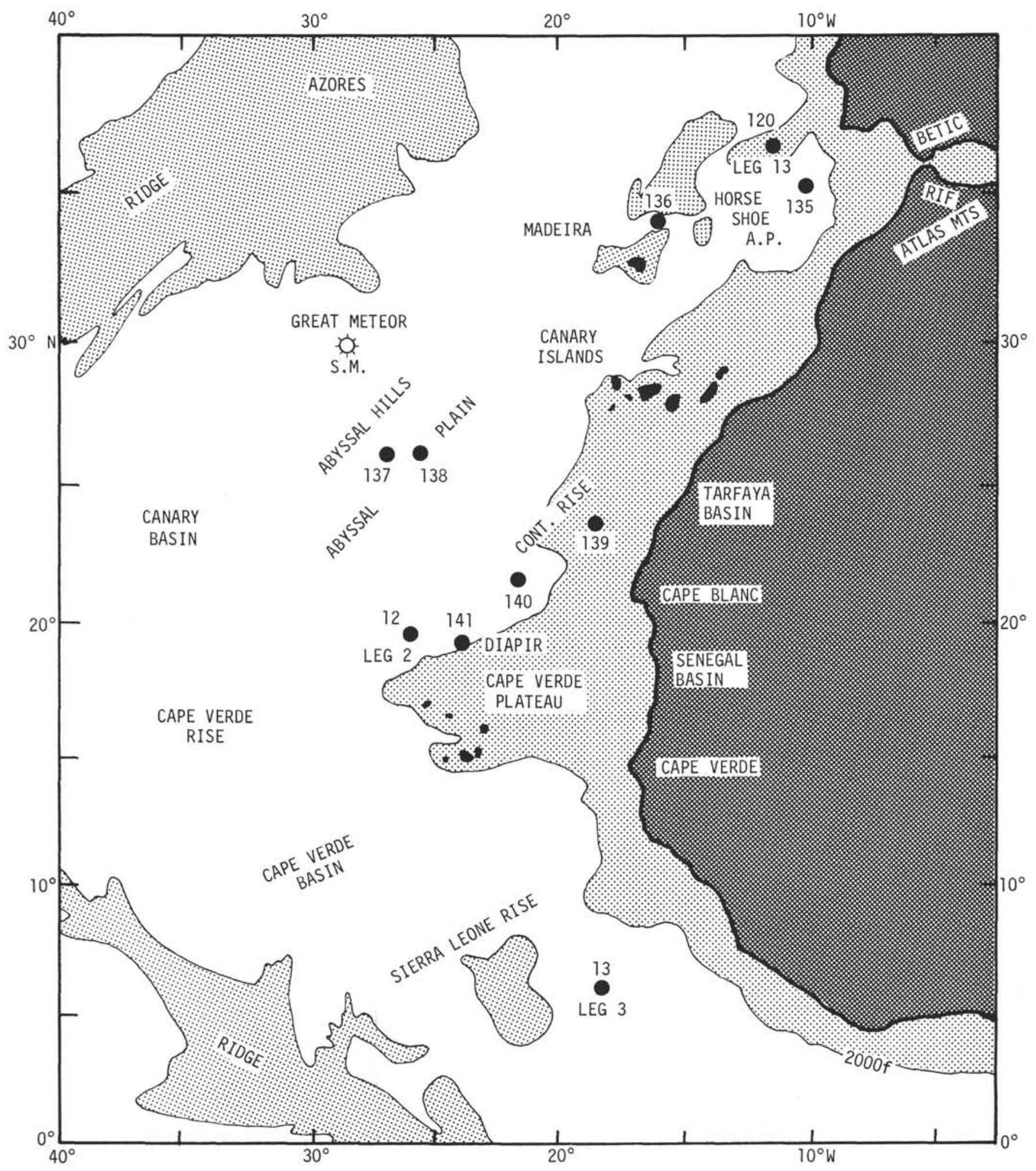

Figure 1. Drill sites off NW Africa. 

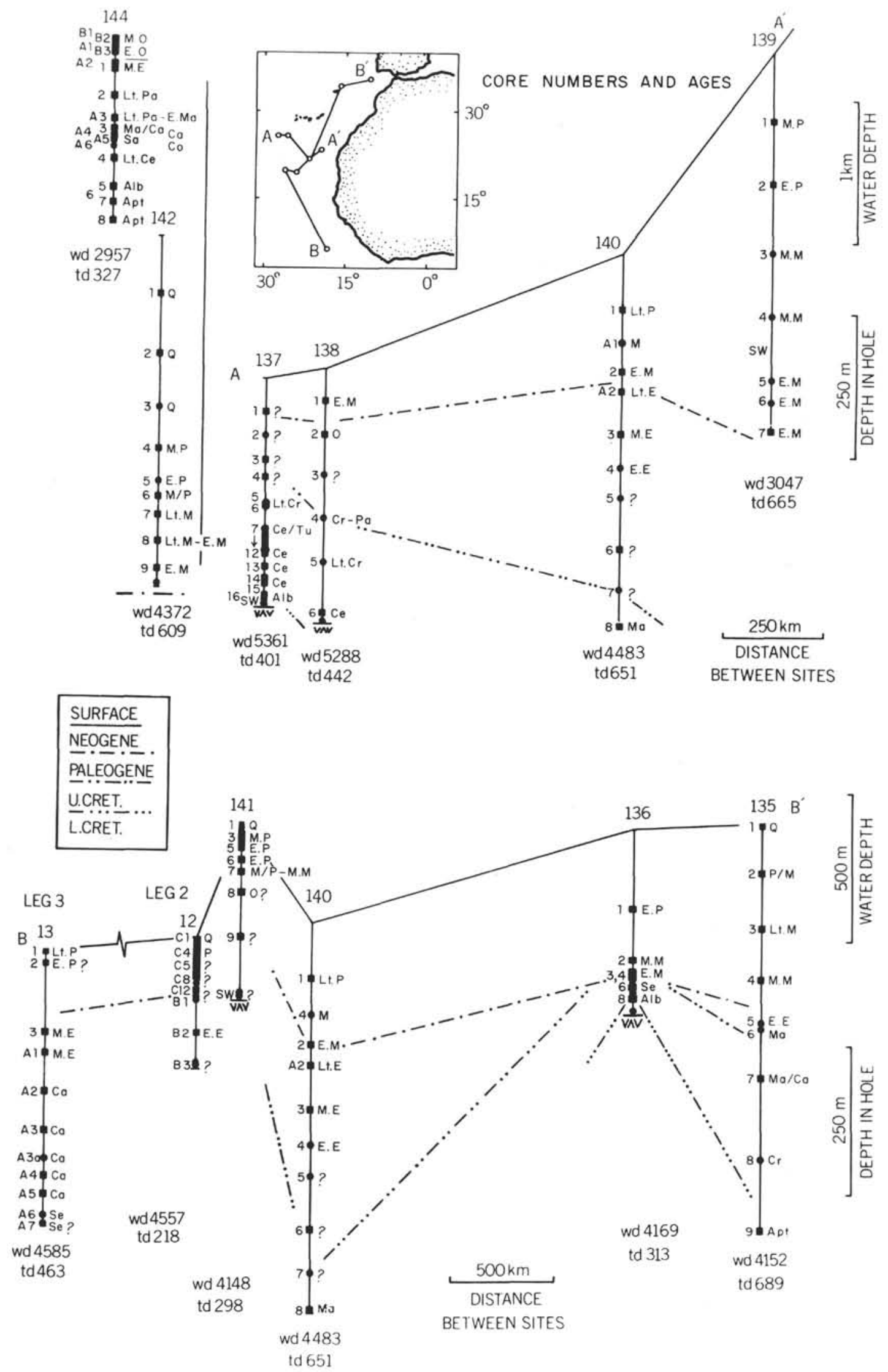

Figure 2. Core numbers and ages. Squares: More than $1 \mathrm{~m}$ of sediment. Circles: All others. Age symbols: Q, Quaternary; P, Pliocene; M, Miocene; O, Oligocene; E, Eocene; Pa, Paleocene; $\mathrm{Cr}$, Cretaceous; Ma, Maestrichtian; Ca, Campanian; Se, Senonian; Sa, Santonian; Co, Coniacian; -Tu, Turonian; Ce, Cenomanian; Alb, Albian; Apt, Aptian. Lt., Late; M., Middle; E., Early. 


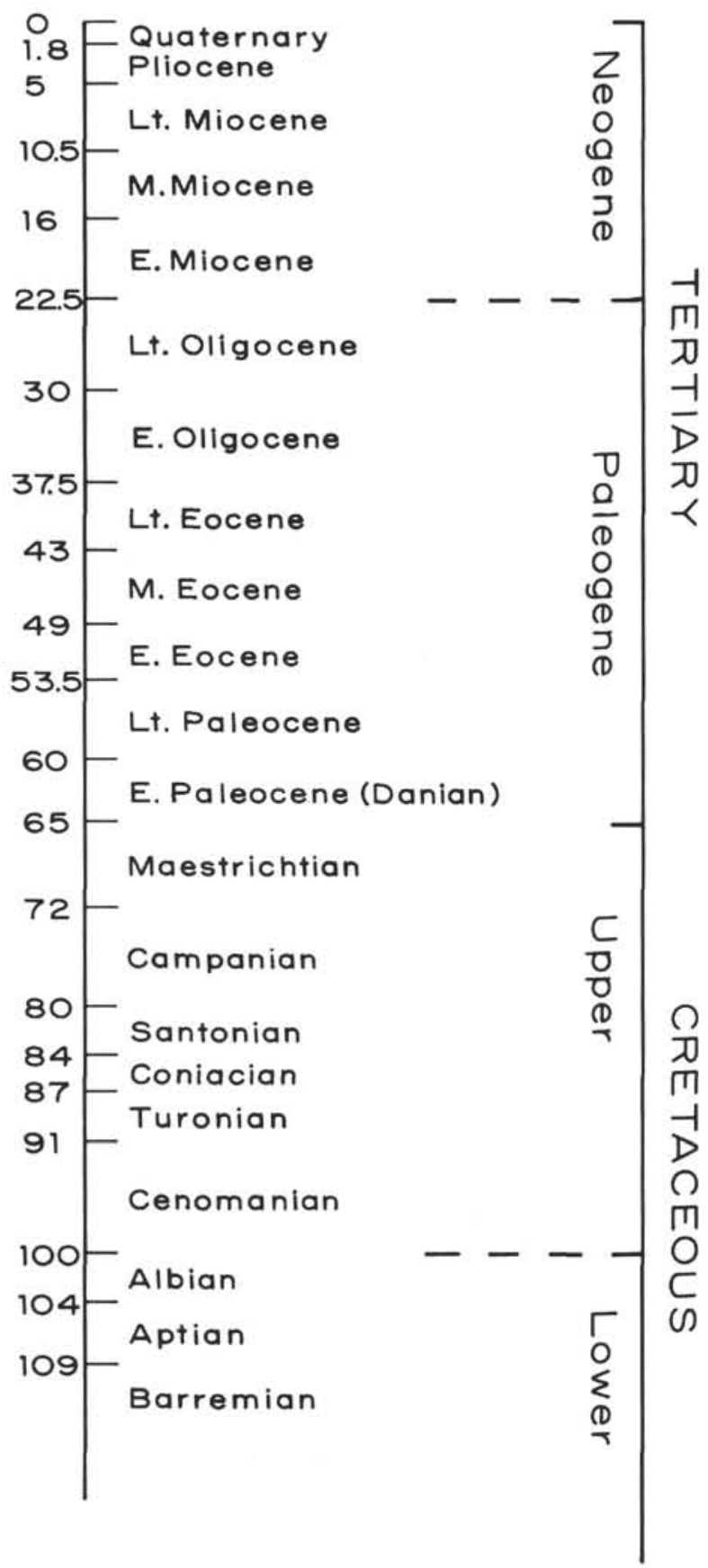

Figure 3. Time scale used in the present report. Tertiary after Berggren (1972); Cretaceous, estimated from various sources. See text.

\section{Site Summaries}

\section{General}

An outline of the sediment classification used on board ship and in this report is given in Appendix 1. The chief results for each site are given in Appendix 2 for quick orientation. Appendices 3 and 4 summarize smear slide results and coarse fraction analyses. Sites 12 (Leg 2), 13 (Leg 3), and 120 (Leg 13), are included in both Appendix 2 and Figure 1, for comparison with Leg 14 results. During Leg 14, nine successful sites were completed. In all, 5042

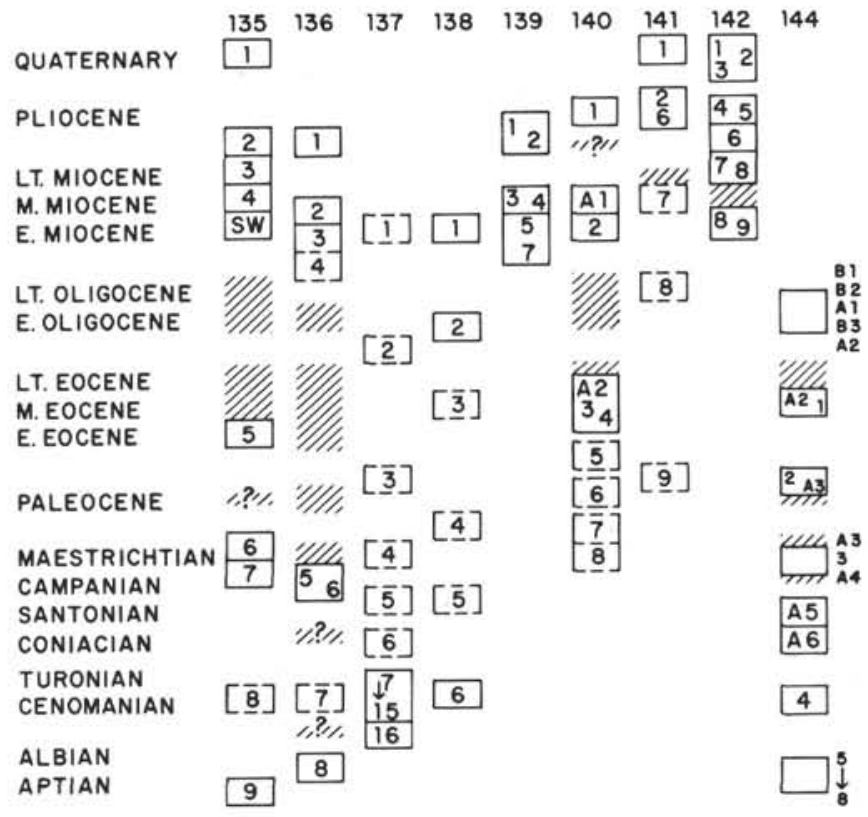

Figure 4. Bio-ages (solid lines) and interpolated ages (broken lines) of cores (numbers) of Sites 135 to 144.

meters were penetrated; of these 747 meters were cored and 406 meters of sediment were recovered. This was somewhat less than 10 per cent of the total sequence penetrated.

\section{Site 135}

Site 135 lies on a topographic high (750 meters above plain) near Horseshoe Abyssal Plain (Figure 5). The upper sediment cover consists of about 330 meters of calcareous ooze of Early Miocene to Quaternary age. The Oligocene and most of the Eocene are missing. The chalks are underlain by a (?)270-meter-thick section of predominantly silicate-rich terrigenous and pelagic sediment, low in carbonate, which ranges in age from Cretaceous (Cenomanian(?), based on sed. rates) to Early Eocene. The Cenomanian(?) consists of black shale with chert and limestone layers. Calcareous sediments, rich in organic matter, characterize the lowermost part of the cored sequence, below about 600 meters. They were deposited during Aptian time.

\section{Site 136}

Site 136 lies north of Madeira on a basement high in an area of abyssal hills (Figure 5). Calcareous ooze 240 meters thick and of Early Miocene to Recent age rests on a thin $(10 \mathrm{~m})$ clay section, containing some Early Miocene coccoliths. The entire Paleogene and latest Cretaceous are missing. The Neogene sediments overlie Late Cretaceous (Senonian) brown clays with reworked(?), partly limecemented ashes, with a multicolored mineralized zone at the base. This layer rests on Aptian to Albian dark nanno marl ooze. The Late Cretaceous comprises less than 30 meters of sediment, apparently mostly of volcanic derivation, suggesting that there is virtually no pelagic record for this time span as well. In case this pattern of missing record continues within the uncored 20 meters of sediment overlying basalt, the basalt at 308 meters, if basement, is considerably older than Aptian. 


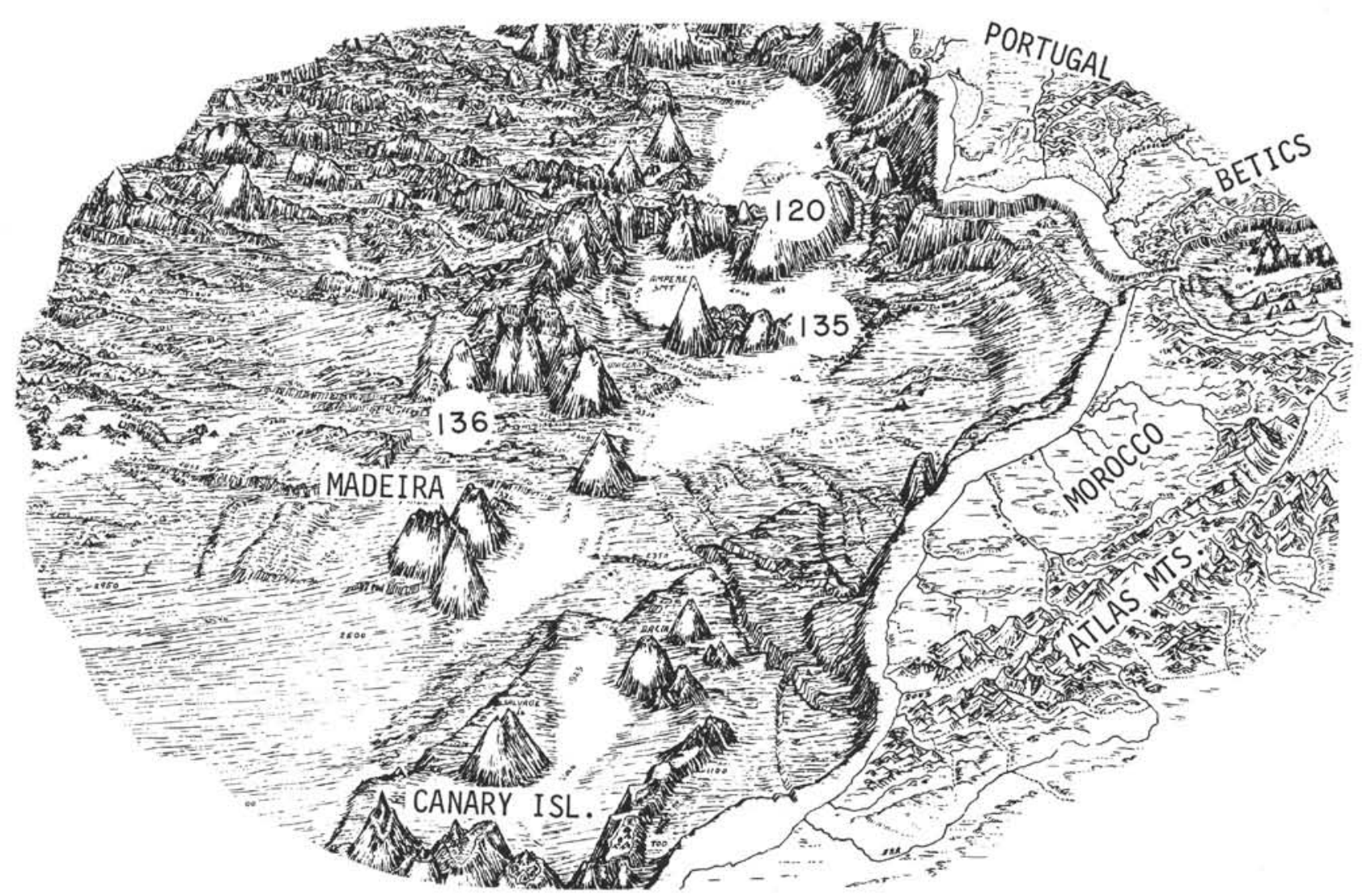

Figure 5. Physiographic setting of Sites 120 (Leg 13), 135 and 136. Base map from Heezen and Tharp (1968).

Site 137

Site 137 lies west of Cap Blanc in an area of abyssal hills, between the flank of the Mid-Atlantic Ridge and the continental rise (Figure 6). Calcareous sediments, 130 meters thick and consisting of varicolored nanno marl and chalk oozes, were deposited during Albian to Cenomanian time. This is followed by a transition zone of Late Cenomanian to Senonian age consisting of 30 meters of nanno marl ooze, clay, and silicified mudstone. The unit is rich in pyrite. The sequence is capped by 250 meters of pelagic clay, zeolite- and radiolarian-bearing in the Cretaceous part, but barren in the Tertiary. The basalt at 397 meters, where the hole terminates, should be Albian in age if it is basement. Various lines of evidence (see section on paleobathymetry) suggest that the basalt at Site 137 is indeed basement.

\section{Site 138}

Site 138 lies at the foot of the continental rise, about $850 \mathrm{~km}$ northwest of Cap Blanc (Figure 6). The site has been below the Calcite Compensation Depth (CCD, see footnote 8) since the Late Cretaceous, and has accumulated an abyssal sequence of clay about 400 meters thick. The clay shows strong terrigenous and siliceous influence during mid-Tertiary. The deepest part of the hole contains interlayered dolomitic silty clay and carbonaceous mud. Radiolarians suggest a Cenomanian age. Comparing this age with that of the basal sediment at Site 137, the basalt appears too young to be basement, and at least 100 meters of calcareous ooze are missing. An additional 100 meters of sediment would be consistent with seismic reflection profiles (D. Hayes, personal communication). Sedimentation rates apparently decrease from Cretaceous carbonates to Tertiary clay both at Site 137 and Site 138 (Figure 7). For each age, rates appear slightly higher at Site 138 than the corresponding rates at nearby Site 137. A topographic barrier between Sites 137 and 138 (D. Hayes, personal communication) may have blocked Site 137 from receiving continental rise sediment. Alternatively, or in addition, the difference in sediment pattern may largely be due to the geometry of sea floor spreading and subsidence (see section on geologic history). In accordance with the hemipelagic sedimentation at Site 138, the topography at 138 is smooth, while that at 137 is rather rough.

\section{Site 139}

Site 139 lies on the continental rise about $250 \mathrm{~km}$ northwest of Cap Blanc (Figure 6). The airgun record shows a relatively smooth topography and distinct stratification of sediments. Nanno marl to chalk oozes make up the upper 400 meters of the sequence. Pliocene ooze is poor in siliceous fossils, but radiolarians and diatoms, as well as terrigenous material, become increasingly more important downward, until in the last core taken at 600 meters depth, mid-Miocene nanno marls give way to earliest Miocene quartz sand and diatom mud. Olive and greenish colors predominate everywhere, as is typical for hemipelagic deposits. 


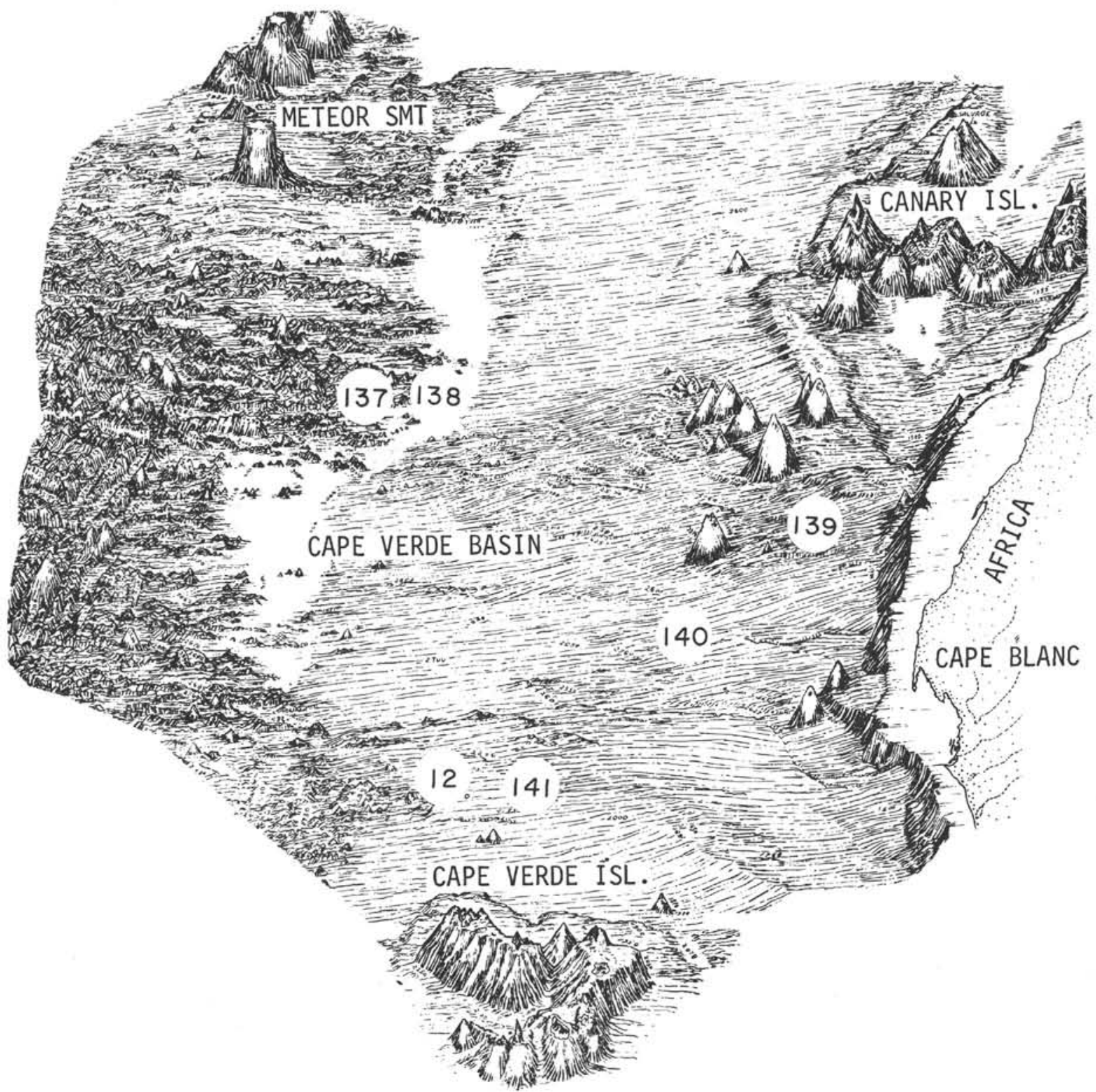

Figure 6. Physiographic setting of Sites 137 to 141 (Leg 14), and Site 12 (Leg 2). Note that Site 137 lies within an abyssal hills region at the outer edge of the ridge flank domain, whereas 138 lies in an abyssal plain at the outer edge of the continental rise domain. Base map; Heezen and Tharp (1968).

Sedimentation rates are rather variable. Early Miocene sediments, with their strong terrigenous influx but low carbonate content, accumulated at about $30 \mathrm{~m} / \mathrm{My}$ (Figure 7). Major redeposition may be indicated for mid-Miocene sediments since Cores 3 and 4 (100 meters apart) belong to the same foraminiferal and nannofossil zones. This gives an apparent rate of roughly $100 \mathrm{~m} / \mathrm{My}$. Late Miocene marls must have accumulated at between 10 and $20 \mathrm{~m} / \mathrm{My}$ whereas the thickness of Pliocene to Holocene chalk corresponds to a rate of $45 \mathrm{~m} / \mathrm{My}$.

\section{Site 140}

Site 140 lies at the foot of the continental rise, about $450 \mathrm{~km}$ west of Cap Blanc (Figure 6). Pliocene to Recent carbonate ooze, about 120 meters thick, overlies 100 meters of Miocene clay and diatom mud. Oligocene and Late Eocene sediments are missing. Slightly siliceous clays (200 meters) of Eocene age underlie the Neogene deposits. Core 4 is dated as Early Eocene, and Core 8 as Maestrichtian, on the basis of radiolarians. Thus, the Paleocene apparently is represented by about 100 meters of olive clays and silty dolomitic, palygorskite-rich clay, locally chertified. Late Cretaceous black shales, chert layers, and zeolitic clays with subarkosic sand beds of undetermined thickness underlie the Early Tertiary sediment. Sedimentation rates for Eocene sediment are $16 \mathrm{~m} / \mathrm{My}$, for Miocene 8 $\mathrm{m} / \mathrm{My}$, and for Pliocene to Recent $23 \mathrm{~m} / \mathrm{My}$ (Figure 7). The depth of the CCD at the Miocene-Pliocene boundary was at 4600 meters (total depth) in this hole, which is in good agreement with nearby Site 12 . 


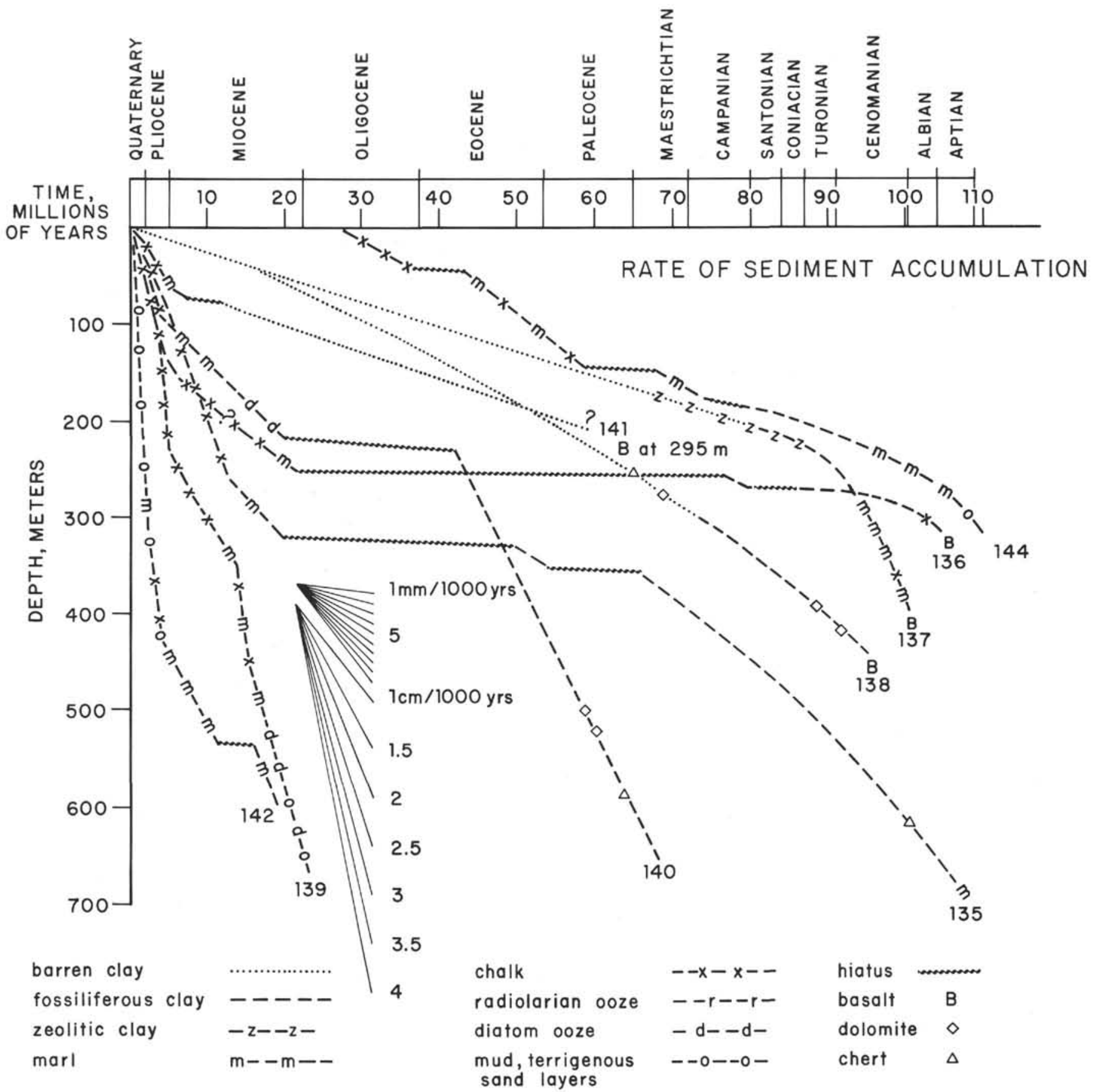

Figure 7. Rates of accumulation based on bio-ages and drilling depths. (Core locations not given, see Appendix).

Site 141

Site 141 is located on top of a "diapiric structure" north of Cape Verde Islands (Figures 6, 8). Pliocene to Pleistocene calcareous ooze, about 80 meters thick, overlies at least 120 meters of pelagic clay. The lithology of the lowermost 100 meters of sediment is unknown; relatively rapid drilling suggests unconsolidated deposits. A side-wall core at 287 meters, 8 meters above basalt, yielded a sample of greenish gray subarkosic sand. The age of the basal sediment is unknown but from sedimentation rates at nearby sites a Late Cretaceous age is inferred.
The formation time of the diapiric structure is unknown. Relatively recent uplift is suggested by the presence of presumably shelf-derived, shallow-water benthic forams in 141-6 (J.P. Beckman, pers. comm.). This indicates that a hill did not exist in earliest Pliocene time. During post-midMiocene time, Site 141 was a site of nondeposition and reduced sedimentation. Late Miocene sediments are thin or absent, and Pliocene chalks accumulated at the relatively low rate of $10-15 \mathrm{~m} / \mathrm{My}$. The unusually high proportion of foraminifera indicates that winnowing reduced sedimentation rates. This suggests the action of bottom currents on an exposed hill. Fish teeth in Core 8 suggest an Oligocene 


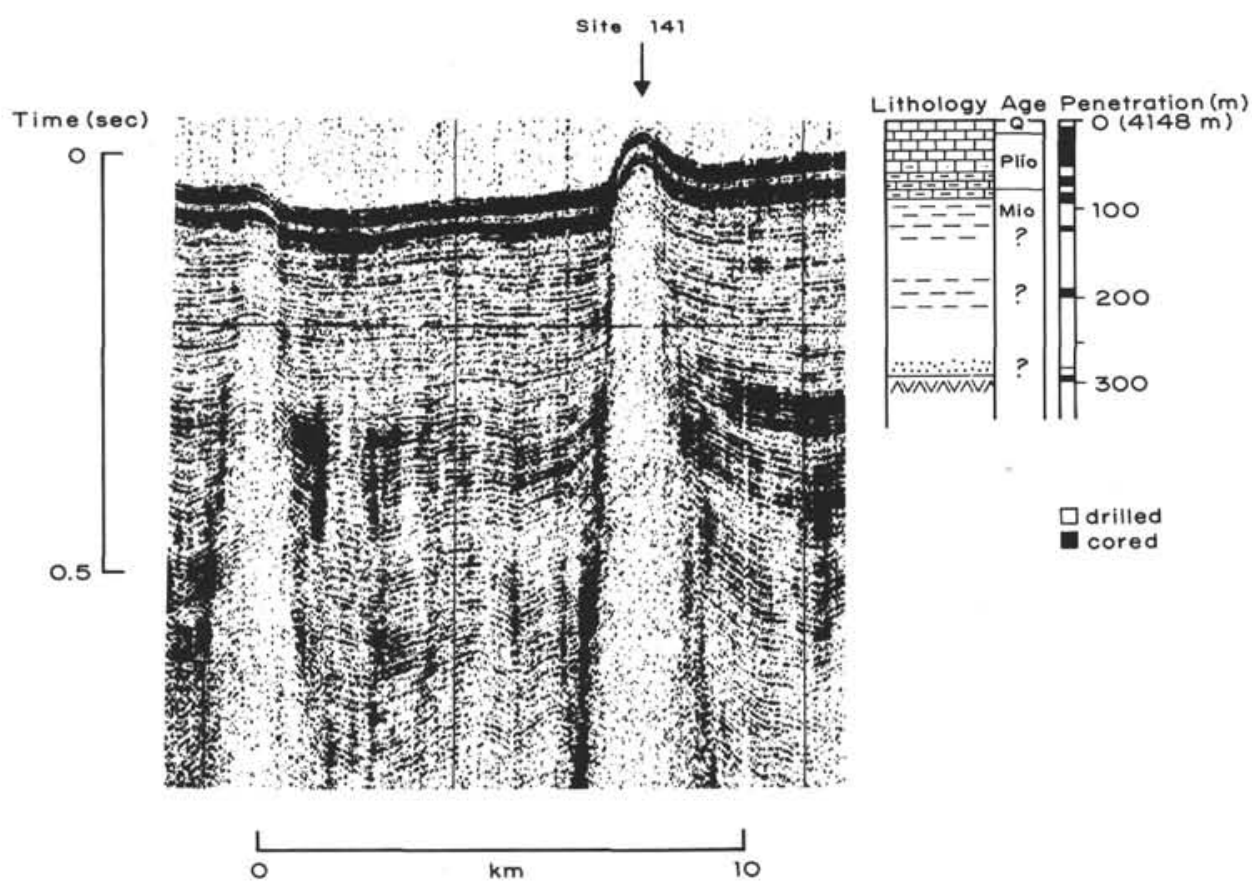

Figure 8. Airgun profile across Site 141 (Glomar Challenger record), compared with drilling results.

age (Phyllis Helms, personal communication), so that sedimentation rates do not appear reduced for the pre-midMiocene clays. Accordingly, the hill appears to be Neogene in age.

The significance of the basalt within the structure is obscure; it may be an intrusion causally linked to the diapir, or (perhaps more likely) a sill partaking passively in diapir formation produced by deep-seated processes (such as salt tectonics; see Rona, 1969; Pautot et al., 1970) Conceivably it could also be a post-diapir sill intruding the deformed sediment layers.

\section{Site 142}

Site 142 lies in the Ceara Abyssal Plain, about $6 \mathrm{~km}$ south of the steep southern flank of Ceara Rise, $420 \mathrm{~km}$ from the shelf edge, and about $750 \mathrm{~km}$ northeast of the Amazon Estuary (Figure 9). The sedimentary sequence cored consists of Neogene terrigenous sediments and biogenous oozes (largely redeposited) in variable proportions. Quaternary calcareous muds and oozes are interbedded with thick graded layers of olive gray subarkosic terrigenous sand. Terrigenous components appear to decrease downward in this 350-meter thick Pleistocene unit. The next deeper 200 meters consist of Pliocene to Late Miocene banded and varicolored bluish gray clay, calcareous mud, and marl ooze, with graded layers of foraminiferal calcarenite and calcisiltite, as well as terrigenous subarkosic sand. The deepest core recovered Early Miocene indurated, greenish gray to bluish gray, highly burrowed nanno marl mud.

Sedimentation rates at this site are extremely high (Figure 7) due to redeposition processes (as shown by high proportions of terrigenous material, and a wide range of preservation within calcareous assemblages). Average Quaternary rates are close to $150 \mathrm{~m} / \mathrm{My}$, but at times they may be considerably greater. Rates decrease downward throughout the Miocene. The pelagic Early to Middle Miocene sediments accumulated at about $10 \mathrm{~m} / \mathrm{My}$.

\section{Site 143}

Site 143, at the foot of the Demerara Rise, was occupied without success due to a number of technical difficulties. Only some surficial sediment was recovered. It consisted of a muddy mixture of greenish clay fragments and foraminiferal sand, with mid-Cretaceous and Quaternary fossils.

\section{Site 144}

Site 144 lies on the flank of Demerara Rise, off Surinam (Figure 10). More than 300 meters of Oligocene to Aptian sediment were penetrated. The sequence is characterized by successively "deeper" facies from Aptian to Oligocene. Cretaceous upper slope and shelf sediments underlie biopelagic Tertiary deposits. Superimposed on the deepening of the facies are: (1) increasing oxygenation through time, especially in post-Cretaceous sediments; (2) redeposition, adding successively "deeper" sediments to the indigenous deposits, from terrigenous material to detrital(?) calcisilt, to glauconite and phosphorite, to pelagic fossils; (3) a general increase in carbonate through time, but with a possible low in deposits of latest Cretaceous age; (4) low proportions of siliceous fossils in Cretaceous, but relatively high proportions in Tertiary sediment, with a peak in the mid-Eocene; and (5) high zeolite content near the Cretaceous-Tertiary boundary. Sedimentation rates (Figure 7) generally vary between 2 and $7 \mathrm{~m} / \mathrm{My}$. Danian sediments are missing within the sequence, as is the Late Eocene. 


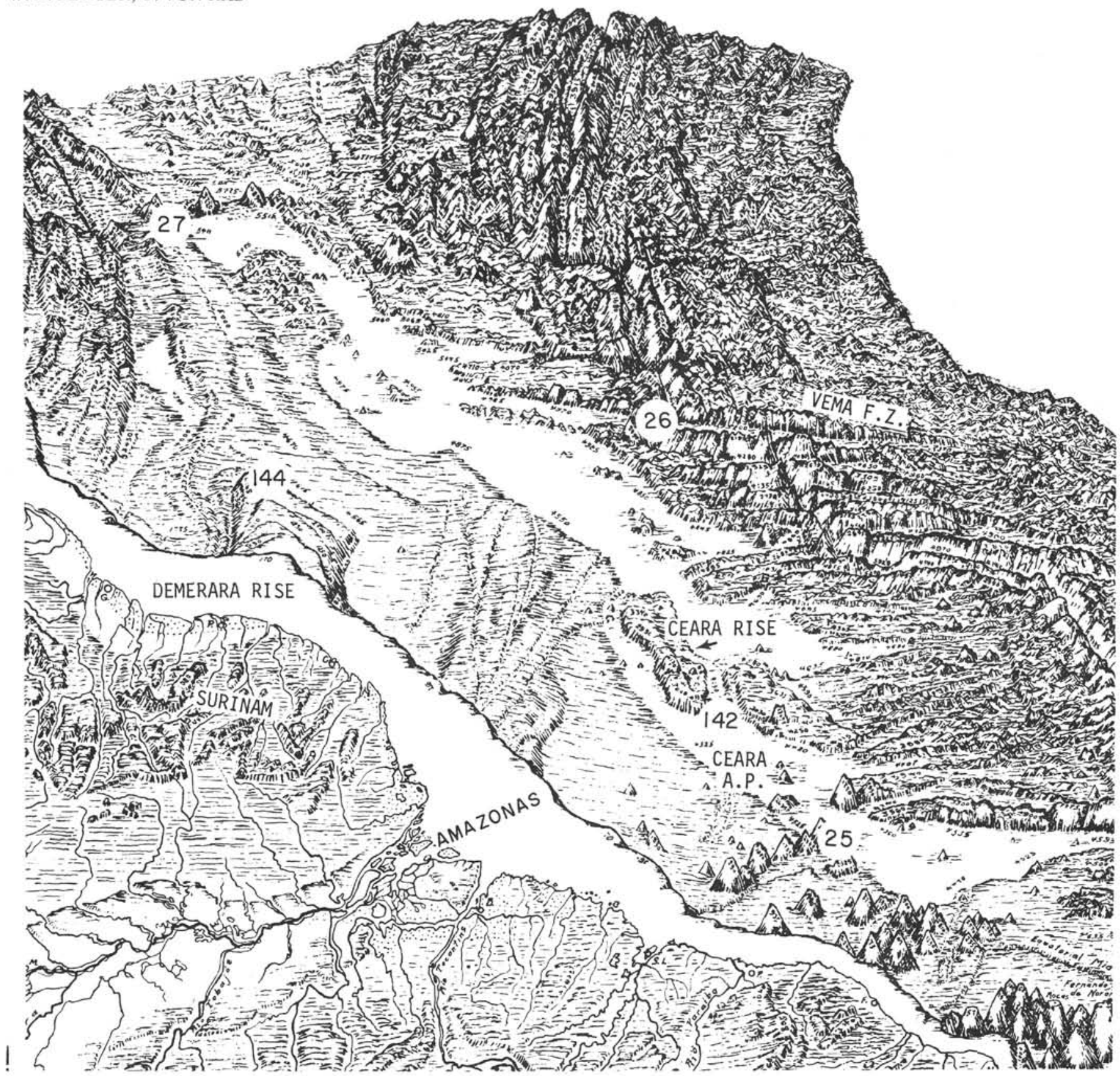

Figure 9. Drilling sites off NE South America, Leg 4 (25 to 27) and Leg 14 (142 and 144). (Site 143, downslope from Site 144 was occupied without success). Base map: Heezen and Tharp (1961).

\section{Regional Patterns}

Dominant components from the smear-slide analyses provide a means for depicting regional patterns of sedimentation (Figure 11).

The following components are dominant (i.e.they rank first or second within the various cores): calcareous fossils (nannos and forams), undifferentiated clay, terrigenous minerals (mainly quartz), siliceous fossils (radiolarians and diatoms), undifferentiated carbonates, zeolites, chert, dolomite, and volcanic ash and glass.

Off northwest Africa Late Neogene carbonate covers a Cretaceous to Tertiary clay sequence with a strong hemipelagic (terrigenous and siliceous) admixture in Eocene, Oligocene, and Miocene deposits. The carbonate cover is missing at the deepest sites $(137,138)$, and the hemipelagic components are lacking farthest from land (137) and in some highly incomplete sections $(135,136$; possibly also at 141, and Site 12 of Leg 2). After penetrating pelagic clay, several holes terminate in Cretaceous marls, thus completing the sequence from clay to carbonate expected from general subsidence of the sea floor. The Late Neogene carbonate cover appears to be mainly due to a lowering of the CCD, unrelated to subsidence or uplift, with a minor contribution from shallowing due to sediment build-up. Cherts were found in sediments ranging from Late Creta. ceous to Early Eocene in age. Association with hemipelagic deposits in many places suggests that redeposition may play a part in the origin of at least some of the cherts. 


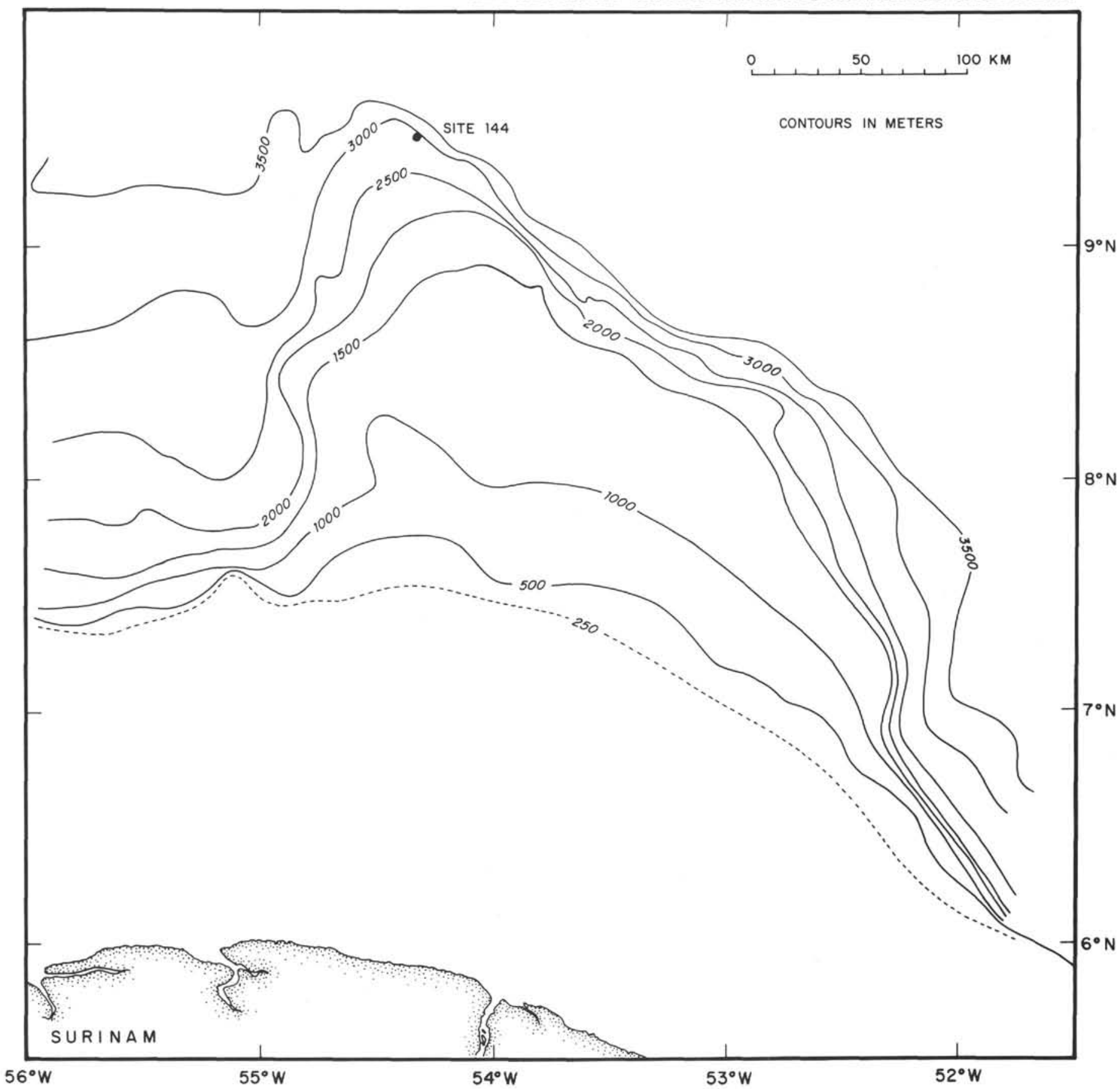

Figure 10. Location of Site 144 on Demerara Rise. Courtesy F. Emmel (SIO) compiled from H. O. 5728 and unpublished records of $J$. R. Curray.

Sedimentation off the Amazon (Site 142) is characterized by redeposition, and the muds and clays recovered are usually quite calcareous due to displaced carbonates. Significantly, the mid-Miocene is missing at this site, probably largely due to intense dissolution of carbonate and bottom current scour. A similar unconformity is indicated at Sites 14, 17, 19, 20 (Leg 3) and at nearby Site 25 (Leg 4).

On Demerara Rise (Site 144), marls, calcareous clays, and calcareous muds accumulated throughout the time represented. Interestingly, the Maestrichtian shows some of the lowest carbonate values. The early Paleocene is missing entirely, as recorded elsewhere by previous Legs.

\section{DISTRIBUTION OF COMPONENTS AND ASPECTS OF SEDIMENTS}

\section{Major Biogenous Components (silt and sand)}

\section{Coccolithophorids}

Calcareous nannofossils (coccolithophorids, "coccoliths," "nannos") are the dominant component in many Leg 14 deep-sea chalks and marls, as determined from smearslide examinations (Figure 12). In many places these skeletal particles from microscopic planktonic algae are abundant enough to form virtually pure nannofossil ooze (square symbols, Figure 12). Nannofossils contain a large amount of sedimentologic information besides being guides 
to age and paleoecology. They consist of calcite and form part of the clay and fine silt fraction. Accordingly, they participate in solution and recrystallization processes of the carbonate system and in redeposition processes affecting very-fine-grained particles.

In this preliminary report only limited advantage was taken of the fact that coccoliths dissolve selectively (McIntyre and McIntyre, 1971; Bukry, 1971). We noted, as did others, that the proportion of discoasters greatly increases with increasing dissolution in Tertiary calcareous sediments. On the basis of similar but much more numerous clues, as well as from aspects of single platelets, P. H. Roth determined the degree of solution and of overgrowth on coccoliths according to the following schedule:

Degree of solution

0 - No etching

1 - Slight; delicate features destroyed by etching

2 - Obvious; delicate species destroyed, many remaining specimens etched

3 - Strong; many isolated shields; only resistant species are preserved

Degree of overgrowth

0 - No overgrowth

1 - Slight thickening of discoaster arms, elements of coccolithophores show incipient overgrowth.

2 - Arms of discoasters strongly thickened, delicate central structures obscured

3 - Discoasters show very much calcite overgrowth, delicate coccolithophores covered, difficult to identify.

In some instances, and especially in Cretaceous sediments, notes on preservation are given as "good" (G) and "poor" (P). Examples of the effects of etching and recrystallization on coccoliths are given in Plate 1.

The percentage of nannofossils is controlled by supply, preservation, and dilution effects, as is that of other components. Proportions increase where relative supply is high and dilution is small. Examples of pure nannofossil chalk are Pliocene chalks located above the CCD and protected from terrigenous influx (Sites 135, 136, Figure 12). Although the absolute supply of coccoliths is probably higher in more fertile areas $(25 \mathrm{~m} / \mathrm{My}$ of nannofossils in the Pliocene of Site 139 [some redeposition?] versus $15 \mathrm{~m} / \mathrm{My}$ at Sites 135 and 136; by multiplication of sediment rates with estimated nanno percentages), planktonic foraminifera increase disproportionately, thus leading to lower nannofossil percentages in the fertile area. This effect is also seen in the foram-rich siliceous Oligocene chalks of Site 144.

Besides increasing fertility, winnowing by bottom currents may decrease coccolith concentrations near continents. The effect of winnowing currents on an exposed hill is seen in the relatively low proportion of nannofossils in the Pliocene chalks of Site 141. These chalks accumulated at $15 \mathrm{~m} / \mathrm{My}$, with the coccoliths contributing no more than $8 \mathrm{~m} / \mathrm{My}$. This is considerably less than expected when compared with Sites 135, 136, and 139. In contrast, the planktonic foraminifera are in relatively high supply at Site $141(1 \mathrm{~m} / \mathrm{My}$ at Sites 135 and $136,7 \mathrm{~m} / \mathrm{My}$ at Site 139 , and $5 \mathrm{~m} / \mathrm{My}$ at Site 141). Since solution should decrease the sedimentation rate of planktonic foraminifera more than those of coccoliths, this concept cannot be invoked to explain the low nannofossil percentages at Site 141.

Carbonate dissolution is reflected in both abundance and etching patterns of nannofossils. Partial solution of chalk may leave the relative abundance of nannos unchanged or lead to a relative increase as the more susceptible foraminifera are removed $(135-4 ; 136-2,140-1,141-7 ; 141-8)$. More severe solution, however, quickly decreases nanno percentages as the insoluble components gain in proportion. Degree of dissolution increases with depth of deposition (Neogene of Sites 137, 138 versus Sites 140,139) and with increasing fertility (i.e., increasing supply of carbonaceous matter to the sediments, with concomitant formation of interstitial $\mathrm{CO}_{2}$ and intensified reworking by benthic organisms). Thus, considerable dissolution occurred at shallow Site 139, which lies below a fertile area. Solution patterns also change with time: Miocene sediments have undergone much more dissolution than have Pliocene sediments, other factors being nearly equal (sequences at Sites 135, 136, $139,140,141,142$ ).

Mass redeposition at Site 142 leads to unusually well preserved assemblage for the depths of deposition, but results in much breakage. Although less spectacular than at Site 142, redeposition phenomena appear widespread, as suggested by alternations between less strongly and more strongly dissolved assemblages in virtually all calcareous sequences.

While the etching patterns can be largely explained in terms of environment of deposition, the overgrowth patterns apparently are diagenetic phenomena: nannofossils near the surface show little or no overgrowth, whereas older and deeper ones do (Sites 135, 136, 142).

Bramlette's (1958) observation that nannofossils are much more abundant in pre-Quaternary calcareous oozes than in Quaternary oozes is amply supported by our data, as well as by those of earlier legs. The change is very drastic: in most pre-Quaternary calcipelagites, nannofossils constitute one-half to three-fourths of the sediment, whereas in modern Atlantic chalks below the low fertility southern central gyre, values scatter around 30\% (McIntyre and McIntyre 1971, Figure 16.1).

While local changes in nannofossil proportions can be related to changes in fertility, dissolution, and redeposition patterns, the ocean-wide Tertiary-Quaternary discrepancy remains a mystery. This problem is taken up again in the section on composition of calcareous oozes.

\section{Foraminifera}

Planktonic foraminifera ("forams") constitute the bulk of the coarse silt and sand fraction in calcareous oozes. In most cases, the sand fraction gives an estimate of foram proportions lower than the smear-slide result by a factor of about 2. Figure 13 shows five classes of total percentages based on both smearslide and sand fraction analyses. Within chalk ooze, foraminiferal proportions are complementary to nannofossil proportions, as discussed above. Elsewhere, abundances are largely a function of dissolution and dilution by other components. A large number of Neogene and of Cenomanian foram assemblages were recovered, other ages were but sparsely represented. 
In Figure 13, the states of preservation given as numbers (FS codes), best preserved in any one core to the left of the core symbols, least preserved to the right. These ranges are not all equally well established because of the differing numbers of samples per core (see Appendix 4). Where only one sample was available, one value is given and a question mark is entered on the other side.

The FS code numbers refer to the schedule shown in Table 2.

For the Quaternary, the important resistant species are Globorotalia menardii, Pulleniatina obliquiloculata, Sphaeroidinella dehiscens, Globorotalia tumida, Globorotalia crassaformis, Globoquadrina dutertrei, Globorotalia truncatulinoides, Globorotalia inflata (see Berger, 1971, p. 358). Additional resistant species for the Miocene and Pliocene are the relatives of the modern resistants as given by Parker (1967, p. 121): Globorotalia merotumida and $G$. plesiotumida, as well as other globorotaliids, Globoquadrina dehiscens and $G$. venezuelana, $G$. acostaensis and $G$. humerosa, and the various species of the genera Pulleniatina and Sphaeroidinella. In addition, Globigerina nepenthes appears to be resistant, from its association with other robust forms in poorly-preserved samples. Examples for Neogene assemblages in various states of dissolution are given in Plate 2, together with some typical representatives of resistant species.

For older assemblages, the solution series based on Recent foraminifera is less and less applicable, and more

TABLE 2

Solution Facies Based on Foraminifera (Minimum Requirements) ${ }^{\mathrm{a}}$

\section{FS Criteria}

Approximate

Loss

Per Cent

1 Foraminifera undissolved (aragonitic pteropods present)

2 Hastigerina present. Many globigerinids bear spines. $\mathrm{R}<5 \%$.

3 More spined than non-spined species. $5 \%<\mathrm{R}$ $<25 \%$.

4 Maximum equitability of assemblage. $25 \%<\mathrm{R}$ $<50 \%$.

5 Solution obvious. Whole tests $>$ fragments. $\mathrm{R}>$ $50 \%$.

6 Fragments $>$ whole tests. Plankt. whole tests $>$ calc. benth. f.

7 Calcareous benthonics $>$ planktonics. (Plankt. $\neq 0$ ).

8 No whole planktonics. Calcareous benthonics present.

9 Fragments of calcareous foraminifera only.

$\mathrm{X}$ No calcareous fragments.

0

$\sim 10$

$<50$

$50-80$

$80-90$

$>90$

$>95$

$>98$

$>99$

100

${ }^{a}$ FS values (foram solution codes) 7 and 8 are applicable to the deep sea only, since near continents the supply of benthonics is very large in places. Hastigerina does not include Globigerinella. The resistant forms (R) are species belonging to the Neogene genera Turborotalita, Sphaeroidinella, Globoquadrina, Pulleniatina, Globorotalia, sensu Parker, 1967 (see text). The per cent ranges of $\mathrm{R}$ given are based on modern subtropical to tropical assemblages. In temperate assemblages the initial $\mathrm{R}$ is greater, due to abundant Globorotalia truncatulinoides and $G$. inflata. Equitability is a measure of diversity and may be defined as $\mathrm{E}=1-\Sigma \mathrm{p}_{\mathrm{i}}{ }^{2}$. emphasis had to be given to the criteria: whole vs. fragmented tests, planktonic vs. benthonic forams, spined vs. nonspined forms, delicate vs. heavy-shelled (cortified, keeled) forms, with somewhat greater subjectivity in assigning FS numbers (see Table 2). In Cretaceous samples, fragments tend to be absent, but clues to different states of preservation could still be gained from the other criteria listed (see Plate 3).

In some cases a coarser scale than the FS scale of Table 2 is desirable for summary or for somewhat more subjective assessment. For this purpose we use the following terms:

"P-facies" (Plenty of delicate forms, Preserved assemblage, $\mathrm{FS} \cong 1$ to 3 ),

"L-facies" (Lowered abundance of delicate forms, Lysocline zone, maximum secondary diversity; $F S \cong 4$ ),

"R-facies" (Rare delicate forms, Resistant forms greatly enriched; $\mathrm{FS} \cong 5$ to 6 ),

"N-facies" (No delicate forms, Nannofossils relatively enriched; $F S \cong 7$ to 9 ).

The distribution patterns of foraminiferal solution facies compare well with the patterns of nannofossil solution facies (Figures 12 and 13). In the low solution ranges, the foram scale is more sensitive but in the high ranges the nanno "etching" scale yields additional information. Preservation is best in the relatively shallow samples from Site 144 and in some redeposited assemblages from Site 142. Elsewhere, Quaternary and Pliocene chalks yield moderately-well-preserved faunas (Sites 135, 139, 141) with progressively greater dissolution downward into Miocene sediments.

There is a striking difference in the preservation patterns of Neogene and Cenomanian foraminifera, which is but incompletely reflected in Figure 13. The range of FS values is moderate in Neogene samples from any one core (Sites $135,136,139,140,141)$, indicating similar states of dissolution, except in cases of large-scale redeposition (Site 142). Also, all transitions exist between cores from well-preserved to highly fragmented and impoverished faunas (Plate 2). In contrast, the range of FS values is large in Cenomanian samples from within cores of Site 137. Excellently-preserved assemblages (Plate 3) alternate with extreme residual faunas consisting mainly of benthonic forams. While incomplete tests are quite common in some samples, extensive fragmentation is not seen, suggesting almost a "nothing-or-all" situation with regard to preservation.

If this observation is correct, one must envisage two facies regimes on the Cenomanian Mid-Atlantic Ridge, one of excellent preservation and one of virtually complete dissolution, with a rather narrow boundary zone between. Such a situation could possibly be provided by anaerobic sedimentation near the Ridge crest, under control of a deep-reaching oxygen minimum intersecting the Ridge. Epigenetic sulfide formation by bacterial sulfate reduction would increase alkalinity in pore waters and stop dissolution of calcite (see Berner et al., 1970; Berger and Soutar, 1970). Evidence for sedimentation under reducing conditions on the Cenomanian Ridge crest will be presented in later sections (authigenic minerals, colors, sedimentary structures). A rather sharp boundary between P- and $\mathrm{N}$-facies regimes could be produced if a hydrographic 
lysocline ${ }^{2}$ intersecting the ridge flank provided sufficiently different sedimentation rates to create an anoxic to oxic transition from a virtually closed pore water system (no burrowers, no interchange, high alkalinity) to a more open one (burrowers, interstitial water-bottom water exchange, undersaturated pore water). Conceivably, slight changes in oxygenation or lysocline position could then provide for large movements (horizontally and vertically) of the facies boundary, with correspondingly large ranges in dissolution states of forams in any one core. Alternatively, and perhaps more likely, redeposition of $\mathrm{P}$-assemblages into the $\mathrm{N}$-facies zone could bring about a similar result, if dissolution rates were insufficient to attack displaced P-assemblages to a significant degree before burial.

The overall deepening of the $\mathrm{CDD}$ and other solution facies boundaries since the Miocene, the relatively poor preservation of Neogene faunas near Africa, the displacement of better preserved assemblages into areas of more dissolved in situ faunas, especially in Ceara Abyssal Plain, and the rapid alternations in state of preservation in the Cenomanian sediments provide for complex solution patterns (Figure 14). Tectonic movements also need to be considered, as is obvious from a study of Sites 137 and 144, which apparently subsided by several thousand meters. This problem will be discussed in the section on paleobathymetry.

There are some striking differences in shell morphologies between Neogene and Cenomanian assemblages. In general, Neogene foraminifera, especially small forms, seem to have a greater propensity to develop kummerform and pachyform tests $^{3}$ (see Plates $4,5,6,7$ ). These differences apparently cannot be entirely ascribed to evolution, since they cut across taxa, nor to preservation effects, since they hold true even if only well-preserved samples are compared.

\footnotetext{
${ }^{2}$ A distinction is made between "hydrographic lysocline," corresponding to a level of calcite solution increase in the water, as found by Peterson (1966) and a "sedimentary (here foraminiferal) lysocline," being a mappable facies boundary between well and poorly preserved calcareous assemblages.

${ }^{3}$ Kummerform: having a small terminal chamber, i.e. $\mathrm{q}<1$, where $\mathrm{q}$ $=$ diam. (last chamber) $/$ diam. (previous chamber). Pachyform: having thick walls or cortex.
}

The Neogene morphology modifications, in particular shell thickening, would appear to require above all a sufficient amount of time; that is, a considerable lengthening of the life span of those individuals who produce kummerforms or pachyforms. Relatively rapid settling, especially of heavy tests, would tend to remove the organisms from their photic habitat to the sea floor. Enhancement of processes favoring suspension, therefore, seems necessary. This enhancement may include cooling of subsurface waters (increase of viscosity, slowing of settling), and mixing and upwelling in upper waters. Increased mixing may also provide stressful conditions favoring kummerform development (Berger, 1970b; Hecht and Savin, 1970).

\section{Other Calcareous Fossils}

In addition to nannoplankton and foraminifera, other calcareous shells are occasionally present and in some instances are very abundant. These include echinoderm remains (largely spines), ostracods, bryozoans, mollusks and calcareous algae. Such fossils are abundant in shallow-water deposits of Site 144. Where associated with deep-water sediments, they indicate redeposition (Site 142). Certain rare components of chalks, such as echinoid spines can apparently be enriched by differential dissolution of less resistant fossils (Sites 135, 136, see Appendix 4).

\section{Siliceous Fossils}

Siliceous fossils, mainly radiolarians and diatoms, were recorded in both smear slides (patterns in Figure 15) and in the sand fraction (symbols in Figure 15). Abundance patterns show 3 major features: (1) an increase toward the high fertility areas off northwest Africa (Site 139), where the eastern boundary current provides for high plankton production and silica supply; (2) a general tendency toward increased proportions in Middle Eocene, Oligocene and Early Miocene sediments (Sites 138, 139, 140, 142, 144); and (3) a possible equatorial fertility effect in sediments of the Middle Cretaceous (Sites 137, 138) when the sites of deposition presumably were some 20 degrees farther south, beneath an east-west current belt that may have been circumtropical (see section on paleogeography). Pyritized siliceous fossils (Sites 135 [Aptian], 144 [Aptian], 137 [Cenomanian], 138 [Cenomanian], 144 [Maestrichtian],

Figure 11. Regional patterns of dominant components. A component has the rank 1 if it ranks first in more than $50 \%$ of the sediment in a core, rank 2 if it ranks first in more than $10 \%$ or ranks second within more than $50 \%$ of the core. Patterns refer to 1st rank (except for siliceous fossils); symbols to 2 nd rank.

\begin{tabular}{|c|c|c|c|}
\hline \multicolumn{2}{|l|}{ Patterns } & \multicolumn{2}{|l|}{ Symbols } \\
\hline Brick & $\begin{array}{l}\text { nannofossils and foraminifera (chalk: complete; } \\
\text { marl: broken }\end{array}$ & $N$ & nannofossils \\
\hline Blank & undifferentiated clay. & Z & $\begin{array}{l}\text { quarlz } \\
\text { zeolite }\end{array}$ \\
\hline Wavy & $\begin{array}{l}\text { radiolarians and diatoms (heavy: 1st rank; light: } \\
2 \text { nd rank). }\end{array}$ & $U$ & $\begin{array}{l}\text { undifferentiated carbonates, including fine } \\
\text { carbonate "flour" and reworked shallow water }\end{array}$ \\
\hline Stippled & terrigenous minerals, mainly quartz. & & shell material. \\
\hline & & $C$ & carbonaceous matter \\
\hline & & $A$ & ash, glass \\
\hline & & Diamonds & dolomite \\
\hline & & Triangles & chert \\
\hline
\end{tabular}



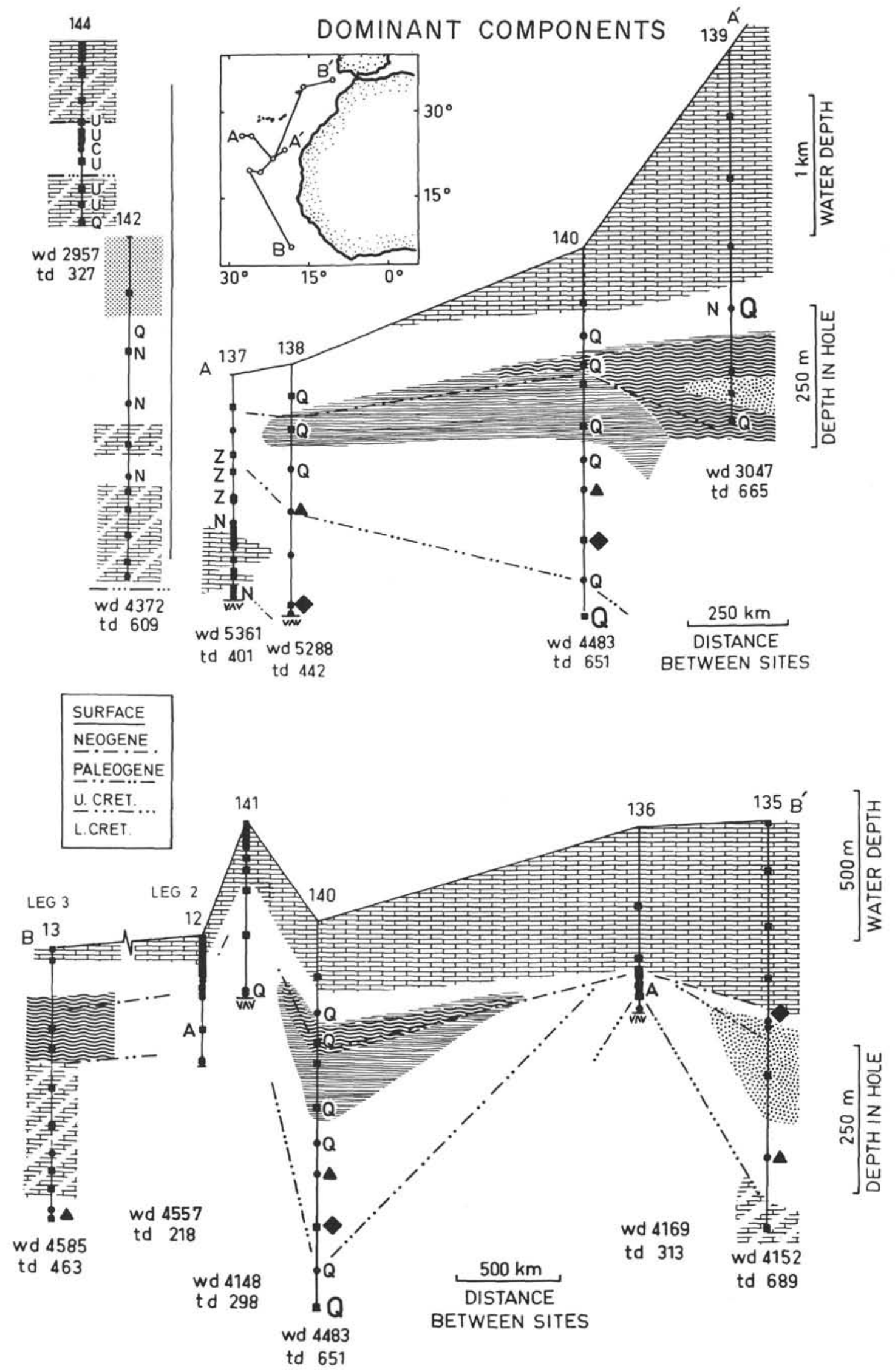

Figure 11. 

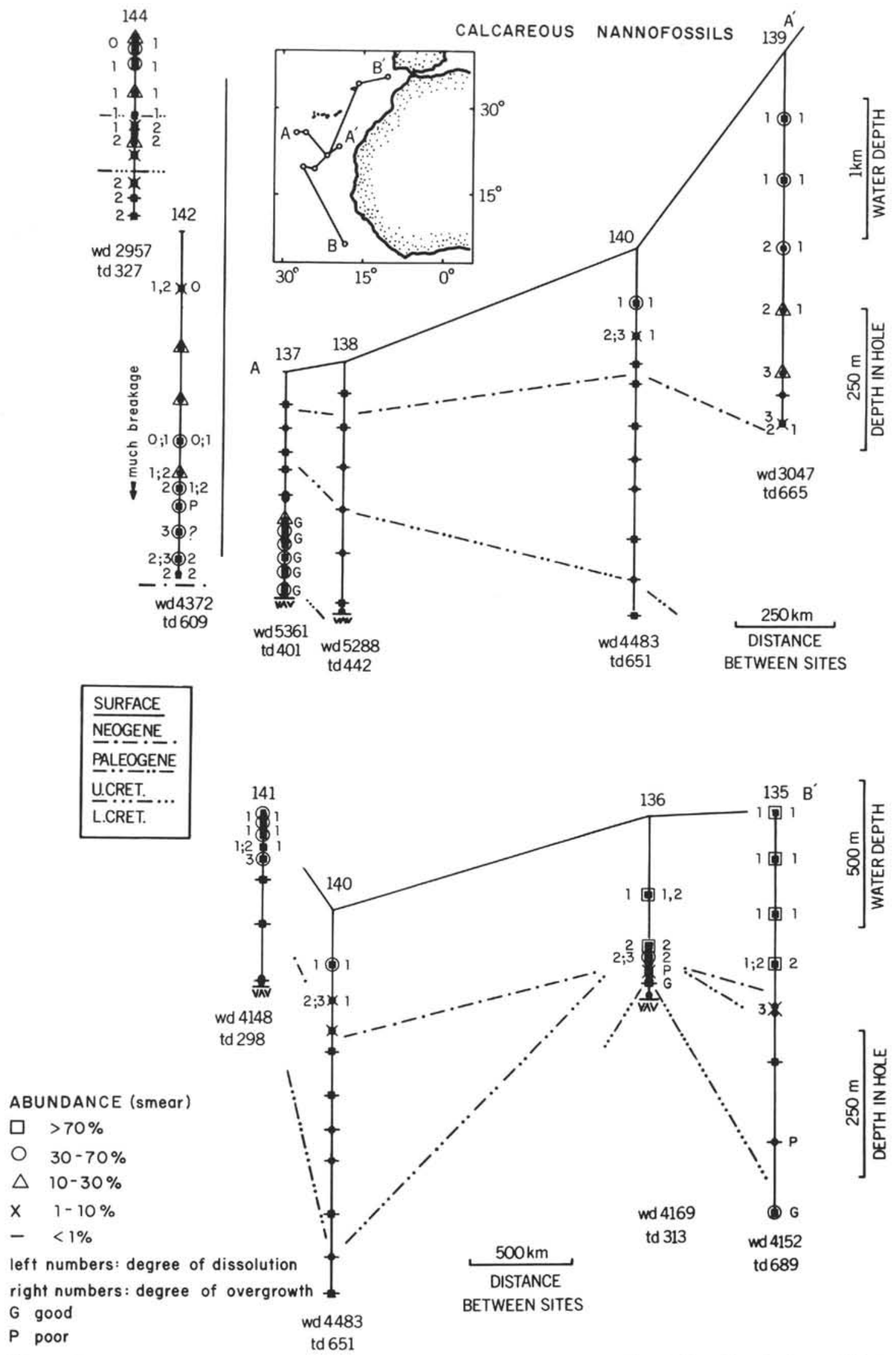

Figure 12. Distribution and preservation of calcareous nannofossils. Left: dissolution. Right: overgrowth. $O$, no dissolution. 3 maximum etching. Similar for overgrowth. $G$ (good) and $P$ (poor) refer to preservation. Determinations by P.H. Roth (for criteria see text). 


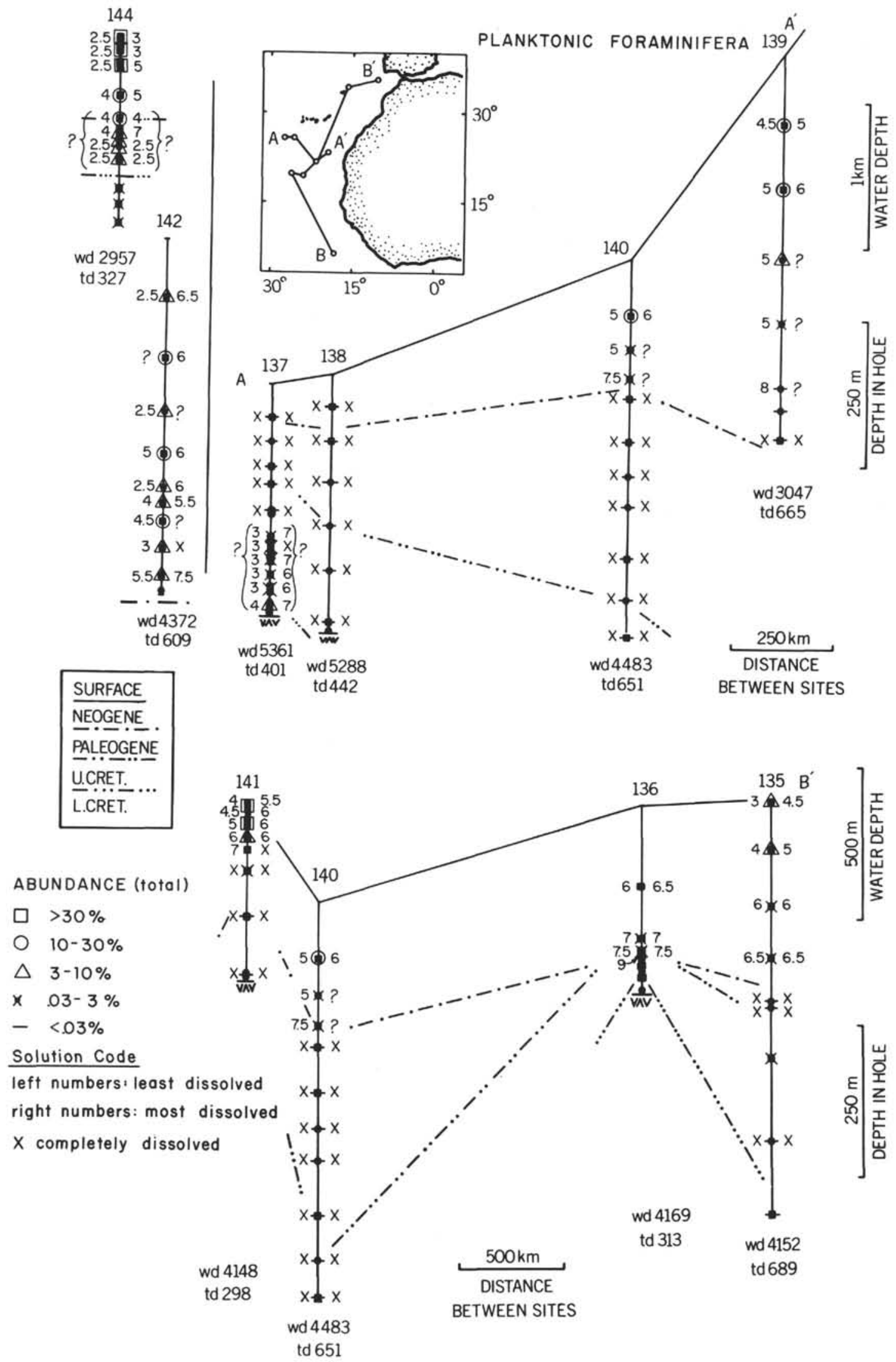

Figure 13. Distribution ("total" = silt and sand) and preservation (sand fraction only) of planktonic foraminifera. Low numbers, little dissolution; high numbers, much dissolution. For codes see Table 2. 


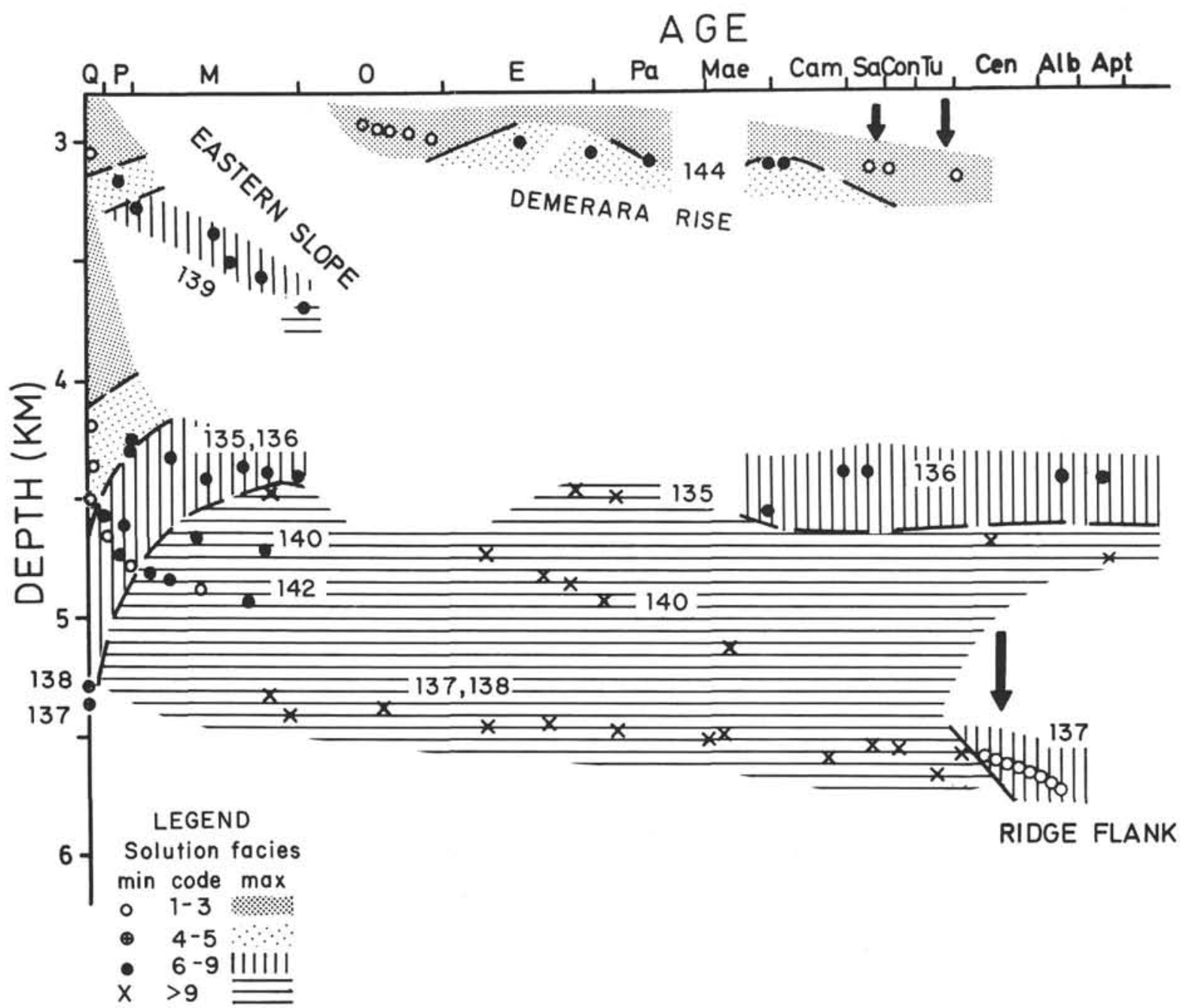

Figure 14. Foraminiferal solution facies in a depth-age diagram. Depth: water depth + drilling depth. 3-digit numbers refer to sites. Code numbers (legend) refer to state of dissolution: 1 to 3, least dissolved; 6 to 9 , most dissolved (see Table 2), X, completely dissolved. Symbols refer to least dissolved sample in any one core at any one age, patterns refer to most dissolved sample in any one core and age. The distribution of patterns shows the shallowest depths to which any one solution facies reaches, the distribution of symbols the greatest depths, for each age. Arrows show inferred tectonic movement. Note considerable (>1000 m) apparent displacement of well preserved samples into indigenous noncalcareous facies at Site 142.

140 [Eocene], and 139 [Miocene]) indicate strongly reducing conditions within the sediment, apparently largely an effect of initial preservation of organic matter as indicated by the co-occurrence of organic matter and pyritized microfossils. Radiolarian internal zeolite casts, very common in the Late Cretaceous of Site 137, record a complicated diagenetic history: initial preservation of radiolarian tests, subsequent growth of clinoptilolite within the tests with complete disappearance of any other material filling this space, and, finally, dissolution of the opaline shell followed by corrosion of the zeolite (see Plate 18).

The preservation of siliceous fossils is usually directly correlatable with their relative abundance in the sediment because the original proportions are $<30$ per cent in most cases. Thus, if the initial proportion of siliceous fossils is 20 per cent and two-thirds are dissolved, the final proportion will be 7.5 percent, a rather straightforward reduction. In contrast, calcareous oozes with $>60$ per cent carbonate cannot be expected to show such quasi-linear correlations. For example, if the initial carbonate content is 90 per cent $(9 \mathrm{~g}$ carb. $+1 \mathrm{~g}$ clay) and two-thirds are dissolved, the final content is 75 per cent ( $3 \mathrm{~g}$ carb. $+1 \mathrm{~g}$ clay).

A preliminary solution scale for siliceous components can be constructed, for example, by ordering fossils as follows (from least to most resistant): Phaeodarians (not observed), silicoflagellates, diatoms, delicate polycystins, robust polycystins (such as orosphaerids, cyclodiscids, heavy nassellarians), and sponge spicules. Unfortunately, initial proportions are difficult to estimate, and diagenesis obliterates much or all of the epigenetic preservation record in older sediments (see also Moore, 1969).

According to this rough scale, very well preserved siliceous assemblages occur in Miocene sediments on the continental slope (139-3, -4, mid-Miocene; $139-5$, 07, Early Miocene; and 140-2, Early Miocene), fully coinciding with high abundances and a diverse flora of diatoms and other 

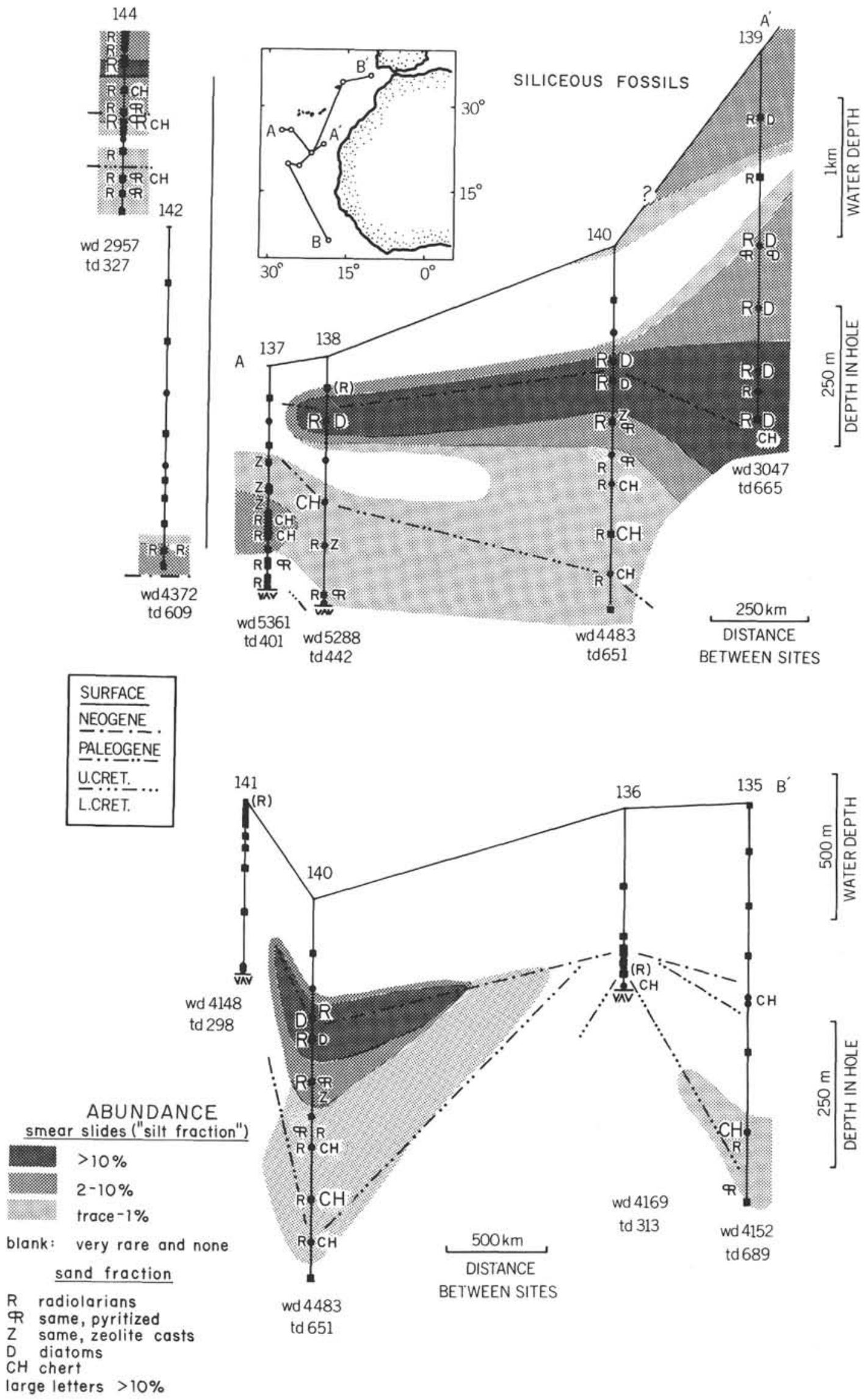

Figure 15. Distribution of siliceous fossils and chert from smear slide and coarse fraction analysis. 
siliceous algal remains. On the whole, Pliocene siliceous fossils are much more dissolved than those of the Miocene (see Plate 8).

Some relatively well preserved siliceous assemblages occur also in Oligocene sediments of Site 138 even though this site is quite distant from land. The state of preservation shows great variation, however (Plate 9). One important factor in producing these fluctuations may have been a sporadic occurrence of terrigenous resedimentation which provided for rapid burial at times and thus prevented leaching of silica. On the present sea floor off Portugal and Morocco, this leaching almost completely destroys siliceous fossils in the upper $50 \mathrm{~cm}$ or so of the sediment within about 4000 years (Schrader, 1971 b, 1972). The siliceous flora, where partially preserved, is considerably modified by selective dissolution (see Schrader, 1971a) with the more robust skeletons in each group having the best chance to enter the sedimentary record (Plate 10). Other factors, such as selective transfer to the sea floor in fecal pellets of selectively feeding copepods, also may play an important role in the total fossilization process (Schrader, 1971c). In no case, therefore, can the fossil siliceous assemblage be expected to furnish an even approximately correct sample of the living assemblage that produced it.

Selective dissolution removed diatoms and the more delicate radiolarians from siliceous assemblages of the Eocene (Plate 11). Orosphaerid fragments are among the most resistant siliceous skeletal remains (Friend and Riedel, 1967) and typically are the only fossils (with fish teeth) in some otherwise barren slightly siliceous clays (Plate 11, Figures 1 to 3 ).

In some of the Eocene assemblages, zeolite-filled pyritized and non-pyritized radiolarians occur together. This suggests a mixing of different fossil faunas by redeposition. This is also indicated by admixed terrigenous silt and sand (Plate 11, Figures 4 to 6). Alternatively, local or periodic variations in the in situ microenvironment may have played a role. Partially pyritized tests are rare.

Late Cretaceous radiolarian faunas are generally poorly preserved (Plates 12,13). Presumably selective destruction first impoverished the fauna near the sediment interface at the time of deposition and after burial diagenesis caused further changes. Within calcareous and dolomitic deposits, corrosion seems especially strong (Plate 12, Figures 1 to 4; Plate 13, Figures 2 to 4 ). Within clay, preservation of surface ornamentation and other details is quite good (Plate 12, Figure 7; Plate 13, Figure 1). The presence of a silica-rich environment, either from dissolution of fossils or from alteration of volcanic ash, or both, is indicated in many instances by abundant silica spherules ${ }^{4}$ and by abundant clinoptilolite (Plate 12, Figures 6, 7).

Site 144 has siliceous fossils in most parts of the section, from Oligocene to Aptian (Plate 14). Preservation is generally poor and heavy-shelled radiolarians are the most common fossils. Much of the pitting and etching on radiolarian surfaces may be diagenetic. Even in poorly preserved assemblages smooth test surfaces are common,

\footnotetext{
4 "Spherulitic aggregates" of Wise and Hsü (1971) consisting of (disordered) cristobalite (Wise et al., 1972; O.W. Flörke, pers. comm. 1972).
}

where diagenesis was apparently of minor importance, that is in relatively young formations and in non-carbonate sediments in older ones, especially where carbonaceous.

\section{Other Noncalcareous Fossils}

Of the less abundant fossils, fish debris and agglutinated foraminifera are most important. Fish debris is abundant only where diluting components are in low supply. Typically, therefore, fish debris characterizes pelagic clay or winnowed deposits with low sedimentation rates (Figure 16). For this enrichment to occur, however, fish debris must be both supplied and preserved. Conditions for supply of the phosphatic fossils apparently were optimal in the Early Miocene. This suggests that fish debris, like siliceous material, is an indicator of high oceanic fertility. The general association of phosphate deposits with upwelling areas (Sheldon, 1964) supports this contention.

Preservation aspects of the fish debris are contained in fragmentation and probably in the coloration, which varies from translucent to opaque and from colorless to brown and black. Translucent fish teeth are restricted to Oligocene and Miocene sediments (with two exceptions noted in Late Cretaceous samples). White, finely etched fish debris occurs throughout the sequence. Brown debris also is ubiquitous, except for samples of Early Miocene age from slowly accumulating facies. Fragmentation is relatively low in mid-Miocene, Oligocene and Eocene sediments. Interestingly, fragmentation of teeth is quite prominent in Early Miocene deposits, despite the high abundance of fish debris here (Plate 15). No evidence for diagenetic corrosion or destruction was noted.

Agglutinated foraminifera often are found associated with fish debris, being another fossil type with a low sedimentation rate and one which is easily masked by dilution. The relative proportions of fish debris and agglutinated foraminifera in the sand fractions of Leg 14 samples apparently show a trend (Figure 17). PostPaleocene sediments show a higher fish to foram ratio than do Cretaceous and Paleocene sediments. Possibly this is an effect of enhanced preservation of organic binding material in agglutinated foraminifera during the Cretaceous. In contrast, the highly oxygenated bottom waters of the Middle and Late Tertiary should more easily destroy any organic binding material.

\section{Terrigenous Components (Silt and Sand)}

\section{General}

The coarse (sand and silt size) terrigenous components essentially are indicators of near-bottom redeposition of continental sediments. Excepting very fine silt, their presence ultimately depends on downhill transport. Their oceanward limit marks the boundary between the lower flank of the Mid-Atlantic Ridge and the foot of the continental rise off Africa, as strikingly illustrated by the contrasting lithologies of Sites 137 and 138.

The abundance of terrigenous components depends on supply from the continent and on dilution by biogenous and other sediment. Obviously, supply is increased during regressions and times of orogenesis, uplift, and high denudation rates in the hinterland. It is decreased during transgressions. The composition of the terrigenous fraction 
RATE OF SEDIMENTATION ( $\mathrm{m} / \mathrm{My}$ )

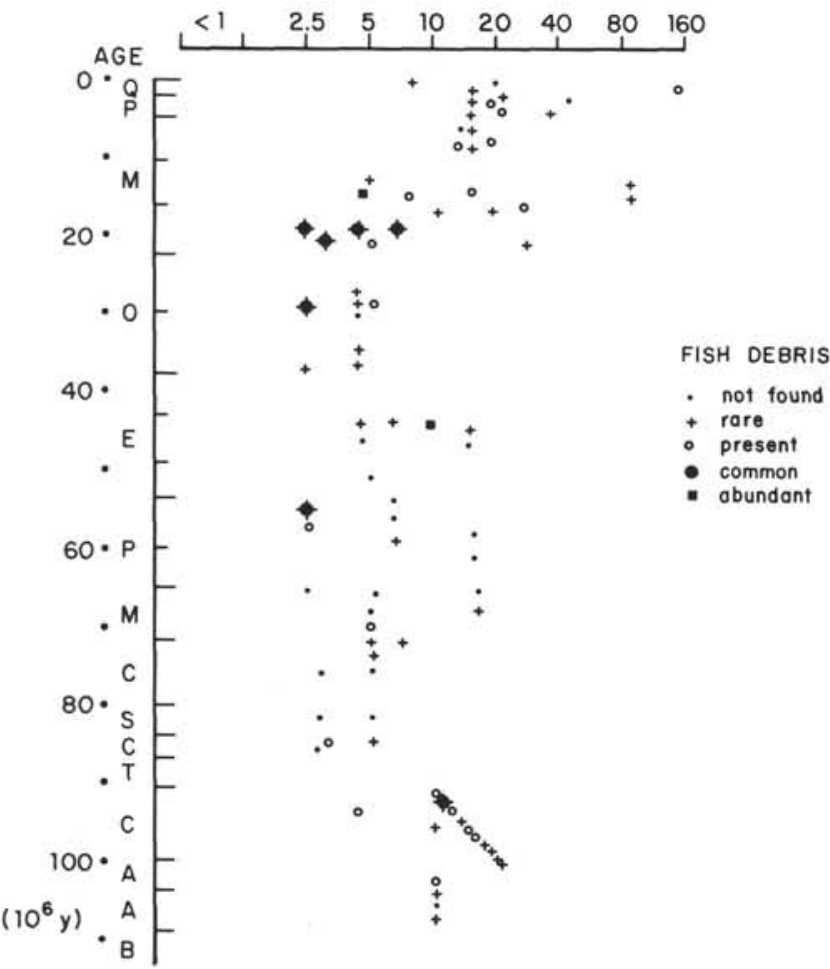

Figure 16. Distribution of fish debris (teeth, bones) through time, in relation to sedimentation rates. 3-digit numbers refer to drill sites.

RATE OF SEDIMENTATION (m/My)

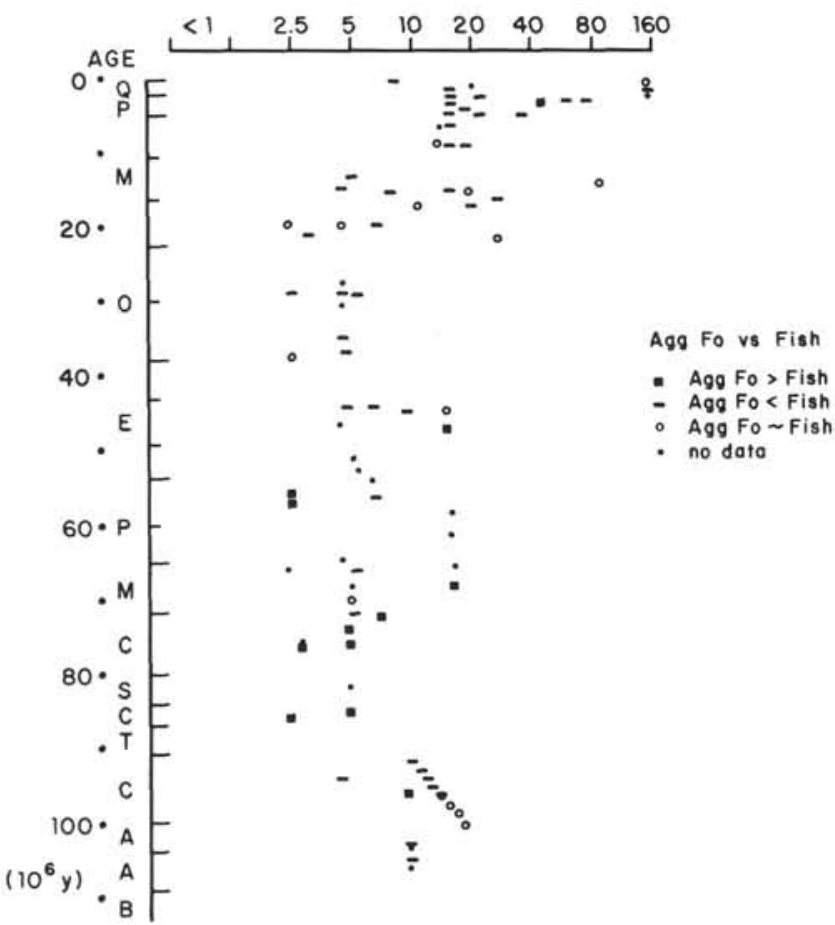

Figure 17. Relative abundances of agglutinated foraminifera and fish debris in the coarse fraction. Visually estimated abundances (by volume). Differences shown only where distinct. may give important clues to the kinds of rocks and the degree of weathering prevailing in the source areas.

\section{Quartz}

Quartz is the most abundant of the terrigenous components and almost always dominates the terrigenous assemblages. Its relative abundance and apparent sedimentation rates are highly variable (Figure 18; Appendices 3 and 4). The highest rates of sedimentation of quartz (up to 30 $\mathrm{m} / \mathrm{My}$ ) were found in the Quaternary deposits of Site 142. On the African side, only 139-4 yields a comparable rate (15 m/My), apparently because large scale slumping took place here, as deduced from biostratigraphy (139-3 and 139-4 belong to the same nanno- and foram-zones). Elsewhere, high quartz accumulation rates occur in the Late Cretaceous of Site $135(1-3 \mathrm{~m} / \mathrm{My})$ in the earliest Miocene at Site $139(10 \mathrm{~m} / \mathrm{My})$, in the Pliocene at Site $142(2-6$ $\mathrm{m} / \mathrm{My}$ ) and in the shallow water Aptian deposits of Site 144 $(0.5-3 \mathrm{~m} / \mathrm{My})$. The numbers given are averages. In reality, the quartz content within these cores is usually quite variable and tends to be concentrated in sand layers. This indicates sporadic events supplying terrigenous material, as discussed in the sections on sedimentary structure and on facies.

The size distribution of the quartz fraction varies greatly; it usually is strongly related to abundance. Relatively high proportions of quartz sand occur in certain cores of all holes except Sites 136 and 137 (Figure 18, circled samples). Within the sand fraction, the quartz grains display various degrees of rounding, the coarser ones tending to be most rounded (see section on facies).

\section{Feldspar}

Relatively large concentrations of feldspar are found in the silt and sand fractions of some samples ( $F$ in Figure 18). In most cases the feldspar (plagioclase mostly, except at Site 142) is associated with quartz and is of continental origin (especially in 135-7 [Camp./Maestr.] ; 141-SW1 [?Lt. Cret.] ; $140-8$ [Maestr.] ; $142-1$ to 5 [Plio.-Quat.]). In several instances, the feldspar apparently is of volcanic origin since it is associated with volcanogenic material (ash layers in 136-6, 136-8, 138-6: K-feldspar, probably sanidine in most cases). The mineralogy and distribution of feldspars is discussed in some detail, within the context of terrigenous sediments, in the section on facies.

\section{Mica}

Terrigenous mica is everywhere associated with quartz, but with strongly varying abundance $(\mathrm{M}, \mathrm{m}$ in Figure 18; max. conc. in $135-7,142-1$ to $6,144-8)$. The amount of mica is strongly influenced both by the original supply, reflecting the maturity of the hinterland source, and by size sorting on the ocean floor, since micas tend to follow the very fine silt and the clay fractions. Both factors may explain the relatively low mica abundances in the Neogene of Site 139.

\section{Other Terrigenous Components}

Common additional constituents of predominantly terrigenous sediment assemblages are heavy minerals, iron 

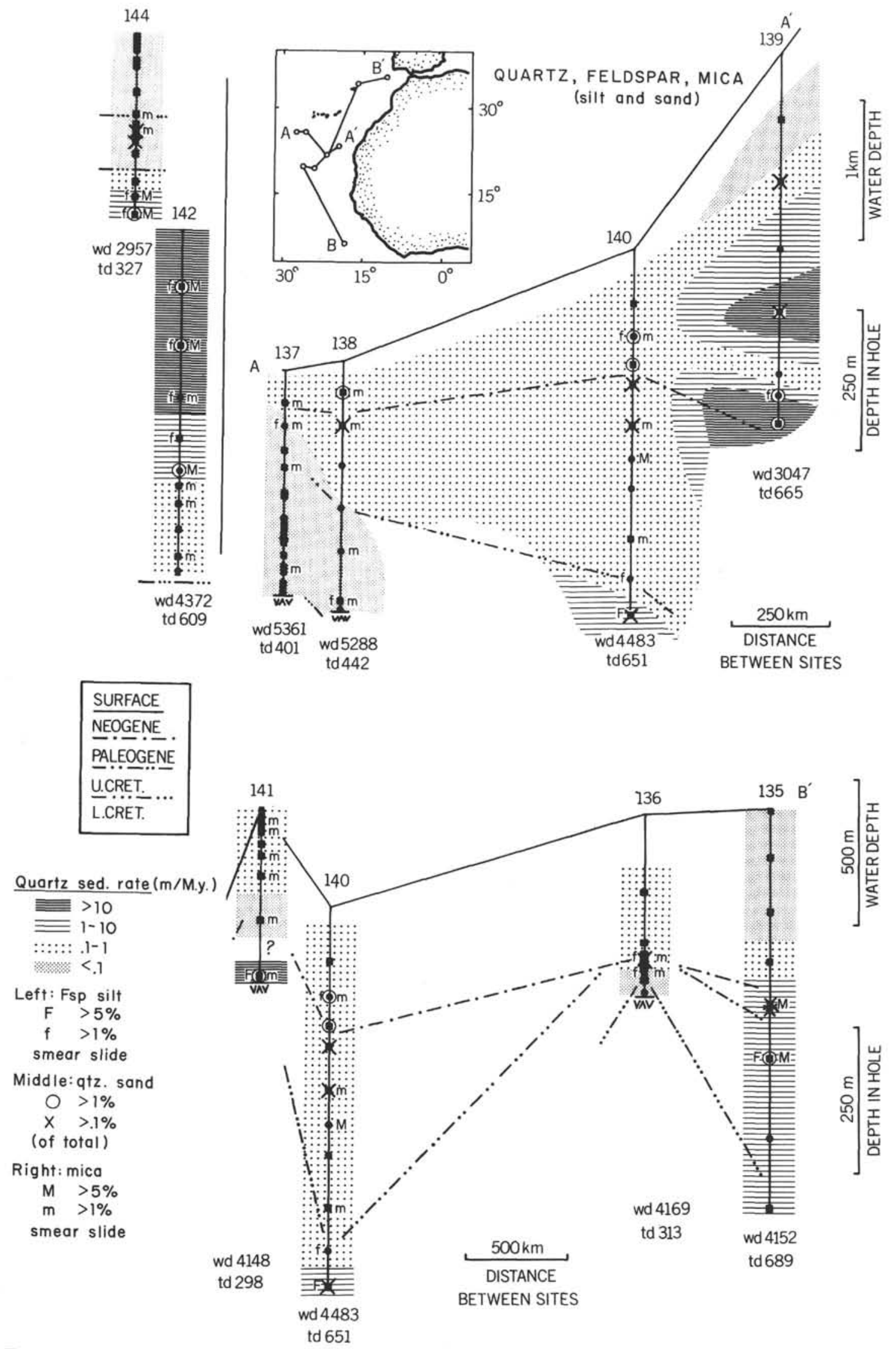

Figure 18. Distribution of major terrigenous minerals. "Quartz sed. rate" is product of average percent quartz in core and accumulation rate for the core. Distributions based on smear slide data, except for quartz sand symbols (from coarse fraction). 
oxides, glauconite, fragments of sedimentary rocks (limestones, sandstones, chert fragments, etc.), igneousmetamorphic rocks, and shallow water fossil remains, as well as plant debris (see section on facies; Appendices 3 and 4).

\section{Clay Minerals}

\section{General}

The clay fraction of Leg 14 sediments contains continental detrital minerals (mica-illite, kaolinite, occasionally chlorite), associated with high proportions of quartz, alteration products of volcanic material (montmorillonite), and more or less authigenic phases (mixed-layer chloritemontmorillonite, palygorskite, sepiolite, fine-grained zeolite). The boundaries between these different modes of origin are not always sharp. Detrital clay minerals may change during diagenesis, and alteration products may obliterate all memory of a pre-existing solid structure, thus becoming indistinguishable from authigenic phases. The main clay mineral associations are illustrated in Figure 19, showing that apart from the almost ubiquitous montmorillonite, detrital minerals (chlorite, mica-illite, kaolinite) are generally more abundant in Neogene sediments, and diagenic/authigenic ones (palygorskite-sepiolite, mixed layer minerals) in Cretaceous to Paleogene deposits.

\section{Detrital Minerals}

Quartz is ubiquitous, being especially abundant in all terrigenous sands, and common, or at least present in traces, virtually everywhere. Feldspar (mostly plagioclase) is common in many quartz-rich sediments (135-7 and 9; 139 ; 141-SW1; 142-2 and 6; also to some extent 138-6) and occurs in traces elsewhere.

Mica is common to abundant in terrigenous muds (e.g. $135-7 ; 141-6 ; 142-2$ to 6 ) as a companion to quartz, feldspar, and kaolinite. It is also common in some siliceous mudstones (135-8), in volcanogenic sediments (136-4, 5 and 8), and in zeolite-rich muds and black shales on Demerara Rise (144). In traces it occurs almost everywhere, in marl oozes, muds, and pelagic clays. Biotite is usually more abundant than light micas.

Kaolinite essentially follows the quartz and mica pattern. It originates from chemical weathering of feldspars on the supplying continent (Griffin et al., 1968). A noteworthy, somewhat anomalous occurrence at $137-14$ is in a green phyllosilicate sand layer (?ash). This layer also contains quartz and mica as common constituents.

Chlorite is rather rare except at Sites 135 (Core 7) and 142.

\section{Alteration and Authigenic Minerals}

Hydrated alumino-silicates of the montmorillonite group ("smectite") are ubiquitous. They are dominant in some volcanogenic clays (136-5 to 8); in certain pelagic clays (137-4 and 6; 141-9), with and without much zeolite; in Cretaceous marls at Site 137; and also in some predominantly terrigenous muds (139-3; 140-3; 141 SW1), with and without palygorskite. There appears to be no obvious age trend in accumulation rate distributions. There seems to be little doubt that montmorillonite originates from the alteration of volcanogenic products. However, to what extent this happened subaerially with subsequent transport to the deep sea or by submarine weathering and diagenesis, must be determined for each individual location and time (Goldberg and Griffin, 1970). A Mg-rich variety (saponite) represents the montmorillonites in two samples of pelagic brown clay, one from 136-5, the other from 137-4.

A mixed-layer mineral, interpreted as montmorillonitechlorite, is quite common in several pre-Neogene samples $(-136-8 ; 141-8)$. It possibly is due to diagenetic alteration of montmorillonite. The fibrous, hydrous, and hydrated magnesium silicate palygorskite ("attapulgite") is common in a great variety of sedimentary facies, mostly of pre-Miocene ages. It is present in: volcanogenic brown clays (136-5 and 8 ), pelagic, partly zeolitic clays (137-2 to $6 ; 138-3$ and 5; $141-7$ to 9$)$, hemipelagic muds $(135-7 ; 140-3 ; 141-\mathrm{SW} 1)$, marl oozes (137-7, 8, 9 and 12; 141-6), and cherts (140-6). Compared with smectite, high abundances of palygorskite are more restricted to facies with low sedimentation rates, indicating authigenic growth and dilution by calcareous and terrigenous matter.

The similar mineral sepiolite (containing more $\mathrm{Mg}$ and less $\mathrm{Al}$, see Caillère and Hénin, $1961 \mathrm{a}, \mathrm{b}$ ) is less common than palygorskite but shows no obviously different pattern. One of the two samples rich in saponite (137-4) is also one of the two samples rich in sepiolite. This core contains pelagic brown clay deposited at the very end of the Cretaceous, possibly at a very low sedimentation rate. It is also rich in (corroded) zeolite and rhodochrosite.

Traces of gypsum were recorded in samples from 136-4; 137-2, 7 and 8 and 141-7, 8 and 9 .

\section{Authigenic Minerals (Silt and Sand)}

\section{General}

The coarse (silt and sand size) authigenic components include oxides and hydroxides $(\mathrm{Fe}, \mathrm{Mn})$, heavy metal sulfides ( $\mathrm{Fe}, \mathrm{Zn}, \mathrm{Cu}, \mathrm{Ni}, \mathrm{Co}, \mathrm{Pb}$ ), sulfate ( $\mathrm{Ba}, ? \mathrm{Sr}$ ), carbonates ( $\mathrm{Ca}, \mathrm{Mg}, \mathrm{Mn}, \mathrm{Fe}$ ), and zeolite (clinoptilolite). Some of the minerals in this group originate from alteration of pre-existing material. For example, pyrite and glauconite, upon being displaced from shallower regions into the deep sea, may be partially or completely oxidized yielding iron-oxides. Conversely, terrigenous iron oxide may be the source of much of the iron in hemipelagic pyrites. Other minerals grow by replacement, as in pyritized radiolarian skeletons, and some may precipitate from interstitial solutions, such as dolomite rhombs, heavy metal sulfides, and manganese oxides.

\section{Oxides and Hydroxides}

Small manganese nodules (coarse sand and small pebbles) are common in sediments associated with hiatuses at Sites 135 (Eocene-Miocene, Core SW1), 136 (Late Cretaceous-Miocene, Cores 3 to 6), and to a lesser extent at 141 (Middle Miocene-Pliocene, Core 7). Additional occurrences were noted in the pelagic clays at Site 137 (Late Cretaceous to Miocene). At 135-8 (Cenomanian) micro-nodules occur within a mixture of siltstone fragments, compressed planktonic foraminifera, fish debris, as well as chert pebbles and other redeposited components. Manganese concretions are 

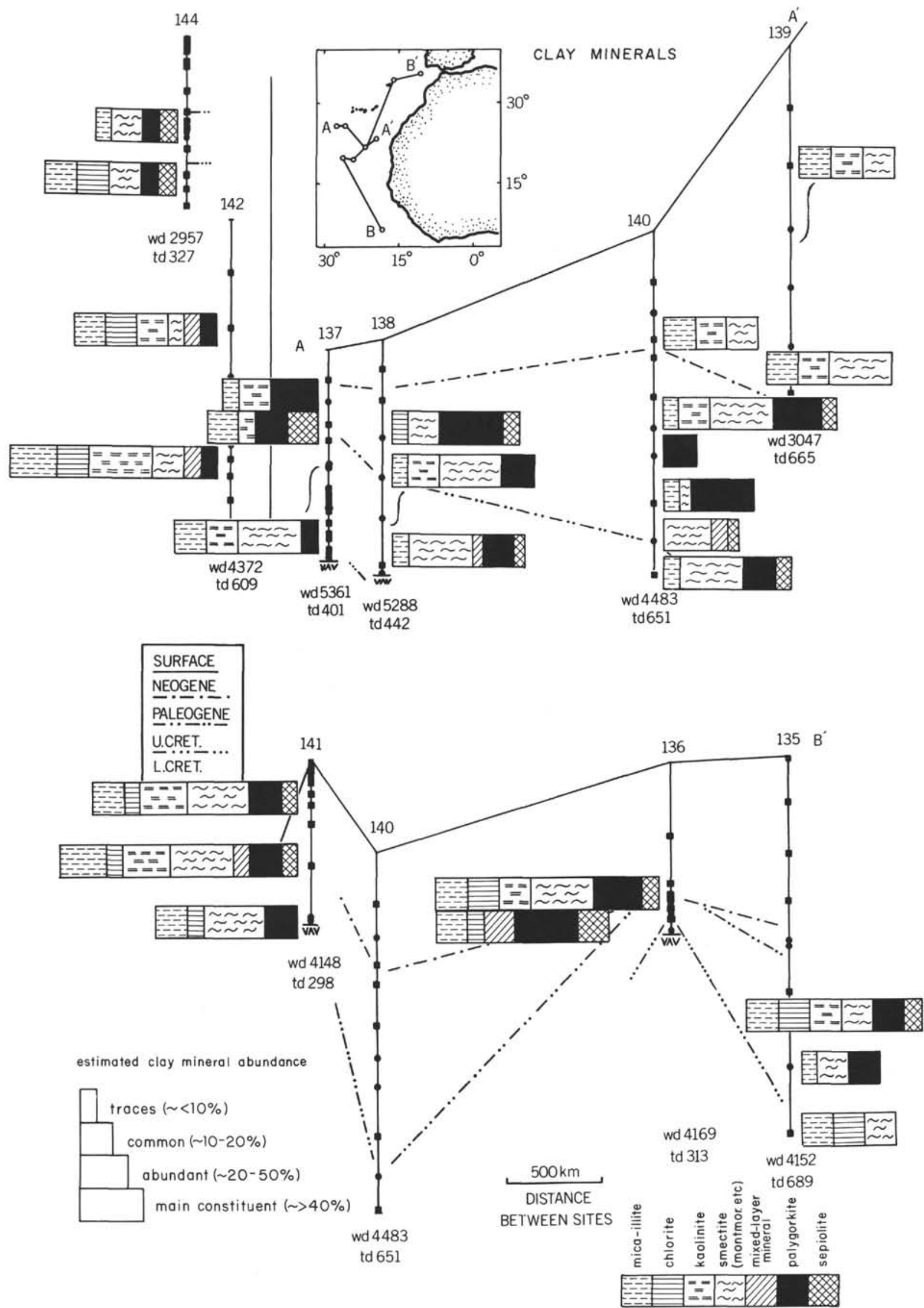

Figure 19. Clay mineral distribution. Based on X-ray analyses by v. Rad and Rösch (this volume). 
generally younger than Turonian and are restricted to the predominantly oxidized part of the sequences, that is, where sediments are mostly red, brown, or yellow-colored (see Figure 20).

In the coarse fraction, iron-oxide is commonly found as an alteration product of "glauconite" (e.g. brown rim) and of pyrite (e.g. oxidized burrow casts) and as cement of claystone particles. Pieces of "crust" were recorded in 135-SW1 at the hiatus. They were associated with quartz, up to pebble size; fish debris; poorly preserved benthonic foraminifera; and pyrite burrow casts. The association suggests winnowed, mostly reworked deposits. Occurrences at $136-3,4,5$ suggest a similar environment. Elsewhere also, iron-oxide occurs largely with redeposited material in an oxidizing setting associated with unconformities and/or slow accumulation rates.

\section{Sulfides}

Pyrite is ubiquitous within reduced sediments (Figure 20) occurring in finely disseminated form (recorded as "opaques" in smear-slide analysis), as irregular grains, as casts and replacement of fossils and burrows, and as euhedral crystals (Plate 16, Figures 7 to 9). Sphalerite was identified optically in the coarse fraction of Cenomanian sediments from Site 137, and the presence of $\mathrm{Zn}$ was verified by $\mathrm{X}$-ray fluorescence (see below). The great majority of sulfides consists of pyrite, however.

The pyrites seem to have a two-fold origin. First, in some places they occur in deep sea sediments rich in quartz and other terrigenous components (135-SW1, SW2, 8, 9; $136-5 ; 138-2 ; 139-4 ; 140-3,4,8 ; 140 \mathrm{~A}-2 ; 142-5)$ thus suggesting that the iron was brought in as oxide, sulfide and glauconite from shallow water regions and that organic-rich high-rate sedimentation provided the necessary reducing conditions for stability of pyrite. Occasionally this stability is marginal, as witnessed by partial oxidation of pyritic or glauconitic material (135-9; 140-3). (Partial oxidation of pyrite also was noted in $144 \mathrm{~A}-4$, a relatively shallow environment with slow sedimentation rates.) Secondly, in other places, pyrite occurs independently of redeposited shallow water sediments in black carbonaceous nanno marl oozes or carbonaceous muds with local chert layers (notably at Site 137). In this setting, large euhedral crystals are common. The largest concretion $(137-7-1)^{5}$, an almost euhedral pentagondodekahedron, measures $6 \mathrm{~cm}$ across. Spherical pyrite nodules with a diameter of 5 to $20 \mathrm{~mm}$ were found in 137-7-2 (carbonaceous marl mud). Oxidation rims were observed here also (137-9 and 10) suggesting a changing environment, perhaps through redeposition processes as suggested by the co-occurrence of red clay, pink marl, greenish marl-chalk with sulfide, poorly preserved benthic-rich calcareous foram assemblages, and wellpreserved small planktonic foraminifera. The ultimate source of iron should be no problem at Site 137 since smectites and palygorskite are common and their source material-presumably volcanogenic particles-should have yielded sufficient iron for both the sulfides and the more finely disseminated oxides within the reddish clay. The

${ }^{5}$ Read "Site 137, Core 7, Section 1." sulfide ion presumably stems from bacterial sulfatereduction during epigenesis taking place in a reducing environment close to the interface, the reaction being favored by the presence of organic material. Larger crystals and aggregates $(135-9 ; 137-7$ and $8 ; 138-6 ; 140-8 ; 144-\mathrm{A} 3$, A4, and 4) may form diagenetically by cannibalizing the initial precipitate.

In general, high sulfide abundances are associated with relatively high sedimentation rates (preventing complete oxidation of the more easily decomposable organic matter near the surface; E. Sholkovitz, pers. comm.), independently of age (Sites 139, 140) and with Cretaceous ages rather independently of rates (Sites 137, 144), excepting pelagic brown clays. Apparently aeration of the deep sea was less well developed in Cretaceous than in Tertiary time, as suggested above on the basis of trends in the agglutinated forams to fish debris ratio (see also section on colors and on pelagic clays).

\section{"Glauconite" and Other Greenish Minerals}

Sand-sized grains of yellowish green, green, and bluish green homogeneous and aggregate material of irregular shape (fragments, cracked spheres, botryoids, and foram casts) were found in many sediments which were intermediate between oxidized and reduced (Figure 20). The mineral "glauconite" (s. str.), however, was not found in the X-ray analyses. In cases where these greenish grains are associated with quartz and other terrigenous sediments (almost everywhere except Sites 137, 141-9, and 144A-5), derivation from a shallow-water environment seems clearly indicated, especially where casts are those of shallow-water fossils. In some cases, "glauconite" was oxidized in its depositional environment (i.e. the grains have brown rinds), indicating that it is out of equilibrium with the surroundings (144A-4 and 5).

Very large greenish particles, apparently partly oxidized (brown rims), occur in 141-9 (?Paleocene), and do not consist of glauconite. The cores of these pellets are dark green to black and are malleable. Only fish debris and arenaceous foraminifera, and some very fine quartz sand are associated with this mineral. X-ray fluorescence gave a $\mathrm{Cu}$ peak. Green mineral grains elsewhere did give an $\mathrm{Fe}$ signature only. This included "glauconite" at Site 137 (especially in 9, 10, 11, and some in older samples, see Appendix 4), where deep-sea conditions prevailed throughout. The Cenomanian sediments of Site 137 are characterized by intimate intercalation of brownish and greenish sediments, indicating an environment where $\mathrm{Fe}^{3+}$ and $\mathrm{Fe}^{2+}$ can coexist, as is required by the chemical formula of glauconite (see Füchtbauer and Müller, 1970, p. 179). Introduction of pyrite by redeposition, from higher up on the Ridge and subsequent alteration, within more oxidizing conditions, may have played a role. Associated palygorskite, zeolite, and especially radiolarians, attest to the availability of reactive silica. Thus, pelagic glauconite may have formed at this site.

\section{Heavy Metals in Manganese Concretions, Sulfides and "Glauconite"}

(This section by W. H. Berger and E. Suess, Kiel)

Sphalerite and chalcopyrite were noted in samples from 137-11 during optical examination of the coarse fractions 

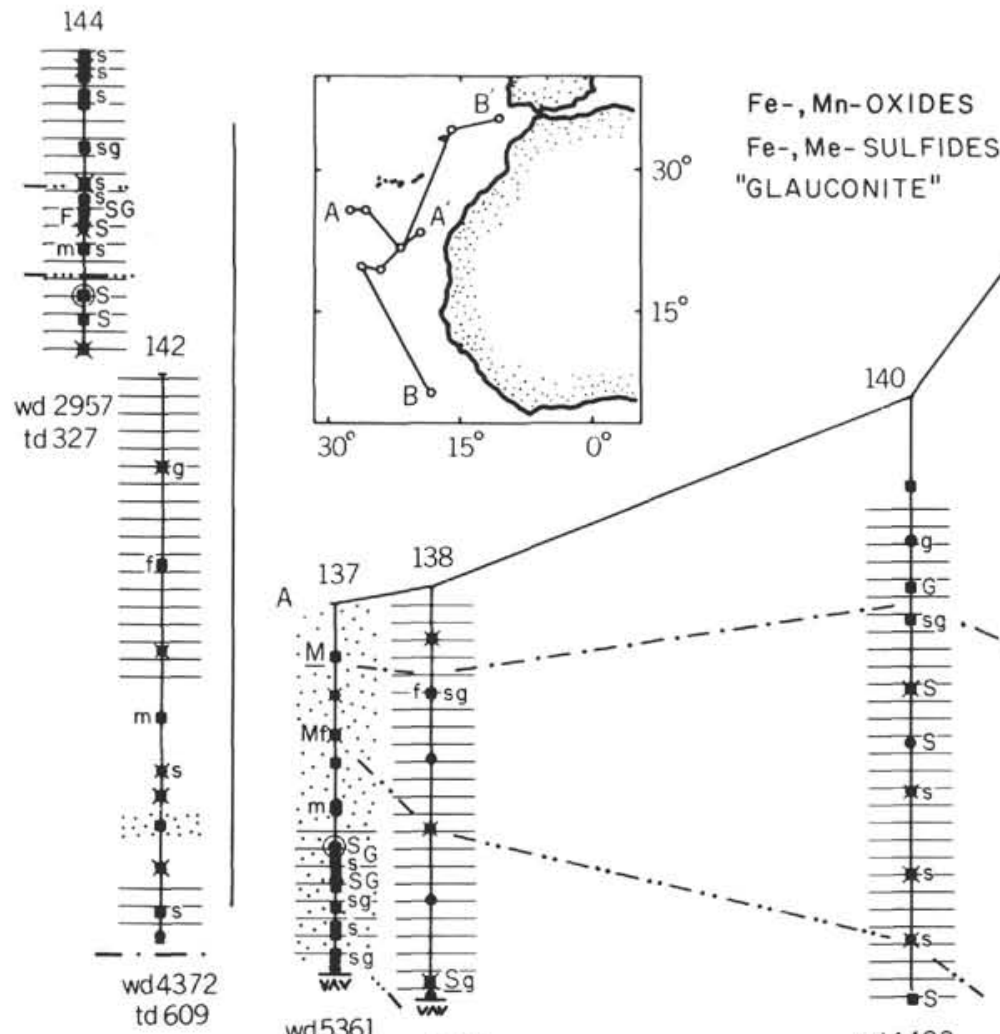

A

137

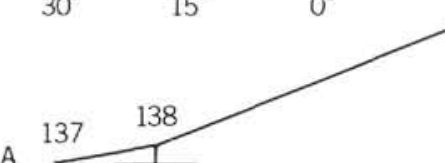

"GLAUCONITE"

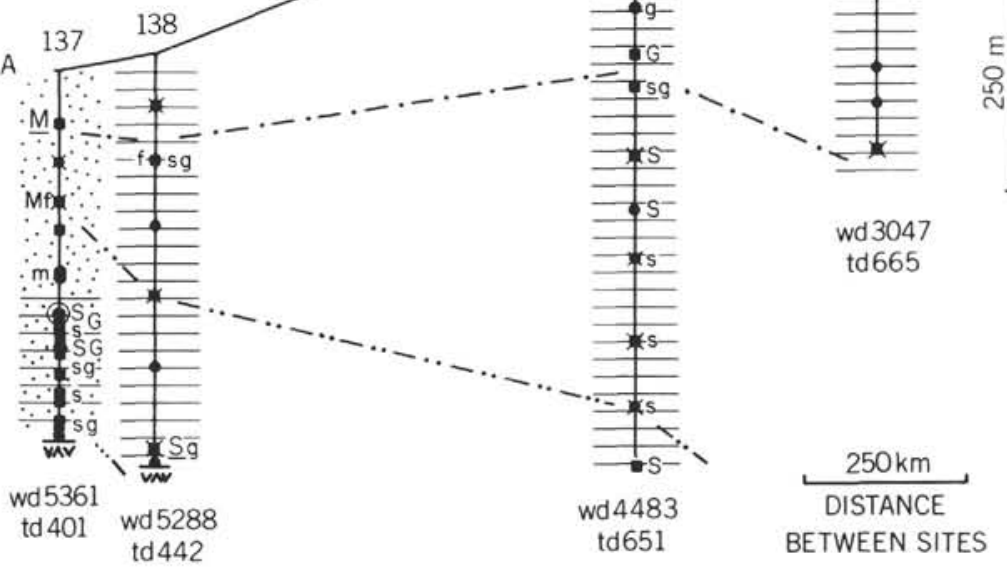

SURFACE

NEOGENE.

PALEOGENE

U.CRET

L.CRET.

Smear-slides: opaques O> $10 \% x>2 \%$ of total

$\frac{\text { Coarse fraction }}{\text { oxides (common): }}$

$M$ manganese concretions

$F$ ferric oxides

S sulfides (pyrite, except 137)

$G$ "glauconite":

G-abundant g-rare

Color (oxidized-reduced)

$\because$ predom yl, brn, rd

ב predom. olive, grn,blk

blank: neither is dominant

$$
\begin{aligned}
& \text { wd } 4148 \\
& \operatorname{td} 298
\end{aligned}
$$

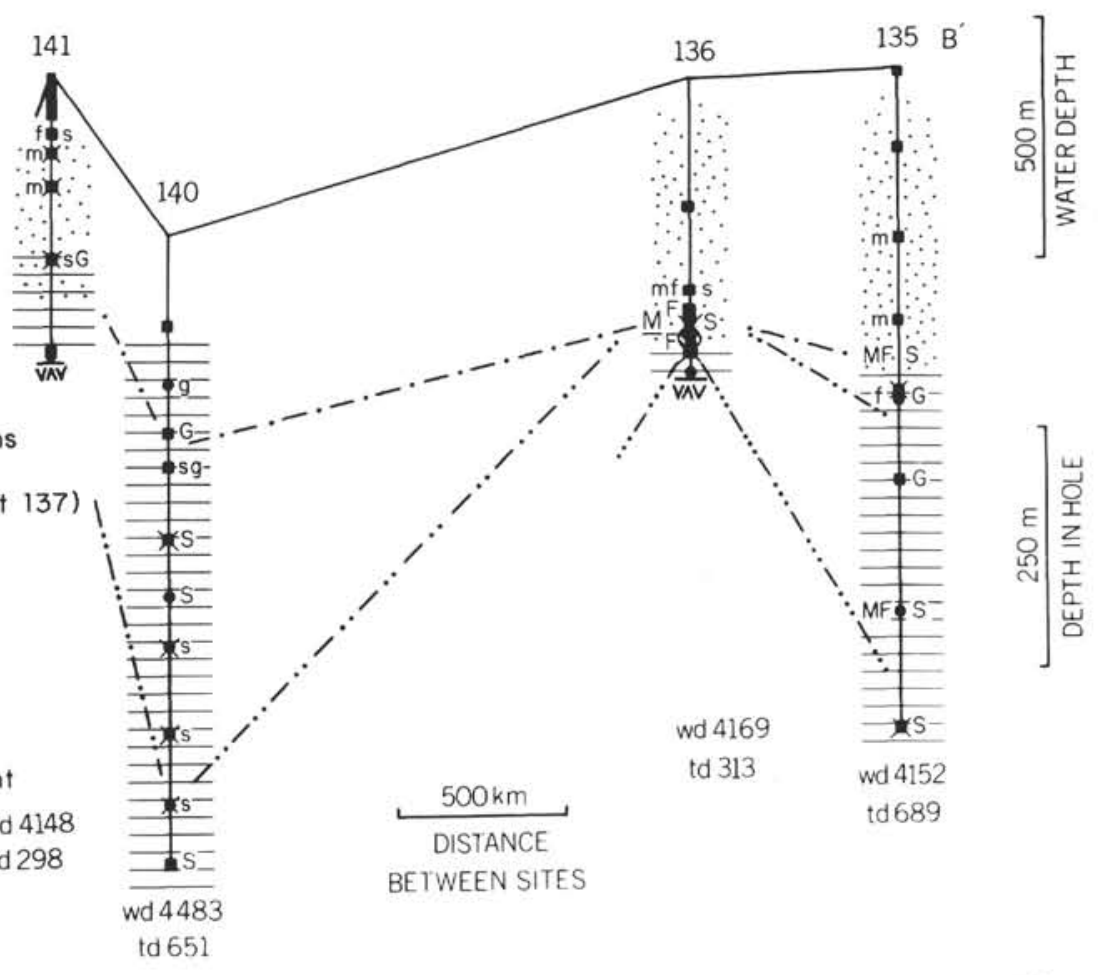

Figure 20. Distribution of oxides, sulfides and "glauconite" (including other authigenic greenish minerals) in the coarse fraction, compared with smear slide "opaques" and with sediment color (stippled: indicating oxidizing conditions; ruled: reducing conditions). 
of Leg 14 sediments. X-ray fluorescence showed that other heavy metals are also present. To determine the distributional patterns of these elements, hand-picked specimens (W.H.B.) visually identified as "manganese-concretions," "sulfides," and "glauconites," as well as some other categories, were crushed and mounted on inert plastic foil and subsequently analyzed by X-ray fluorescence (E.S.). Blanks were prepared by keeping all operations identical, including "grinding" with the pestle, and "transfer" with the brush from mortar to plastic foil. Results are given in Table 3, and Figure 21. All occurrences shown as weak are quite distinct and well above both traces and blank noise. Traces of $\mathrm{Fe}, \mathrm{Zn}$, and (?) $\mathrm{Pb}$ were indeed found in many samples, but were omitted, because, if present, they would be of minor significance within the bulk sample. ${ }^{6}$

The available data-admittedly spotty-allow the following observations:

1) The separation of $\mathrm{Fe}$ from $\mathrm{Mn}$ is rather striking in the samples investigated. In only two cases (136-3 and 5, associated with a major hiatus) were $\mathrm{Mn}$ and $\mathrm{Fe}$ found within the same specimens. Fe-oxide was noted in 136-3 and pyrite in 136-5, apparently partially oxidized and possibly introduced from elsewhere. The manganese concretions in adjacent samples $(136-4 ; 136-6)$ show no $\mathrm{Fe}$. This does not mean, of course, that $\mathrm{Fe}$ was not present, since the analysis is not extremely sensitive. It means, however, that $\mathrm{Fe}$ was much less abundant than Mn.

2) Sulfides are mainly iron-sulfide. All samples with "pure" Fe-sulfide came from sediments with hemipelagic influence (Sites 139, 140, 144).

3) All samples registering heavy metals other than $\mathrm{Mn}$ and $\mathrm{Fe}$ came from a pelagic setting (Sites 137, 141).

4) $\mathrm{Zn}$ was noted in 7 samples from 5 cores of Site 137. It was associated with $\mathrm{Mn}$ in the oxidized part of the sequence (cores 1,3), and alone, as well as associated with other heavy metals, in the reduced part (cores $8,11,14)$.

5) Cu was noted in 6 samples from 5 cores, two of which were at Site 141 (cores 6 and 9), two at 136 (3 and 4), and one at 137 (Core 11). At Site 141-6 the Cu signature came from an irregular network of red strands in a chalk matrix. The material could not be ground since it is completely malleable. It appears to be native copper. Associated sediments are highly dissolved foram ooze containing elongate, slender irregular veinlets reminiscent of burrow casts and in part intergrown with foram shells. In 141-9, Cu-bearing "glauconite"-like spherules, with a cracked rind and a solid dark green to black sulfide (?) core, occur in slightly greenish and brownish zeolite clay, along with pyrite and glauconite as well as fish debris and fragments of agglutinating foraminifera. At $136, \mathrm{Cu}$ is in manganese micronodules, at $137-11$, it is part of a multi-metal-sulfide suite.

6) Ni was noted in three samples from three cores of Site 137 (Cores 1, 11, 14), associated with both Mn-oxide and multi-metal sulfide.

7) $\mathrm{Co}$ and $\mathrm{Pb}$ were noted in the same sample, from 137-14, which showed all the minor metals except $\mathrm{Cu}$.

\footnotetext{
${ }^{6}$ Miss Ursula Titz, Kiel, assisted in analyzing the samples. We thank Miss Titz for her patience and diligence.
}

8) Samples other than manganese concretions, sulfide crystals and "glauconite"-like grains, gave no results or merely weak Fe-peaks, mainly due to the limitations of sensitivity inherent in the method.

In discussing these results, several factors influencing heavy metal distributions should be considered: (1) ultimate source (e.g. weathering, volcanic or hydrothermal emanation), (2) transportation to depositional site (e.g. by vertical diffusion through the sediment, by horizontal diffusion along the interface, by rain of remains of pelagic organisms, or through introduction of detrital material by turbidity currents), (3) mechanism of precipitation and recrystallization, and (4) likelihood of preservation near the sediment interface. From our meager data, little can be contributed to solving such problems. Some general remarks may be allowed, however.

The difference between the "hemipelagic" sulfides at Sites 139, 140 and 144 and the "eupelagic" ones at Sites 137 and 141 suggests the geochemical fractionation of iron from similar metals, well-known from limnic sediments (e.g. Landergren, 1948; Ljunggren, P., 1953; Manheim, 1965) and also from present deep-sea sediment (Price and Calvert, 1970). With regard to this fractionation, it may be crucial that hemipelagic sediments are generally more reducing than pelagic ones (compare Figure 20, previous section) and also contain much redeposited material from iron-rich shallow water sediments.

The maximum diversity of heavy metals occurs in the Cenomanian pelagic marls, which accumulated on the ridge flank near the equator under relatively fertile conditions (see section on paleogeography) and are alternatingly oxidized (brown) and reduced (green). This alternation may form a barrier to diffusion of heavy metal ions out of the sediment, once they are embedded. It is possible that much of the sediment is redeposited, and that the heavy metal sulfides originally formed closer to the ridge crest, perhaps beneath a deep-reaching low oxygen water layer. In this connection, the presence of oily substances in marl fragments from 137-14 and 16 is noteworthy (seen as films when applying hydrochloric acid to the fragments).

Heavy metal concentrations on mid-ocean ridges have been noted in previous studies (Boström and Peterson, 1969; von der Borch and Rex, 1970; Cronan et al., 1972) and have been linked to hydrothermal emanation connected with sea floor spreading (Boström and Peterson, 1969) and to anaerobic deposition (Turekian and Bertine, 1971). It appears that even for oxidized ferruginous ridge crest sediments (Cronan et al., 1972) a purely sedimentary in situ growth (regardless of ultimate source) cannot be excluded (von der Borch et al., 1971). Low sedimentation rates on crestal parts of the upper mid-ocean ridges (Ewing and Ewing, 1967), possibly largely due to redeposition processes (van Andel and Komar, 1969), may form sites of $\mathrm{Mn}$ - and $\mathrm{Fe}$-accumulations which are able to incorporate other heavy metals. With regard to the heavy metal sulfides at Site 137, however, initial sulfidic precipitation in an anaerobic setting appears most likely. [End of section by W. H. Berger and E. Suess.]

\section{Phosphates}

Apatite (?) was occasionally recorded in smear slides, though it was not systematically looked for since the 
TABLE 3

Heavy Metals in Selected Specimens from the Coarse Fraction (X-ray Fluorescence) ${ }^{\mathrm{a}}$

Sample

(Site, Core, Section, Cm)

No. $\mathrm{Fe} \quad \mathrm{Mn} \quad \mathrm{Zn} \quad \mathrm{Cu} \quad \mathrm{Ni} \quad \mathrm{Co} \quad \mathrm{Pb}$

Visual Description

\section{MANGANESE CONCRETIONS}

$136-3-2,119$

$136-4-1(92) \&-2,119$

$136-5-1,41$

$136-6-1,119$

137-1-1, 116

$137-1-1,116$

137-1-3, 119

137-3-3, 119

$141-8-2$ (nd)

144B-1-4, 119

\section{SULFIDES (AND METAL)}

$137-8-2,105$

$137-8-2,105$

$137-11-3,119$

$137-11-5,118$

$137-14-6,25$

$138-6-2,25$

139-1-CC

139-2-CC

$139-3-\mathrm{CC}$

139-4-CC

$140-3-1,104$

$140-4-3,141$

$140-5-C C$

$140-8-2,105$

$141-6-3^{b}, 119$

142-9-1, 59

144-2-1 (nd)

144-2-5, 150

$144-5-1,107$

$144-7-1,97$

$144 \mathrm{~A}-2-5,119$

144A-3-2, 119

$144 \mathrm{~A}-4-1,131$

144A-4-CC

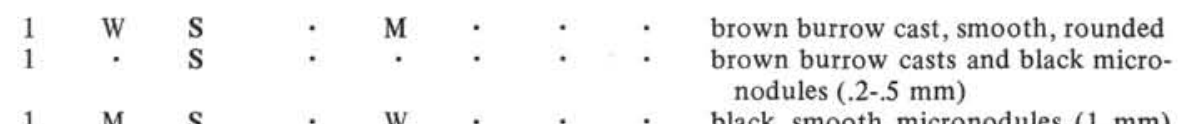
nodules $(.2-.5 \mathrm{~mm})$

black smooth micronodules $(1 \mathrm{~mm})$ brown to black burrow casts and micronodules $(.5 \mathrm{~mm})$

brown botryoidal micronodules (.5 $\mathrm{mm}$ )

black micronodules

black to dark brown micronodules, round and elongate $(1.5 \mathrm{~mm})$

black and dark brown fragments of micronodules $(.2 \mathrm{~mm})$

single $3 \mathrm{~mm}$ micronodules, dark brown, round, smooth

foraminiferal marl with black material

sphalerite crystal

sphalerite (?) crystals in marl matrix sphalerite (?) crystals in marl matrix sphalerite (?) crystal

sulfide aggregates $(.3 \mathrm{~mm})$

sulfide aggregates, coarsely crystalline (see Plate 16, Figure 9)

irregular burrow cast (5 mm long) burrow cast, finely crystalline $(2 \mathrm{~mm})$

irregular fragments of burrow (?) calcareous shell fragments

burrow casts, medium and finely crystalline

pyritized radiolarians (15 and 10 specimens)

pyritized radiolarians (50 and 20 specimens)

coarsely crystalline partly oxidized aggregates $(1 \mathrm{~mm})$

aggregates $(150 \mu)$ (see Plate 16, Figures 7 and 8 )

irregular strands of reddish malleable material in chalk, copper?

pyritized radiolarians (20 specimens) burrow cast, coarsely crystalline (1 $\mathrm{mm}$ )

spher. radial aggregates (fragment) $(1.5 \mathrm{~mm})$

framboidal aggregates (recrystallized radiolarian cast?) (20 specimens) $(.1-.2 \mathrm{~mm})$

pyritized radiolarians (5 specimens, $.05 \mathrm{~mm}$ )

foraminiferal casts ( 2 specimens, . 1 , $.2 \mathrm{~mm}$ )

euhedral octahedral pyrite (6 specimens, $.05 \mathrm{~mm}$ )

coarsely crystalline pyritized aggregates $(\sim 1 \mathrm{~mm})$

coarsely crystalline pyrite aggregates (2-3 mm) 
TABLE 3 - Continued

Sample

(Site, Core, Section, Cm)

No. $\mathrm{Fe} \quad \mathrm{Mn} \quad \mathrm{Zn} \quad \mathrm{Cu} \quad \mathrm{Ni} \quad \mathrm{Co} \quad \mathrm{Pb}$

Visual Description

\section{GREEN MINERAL}

$137-9-1,31$

$137-12-4,93$

$140-2-3,119$

$141-9-2,119$

$141-9-4,119$

$144-2-1$ (nd)

$\left(\frac{10}{10}\right.$

$144 \mathrm{~A}-4-\mathrm{CC}$

$3 \mathrm{~S}, \mathrm{M}$

\begin{tabular}{|c|c|c|c|c|c|c|c|c|}
\hline 1 & M & . & . & . & . & . & . & $\begin{array}{l}\text { "glauconite" grains, sand-size green } \\
\text { to pale green, round, soft. }\end{array}$ \\
\hline 1 & • & . & . & . & - & . & . & $\begin{array}{l}\text { green mineral aggregates (glauconite?) } \\
(2 \mathrm{~mm})\end{array}$ \\
\hline 1 & S & . & - & . & - & . & - & $\begin{array}{l}\text { "glauconite" grains, yellow green, } \\
\text { botryoidal (redeposited?) }\end{array}$ \\
\hline 1 & . & . & . & $\mathbf{S}$ & . & . & . & single grain each, $1.5 \mathrm{~mm}$ \\
\hline 1 & . & $\cdot$ & - & $\mathrm{S}$ & . & - & . & $\begin{array}{l}\text { and } 1 \mathrm{~mm} \text {, spherical, cracked, light } \\
\text { yellow green rind. Core: dark green } \\
\text { to black; malleable, like metal }\end{array}$ \\
\hline 1 & M & . & - & . & . & . & . & $\begin{array}{l}\text { "glauconite" fragment, angular, dark } \\
\text { yellow green, opaque to translucent, } \\
1 \mathrm{~mm}\end{array}$ \\
\hline 3 & $\mathrm{~S}, \mathrm{M}$ & - & . & - & - & . & - & $\begin{array}{l}\text { "glauconite" grains, dark green, } \\
\text { cracked rind and smooth, in part } \\
\text { oxidized. }\end{array}$ \\
\hline
\end{tabular}

MISCELLANEOUS (weak Fe or no peaks)

$137-3-3,119$

$137-9-6,119$

$137-14-3,113$

$137-16-\mathrm{CC}$

137-16-2, 119

$137-16-3,128$

$137-16-3,130$

$141-3-4,81$

$144-4-1$ (nd)

144-7-1, 97

$144-8-3,83$

$144 \mathrm{~A}-5-\mathrm{CC}$

144A-6-1, 112

\section{CONTROLS}

Pipe fragments

Blanks

1 Strong Fe only

10 All intensities well below "W."

asymbols: S-strong; M-medium; W-weak; ·-checked but not present.

brobably native copper.

distribution of fish debris should be similar. In the coarse fraction, apatite (?) crystals were seen in 136-4, 137-12, 141-7, 144-3. Besides fish debris, yellowish brown, microfibrous, faintly birefringent collophane, partly recrystallized to francolite (?), is common in the glauconitic, phosphatic limestone of 144A-5cc (Plate 24). The distribution of fish debris is discussed in the section on biogenous sediment components.

\section{Sulfates}

Gypsum was noted in the X-ray diffractions of samples from Sites 136 (Core 4), 137 (Cores 2, 7, 8) and 141 (Cores $7,8,9)$. It is not known to what extent this is due to oxidation of sulfides and subsequent reaction with calcium carbonate. Gypsum was not expressly looked for nor seen in the coarse fraction.

Barite crystals, up to $0.5 \mathrm{~mm}$ in size, were noted in the coarse fraction of Site 137, Core 6 (Plate 16, Figures 3, 4).
Large, in part corroded, crystals were seen in 137-8, and in rare occurrences in Cores 9,11 and 12 of this site. Barite also was noted in 141-8 (by smear slide, in pale yellowishgreen silty clay; in the coarse fraction, however, an authigenic clear platy mineral common in $141-8$ and of barite-like outline was optically negative) and in 144-3 (in the coarse fraction and by X-ray and in a thin section of artificially impregnated sediment, in light greenish gray siliceous zeolitic mudstone, see Plate 28). The associated facies is predominantly zeolitic and rich in biogenic matter, heavy metals and, in places, unusual carbonates (see below).

\section{Carbonates}

Types. Authigenic carbonates in Leg 14 sediments include calcite (as overgrowth, cement, or recrystallized (?) shell material), dolomite, siderite, ankerite, and rhodochrosite (Plate 16, Figures 1, 2, 5). In the coarse fraction, optical calcite was noted in the cores at Site 136 (below the 

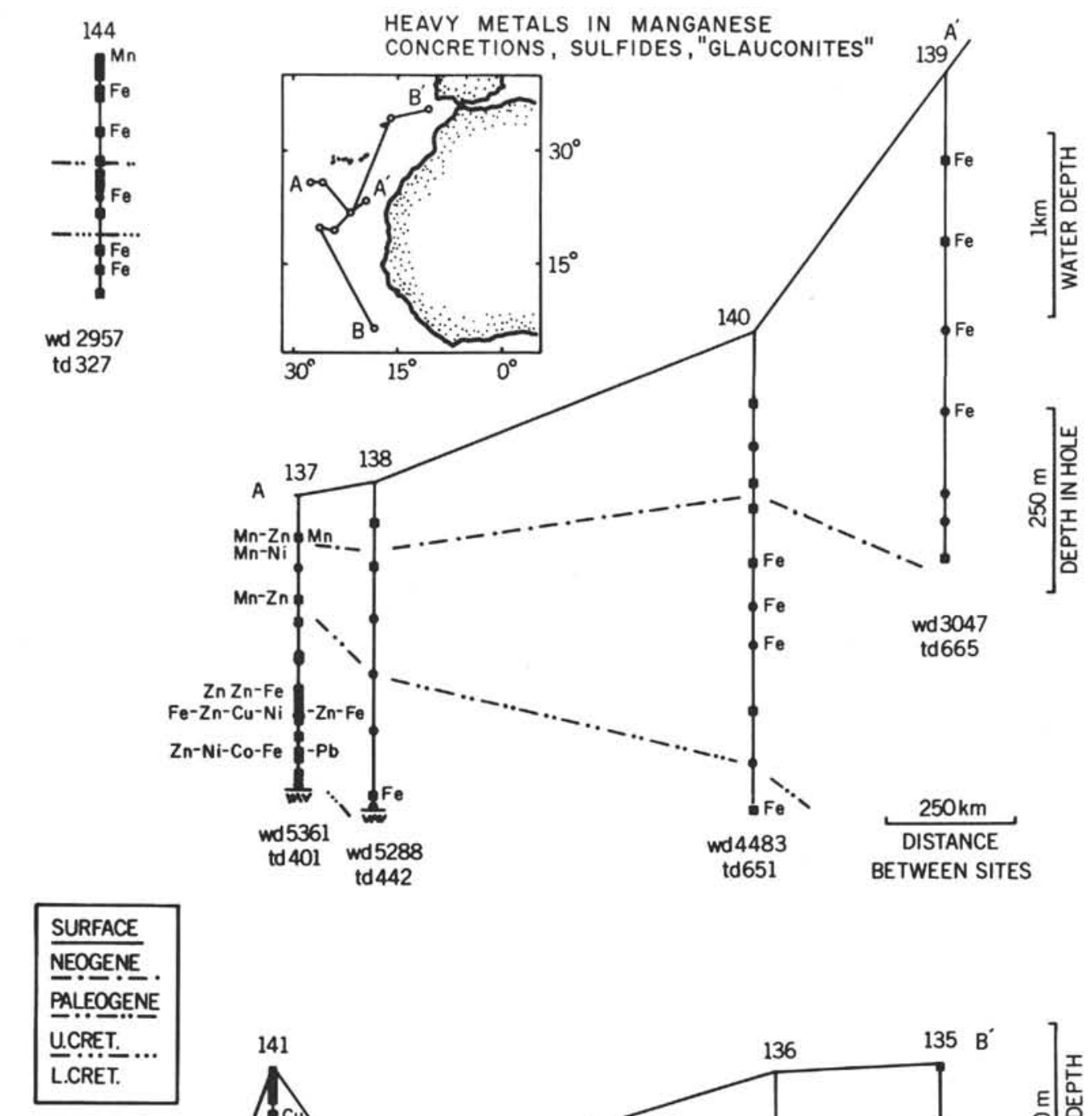

METALS TESTED

$\begin{array}{ll}\text { Iron } & \mathrm{Fe} \\ \text { Manganese } & \mathrm{Mn} \\ \text { Zinc } & \mathrm{Zn} \\ \text { Copper } & \mathrm{Cu} \\ \text { Nickel } & \mathrm{Ni} \\ \text { Cobalt } & \mathrm{Co} \\ \text { Lead } & \mathrm{Pb}\end{array}$

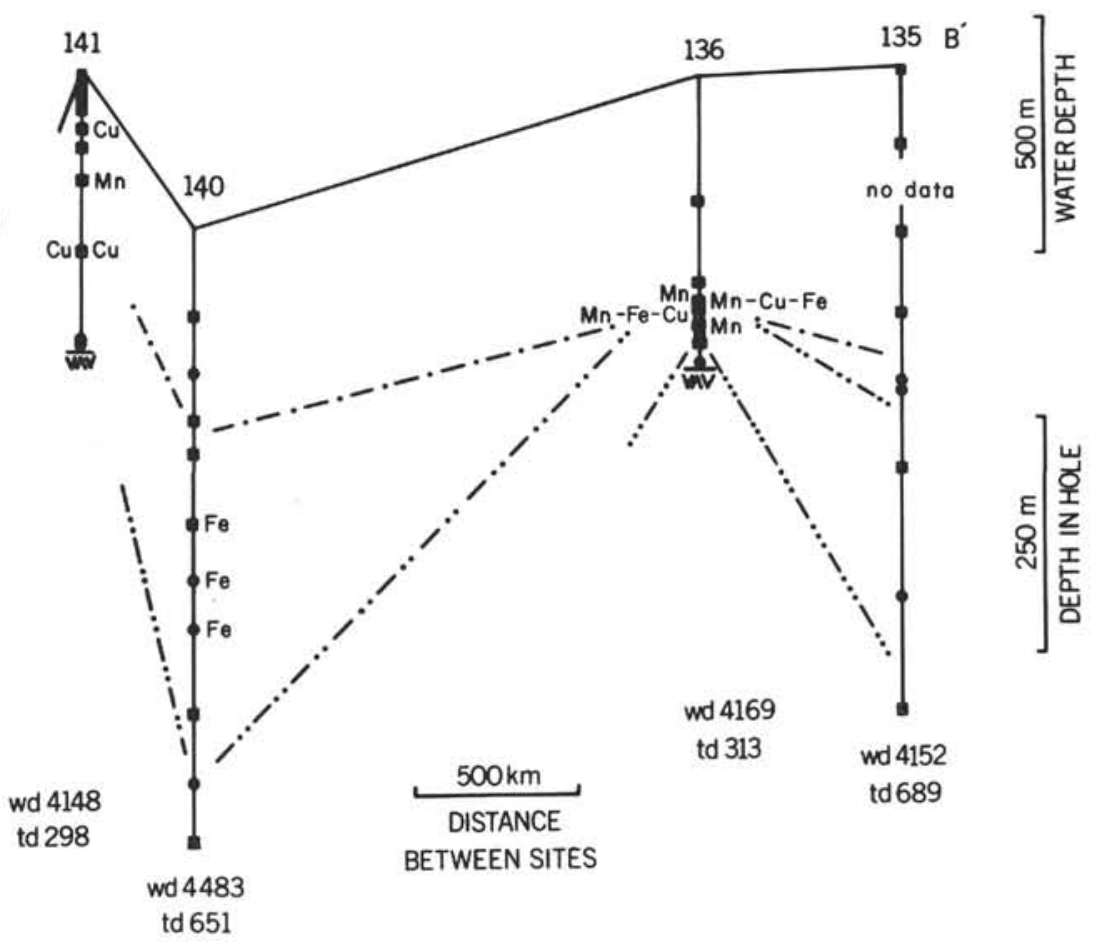

Figure 21. Occurrence of heavy metals in minerals hand picked from the sand fraction of various samples. "Glauconite" includes various other green minerals (see text). A hyphen between symbols means the metals co-occurred in the same specimen. Determination by $X$-ray fluorescence. 
hiatus-Cores 5 and deeper), and dolomite was identified in $135-9,138-6$, and 144-3 merely on the basis of morphology and reaction rate with $\mathrm{HCl}$ solution. Similarly, rhodochrosite was noted in brown pelagic clay in $137-4(1 \mathrm{~mm}$-size rhombic crystals identified by X-ray) and 137-6, 8, 9 (spindle shaped crystals with irregular outline, identified by A. Pimm from the SEM photographs). Smear-slide analysis showed "dolomite rhombs" of silt size in a large number of samples (Figure 22). These identifications were confirmed by X-ray analysis in most cases (von Rad and Rösch, this volume). In addition, X-ray analysis showed the presence of siderite (136-5, in light brown silty clay, with dolomite; (?) $140-3$ in greenish gray siliceous silty clay, with dolomite; 144-4 in olive gray zeolitic marl) and ankerite (138-6-3, forming a layer of ankerite stone, overlain by alternating dolomitic silty clay and carbonaceous black mud).

Calcite. Overgrowth on nannofossils has been discussed (Figure 12; Plate 1). It is, of course, restricted to facies bearing nannofossils, and appears to be largely a function of age and overburden. Large optical calcite grains and abundant calcite silt were noted at Site 136, Cores 5 to 8 . Silt-sized (and up to $5 \mathrm{~mm}$ long), spindle shaped grains occur abundantly in Core 5 (Section 5), and sizes of the grains generally increase downward, the spindles forming large aggregates in Cores 7 and 8 . The spindles seem to be disintegration products of calcite veinlets within reddish lithified volcanic ash. This ash apparently is redeposited from shallower areas, and much reworked, forming more or less discrete layers within a brown clay sequence below the Cretaceous/Tertiary unconformity (see section on volcanogenic sediments).

Euhedral calcite fills the tests of planktonic foraminifera at Site 144, Cores 4 and 5, within thin layers of very clean foraminiferal limestone, which are intercalated with pyritiferous marlstone bearing well-preserved foraminifera not filled by calcite (Plate 25).

Limestone (in part recrystallized), marlstones, and calcite-cemented sandstones and ashes occur within the hemipelagic regime and are treated in their respective sections on facies associations. $\mathrm{Mg}$-rich (about $30 \% \mathrm{MgCO}_{3}$ ) calcite is present in the limestones of $135-8$ and 9 .

"Dolomite rhombs", that is silt-sized carbonate rhombs as observed in smear-slide preparations, occur practically everywhere except in carbonate-free deep sea clay facies. There seems to be no need, from the present data, to invoke special conditions of formation (such as hydrothermal activity or basalt intrusions), other than the presence of calcium carbonate and the availability of magnesium from, for example, weathering of volcanogenic or terrigenic particles or from sea water. Other sources of dolomite may be found in $\mathrm{Mg}$-rich, displaced shallow water carbonates or in redeposited lagoonal dolomite. Regardless of ultimate source, dolomite appears somewhat enriched near the boundary of carbonate and noncarbonate facies (Sites 135, 136, 137). Possibly, slow dissolution of calcite favors dolomite formation, but more likely this enrichment is an effect of differential dissolution within the (displaced?) carbonates near the boundary. The redeposition hypothesis also provides an explanation for the striking dolomite concentrations at $138-6$ and $140-6$, to be discussed in the section on facies.
Siderite may be quite common, considering the relatively few X-ray analyses, and the fact that it was not looked for in smear-slide and coarse fraction analysis. The formation of this mineral is favored in a reducing, iron and $\mathrm{CO}_{2}$-rich environment (see Borchert, 1965), for example, by reaction of organic matter with iron-oxide after burial. Such conditions may be common in many hemipelagic sediments where iron-oxide and organic matter are introduced together with terrigenous material and with redeposited carbonates (Sites 135, 139, 140 and especially in 144, here siderite occurs in small white concretions in black zeolitic, carbonaceous shale). Site 136 poses a special situation, that of iron possibly being delivered from the weathering of ashes and carbonate being freed by magnesium (and calcium ?) entering clays. The very high concentration of saponite in a siderite-bearing silty brown clay from $136-5$ and the absence of the usually ubiquitous montmorillonite is of interest in this context. Since the montmorillonite is iron-free elsewhere, a conversion of nontronite to saponite (Drever, 1971) does not seem applicable in this case.

Ankerite was found by $\mathrm{X}$-ray analysis as the main component of a thin layer of consolidated carbonate sediment associated with quartz, pyrite, and smectite, within a facies of dolomite-black mud alternation. The ankerite crystals are euhedral and float within ankerite cement (Plate 45, Figs. 6,7). Ankerite may be considered a mixture between dolomite and siderite (Correns, 1949); arguments for its origin, therefore, are analogous to those given above for these two minerals.

Rhodochrosite (Site 137), the pelagic carbonate most resistant to dissolution, appropriately occurs between the well oxidized, carbonate-free zone rich in manganese concretions, and the partially reduced, calcareous zone rich in carbonaceous matter and sulfide. Two crystal habits were observed in the coarse fraction, blocky and elongate (Plate 16, Figs. 1, 2). The blocky kind only occurs in Cores 4 (verified by X-ray) and 5. The elongate kind morphologically somewhat resembles burrow fillings and fecal pellet replacements (a mode of occurrence reported by Peterson et al., 1970). The two kinds do not co-occur in the samples studied. For the formation of this mineral, the alternation of oxidized and reduced facies types within this intermediate zone may be of importance. Oxygenated bottom water would allow formation of manganese oxides, preventing escape of $\mathrm{Mn}$ from the sediment. Intermittent introduction of carbon-rich sediment (possibly displaced from a shallower area on the Late Cretaceous Mid-Atlantic Ridge, intersected by an extensive oxygen minimum) would provide for reduction to manganese-carbonate (compare Hartmann, 1964; p. 12 and p. 17). The site of formation must have been close enough to the CCD to prevent complete dissolution of carbonates, but far enough below to allow destruction of calcite and, in most cases, dolomite. Other possible explanations, such as hydrothermal activity (Peterson et al., 1970) also should be considered.

\section{Zeolites}

Zeolites were found in a great variety of Leg 14 sediments, and by various methods: in smear slides (as \pm euhedral laths), in the coarse fraction (as radiolarian and 

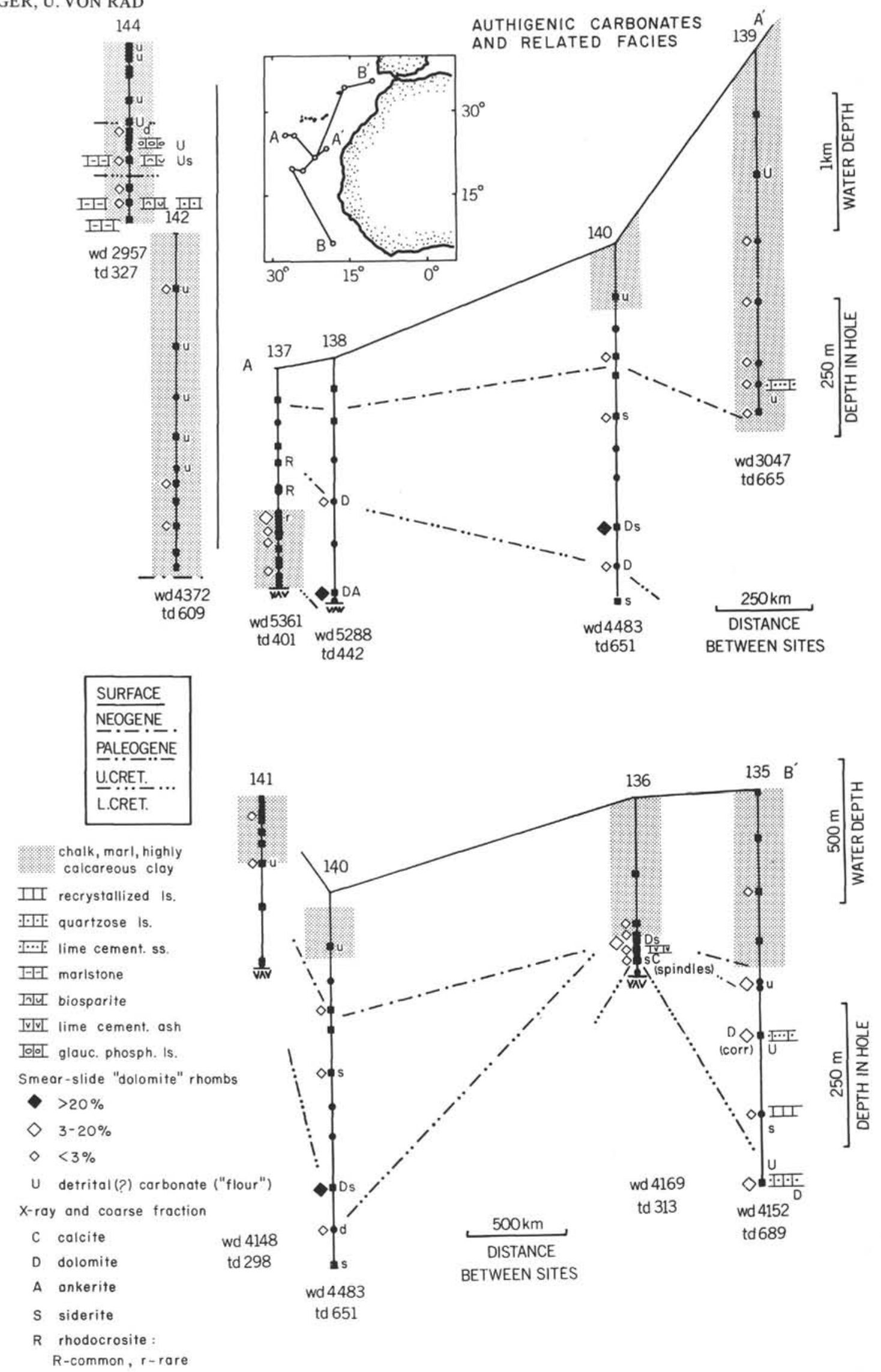

Figure 22. Authigenic carbonates as related to carbonate sediment patterns. Note relative enrichment of solution resistant carbonates near calcareous-noncalcareous facies boundaries $(C C D)$. 
foraminiferal casts) and in X-ray diffraction analysis, which showed the zeolites to be clinoptilolite, a silica-rich alkalic to slightly calcic zeolite of heulandite structure (Hay, 1966). Two varieties of clinoptilolite were recorded, a "normal" form similar to the clinoptilolite described from Hector, California (Mumpton, 1960) and an "untypical" form with 9.8 and $11.2(20)$ intensities different from the "normal" form. The untypical variety was found only at Site 144 (Plate 16, Fig. 6; Plates 17, 18).

In many cases more than a trace of zeolite was noted on board but not confirmed by subsequent optical and X-ray studies in the laboratory. These questionable occurrences are indicated by brackets in Figure 23. Zeolites must be rather concentrated (well over $5 \%$ ) in a sediment to be identified by X-ray diffraction. Almost all X-ray analysis by von Rad and Rösch (this volume) were checked by smear slide analyses and in many samples zeolite was observed optically, but not confirmed by X-ray diffraction.

Site 135 had some zeolite in Core 7 (Campanian/ Maestrichtian) and abundant zeolite in Core 8 (Cenomanian) within olive black sapropelite. Traces of zeolite were found in the Cretaceous volcanogenic sediments at Site 136. Relatively high zeolite concentrations (up to $>10 \%$ ) were found in Sites $138(1,5)$ and $144(3$, A5, A6, 4, 8). Except for 138-1 (Miocene), these sediment samples are of Cretaceous age. Zeolite was also noted in 141, Cores 7, 8, 9 (Miocene- ?Paleocene). The youngest reliable occurrence is in 142-6 (Miocene/Pliocene), but it may involve redeposited material. Maximum abundances were found in Late Cretaceous to Paleocene(?) deposits of Site 137. Zeolites occur in Cores 4,5 and 6 as radiolarian fill, internal casts, and crystal aggregates showing signs of corrosion. Corrosion of both radiolarians and zeolites is so severe that the original nature of the zeolite aggregates (as radiolarian casts) is rather obscure in many samples (see Plate 18). This highly zeolitic interval also bears the large rhodochrosite crystals mentioned earlier. Interestingly, fish teeth are virtually absent, although quite common above and below (Cores 3 and 7). In the same manner, neither clay clasts nor limestone or chert fragments occur in these samples, suggesting absence of silicification. Apparently, the clinoptilolite formed within radiolarian tests in an environment of high silica availability and experienced subsequently an environment of undersaturation of both silica (corrosion) and phosphate (missing fish teeth). This linkage suggests a change in the environment of deposition; that is a change in bottom water saturation through time or displacement from site of formation to site of corrosion, for example by downslope resedimentation or by subsidence of the sea floor or by plate motion away from the equator. Uptake of silica by clays to form the associated palygorskite and smectite is also conceivable, but leaves unexplained the apparent change in chemical environment and the loss of the phosphate debris that should originally have been associated with the radiolarians. Any hydrothermal activity, as invoked for the formation of rhodochrosite elsewhere (Peterson et al., 1970), should also affect zeolites thus providing an additional hypothesis for the cause of corrosion.

If our supposition of silica and phosphate leaching is correct, the leaching involved about 50 meters of sediment suggesting that corrosion must have been contemporaneous with formation and thus favoring short term fluctuations in ocean water chemistry or redeposition as possible causes. Corrosion was at its maximum probably during Early Paleogene, since by the time of Core 3 , fish teeth were preserved again. The most likely age for Core 3 is very early Tertiary, on the basis of sedimentation rate interpolation.

According to these observations, the cores of Site 137 showing the most conspicuous abundances of zeolite record a setting of poor preservation, rather than one of formation of zeolite. Elsewhere, zeolite occurrences appear associated with organic-rich, more or less siliceous sediments within relatively slowly accumulating deposits. Within the chemical limits represented by these marine deposits, Eh and $\mathrm{pH}$ seem of secondary importance; zeolite occurs as casts in siliceous shells in brown and in green clay (137, 138 ) and in both siliceous and pyritized shells in quartz-rich hemipelagic sediments (140, Core 3 and 4). At Sites 137 and 144 , much zeolite occurs within calcareous sequences while at Sites 138 and 140 it occurs within lime-free sediments. In addition, zeolite is associated with olive and black sapropelitic layers $(135-8,138-6,144 \mathrm{~A}-4$ and 5, 144-4). At Site 136, traces of zeolite occur in the reworked (?) volcanic sediments of Cretaceous age.

The presence of any of these facies, however, does not necessarily imply occurrence of zeolite. Distributions suggest that high silica availability - whether from the alteration of volcanic material or from the dissolution of siliceous fossils - and a slight tendency toward calcite solution are favorable for zeolite formation. Age appears to be a more important factor than depth of burial. Most zeolitic samples are Cretaceous to Eocene in age and depth of burial ranges widely. Younger occurrences (Miocene) may be at least in part reworked from older sediments especially at Site 142. Formation (or regrowth of any transported, broken laths) within Miocene sediments, however, also is possible, in accordance with the high silica availability in these deposits.

\section{Volcanogenic Components (silt and sand)}

Volcanic glass (sideromelane) and palagonite, sand sized white "pumice" spherules and ash layers, in part highly altered, were noted at Sites 135, 136, 137, 138, and 141 (Figure 24). Volcanogenic deposits make up most of the 30 meters of Late Cretaceous sediments at Site 136. They are described in the facies section. In Sites 137, 138, and 141, traces of volcanic glass and white pumice spherules (lapilli?) were found in the sand fraction of pelagic clays besides fish debris, ferromanganese oxides, and detrital minerals. The volcanogenic components may be redeposited material from submarine ash layers or may have come from local continental or shallow-marine volcanic sources (such as Great Meteor Seamount, Canaries, Cape Verde Islands), as ash fall and as drift.

\section{Color}

\section{General}

To a first approximation the hue of a sediment color reflects the state of oxidation because iron compounds tend to be the chief coloring agent. Complications may arise 

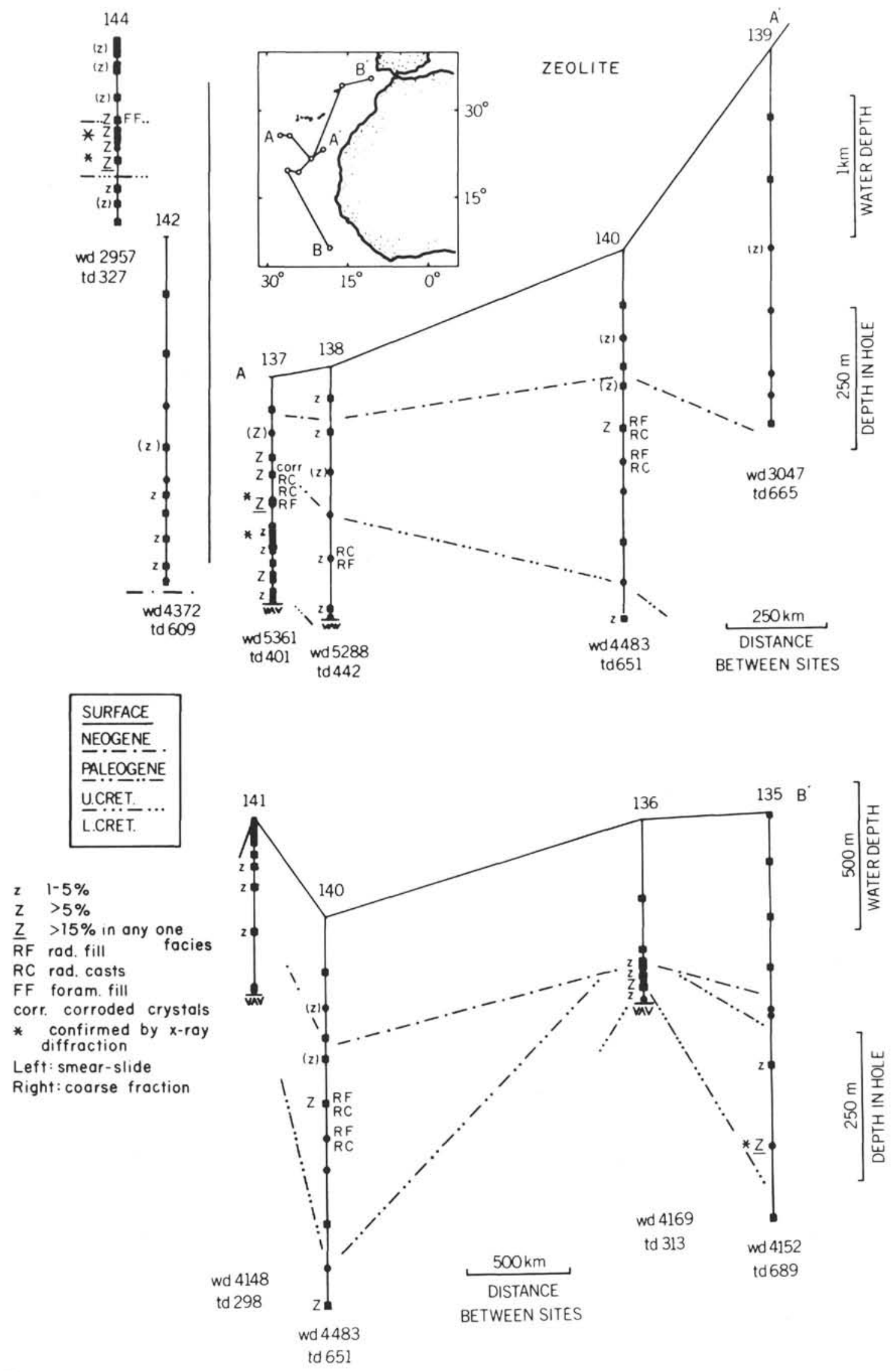

Figure 23. Distribution of zeolite (clinoptilolite). Symbols in brackets: shipboard record, not confirmed on shore. 


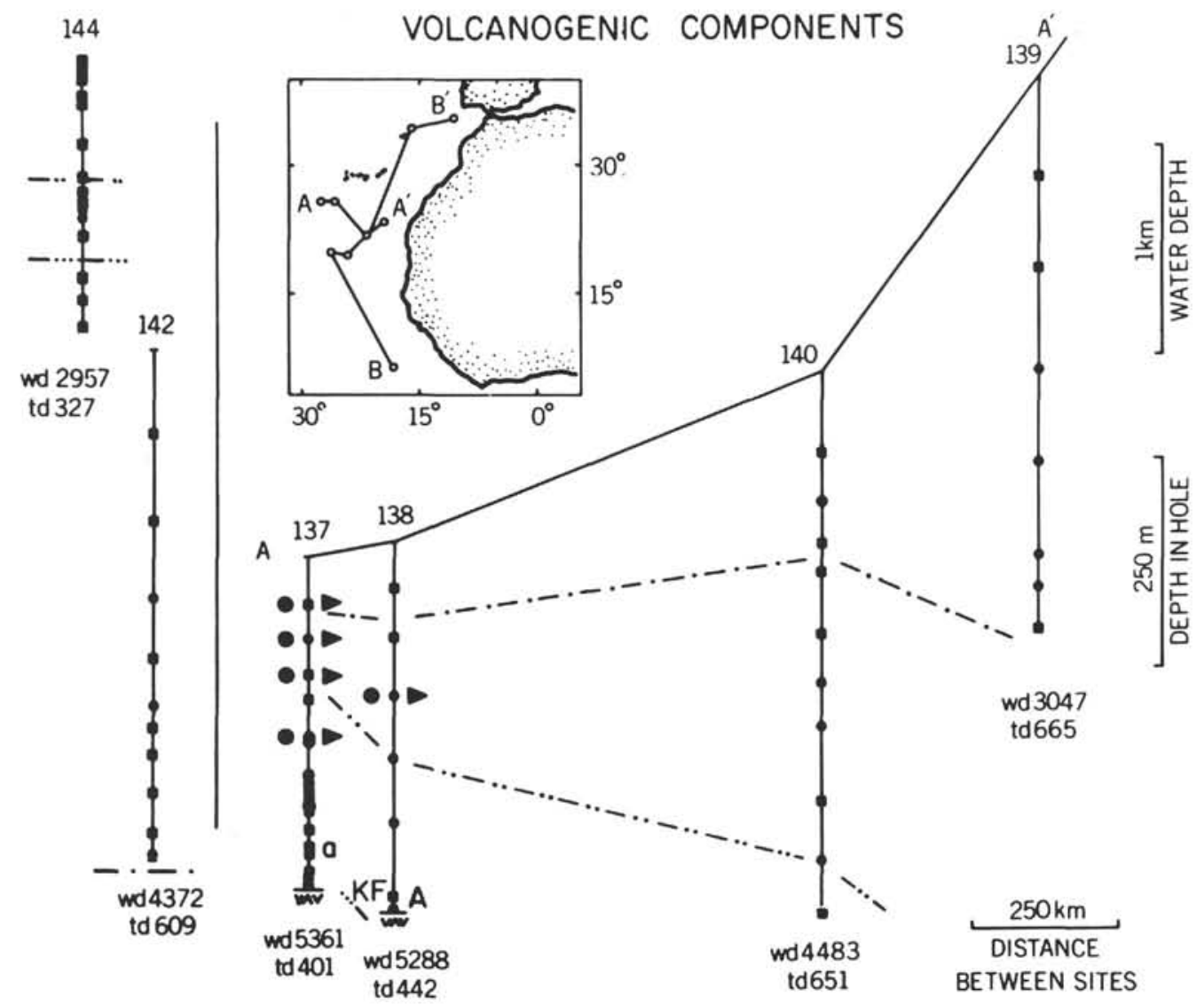

\section{LEGEND}

- volc. glass, palag.

- pumice spherules

A vitr. ash ( \pm altered)

a grn. phyllosil. sd. (? alt. ash)

KF K-fspar (volc. ?) $\mathrm{O}$ obundant - common rest: traces

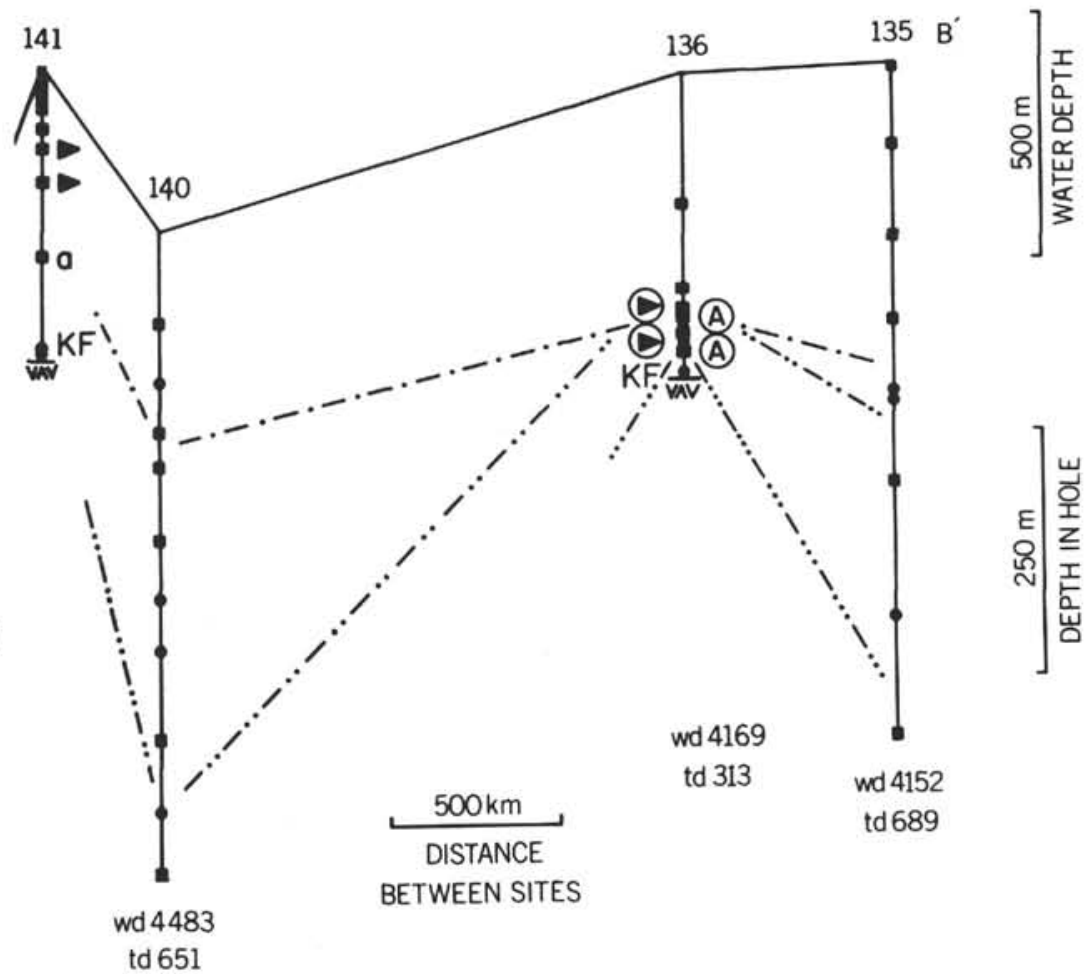

Figure 24. Distribution of silt and sand sized volcanogenic components. 
from high organic content, although black carbonaceous matter, like iron sulfide, indicates reducing conditions. However, finely disseminated black manganese oxide within chalk ooze may be more seriously misleading (Olausson, 1961a). The shade of color largely indicates the concentration of the coloring agent.

In describing colors, the site reports make use of the rock-color chart based on the Munsell System and distributed by the Geological Society of America. The main hues are used for the present summary, that is R (red), YR (orange and brown), Y (brown, yellow, olive), GY (yellowish green), G (green), B (blue), as well as the shade "black" with brown, olive and green hues. Colors appearing in any one core are given as vertical bars in a spectrogram, starting with red and brown at the left and ending with green, blue, and black on the right (Figure 25). Hydrogen sulfide odor was noted in olive colored sediments (Site 139), and abundant pyrite occurs in all colors to the right of olive. Manganese and iron-oxides are associated with colors to the left of olive.

\section{Red}

Red color (R) is rare. It occurs at Site 136 in Late Cretaceous volcanogenic "red clay" and marl mud (Cores 6 , 7) and at Site 137 in Cenomian reddish brown and greenish gray nannofossil marl to chalk ooze (Core 11).

\section{Brown}

Brown colors (YR) are abundant at all sites except the two closest to land (139 and 144). Generally, cores contain sediments of various shades and hues of brown, even though the composition of the facies may vary but little. At Site 135 (Core 1) for example, alternating nanno chalk layers (about a foot or so thick) were noted, with the following colors:

$\begin{array}{llll}10 \mathrm{YR} \mathrm{5/2,} & 10 \mathrm{YR} 7 / 2, & 2.5 \mathrm{YN} 7 / 2, & 2.5 \mathrm{YN} \mathrm{6/2,} \\ 2.5 \mathrm{YN} \mathrm{6/4,} & 10 \mathrm{YR} 7 / 1, & 10 \mathrm{YR} \mathrm{8/1,} & 2.5 \mathrm{Y} \mathrm{6/2,} \\ 2.5 \mathrm{Y} 7 / 2, & 10 \mathrm{YR} 6 / 1, & 10 \mathrm{YR} \mathrm{5/1.} & \end{array}$

These were largely grays with brownish to slightly olive hues. Transition between the zones were both gradual and sharp. It is not known to what extent the color variations represent changes in the state of oxidation, in the varying concentration of insoluble material due to enrichment by dissolution or varying supply, or in slight changes in organic composition, as well as other factors.

In general, brown hues are more abundant in Tertiary deposits than in older ones (Figure 25) and tend to be associated with slowly accumulating facies, and with sediments where silica and terrigenous material are rare. The type facies for this color is pelagic clay (Site 137).

\section{Yellow}

Brownish and yellowish grays tending toward olive hues (Y) are abundant in the chalks of Sites 135 (Cores 2, 3, 4), 139 (Core 2), 140 (Core 1), 141 (Cores 1-6), and in the series of resediments at Site 142.

Olive color (Y) is typical for hemipelagic muds and clays partly rich in silica $(135-5,7 ; 139-5,7 ; 140-2$, A2, 4; 142-1, $2,3,6 ; 144-4,5,6)$. The nannofossil chalk ooze at Site 139, Core 1, also has olive hues. The ooze is slightly siliceous and smells of $\mathrm{H}_{2} \mathrm{~S}$.

\section{Green}

Greenish colors are ubiquitous in sediments of the hemipelagic domain (135-8; 138 throughout; 140 throughout; $142-8,9 ; 144$ throughout). Occasionally, bluish hues appear with greens. In addition, these colors occur in Cretaceous calcareous ridge flank facies (Site 137) and other Cretaceous marls (135-9, 136-8).

\section{Black}

Black (carbonaceous) deposits have a distribution similar to green ones, but are more restricted. The typical facies is Cretaceous hemipelagic sediment (135-6, 8).

\section{Sediment Structures}

\section{Primary Structures}

The observation of structures was restricted to those visible in cross section, in cores showing little or no disturbance (Figure 26).

Banding was noted in Late Neogene chalk and marl facies which usually are characterized by slight but distinct color alternation, on a scale of a few decimeters (Sites 135, $136,139,141)$. Some representative descriptions read as follows: "135-3-2, three distinct colors are interbedded with reasonably sharp contacts, but there is no apparent difference in composition (light gray, light olive gray, brownish white)." "141-5, bad flow-in, but originally two color groups: (1) white to light yellowish gray, (2) light gray to light brownish gray. Core shows mostly the lighter colors; the darker colors are local occurrences. Darker zones are more clayey."

These records are somewhat subjective. Also, alternation phenomena may be obscured through coring disturbance or by insufficient color contrast. The band widths recorded are between $5 \mathrm{~cm}$ and 1 meter, corresponding to time periods between about 5000 and 50,000 years. Climatic fluctuations leading to variations in carbonate production and solution, degrees of oxidation, eolian supply, and redeposition processes must be considered as possible causes for banding in calcareous oozes.

Bedding, involving clearly different lithologies in contrast to banding, is especially common in boundary zones of different facies domains and in areas of hemipelagic deposition where sediments are derived from various upslope environments, such as littoral, neritic and bathyal zones. Domain boundaries include chalk-clay transitions (CCD-facies) and eupelagic-hemipelagic alternations (trough-facies).

Tertiary CCD facies is present in 136-3, 4, and is well developed in 141-7. In both cases the change from marl to clay occurs within a foot or so, although unknown alternations may be present within adjacent drilled intervals. A similar CCD facies was found in Site 12 Leg 2 (see Cita, 1971). Site 142, Core 8 also contains both calcareous ooze and pelagic clay, due to large scale displacement of carbonate below the CCD. The bedding here is not so much a CCD phenomenon as a redeposition effect, albeit redeposition traversed the $\mathrm{CCD}$ in most cases.

Cretaceous CCD facies was cored within the Cenomanian of Site 137. Unfortunately, part of the critical section between Cores 6 and 7 was not cored, but fine-scale 


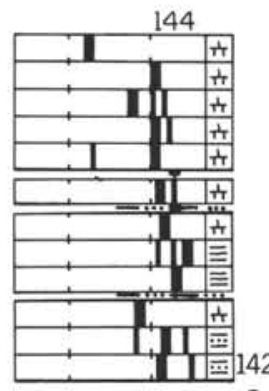

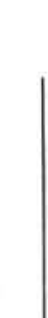
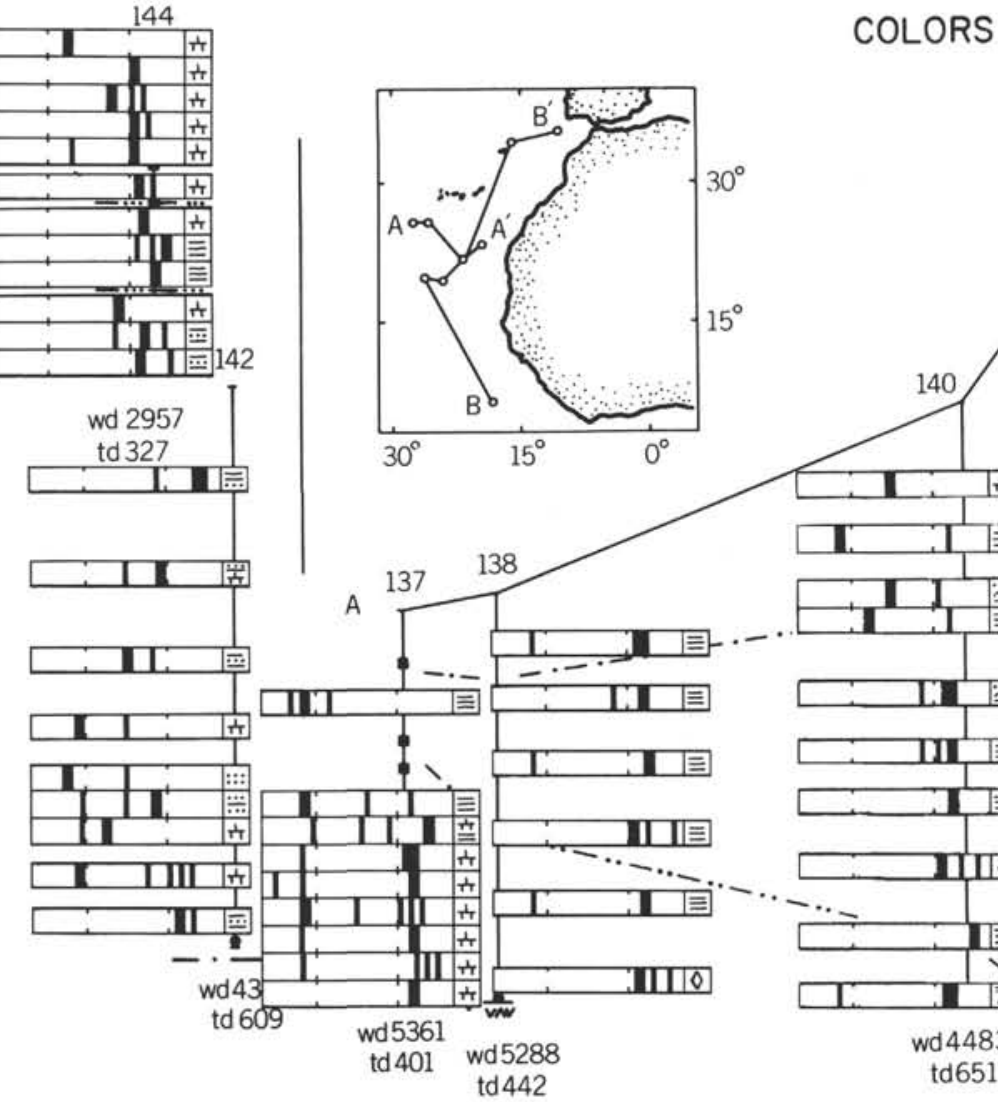

A
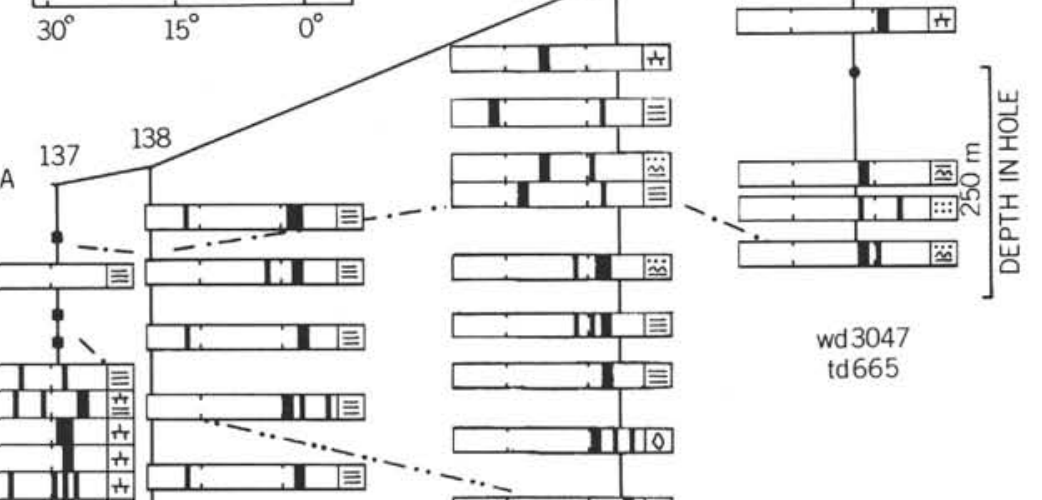

wd 3047

td 665

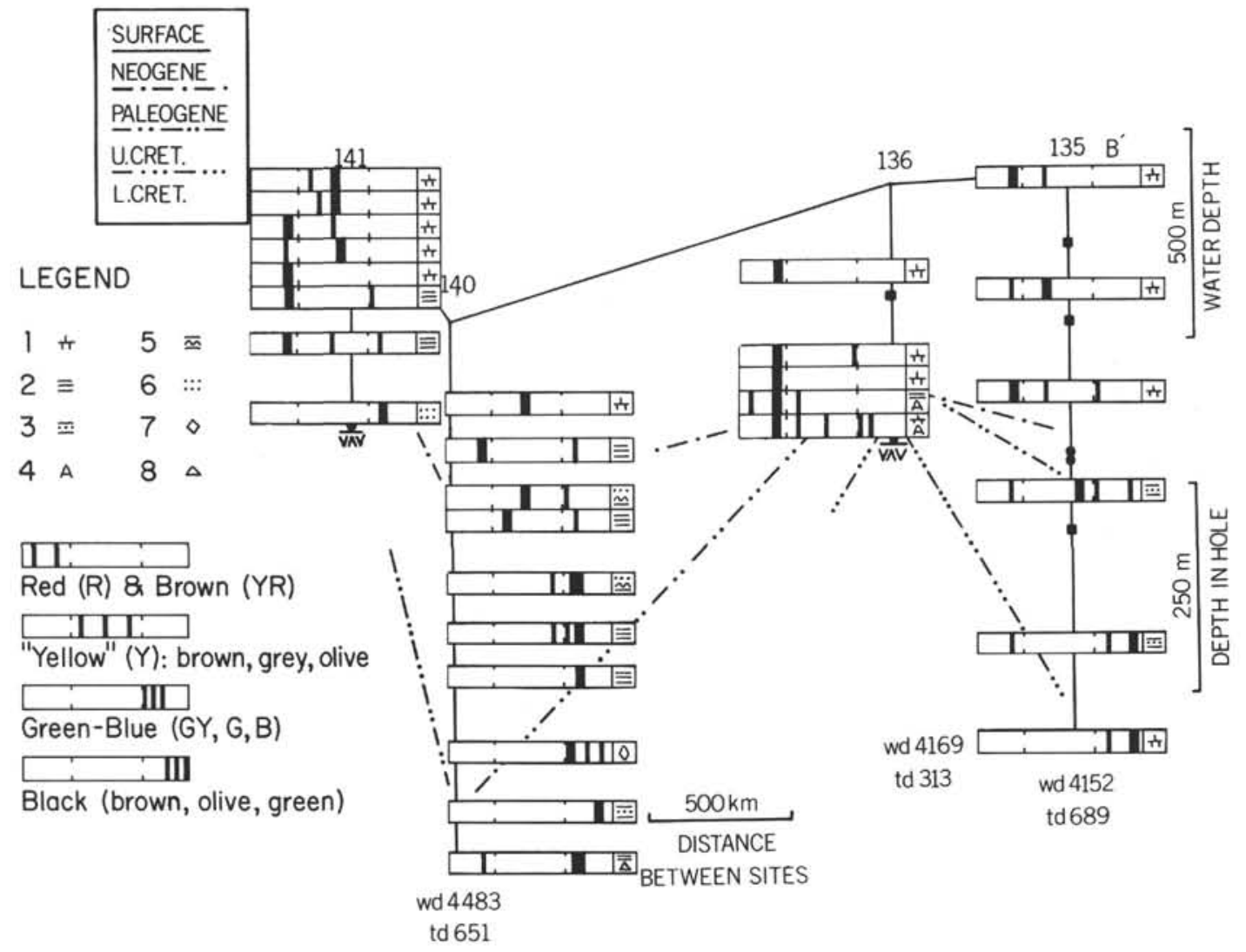

Figure 25. Distribution of colors. Vertical bars in the left part of spectrogram: colors indicating oxidation; at the right, reduction of iron (see text). Facies symbols: 1, calcareous ooze; 2, clay; 3, mud; 4, ash; 5, siliceous clay; 6, sand layers; 7, dolomite; 8 , chert. 
bedding is present in Core 7 , as alternations of dark carbonaceous clay, nannofossil ooze, and laminated silicified mudstone (chert). Cores 8 and 9 also show interlayering of clay-rich and carbonate-rich sediments. In Core 9 the alternations are associated with color contrast between brownish and greenish hues (see Figure 25), the greenish zones usually being apparently somewhat richer in carbonate. The color alternation continues into deeper cores, although without clay facies being present (Plate 19). Occasional foram-rich layers indicate that sorting and redeposition processes may play some role in producing this sequence (Davies and Jones, 1971). These Cenomanian ridge-flank deposits are discussed in more detail in the sections on facies and on paleoenvironment.

Bedding typical of trough facies is present at Site 138. Indeed, the sediments at this site may consist entirely of alternations between distal hemipelagic resediments and indigenous pelagic sediments from Cenomanian to the present time. Interbedding of greenish and brownish clay is visible in Cores 1, 3 and 5; more or less quartzose or siliceous layers, or both, alternate in 1 and 2 . Mudstone, shale and chert are interbedded in the short sequence recovered from Core 4 , and dolomitic clay, dolomite silt, and black mud alternate in Core 6.

Bedding due to interlayering of allodapic facies of various origins is evident at Site 135 , below the EoceneOligocene hiatus (terrigenous sands, limestone, hemipelagic chert); at Site 136, below the Late CretaceousOligocene hiatus (various volcanogenic sediments, terrigenous detritus); at Site 139, Core 7 (calcareous ooze, quartz sand); at Site 140, especially below the Eocene-Oligocene hiatus (siliceous silt, quartz sand, dolosilt [allodapic?]); at Site 142, in large parts of the section (redeposited calcareous ooze, terrigenous sands and silts) (see Plates 21, $22,23)$.

At Site 144, the distinction between alternations of indigenous deposits with resediments and alternations of resediments of differing origin is difficult, since a bathymetric facies zonation is lacking. Site 144 sediments show pronounced layering in Paleocene and older sediments. In the Tertiary section, much of the material recovered is disturbed, with lumps of semiconsolidated ooze and clay interspersed in a soupy matrix (B2, B3, A2, 1, 2). The extent of this phenomenon, down to 100 meters below sediment surface, is somewhat surprising and seems to indicate some primary property of the sediment favoring the disturbance. Possibly, quite firm layers (e.g. partly silicified foram ooze) alternate with soft layers through much of the section (e.g. in Cores Al and 1). The scale varies from $5 \mathrm{~cm}$ to $25 \mathrm{~cm}$ (Core Al) to larger and less distinct alternations (Core 1). Apparently, during coring the soft layers tend to flow, arching upward, while the brittle firm layers break under this strain, thus producing a mixture of clasts and soft matrix. The degree of fossil consistency excludes much reworking or talus mixing (P. H. Roth, personal communicaton). The Cretaceous marls of Site 144 vary greatly in carbonate content over short intervals (within one section) and contain intercalations of allodapic calcilutites and calcarenites (A3, A6, 4, 6), intraclasts (A3), pyrite-rich laminae (A3), silicified clay and marlstone $(3, \mathrm{~A} 4)$, black shale or clay (A5, A6, 4, 5, 7) and, in the lowermost section $(6,7,8)$, shell beds.
Laminations, that is successions of layers about $1 \mathrm{~mm}$ thick, were found in a great number of cores of Leg 14. On the one hand they were associated with sapropelites and similar sediments especially in the Cretaceous, and on the other with very slowly accumulating deposits subject to long term reworking on the ocean floor (Site 136). Detailed investigations may make it possible to determine exactly how the laminations originated-at the time of original deposition or afterward by winnowing and sorting processes on the ocean floor.

Textural differences between laminations are especially obvious in reddish and brownish clays at Site 136 (Cores 5 to 8 ), and the laminae are not always parallel but grade into fine cross-bedding (136-5-5; 125-140; see Plate 43). The combination of lithology, structure, and low average sedimentation rate at this site, suggest long periods of nondeposition during accumulation of these volcanogenic deposits, leading to reworking and fine scale sorting. Organic sediments were being carried away or completely oxidized during these periods (any burrowing would have been unprofitable) thus, the laminae were left intact. Other laminations not associated with obviously reduced sediments are occasionally seen at Site 137 (gray, slightly calcareous siliceous silty claystone, Core 7; and possibly in some brownish layers in Core 14, see Plate 19) and at Site 142 (5 mm rhythms in foram nanno chalk ooze, and manganese oxide laminae within a $4 \mathrm{~mm}$ thick layer, Core 4). Where laminae were not noted, they are not necessarily absent. One shipboard description of foraminiferal marl ooze at $142-7-3$, for example, reads as follows: "Very pale brown, finely and irregularly laminated and streaked, as well as finely and densely mottled. Homogeneous at first sight, since colors are very similar".

Probable "hidden lamination" was inferred from the fissility of dolomite silts at 140-6 and proven by thin section study of impregnated specimens (Plate 30). In the similar deposits at 138-6 it was noted that lensy and streaky laminations occur, especially in the transition zones from dolomitic silty clay to carbonaceous black mud (Plate 46). It appears that this observation also is simply a matter of contrast and visibility, since there are very thin laminae with radiolarians within the black mud, attesting to its layering.

Besides the dolomite cycles, other greenish deposits show laminations; soft claystone at 135-8 (sharp lower contact), nanno marl ooze at 137 , Cores 8 to 16 (Plates 19 , 20 ) and occasionally within silicified mudstone (Core 8 ) or claystone (Core 12). At 140-5 (cc only) thin pyrite concentrations occur within a green pelite, and laminated gray green clay is present at $140-8$. Site 144 has a great variety of greenish laminated facies: pale green foram chalk ooze (Core A2, in places), zeolitic nanno marl (Core A4, streaky lamination), carbonaceous limestone (Core 4, laminae vary from 0.3 to $2 \mathrm{~mm})$, layered $(2 \mathrm{~cm})$ marl with indistinct laminations at an angle to the bedding plane (Core 5), and irregularly laminated mudstone (Core 7).

Typical laminated black shales occur at $135-8\left(\mathrm{H}_{2} \mathrm{~S}\right.$ odor), 135-9 (irregular laminae), $144-4$ (mud, $\mathrm{H}_{2} \mathrm{~S}$ odor), and 144-A5 (extremely fine laminae, occasionally creamcolored calcareous layers). Dark cherts at 135-8, 138-4 and elsewhere also show laminations. Not all dark deposits are laminated, however. At 135-9 a homogenous bed of slightly 
quartzose nanno marl ooze shows a transition upward to irregularly laminated shale. At $138-4$ indurated carbonatefree mudstone shows no obvious layering and neither does a (greenish) zeolitic coquina marl mud bed at 144-7.

From the great variety of settings in which various kinds of laminations do or do not occur, it is clear that detailed scrutiny is necessary before these structures can be used to interpret the environment of deposition. Here we take laminae merely as a clue to the fact that burrowers were absent after the layers were created. In general, laminated sediments are much more abundant in Cretaceous deposits than in Tertiary ones suggesting an increase of infauna density on the deep sea floor through time, if mechanical factors stayed similar.

Sand and silt layers and lenses, clay lumps, lensy bedding and graded bedding are generally associated with redeposition processes, with turbidity currents being responsible for introducing upslope sediments into abyssal sequences (Plates 21, 22, 23). Besides being common in hemipelagic sediments (Figure 26) where they tend to introduce shelf and upper slope material, such processes are also active within the ridge-flank domain. For obvious reasons, however, allodapic chalks within indigenous chalks are difficult to recognize without intensive study, although foraminifera-rich layers were occasionally noted within nanno ooze sections at Site 137 (Cores 8,9). The allodapic foraminiferal calcarenites and calcilutites at Site 142 are described in the section on calcareous and terrigenous sediments respectively.

\section{Grading and Spacing}

Grading was noted in many of the terrigenous sands and silts (Figure 26). Grading is generally accepted as an indication of emplacement of a layer by a single event such as a turbidity flow. Both the time spans separating such events and the resulting thickness of sediment appear highly variable.

The Quaternary section of Site 142 has the thickest graded beds. Individual sand layers are up to 3 meters thick. Most of the layers are massive, and apparently have sharp lower and gradational upper contacts. Grading is rather indistinct and sorting is poor. A thick terrigenous turbidite was deposited about every 1000 to 5000 years. This timing compares with a frequency of emplacement of 50,000 to 100,000 years for the allodapic carbonate sands in Core 6 (Miocene). Sorting by settling out of suspension involves both size and composition, so that these layers are graded both by size and composition.

In addition to the Late Neogene section of Site 142 , striking examples of grading were cored in the latest Cretaceous section of Site 135. Both size grading and composition grading are obvious (Plates 39, 40). About a dozen silt and sand beds occur in the 5 meters of the section recovered in $135-7$, making up approximately one-half of the sediment (Plate 22). The time represented by the 5 meters of sediment is around 1 million years, for an emplacement interval of roughly 100,000 years. The thickness distribution appears log-normal, with a mode near $15 \mathrm{~cm}$ and with beds half and double this thickness being about equally common.
The Maestrichtian flysch-like sequence at Site 140, Core 8 , affords another opportunity for this type of analysis (Plate 22). About 4.5 meters were recovered, consisting of interlayered (dark) greenish gray clay, clayey silt, and light orange, slightly arkosic quartz sand-silt layers with one dark brown chert layer. Two distinct periods are indicated for the interval represented, which may have lasted some 300,000 years. The earlier part (section $8-3,1 \mathrm{~m}$ long) has a dozen very thin sand layers with thicknesses ranging from 1 $\mathrm{mm}$ to $10 \mathrm{~mm}$, and a strong mode at $5 \mathrm{~mm}$. Several of these layers appear graded. If they represent single events rather than local lag deposits, turbidity intervals appear on the order of 5,000 to 10,000 years. The later part (uppermost section $8-3$, as well as $8-2$ and $8-1$ ) is separated from the earlier one by 0.5 meter of clay and begins with a relatively thick $(\sim 20 \mathrm{~cm})$ graded sand-silt layer. There are 8 layers within 3 meters of sediment, ranging from less than $5 \mathrm{~cm}$ to $20 \mathrm{~cm}$, with a mode at 5 to $8 \mathrm{~cm}$. Turbidity intervals are estimated as roughly 20,000 years.

\section{Bioturbation}

Three kinds of bioturbation features were distinguished: mottling, various tube-like burrows, and tiny dendritic "fucoid"-like burrows probably caused by small mudingesting worms ("chondrites" etc.) (Figure 26). There seems to be no obvious pattern to the distribution of these burrowing structures, except that they are best developednot surprisingly-where different lithologies are interbedded, providing for contrast between disturbed and undisturbed sediment. With regard to mottling, effects of organisms and of drilling operations are not always clearly separable. Well-developed burrow structures tend to cluster within a core. Fucoid-like burrows, especially, usually occur in one thin bed, being absent above and below (e.g. 135-7-3, within a thin bed of calcilutite; 137-16-4, within thin zone in a laminated marl ooze; 140-3-1, within thin zones in greenish gray slightly siliceous clay; 140-6-2, as fress-spuren along bedding planes in olive clay; 142-9-2, as tiny chondritic burrows, horizontal, 1-2 mm wide, maximum, $20 \mathrm{~mm}$ long, within a $40 \mathrm{~cm}$ thick layer containing large burrows as well, in greenish-gray nanno marl [Plate 21]; 144A-3-1, in several $5 \mathrm{~cm}$ thick zones, also within greenish gray nanno ooze; Figure 27). Distinct burrows with diameters greater than $3 \mathrm{~mm}$ occur mainly in hemipelagic sediments (Figure 26). Large $(5-12 \mathrm{~mm}$ diameter, 10-50 mm long), tube-like burrows were seen in 142-8. They tend to be horizontal; some show concave disk filling.

The usefulness of the burrows consists in showing that conditions were sufficient for faunal existence, that is, sufficient food and oxygen were available. The depth of a burrow below the upper boundary of the color indicating original substrate (never more than about $3 \mathrm{~cm}$ ); the relationship to associated layers, any mineralization of the burrows; and similar observations may give environmental clues (Plate 21). Unfortunately, no X-radiography unit was available on board. We cannot even be sure, whether "abundant bioturbation" indicates an abundant fauna on the ocean floor at the time. Possibly, these delicate structures were best preserved where mechanical disturbance (including bioturbation!) was at a minimum, or where 

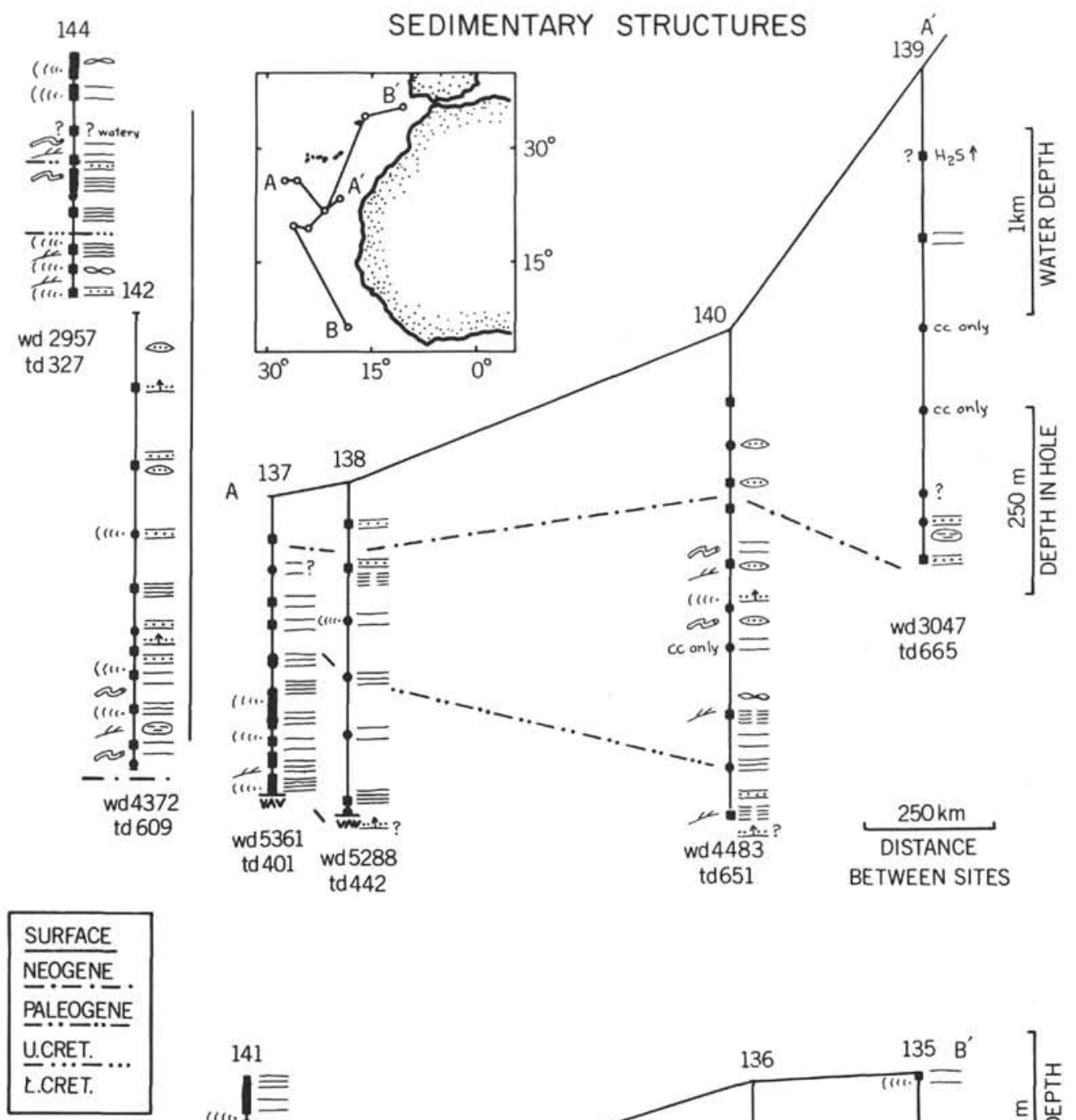

LEGEND

Primary structures

$1=6 \infty$

$2 \equiv 7 \otimes$

$3 \equiv 8 \ldots$

$4 \equiv 99$

$5 \div$

Bioturbation

$1 \approx$

$2 \pi$

3 (แi..

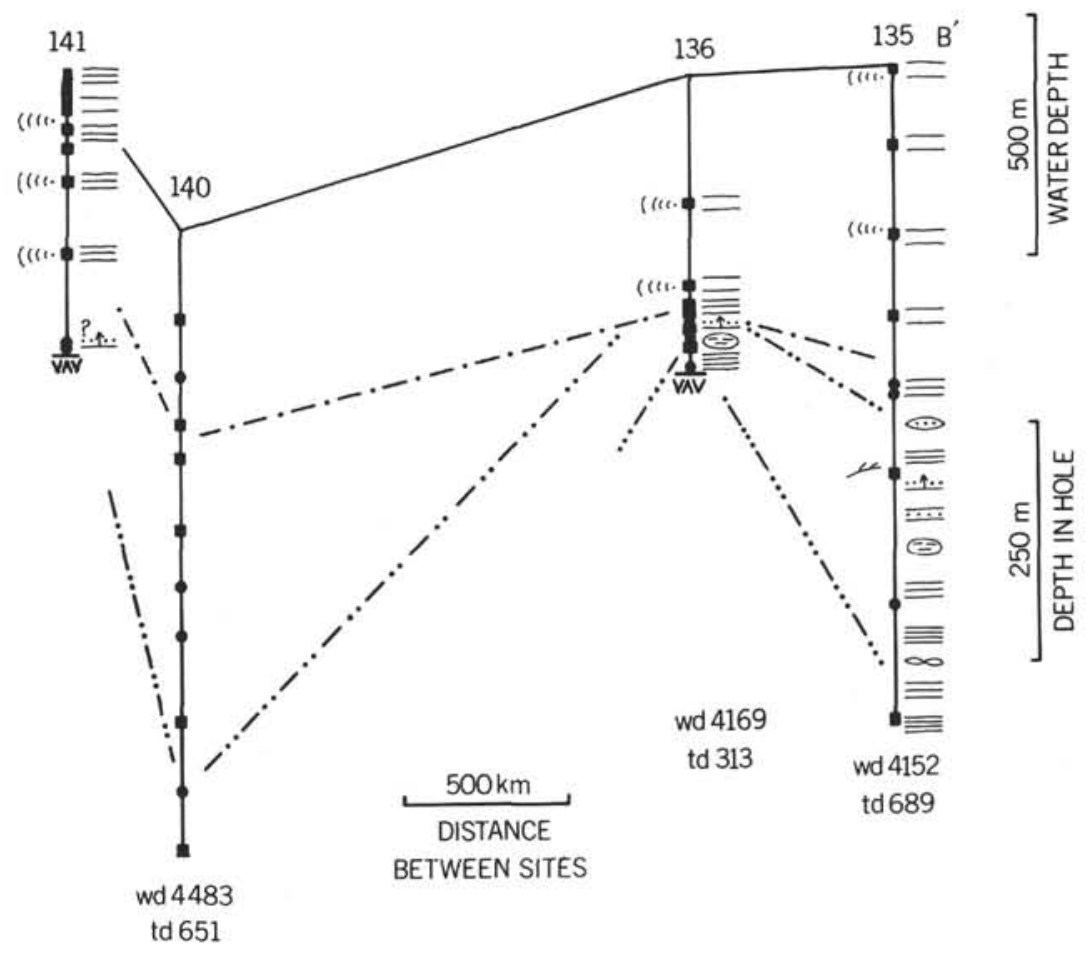

Figure 26. Distribution of sedimentary structures. Symbols: Primary structures -1 , banding (color); 2, bedding (lithology); 3, lamination $(\mathrm{mm}$ ); 4, indistinct lamination; 5 , grading; 6 , lensy bedding; 7, sand and silt lenses; 8 , sand and silt layers; 9, clay lumps. Bioturbation 1, tube-like burrows; 2, "fucoid" burrows; 3, mottling. 


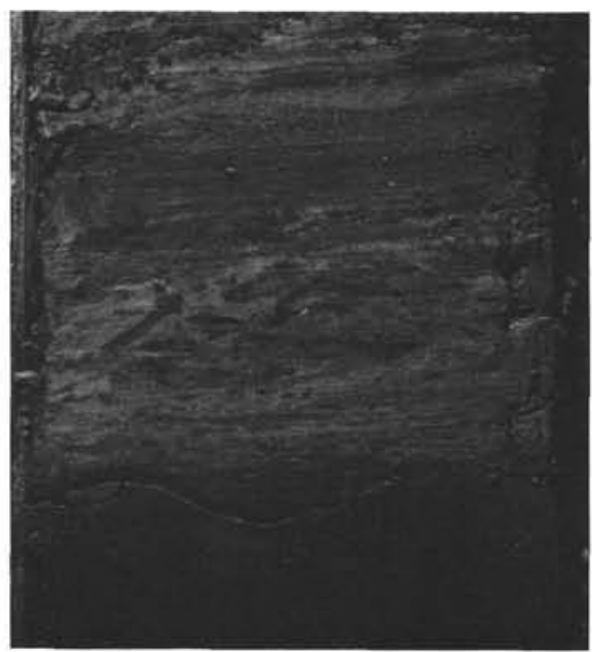

Figure 27. 135-7-2 46-53 cm. "Fucoid" burrows in pelagic clay within Late Cretaceous flysch-like sequence.

finely layered sediments were first burrowed and then quickly covered.

\section{FACIES TYPES AND ASSOCIATIONS}

\section{Classification}

The various components and aspects tend to form natural groupings that may be taken to define "facies", which are usually named after the dominant properties (e.g. greenish gray siliceous chalk, brown quartzose clay). Originally, any aspect of a sedimentary unit defines a "facies" (Dunbar \& Rodgers, 1957, p. 136), for example, the pelagic clays of Leg 14 would include a "zeolitic facies". Following general usage, however, we retain "facies" as a loosely defined term employable in such conceptually different connotations as "zeolite facies", "chalk ooze facies", "ridge-flank facies", "hemipelagic facies" and "Atlantic facies".

Facies types are defined mainly according to a classification used by Olausson (1960) (see Appendix 1). Olausson (1961a) reviewed previous classifications and pointed out the many difficulties associated with separating the various "pelagic" facies from the various "terrigenous" ones. $\mathrm{He}$ distinguishes three main kinds of deep-sea deposits: (1) typical "red clay" and oozes (white, yellow, red or brown in color), (2) atypical "red clay" and oozes in which the color differs from that of the typical ones (gray, blue, green and black); these he designates as muds, and (3) deep-sea deposits with appreciable amounts of terrigenous matter.

With few exceptions his classification, developed mainly from Quaternary sediments, is useful for categorizing the Cretaceous and Cenozoic sediments of Leg 14. We prefer to use the term "mud" only for deposits rich in silt and sand sized terrigenous, shallow water and volcanogenic components. This requires disregarding the use of color for distinguishing "clays" from "muds". Certain pelagic clays show both green and brown hues (Site 137) and it is not satisfactory to describe such changes as from "brown red clay" to "green red clay" or from "red clay" to "green mud". Also, in making the distinctions between "pelagic", "volcanogenic", and "terrigenous", we use only components larger than about 4 or $5 \mu$, that is those identifiable with a petrographic microscope. A pelite ${ }^{7}$ may be dominated by quartz, mica, and kaolinite (e.g. X-ray analysis of 137-2-cc; 141-9-5-149) and still be classed as pelagic clay, since there is evidence that the terrigenous material settled through the water column like other pelagic components.

Our results show that redeposition is likely to occur in all kinds of sediments, whether of biogenic, terrigenous, or volcanogenic origin. For such sediments, which are no longer "indigenous" to their environment, it is sufficient to add "displaced" or "allodapic" (Meischner, 1964; p. 173) to the descriptive facies term, for example, "displaced foram ooze", "allodapic limestone". Many of these displaced sediments may be turbidites (that is, introduced in concrete events involving gravity-driven suspensions of densities greater than that of bottom water) whereas others apparently were redistributed by bottom currents after having been brought to greater depths in this manner (see Hollister and Heezen, 1966).

\section{Facies Cored}

A great variety of facies types were sampled. This included chalk and marl oozes, pelagic clays, and quartzose muds throughout the section; and dolomite cycles, calcareous mud, zeolitic clay, cherts, carbonaceous sediments and thick volcanogenic sequences mainly from Paleocene and older deposits (see Table 4). Highly siliceous clays and marls were restricted to Eocene, Oligocene, and Miocene samples, although Cretaceous sediments also are in part siliceous, especially at Site 137 .

\section{Pelagic Clays (Pelites)}

\section{Occurrence}

Pelites are slowly accumulating deposits with low proportions of sand-and-silt-sized components. They occur where introduction of calcareous and siliceous tests is small, or balanced by dissolution, and where supply of volcanogenic and terrigenous components is essentially restricted to clay-size material. Red, brown, and yellow pelites are the end-members in a series of pelagic clay types, for which these conditions are especially well developed. They accumulate below the $\mathrm{CCD}^{8}$ and away from highly productive oceanic areas, land and volcanoes (Table 5). The best example of this situation is Site 137 , cores 1 to 6 . Hemipelagic influx at nearby Site 138 enriches the profile with pelites of olive and greenish colors containing a notable admixture of silt-sized terrigenous and/or siliceous material (Figure 28).

\footnotetext{
${ }^{7}$ Here and elsewhere the term "pelite", when alone, stands for "low-carbonate or non-calcareous clay".

${ }^{8}$ The CCD (Calcite Compensation Depth) is the facies boundary between pelagic clay and calcareous ooze. It marks the level where rate of supply of calcium carbonate and its rate of dissolution are equal (hence "compensation"). As a rate-governed phenomenon in the interface sediment, the CCD has but very tenuous connections with saturation profiles in the water column, as derived from equilibrium theory.
} 
TABLE 4

\begin{tabular}{|c|c|c|c|c|c|c|c|c|c|c|c|c|c|c|c|c|c|}
\hline Age & 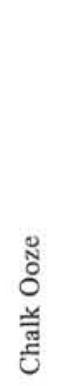 & 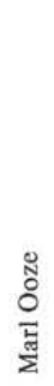 & 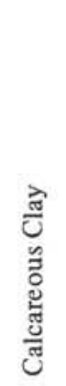 & 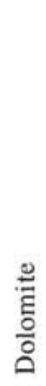 & 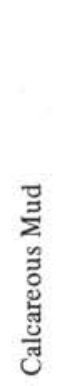 & 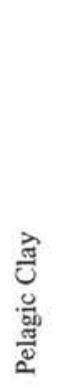 & 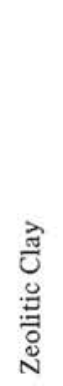 & 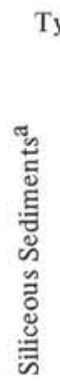 & $\begin{array}{l}\overrightarrow{5} \\
\frac{5}{U}\end{array}$ & 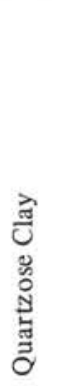 & 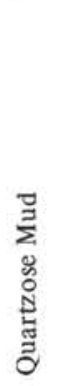 & 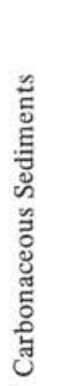 & 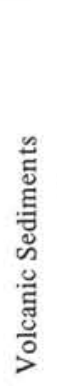 & 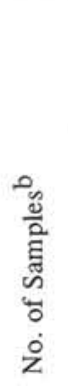 & 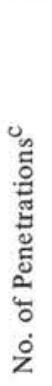 & 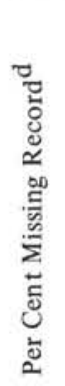 & Remarks \\
\hline Recent-Pliocene & 77 & 7 & 4 & & 2 & 1 & & & & & 8 & & & 16 & 9 & 6 & Clay in 137,138 drilled, not cored \\
\hline Miocene & 32 & 25 & 4 & & & 12 & & 12 & tr. & 6 & 8 & & & 20 & 9 & 22 & \\
\hline Oligocene & 66 & 17 & & & & & & 33 & & & & & & 6 & 6 & 54 & Chiefly Site 144 (rel. shallow water) \\
\hline Eocene & & 14 & 13 & & & 37 & & 41 & tr. & 7 & 1 & & & 7 & 6 & 37 & \\
\hline Paleocene-Maestrichtian & 3 & 5 & & 8 & 24 & 18 & 15 & & 4 & 3 & 9 & 12 & & 11 & 6 & 25 & \\
\hline Campanian-Turonian & & 9 & & 8 & 7 & 20 & 15 & & 1 & & 15 & 17 & 9 & 9 & 5 & 8 & \\
\hline Cenomanian & 2 & 63 & 6 & & 2 & & 6 & & 5 & & & 9 & 8 & 11 & 4 & 7 & Chiefly Site 137 \\
\hline Aptian-Albian & & 15 & & & 52 & 3 & & & & & 18 & 8 & 3 & 5 & 3 & 0 & \\
\hline
\end{tabular}

${ }^{\mathrm{a}}$ Contains siliceous marls

${ }^{\mathrm{b}}$ Cores, sidewall samples

${ }^{\mathrm{c}}$ Drilled and/or sampled, all holes

$\mathrm{d}_{\text {Estimated minimum, based on hiatuses in Figure } 4}$

NOTE: Sidewall cores and drill bit samples not bracketed by age determinations were not considered.

TABLE 5

Occurrence of Pelagic Red, Brown and Yellow Clays ("Oxypelites")

\begin{tabular}{|c|c|c|c|c|c|c|}
\hline Site & Core & Per Cent & Age & $\begin{array}{l}\text { Association/Main } \\
\text { Silt Components }\end{array}$ & Color & Structure \\
\hline 135 & $\begin{array}{l}5 \\
7\end{array}$ & $\begin{array}{l}10 \\
10\end{array}$ & $\begin{array}{l}\text { E. Eocene } \\
\text { Camp./Maestr. }\end{array}$ & $\begin{array}{l}\text { Terr. mud/quartz } \\
\text { Terr. \& volc. mud/qtz., calc. }\end{array}$ & $\begin{array}{l}5 \text { YR } 5 / 2-3 \\
10 \text { YR } 3 / 3 \text { (gr. gr. patches) }\end{array}$ & $\begin{array}{l}\text { Thin layer } \\
\text { Thin layers }\end{array}$ \\
\hline 136 & $\begin{array}{l}4 \\
5 \\
6 \\
8\end{array}$ & $\begin{array}{r}100 \\
80 \\
80 \\
15\end{array}$ & $\begin{array}{l}\text { E. Miocene(?) } \\
\text { Campan.? } \\
\text { Campan. } \\
\text { Albian }\end{array}$ & $\begin{array}{l}\text { Marl, hiatus/quartz } \\
\text { Clay, hiatus/Mn ox. rich, rhombs } \\
\text { Ash layers/volcanogenic } \\
\text { Ash, marl/volcanogenic }\end{array}$ & $\begin{array}{l}5-10 \text { YR } 5 / 2-6 / 3 \\
10 \text { YR } 4 / 2-6 / 4 \\
5-10 \text { YR } 3 / 4-7 / 2 \\
2.5-5 Y 5 / 4-7 / 6\end{array}$ & $\begin{array}{l}\text { Mottled } \\
\text { Banded } \\
\text { Laminated } \\
\text { Banded }\end{array}$ \\
\hline 137 & $\begin{array}{l}1 \\
2 \\
3 \\
4 \\
5 \\
6\end{array}$ & $\begin{array}{l}100 \\
100 \\
100 \\
100 \\
100 \\
100\end{array}$ & $\begin{array}{l}\text { Miocene? } \\
\text { ?Oligo-Eocene? } \\
\text { Paleocene? } \\
\text { Maestricht? } \\
\text { Sant./Camp.? } \\
\text { Coniacian? }\end{array}$ & $\begin{array}{l}\text { Clay/quartz, feldspar } \\
\text { Clay/quartz, clay aggr. } \\
\text { Clay/(zeolite, quartz) } \\
\text { Clay/zeolite } \\
\text { Clay/zeolite } \\
\text { Clay/zeolite }\end{array}$ & $\begin{array}{l}10 \text { YR } 4 / 2-5 / 6 \\
5 \text { YR } 5 / 2 \\
5-10 \text { YR } 4 / 2-6 / 4 \\
5 \text { YR } 5 / 4 \text { (gr. gr. layers) } \\
7.5 Y R 5 / 4 \\
5 \text { YR } 4 / 3-6 / 4 \text { (gr. gr. also) }\end{array}$ & $\begin{array}{l}\text { Disturbed } \\
\text { Disturbed } \\
\text { Disturbed } \\
\text { Layers } \\
\quad ? \\
\text { Thin layers }\end{array}$ \\
\hline 138 & $\begin{array}{l}1 \\
3 \\
5\end{array}$ & $\begin{array}{l}90 \\
50 \\
50\end{array}$ & $\begin{array}{l}\text { E. Miocene } \\
\text { ?Eocene? } \\
\text { ?Sant./Camp.? }\end{array}$ & $\begin{array}{l}\text { Clay/(terrig.) } \\
\text { Bluish clay/(quartz) } \\
\text { Green clay/(quartz, zeolite) }\end{array}$ & $\begin{array}{l}\text { 10GY } 7 / 2 \text { (10YR } 6 / 4 \text { bands) } \\
\text { YR (light reddish brn) } \\
5 \text { YR } 5 / 3\end{array}$ & Banded \\
\hline 140 & $\begin{array}{l}\text { A1 } \\
\text { A2 }\end{array}$ & $\begin{array}{l}50 \\
50\end{array}$ & $\begin{array}{l}\text { M. Miocene } \\
\text { M. Eocene }\end{array}$ & $\begin{array}{l}\text { Gr. gr. clay/(quartz) } \\
\text { Gr. gr. clay/(rads, qtz) }\end{array}$ & $\begin{array}{l}10 \text { YR } 5 / 3 \\
2.5 \text { YR } 6 / 2-6 / 4\end{array}$ & $\begin{array}{l}\text { Silty layers } \\
\text { Mottled }\end{array}$ \\
\hline 141 & $\begin{array}{l}7 \\
8 \\
9\end{array}$ & $\begin{array}{l}30 \\
90 \\
20\end{array}$ & $\begin{array}{l}\text { M. Miocene } \\
\text { Oligocene? } \\
\text { Maestr./Paleo? }\end{array}$ & $\begin{array}{l}\text { Marl/quartz } \\
\text { Pl. yl. green/clay/(terrig.) } \\
\text { Gr. gr. clay/zeolite(?) }\end{array}$ & $\begin{array}{l}\text { 10YR } 5 / 5-6 / 4 \\
7.5 \text { YR } 6 / 6-7 / 6 \\
7.5 \text { YR } 6 / 6\end{array}$ & $\begin{array}{l}\text { Mottled } \\
\text { Mottled } \\
\text { Mottled }\end{array}$ \\
\hline
\end{tabular}

${ }^{\mathrm{a}}$ Sites 139,142 , and 144 had none.

\section{Main Types}

The types recognized by visual description and smear slide analysis are shown in a carbonate-color diagram (Figure 29). Two major groups of pelites emerge according to color: (1) red, brown, orange and yellow pelagic clays, containing predominantly ferric (and oxidic Mn-) minerals; and (2) olive, green, blue and black (hemi-) pelagic clays, characterized by the presence of ferrous minerals, mainly sulfide and-especially in the case of sapropelites-by carbonaceous matter. Sapropelites will be discussed in a separate section.

A large proportion of both oxidized and reduced pelites contains no more than traces of carbonate. They cluster around reddish brown and yellowish green to green colors (Figure 29). In other pelites carbonate is present as low percentages of nannofossils, undifferentiated fine-grained 

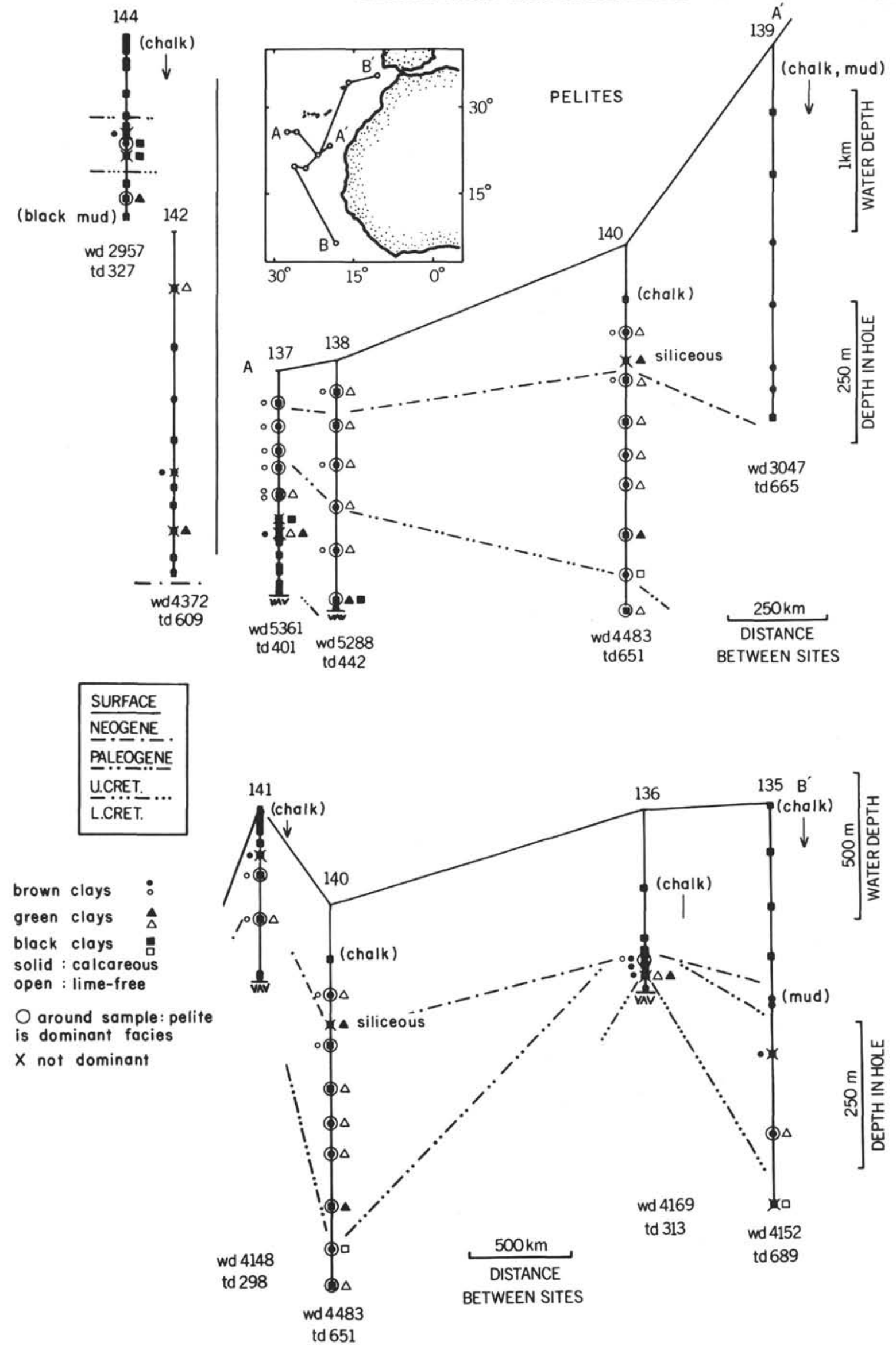

Figure 28. Distribution of pelite facies (clay with little or no carbonate). 


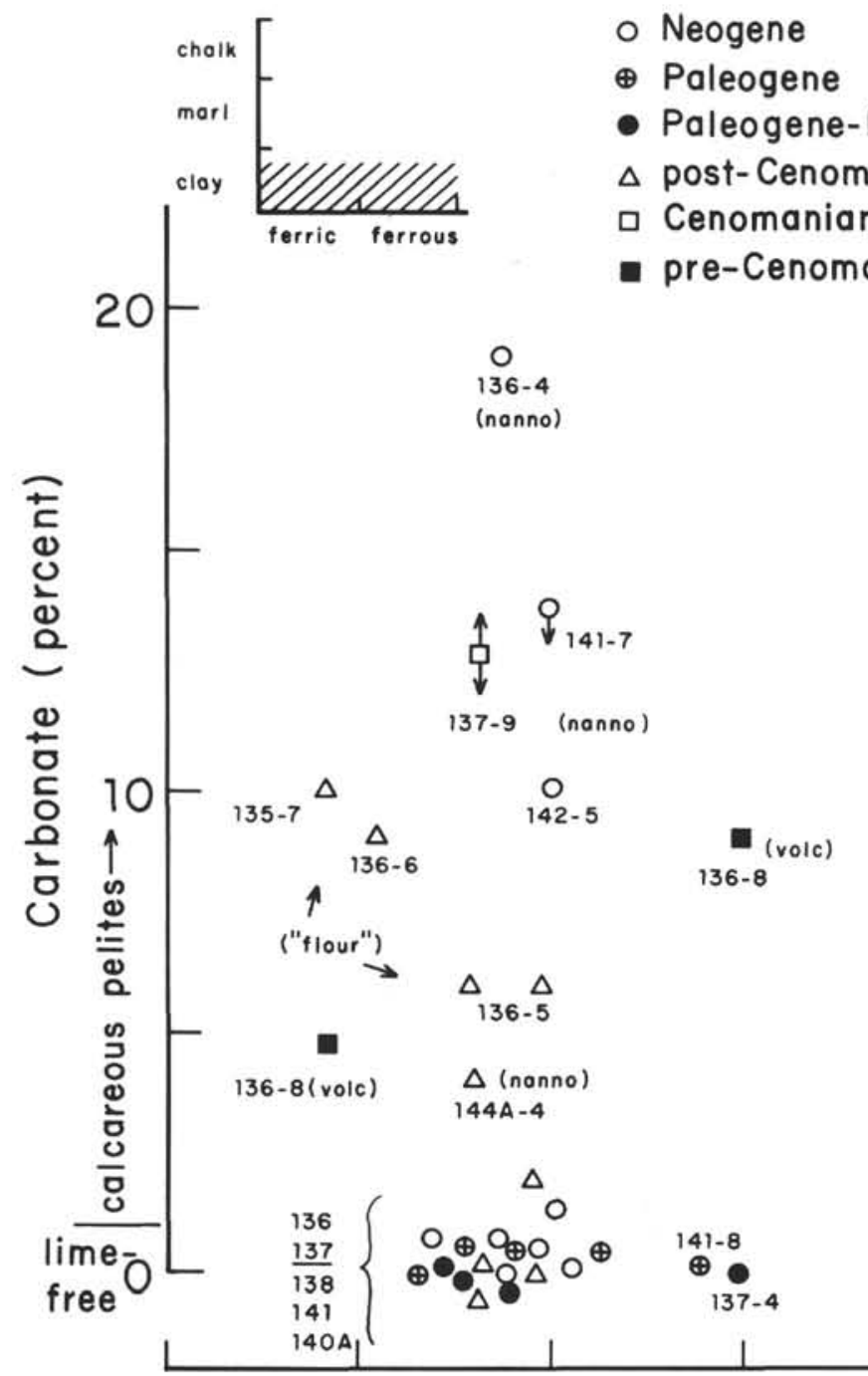

red

(R) rd.brown yl.brown yl.gray

(YR)
(Y) olive

(Y)
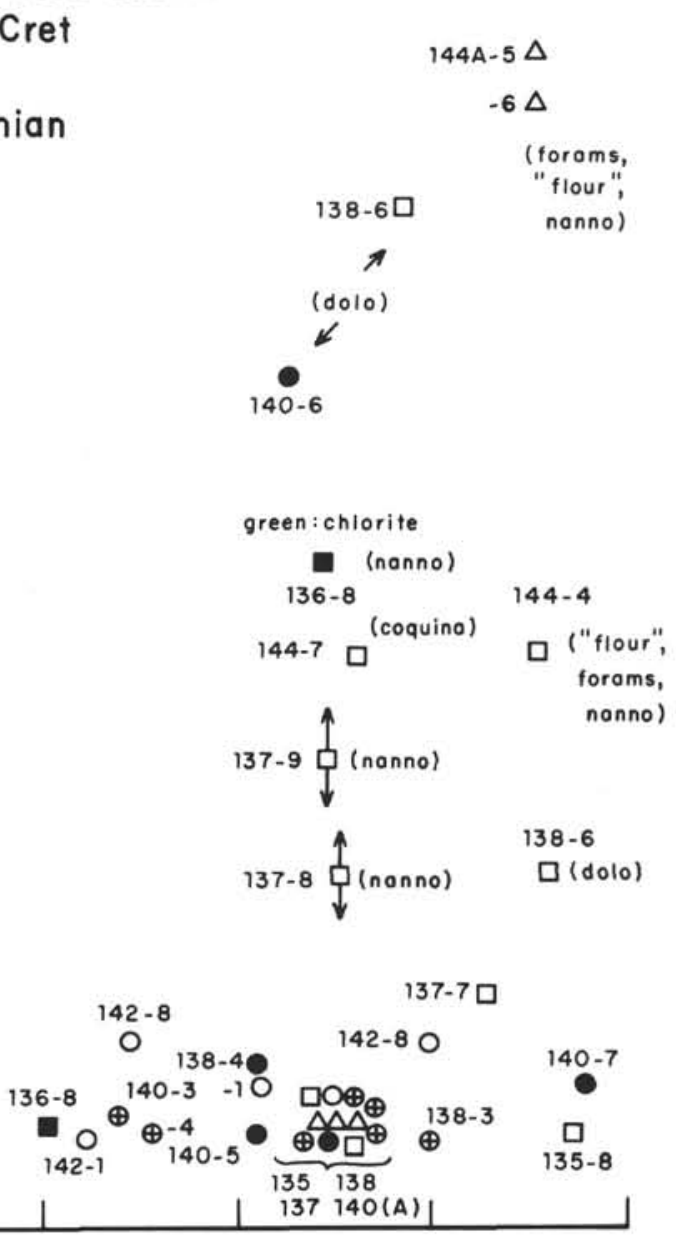

(1)

\section{$\longleftarrow$ Brown clays $\longrightarrow$ (oxidized pelites)}

\section{Ferric minerals dominant}

\section{$\longleftarrow$ Green and Black clays (reduced pelites; sapropelites: carbonaceous)}

\section{Ferrous minerals dominant}

Figure 29. Pelite occurrences in a carbonate-color diagram.

carbonate ("flour"), reworked cement of volcanic ashes, and, in a few cases, foraminifera and coquina. These patterns do not necessarily reflect general trends, but only those of Leg 14 samples. Also, fossils are typically absent or rare and the age, therefore, was commonly estimated from interpolation and extrapolation of sedimentation rates, or, in some instances, from fish teeth.

Both oxidized and reduced pelites occur in both Tertiary and Cretaceous sediments, but some trends, albeit weak, are visible in the distribution of ages within the carbonate-color diagram. Neogene (mainly Miocene) pelites are notable for low carbonate content and high oxidation except where displaced carbonates are present $(141-7 ; 142-5)$ and where reduced (pyritiferous) resediments are introduced at a high rate (Site 140). Paleogene pelites (mainly Eocene) also are dominated by lime-free brown clays, the main exception being the sequence at Site $140(\mathrm{~A} 2,3,4)$ which has a strong hemipelagic aspect. Pelites near the Cretaceous-Tertiary boundary (Maestrichtian-Paleocene) show a similar distribution to Paleogene ones, but pelites of greater age (TuronianCampanian) are more commonly reduced and have a greater proportion of calcareous representatives. The oxidized pelites of pre-Maestrichtian age occur largely within the sequence of volcanogenic clays and reworked ashes at Site 
136. Late Cretaceous oxidized clays do occur at Site 137, however, establishing the important fact that oxidizing (and $\mathrm{CaCO}_{3}$ undersaturated) bottom waters were present at this time.

In general, carbonate-free and carbonate-poor pelites are restricted to abyssal depths. Site 144 has some interesting examples of reduced black calcareous pelites occurring at quite shallow depths within Cretaceous (CenomanianCampanian) deposits.

\section{Texture}

The red, brown and yellow oxidized pelites, or "oxypelites" tend to have less silt and sand than the greenish reduced pelites (Figure 30). The reason for the lack of pronounced textural difference, despite a higher proportion of coarse terrigenous material in hemipelagic pelites, is that many eupelagic pelites contain silt-and-sand-size zeolites, clay aggregates, manganese nodules, fish teeth, arenaceous foraminifera and other indigenous coarse components (Table 6).

In cases where the authigenic silt-and-sand-fraction is small compared to the extraneous one, the ratio of total sediment to clay fraction (1/clay) is a rough measure of sedimentation rate. The eupelagic oxypelites of the classic ridge-flank sequence at Site 137 contain 0 to 2 per cent sand, 7 to 19 per cent silt, and 80 to 93 per cent clay (12 values). Means for 137-1 (?Miocene, 4 values) are 0.2 per cent sand, 18 per cent silt, 82 per cent clay. The pelites at 136 and 138 contain more coarse material due to volcanogenic and terrigenous supply. If it is assumed that clay is "background" sedimentation while biogenous, and coarser terrigenous and volcanogenic deposits are superimposed, the companion Sites 137 and 138 may be compared as follows: Taking 137-1 for the base-line, one obtains a clay inverse ratio of 1.2 for an interpolated sedimentation rate of about $2.5 \mathrm{~m} / \mathrm{My}$, that is the clay inverse ratio is about one-half the rate in $\mathrm{m} / \mathrm{My}$. The contemporaneous pelite at 138-1 with clay percentages of between 21 and 74 (5 values, median is 59) has a clay inverse ratio of 1.7 , suggesting a rate of $3.4 \mathrm{~m} / \mathrm{My}$. The interpolated sedimentation rate for $138-1$ is $4 \mathrm{~m} / \mathrm{My}$. Both at $136-4$ (1 value) and at 141.7 ( 6 values) the clay content corresponds to 2.6 $\mathrm{m} / \mathrm{My}$, a reasonable value in view of other evidence.

Obviously, winnowing and other bottom transport processes may change clay proportions considerably, depending on the local setting, and therefore, textural clues to sedimentation rate should not be overvalued. The relatively clay-poor but low-rate Cretaceous deposits of Site 136, where most of the sedimentary record is missing, apparently exemplify such winnowing. The comparison of the twin Sites 137-1 and 138-1 does suggest, however, that the clay fraction here is pelagic, that is, it was introduced into the abyssal trough largely as fallout, and that additional silt and sand at Site 138 was brought in along the bottom. An elongated topographic high between Sites 137 and 138 may have blocked the bottom-near sediment transport from proceeding westward.

The highest clay proportions in the oxypelites of Site 137 occur in Core $3(90 \%)$, estimated to be Paleocene in age. A very low sedimentation rate may be indicated, especially since much of the coarse fraction consists of fish teeth, agglutinated foraminifera, and undispersed clay.

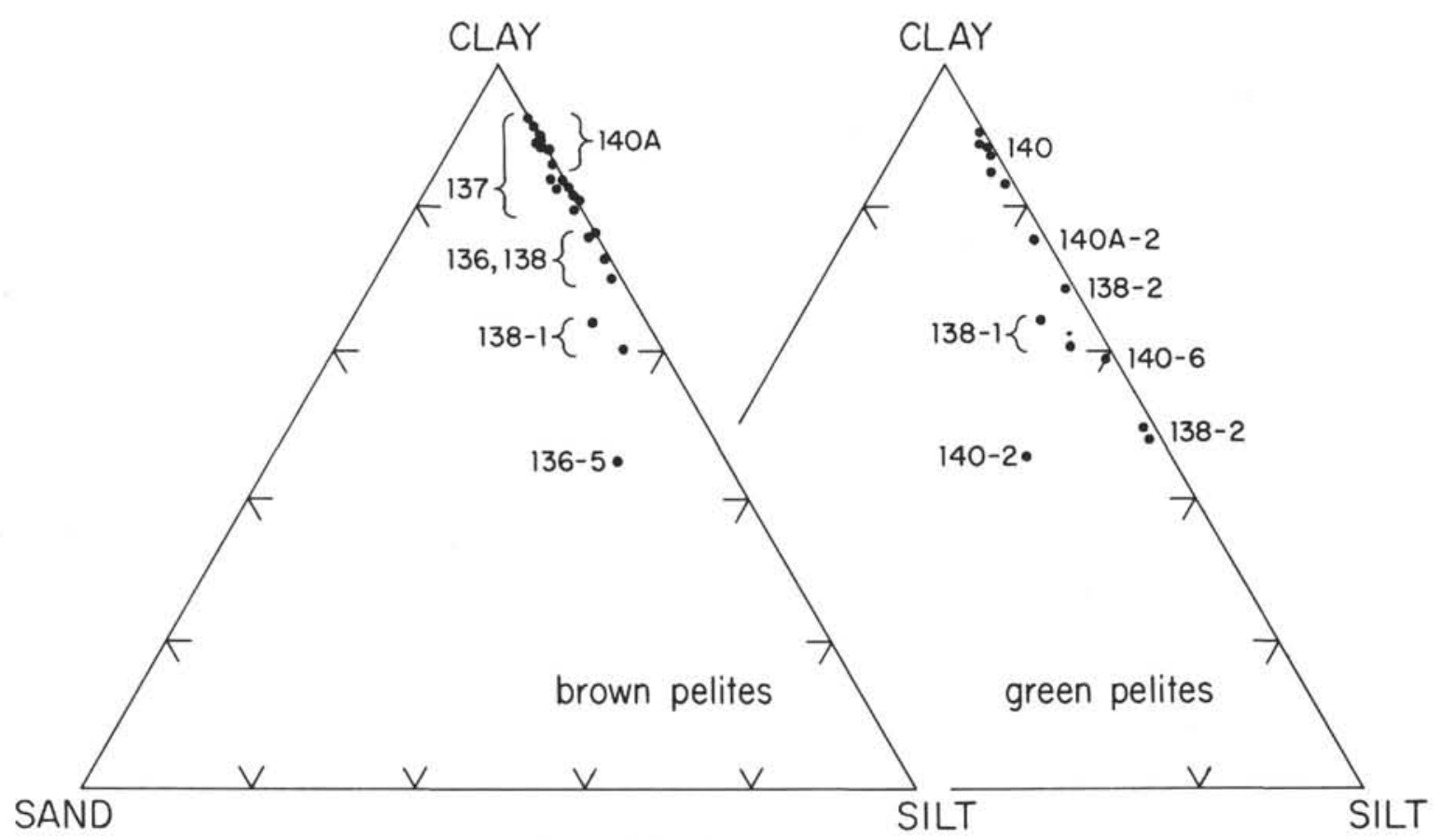

Figure 30. Texture of pelagic clay samples (DSDP laboratory analysis). 
TABLE 6

Dominant Components of Oxidized Pelites Ordered by Abundance ${ }^{\mathrm{a}}$

\begin{tabular}{lcccc}
\hline & Clay & Sand & & \\
Samples & $\%$ & $\%$ & X-ray $^{\mathrm{b}}$ & Smear $^{\mathrm{c}}$ \\
\hline
\end{tabular}

\section{TERTIARY}

$\begin{array}{llll}140-\mathrm{A} 1 & 93 & 4 & \\ 141-7 & 60 & 0.2 & \text { kao, qtz, mic, fsp (paly, mont, gyp) } \\ 137-1 & 86 & 0.3 & \\ 136-4 & 70 & 1 & \\ 138-1 & 93 & 0.5 & \\ 141-8 & 79 & <0.1 & \text { paly, qtz, mic, kao, chl, mont, ML, fsp } \\ 137-2 & 90 & 2 & \text { kao, qtz, fsp, mic, paly (mont, gyp) } \\ 138-3 & 91 & ? & \\ 140-\mathrm{A} 2 & 90 & 0.1 & \\ 135-5 & 66 & 2 & \\ 137-3 & 84 & 0.6 & \\ 141-9 & 86 & 0.2 & \end{array}$

quartz, mica, zeolite
qtz, op, nan, mic (terr)
qtz, mic, fsp, opaques
qtz, nan, mic, fsp, zeo (dolo, heav)
mic, op, qtz, fsp, heavies
qtz, mic, op, zeo, heavies
op, fsp, mic, qtz
qtz, mic, heav, op, zeolite
sil, qtz, opaques
dolo, qtz, mic, op (nanno)
zeo, op, qtz, mic, heav
zeo, opaques

quartz, mica, zeolite

qtz, op, nan, mic (terr)

qtz, nan, mic, fsp, zeo (dolo, heav)

op, fsp, mic, qtz

qu, mic, heav, op, zeolite

dolo, qtz, mic, op (nann

zeo, opaques qtz, ls, cbf (pf, ech, agg, fish, glc)

pf, cbf, fish (ech)

agg, fish, Mn, clay

fish, Mn, agg, qtz (chalk, clay, cbf, rad)

agg, fish, qtz, clay (rad)

fish, platy mineral (agg, Mn, qtz)

clay, agg, fish

("barren")

fish, rad, agg (glauconite)

qtz, clay, mic, chert, sed. rx

agg, fish, Mn, clay, Fe-oxide

agg, fish, glc, clay (pyr, qtz)

\section{CRETACEOUS}

\begin{tabular}{cccl}
$137-4$ & 83 & 0.6 & mont, qtz, mic, paly, sep (fsp, kao, rhodo) \\
$136-5$ & 70 & 3 & mont, paly, qtz (terr, dolo, sep, calc, sid) \\
$136-6$ & 75 & 12 & mont, san, qtz (phos, paly, sep) \\
$137-5$ & 86 & 1 & \\
$137-6$ & 75 & 0.9 & \\
$138-6$ & 90 & 3 & \\
\hline
\end{tabular}

${ }^{\mathrm{a}}$ Bold print: $>20 \%$; in brackets: $<4 \%$. Age increases downward.

$\mathrm{b}_{\mathrm{v}}$. Rad and Rosch, this volume.

c see Appendix. Exclusive of "undifferentiated clay."

dee Appendix.

Abbreviations: agg, agglutinated foraminifera; calc, calcite; cbf, calcareous, benthonic forams; chalk, chalk fragments; chl, chlorite; clay, clay clasts; ech, echinoid remains; fish, teeth and bone fragments; fsp, feldspar; glc, "glauconite"; gyp, gypsum; heav, heavy minerals; kao, kaolinite; Is, limestone fragments; mic, mica (-illite); ML, mixed layer mineral; Mn, manganese concretions; mont, smectite; nan, nannofossils; op, opaques; paly, palygorskite; pf, planktonic foraminifera; phos, phosphate; pyr, iron sulfide; qtz, quartz; rad, radiolarians; rhodo, rhodochrosite; san, sanidine; sep, sepiolite; sid, siderite; sil, siliceous fossils; terr, quartz, mica, feldspar, heavy minerals (also kaolinite); volc, glass, ash clasts, volcanic rocks; zeo, zeolite (=clinoptilolite).

Much of the silt fraction apparently was produced by authigenic growth (palygorskite, zeolite, opaques). Consequently, "background" and "extraneous" components have little or no correlation with grain size in these sediments.

\section{Composition}

The bulk of material (70-90\%) within the deep-sea pelites is in the clay fraction, essentially inaccessible to optical determination. X-ray analysis of pelites identifies the main components as products of alteration and authigenic growth (palygorskite, zeolite and probably most of the montmorillonite) with terrigenous admixtures (quartz, feldspar, mica-illite, kaolinite, and perhaps some of the montmorillonite) (see Figures 19, 31). Tertiary oxypelites resemble one another closely, but differ markedly from Cretaceous ones (Appendix 5).

Quartz, $10 \AA$ minerals (mica, illite), and kaolinite dominate the terrigenous assemblage of the Tertiary samples. The micas apparently are mainly biotite, according to smear-slide results. These minerals are derived from continental erosion by wind and by rivers, so that their abundance is a measure of exposed land surface and of activity of erosional agents (climate, relief). Kaolinite, the most abundant mineral (after smectite) in the Tertiary samples of Sites 137,138 , and 141 , is a typical product of tropical weathering and characterizes modern tropical deep-sea sediments (Griffin et al., 1968). zeo, qtz, mic, fsp, opaques volc, op, qtz, zeo, calcite op, volc, dolo, calc, zeo (terr) zeo, qtz, fsp, mica zeo, op (qtz, mic, heav) dolo, qtz, fsp, mic, calcite zeo-rad, rhodo (clay)

calcite, clay, agg, Mn (pyr, qtz, volc) calcite, clay, Mn, 1s, volc (agg) zeo-rad (agg, Mn)

zeo-rad, rhodo (agg, barite) calcite, volc, clay
The Cretaceous oxypelites contain much lower proportions of terrigenous minerals than the younger ones, suggesting some combination of low relief in the source areas and inefficient transporting agents. The clay minerals are dominated by volcanic alteration products, montmorillonites and related minerals being dominant. To what extent montmorillonite was formed in place is not known. If much of the montmorillonite is a result of in situ halmyrolytic devitrification, the growth of authigenic minerals (palygorskite, zeolite) may have profited from the reaction. Alternatively, volcanic deposits, and/or their weathering products, may be redeposited from shallow places. At Site 136 there are indications of such redeposition, based on coarse fraction analysis.

The most abundant kind of montmorillonite encountered in deep-sea pelites (as well as in other sediments) is "normal" montmorillonite, with the basal reflex displaced to $17 \AA$ in ethylene-glycolated, oriented aggregates. It occurs virtually everywhere in considerable amounts, regardless of facies or age.

In samples from 137-4-2 and 136-5-1 a mineral of the hectorite-saponite series (trioctahedral Al-Mg montmorillonite) is the main constituent. "Normal" montmorillonite is not noted in these samples, thus, the H-S form may represent or replace the "normal" form. A mixed-layer (chlorite-montmorillonite) clay mineral was found in 141-8-2 and 141-9-1. 
$137-14-4,52-53 \mathrm{~cm}$

green phyllosilicate sand layer (?altered ash) (Cenomanian)
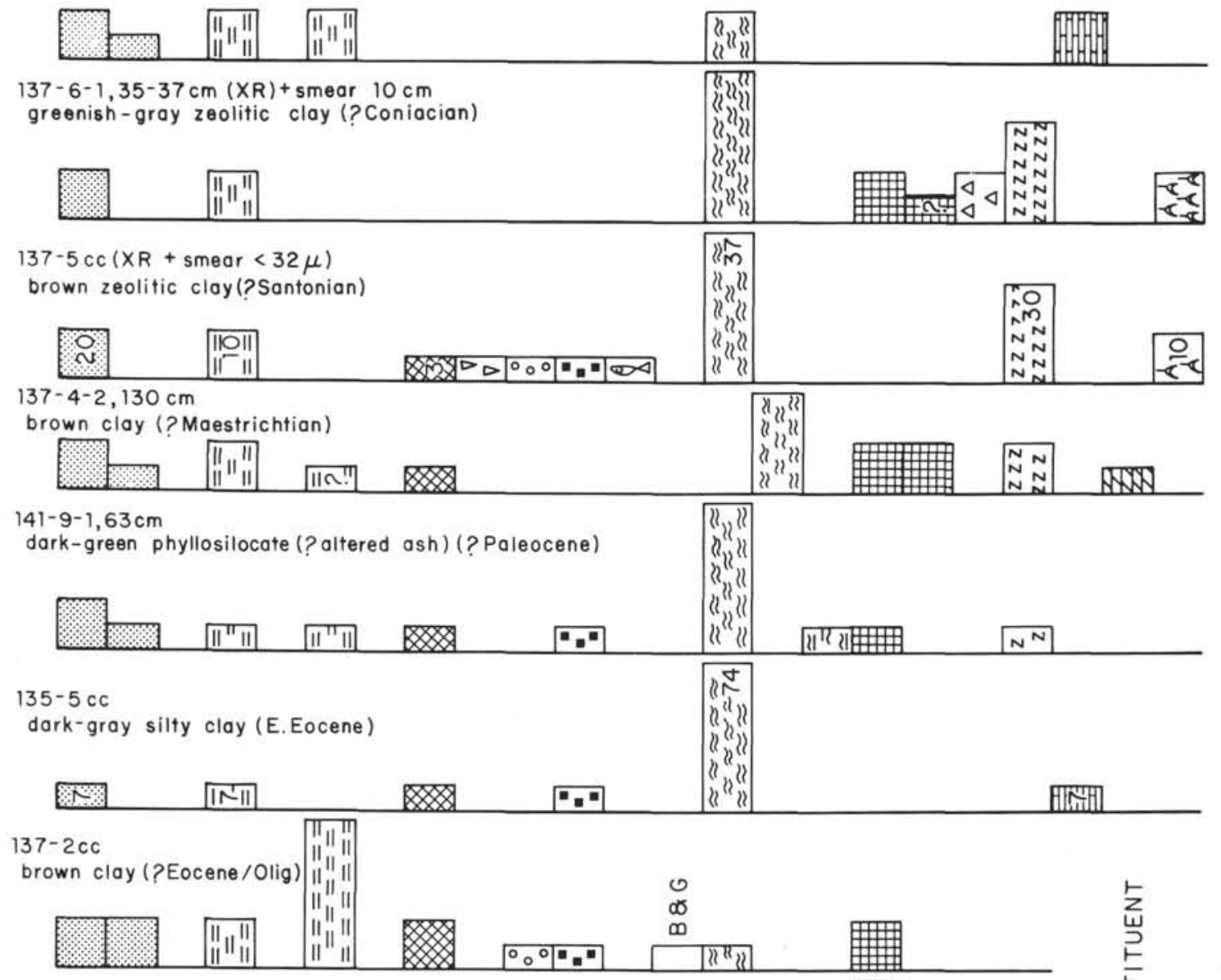

$138-3-1,121-123 \mathrm{~cm}$

bluish-gray-green clay (?Eocene)
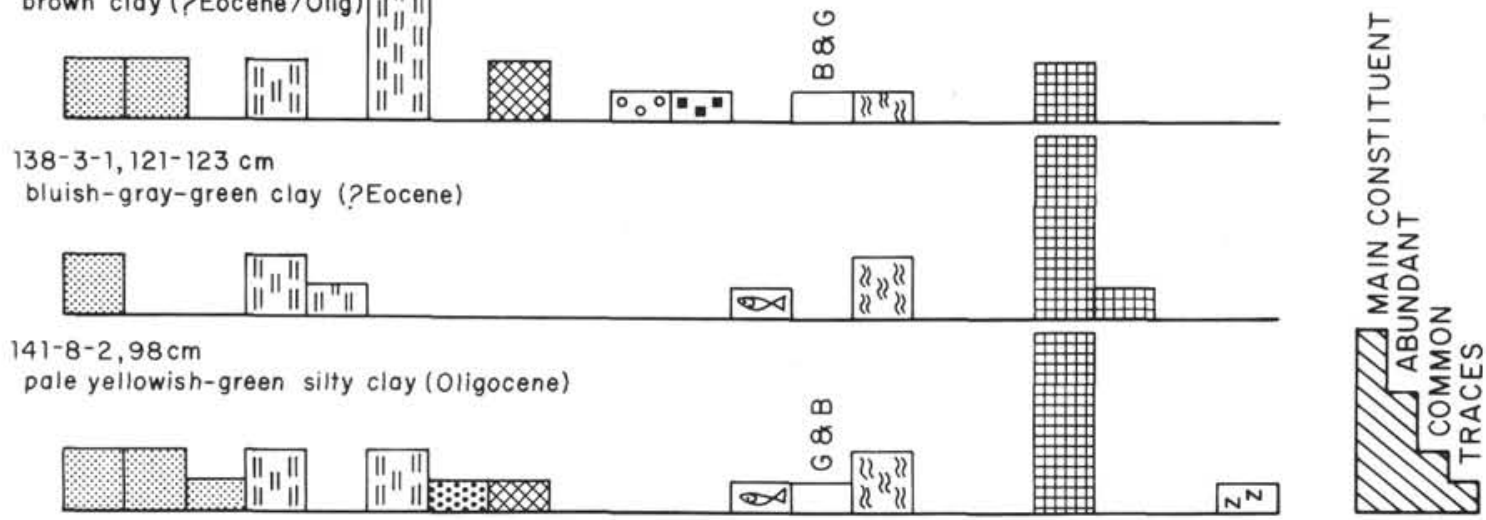

$141-8-2,98 \mathrm{~cm}$

pale yellowish-green silty clay (Oligocene)
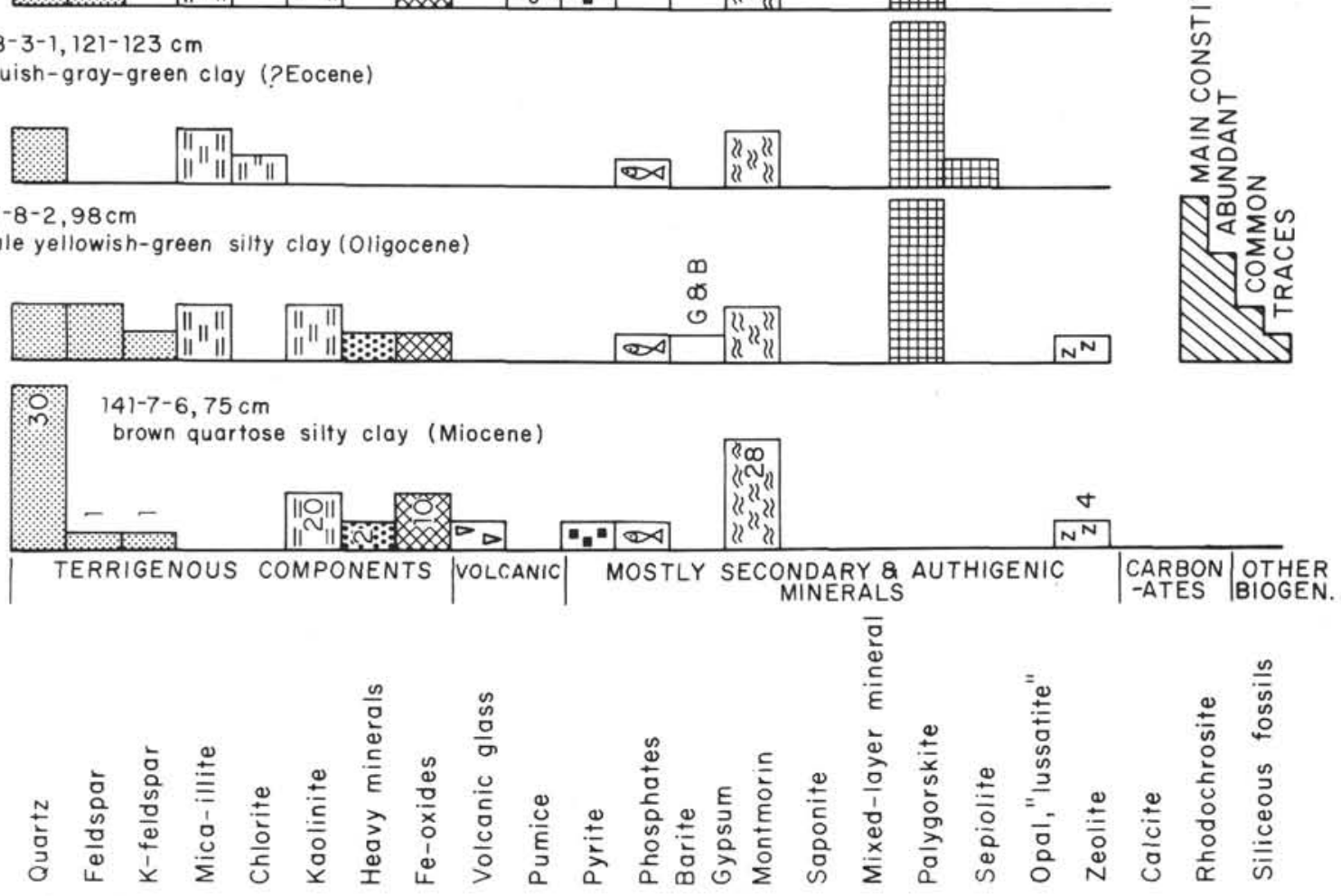

Figure 31. Composition (semi-quantitative) of 10 representative samples of pelagic (in part volcanogenic and zeolitic) clays. 
Of the authigenic minerals, palygorskite is the most abundant (see Figure 31). Sepiolite and zeolite are additional important constituents in Cretaceous pelites. Palygorskite usually shows a high degree of ordering. Transmission EM shows clusters and aggregates of needles and fibers, typical for both palygorskite and sepiolite (Plate 32 , Figure 2). In the oxypelites analyzed, as well as in other pelite samples, sepiolite is a subordinate admixture of palygorskite-rich clays. Sepiolite is especially abundant in 137-4-2, where it is associated with hectorite-saponite, palygorskite, zeolite (clinoptilolite) and rhodochrosite.

Both palygorskite and sepiolite are hydrated $\mathrm{Mg}$-rich silicates, which apparently form in pore solutions rich in $\mathrm{Mg}$ and hydrous silica (Wollast et al., 1968; Füchtbauer and Müller, 1970; Hathaway et al., 1970). The necessary silica may be derived from alteration of volcanic glass and palagonite to montmorillonite and/or by the dissolution of opaline microfossils.

As determined optically, zeolite, apparently largely derived from alteration of volcanogenic matter, is quite abundant in brown clays of Late Cretaceous age (Table 6). $\mathrm{X}$-ray analysis is not able to detect small $(<5 \%)$ quantities of zeolite, while optical analysis may overestimate it, since much of the zeolite is quite coarse (e.g. radiolarian casts, laths, see Plates 17, 18). The only kind of zeolite found in any sample of Leg 14 was clinoptilolite, a silica-rich variety of heulandite. Philippsite, reported as the dominant zeolite in post-Miocene sediments of Leg 2 (Peterson et al., 1970) was not encountered. Most highly zeolitic samples are Latest Cretaceous to Paleogene in age and are associated with low rates of sedimentation (see section on zeolites).

Smear-slide analysis emphasizes the silt fraction, consisting of between 10 and 30 per cent of the pelites. The main components within this fraction (Table 6) show a pattern consistent with that obtained through X-ray analysis. Quartz and associated terrigenous minerals tend to dominate the Tertiary samples, zeolites and opaques (largely ferromanganese oxides) the earliest Tertiary (?) and Cretaceous ones. Siliceous fossils, carbonate (including dolomite rhombs), and volcanogenic material respectively are the dominant components at one brown clay locality each $(140-A 2 ; 135-5 ; 136-5)$. Heavy minerals found in the fine to medium silt fractions off northwest Africa are mostly very stable (tourmaline, zircon, sphene); traces of green amphibole are common.

Coarse fraction analysis, in the case of brown, red and yellow clays, usually includes less than 1 per cent of the total sediment. Typical indigenous components of Tertiary oxypelites are agglutinated foraminifera, fish teeth and bones, and ferromanganese oxides (Table 6, 137-1 and 2). The agglutinated foraminifera living on these sand-free pelites used silt and clay to construct their shell (Plate 15, Figure 1). Many of these shells are slightly compressed. Compaction of (pelagic) clays to semiconsolidated pelites takes place at between 100 and 200 meters overburden pressure. Consolidated mudstones (shales) are found at burial depths of 300 to 400 meters. Fish teeth and bones are the only biopelagic remains in many oxypelites, thus, they are of considerable stratigraphic and paleoecologic interest (see Figures 16 and 17). The tooth figured in Plate 15, Figure 2, belongs to type A1 of Helms and Riedel (Leg
7), who found it in Eocene sediments elsewhere. The nannofossil age of this core (136-4), based on a strongly etched assemblage, is earliest Miocene, which extends the known range of type $\mathrm{A} 1$, to that of A2 (Eocene-Early Miocene). Small manganese nodules are quite common. At Site 137 they are rich in heavy metals (Figure 21). Additional coarse fraction components are shredded lightcolored glass ("Pele's Hair"), brownish pumice spherules, and milky white sheafs and platelets of ? volcanic glass (e.g. $140-3-1,90 \mathrm{~cm} ; 137-2 \mathrm{cc} ; 137-3 \mathrm{cc})$.

The elemental composition of two oxypelite samples was determined by O. I. Joensuu (this volume). Samples are from 137-1-2 $(5-7 \mathrm{~cm})$ and 141-9-2 $(80-82 \mathrm{~cm})$. They show great similarity in the proportion of major constituents $\mathrm{Al}_{2} \mathrm{O}_{3}(\sim 19 \%), \mathrm{Fe}(\sim 5 \%), \mathrm{MgO}(2.2 \%), \mathrm{TiO}_{2}(\sim 1 \%), \mathrm{CaO}$ $(0.7 \%)$, but not in Mn which is much higher at 137-1 (0.83 vs. $0.02 \%) . \mathrm{P}_{2} \mathrm{O}_{5}$ is somewhat higher in the sample from $141-9(0.9$ vs $0.5 \%)$. Trace elements having similar abundance (less than a factor of 1.5 ) are $\mathrm{B}, \mathrm{Ba}, \mathrm{Cr}, \mathrm{V}$; those with dissimilar abundance (enriched at 137-1) are Co (3.7X), $\mathrm{Cu}$ $(2.8 X)$, Mo $(>2.2 X)$, Ni (1.7X), $\mathrm{Zn}(1.5 \mathrm{X}), \mathrm{Hg}(8 \mathrm{X}) \mathrm{Pb}$ also is slightly higher at $137-1$ than at $141-9$, as is $\mathrm{Ba}$. The probable age of the samples is ? Early Miocene for 137-1 (sed. rate) and ? Paleocene for $141-9$ (sed. rate, fish teeth).

\section{Calcareous Sediments}

\section{Occurrence, Percent Carbonate}

Carbonate-rich sediments are typical of the relatively shallow depositional sites $(144,139,141,135,136)$, of Middle and Early Cretaceous ages (Sites 135, 136, 137, 138; presumably largely due to the depth of deposition having been shallower at that time) and for displaced sediments not far below the CCD (142-5, 6; 135-8) (Figure 32, compare also Figure 22).

Carbonate percentages are highest for the Neogene (mainly Pliocene) biopelagites capping the noncalcareous sequences at 135, 136, 139, 140 and 141 (Figure 33). They range from 35 per cent (minimum value in 135-1) to 91 per cent (maximum value in 136-1) and cluster around 70 to 85 per cent. Values are distinctly lower for corresponding deposits of Cretaceous age $(137,10-16$, average: 50 to $65 \%)$ and the continental margin deposits at 144 (40 to $70 \%)$. Because of large terrigenous admixtures the resediments at 142 show great variation, and values are usually low except for cores 4 (Pliocene) and 7 (Miocene), which are classed as foram-nanno marl-chalk ooze.

\section{Main Types, Oxidation}

Calcareous sediments of Leg 14 vary greatly in composition, color, texture, and degree of consolidation. The chief distinction is between (pelagic) oozes and (hemipelagic) muds, on the basis of composition (see Figure 34).

In general, the main types of calcareous ooze are a function of fertility (supply), epigenetic reactions (preservation) and transport (winnowing, sorting). The state of oxidation also is controlled by these factors. In addition, the oxygen content of the bottom water is important. In calcareous muds, the source for the displaced portion is of great interest, as well as the mechanism of transport. 

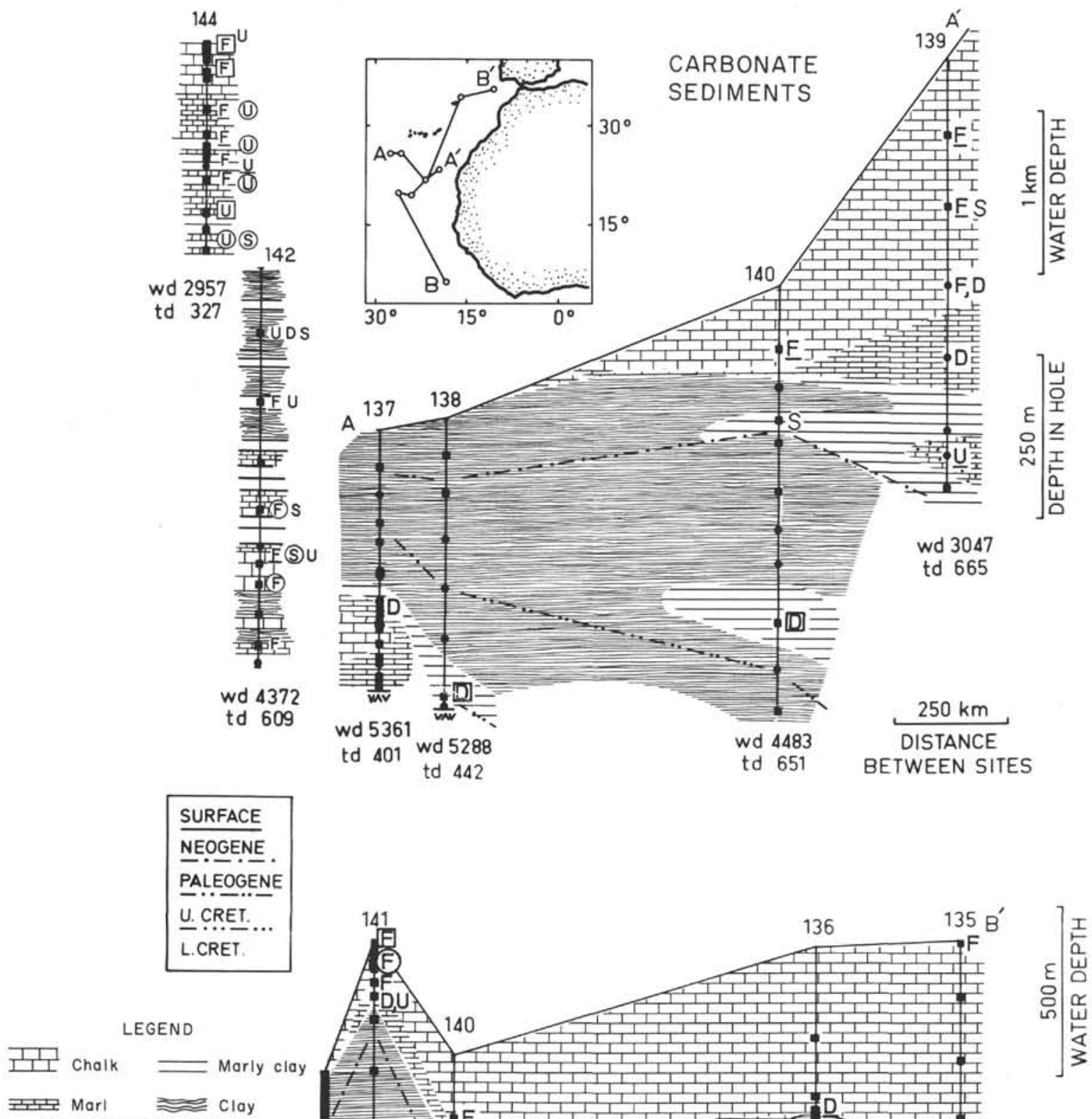

Nannos: usually dominant Shallow water carbonate:

$S$ common

(5) abundant

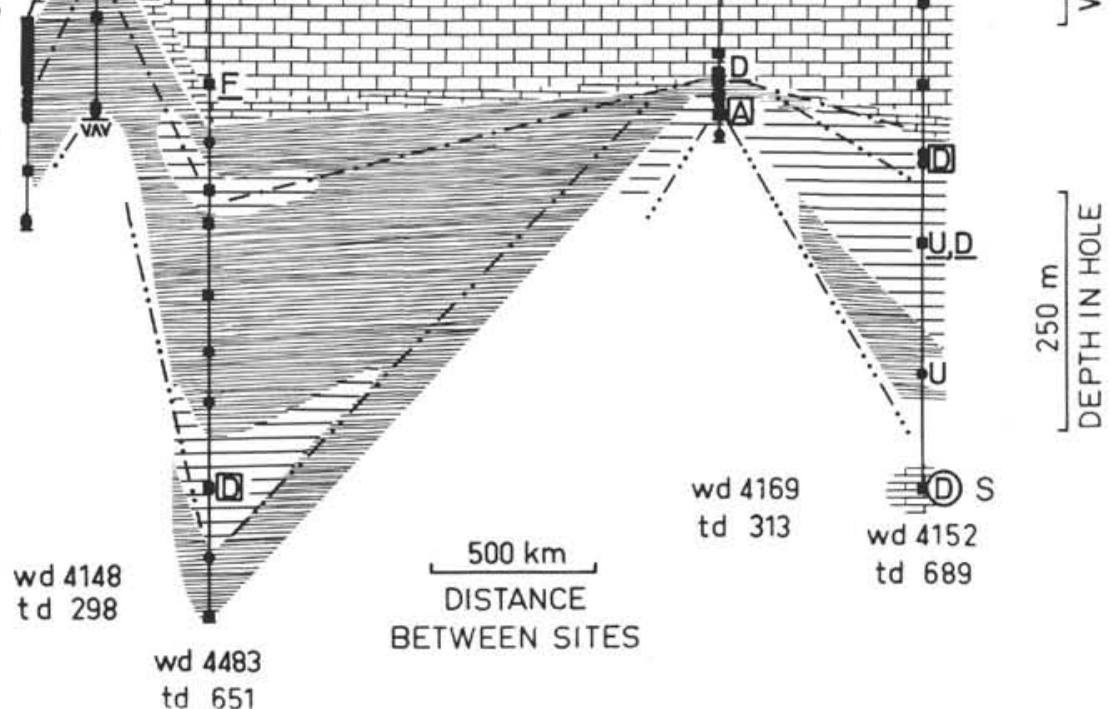

Figure 32. Distribution of chalk, marl, and clay, with major components. $U$, undifferentiated carbonate, including triturated "flour," and $M$, detrital calcareous mud. For distribution of linestone layers, see Figure 22. 


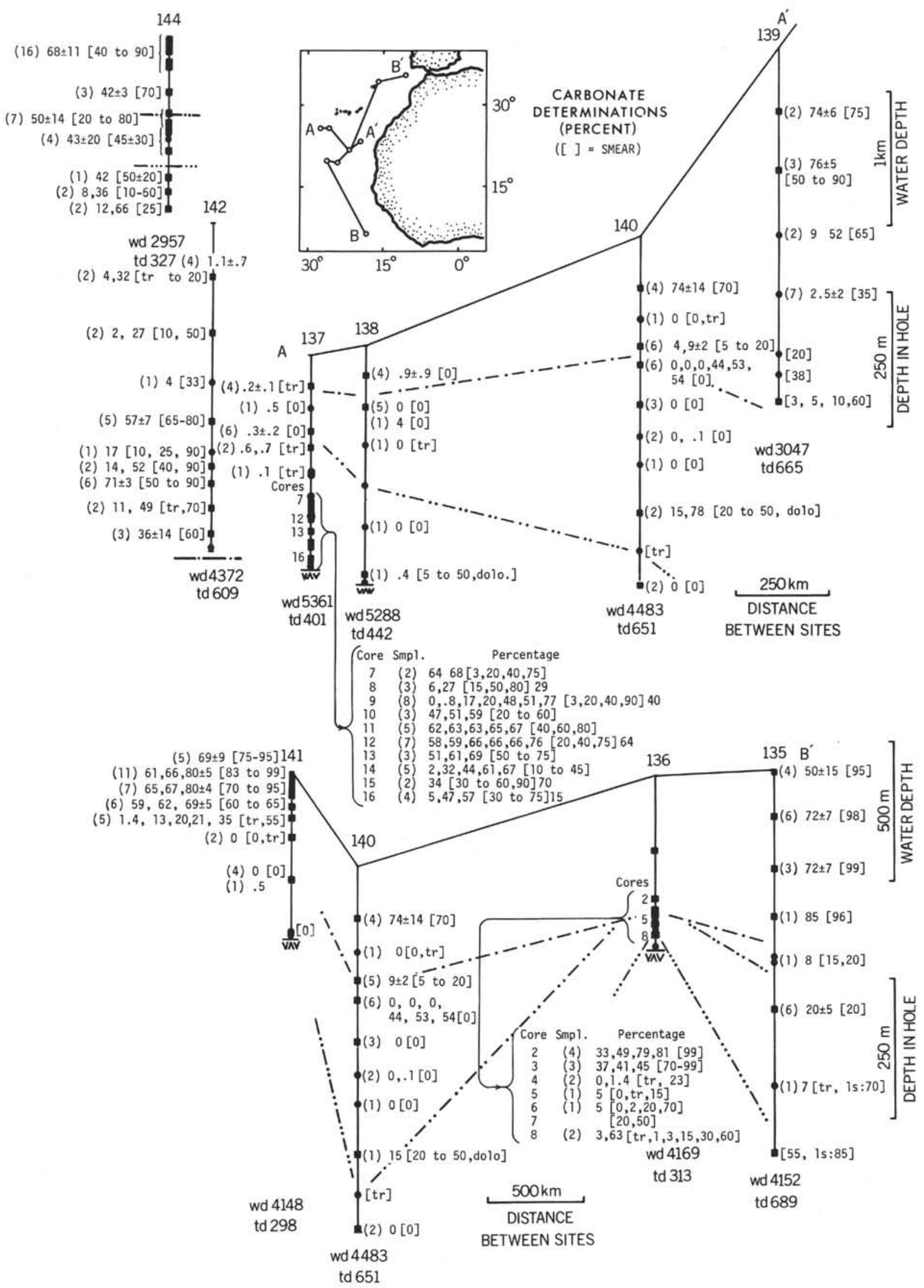

Figure 33. Distribution of carbonate in percent of total sediment (DSDP laboratory analyses and 12 analyses from BfB, Hannover). Smear-slide determinations refer to silt fraction, mainly. 
135-9-1,99-109 cm (Aptian)

greenish-gray quartzose recrystallized limestone

$\underline{\curvearrowleft}$

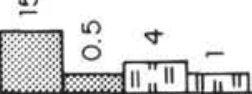

N

(x)

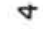

136-8-2, 27-30 cm (Aptian)

gray nanno marl mud

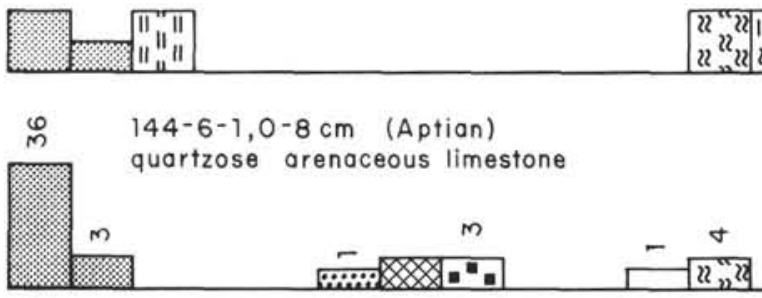

135-8-1, 129-132 cm (Cenomanian)

greenish-white recrystallized spherulitic limestone

\begin{tabular}{|c|c|c|c|}
\hline (م) & $m$ & ம & in \\
\hline $8 \times$ & $11 "$ "I & x & $22 \pi$ \\
\hline
\end{tabular}

137-12-5,147-150 cm (Cenomanian)

greenish-gray nanno chalk ooze

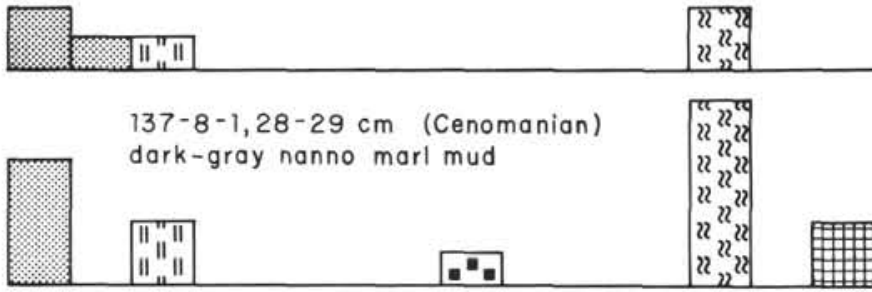
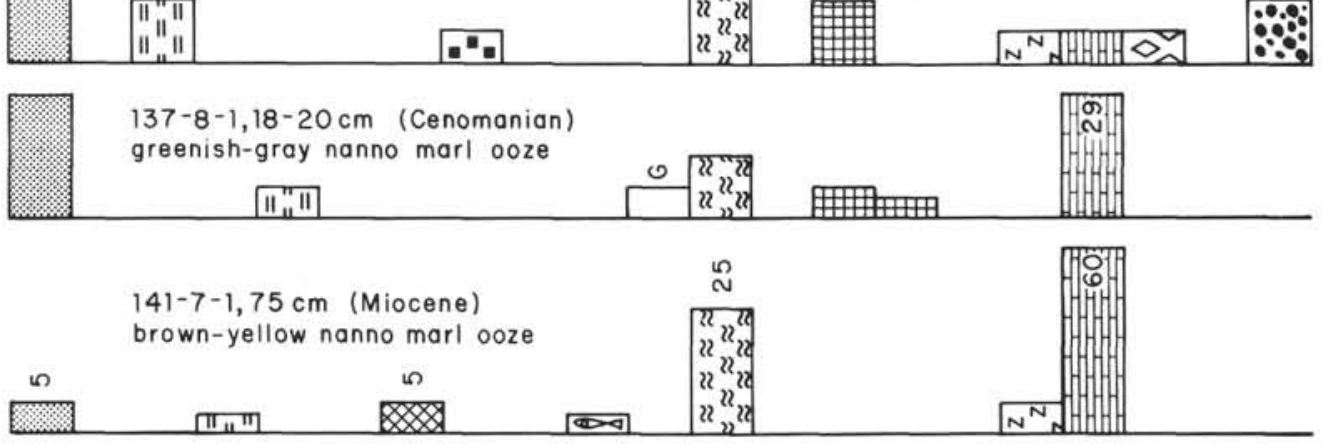

141-6-4, $92 \mathrm{~cm}$ (Pliocene)

light brown nanno chalk ooze

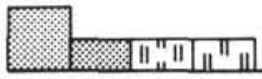

\section{ma".} $\mid$\begin{tabular}{c|c} 
TERRIGENOUS COMPONENTS & MOSTLY SECONDARY \& AUTHIGENIC \\
MINERALS & $\begin{array}{c}\text { CARBON } \\
\text {-ATES }\end{array}$ 吕IOTHER \\
BIOGEN
\end{tabular}

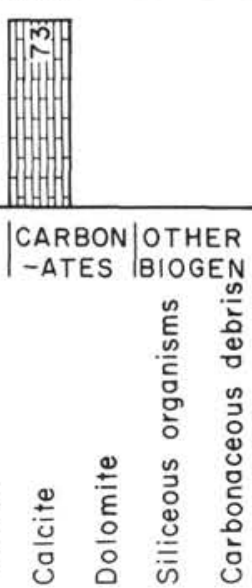

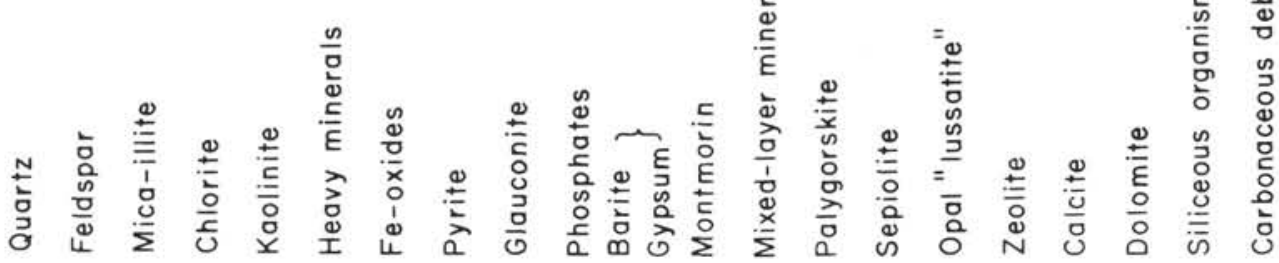

Figure 34. Composition (semi-quantitative) of 9 representative foraminiferal nanno chalk/ marl oozes and limestone samples. 
Virtually all carbonate in the Neogene oozes at 135 , $136,139,140$ and 141 is derived from nannofossils and planktonic foraminifera which also furnish, by inference, most unidentifiable calcite crystal grains. Although the Neogene oozes are generally white or light gray, noncalcareous components give them a brownish or greenish hue, making it possible to distinguish oxidized and reduced facies. The light olive gray ooze at $139-1$ had a strong $\mathrm{H}_{2} \mathrm{~S}$ odor; the deeper cores also contain reduced sediments. Site 140 chalk ooze is apparently slightly reduced, whereas the one at Site 136 is well oxidized, suggesting relatively low fertility. The oozes at 135 are, in general, oxidized but less so than those at 136 (see Figure 25). Site 141 shows a sequence from mixed oxidation-reduction to greater oxidation toward the deeper, more slowly accumulating, strongly dissolved carbonates.

The near-continent Paleogene slope oozes at Site 144 are distinctly reduced similar to the Neogene slope oozes at 139. The oozes at 142 , apparently in large part displaced, are both reduced (Cores 2, 6, 7, 8) and oxidized (Cores 4, $6,7,8$ ). The calcareous muds at this site (Cores 2, 3,6,9) are reduced, as are the Cretaceous muds at Site 144. The Cretaceous oozes at Site 137 alternate between greenish and brownish hues. The Aptian nanno oozes at 135 and 136 are olive and black.

\section{Texture of Calcareous Oozes}

Some remarkable features of sand-silt-clay proportions in Neogene chalk and marl oozes are: (1) In a large number of samples, silt is somewhat less than one-half of the clay fraction. Notable exceptions are the chalks at Site 135, which have unusually high clay fractions in Quaternary, Pliocene and Miocene deposits. (2) Sand content is a function of foraminiferal content and varies considerably ( 0.5 to $18 \%$ of total). The highest values are at Site 141 ; the lowest ones at Site 136 and in Miocene chalks of Site 135. (3) Except for sand content, which correlates with the foram percentages, texture is remarkably independent of other sediment properties, such as percent carbonate, foram solution number, age, and sedimentation rate (see Table 7). (4) As a consequence of this independence, Neogene chalk and marl oozes form clusters on the basis of texture, which are entirely tied to sites, rather than to age, rate of deposition or percent carbonate. Dissolution influences the clustering only when extreme $(\mathrm{FS}=6.7 .5$; type $\mathrm{D}$; see Table 8).

The great similarity of texture between samples of the same core also is noteworthy (Figure 35) although on occasion there are distinct foram layers. The Cretaceous calcareous oozes at Site 137 are also of very homogeneous texture despite differences in sediment coloration and in preservation of foraminifera. Sand content is extremely low, most foraminifera are in the coarse silt fraction. Higher sand values in the deepest cores appear due to difficulties in segregating the original particles making up the sediment and probably have no bearing on the original texture of the ooze.

Aggregates which were undispersed even after several hours of treatment with buffered hydrogen peroxide, were noted in this Cenomanian nannofossil marl ooze, and elsewhere. The clasts consist mostly of slightly silicified
TABLE 7

Comparison of Neogene Chalk and Marl Oozes (Average Values)

\begin{tabular}{|c|c|c|c|c|c|c|c|c|}
\hline Core & Age & $\begin{array}{c}\mathrm{CaCO}_{3} \\
\text { Per } \\
\text { Cent }\end{array}$ & $\begin{array}{l}\text { Sand } \\
\text { Per } \\
\text { Cent }\end{array}$ & $\begin{array}{c}\text { Silt } \\
\text { Per } \\
\text { Cent }\end{array}$ & $\begin{array}{l}\text { Clay } \\
\text { Per } \\
\text { Cent }\end{array}$ & $\begin{array}{l}\mathrm{F} /(\mathrm{N}+\mathrm{F}) \\
\text { Per Cent }\end{array}$ & FS & $\begin{array}{c}\text { Sed. } \\
\text { Rate } \\
(\mathrm{m} / \mathrm{My})\end{array}$ \\
\hline $135-1$ & Quat. & $50 \pm 15$ & 4.0 & 17 & 79 & 8 & 4.0 & 20 \\
\hline $135-2$ & Plio. & $72 \pm 7$ & 2.7 & 21 & 76 & 3 & 4.5 & 20 \\
\hline $135-2$ & Mio. & $74^{\mathrm{a}}$ & $4.0^{\mathrm{a}}$ & $22^{\mathrm{a}}$ & $74^{\mathrm{a}}$ & 3 & 4.5 & 20 \\
\hline $135-3$ & Mio. & $72 \pm 7$ & 0.5 & 29 & 71 & 1 & 6.0 & 20 \\
\hline $135-4$ & Mio. & $85^{\mathrm{a}}$ & 0.6 & 29 & 70 & 3 & 6.5 & 15 \\
\hline $136-1$ & Plio. & $87 \pm 4$ & 0.5 & 36 & 63 & 2 & 6.5 & 20 \\
\hline $136-2$ & Mio. & $33-81$ & 0.6 & 33 & 66 & 2 & 7.0 & 7 \\
\hline $136-3$ & Mio. & $37-45$ & 0.3 & 27 & 73 & 0 & 7.5 & 6 \\
\hline $139-1$ & Plio. & $74 \pm 6$ & 4.0 & 30 & 67 & 20 & 4.5 & 45 \\
\hline $139-2$ & Plio. & $76 \pm 5$ & 5.0 & 28 & 67 & 16 & 5.5 & 35 \\
\hline $139-3$ & Mio. & $\sim 60^{\mathrm{a}}$ & 1.4 & 25 & 74 & 13 & 5.0 & 100 \\
\hline $141-1$ & Quat. & $69 \pm 9$ & 18.0 & 25 & 58 & 45 & 4.5 & 8 \\
\hline $141-2$ & Plio. & $61-85$ & 15.0 & 27 & 59 & 55 & 4.5 & 15 \\
\hline $141-3$ & Plio. & $66-86$ & 13.0 & 34 & 54 & 30 & 5.0 & 15 \\
\hline $141-4$ & Plio. & $84^{\mathrm{a}}$ & 14.0 & 34 & 52 & 40 & 5.5 & 15 \\
\hline $141-5$ & Plio. & $65-84$ & 6.0 & 34 & 60 & 30 & 5.5 & 15 \\
\hline $141-6$ & Plio. & $59-74$ & 0.6 & 27 & 72 & 15 & 6.0 & $\sim 8$ \\
\hline
\end{tabular}

${ }^{\mathrm{a} O n e}$ sample only.

TABLE 8

Kinds of Neogene Chalk and Marl Oozes

A. Foraminiferal ooze, $\mathrm{F} /(\mathrm{N}+\mathrm{F})>30 \%$, sand $>1 \%$. Site 141 , Cores 1 to 6 .

Age: Quaternary to Pliocene; Preservation: FS $=4$ to 6 , sand, 6 to $18 \%$; silt 25 to $43 \%$; clay, 52 to $60 \%$. $\mathrm{CaCO}_{3}: 65$ to $85 \%$. Sedimentation rates: 8 to $15 \mathrm{~m} / \mathrm{My}$.

B. Foram-rich ooze, $\mathrm{F} /(\mathrm{N}+\mathrm{F})=10$ to $20 \%$, sand $>1 \%$. Site 139 , Cores 1 to 3 .

Age: Pliocene to Miocene; Preservation: FS $=4.5$ to 6 , sand, 1.4 to $5 \%$; silt, 25 to $30 \%$; clay, 67 to $74 \%$. $\mathrm{CaCO}_{3}: 60$ to $80 \%$. Sedimentation rates: 35 to $100 \mathrm{~m} / \mathrm{My}$.

C. Low foram ooze, $\mathrm{F} /(\mathrm{N}+\mathrm{F})=3$ to $9 \%$, sand $>1 \%$. Site 135 , Cores 1 and 2.

Age: Quaternary, Pliocene, Miocene; Preservation: FS $=3$ to 5 ; sand, 2.7 to $4 \%$; silt, 17 to $22 \%$; clay, 74 to $79 \%$. $\mathrm{CaCO}_{3}: 40$ to $80 \%$. Sedimentation rates: $20 \mathrm{~m} / \mathrm{My}$.

D. Foram-poor ooze, $\mathrm{F} /(\mathrm{N}+\mathrm{F})<1 \%$. Sites 135 , Cores 3 and 4 ; Site 136, Cores 1 to 3 ; Site 141, Core 6 (conditional, F are mostly silt-sized fragments).

Age: earliest Pliocene to Miocene; Preservation: FS $=6$ to 7.5 ; sand, 0.3 to $0.6 \%$; silt, 27 to $36 \%$; clay, 63 to $73 \%$. $\mathrm{CaCO}_{3}: 30$ to $90 \%$. Sedimentation rates: 6 to $20 \mathrm{~m} / \mathrm{My}$.

marlstone of various colors. Generally, calcareous oozes rich in siliceous fossils tend toward much greater lithification than non-siliceous calcareous oozes and this lithification may pose problems in textural analysis.

A graphic portrayal (Figure 36) of silt and sand sedimentation rates versus clay sedimentation rates summarizes the textural features discussed, especially the high fidelity of textural aspects within the same site. Arrows indicate how various processes are expected to influence the ratio of sand sediment rate to clay sediment rate, suggesting that deposits at Site 141 (1-4) are winnowed, those at 141-6 and 136-1 are highly dissolved, those at Site 135 indicate low fertility, and those at $139-3$ are redeposited sediments with a high admixture of fines. 


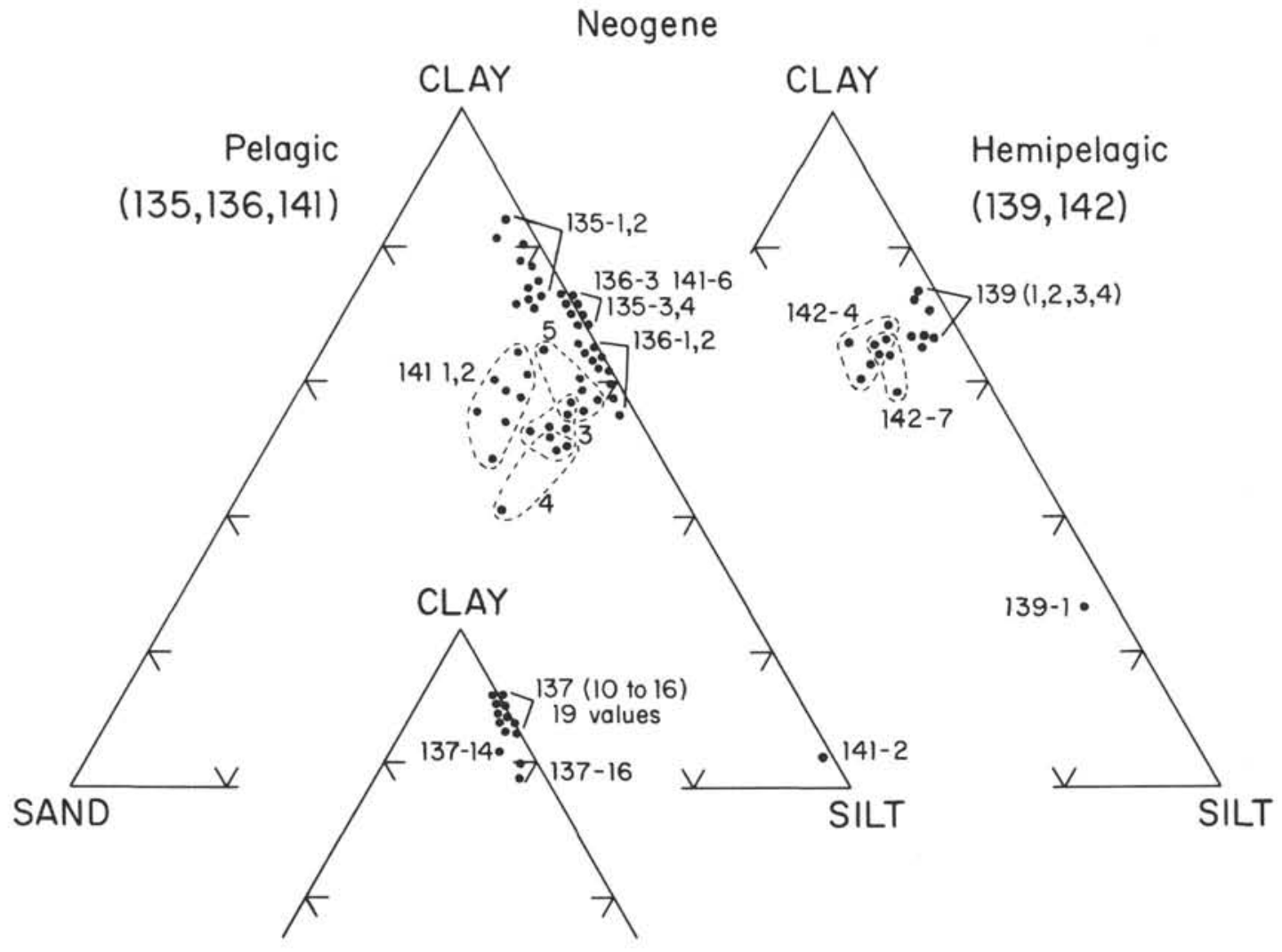

Cretaceous

Figure 35. Texture of Neogene pelagic and hemipelagic calcareous oozes and of Cretaceous pelagic calcareous oozes (chalk and marl). Note clustering of values according to sites and cores, indicating local control.

\section{Composition of Calcareous Oozes}

The major components of chalk and marl oozes comprise foraminifera and foraminiferal fragments (sand and coarse silt), and nannofossils and undifferentiated calcite crystallites (fine silt and clay). Foraminiferal proportions are usually quite low in pelagic chalks and marls both in the Neogene and the Cretaceous (Figure $37 ; \mathrm{A}, \mathrm{C}$ ). A striking exception is the sequence at Site 141, interpreted as winnowed chalks on the basis of comparison with Site 139 which shows similar foraminiferal sedimentation rates but higher nannofossil rates. The Paleogene marl/chalk oozes at Site 144 also have a high foraminiferal content (Figure 37; B), likewise interpreted as a winnowing effect, as suggested by the sedimentation rate of $5 \mathrm{~m} / \mathrm{My}$, which is low for this facies,

The high proportions of nannofossils in the cores of Sites $135,136,137$ and 139 are puzzling in view of the relatively low proportions usually ascribed to nannofossils in Quaternary pelagic chalk oozes. For example, McIntyre and McIntyre (1971) report values near 30 per cent for modern, presumably undissolved, ridge chalks below the subtropical South Atlantic gyre. Earlier, Bramlette (1958) drew attention to this problem, pointing out that coccoliths are more abundant than foraminifera in Tertiary calcareous oozes, whereas they play a subordinate role in Quaternary ones. Olausson (1961b) suggested several possible mechanisms to account for high nannofossil proportions: The relative importance of the autotrophic coccolithophorids increases when going from a more fertile to a less fertile region, consequently (1) dominance of nannofossils may indicate low productivity conditions. In the southeast Atlantic, coccolithophorids are much more abundant (than foraminifera) within Angola and Cape Basin than on either Mid-Atlantic or Walvis Ridge. The higher proportion of coccoliths at depth suggests that (2) forams dissolve more readily than nannofossils, or that (3) many more coccoliths than forams are moved downslope by near bottom current transport, leading to foraminiferal enrichment on ridges and coccolith enrichment in basins.

Leg 14 deep-sea carbonates offer evidence for the operation of all three of these mechanisms, differential productivity, differential dissolution and differential transport. Sites 135 and 136 lie at the eastern boundary of the sterile North Atlantic subtropical gyre, between upwelling regions to the north, off Iberia, and to the south off Morocco. The oozes at 136 show considerable dissolution (FS $>6$ ) and high nanno proportions may reflect removal of forams, rather than low fertility. However, 135-1 has rather well preserved foram faunas (FS 4) so that coccolith enrichment by dissolution appears to be excluded in the Quaternary sediment. Also, Site 135 was drilled on a topographic high, about 750 meters above the abyssal plain, and any bottom current action should have concentrated foraminifera by winnowing (as in Site 141) rather than enriching the sediment with coccoliths. 


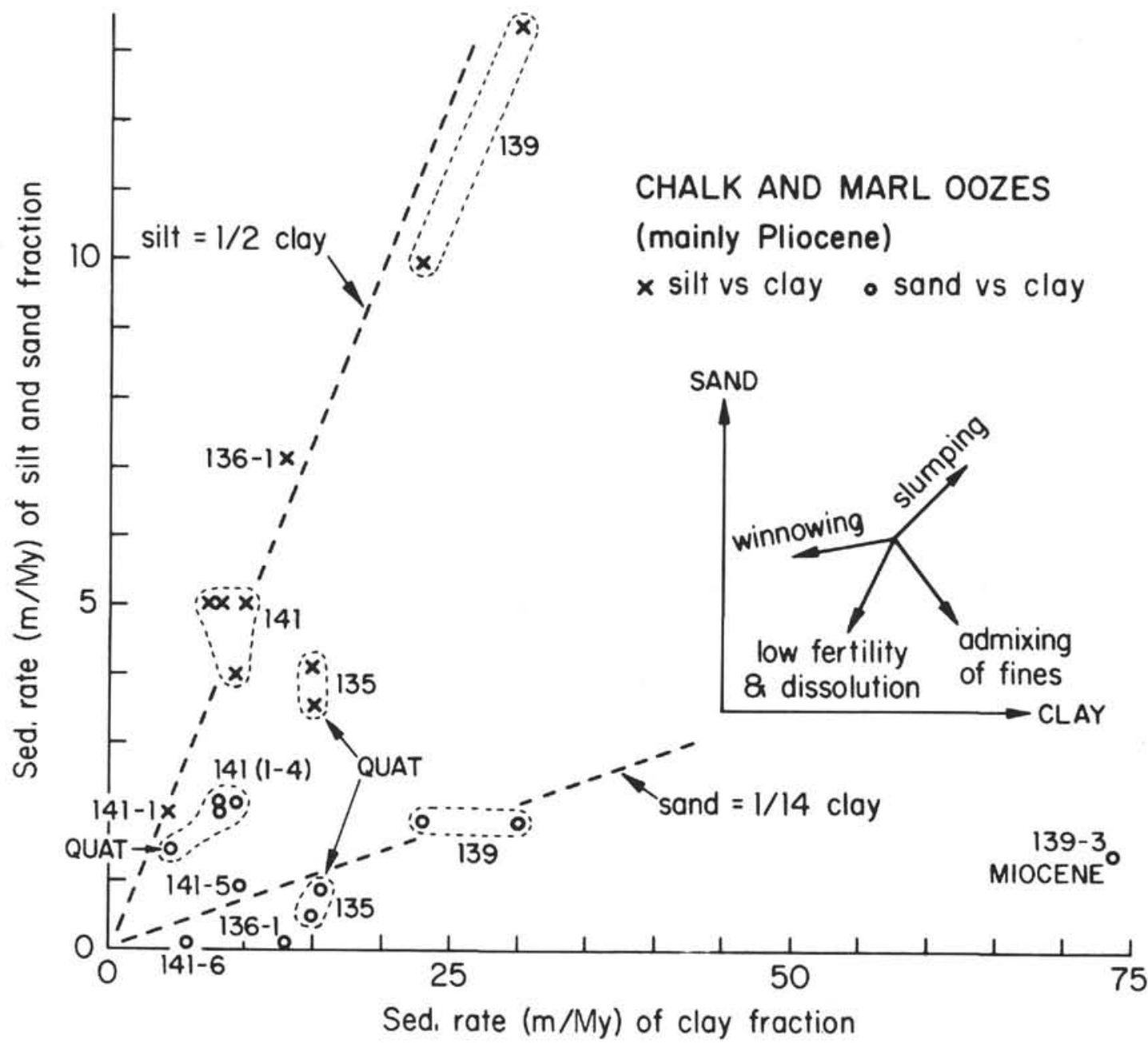

Figure 36. Sedimentation rates (drill depth intervals/bioage differences $X$ per cent fraction) of sand and silt fractions compared with clay fractions. Anticipated directions of movement of a sand $v s$ clay point in response to various processes are suggested in inset graph.

The Quaternary chalks at Site 135 are extremely "clean," all noncalcareous matter is in the clay fraction. There are no fertility indicators such as siliceous skeletons or fish teeth. Organic carbon content also is very low $(0.2 \%)$. Influence of the "low fertility" factor also is suggested by the high abundance of Globigerinoides ruber in the sediment. This species is typical of the sterile North Atlantic subtropical gyre (e.g. Ruddiman, 1969).

The chief difficulty in explaining the high coccolith proportions of these Quaternary chalks by low fertility alone is the relatively "normal" sedimentation rate of 20 $\mathrm{m} / \mathrm{My}$. However, subtracting the noncalcareous fraction (50\%), leaves a calcite supply rate of $10 \mathrm{~m} / \mathrm{My}$, corresponding to less than $1 \mathrm{~g}$ per $\mathrm{cm}^{2}$ per $1000 \mathrm{yrs}$. A slight upward adjustment for greater dissolution of these chalks than those above 4000 meters depth beneath the North Atlantic gyre makes this rate about $1 \mathrm{~g} / 1000 \mathrm{yrs}$, comparable to rates beneath the North Atlantic gyre (Turekian,
1965 ; p. 102). Unless an additional factor is operative the high nannofossil proportions, or conversely the low foram percentages of less than 10 in 135-1, must be considered "normal" for these oozes generated below waters of low fertility. In the deeper Neogene samples at this site, dissolution further reduces the foram proportions, but it also increases the proportion of undifferentiated fragments (Figure 36, N-facies).

To what extent can low fertility be invoked to "explain" high nannofossil proportions elsewhere? At Site 139, off Cape Blanc, coccoliths are also much more abundant than forams (Figure 36), although the difference is not as great as at Site 135. Disregarding, for the moment, the Miocene chalks which are quite strongly dissolved (FS 5), we find that Core 139-1 shows intermediate dissolution (FS 4.5) and also contains diatoms and much carbonaceous matter $(>0.5 \%)$, indicating high productivity and rapid rates of burial. A strong $\mathrm{H}_{2} \mathrm{~S}$ odor was noted upon cutting this core. 


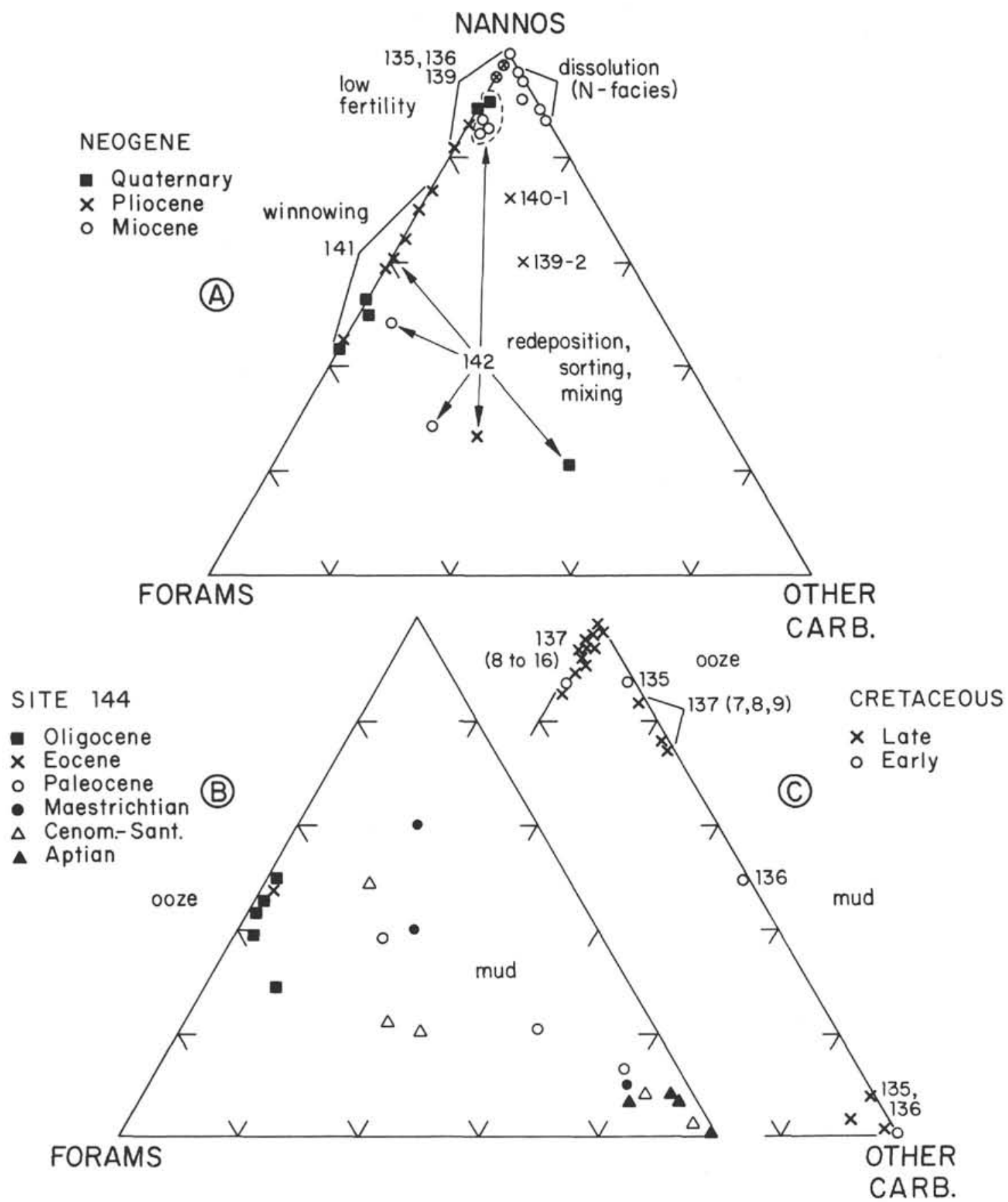

\section{$\begin{array}{llll}\text { A) Neogene } & \text { B) Site } 144 & \text { C) Cretaceous, except } 144\end{array}$}

Figure 37. Composition of chalks and marls, with respect to calcareous nannofossils, planktonic foraminifera, and undifferentiated other carbonate (finely triturated "flour", shallow water carbonates, detrital fragments). Suggested explanation for variations include fertility, winnowing, dissolution ( $N$-facies: foram tests destroyed), redeposition, sorting, mixing. Note the clustering of points for specific sites, indicating strong local control over long period of time.

Therefore, neither low fertility nor dissolution can be made responsible for the high nannofossil and low foram proportions. Admixing of fines (the nanno concentration mechanism of selective transport) also seems unlikely, since the site lies on a smooth slope and any coccolith influx would have to come from places even closer to the continent with consequently stronger influence of upwelling. Again, the high nanno-to-foram ratio would appear to present the "normal" situation, based on relative supply. Foram proportions are, however, twice those at 135-1, possibly reflecting the increased fertility. If our reasoning is correct, the low nanno proportions in Quaternary sediment 
in general, and at Site 141 in particular, constitute a deviation from the norm which needs additional explanation.

Considering Leg 14 evidence, changing supply patterns through differential production appear insufficient to account for much variability of nannofossil/foram ratios, while effects of selective destruction of forams before nannos appear obvious only in badly dissolved oozes. A very efficient mechanism for changing $\mathrm{N} / \mathrm{F}$ ratios appears to be size sorting by bottom currents, including turbidity currents (Site 142). Fertility patterns influence this mechanism to the extent that benthonic organisms tend to resuspend fines so they can be carried to a more "quiet" environment. Such a mechanism would work rather independently of purely physical relationships between cohesiveness and texture of sediment, current strength, and bottom roughness. Any long distance redeposition is more likely to involve fine material, such as nannos rather than coarse material such as forams. Therefore, forams should tend to form in situ lag deposits whereas nannos should tend to resettle elsewhere. This greater mobility of nannofossils is indicated, for example, by the frequency of contamination of younger deposits by older nannofossils. Suspended sediment increases the density of the suspension, thus, any transport on the ocean floor makes it likely for a particle to come to rest at a place that is deeper than the one it started from. Being more susceptible to resedimentation, coccoliths, therefore, have a greater chance than forams of arriving at depths where they dissolve.

In conclusion, at times when redeposition processes on the ocean floor are most active due to high fertility (engendering benthic activity) and strong bottom circulation (providing for transport), foraminiferal content of calcareous oozes is likely to be high, because of the removal of coccoliths to greater depths where they dissolve. According to this conceptual model, high nannofossil proportions and very low foram percentages in the ridge chalks at Site 137 indicate that redeposition by a combination of benthic activity and bottom circulation was absent on the Cenomanian Ridge. Fine layering, lensing, and laminations in various parts of these sediments also point to subdued benthic activity.

Minor components of calcareous oozes include terrigenous minerals, ferromanganese oxides, pyrite, glauconite, zeolite, authigenic carbonate ("dolomite" rhombs), fish debris, undifferentiated calcareous fragments, siliceous fossils, and carbonaceous matter (see Appendix 5). The decalcified clay fraction is characterized by abundant smectite, quartz, mica, kaolinite, and palygorskite. The distribution of all these components, except calcareous fragments and calcite "flour," is rather independent of that of carbonate, which merely acts as a dilutant (see sections on individual components, pelagic clays).

\section{Distribution and Composition of Unconsolidated Calcareous Muds}

According to the classification adopted, the calcareous (chalk or marl) muds are those sediments that have more than 30 per cent $\mathrm{CaCO}_{3}$ and more than 25 per cent terrigenic, volcanogenic, and/or neritic components in the silt plus sand fraction. Unconsolidated calcareous muds are common at Site 142 (Cores 2-6) within a flysch-like Neogene sequence characterized by nanno marl mud, calcareous ooze, terrigenous and bioclastic turbidites, and (hemi-) pelagic clays. All other occurrences of calcareous muds are of Cretaceous age and are more or less lithified (except for some examples at Site 144).

Calcareous muds tend to be reduced (greenish) rather than oxidized (brownish) wherever they occur. Texture and composition vary greatly and depend mainly on sources, degree of dissolution and sorting, and recrystallization. The range of variation within the Neogene deep-sea muds at Site 142 may be illustrated by a typical sequence of intercalated graded foram-rich layers and clayey nanno marl mud (Plate 23). A graded bed, interpreted as a bioclastic turbidite, occurs at $142-6-2-140 \mathrm{~cm}$. Silty foraminiferal sand at the base grades into foram silt and nanno foram mud. The median size decreases upward, the more heavy shells and shell fragments being found near the base. The proportion of sand does not decrease regularly in the lower part of the bed. This probably simply reflects differences in hydraulic equivalence between the sand particles, that is, basal sand particles tend to be solid (note molluscs) while the superjacent ones are enriched in the lighter kinds of foraminifera. Changes in foraminiferal composition can also explain the constancy of the maximum grain size. The composition as a whole indicates a mixture of pelagic, neritic, and terrigenous matter in this Late Miocene sequence. In the adjacent Core 5 (Early Pliocene), there is an example of interlayering of terrigenous and foraminiferal sand, with the terrigenous layer bearing forams and nannos but the foraminiferal one having only traces of quartz besides appreciable neritic material. Without information on the lateral extent of the sands it is difficult to decide whether the foraminiferal turbidites came from the same direction as the terrigenous ones (i.e. from the Amazon shelf, with shelf and slope sediments being admixed) or whether they are largely derived from the pelagic realm (e.g. from the Ceara Rise).

\section{Lithified Calcareous Sediments}

All gradations occur between unconsolidated calcareous muds and oozes and their lithified counterparts: calcareous mudstone, marlstone and limestone (Figure 38). Except for the Neogene sequence at Site 142, lithified calcareous muds and limestones are of Cretaceous age (see Figures 22 and 34). Lime- and marlstones are characteristic of flysch-like sequences (Site 142, Neogene; Site 135, Late Cretaceous) and of the Cretaceous shelf-slope sequence at Site 144. The composition of selected samples is given in Appendix 5 . Slightly silicified calcareous ooze was discussed above (see section on texture of calcareous ooze). The following remarks pertain mainly to lithified sediments with redepositional aspects.

Consolidated calcareous muds and oozes in which compaction by overburden pressure appears to play the major role in lithification are typical for Site 142. Shipboard penetrometer measurements help to give a rough estimate of the degree of consolidation. According to a scale of consolidation proposed by Beall and Fischer (1969, p. 579), "unconsolidated" sediments have penetrometer values of more than $30(=3.0 \mathrm{~mm}$ needle penetration $)$, 


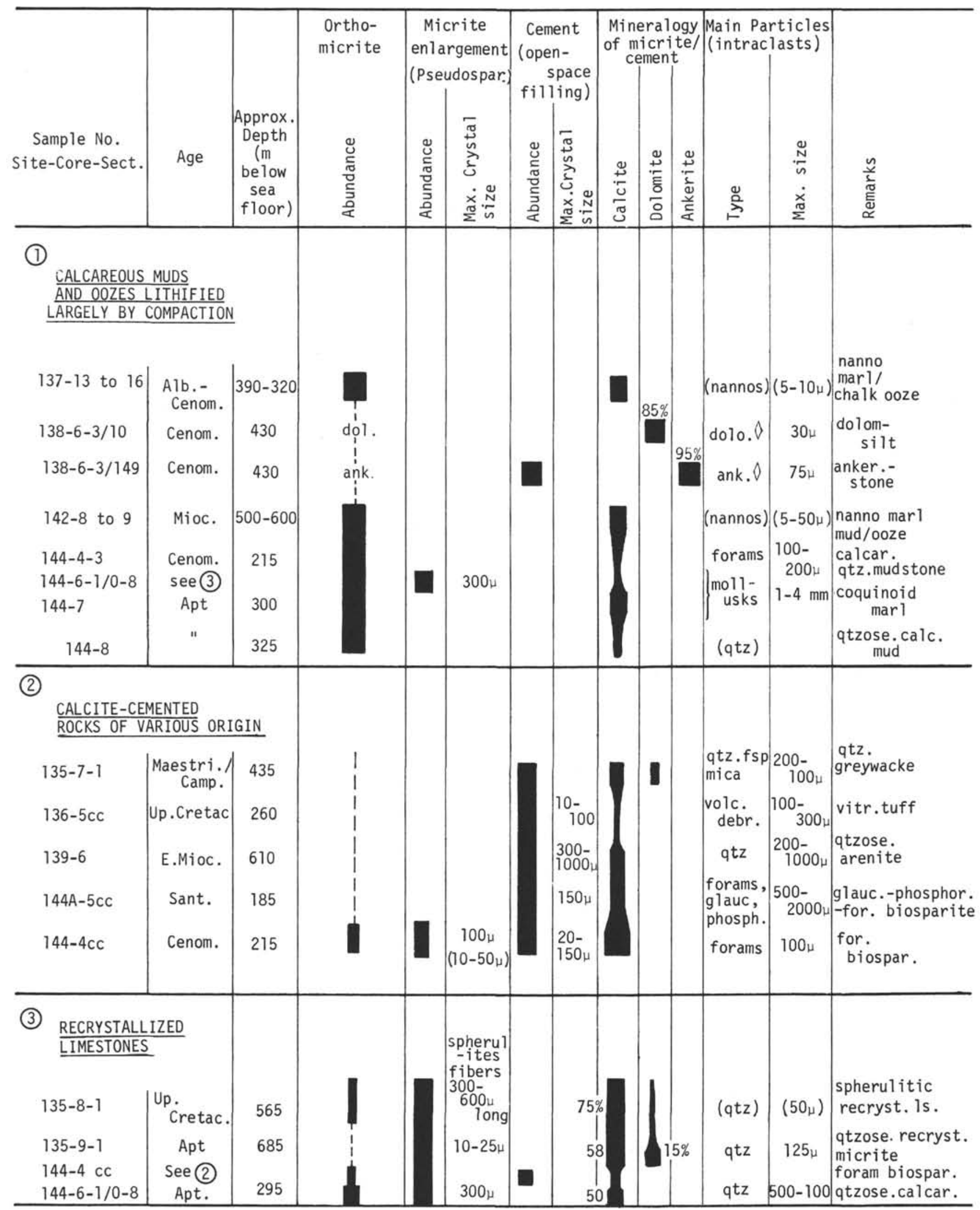

Figure 38. Various characteristics of carbonate rocks. The rocks are grouped according to the inferred main diagenetic mechanisms which lead to lithification: compaction, grain growth (micrite enlargement) and cementation. The separations are not always clear-cut, thus, two samples (144-4cc and 144-6-1) appear each in two of the three genetic groups. 
"semiconsolidated" ones of between 10 and 30 , and "consolidated" ("indurated") sediments of less than 10 units. The boundary between un- and semiconsolidated sediments lies at a depth of between 100 and 200 meters in most sites, more or less independently of age. The depth below which consolidated sediments occur is approximately 300 meters, but at Site 142 this boundary is somewhat deeper, possibly due to the extremely high PliocenePleistocene sedimentation rates.

At Site 142 Cores 2 and 3 contain calcareous muds, interbedded with feldspar-rich quartz graywackes, silty clays, and displaced, graded, partly muddy foram-nanno layers of Quaternary age. The unconsolidated Pleistocene calcareous muds have porosities of about 50 per cent. Middle Pliocene to Early Pleistocene calcareous muds, marl and chalk oozes of Site 142 are semiconsolidated and have porosities between 40 and 45 per cent. Miocene to Middle Pliocene foram-nanno marl oozes and nanno marl muds of the same site are well consolidated and have minimal porosities of 30 per cent. Consolidation of the relatively young, deeply buried oozes may be largely due to compaction by the lithostatic pressure of overlying sediments. In addition, the fact that large amounts of calcareous matter were redeposited in water depths at which calcite dissolved may be important in explaining the consolidation processes at Site 142. Due to the sudden and ample introduction of carbonate, dissolution was incomplete, and partial calcite solution and reprecipitation may have contributed to lithification as suggested by overgrowth on coccoliths (Fig. 12). As overburden grain contact pressure increased, tangential welding also may have contributed.

Calcareous muds and various kinds of lithified marls and limestones are abundant in the mid-Eocene to Cretaceous parts of the sequence at Site 144 (Appendix 5). There is a successive change from younger beds rich in zeolite, nannofossils, and planktonic foraminifera to older beds rich in quartz and mollusc fragments. The succession apparently is a record of depth-controlled facies from deep to shallow, but associated sediments suggest that the limestones themselves derive from redeposition. This reflects a deepening of the source areas during subsidence of Site 144.

The Aptian limestones in 144-6 and 144-7 are distinctly quartzose and rich in remains of gastropods, pelecypods and other shallow water skeletal debris (Plate 25, Figs. 5-8). At 144-6 a number of thin $(5-10 \mathrm{~cm})$ coquinoid marlstone beds are interlayered with marlstone and calcareous silty mudstone. The shelly ("coquinoid") marl(stone)s apparently are one end member of a facies spectrum characterizing the Aptian sequence. The other extreme type is the quartzose and pyritic carbonaceous clay in core 7 , which is interpreted as the "deepest" facies reflecting in situ deposition. Most of the other sediments in cores 6,7 and 8 may be considered mixtures of these two types. A well sorted quartzose calcarenite from 144-6 is figured (Plate 25, Figure 5). It consists of 36 per cent angular quartz $(50-100 \mu), 3$ per cent feldspar, 3 per cent pyrite spherules and cubes, carbonaceous plant fragments, reworked clay fragments, and 50 per cent granular calcite with irregular borders $(10-100 \mu, \max .300 \mu)$. This calcite is recrystallized clay-rich micrite ("pseudo-sparite"), and the limestone has experienced grain growth by micrite enlargement. A micritic limestone from 144-7 (Plate 25, Figs. 7, 8) consists of mollusk shells (38\%); a very fine-grained mixed clay $(24 \%)$; calcilutite $(18 \%)$; matrix, rich in iron oxides $(12 \%)$, and quartz (7\%). The coquinoid marlstone is irregularly layered and occurs between quartzose carbonaceous clay (above) and a chaotic mixture of clay and shell (below) which rests in turn on layered, burrowed claystone with shell fragments. The chaotic mixture may be due to slumping and other redeposition processes, with the coquina on top being a lag deposit due to winnowing. An explanation of the alternation between carbonaceous clays and shelly limestone involving transgression-regression cycles in the hinterland is also conceivable, but such cycles appear less likely than redeposition.

Calcite-cemented rocks of various origins occur as all kinds of arenites (graywackes, quartz sandstone, tuffs, glauconite-phosphorite biosparite, foraminiferal calcarenite) in which calcite cement fills the open pore space. The upper part of a graded graywacke-type sand layer in core $135-7$ is cemented by calcite. Well sorted quartz-arenites at Site 139-6 contain 30 per cent clean macrocrystalline $(300-1000 \mu)$ calcite cement (Plate 35, Figure 3). The large calcite crystals envelop several quartz grains and show straight crystal boundaries with "enfacial" (triple) junctions. This suggests open-space filling by competitive growth (Bathurst, 1971, p. 452). A vitreous tuff (136-5cc) is cemented by microcrystalline calcite $(\max .100 \mu)$ (Plate 41 , Figure 7). The most striking example of an allodapic limestone found on Leg 14 is the dark grayish olive green, glauconite, phosphorite and pyrite-rich foraminiferal biosparite of Santonian age at $144 \mathrm{~A}-5$ (Plate 24). It is intercalated in laminated calcareous zeolitic sapropelite. Pointcount analysis of a thin section gave 46.6 per cent sparry cement, 12.1 per cent small planktonic foraminifera (Hedbergella, Heterohelix sp.), 24.2 per cent bright green round, lobate "glauconite" grains (with calcite- and pyritefilled dessication cracks) and broken pellets (foram casts), 11.1 per cent phosphates (fish teeth and bones, organic apatite, collophane, dahlite, etc.) and 5.6 per cent tiny framboidal pyrite spherules. Phosphates consist of: (a) sharp, broken fragments of fish vertebrae and teeth (with preserved canules, etc.), (b) reddish brown fish-scales, (c) brownish collophane pellets and spherules, and (d) microfibrous francolite, or dahlite, as diagenetic recrystallization products of collophane (faint birefringence). Almost all foraminiferal tests are filled with either single or multiple anhedral calcite crystals. Also, the micro- to macrocrystalline (20-150 $\mu)$ sparry calcite appears to be a genuine (secondary) chemical cement, precipitated in situ from interstitial solutions and filling the open pore space between the sand grains. The coarseness of the glauconite and phosphate grains, the good sorting of the foraminifera, and the lack of any clay matrix suggests winnowing of fines by bottom currents in the source area (? outer shelf) or at the site of deposition (? upper slope).

Fine laminated marlstones with coarse-grained foram layers and dark fine-grained layers were noted throughout the Late Cretaceous section at Site 144 (see Plate 25, Figure 1; Plate 7, Figure 6). The core catcher of 144-4 contained a well cemented, slightly argillaceous foraminiferal biosparite. It is finely laminated $(0.5$ to $1 \mathrm{~mm})$, with 
alternations of grain supported foraminiferal laminae $(50-150 \mu)$ and micrite to (pseudo-) sparite. The foraminifera are filled with large calcite crystals $(20-150 \mu)$. The dark laminae are iron rich and appear to consist largely of a mixture of fine-grained calcite with traces of clay. The sparite with a size range $10-20 \mu(\max .100 \mu)$, is probably recrystallized from fine-grained carbonate particles ("pseudosparite"). The laminae are lensy, neither sharply defined nor continuous. In view of the apparently excellent foram preservation, solution and reprecipitation of calcite seems less likely than crystal growth into a void, as an explanation for the sparite-filled forams. The laminae appear to have been formed by gentle bottom current shear which produced a segregation of grain sizes. Original emplacement of the foram rich layers at this site, where calcareous sapropelites accumulated, may have been by suspension currents from shallower depths. Alternatively, the limestones may be lag deposits due to winnowing.

Recrystallized Cretaceous limestones show two types of recrystallization fabrics: (1) formation of neomorphic "pseudosparite" by micrite enlargement, and (2) formation of a spherulitic texture of fibrous replacement calcite. Some examples of limestones with a slightly recrystallized ("pseudosparitic"), originally cryptocrystalline calcite matrix, have been described above (e.g. foraminiferal biosparite of 144-4cc, quartzose calcarenite of 144-6). Typically, the neomorphic spar contains floating relicts of micrite and clay, and has irregular, curved intracrystalline boundaries (see Chilingar et al., 1967; Füchtbauer and Müller, 1970, p. 355; Bathurst, 1971). A typical example of this group is the quartzose and dolomitic, micritic limestone at Site 135-9 (Aptian). This greenish gray limestone bed is $13 \mathrm{~cm}$ thick and contains 15 per cent quartz, 5 per cent mica-chlorite, and 74 per cent carbonate (Appendix $5)$. Most of the carbonate is micritic low Mg-calcite (3\% $\left.\mathrm{MgCO}_{3}\right)(1-10 \mu)$ and microsparite $(10-25 \mu$ : "pseudosparite"); also, 10 to 25 per cent euhedral to anhedral dolomite rhombs (proved by X-ray) can be observed in thin-section and in SEM micrographs (Plate 26). The SEM micrographs show that this limestone is incompletely recrystallized because it still contains recognizable nannofossils. A few coccoliths (e.g. Watznaueria sp.) are well preserved and some show overgrowth, but most of them are partly etched, partly fused together, or welded to carbonate rhombs (?). These sub- to euhedral, sometimes broken carbonate (probably dolomite), rhombohedra have corroded and pitted crystal surfaces. Much of this dolomite may have been concentrated by differential removal of calcite at the time of deposition. Apparently, the dolomite rhombs, coccoliths, and terrigenous minerals are "cemented" together by fine-grained calcite (secondary microsparite ?), mobilized and reprecipitated from partly dissolved micron-sized carbonate particles (? coccoliths). The limestone bed is indistinctly graded, the largest grain size of quartz ranging from $50 \mu$ near the top to 80 to $125 \mu$ near the base of the bed. Reworked dolomite rhombs, quartz, and feldspar are also more frequent near the base (20\% quartz) than near the top (5-10\% quartz). The upper part of the limestone layer is intensely burrowed, one burrow reaching $3 \mathrm{~cm}$ from the top. The bed is underlain by dark gray, in part laminated, nannofossil marl ooze with
5 per cent quartz, 3 per cent pyrite, and 2 per cent dolomite rhombs. The marl has intercalated thin silty layers rich in quartz and mica, and low in carbonate. The facies association, composition and grading suggest emplacement of a calcareous turbidite into a poorly oxygenated basin (laminations) with relatively good preservation of calcareous nannofossils. Shallower parts of the basin probably were better oxygenated so that turbidity currents would have brought oxygen, which may (in part) explain the burrowed top of the limestone bed.

A recrystallized spherulitic limestone was recovered at 135-8-1 (? Cenomanian). This completely recrystallized layer of greenish white impure limestone is $8 \mathrm{~cm}$ thick (see Plates 26, 27). It has sharp boundaries to the underlying carbonaceous, zeolitic olive black clay and to the overlying dark greenish gray silicified laminated mudstone ("chert"). This in turn has a sharp contact with overlying olive black quartz-bearing zeolitic carbonaceous black shale. The limestone contains 3 per cent angular quartz $(10-30 \mu), 2$ per cent biotite, 3 per cent pyrite, 9 per cent clay minerals and opaque matter, 3 per cent small dolomite rhombs (not verified by X-ray) and 80 per cent recrystallized calcite. Recrystallization of the carbonate into large coalescing spherulites of fibrous replacement calcite destroyed any fossils originally present. The SEM micrograph shows a cryptocrystalline fabric of micron-sized anhedral calcite grains with quartz (?) inclusions. Thin sections indicate that most of the calcite aggregates are more or less spherical fibro-radiated bodies (0.5-2 $\mathrm{mm}$ diameter) or elongated clusters of fibers. They consist of radiating calcite fibers a few microns wide and 300 to $600 \mu$ long. The spherulites are pure (clay-free), slightly undulose stable low-Mg calcite $(3 \pm$ $0.5 \% \mathrm{MgCO}_{3}$ by $\mathrm{X}$-ray) with inclusions of silt-sized grains of angular quartz, pyrite and mica. The interstices between the coalescing calcite spherulites are partly open pores. They are partly filled by a carbonate-free micaceous and carbonaceous (?) clay matrix, apparently pushed aside by the successive growth of the calcite spherulites during late diagenesis. The limestone contains $1 \mathrm{~mm}$-thick dark laminae of small framboidal pyrite spherules $(10-30 \mu)$ and biotite flakes. The growth of the fibrous calcite spherulites cuts this apparently prediagenetic structure (Plate 27). Since no nucleation centers from which the spherulitic calcite growth might have started are preserved, the origin of this late-diagenetic fabric is obscure. Similar structures have been described by Carozzi (1960, pp. 211 and 349, Figure 66) from nonmarine limestones and recrystallized fibroradiated siderite in argillaceous rocks.

Facies association and presence of quartz, biotite, and carbonaceous matter suggest influx of carbonate by turbidity flow from shallower depths into a poorly oxygenated region well below the $\mathrm{CCD}$. This calcareous deposit was buried by a layer rich in siliceous fossils, which may be a solution lag deposit on top of the calcareous layer or a later turbidite. This layer, by curtailing interchange of interstitial waters with sea water and possibly by allowing sulfate reduction and alkalinity increase beneath itself, prevented complete dissolution of the allodapic carbonate. Subsequently, calcite was mobilized during diagenesis, and gradual recrystallization (by micrite enlargement?) took place beneath this protective cover and also later, after deep 
burial, when aided by high grain contact pressures. Some of the carbonate in this allodapic limestone (as in others) may have come from reworked shallow water limestones (and oolites?). Evidence for such reworked rocks comes from fragments in cores 7, 8 and 9 in Site 135. Site 140A-1 also contains prelithified calcareous clasts.

In considering the cemented and recrystallized limestones of Leg 14 as a whole, we are impressed with the fact that, in general, an origin by displacement of relatively more shallow carbonate into deeper areas of carbonate dissolution is extremely likely, that is, they are of allodapic nature and cut across solution facies boundaries (see Meischner, 1964; Eder, 1971; Scholle, 1971a, b). The diagenetic processes leading to the lithification of carbonate sediments in the deep sea are as yet poorly understood and our genetic interpretations (Figure 38 ) should be considered as tentative.

\section{Siliceous Oozes and Muds}

While siliceous fossils are widespread (Figure 15), cores in which they attain more than 30 per cent within any one distinct facies are quite rare. They are restricted to Eocene (144-1), Oligocene (138-2) and Miocene sediments (139-5 and $7 ; 140-2$ ). Rather pure diatom ooze occurs in 139-5, with about 50 per cent siliceous skeletons and the rest carbonate and clay. Similarly pure, but less calcareous, diatom ooze occurs at 139-7, interbedded with quartzose sand and silt. Mixture of these facies-in situ or during large-scale redeposition-provides for diatom mud. At $140-2$, slightly quartzose diatom ooze predominates, with occasional intercalations of more calcareous layers. Terrigenous and siliceous components are more intimately mixed than at Site 139. The greenish gray sequence of siliceous silty clay with sand layers at 138-2 has zones of radiolarian ooze, which are clay-rich rather than quartzrich, suggesting the presence of two, originally distinct facies: pelagic radiolarian clay and terrigenous silt and sand.

Site 144, on the Demerara Rise, has siliceous sediments from the top (mid-Oligocene) to about 110 meters down (late Paleocene). Only traces of siliceous organisms occur in the older sediments, especially in the zeolite-rich Late Cretaceous sequence. Radiolarian ooze ( $30 \%$ siliceous) is present in 144-1 (mid-Eocene), with forams and nannos providing the rest of the sediment. The low proportion of diatoms is noteworthy. Winnowing by bottom currents may be responsible in view of the low coccolith proportion and low sedimentation rates. Relatively low supply of diatoms and differential dissolution also may play a role, although the presence of (very fragile) silicoflagellates was noted.

Siliceous sediments with more than 8 per cent, but less than 30 per cent siliceous skeletons, are present in 139-3 (Miocene), 144B-2 (Oligocene), and 140-3 (Eocene).

Siliceous marl resistant to disaggregation (including Oligocene sediments) was abundant at Site 144. The cohesion of these sediments suggests partial mobilization of silica providing silica-silica and silica-carbonate bondings (the latter observed under the SEM). The "welding" phenomenon described by Heath \& Moberly (1971, p. 989) may apply. Age and/or overburden apparently were insufficient for chertification in these sediments.

\section{Cherts}

\section{Occurrence, Age and Depth of Burial}

Chert layers were found at all sites except Sites 141 and 142 , almost exclusively in sediments of Eocene age and older (Figures 39, 40). An exception is Site 139 (Core 7, Early Miocene) where up to $3 \mathrm{~cm}$ long fragments of silicified brown foraminiferal marl ooze and silicified radiolarian mudstone were found in sections 3,5 and 6.

Distribution of Leg 14 cherts with respect to age is as follows: (a) The youngest occurrence is Early Miocene (23 My, 139-7; as clasts). (b) Most cherts were between Santonian ( $82 \mathrm{My}, 144 \mathrm{~A}-5 \mathrm{cc}$ ) and Early Eocene (50 My, $135-5 \mathrm{cc}$ ) in age, with a concentration in the Maestrichtian and ?Paleocene $(140-5,6,7 ; 144-2,3)$. Most cherts described from previous Deep Sea Drilling Project legs (Atlantic and Pacific) have a (mid-) Eocene (to Oligocene) age: Leg 1 found graded Eocene spiculites (Beall and Fisher, 1969); Leg 2 found Eocene flint-like cherts and silicified quartz silts (Peterson et al., 1970); Leg 6 found chert nodules in pelagic chalk oozes and impure radiolarian mudstones (Pimm et al., 1971); Leg 7 found nodular and bedded cherts (Heath and Moberly, 1971). In view of these rather widespread Eocene chert occurrences, the failure to find abundant Eocene chert in Leg 14 sediments is somewhat surprising. (c) The oldest cherts occur near the Early/Late Cretaceous boundary, during AlbianCenomanian (Turonian) time (100-90 My; 135-8, 137-7, $8,12,16)$. Radiolarian cherts of the Northwest Atlantic of the same age (Leg 1; Beall and Fischer, 1969) have a similar composition.

In Leg 14 cherts, age appears to be inversely proportional to burial depth: the Cretaceous cherts were formed in shallow burial conditions (e.g. only $110-165 \mathrm{~m}$ for Paleocene/Maestrichtian chert at Site 144), whereas Neogene cherts were found at much greater burial depths (about $700 \mathrm{~m}$ for the Early Miocene chert at Site 139). In part this inverse relationship may be an artifact of the sampling space: older, chert-bearing rocks were reached where the overburden was small. Most cherts were found deeper than 250 meters below sea floor.

\section{Types and Composition}

The compositional variation in the silicified sediments of Leg 14 allows separation of various kinds of chert (see Figure 41). One primary distinction is suggested by the amount of terrigenous impurities present, for example, pelagic (Sites 137, 144) and hemipelagic cherts (rest). The pelagic cherts are low in detrital quartz and feldspar, and in pyrite, but contain traces of calcareous fossils. The hemipelagic cherts show a distinct terrigenous component, pyrite and/or iron oxides, and in some cases dolomite $(135-8,140-5,6)$. Assuming that much of the silica is derived from siliceous fossils dissolved in the vicinity of the site of chert formation, these two types of chert differ from each other as does siliceous (radiolarian) ooze from siliceous mud, the latter containing a considerable amount of redeposited siliceous organisms and quartz in the silt and sand fractions. A contribution of silica from alteration of volcanic glass, of course, would be possible in both pelagic and hemipelagic chert. 

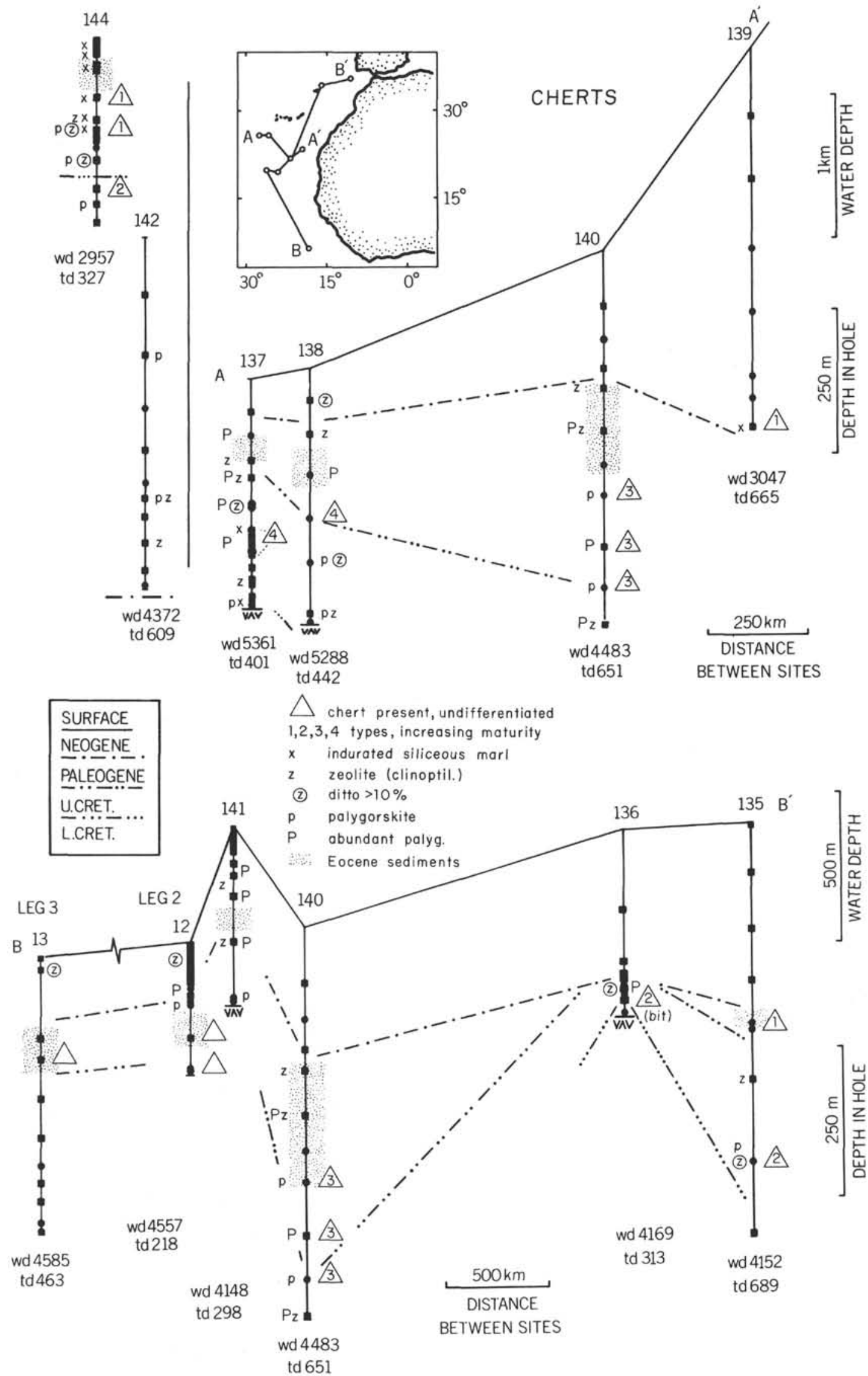

Figure 39. Distribution of cherts and associated authigenic silicates (clinoptilolite, palygorskite). Chert type numbers indicate increasing degree of crystallization, from opal-rich porcelanites to quartzitic cherts (see text and Figure 41). Note the preEocene age of most cherts, and the common association with clinoptilolite, palygorskite and carbonaceous matter (compare Fig. 50). 


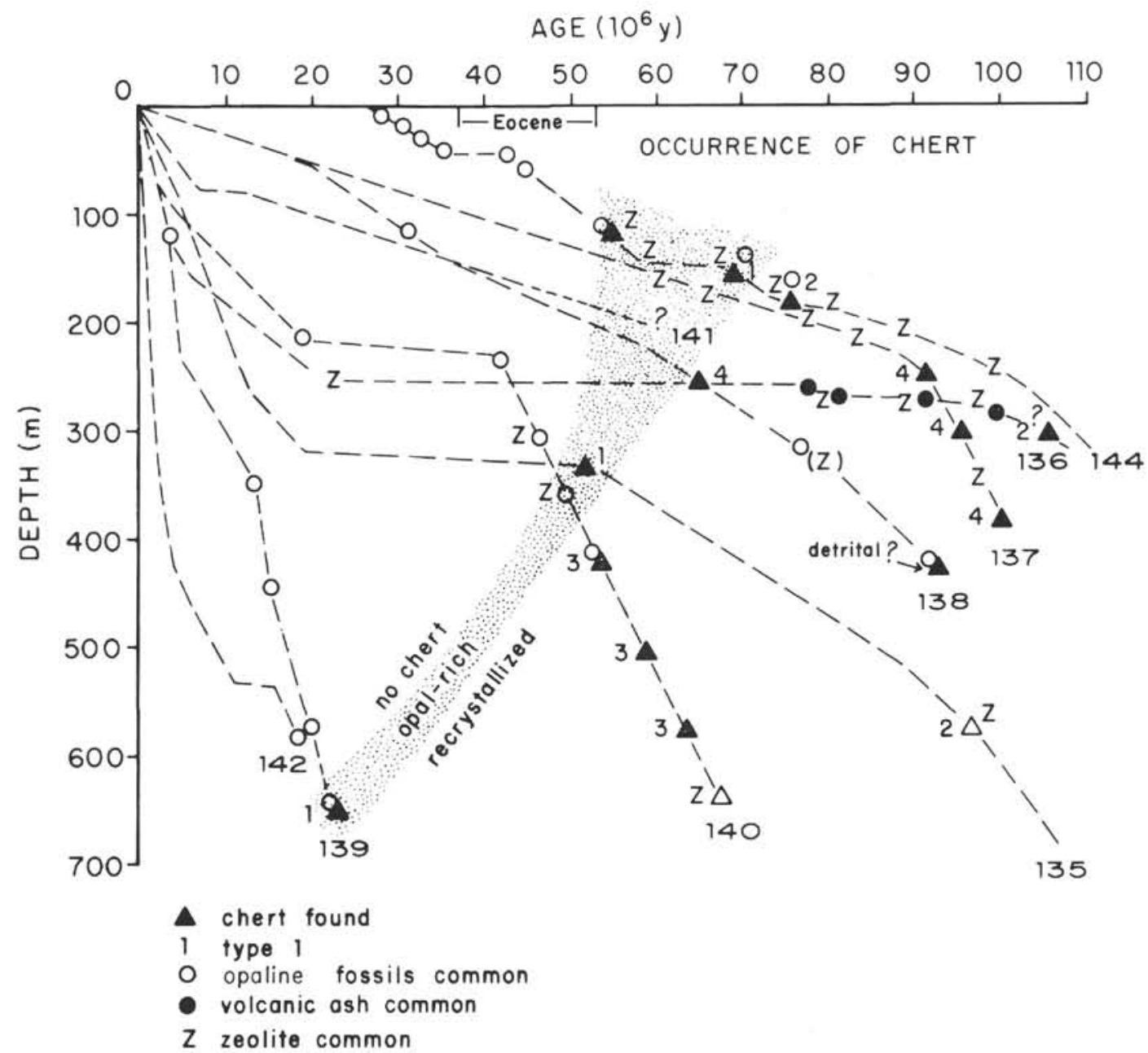

Figure 40. Distribution of chert types 1 (opal-rich), 2, 3 and 4 (lussatite-chalcedony-quartz) with respect to age and depth in hole, and with regard to other silica-rich sediments. Note the rarity of cherts in Eocene and younger deposits.

Another way of classifying the cherts of Leg 14 is according to their texture, sedimentary fabric, and the proportion of the various $\mathrm{SiO}_{2}$ phases in the matrix (i.e. opal, cristobalite [disordered: "lussatite"], chalcedonic and microcrystalline quartz; see Figure 41). This tentative descriptive-genetic classification considers the nature, preservation, and filling of siliceous tests as well as the silicification process proper, rather than the original material that is being silicified. The classification is founded on thin section, X-ray, SEM and TEM analyses.

Four types of chert were distinguished in this manner. They range from early diagenetic, poorly crystallized, "immature" cherts to highly crystallized, late-diagenetic, "mature" cherts, implying a general decrease of opallussatite and an increase of chalcedonic and microcrystalline quartz content from types I to IV. Occurrence and various characteristics, such as lithofacies, age, burial depth, lithology, texture, and composition are shown in Figure 41. All cherts are impure and have high clay contents (up to 40\%) (Figure 42). The percentages of opaline-preserved radiolarians and sponge spicules decrease from type I (20\%) to type IV (near 0\%). The lumina of these fossils vary from "open pores" in type I to mainly quartz (and chalcedony) filled ones and fossil "ghosts" in chert type IV.

(1) Immature, brown, clay-rich, opaline-lussatite chert or porcelanite ${ }^{9}$ (Type I, age: $23.72 \mathrm{My}$, mostly Paleogene). Microcrystalline quartz is rare. Siliceous skeletons are well-preserved as opal-lussatite; fossil "ghosts" are rare. The lumina of the fossils are mostly unfilled, that is they have open pores.

A typical example is the pelagic silicified radiolarianforaminiferal mudstone of 144-3-2 (Campanian/Maestrichtian). The matrix is a mixture of very fine-grained clay and cryptocrystalline silica (?lussatite), containing about 20 per cent poorly preserved radiolarians (ghosts)

\footnotetext{
${ }^{9}$ Following Bramlette (1964), Ernst and Calvert (1969) and Calvert (1971) distinguish between porous, fine-grained cristobalitebearing "porcelanites" and dense, vitreous "true cherts", consisting of microcrystalline quartz. Since most silicified rocks of Leg 14 are heterogeneous mixtures of opal-lussatite (disordered cristobalite) and microcrystalline quartz, the general rock term "chert" is used throughout this paper, with compositional prefixes, wherever possible (e.g. quartz-lussatite chert).
} 


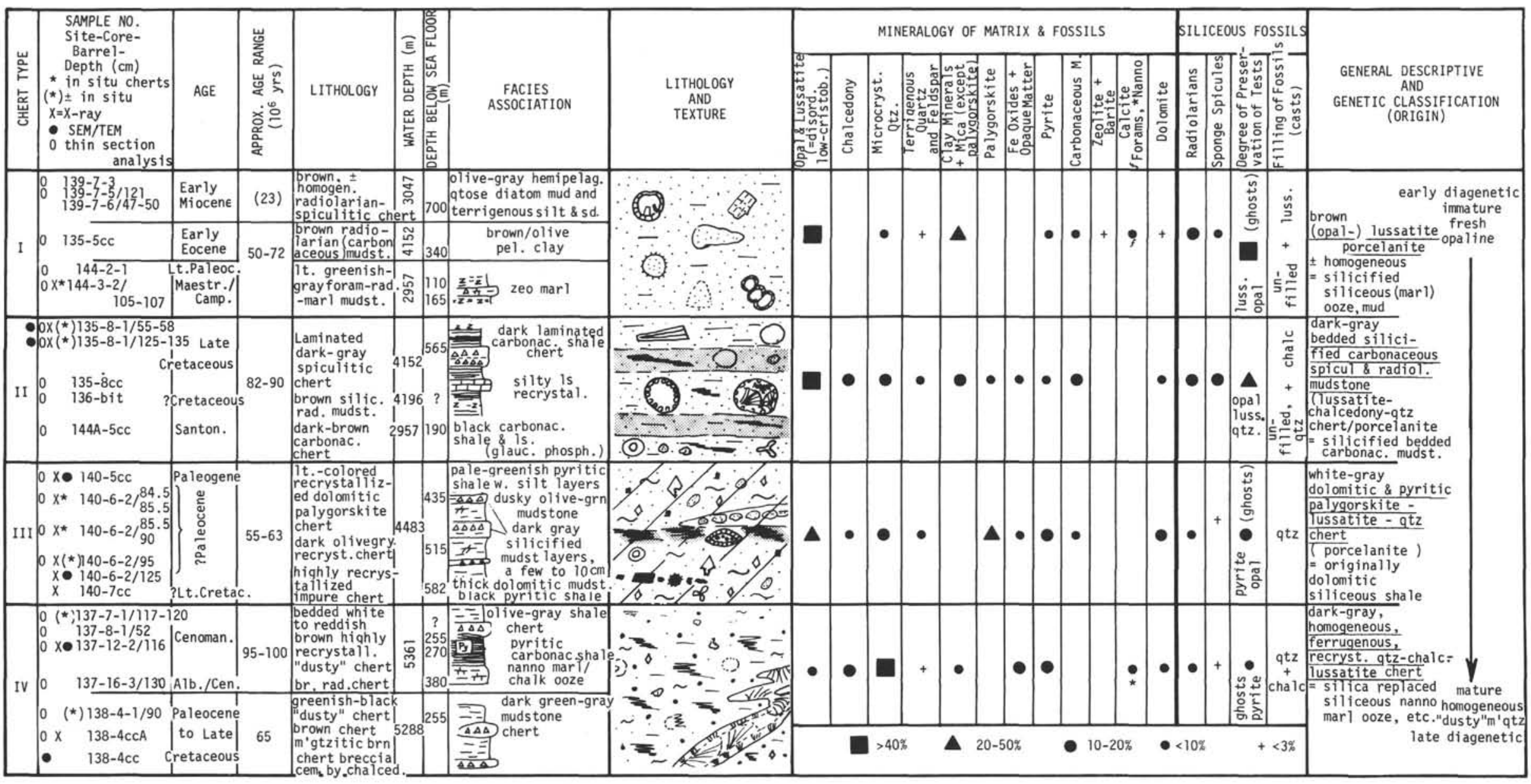

Figure 41. Composition and genesis of chert types I to IV. The sketches in column "Lithology and Texture" are meant to represent the following features (I to IV): (I) light stipples, opal-lussatite ("cristobalite"); dashes, montmorillonite, kaolinite, etc.; particles, open and filled radiolarians and forams, "ghosts" etc.; (II) shaded areas, laminae enriched in carbonaceous matter (stipples), and ferruginous zones (lines), particles, spicules, "ghosts", in part filled with chalcedony and quartz; (III) hachure, mass polarization, birefringent matrix oriented parallel to bedding; ( , palygorskite); particles, black: pyritized radiolarians, pyrite crystals; other; as before, also (in part) corroded dolomite crystals; stippled grains: silt size terrigenous quartz; (IV bold stipples, microcrystalline quartz and chalcedony; note homogenization, healed fracture (chalcedony). 
and 15 per cent foraminifera with their calcitic tests left intact (Plate 28, Figure 1). Large crystals of authigenic barite and tiny laths of zeolite (?clinoptilolite) are concentrated in vugs and lumina of fossils that have not been filled by secondary silica, probably indicating an early stage of diagenesis (Plate 28, Figures 2-6).

Another example of this type of immature chert is the porcelanite found in the hemipelagic quartz-rich siliceous muds of Site 139-7. In this case, opaline (?) radiolarian tests were observed, with geopetal filling and secondary zeolite crystals growing upwards into the open pore space (Plate 28, Figure 4).

(2) Dark-gray, bedded, silicified, carbonaceous, spiculitic and radiolarian mudstone: lussatite-chalcedony-quartz chert or porcelanite (Type III; age: $80-90$ My, Late Cretaceous).

The matrix consists of clay minerals, carbonaceous matter and silica (opal-lussatite, chalcedony, and cryptocrystalline quartz). The preservation of siliceous fossils is medium, that is, as opal-lussatite and quartz. Approximately one-half of these fossils are empty (open pores); the rest are filled by chalcedonic (and microcrystalline) quartz (Plates 29; 33, Figure 3).

To this type of chert belong the dark-gray, laminated, silicified mudstone beds of Site 135-8. They are interbedded with black zeolitic carbonaceous muds with intercalations of turbiditic recrystallized silty limestones. These mudstones consist of a silicified, yellowish brown clay matrix full of tiny $(5-20 \mu \phi)$ bituminous spherules. Dark laminae, about $0.5 \mathrm{~mm}$ thick, rich in carbonaceous matter, alternate with lighter-colored ones. Streaky burrows, parallel to the bedding plane, are common (Plate 29, Figure 1). Various types of sponge spicules (15\%) are more abundant than large (up to $90 \mu$ ) radiolarian cross sections (Plate 29, Figure 2-4). The tests of the radiolarians are mostly converted from opal to globular $(3-10 \mu)$ silica spherules. Silt-sized terrigenous quartz and silica spheres (lussatite) can be observed in the matrix on SEM micrographs (Plate 31, Figure 4; see also section on siliceous fossils, footnote 4).

(3) Faintly bedded, partly homogenized, light gray-olive green, dolomitic and pyritic palygorskite-lussatite-quartz chert or "porcelanite" (Type III; age: 55-65 My, Paleogene). The thin $(5-30 \mathrm{~mm})$, dusky olive green, silicified claystone layers alternating with light (greenish to bluish) gray, dolomitic silty clay cycles of Site $140-6$ represent this type of chert (see also section on dolomite). The matrix consists of an intimate intergrowth of clay minerals (mainly fine-grained palygorskite) with cryptocrystalline silica (opal-lussatite and microcrystalline quartz). X-ray analyses show predominant lussatite, palygorskite, quartz (in that order) with traces of feldspar, mica and pyrite. The palygorskite (possibly also the silica?) shows "mass polarization", that is, mass extinction under crossed nicols parallel to the bedding (see Plate 30, Figures 2 and 3). This effect is probably produced by "mineral parallelism effected during crystallization" under directional stress (compaction?) which produces a foliation parallel to the original bedding plane (Carozzi, 1960, p. 317). Floating silt-sized quartz grains, laminae with quartz silt concentrations (Plate 30, Figure 2) and dolomite rhombs do not show this polarization effect. The dolomite rhombohedra are somewhat corroded (Plate 30, Figures 1, 5; Plate 32, Figure 4) and possibly are of relict origin. They are present in three size classes: $1-2 \mu, 5-10 \mu$ and $>20 \mu$. Siliceous fossils (mainly radiolarians) are preserved as "ghosts" or largely as pyrite pseudomorphs; and pyritized radiolarians are concentrated in distinct laminae, possibly explainable as (pre-diagenetic) placer deposits (Plate 30, Figure 4). A few, very well preserved, radiolarians consisting of (?) aged opal, however, were found in or near dark (ferruginous or carbonaceous) layers (Plate 33, Figure 5). Possibly the preservation of opaline skeletons was favoured by special physico-chemical conditions in certain microenvironments. Core 140-8 (cc) (Late Cretaceous) contains a chert fragment consisting of silicified quartzose silty mud with abundant sponge spicules, mostly recrystallized to (chalcedonic) quartz. The matrix is lussatite-rich and montmorillonitic.

(4) Dark-gray, "mature", homogenized, ferruginous, recrystallized quartz (-lussatite) chert (Type IV; age: 65-100 My, Cretaceous). These are the most highly recrystallized and homogenized ("mature"), although not necessarily oldest, "true" quartzitic cherts of Leg 14. They occur as distinct layers in carbonaceous nanno marl oozes (137-12), in black carbonaceous shales (137-7), and in dark-green mudstones (138-4).

The matrix, usually brown, is colored by disseminated grains of brown $\mathrm{Fe}$-(hydr)oxides, intimately associated with clay minerals, and shows the "pin-point extinction" (Plate 31, Figure 1), typical of crypto- to micro-crystalline quartz ("pseudoquartzitic structure"; Carozzi, 1960, p. 310, Folk and Weaver, 1952). Diffuse banding of $1 \mathrm{~mm}$-thick limonitic zones might indicate former laminations (Plate 31, Figure 1). Siliceous fossils are mostly destroyed, leaving behind diffuse outlines of fossil "ghosts" (maximum diameter $250 \mu$, see Plate 31, Figure 2). They are filled by chalcedonic or by microcrystalline quartz (Plate 33, Figure 6). Some fossils are secondarily carbonatized. Open pores are absent.

A chert breccia $(138-4 \mathrm{cc})$ consists of angular chert fragments, cemented by chalcedony (Plate 31, Figure 3). The open cracks were filled by two generations of length-fast chalcedonic quartz: (a) as small fibers growing perpendicular to the boundary ("A-cement"), and (b) as large fibro-radiated clusters and spherolites filling the remaining vein space. The age and cause of the brecciation is unknown, as is the time of the repeated ingressions of silica-precipitating pore solutions during late diagenesis.

The very old (Cenomanian), "dusty" chert of $137-12$ contains relict carbonate in the clay-silica matrix, and a few coccoliths were observed on SEM micrographs (Plate 31, Figure 5).

\section{Mineralogy of Silica Modifications}

All cherts found have features inherited from the original sedimentary environment, such as detrital quartz grains, feldspar, dolomite rhombs, radiolarians, sponge spicules, or, at least, replaced (pyritized etc.) fossils or "ghost" features of siliceous organisms. Laminations are distinct in type II and indistinct in type III cherts. The 


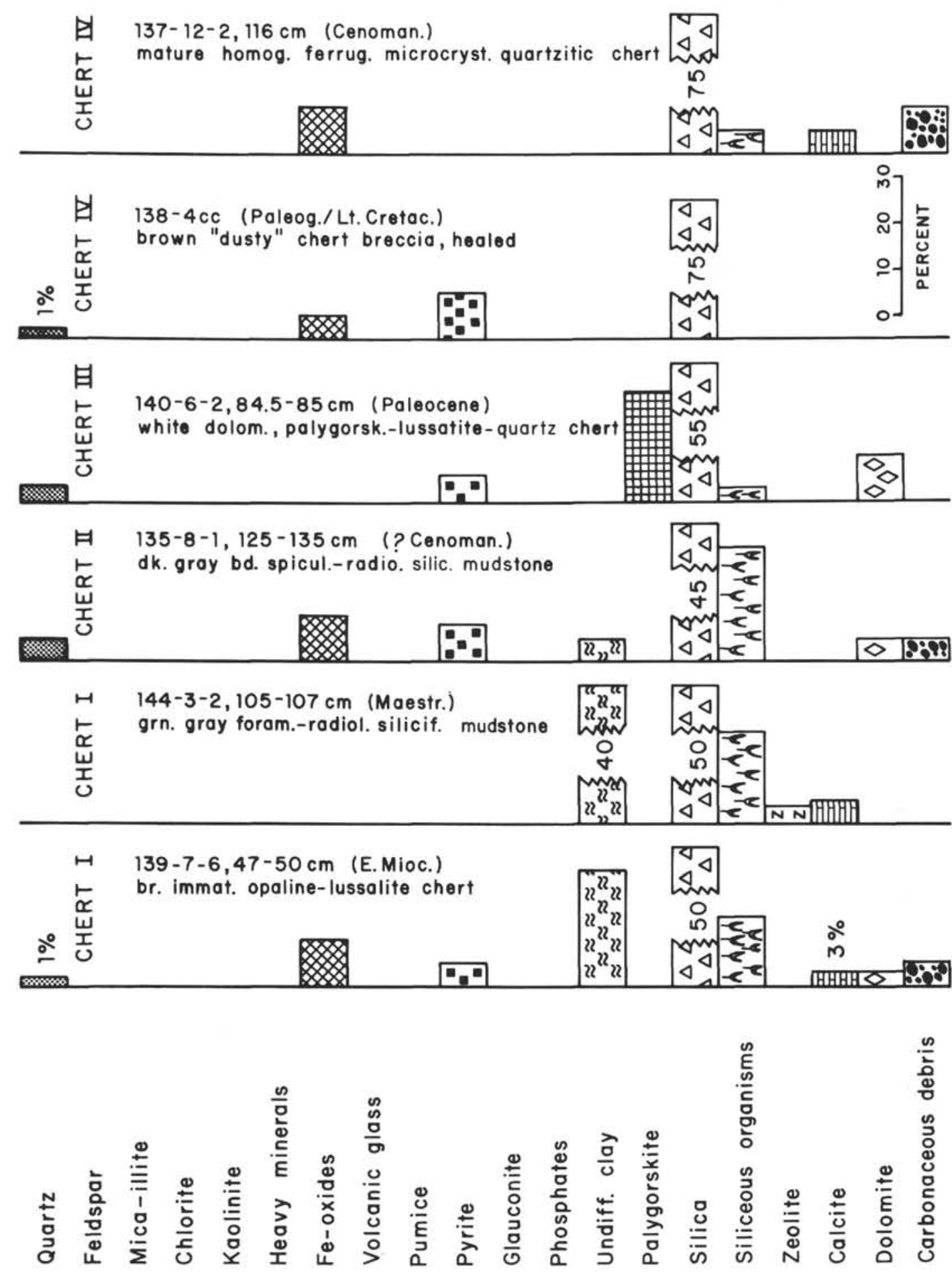

Figure 42. Composition of selected representative chert samples of 4 types.

other cherts are more or less homogeneous (type I) or homogenized (type IV).

In general, chertification appears to proceed from an opal-lussatite matrix ${ }^{10}$ (type I) with unfilled opaline fossils to a quartzitic rock with mostly quartz-replaced and -filled fossils (type IV). Thus opal will finally end up as

\footnotetext{
${ }^{10}$ Within the isotropic siliceous groundmass, "opal" and lussatite
} (disordered cristobalite) cannot be distinguished optically. microcrystalline quartz, with lussatite (disordered lowcristobalite) and chalcedony belonging to intermediate diagenetic stages (see also Flörke, 1955, 1962; Mizutani, 1966; Jones et al., 1964; Segnit et al., 1970; Jones and Segnit, 1971; Ernst and Calvert, 1969; Heath and Moberly, 1971). The mineralogy, crystal structure, and other properties of the amorphous and microcrystalline silica varieties (opal, lussatite, chalcedony, quartz) of the cherts of Leg 14 are compiled in Table 9 and are discussed in more detail in von Rad and Rösch (this volume). 
TABLE 9

Characteristics of Amorphous and Microcrystalline Silica Varieties of Leg 14 Cherts,

Supplemented by Data from the Literature

\begin{tabular}{|c|c|c|c|c|c|}
\hline & Mineralogy and Crystal Structure ${ }^{a}$ & X-Ray Pattern ${ }^{a}$ & SEM & Occurrence, Paragenesis & Genesis \\
\hline $\begin{array}{l}\text { OPAL } \\
\text { (="Opal-A" } \\
\text { Jones \& } \\
\text { Segnit 1971) }\end{array}$ & $\begin{array}{l}\text { Highly disordered, nearly amorphous natural } \\
\text { hydrous silica. Crystallite size } \perp(101): \mathrm{b} \\
11-15 \AA \text { discontinuous framework of } \mathrm{SiO}_{4} \\
\text { tetrahedrons + water }\end{array}$ & $\begin{array}{l}\text { Prominent very diffuse } \\
\text { band at } \sim 4.1 \AA \text {, no } \\
\text { tridymite reflections }\end{array}$ & $\begin{array}{l}\text { Close-packed aggregates } \\
\text { of silica spheres of uni- } \\
\text { form size }(0.1-0.4 \mu)\end{array}$ & $\begin{array}{l}\text { Tests of siliceous organisms } \\
\text { (rads, sponge spic., diatoms, } \\
\text { etc.) } \\
\text { [also in precious opal, } \\
\text { "potch", diatomites, gey- } \\
\text { sirites, glass-clear hyalites] }\end{array}$ & $\begin{array}{l}\text { Original organic skeletons } \\
<30-60 \mathrm{~m} . \mathrm{y} . \\
\text { (precipitation from hydro- } \\
\text { thermal solutions, meteoric } \\
\text { waters, etc.) }\end{array}$ \\
\hline $\begin{array}{l}\text { LUSSATITE } \\
\text { (=“"Opal CT" } \\
\text { Jones \& } \\
\text { Segnit 1971) }\end{array}$ & $\begin{array}{l}\text { Obviously crystalline, natural hydrous silica= } \\
\text { unidimensionally highly disordered low- }(a) \\
\text { cristobalite consisting of irregularly stacked } \\
\text { low-cristobalite or "k"-layers (cubic densest } \\
\text { packing) and low-tridymite or "h"-layers } \\
\text { (hexagonal densest packing), water and } \\
\text { foreign ions } \\
\text { a) fibrous variety = "lussatite" } \\
\text { b) cryptocrystalline - spherulitic variety } \\
(0.2-1 \mu)=\text { "opal-cristobalite"b } \\
\text { crystallite size } \perp(101): 45-130 \AA\end{array}$ & $\begin{array}{l}\text { Broadened, but well- } \\
\text { defined peaks of low- } \\
\text { cristobalite (mainly } \\
\mathrm{d}_{(101)} \text { at } 4.1 \AA \text { and } \\
\mathrm{d}_{(200) \text { at }} 2.5 \AA \text { with } \\
\text { tridymite peaks, e.g. } \\
\text { at } 4.25-4.3 \AA)\end{array}$ & $\begin{array}{l}\text { Closely packed silica } \\
\text { spheres of irregular size } \\
\text { and packing order (3-8, } \\
\text { max } 20 \mu \phi) \text {, consisting of } \\
\text { a network of minute, } \\
\text { irregularly oriented } \\
\text { needles, blades and fibers } \\
(=\text { "lussatite" s.str.) }\end{array}$ & $\begin{array}{l}\text { Cherts of low to inter- } \\
\text { mediate maturity (types } \\
\text { I-III) } \\
\text { [most common opals, ben- } \\
\text { tonitic clays, silica glass, } \\
\text { porcelanites] }\end{array}$ & $\begin{array}{l}\text { Early diagenetic origin at low } \\
\text { temperatures }\left(<80^{\circ} \mathrm{C}\right) \text { from } \\
\text { skeletal opal, volcanic glass } \\
\text { etc. by dehydration (aging } \\
\text { etc.) }\end{array}$ \\
\hline CHALCEDONY & $\begin{array}{l}=\text { disordered quartz, fibrous } \perp[0001]=\| \\
{[1120] \text { length-fast, crystals mostly } \gg>1 \mu}\end{array}$ & Quartz peaks & & $\begin{array}{l}\text { Filling of fossil lumina } \\
\text { (especially type II) and in } \\
\text { matrix of intermediate- } \\
\text { mature qtzit. cherts (type } \\
\text { II-IV) }\end{array}$ & \\
\hline QUARTZ & $\begin{array}{l}=\text { quartz } \\
\text { a) cryptocrystalline }(<1 \mu) \text {, no orientation } \\
\text { b) "quarzin" }(<1 \mu) \text {, fibers } \|[0001]= \\
\text { length-slow } \\
\text { c) microcrystalline quartz }(>1 \mu)\end{array}$ & Sharp quartz peaks & & $\left\{\begin{array}{l}\text { in the matrix of mature } \\
\text { cherts (type III-IV) }\end{array}\right.$ & $\begin{array}{l}\text { "Late" diagenetic origin in } \\
\text { sediments }>50 \text { My old }\end{array}$ \\
\hline
\end{tabular}

I In part after Florke, 1955, 1962; Mizutani, 1966; Calvert, 1971; Jones and Segnit, 1971.

According to Heath and Moberly, 1971 (Central Pacific).

After Segnit et al., 1970.

see Plate 34, Figures 3 and 6.

See Figure 41 .

See Plate 32, Figure 6. 
Lussatite is a highly disordered low-temperature cristobalite/low-tridymite with various degrees of stacking disorder (Flörke, 1955). Apparently it originates from the dehydration and crystallization of aged opal under low temperature conditions. Thin section (Plate 33, Figure 4) and SEM micrographs (Plate 34) show globular bodies (spherulites of $3-20 \mu$ diameter) of silica lining the walls or filling the interior of partly dissolved or recrystallized siliceous tests. The interior of each of these closely packed silica spherules consists of an irregular network of randomly oriented lussatite (s.str.) needles, blades or fibers, about $0.1 \mu$ in diameter (Plate 34, Figures 3 and 6). Apparently, these lussatite fibers were slowly crystallized from the originally amorphous silica gel (0.W. Flörke, personal communication, 1972; Wise et al., 1972). Much smaller spherules and polygonal grains $(0.2-1 \mu$ in diameter), aligned in a "cobblestone pattern", were observed on transmission electron micrographs of freshly broken chert surfaces (Plate 32 , Figures 5, 6) and tentatively identified as lowcristobalite (the "opal-cristobalite" variety of Table 9, 2b).

Chalcedony typically fills partly recrystallized siliceous tests, especially in type II cherts, in the form of coalescing excentric radial fiber bundles starting at the wall and growing toward the inside (Plate 33, Figure 3), or as one single spherulite of radiating fibers centered in the middle of the lumen.

Quartz is usually micro- $(>1 \mu)$ or cryptocrystalline $(<1 \mu)$. It sometimes occurs as a single large grain filling a recrystallized test or the axial canal of a sponge spicule (Plate 29, Figures 2, 3). Also, microcrystalline quartz replaces the tests of siliceous organisms (Plate 33, Figure 1). The fine-grained quartz provides the matrix of the more mature cherts: that is minute interlocking equant grains in random orientation (Plate 31, Figure 1).

\section{Origin and Diagenesis}

The questions arising in connection with the chert occurrences include the following:

1) What kinds of sediment were originally present at and near the site of chert formation?

2) What is the source of the free silica?

3) How was it mobilized and transported to the site of chertification?

4) What are the processes and factors responsible for replacement phenomena and recrystallization?

The first two questions are of primary significance in that they ask for the geologic setting in which cherts occur. The other two questions are of a more specialized chemical nature, but must be considered before questions (1) and (2) can be answered with confidence.

A tentative genetic interpretation for the four types of chert here distinguished is given in Table 13. It is perhaps noteworthy that pelagic brown clay was not found associated with chert, regardless of the presence of volcanogenic components, and that the Cretaceous volcanogenic sequence at Site 136 is essentially free of chert, except for a fragment of unknown depth found in the bit. On the other hand, facies associated with cherts tend to be rich in siliceous fossils and/or zeolite (or palygorskite), attesting to high silica availability (Figure 39).
In cases where chertification is at an early stage, the original sediment is not too difficult to reconstruct, as in the foraminiferal and radiolarian silicified mudstones of chert type I. The original, unsilicified sediments of the cherts of type II probably consisted of hemipelagic, laminated, zeolitic and partly carbonaceous, siliceous and carbonate-free silty mudstones. They are probably "replacement cherts" with biogenous opal as precursor (Figure 41).

Reconstruction of the original sediment is rather more difficult where chertification has proceeded to a more advanced stage. If we look for the unsilicified original sediments for the type III cherts of 140-6 (Plate 30; Figure 41 ), the composition of the semi-indurated, yellowish mid-Eocene mudstone of Site 140-3-2 might give some clues (Plate 33, Figure 2). Compared with the chert of $140-6$, this mudstone is about 10-15 My younger and is buried by about 200 meters less sediment. The matrix consists of a mixture of kaolinite, montmorillonite, palygorskite and sepiolite, with no carbonate being present. Bedding is produced by lenses and layers of dark carbonaceous and ferruginous material. The cohesion of these siliceous sediments suggests partial mobilization of silica, providing silica-silica bondings. Although not quite silicified, the clay matrix does show mass polarization, apparently an early stage of diagenesis under compaction. This mudstone contains about 20 per cent siliceous organisms with well preserved although mostly fragmented opaline skeletons, largely radiolarians and sponge spicules, but traces of the more easily dissolvable diatoms were also seen. In contrast, in 140-6 epi- and diagenetic processes presumably obliterated most of the original fossil record.

The composition of these (?)Paleocene cherts (type III) is very similar to that of the Eocene porcelanites of the nearby Site 12 (Leg 2: Peterson et al., 1970, p. 259; Calvert, 1971). These "chert" layers consist also of palygorskite, "cristobalite" and quartz (with traces of sepiolite and feldspar). They are also only slightly more silicified than the associated greenish gray, zeolitic palygorskite clays. No siliceous fossil remains were observed. Because of the typical association of clinoptilolite-cristobalitepalygorskite, Calvert (1971) suggests that the silica was originally precipitated as "volcanogenic" opal, either by derivation from dissolved, altered volcanic glass (forming authigenic palygorskite and/or clinoptilolite + amorphous opal), or by direct precipitation of palygorskite and opal from hydrothermal solutions, supersaturated in amorphous silica. The question of the origin of silica from sources that have vanished in the process of delivering the silica is, of course, difficult to decide without additional information (see Bramlette, 1946, p. 55). Although our type III cherts contain traces of siliceous fossils, it is quite possible that biogenous opal was insufficient as silica source. An additional "volcanogenic" silica source, such as devitrification of volcanic glass, appears very likely in view of the associated clay minerals.

$\mathrm{X}$-ray analyses show that disordered low-cristobalite (lussatite) occurs also in unconsolidated sediments and is by no means restricted to porcelanites. Low-cristobalite is commonly associated with clinoptilolite, especially in hemipelagic (olive) black carbonaceous marls of 144 (A4 and 4), in black carbonaceous, zeolitic shales (135-8) and in pelagic 
greenish gray, zeolitic clays of 137-6. Most of these sediments contain little or none of the montmorillonite that is supposed to form before clinoptilolite and amorphous silica as an intermediate alteration product of rhyolitic-dacitic ashes (Hay 1966, p. 82; Calvert, 1971).

Some of the "mature," recrystallized cherts of type IV (137-12) contain a few percent of relict coccoliths (Plate 31 , Figure 5). This suggests that the original sediment was a nanno marl ooze similar to the associated sediments in that core, but with admixtures of siliceous organisms. A similar replacement origin is indicated for the "immature" cherts of type I: siliceous foraminiferal marl mud in 144, and quartzose siliceous nanno marl mud to quartzose silty siliceous mud in 139-7. The high proportions of (solutionresistant) "sponge spicules" noted in most cherts (which actually may include some other thick siliceous skeletal elements such as orosphaerid remains) indicates that most of the original fossil assemblage within the cherts is obliterated. The destruction may have occurred long before chertification, with silica escaping into overlying bottom waters, or (perhaps to a greater degree) in connection with diagenetic mobilization of silica and during recrystallization.

While suggestive, the presence of siliceous fossils within cherts does not, however, necessarily indicate the source of silica. If siliceous fossils are to be available for later production of chert, important requirements would seem to be a relatively silica-rich bottom water, and the presence of a reasonably high burial rate. These conditions would tend to prevent the dissolution of siliceous skeletons at the sediment interface. If this burial can be achieved without considerable dilution of opaline skeletons (e.g. near fertile areas by high supply of siliceous sediment, indigenous or displaced, or by initial burial with allodapic carbonate which is later dissolved) the chances for later chert formation would appear much improved. Volcanic ash supply also would be a favorable means of burial if later devitrification adds to the silica supply.

The processes involved in the mobilization and migration of the silica during diagenesis are poorly understood. Presumably, opaline skeletons dissolve and volcanic material (where present) releases silica during devitrification, and the silica-rich interstitial solutions migrate along bedding planes or fractures and vertically (in the order of $\mathrm{cm}$ to $\mathrm{m}$ ?) from areas of silica depletion to nearby more permeable lenses or layers (Heath and Moberly, 1971, p. 996). According to these authors, the silification process (studied in the nodular cherts of Central Pacific Cherts) proceeded in three major successive stages (see also Ernst and Calvert, 1969; Calvert, 1971):

(1) early diagenetic precipitation of macrocrystalline chalcedony in the empty chambers of foraminifera with preserved calcitic tests;

(2) rapid replacement of nannomicrite (or clayey matrix) by the precipitation of cryptocrystalline "lowcristobalite" along sharply defined silicification fronts and at low temperatures ("porcelanite"); at the same time "chalcedonization" of calcitic foram tests;

(3) late-diagenetic, slow conversion of cryptocrystalline low-cristobalite into quartz, the only stable silica phase in the "mature," dense, "vitreous cherts" where all fossils are obliterated and all porosity is lost. The reaction time of this solution-precipitation mechanism (or solid-solid reaction?) depends mainly on the temperature and pore water chemistry.

Except for some of the cherts of type IV, our cherts (types I-III) have only experienced the first two stages of silicification; they belong to the type of impure, porous cristobalite-"porcelanites" with partly preserved or recrystallized siliceous organisms and with an originally nannomicritic or clayey (-dolomitic) matrix that is partly replaced by lussatite. Chalcedony (and microcrystalline quartz) fill some of the (siliceous) fossil chambers. Some of the chert layers appear to be localized in silty mudstones (type II and III), apparently due to their greater permeability for silica-rich interstitial solutions. Reducing conditions also appear to favor the precipitation of low-cristobalite in the laminated, carbonaceous mudstones of chert type II. ${ }^{11}$ Silicified graded sand layers (turbidites) or ash beds, however, described from other DSDP Sites (e.g. Beall and Fischer, 1970), were not found on Leg 14. Also, nodular cherts associated with carbonate oozes (Heath and Moberly, 1971) appear to be absent.

\section{Terrigenous Sediments}

\section{Occurrence and Main Types}

The distribution of terrigenous sediments in Leg 14 cores is indicated by the occurrence of quartz dominance (Figure 18), of sand layers and lenses (Figure 26) and by overall quartz sedimentation rates $>1 \mathrm{~m} /$ My (Figure 43) and quartz sand proportions $>0.1 \%$ of total sediment. Terrigenous sands and coarse silts are especially abundant in the Cretaceous hemipelagic sequences (Sites 135-7, 140-8, 141 [SW1, ?Lt. Cretaceous], 144). Virtually all of these terrigenous layers are graywackes or quartz-graywackes with different proportions of feldspar (Figure 44). Within the hemipelagic domain in the mid-Tertiary, terrigenous sands and silts also are quite common Sites 138-1, 2; 139-6, $7 ; 140-3)$. This apparently is due to a combination of high terrigenous supply from the African continent (Sites 138, 140) and decreased dilution by carbonate (Site 139). Virtually all of these silts and sands are highly quartzose and low in feldspar and phyllosilicates (Figure 44). Site 142 (off the Amazon estuary) presents a special case of mixed terrigenous and calcareous turbidite sedimentation (feldspar-rich graywackes) during Plio-Pleistocene times.

\section{Texture, Composition, and Origin}

Texture and composition of Leg 14 terrigenous sediments vary considerably (see Figures 45,46 ). Four major groups of sand types can be distinguished according to composition and age.

(1) Plio-Pleistocene feldspar-rich graywacke sands of Site 142. The Quaternary flysch-like sequence at Site 142 has both poorly sorted, in part calcareous terrigenous muds,

\footnotetext{
${ }^{11}$ Experiments show that silica can precipitate on carbonaceous matter (Miriam Kastner, pers. comm. 1972). Precipitation in organic-rich layers in the sediment would create a gradient allowing silica to immigrate from elsewhere.
} 

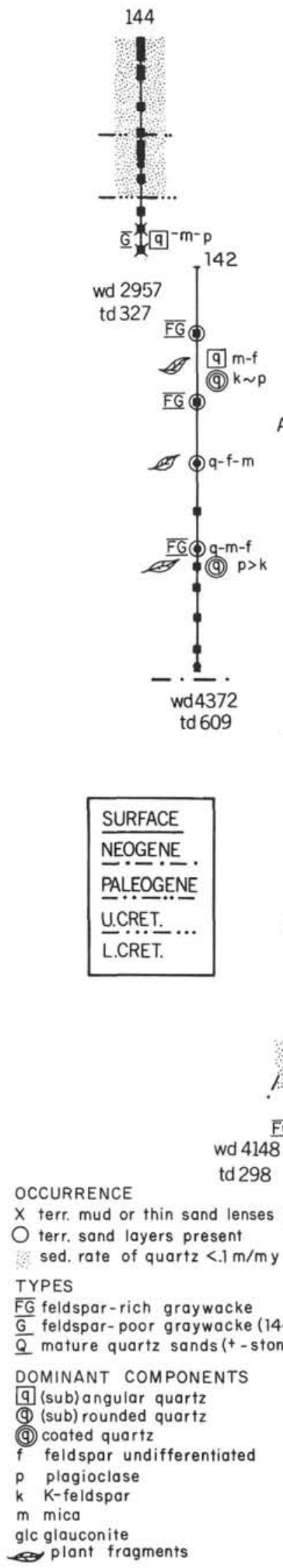

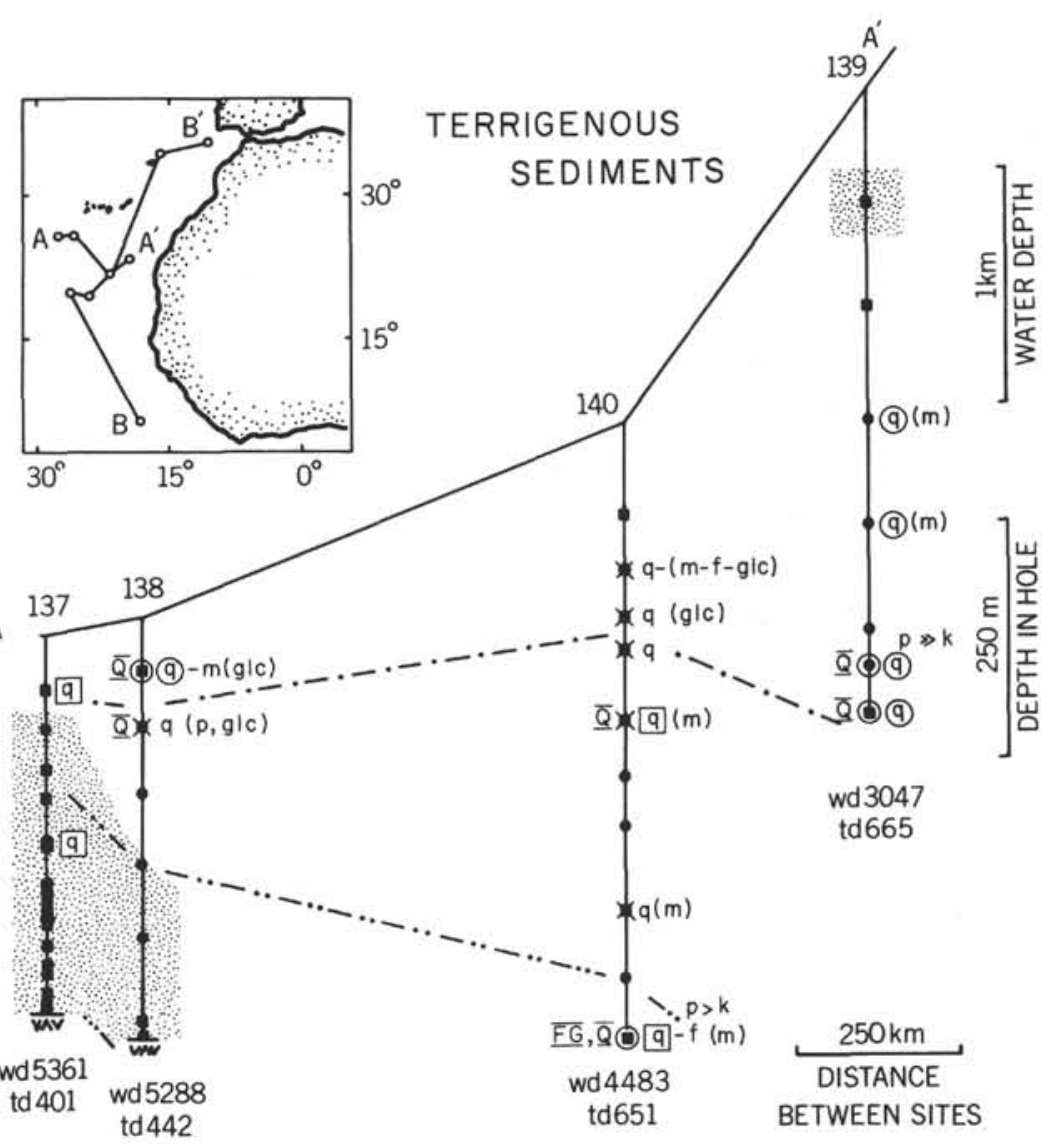




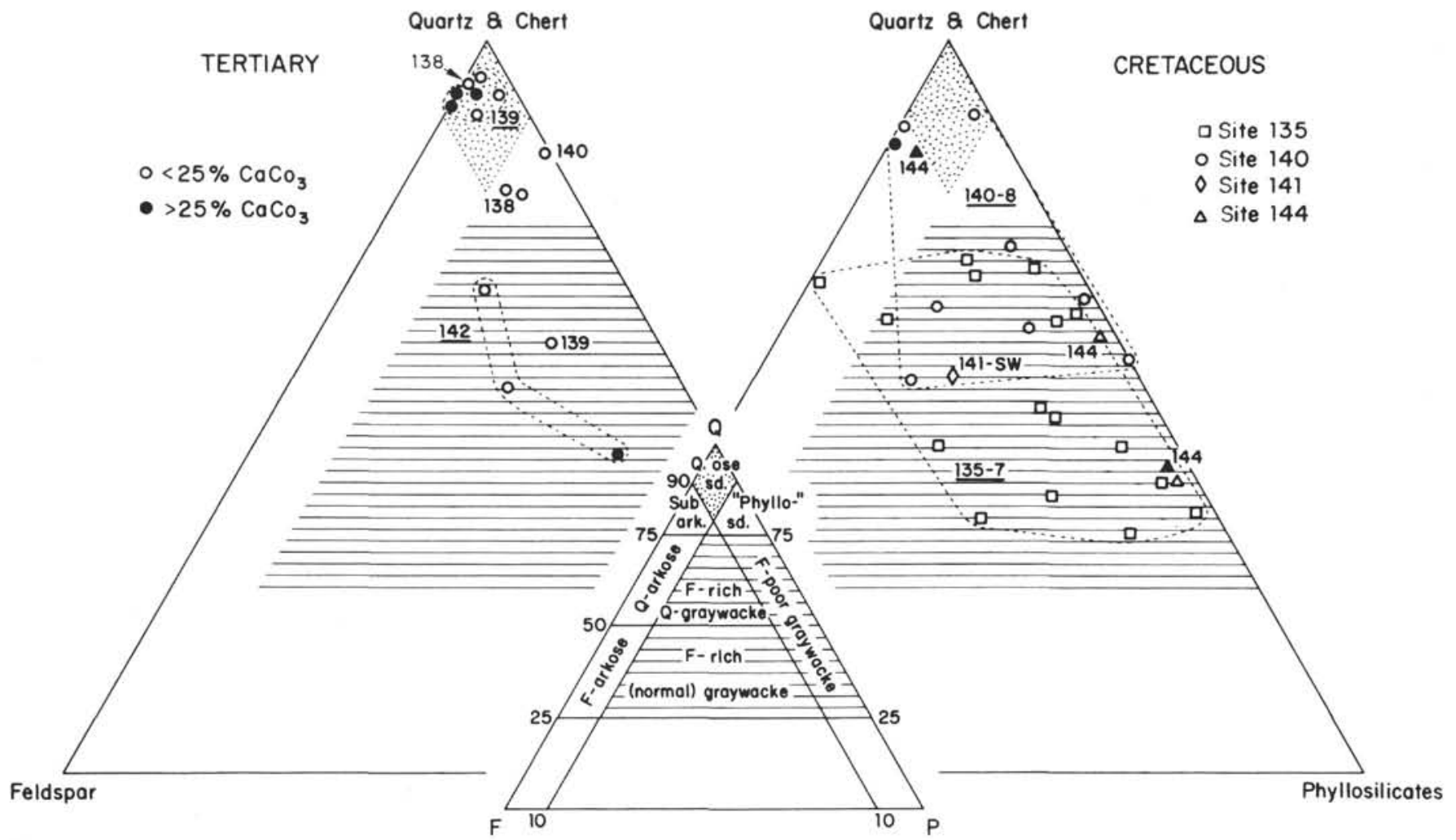

Figure 44. End member composition of terrigenous sands with (quartz + feldspar + mica) $>30 \% . Q+F+P=100 \%$.

Numbers refer to sites (three digits). Core numbers are as follows: Tertiary: Site 138, Cores 1 and 2. Site 139, Cores 6 and 7. Site 140, Core 3. Site 142, Cores 1, 2 and 5. Cretaceous: Site 135, Core 7. Site 140, Core 8. Site 141, Sidewall core 1. Site 144, Cores 6, 7 and 8.

and rather well sorted silt and sand layers, of which two examples are illustrated (Figure 46). A dark olive gray quartz-rich sand-silt layer at the base of 142-1, Section 1, has high proportions of feldspar, mostly altered sanidine, and mica, as well as considerable iron oxide, but it only has traces of carbonate (Appendix 5). The coarse fraction is rich in mollusc fragments, forams, plant material, and fecal pellets. Chert fragments also were noted. The layer appears indistinctly graded. A similar sand-silt layer in the core catcher of 142.2 is somewhat better sorted, more sandy, and contains more than 20 per cent forams in the coarsest fraction (Figure 46). In the coarse fraction survey (Appendix 4), glauconite and igneous metamorphic rock fragments also were noted in terrigenous sediments. Foraminifera are occasionally quite well preserved in these layers although assemblages generally are highly dissolved in the in situ pelagic sediments.

Compositionally, the sands are "subarkoses" according to Folk's (1968) quartz(Q), feldspar(F), rock fragment (R), compositional triangle. The average end member composition is about $Q_{86} F_{12} R_{2}$, but these percentages neglect the characteristically high content of chlorite and greenish biotite (up to $20 \%$ ), reworked glauconite, plant fragments (terrigenic leaves and wood, heavy minerals [2-5\%], and displaced biogenous carbonate $[5-10 \%]$. Also, the sands are rich in clay matrix $(>10 \%)$, so that they are here classified according to Huckenholz (1963) purely descriptive quartz-feldspar-"phyllosilicate" (P) nomenclature as "feldspar-rich quartz-graywacke" (with $\mathrm{Q}_{44-60}$
$\mathrm{F}_{12-21} \mathrm{P}_{17-44}$ ) poor in lithic fragments (see Figure 44 ). Quartz is mostly (sub) angular and sometimes stained red (by ?hematite). K-feldspar (sanidine etc.) is more abundant than plagioclase (mostly sericitized and kaolinized). Much of the biogenous carbonate appears to consist of displaced pelagic components (coccoliths, thin-walled planktonic foraminifera). A considerable part of the biogenous constituents can only be derived from the shelf (or upper slope) environment (some benthonic foraminifera, such as Bolivina, bryozoans, Turritella-type gastropods, Limacina-type pteropods, and pelecypods. Analysis by J. P. Beckmann). The heavy mineral suite is very diverse, with minerals of intermediate to low transport stability and of plutonic (to volcanic) origin, such as amphiboles (>pyroxenes), dominating stable minerals like zircon, rutile, sphene, etc. A similar composition, but with higher feldspar content (up to $35 \%$ ) was reported by Damuth and Fairbridge (1970) from Late Pleistocene (latest Wisconsin) sediments of the Ceara Abyssal Plain.

Feldspar-rich sands were derived from the Brazilian and Guiana Shields. Because of the relatively dry Pleistocene climate (Damuth \& Fairbridge, 1970) the sands were not chemically weathered to lateritic clay (gibbsite and kaolinite) as they are today, but were transported by the Amazon and Para (Tocantins) Rivers to the sea as bedload. During the time of maximum regression, the shelf off the Amazon River mouth was only 20 to $50 \mathrm{~km}$ wide (170-340 km today). Thus the coarse-grained sediment could easily bypass the shelf and reach the Ceara Abyssal Plain via the 

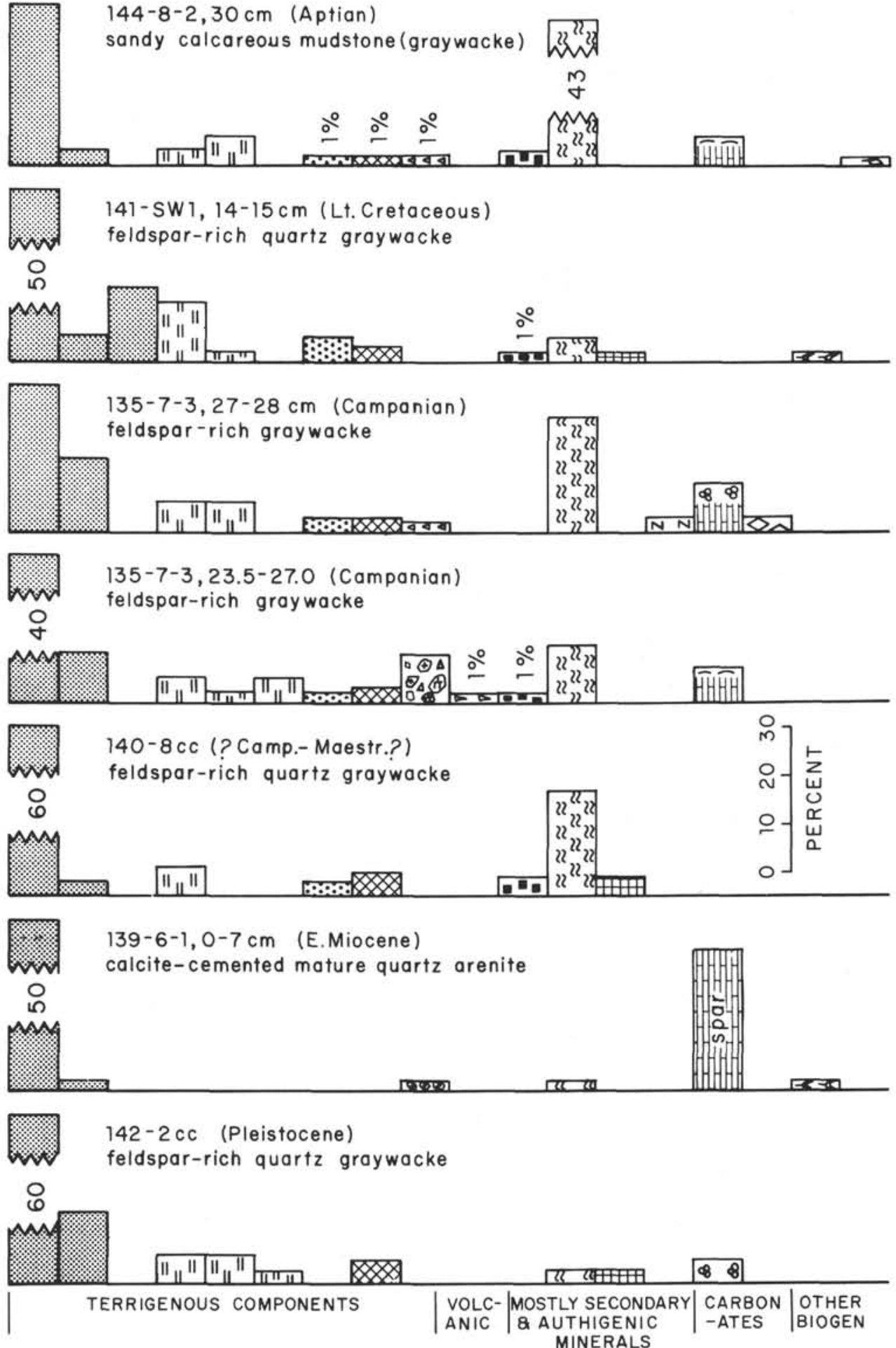

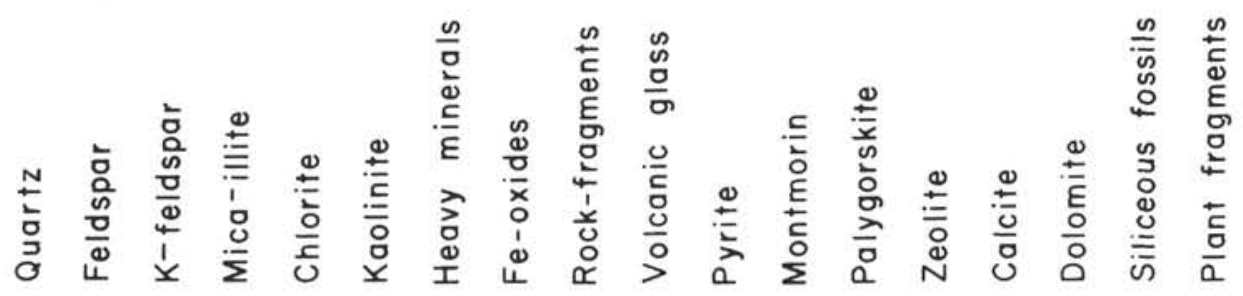

Figure 45. Composition of selected, representative terrigenous sand and silt layers. 


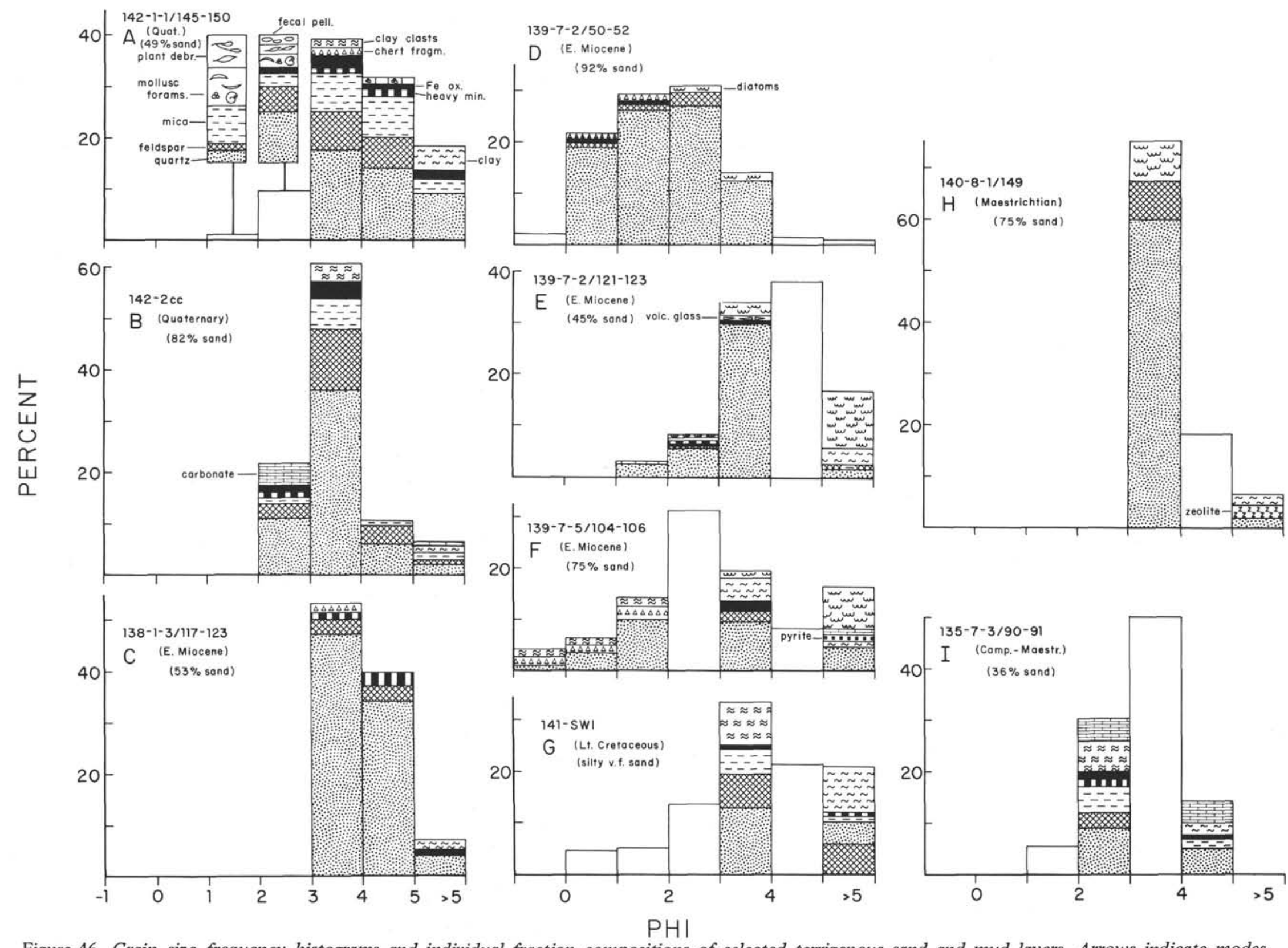

Figure 46. Grain size frequency histograms and individual fraction compositions of selected terrigenous sand and mud layers. Arrows indicate modes. Approximate Md. and $\sigma$ values (in phi units): A: 4.0; 2.0 (moderately sorted); B: 3.3; 1.3 (moderately well sorted); C: $3.75 ; 1.5$ (well sorted) D: 1.9;-(poorly sorted); E: 4.15;-(moderately sorted, bimodal); F: $2.8 ; 3.7$ (very poorly sorted); $\mathrm{G}: 3.65 ; 2.55$ (very poorly sorted) $\mathrm{H}: 3.0 ; 2$ (moderately sorted); I: 4.3; 1.6 (moderately to well sorted). 
continental slope and the Amazon Canyon and Abyssal Cone (located to the northwest).

Similar terrigenous turbidites, also probably derived from the Amazon River were cored at Site 26 (Leg 4) in the Vema Fracture Zone, a deep cleft, apparently acting as a sediment trap (Bader et al., 1970). The thickness of sand layers and the composition (plant fragments, feldspar and heavy mineral content) are similar to Site 142 , but the rate of deposition is about five times higher at Site 26.

Pliocene and Late Miocene terrigenous muds of Site 142 tend to be rather more calcareous than Quaternary ones (Appendix 5). Some Miocene sediments, however, contain virtually no planktonic foraminifera, suggesting that the site of deposition was at least part of the time below the general foraminiferal compensation depth (Figure 13). Only one graywacke-type sand layer was cored in the Mio/Pliocene section indicating reduced terrigenous influence. The $35 \mathrm{~cm}$ thick layer (Core 5-1) is distinctly graded from silty sand via sandy silt to clayey silt, and is overlain by slightly silty clay, containing a non-reworked foraminiferal fauna. The natural gamma radiation correlates well with the gradual upward decrease of grain size (and increase of mica). Compositionally, the sand layer is very similar to the Pleistocene sands. Core 8 contains a $40 \mathrm{~cm}$ thick section where two lithologies, a brown and a white clayey foram-nanno-calcilutite, are thoroughly mixed, apparently by postdepositional slumping.

(2) Bioclastic turbidites and slump deposits of Site 142 (Cores 5, 6, 8) (Mio-Pliocene) $)^{12}$. Light-colored foraminiferal calcarenite to calcisiltite layers, sometimes grading into the overlying nannoplankton calcilutite, were observed in cores 5 and 6 . The calcarenites, up to $25 \mathrm{~cm}$ thick, have sharp lower boundaries and consist of up to 70 per cent foraminifera and foraminiferal fragments (Plates 23; 38, Figure 3 ), 15 to 20 per cent nannoplankton, small amounts of polyaxial calcareous tunicate or sponge spicules (Plate 38, Figure 5), mollusc and echinoid (Cidaris) fragments, calcareous algae, finely ground calcite "flour," traces of quartz, mica, chlorite, pyrite, and clay minerals. Shallow water (corroded or broken) benthonic foraminifera (e.g. Elphidium, Bolivina, Amphistegina, Nonionidae) probably were derived from the inner shelf. Displaced well-preserved thin-walled planktonic foraminifera - as opposed to highly corroded indigenous planktonic faunas - are quite common in calcarenites and calcisiltites. A typical (graded) cycle starts above a sharp lower boundary with white foraminiferal sand (median grading from 100 to $50 \mu$ ) that is overlain (with gradational to sharp contact) by light brownish-gray clayey nanno calcilutite to -siltite (Plate 23). This nanno marl mud is typically burrowed at the top. Some cycles appear to start with a calcisiltite or even nanno-calcilutite at the base (no size grading). Apparently most of these layers are bioclastic turbidites. This is based on their texture (size grading in some cases, lack of laminations), the sharp lower and mostly gradational upper contacts and gradational color changes, the faintly mottled

\footnotetext{
${ }^{12}$ Helpful comments by J. P. Beckmann (Zurich, 1971) on the nature and interpretation of calcareous fossils are gratefully acknowledged.
}

(hemi-) pelagic zones overlying these layers, and their redeposited microfauna. Even some of the nannoplanktoncalcilutites might be displaced; the highly broken discoasters (Plate 38, Figure 2) suggesting redeposition from-higher areas - possibly also from the Ceara Rise. Some thin layers of well sorted foraminiferal sands (e.g. in Core 4) might also be explained as lag deposits from reworking bottom currents, although such reworking should have led to considerable dissolution in a relatively short time.

(3) Middle Tertiary, mature quartz sands off Cape Blanc $(138,139,140)$. The Middle Eocene to Early Miocene terrigenous sands of 138-1 and 2;139-6 and 7; and 140-3 are noteworthy for being highly quartzose and having a high degree of mineralogical maturity. The quartz: feldspar ratio ranges from 6 to 20 and the composition averages $\mathrm{Q}_{80-90} \mathrm{~F}_{4-6} \mathrm{P}_{6-14}$ (Figure 44). The degree of sorting varies (Figure 46) partly as a function of the presence of clay clasts, but largely as a result of the size distribution of quartz grains. Of the quartz grains $>500 \mu$, two-thirds are glossy (with polished surface) and one-third are milky (pitted and frosted surface). Except for fractured grains, all quartzes $>250 \mu$ are well rounded (see Appendix 5). Thin sections of the calcite-cemented sandstone of 139-6-1 show secondary quartz overgrowths (Plate 36, Figure 5 and 6). The overgrowths are apparently due to reprecipitation of silica around detrital quartz grains. The silica can be derived from the dissolution of siliceous fossils also present in this sandstone. Subangular K-feldspars (microcline, orothoclase; Plate 35, Figure 4) and crystalline rock fragments (Figure 47 ) point to a plutonic-metamorphic source (e.g. perthite myrmekitic quartz-feldspar intergrowth; metaquartzite; Plate 36, Figures 2 and 3). Reworked large (? fecal) clay pellets, fresh glauconite, and coated (ooid-like) phosphates (Plate 36, Figure 4) are rare admixtures. Mica and clayey matrix is practically absent. The high degree of rounding, high mineralogical maturity (high quartz/feldspar ratio, stable heavy minerals, see Figure 47) and the good sorting (lack of mud matrix) suggest a multicycle origin with intermediate stages, such as beach or littoral sand before redeposition to abyssal depths. Several components (crystalline rock fragments, quartz-feldspar intergrowth; amphibole, zircon etc.) indicate an ultimate crystalline source, possibly the Precambrian Reguibat Massive (NE of Cape Blanc) that was probably eroded during Oligo-Miocene uplift.

Siliceous fossils are associated with the sand layers at Site 139 but occur only in traces at 138-1. Occasionally the siliceous sediments in $139-7$ are quite pure (maximum $60 \%$ siliceous organisms, 10\% quartz), suggesting that they were deposited in situ, in addition to being emplaced by entrainment and mixing with terrigenous resediments. The excellent degree of preservation (see section on siliceous fossils) suggests protection from dissolution by rapid burial. Similar observations apply to the Oligocene quartz sands and silts at 138-2 (associated with radiolarian oozes) and to the Eocene ones at 140-3 (Table 15; Plate 38, Figure 1).

(4) Cretaceous (feldspar-rich) graywacke sands (135-7, 140-8, 141-SW1, 144-6, 7, 8). During the late Cretaceous, the Atlantic Ocean was considerably narrower (see section on history) and sediments derived from the adjacent continents and shelves typically are intercalated with 

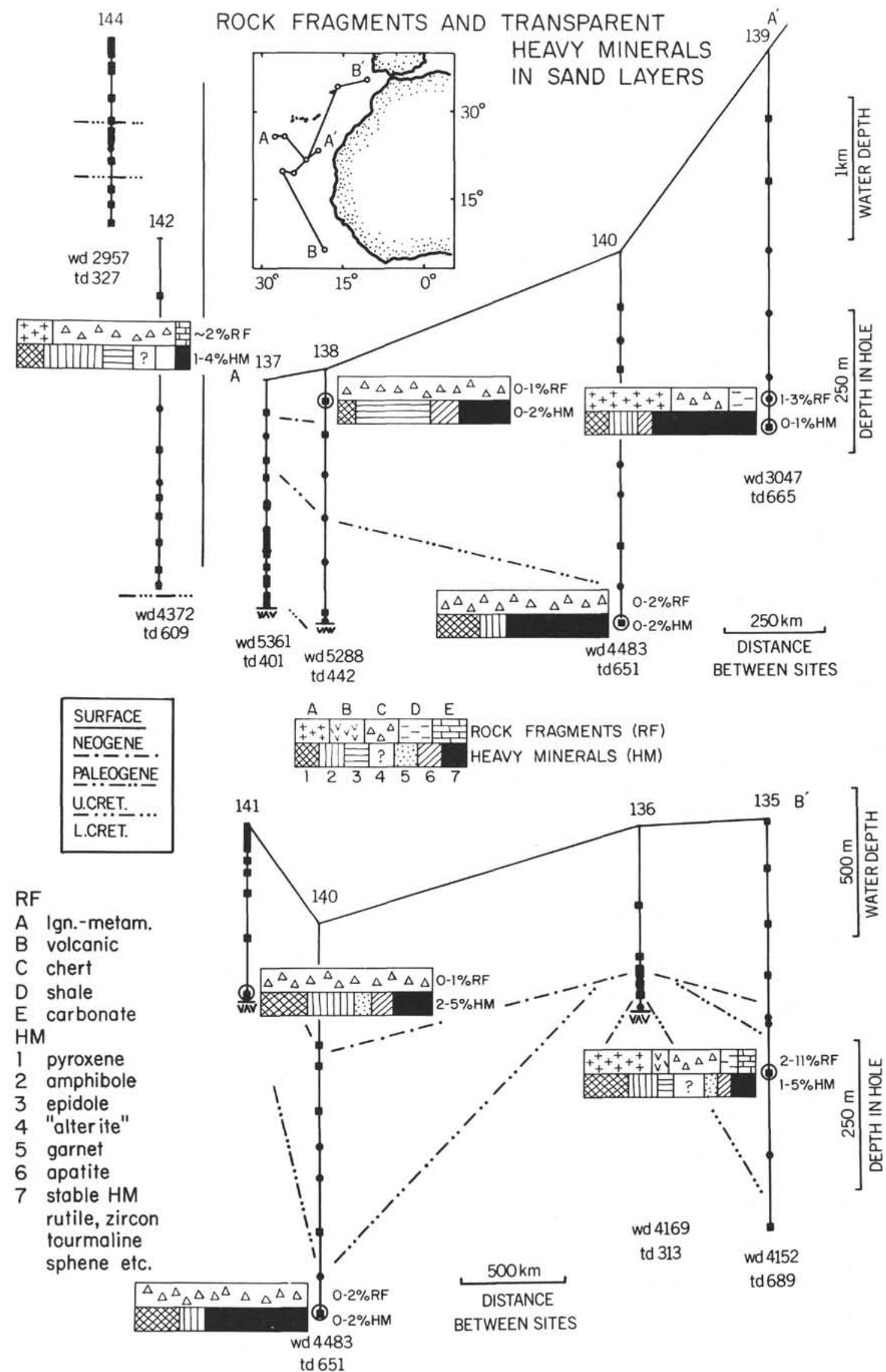

Figure 47. Distribution of rock fragments and transparent heavy minerals in sand layers. 
off-ridge pelagites in flysch-like fashion. Generally, terrigenous sediments are rich in both feldspar and phyllosilicates, indicating low maturity (Figure 44). Also, quartz grains tend to be angular and subangular.

Heavy minerals include a large proportion of pyroxene, hornblende, and other unstable types (Figure 47). Iron oxides or sulfides usually are rather more prominent in the Cretaceous sands than in the Tertiary terrigenous deposits. The same is true for the lithic fragments (mainly chert and igenous-metamorphic rocks, also limestone, sandstone, shale). Siliceous fossils generally are less abundant, excepting 140-8 (Maestrichtian) which contains traces of radiolarians and sponge spicules.

Compared with terrigenous muds, the graded (and ungraded) sand and silt layers generally have more terrigenous clay minerals (mica, kaolinite, chlorite) and less montmorillonite and palygorskite, suggesting predominantly oceanic derivation for these last two minerals.

Site 135, Core 7 (Campanian/Maestrichtian) has several terrigenous sand layers; the thicker ones $(20-30 \mathrm{~cm})$ are clearly graded and have sharp lower boundaries (see Plate 35 , Figure 1). The sands are poorly sorted (sometimes polymodal), chaotic graywackes with 15 to 25 per cent clayey and silty matrix. The composition is quite variable, depending upon texture and other factors: $\mathrm{Q}_{33-70} \mathrm{~F}_{6-33}$ $\mathrm{P}_{12-56}=$ "feldspar-rich (quartz) graywacke" (see Figures 44, 45).

Mineralogy. Large quartz grains $(>250 \mu)$ are largely (sub) rounded to subangular, milky, and have pitted and frosted surfaces. Smaller quartz grains are mainly (sub) angular with conchoidal fractures and are clear. Traces of reddish stained and greenish grains were noted. Plagioclase is more common than K-feldspar and perthite, and highly altered (sericitized) prochlorite and biotite are abundant. The same is true for mafic heavy minerals (basaltic and green hornblende, augite and titanaugite, epidote, garnet, tourmaline, sphene, etc.). The largest angular rock fragments, dolomite rhombs, large orthoclase and quartz grains (0.2 - $1.1 \mathrm{~mm}$ diameter), Fe-oxide particles, and heavy minerals are concentrated somewhat above the base of graded layers (Plate 35, Figure 1). Pyrite and traces of glauconite and zeolites were also noted.

Rock fragments amount to up to 10 per cent and consist of (in decreasing frequency): metamorphic rocks (e.g. quartz-mica schist, metaquartzite, Plate 36, Figure 1); plutonic quartz-feldspar aggregates (Plate 35, Figure 1), laminated and altered dark chert fragments; reworked calcilutites, dolomite (or ankerite) rhombs, shale fragments, fecal pellets, ferruginous siltstones, graywacke-type and calcite-cemented sandstones. Basaltic glass (with palagonitic rims), pumice, and altered (ferruginous and serpentinized) volcanic rock fragments are rare.

In one remarkably dark lamina in the middle of a ?graded sand layer, carbonized terrigenic plant fragments $(20-60 \%$ ) are concentrated in the fraction $>250 \mu$ (see section on carbonaceous sediments).

Foraminifera (analysis by J.P. Beckmann). Thin (?ungraded) sand layers and the upper part of turbidites contain size-sorted $(150-500 \mu)$ planktonic Globotruncanidae and Heterohelicidae, small numbers of more or less corroded, benthonic foraminifera (Lenticulina, Clavulina, echinoid spines, and phosphatic fish debris. The base part of the turbidites is only slightly coarser grained $\left(\mathrm{Md}_{\text {top }}\right.$ $\mathrm{Md}_{\text {base }}=0.5-0.8 \mathrm{phi}$ ) and is poor in foraminifera. Reworked bryozoan and coral fragments (Plate 35, Figure 2) were also observed. In the clayey mica-rich silt underlying the turbidites, only small Heterohelicidae and Hedbergella are concentrated. The matrix of these graywackes is rich in sericite, chlorite and ?montmorillonite, and is mixed with micritic calcite.

Site 140, Core 8 (Maestrichtian), within a flysch-like Late Cretaceous sequence, contains two different types of sands: (a) well sorted ("clean") quartz sands and silts; and (b) bimodal, muddy quartz graywacke sands (about $\mathrm{Q}_{60} \mathrm{~F}_{10} \mathrm{P}_{30}$, see Figure 44; Plate 35, Figure 5). The graywacke sands are laminated by concentrations of large quartz grains $(200-350 \mu)$ and fine grained limonitic clay with sponge spicules. These siltstones grade into the spiculitic quartz-lussatite chert of $140-8 \mathrm{cc}$. Up to 25 per cent of the coarse fraction of one sand layer (140-8-2, 96 $\mathrm{cm}$ ) consists of euhedral pyrite (octahedrons and spherical microconcretions, $100-500 \mu$ ), apparently a micro-placer deposit.

Site 141, SW1 (?Late Cretaceous) has a graded feldsparrich graywacke sand $\left(\mathrm{Q}_{50} \mathrm{~F}_{20} \mathrm{P}_{30}\right)$ which is of special interest, because it occurs below eupelagic brown clays and only 8 meters above the basalt terminating the hole. All quartz grains $>100 \mu$ are well rounded, some with overgrowths and some coated by ferruginous material (see Plate 37, Figs. 5, 6). K-feldspar, mostly sanidine, is much more frequent than plagioclase, which is either fresh or highly chloritized, sericitized, or calcitized (Plate 37, Figures 2, 3). The quartz/feldspar ratio is only 2 to 4 . Also typical are greenish biotite and a very heterogenous heavy mineral suite, consisting of green hornblends, sphene, garnet, zircon etc. (Plate 37, Figure 4) and traces of colorless volcanic glass. Montmorillonite and palygorskite make up the bulk of the matrix. Most probably the sand has a mixed (?multicycle) origin by a turbidity current picking up and redepositing material from two different sources: (1) a sanidine-rich volcanic realm (similar to that of the Capverde Archipelago, see Correns 1937; Radczewski, 1937); and (2) a terrigenous source (well-rounded quartz, plagioclase, orthoclase, hornblende, zircon, sphene), possibly plutonic rocks from the African Continent. At the time this sediment was deposited the site was part of an abyssal plain (the uplift of the diapiric structure started probably in the Miocene).

Site 144, Cores 6, 7, 8 (Mid-Cretaceous) is characterized by more or less quartzose marls. The quartzose micaceous mudstones of Core 8 (Aptian) can be classified as "normal" (i.e. feldspar-poor) graywackes with about $\mathrm{Q}_{45} \mathrm{~F}_{5} \mathrm{P}_{50}$ (Plate 38, Figure 1). They have a high clay content $(43 \%)$, followed by quartz (33\%) and chlorite-mica $(8 \%)$, with small proportions of feldspar $(4 \%)$ and varying percentages of calcilutite (in this case only $6 \%$ ).

Volcanogenic Sediments

\section{Occurrence}

Ash layers were recognized in various cores other than those at Site 136, especially within sediments deposited at 
relatively low sedimentation rates and with little reworking (see Figure 24, volcanogenic components). A thin bed of white altered ash occurs at the base of a redeposited (?) dolomite layer in the cyclic dolomite-sapropelite sequence of core 138-6-2. Most of the originally vitric material is completely altered to abundant montmorillonite and traces of palygorskite. Besides traces of detrital quartz and mica, $\mathrm{K}$-feldspar (? volcanic sanidine) is common. At Sites 137 and 141 , thin greenish(-black) "phyllosilicate sand" layers are intercalated with pelagic nanno marl oozes and clay. 137-14-4 contains high proportions of X-ray amorphous (highly disordered) material, besides calcite, smectite, and terrigenous quartz, mica, and kaolinite. In 141-9-1 the green phyllosilicates are all smectite (apparently nontronite) with traces of palygorskite, mixed-layer mineral, and quartz.

To the extent that montmorins (smectite group), palygorskite, sepiolite, hectorite-saponite, and clinoptilolite are indirectly derived from oceanic volcanism, a large part of the noncalcareous clay fraction of virtually all sediments, especially pre-Neogene ones, has a volcanic source. However, if one restricts the category of volcanogenic sediments to deposits whose silt and sand fractions are dominated by glass, palagonite, pumice, and volcanic rock fragments, essentially only Site 136 (Cores 5 to 8 ) remains for consideration.

The volcanogenic sequence at this site consists of highly oxidized (silty) clays, and clayey silts, interbedded with layers of sandy volcanic ash, a few $\mathrm{mm}$ to several $\mathrm{cm}$ thick and rich in volcanic rock fragments, glass, palagonite and pumice, as well as anhedral calcite ("spindles"), dolomite, and terrigenous particles. The sequence overlies dark olive nanno marl and is terminated by a hiatus comprising the entire Paleogene.

\section{Texture}

The texture of the volcanogenic muds and clays at Site 136 is highly variable, but clayey silt and silty clay is typical (Figure 48). Much of the coarse fraction consists of reworked cemented material besides rock fragments, glass, pumice, manganese and iron-oxide (Plates 41, 42). In general the degree of sorting is poor.

\section{Composition}

The composition of sediment layers within the volcanogenic sequence of Site 136 varies greatly-mainly by changes in the proportion of relatively few components (Appendix 5). Much of the variation seems to be a reflection of mechanical sorting, reworking, and redeposition mechanisms.

A compositional summary of the volcanogenic deposits is given in Figure 49. Note the high proportion of volcanogenic clays coexisting with vitreous and lithic components, the considerable terrigenous contribution, and the odd composition of the carbonate fraction. For illustration and description of selected thin sections and smear slides see Plates 41 and 42 .

Composition and origin of sandy ashes and tuffs. The sand fraction typically contains lithic fragments, pumice, glass, carbonate-cemented clay and ash clasts, fragments of optical calcite (partly spindle-shaped), manganese nodules,

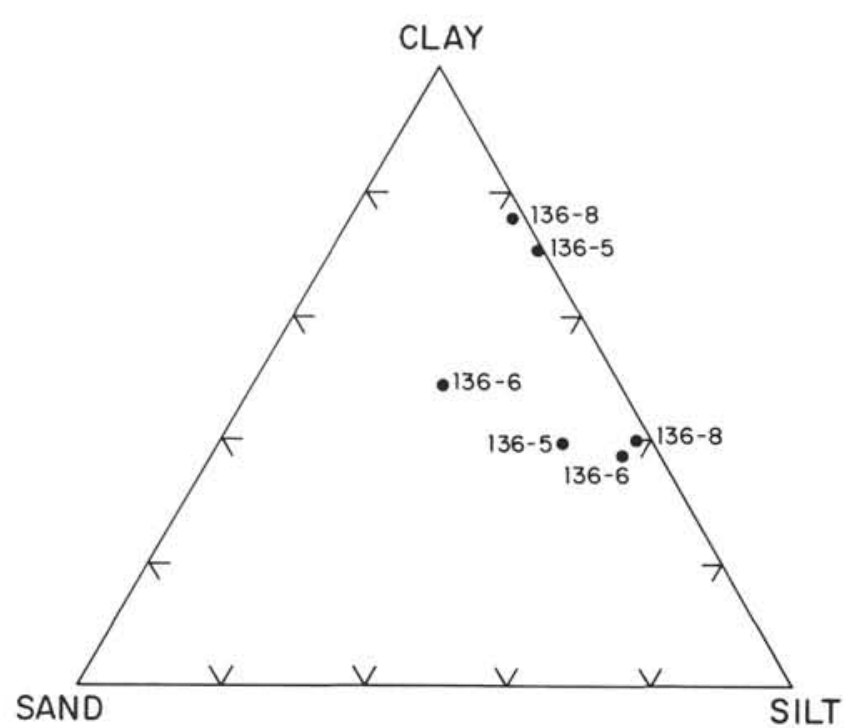

Figure 48. Texture of volcanogenic sediments (Site 136, Cretaceous).

and iron-oxide-cemented clay clasts, quartz, feldspar, dolomite, pyrite (136-5), and agglutinated forams. Occasionally, single specimens of calcareous forams, radiolarians and fish debris are seen. Manganese-nodules from near the Cretaceous-Neogene unconformity showed high copper content. These nodules were the only ones of all the Leg 14 specimens investigated that had a high iron content (see section on heavy metals).

The silt fraction also is characterized by volcanic lithics, glass, and palagonite, $\mathrm{Fe}$ - and $\mathrm{Mn}$-oxides and terrigenous components. Traces of zeolite were noted in many samples Much of the "zeolite" in Table 16 was later found to be high-temperature sanidine (see von Rad and Rösch, this volume). Dolomite is quite abundant in places. Most of the carbonate is in the form of edge-rounded, elongate prisms or corroded combinations of prisms and rhombs, many of which are spindle-shaped (Plate 41). The largest of these "spindles" were found in the coarse fraction of Core 8 , where they form large aggregates, in part star- and lattice-shaped. These aggregates apparently are disintegration products of veinlets noted in pale reddish orange siltstone. In view of the virtual absence of planktonic forams and the poor state of preservation of nannofossils within the entire volcanogenic sequence, dissolution may have played an important role in the production of the calcite spindles by corrosion and disintegration of sparry calcite. The overall decrease in the size of calcite aggregates with time suggests that the calcite spar was formed elsewhere within volcanogenic deposits, possibly through weathering and diagenesis, or alternatively as a result of hydrothermal activity. Subsequently, these deposits were eroded and redeposited at a site near the $\mathrm{CDD}$, with pelagic carbonates being dissolved and washed out during extensive reworking.

Most of the pyroclastic layers are altered vitric ashes with only small admixtures of crystalline minerals, such as K-feldspar, plagioclase, ?pyroxene, and terrigenous biotite, chlorite, and quartz. Light-colored volcanic glass is more abundant than yellowish green sideromelane. The following 
$136-8-2,20-24 \mathrm{~cm}$

olive-yellow silty clay

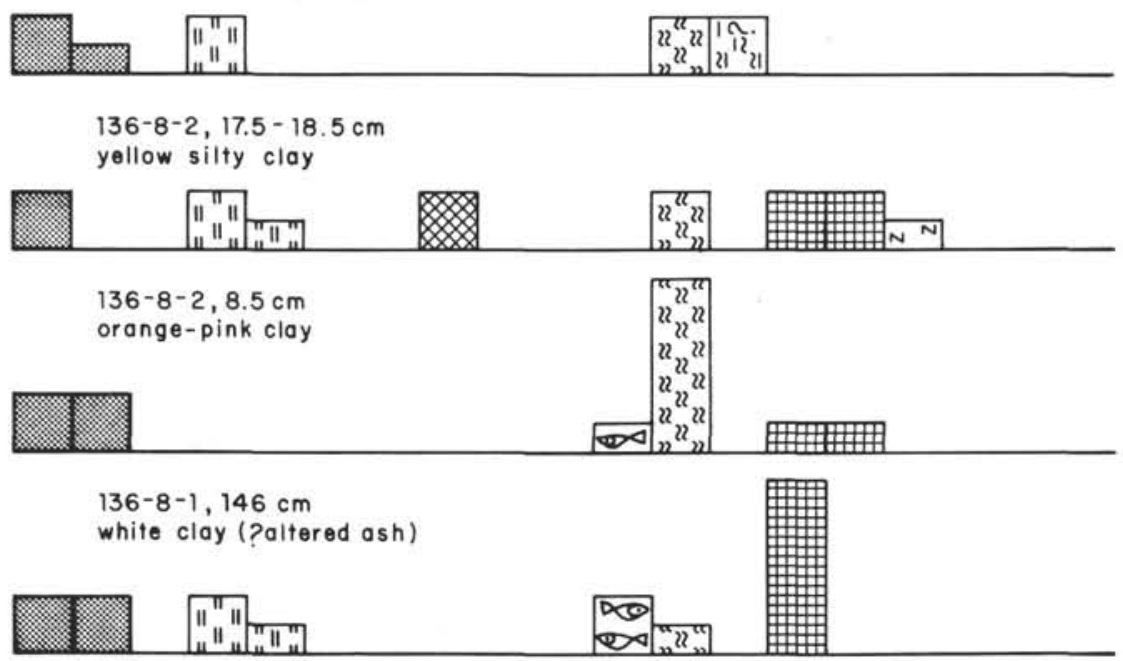

$136-6-2,94-95 \mathrm{~cm}$

dark yellow-brown altered vitreous as $h$

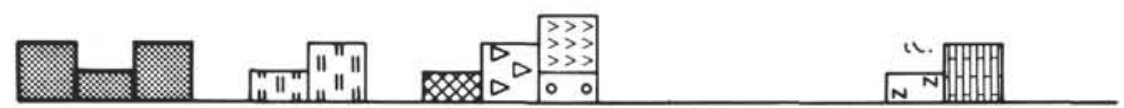

$136-5 \mathrm{cc}$

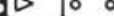
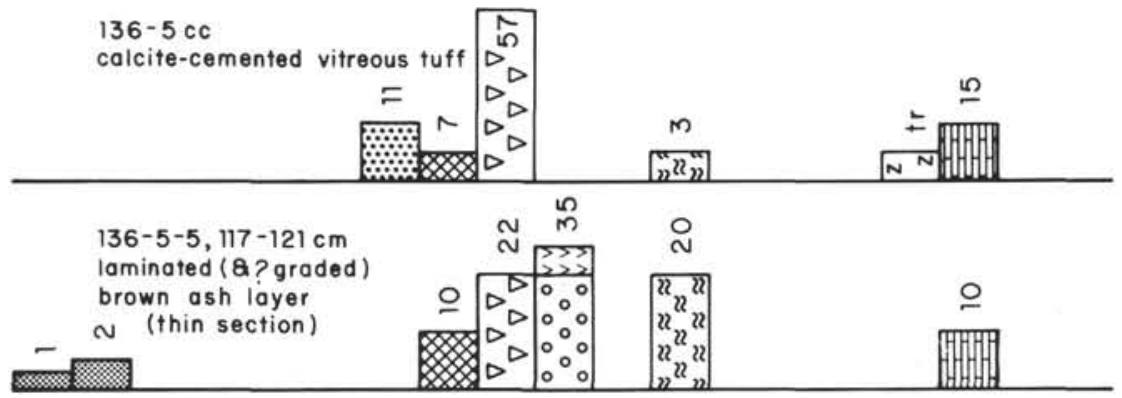

$136-5-5,101-102.5 \mathrm{~cm}$

brick-red vitreous osh

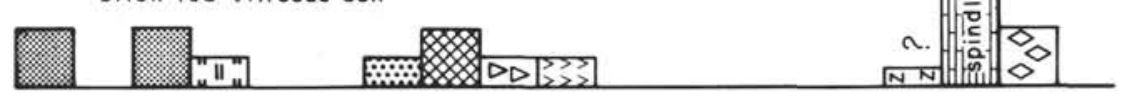

$136-5-1,130 \mathrm{~cm}$

banded brown silty clay
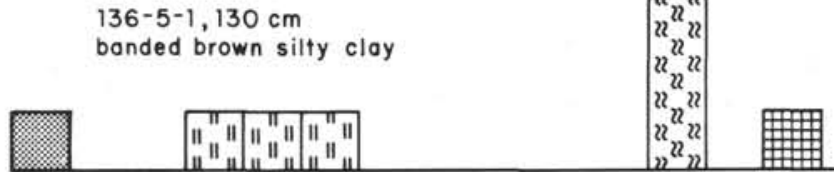

समसमान

$136-5-1,120-124 \mathrm{~cm}$

brown volcanogenic clay

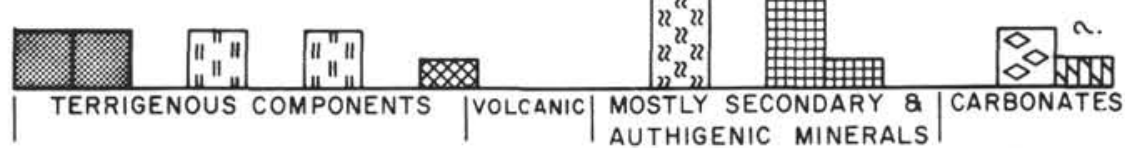

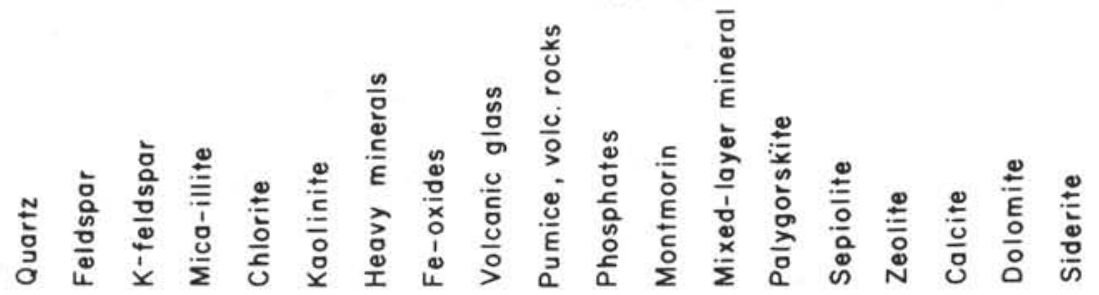

Figure 49. Composition of volcanogenic sediments, Site 136 (Cretaceous). 
varities of volcanic debris are common in the coarse fractions: ferruginous (limonitized) lapilli of hyalobasalt with small plagioclase laths; dark vesicular glass-rich scoria of basaltic components with partly blown-off vesicles; white foamy pumice spherules $(50-200 \mu)$, perfectly spherical, ellipsoidal, or as tubules, in part with contraction cracks and altered to greenish ?nontronite or to brown limonitic aggregates (Plate 41, Figure 2); shredded bits of pumaceous glass; sharp-edged glass shards with central $\mathrm{Fe}$ ore nuclei; crumpled fan-like glass aggregates; and glossy pellets ("Pele's tears"). Only part of the glass has been hydrated to palagonite. In the calcite-cemented vitreous tuff of $136-5 \mathrm{cc}$, unusually fresh (bubble-) shards occur with all colors from colorless over pale yellow to golden yellow (64\% glass + palagonite). The outer rims of the glassy fragments are sometimes palagonitized ("fibropalagonite"; Plate 41, Figure 7), and/or coated by opaque material (limonite, ?goethite, ?Fe-Mn oxides). Part of the pore space of this tuff is filled by microcrystalline calcite with two subsequent cement generations (Plate 42, Figure $2)$. A tuffaceous marlstone $(136-5 \mathrm{cc})$ contains 35 per cent calcite and dolomite and a limonitic montmorillonite matrix. The volcanic origin can only be inferred from numerous limonitic ?pumice spherules and ?plagioclase phenocrysts, fully or partly replaced by paramorphic calcite (Plate 41, Figure 6).

These ashes might have had the following origin (see Bonatti, 1967; Nayudu, 1962, 1964; Peterson and Griffin, 1964): Chilled lava was shattered and granulated during "hyaloclastic eruptions" to a fine-grained mixture of hyalobasalt, glass, and pumice with a few crystals of feldspar, pyroxene, etc. Subsequently, or at the same time, basaltic glass (sideromelane) was partly hydrated to palagonite and partly altered to $\mathrm{Fe}$ oxides (limonite, goethite) and clay minerals. Silicic glass was much more resistant to alteration. Higher degrees of alteration were reached (because of the increased surface area) in finely pulverized (pelitic) ashes. This led to more or less complete alteration of glass and palagonite into either smectite and Fe-oxides or-during late diagenesis and post-eruption volcanic hydrothermal activity (?)-to authigenic silica-rich minerals, such as palygorskite-sepiolite and clinoptilolite. Much of the feldspar appears to be of volcanic and possibly also of authigenic origin by hydrothermal solutions. Euhedral high-temperature sanidine was frequently identified in smear slides, and verified by X-ray analysis (136-5 and 6). At some stage before burial, all these volcanogenic components were mixed with terrigenous debris (quartz, mica) and with reworked calcite and dolomite "spindles," and repeatedly redeposited over wide areas by bottom currents or suspension flows.

Composition and origin of volcanogenic brown and varicolored clays. The clay mineralogy of the volcanogenic sequence at Site 136 is rather similar to that of Paleogene and Cretaceous clays elsewhere, suggesting that those clays are also largely volcanogenic in origin. The red and brown silty clays (Cores 5 to $8-1$ ) are characterized by highly variable carbonate contents that cannot be differentiated by color. These contents range from a few percent to more than 70 per cent "red clays," "(slightly) calcareous clays," and "marl muds." The bulk of the clay mineral fraction consists of smectite (montmorillonite, ?nontronite; hectorite-saponite in $136-5-1,20 \mathrm{~cm}$ ), kaolinite, palygorskite and sepiolite (in decreasing order). Calcite and dolomite (with traces of siderite) are rare to abundant. Common admixtures are volcanic $\mathrm{K}$-feldspar and terrigenous quartz, mica (and chlorite). A thin layer of white palygorskite clay (with common quartz, mica, ?feldspar, ?hematite) is interbedded with brown silty clay in core 136-8-1 (see Plate 43).

This palygorskite layer probably originated from vitreous ash via palagonite and montmorillonitic clay by precipitation from Mg-rich interstitial solutions (possibly under hydrothermal influences) with silica derived from altered silicic ash (Hathaway and Sachs, 1965; Calvert 1971).

A strikingly colored, $30 \mathrm{~cm}$ thick sequence of banded clay was recovered below this palygorskite layer, at the (probable) base of the volcanogenic deposit, overlying a section of nanno marl ooze (see color photo on frontispiece; Plate 43). Colors and composition vary from top to base, as follows: (a) $3 \mathrm{~cm}$ white palygorskite clay (see above); (b) $4.5 \mathrm{~cm}$ reddish brown to pale red-brown clay alternating with olive yellow clay; $0.5 \mathrm{~cm}$ dark olive gray lamina; (c) $4.5 \mathrm{~cm}$ alternating pale olive and pale reddish brown clay, containing some nannofossils; (d) $2 \mathrm{~cm}$ moderate orange pink and moderate reddish orange very fine silty smectite clay (with common quartz and feldspar, and traces of palygorskite, sepiolite, and phosphates); (e) 2 $\mathrm{cm}$ yellowish green and grayish green sandy silt: 85 per cent green smectite (?nontronite), 10 per cent quartz, 5 per cent mica, traces of ?chlorite, zeolite, and calcite (nannofossils); sand fraction consists of greenish spherules, ellipsoids, tubules, and irregular aggregates, probably pumice spherules from altered ash; high degree of X-ray disorder; (f) $6.5 \mathrm{~cm}$ pale olive and light olive brown silty clay; (g) $2 \mathrm{~cm}$ yellow silty clay with common smectite, palygorskite, and sepiolite; quartz, mica, hematite; traces of chlorite and calcite (nannofossils); high degree of amorphous scattering; (h) $5.5 \mathrm{~cm}$ olive and olive yellow clay with common smectite, ?mixed-layer mineral, mica-illite, quartz, and traces of feldspar; high degree of amorphous scattering; and (i) below sharp boundary: very dark gray nanno-bearing (10\%) clay with common quartz, mica, smectite and mixed-layer mineral, and traces of feldspar, palygorskite, and sepiolite; grading downwards into gray and light gray nannofossil marl ooze.

This multicolored banded clay marks the boundary between reduced nanno ooze below and oxidized clay above. The composition varies considerably between the clays of different colors, with regard to nannofossil, quartz and chlorite content. The high degree of crystalline disorder and of amorphous scattering in some of the bands suggests the presence of X-ray amorphous hydrated $\mathrm{Mn}$ and $\mathrm{Fe}$ oxides. It is therefore possible that this clay is enriched with heavy metals, being at the boundary of mobilization and fixation of iron and chemically similar metals, with oxidized sediments being above and reduced sediments below. Unfortunately, the lithology below the short section of nanno ooze is unknown, because the rest of the distance to basalt $(19 \mathrm{~m})$ was not cored. Thus, it is not known if this interval consists of reduced sediments, as we suppose. 
Since similar varicolored mineralized zones of metaliferous sediments ("amorphous goethite facies" etc.) were described from the vicinity of actively spreading midoceanic ridges (see section on heavy metals) and since a hydrothermal origin has been invoked for these deposits, the multicolored clays under discussion also may ultimately owe their presence to hydrothermal activity. Other modes of origin also appear conceivable. They include precipitation of $\mathrm{Mn}$ and $\mathrm{Fe}$ (hydr-) oxides on bare areas near the ridge crest, with subsequent mobilization and fractionation through reduction after burial and reprecipitation somewhere within the basal sediments. Sulfidic precipitation in an Early Cretaceous ocean with a deep-reaching oxygen minimum is another possibility. Dissolution of redeposited calcareous ooze rich in sulfides and partial oxidation could provide a metal enriched lag deposit similar to the mineralized zone found.

\section{Sedimentary Structures}

Extensive reworking of partially lithified sediments, very low accumulation rates, and apparent paucity of burrowing organisms provides for a large variety of structures (Plate 43). Clay is commonly mm-laminated, in various shades of brown, with finely mottled patterns in places and manganese oxide streaks and blebs. Sandy layers, a few mm to $10 \mathrm{~cm}$ thick, are common, and are finely laminated and cross-bedded in places (e.g. 136-5-5, 136-8-1). Contacts between pelite layers can be very sharp, suggesting erosional surfaces. Some pelite layers incorporate clay clasts apparently different from the matrix, and the concentration of such clasts may show a distinct veritcal gradient (e.g. 136-6-1). A striking example occurs in 136-8-1 where small (1-5 $\mathrm{mm}$ ) angular fragments of the underlying white palygorskite layer are incorporated in the overlying $10 \mathrm{~cm}$ thick mud layer. The fragments were probably deposited by the same strong suspension current or mud flow that reworked the upper part of the semiconsolidated palygorskite layer (Plate 43).

\section{Carbonaceous Sediments, Dolomite-Pelite Cycles}

\section{Occurrence and Main Types}

Intercalations of dark (usually olive) layers rich in organic matter characterize much of the Cretaceous sediment in all cores except at Sites 136 and possibly 141 (Figure 50). Such layers also are prominent in Tertiary hemipelagic muds below the CCD (Sites 138, 139, 140, 142).

Tertiary dark layers typically contain a considerable amount of radiolarians, diatoms and/or quartz (Figure 50, Sites $138,139,140,142-1 \& 2)$. It may be assumed that rapid emplacement of these layers at least partially protected silica from dissolution and carbonaceous material from oxidation. Rapid emplacement is compatible with the structure of at least some of the layers (sharp lower, indistinct upper boundaries, burrowing from top; see Plate 44 , Core 140-3, especially near $75 \mathrm{~cm}$ and near $145 \mathrm{~cm}$ ). The origin of much of the organic matter in hemipelagic sediments may be terrestrial, as is the case at Site 142 (plant remains). Alternatively or in addition, the oxygen minimum region on the upper continental slope (especially beneath the fertile upwelling area off Africa) may be an important source area for organic matter, as well as for some of the associated diatoms. In earliest Tertiary and Late Cretaceous sediments, such silica-rich dark layers tend to be partly chertified (Sites 135, 138, 140; see footnote 11).

The corresponding Cretaceous sediments are (olive) allodapic limestones, some of which also are quite dark and rich in organic matter (Figure 51; Plate 27; 135-8-1). Dark Cretaceous nanno-rich sediments (Sites 135, 136, 137) are not of this type, being pelagic oozes. Especially good examples of this type of ooze occur at Site 137 in the Late Cenomanian, with the best example of sapropelite occurrence in an eupelagic environment (137-7 \& 8). These sapropelite layers are in part calcareous (nanno marls) and contain large pyrite concretious (Plate 44). Content of carbonaceous matter is appreciable $\left(\sim 2.0 \% \mathrm{C}_{\text {org }}\right)$. The layers alternate with carbonaceous cherts. The association of these deposits with the facies boundary between nanno ooze and deep sea clay suggests as one possible origin the redeposition of (radiolarian-bearing) nanno marl rich in organic matter, derived from an oxygen deficient zone near the ridge crest. Dissolution of carbonate would have concentrated sulfide, silica, and carbonaceous matter.

A great variety of dark layers was cored at Site 144 (Figure 50), where highly carbonaceous (up to $11 \%$ organic carbon) sapropelites characterize the Cenomanian to Santonian sequence (Appendix 5, Plate 48). These sapropelites are calcareous and highly zeolitic (up to 25\%) and quartzose (up to $20 \%$ ) in places.

Of special interest are the carbonaceous pelites alternating with dolomite silts cored at 138-6 (Cenomanian) and at 140-6 (Paleocene). They are very high in organic carbon at $138-6\left(7.6 \%, \max 17 \% \mathrm{C}_{\text {org }}\right)$. At $140-6$ they are less carbonaceous and, in part, grade into chert. These cycles are discussed later.

\section{Composition}

The common feature of the dark layers, with the occasional exception of manganese-rich clays, is the presence of organic matter and reduced iron (Figure 51). The nature of the organic matter was studied in some detail in samples from 135-7, 138-6 and 144A-5cc. Results are as follows:

135-7-2/120-121 (Campanian-Maestrichtian). Sample of coalified plant remains from a graded dark gray sand layer. Analysis by $\mathrm{H}$. Hufnagel, Hannover.

Microscopic analysis (bright field, reflected light). About two-thirds of the sample are humose material, one-third is fusinitic, that is, it consists of opaque cellular tissue. The gray reflecting huminites consist of humotelinites, corpohuminites and gelinites. The humotelinites, originating from plant cell walls, mostly are somewhat homogenized into gels showing the original stratification only occasionally. With strongly increasing homogenization, alteration to gelinite is observed. The corpohuminites, that is, primary and secondary cell fillings, show a uniform aspect in most cases; more rarely they have fine pores which in part are filled by pyrite. The gelinites occur as slender, long bands without internal structure. The humic grains bear two sets of cracks of different age. The older ones are filled, the younger ones, open. The particles also show some oxidation 

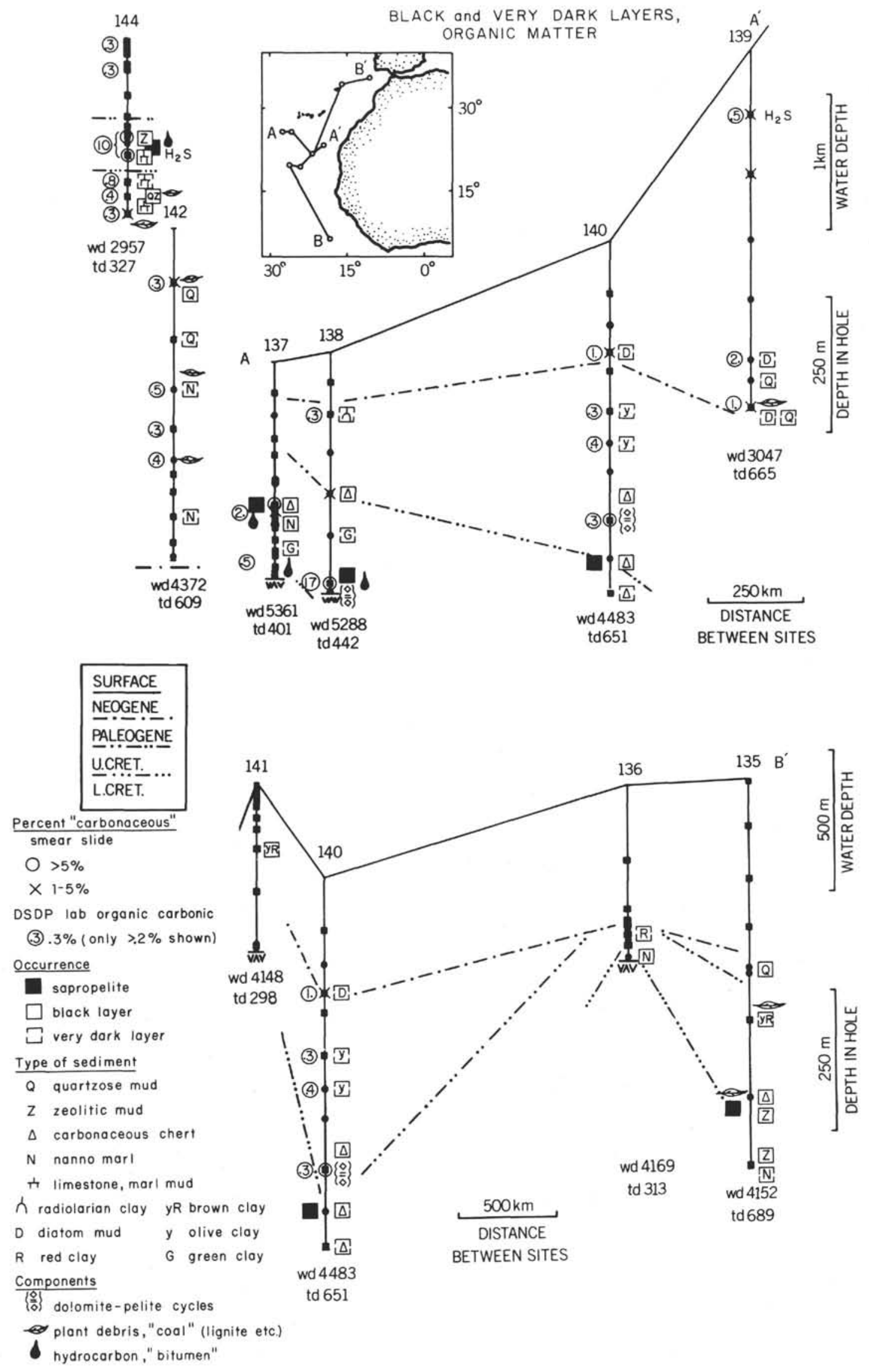

Figure 50. Distribution of organic matter and associated sediment. 

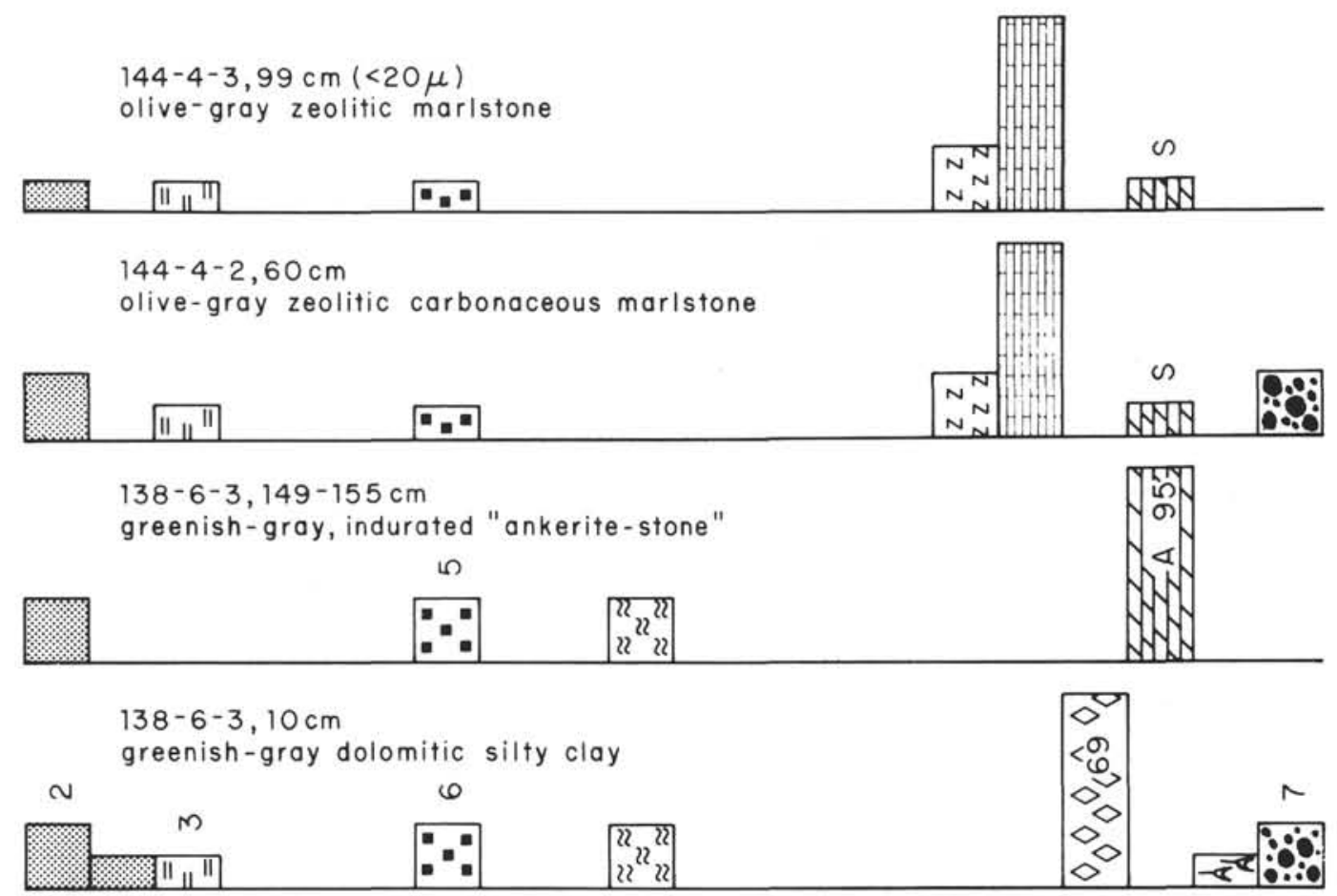

$138-6-3,0-2 \mathrm{~cm}$

olive-black carbonaceous shale

เ)
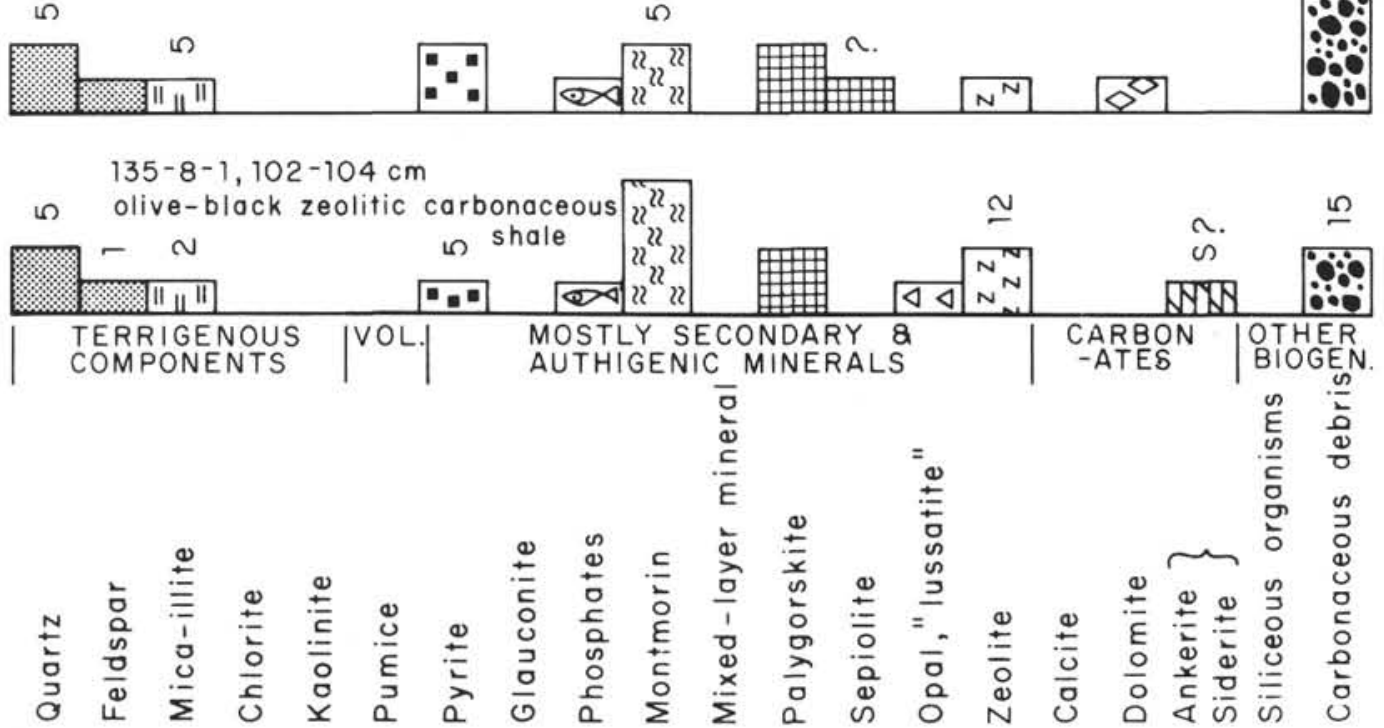

Figure 51. Composition (semi-quantitative) of selected samples of zeolitic, dolomitic, and carbonaceous marlstones and shales.

on their surface. The fusinites reflect between light gray to white. Their preservation usually is very good; cell luminae generally are empty. Within the more weakly reflecting fusinites, the cell wall stratification is still visible.

The mineral components are pyrite, calcite, iron hydroxides and, rarely, quartz. Within the fusinitic grains, calcite and pyrite fill the empty cell luminae in places. Within the humic particles, the (older) cracks are filled with calcite. In these grains, finely granular to spherolitic (framboidal) pyrite is common; also, the pyrite is expecially concentrated toward the parts near the rim and decreases distinctly toward the interior of the grain. Calcite, pyrite, quartz and iron hydroxide (partly after pyrite) occur on the surface of the organic grains in various mixtures.

Microreflection (objective 60:1; oil, $546 \mathrm{~nm}$; glass standard, $1.006 \%$ reflection; patch size, $1.3 \mu$ ): Reflection was determined on the humic components which are representative for the degree of coalification (140 measurements). The maximum of the frequency distribution is 0.35 per cent reflection (range, $0.16-0.45 \%$ ). This indicates that the organic substance is in the rank of lignite ("Mattbraunkohle"). 
Discussion. The organic material studied is wholly derived from plant remains of unequivocally terrestrial origin. It consists mainly of parts (wood, bark, roots) from arboreal angiosperms as well as a few herbaceous ones. These angiosperm remains occur both among the humic and the fusinitic components. In contrast, secondary wood from conifers, although rare, occurs only within the fusinites. Cross-section through a scatter-pored deciduous wood fragment shows growth zones (?annual rings) indicating climatic variations.

The oxidation rims and the fissuring, except the younger cracks which may have formed during preparation, indicate that the coalified material is redeposited. The composition of the humic and fusinitic components strongly argue a common origin. (End of analysis).

Context. The sample comes from a dark lamina in the upper half of a graded (?) sand layer within a sequence of intercalated silty mudstone, graywacke-type sand layers and oxidized pelites. Besides the plant remains, the coarse fraction contains echinoid spines, glauconite and limestone fragments, as well as terrigenous components (quartz, mica, rock fragments). The presence of carbonate (5-20\%) appears due to redeposition, with the indigenous component being unimportant. This suggests deposition below the (pelagic) CCD.

138-6-3/0-2 (Cenomanian). Sample from a black sapropelite layer intercalated into dolosilt. Organic matter was estimated as 50 per cent (smear slide, shipboard). Analysis by $\mathrm{H}$. Jacob (microscope, reflection, discussion; and $\mathrm{H}$. Wehner, organic geo-chemistry, both of Hannover).

Microscopic analysis. See Table 10, Comments.

Reflectivity (oil, $546 \mathrm{~nm}$ ): Reflection values are 0.15 per cent, 0.21 per cent, and 0.31 per cent for bitumens and 0.57 per cent for vitrinite (?).

Organic geo-chemistry. The samples were boiled for 8 hours in benzol/menthanol (7:3), the solvent being changed three times. The evaporation residue was weighed, redissolved in chloroform and the soluble part then fractionated over aluminum oxide and silica gel into saturated hydrocarbons (paraffins), aromatic hydrocarbons, and "resinous constituents" (i.e. molecules that contain other elements such as $\mathrm{O}, \mathrm{N}$, or $\mathrm{S}$ besides carbon and hydrogen) and asphaltenes. The fraction of the saturated hydrocarbons was further analysed by gas chromatography (see Table 10).

The ratio aromate/paraffin is 2 to 3 . Chain-lengths of $\mathrm{n}$-paraffins were between 18 to $32 \mathrm{C}$-atoms. The carbon preference index (odd over even from $\mathrm{C}_{25}$ on) is 1.18 , much lower than for recent soils and marine sediments (e.g. two surface samples from the Shelf off Cape Breton [Biscaya] gave 3.15 and 2.71). This may be due to entire or partial origin from marine plankton rather than terrestrial plants, or formation of hydrocarbons from kerogene during diagenesis.

Discussion. The sample is relatively rich in organic carbon. According to microscopic and chemical analysis it consists largely of mineral oil bitumens. The degree of reflectivity indicates either gilsonite/glance pitch or albertite. A less abundant component, showing rather strong reflection, is likely to be vitrinite (coalified plant remains). According to reflectivity the sample belongs to the rank of subbituminous B-coal ("Glanzbraunkohle/ Flammkohle"). (End of analysis).

Context. See discussion of dolomite-pelite cycles below.

144A-5-cc (Santonian). Sample of calcareous zeolitic mud. Organic matter estimated (smear slide) as 30 per cent, LECO determ.: 11.05 per cent. Analysis by H. Jacob (microscope, reflection, discussion) and H. Wehner (organic geo-chemistry).

Microscopic analysis of polished bricketted specimen (Table 18): During sectioning, bituminous odor was noted. The matrix is clayey with very abundant fine-grained pyrite, occasional calcareous microfossils, and extremely abundant, round to cake shaped, porous organic particles. These have very low reflectivity and fluroescence, with a few exceptions showing higher reflection. Very little liptinite (algae?) is present. The material is finely laminated with microstrata alternatingly rich and poor in organic substance.

Reflectivity (oil, $546 \mathrm{~nm}$ ): Reflection values are 0.15 per cent for bitumen and 0.53 per cent for vitrinite (?).

Organic geo-chemistry. The benzol/methanol extraction yielded 3.3 per cent bitumen from the sample; 1.5 per cent were soluble in chloroform. Resinous components of this fraction provide 90.8 per cent, saturated hydrocarbons 5.5 per cent, and aromatics, 3.7 per cent. Thus, the ratio aromate/paraffin is 2 to 3 (as in sample 138-6). Chain lengths also were comparable, and the carbon preference index also was low, that is, 1:06.

Discussion. The discussion of 138-6-3 (0-2) applies here also. (End of analysis).

Context. The sample comes from a unit several tens of meters thick, consisting of zeolitic black marl, olive marl, and calcareous shale, with intercalated limestone beds, and spanning some 20 million years (Albian/Cenomian to Santonian). The depositional environment was characterized by generally low sedimentation rates (punctuated by sudden emplacement of calcareous layers) at relatively shallow depth $(\sim 1000 \mathrm{~m})$ within a poorly aerated zone (see section on paleobathymetry).

Comparison between the two sapropelite samples. The two samples (138-6-3/0-2 and 144A-5cc) are very similar in abundance and type of organic matter, as well as other components (Table 10). The 144A-5 sample is zeolitic whereas the one from $138-6$ is not. Also, the much shallower 144A-5 sample is rather more calcareous. Resinous constituents and asphaltenes are distinctly higher in the 144A-5 sapropelite. For 144A-5, both age (80-84 My) and overburden $(189 \mathrm{~m})$ are less than the corresponding values for 138-6-3 (91-100 My, $430 \mathrm{~m}$ ). Aromate/paraffin ratios are exactly 2 over 3 in both sapropelites.

\section{Structure}

Typically, fine laminations are associated with sapropelitic sediments (compare Figs. 26 and 50). Sapropelitic shales tend to part along these laminae in most cases (Plate 48). Alternations of organic-rich with calcite (e.g. foram)rich layers make laminations especially obvious (Plate 7, Fig. 6). Some of the most interesting structures are shown 
TABLE 10

Petrography, Reflexivity and Organic Geochemistry of Carbonaceous Sediments

\begin{tabular}{|c|c|c|c|}
\hline Sample No. & $138-6-3, \mathrm{~cm} 0-2^{\mathrm{a}}$ & $144 \mathrm{~A}-5 \mathrm{CC}^{\mathrm{a}}$ & $\begin{array}{c}\quad 135-7-2, \mathrm{~cm} 120 \\
(\text { fraction } 125-1000 \mu)\end{array}$ \\
\hline $\begin{array}{l}\text { Water depth }+ \text { depth below sea } \\
\text { floor }\end{array}$ & $5288+430 m$ & $2957+185 \mathrm{~m}$ & $4162+433 m$ \\
\hline Age & Cenoman. (Late Cretac.) & Senonian & Campanian-Maestrichtian \\
\hline Sediment & $\begin{array}{l}\text { black carbonaceous silty mud } \\
\text { (silt: coated radiolarians), } \\
\text { lamin. intercalated into dolo- } \\
\text { silt layers }\end{array}$ & $\begin{array}{l}\text { black calcareous, zeolitic car- } \\
\text { bonaceous mud (silt and sand: } \\
\text { qtz + forams) }\end{array}$ & $\begin{array}{l}\text { upper half of a dark gray, ? graded } \\
\text { graywacke-type sand layer (black } \\
\text { lamina with plant fragments } \\
\text { ("charcoal") }\end{array}$ \\
\hline Total $\mathrm{C}_{\mathrm{org}}$ of sample & $7.65 \%$ & $11.05 \%$ & $?$ \\
\hline $\begin{array}{l}\text { Coalified plant remains } \\
\text { (? vitrinite; highly reflective) }\end{array}$ & $\sim 30 \%$ ( $\sim 0.57 \%$ reflect.) & $\sim 40 \%(\sim 0.53 \%$ reflect. $)$ & $\sim 65 \%$ huminites (jellified plant tissue) \\
\hline Bitumina (poorly reflective) & \multirow[t]{2}{*}{$\sim 70 \%$ ( $\sim 0.22 \%$ reflect.) } & \multirow[t]{2}{*}{$\sim 60 \%(\sim 0.15 \%$ reflect. $)$} & $\sim 35 \%$ fusinites (plant cell walls) \\
\hline $\begin{array}{l}=\text { Gilsonite or Albertite (round } \\
\text { to cake-shaped porous organic } \\
\text { particles) }\end{array}$ & & & $\begin{array}{l}\text { microreflectivity of humic compo- } \\
\text { nents: } 0.35 \% \text { reflection }\end{array}$ \\
\hline \multirow[t]{2}{*}{$\begin{array}{l}\text { Degree of coalification (and } \\
\text { origin) }\end{array}$} & \multirow{2}{*}{\multicolumn{2}{|c|}{ Subbituminous B-coal (="Glanzbraunkohle/Flammkohle") }} & lignite (="Mattbraunkohle") \\
\hline & & & $\begin{array}{l}\text { Origin: Angiosperm (terrestrial trees } \\
\text { and herbs) }\end{array}$ \\
\hline $\begin{array}{l}\text { benzol-methanol soluble } \\
\text { chloroform-soluble }\end{array}$ & \begin{tabular}{l|l}
$4.4 \%$ & | of total sample
\end{tabular} & $\left.\begin{array}{l}3.3 \% \\
1.5 \%\end{array}\right\}$ of total sample & \\
\hline $\begin{array}{l}\text { a) saturated hydrocarbons } \\
\text { (n-, i-, c-paraffins) }\end{array}$ & $15.0 \%$ & $5.5 \%$ & \\
\hline $\begin{array}{l}\text { b) aromatic hydrocarbons } \\
\text { c) resinous constit. }+\end{array}$ & $10.1 \%$ of chloroform extract & $3.7 \%$ of chloroform extract & \\
\hline asphaltenes & $74.9 \%$ & $90.8 \%$ & \\
\hline aromate/paraffin-ratio & 0.67 & 0.67 & \\
\hline $\begin{array}{l}\text { carbon preference index (odd over } \\
\text { even from } \mathrm{C}_{25} \text { on) }\end{array}$ & 1.18 & 1.06 & \\
\hline COMMENTS & $\begin{array}{l}\text { Clayey matrix with abundant } \\
\text { microcryst. \& framboidal } \\
\text { pyrite (pyrite "dust"); } \\
\text { bitumina w. small but variable } \\
\text { reflexivity \& very small } \\
\text { fluorescence; little to mod. } \\
\text { liptinite (?algae); traces of } \\
\text { chlorophyll (?green algae) }\end{array}$ & $\begin{array}{l}\text { bituminous smell; clayey matrix. } \\
\text { w. abundant pyrite (extremely } \\
\text { microcrystalline); very little } \\
\text { liptinite (?algae) }\end{array}$ & \\
\hline
\end{tabular}

\footnotetext{
a Analyses by H. JACOB and H. WEHNER, Bundesanst. f. Bodenforschung, Hannover.

b Analysis by H. HUFNAGEL, B.f.B., Hannover.
}

by the dolomite-pelite cycles in 138-6 and 140-6 which are discussed below.

\section{Dolomite-Pelite Cycles}

Dolomite lutites alternate with sapropelites in 138-6 (Cenomanian) and with partially silicified dolomitic clay in 140-6 (Paleocene).

Recovery in $138-6$ was 3.2 meters; of these, 0.5 meter belonged to a basalt sill penetrated in Section 2 (see Plate 46). Section $3(1.5 \mathrm{~m})$ shows six complete cycles, with black sapropelite being one extreme type and light greenish gray dolomite lutite being the other. The rest is a mixture between these two facies having a greenish gray color and containing various proportions of dolomite and organic matter (see Plate 45). At the very base of the sequence cored there is a hard ankerite stone, which differs little from the dolomite silt layers in outward appearance. Thin section shows euhedral ankerite (X-ray analysis) crystals $(15-50 \mu \max .80 \mu)$ floating in a micritic carbonate ground mass with anhedral to subhedral carbonate crystals $(<5 \mu)$ and vugs (?fossils) filled with coarse-crystalline almost monomineralic drusy ankerite (hypidiotopic inequigranular fabric) (Plate 45, Figs. 6, 7). The ankerite-stone is rather pure (Appendix 5). Secondary components are framboidal pyrite, montmorillonite, quartz, and mica.

Dolo-lutites (up to $80 \%$ dolomite) also contain pyrite $(5-10 \%)$ and some quartz and mica in addition to carbonaceous matter and clay minerals (Appendix 5). The coarse fraction consists of idiotopic dolomite crystal aggregates, as well as single crystals of very fine sand size. Framboidal pyrite concretions and pyritized radiolarians (up to $70 \%$ of sand fraction) also are present. In addition there are traces 
of nonpyritized radiolarians, glass shards and sponge spicules, fish debris, agglutinated forams, glauconite and polished quartz. The main constituent of the dolomite silts, the euhedral dolomite rhombs, occur in two size classes: $2-10 \mu$ and $20-50 \mu$. Some of the larger crystals have irregular borders and some have small nuclei of dolomite crystals, which are corroded in part, or nuclei of carbonaceous matter (Plate 45, Figure 4).

Sapropelites consist of up to 80 per cent carbonaceous matter, the remainder being quartz, mica, dolomite, pyrite and clay minerals (mainly montmorillonite). Organic carbon contents range from 8 to 17 per cent (Hannover; DSDP lab). A large part of the carbonaceous matter consists of bitumen rich in resinous components, as outlined above. A strong marine influence is suggested by the low (odd over even) carbon preference index; coalified plant remains also seem to be present. The 32 to $63 \mu$ fractions contain up to 20 per cent black coated and pyritized radiolarians and 10 per cent dolomite rhombs, the sand fractions up to 70 per cent radiolarians.

An idealized cycle is as follows:

Sapropelite Very dark brown (10 YR 2/2), streaky lamination, occasional laminae with pyritized or black coated radiolarians. (low GRAPE density: $\sim 1.6$, high nat. gamma radiation: $3500-4000$ counts/7.6 $\mathrm{cm} / 75 \mathrm{sec}$ ).

Transition Greenish gray and black, streaky fine interlayering of sapropelite (in part clay clasts?) and dolomite lutite.

Dolomite lutite Greenish gray (light gray where pure), finely irregularly layered and mottled (?), silty clay and clayey silt.

Lower part transitional to sapropelite or without transition. In core 6-4 (cm 145), lower part contains sandy volcanic ash (high GRAPE-density: 1.95, low nat. gamma rad. $<3000$ counts).

Sharp contact Apparently unconformable (erosional ?) in places (core 6-3, cm 49).

The features to be explained in these cycles include: (1) reason for cyclicity and streaky laminations, (2) origin of organic matter, and (3) origin of dolomite.

The cycles could have been produced in various ways: Since carbonate solubility increases with depth, the sapropelite should be the deeper facies of the two end members. Thus, one possible cause is fluctuating carbonate compensation in a restricted basin due to (a) bathymetric variations at a sill, (b) variations in bottom water circulation, or (c) fertility of the upper waters. Such a mechanism implies in situ wandering of a facies boundary between carbonate and sapropelite over large areas on the ocean floor.

Another possible cause, the one we think likely, is redeposition of pre-existing (shallower) dolomite into the (deeper) sapropelite environment by sporadic events, that is, turbidity flow. Such events would have taken place once every 30,000 years or so. Alternatively, dolomitic and sapropelitic sediments were displaced together, with the lighter carbonaceous material deposited on top of the heavier dolomite grains. Indigenous sediments may have consisted of slowly accumulating volcanogenic clay.
Several characteristics of the cycles indicate redeposition: (1) the overall decrease of grain size from silt to pelite within a cycle, (2) the better development of transitions below sapropelites than above them, with sharp upper contacts of sapropelites in extreme cases, and (3) the fact that corroded dolomite nuclei are present in many of the euhedral dolomite crystals.

This evidence of corrosion suggests the following sequence of events: Dolomite crystals were displaced from shallower areas to a site where they slowly dissolved. Any calcite present, whether pelagic fossils, triturated "flour" or redeposited limestone fragments, was removed entirely, but during its dissolution it enhanced preservation of dolomite by increasing the alkalinity of interface and interstitial waters. Thickness of the carbonate layers sufficed to prevent complete dissolution before burial. After burial, recrystallization took place by cannibalistic crystal growth of dolomite and, locally, diagenetic formation of ankerite, with dissolution of small irregular fragments in favor of growth of rhombs.

While this model explains cyclicity, great difference between cycle end members, absence of calcite, and high concentration of euhedral dolomite, it says nothing about the ultimate origin of the dolomite. Much of the dolomite may have formed pelagically within calcareous oozes which contain at least a few percent rhombs virtually everywhere. As pointed out above, such rhombs appear concentrated near the chalk-clay boundaries as solution lag deposits (see Figure 22). Some or most of the dolomite may be derived from reworked calcareous shelf deposits which are quite common in the contemporaneous sediments at Site 135 (Core 8). Such an origin would be consistent with the probable presence of gypsum (found by X-ray analysis; J. C. Hathaway, personal communication). Finally, the occurrence of the dolomite may be related to the emplacement of basalt, a sill (or flow) of which was found in Section 6-2. Associated hydrothermal activity and/or weathering of basalts might provide the source of magnesium and, for the ankerite, of iron. On the other hand, it appears more likely that the ankerite is derived from a dolomite layer rich in iron (Fe-oxide subsequently reduced by admixed carbonaceous matter, or pyrite originally associated with the dolomite). The fact that pyrite associated with the dolomite gave only the $\mathrm{Fe}$ peak in X-ray fluorescence (Figure 21), suggests a hemipelagic origin for these sediments. The eupelagic pyrites had other heavy metals besides iron.

Mass spectrometric determination of carbon and oxygen isotopes in dolomite silt from 138-6-3 (10-11) gave $\delta^{13} \mathrm{C}=$ -1.9 , and $\delta^{18} 0=-3.3$ (both on PDB scale; analysis by W. Stahl, Hannover). This appears consistent with a marine origin of the carbonate (H. Craig, personal communication).

Recovery in 140-6 (Paleocene?), the one core having dolomite cycles somewhat similar to $138-6$, was 1.7 meters. Cycles are much less distinct and regular, however (see Plate 47). On the average, one dark-light cycle extends over 10 $\mathrm{cm}$, probably corresponding to somewhat less than 10,000 years. Boundaries between dusky olive green layers (5 GY $4 / 2)$ and light bluish gray (5B 7/1) to greenish gray (5G 6/1) layers are quite distinct; streaky mottling and laminations (fissility) are present throughout (caution - saw and 
spatula marks present, Plate 47). The difference between light and dark beds is not as marked as in 138-6. Both are dolomitic silty clays to clayey silts, dolomite silt being somewhat more abundant in the light layers. The "clay" is mostly palygorskite and disordered cristobalite ("lussatite") (X-ray). It occurs in large aggregates which show optical continuity. Silicified claystone (chert type III) is common within the darkest part of olive layers, but silicification does not necessarily follow color changes exactly so that surrounding lighter olive material also is silicified in places. Not all dark layers are silicified. The chert layers are 5-15 $\mathrm{mm}$ thick ( $\max .30 \mathrm{~mm}$ ) (see also section on cherts).

No coarse fractions were available from this core. Smear slide and thin section analysis showed pyrite (partyly as pyritized radiolarian fragments), some carbonaceous matter, and a small terrigenous component (quartz, mica). One layer of dolomitic quartz sand (40\% rounded quartz) was noted near the base of a dark layer.

To explain the origin of these cycles, we suggest redeposition processes. The dark layers tend to have sharp lower boundaries and more gradual upper ones suggesting detrital cycles. Cherts (type III) contain, in part, corroded dolomite rhombs, but whether corroded during diagenesis or before deposition is unknown. Besides by redeposition, as proposed above for the dolomites in 138-6, in situ dolomitization is a distinct possiblity, since the pore waters were $\mathrm{Mg}$-rich as indicated by the abundant palygorskite. In this case, however, the carbonate may have first been introduced by redeposition also, irrespective of the site of dolomite formation. The palygorskite, with little terrigenous admixture, may be the chief indigenous component in these sediments, possibly together with montmorillonite (absent in X-rayed chert samples, not checked in dololutite).

\section{SUMMARY AND PALEO ENVIRONMENT}

\section{Stratigraphic Patterns}

Leg 14 of the Deep Sea Drilling Project cored chalks and marls, pelagic clays, siliceous deposits, and sediments characterized by abundant terrigenous, carbonaceous, dolomitic and volcanic components (Table 4, Figure 52).

As recovered, Quaternary and Pliocene sediments consist mostly of nanno chalk oozes and brown clay indicating a facies regime typical for the present Atlantic. The depth level separating chalk and clay, the CCD, is near 5000 meters. Redeposition of upper slope and shelf sediments is of minor importance off Africa, but provides much of the deposits off the Amazon River (Site 142). Siliceous fossils are rare.

In contrast, chalk oozes of Miocene age are restricted to depths shallower than 4600 meters, and marl oozes and brown clay are common. Redeposition of shallower sediments (mainly quartz) and siliceous fossils contribute significantly to deep-sea sediments off Cape Blanc, but only to a lesser extent at Site 142 off the Amazon River. A part of the Miocene record expected in the samples is missing (see Table 4). This discrepancy is possibly associated with the shallower CCD at that time.

The Oligocene is characterized by a major hiatus, thus, a major portion of the samples expected are missing (Table
4). At Site 144, on Demerara Rise, the Oligocene is represented by slightly siliceous chalk and marl; at Site 138, at the foot of the African Continental Rise, by siliceous hemipelagic silty clay.

Off Africa, the Eocene consists of brown clays, partly zeolitic, and greenish clays rich in quartz and siliceous fossils. On Demerara Rise, (Middle) Eocene sediments also are siliceous, but consist of foram-nanno chalk, due to the shallow depth of the site.

Paleocene rests unconformably on Maestrichtian at Site 144, where the Cretaceous-Tertiary boundary was cored. The brown pelites at 141-9 and at 137-3 also, apparently, are of this age, as are the green pelite and the dolomite-clay (chert) cycles at 140-6.

Post-Cenomanian Cretaceous shows a striking variety of litho- and biofacies. The major deep sea facies are zeolitic radiolarian brown clay; recrystallized limestone, partly with quartz and pyrite; black pyritic carbonaceous shale; and dark bedded silicified radiolarian mudstones and cherts. At shallower depths (Site 144), zeolitic, carbonaceous deposits are calcareous, although clay-rich sediments also are present.

Cenomanian carbonates consist mainly of a thick sequence of nanno marl oozes (Site 137). At Site 144 (Demerara Rise), calcareous carbonaceous clay accumulated, intercalated with limestone beds. Below the CCD, the Cenomanian apparently is represented by black clayey mud and greenish siliceous mudstone with limestone and chert layers (Site 135). Of special interest are cyclic sequences of black sapropelitic shale, rich in carbonaceous spherules, pyrite and radiolarians, and greenish gray dolomite silts and ankerite stones (138-6). These deposits are somewhat similar to the ?Paleocene ones at 140-6.

Aptian and Albian deposits consist of black nanno marl off Africa (Sites 135, 136), and of shelly limestone, quartzose marlstone and carbonaceous clay on the Demerara Rise (Site 144).

For comparison with the unconformities found at Leg 14 sites off Africa, the major orogenic phases in NW Africa and in the Southern Iberian Peninsula are indicated in Figure 52. The Atlas Mountains and the Essaouira, Tarfaya and Aaiun Basins of SW Morocco were folded during the "post-Lutetian phase" and-in part-during an "anteAquitanian phase", leaving a major hiatus marking uplift and erosion which comprises the Late Eocene, most of the Oligocene, and parts of the Miocene. Later phases in the Middle Miocene were important in the Rif Atlas, and in the Betic Cordillera and Guadalquivir Basin in Southern Spain, where transgressive and mostly unfolded Middle Miocene unconformably overlies Paleogene and Early Miocene flysch deposits. A Late Eocene to Oligocene hiatus was also detected in Sites 118 (Leg 12, Biscaya), and 120 (Leg 13, Gorringe Bank).

\section{Sedimentation Rate Patterns}

Sedimentation rates, based on thickness of sediment between dated samples, show a wide range of values between and within the various facies (Figure 53).

The post-Miocene calcareous oozes at Sites 135, 136, 140 , and 141 show rates between 10 and $30 \mathrm{~m} / \mathrm{My}$. Rates are considerably higher at Site 139 which underlies rather 


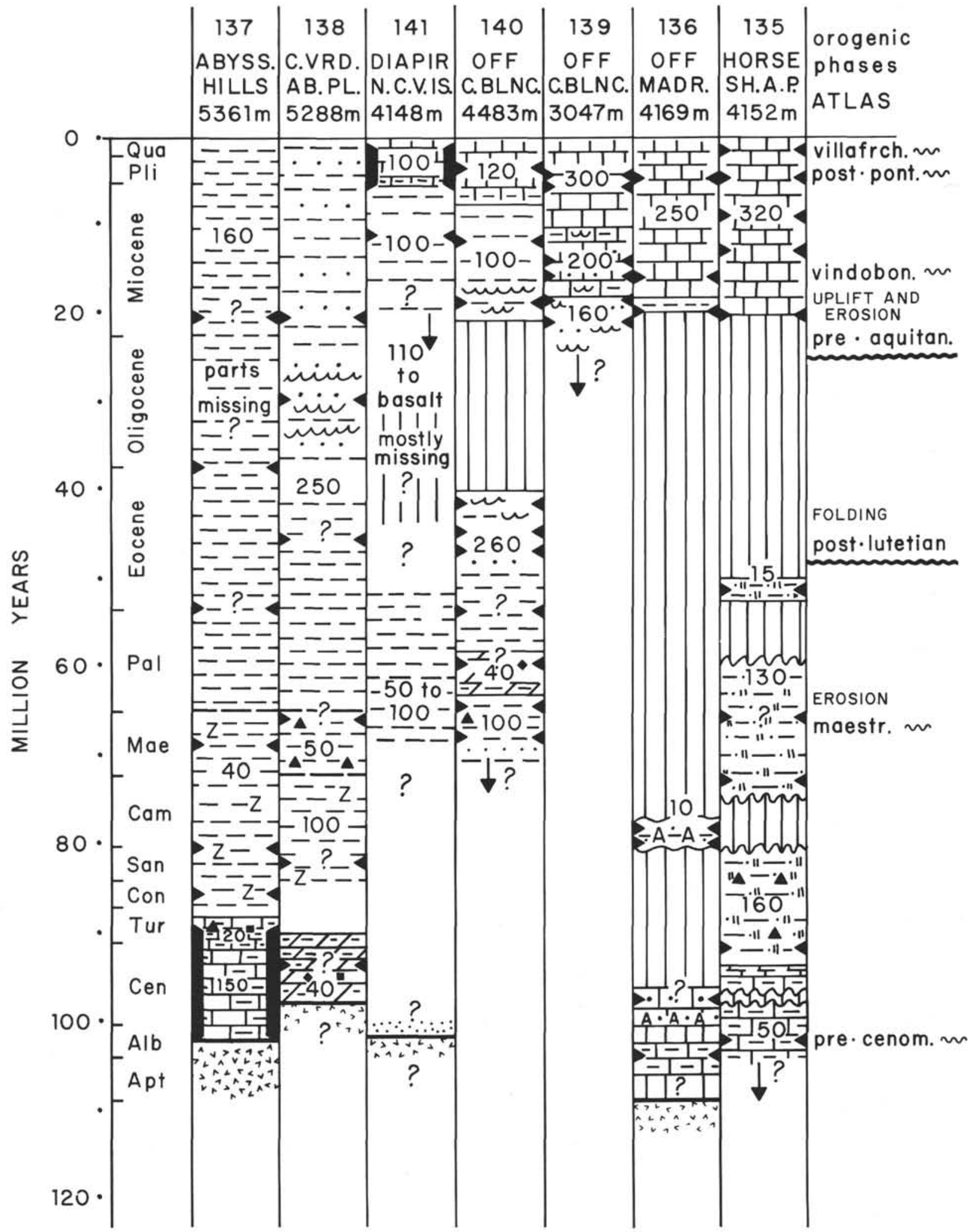

Figure 52. Generalized sedimentary stratigraphy off NW Africa. Triangular tick marks denote approximate sampling ages (for more precise age assignments see Figure 4). Pattern symbols are standard for calcareous sediment, dolomite, siliceous sediment, (terrigenous) sand and silt, clay, igneous rock, and hiatus. Others are Z, zeolite; solid triangles, chert; solid squares, pyrite; $A$, ash. Sediment thicknesses are in meters. Orogenic phases generalized from Choubert and Marcais (1956) and Querol in Reyre (1966). Heavy lines: major phases; villafrch.: Villafranchian phase (post orogenic); post-pont.: post-Pontian phase (postorogenic); vindobon.: Vindobonian phase (mid-Miocene major phase, Rif-Betic complex); pre-aquitan.: pre-Aquitanian phase (major orogenic phase, Atlas); (post-)Lutetian: phase in Atlat (also Pyrenean phase); Maestrichtian and pre-Cenomanian: "embryonic" phases. 


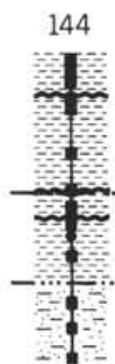

wd 2957 $\operatorname{td} 327$
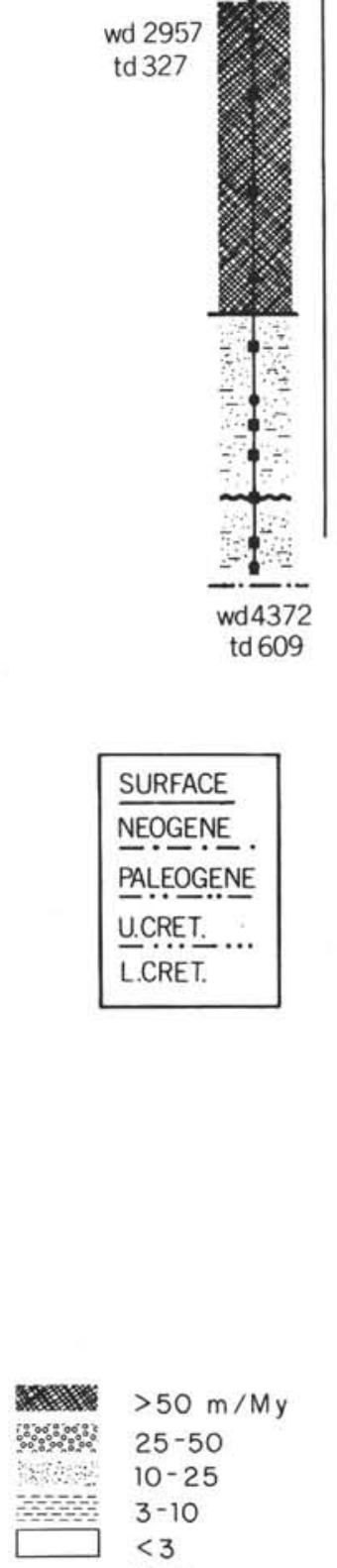

$>50 \mathrm{~m} / \mathrm{My}$

$25-50$

$10-25$

3-10

$<3$

hiatus

.

SURFACE
NEOGENE
PALEOGENE
U.C.RET.
L.C....
L.CRT.
A

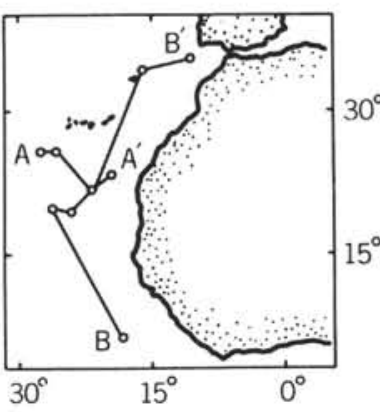

$(\mathrm{m} / \mathrm{My})$

ACCUMULATION RATES

]

E

wd 3647

$1+665$

wd4483

td 651
BETWEEN SITES

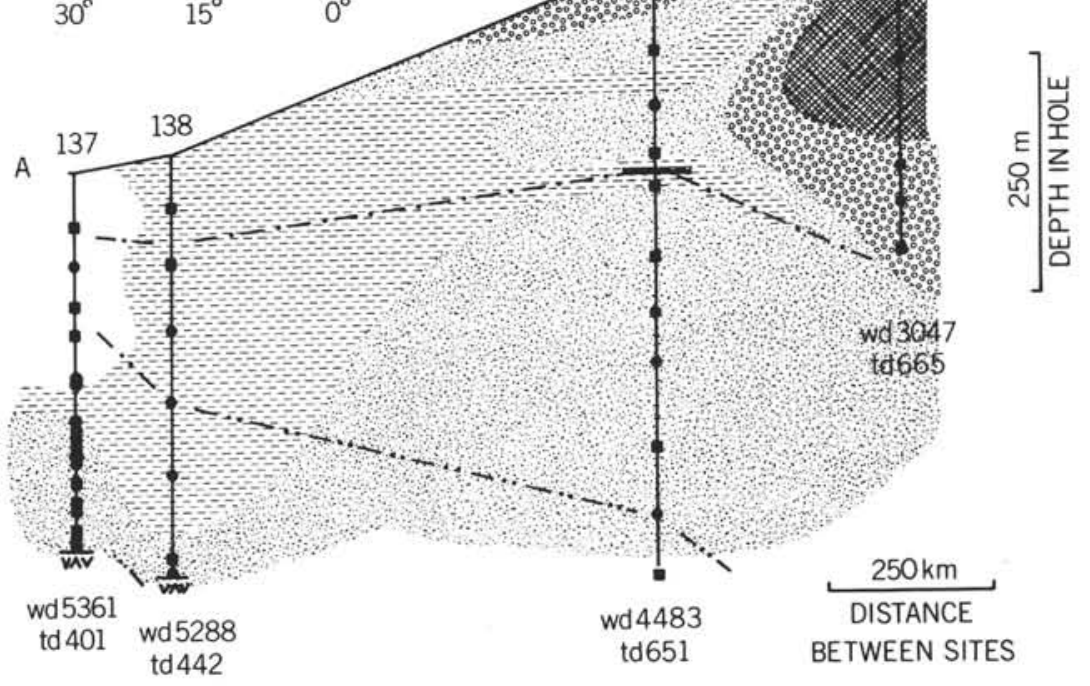

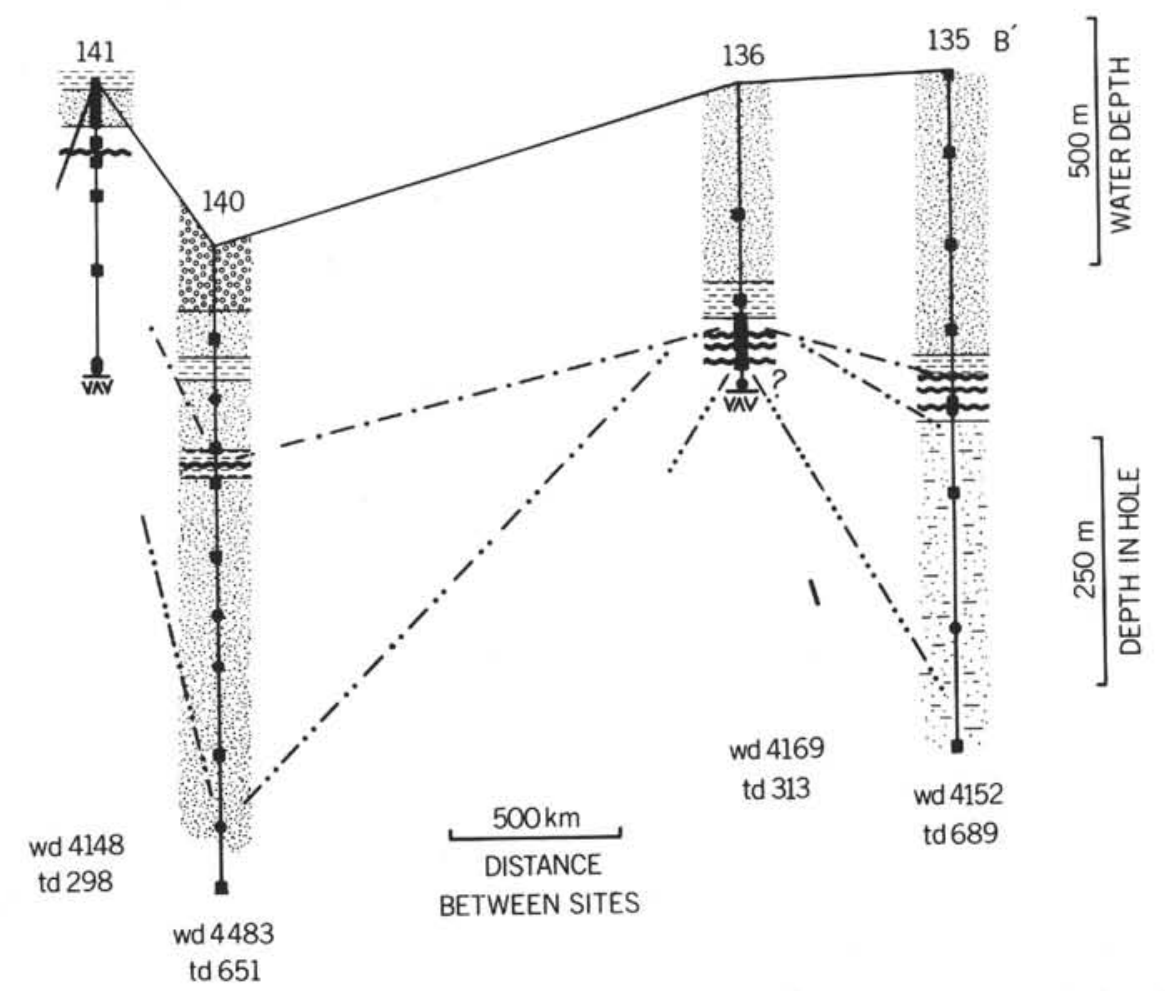

Figure 53. Regional distribution of sedimentation rates in meter per million years ( $m / M y)$. Compare with distribution of dominant components (Figure 11). Rates are obtained by dividing the down-hole distance between two samples by the difference between their ages. No corrections are made for compaction, for heterogeneity of the record, or for possible unrecognized unconformities present. 
fertile waters, close to the continent. Miocene chalks and marls tend to show low rates, from about $6 \mathrm{~m} / \mathrm{My}$ to 20 $\mathrm{m} / \mathrm{My}$ (Sites 135, 136), depending upon the content of lime. Exceptionally high rates occur, however, in the Middle Miocene at Site 139, probably due to redeposition. For the Late Miocene, a rather low rate of $15 \mathrm{~m} / \mathrm{My}$ must be assumed for this site. Cretaceous pelagic chalks (Site 137) accumulated at a rate of about $15 \mathrm{~m} / \mathrm{My}$, using the present time scale for the Cenomanian.

Pelagic clays accumulated at rates between 2 and 4 $\mathrm{m} / \mathrm{My}$. Where siliceous and terrigenous deposits are intercalated with clay, the rates may be substantially higher, as in the Late Cretaceous to Early Tertiary hemipelagic sediments of Site 140 (10 to $20 \mathrm{~m} / \mathrm{My}$ ).

The highest rates occur in Site 142, where values climb from less than $20 \mathrm{~m} / \mathrm{My}$ in calcareous Miocene sediments (a hiatus is present in the middle Miocene) to about $50 \mathrm{~m} / \mathrm{My}$ in the Pliocene, and then to an average of more than 150 $\mathrm{m} / \mathrm{My}$ in the highly terrigenous Quaternary.

Unusually low rates between 3 and $7 \mathrm{~m} / \mathrm{My}$ characterize the marls and chalks on the Demerara Plateau.

Zero or near zero rates mark unconformities which occur especially in mid-Tertiary parts of the sequences. These unconformities pose a major problem. Apparently they are, at least in part, related to orogenies (Figure 52), with uplift of parts of the sea floor resulting in by-passing and erosion. Increased dissolution of calcium carbonate especially during the Miocene also may play an important role (see below).

\section{Paleogeography}

Reconstruction of the depositional environments requires that a geographic map be available, however crude it may be. The position of the continents is of crucial importance in paleoceanography, and for certain interpretations, this position has to be assumed at the outset (see e.g., Seibold, 1969, p. 212). Plate tectonic theory now forms a widely accepted basis for the geographic reconstruction of ocean boundaries through time (McKenzie and Parker, 1967; Morgan, 1968; LePichon, 1968; Menard, 1971) (Figure 54). It also provides the theoretical basis for the hypothesis of age-depth constancy (Sclater and Francheteau, 1970), which is based on the empirical observation that the depth of the sea floor increases with age in a regular manner and rather independently of spreading rate (Menard, 1969; Sclater et al., 1971). The hypothesis states that the present age-depth relationship holds true for any point in geologic time (Berger, 1972), which permits drawing a rough outline of the extent of deep basins in the palinspastic maps (Figure 54).

From these reconstructions it is clear that the environment of deposition in the central Atlantic changed drastically through time and that the geography and, by inference, the paleoceanography of the Late Cretaceous bears little resemblance to that of the present time. Of special interest are the areas that connect the Atlantic with other oceans. Their history is complex, however, and has not been resolved sufficiently for paleoceanographic purposes (see Laughton, 1971; Molnar and Sykes, 1969; Edgar et al., 1971; Malfait and Dinkelman, 1972; Smith, 1971).
The sites drilled during Leg 14 are shown as dots on the palinspastic map. Their changing position with respect to coastline and mid-ocean ridge, as well as to the paleoequator, has an important bearing on the sediments found.

\section{Paleobathymetry}

The rather crude paleobathymetric information in Figure 54, which is based on assuming constant Ridge morphology (and hence spreading rate), can be considerably refined for each site by "back-tracking" the site parallel to a "best fit" subsidence curve (Figure 55), which appears well established for "normal" sea floor clearly related to a spreading center (Sclater et al., 1971). For example, if the depth of a site is 5000 meters, the age of the basement is 80 million years, and the age of the sample is 30 million years, the probable depth of deposition can be found as follows: (1) on the diagram (Figure 55) find the intersection between $80 \mathrm{My}$ and 5000 meters, (2) draw a line parallel to the "best fit" curve and passing through this point, (3) find the intersection of this line with the $30 \mathrm{My}$ age, and (4) from this intersection, move downward by one-half the distance between present water depth at the site and the depth of the sample in the hole. Addition of one-half the depth-in-hole rather than the total allows for isostatic adjustment of the basement to the sediment load. ${ }^{13}$

The "probable" depositional depths found by backtracking ("B-depths") can be further improved by considering information from carbonates that are present. ${ }^{14}$ To this end, the in situ carbonate facies is compared with the (assumed) regional pattern for the time and region in question. The upper limit of noncalcareous clay at any one time and for any one area is an important depth-related marker (Figure 56). Hsu and Andrews (1970) give several points for this marker as distance from Ridge Crest to CCD at $6 \mathrm{My}, 23 \mathrm{My}, 26 \mathrm{My}$, and $37 \mathrm{My}$ ago. Assuming a constant Ridge Crest elevation of 2700 meters, their points can be assigned A-depths and the data can be interpreted as a CCD fluctuation through time (Figure 56, Curve 1). A reinterpretation of Leg 3 data, using backtracking, gives a somewhat similar curve for the level at which the sedimentation rate is $2.5 \mathrm{~m} / \mathrm{My}$ (Figure 56, Curve 3).

That the CCD fluctuates considerably, was pointed out by Hay (1970) whose curve, however, does not contain assumptions about sea floor subsidence, nor does it emphasize the shallowest occurrence of noncalcareous sediment which is necessary to eliminate the effects of redeposition (Figure 56, Curve 2). His curve describing the lower limit of planktonic foraminiferal tests (not shown), is

\footnotetext{
${ }^{13}$ Upper mantle sima: $\rho=3.3$; sediment: $\rho=2.4$; (Holmes, 1965 , p. 30 ). Excess of sediment over water: $\rho_{\text {diff }}=1.4$; hence replacement of 10 meters of water by sediment increases the pressure by an amount equivalent to 4.2 meters of sima. The corresponding sinking of the crust increases the water pressure providing an additional load. Hence, 10 meters of sediment should depress the basement by about 5 meters.

14 "A-depth": depth of basement expected from knowledge of age alone, assuming ridge crest at 2700 meters. "B-depth": depth found by backtracking parallel to subsidence curve, including isostatic adjustment. "C-depth": depth based on comparison of in situ carbonate dissolution facies with general regional pattern.
} 

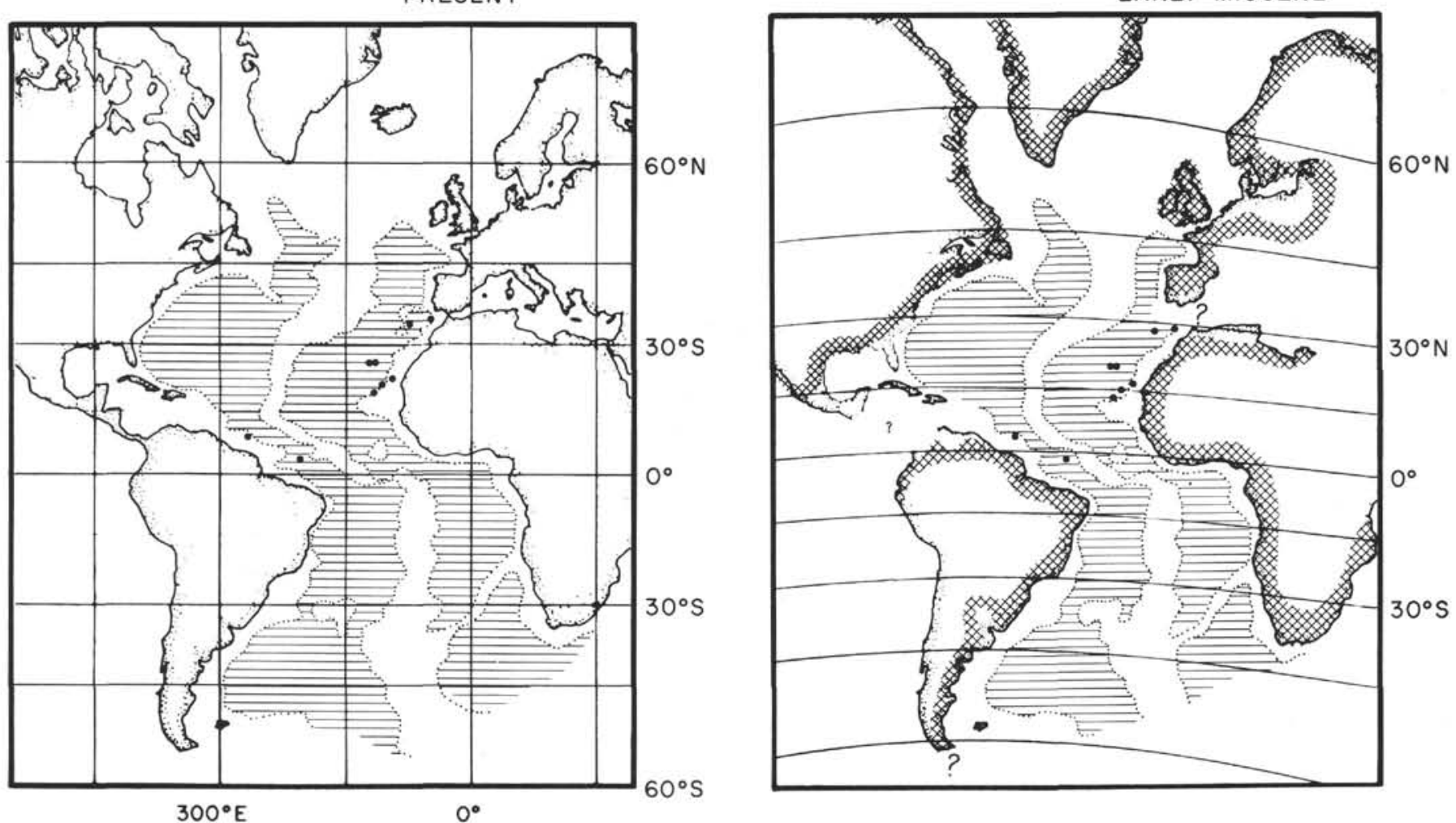

LATE EOCENE

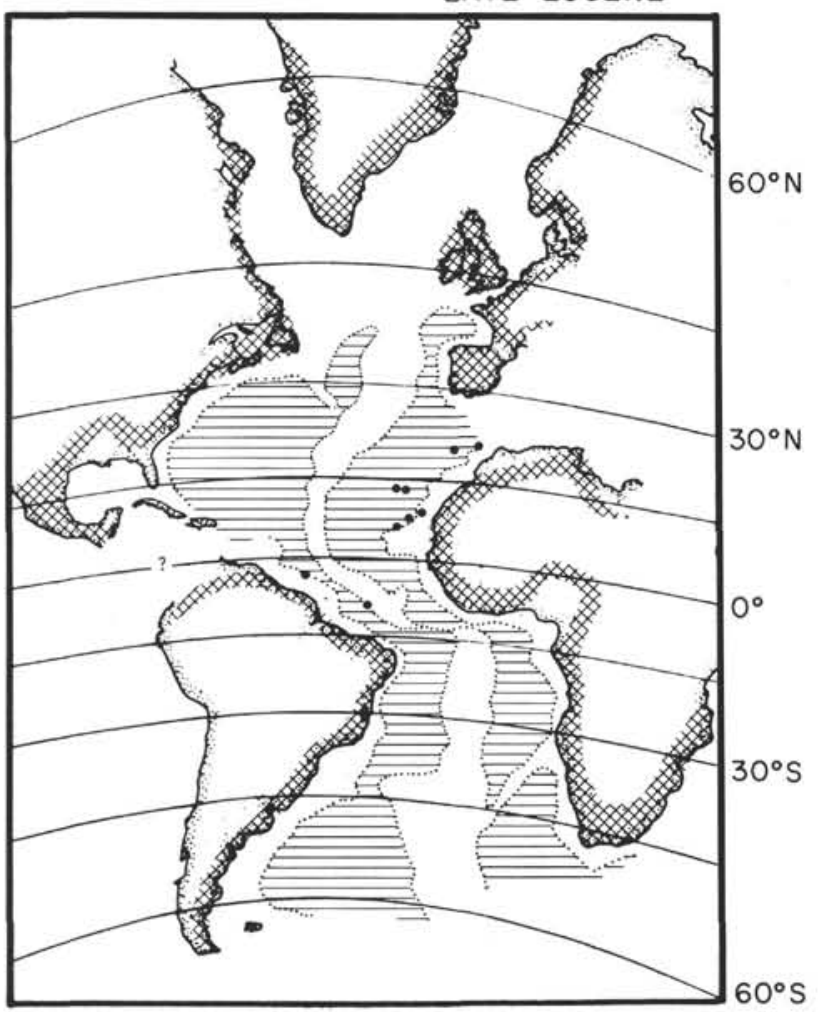

LATE CRETACEOUS

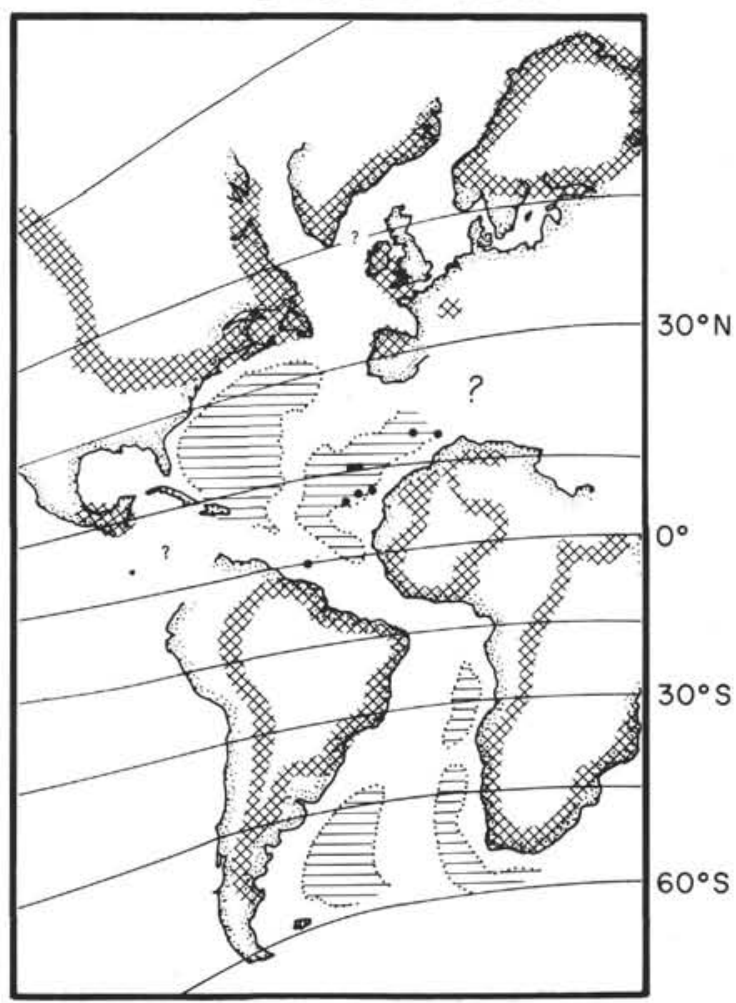

Figure 54. Rough sketch of geography at various geologic times. Continent outlines from Francheteau, 1970; ancient coastlines (cross-hachured) from Fell, 1967 and Brinkmann, 1959; 4000 meter contour (stippled, deep areas ruled) by keeping general morphology of Mid-Atlantic Ridge constant and combining it with the (present) sea floor topography. This topography is assumed to be rigidly attached to the continents and is moved back toward the Ridge by the amount indicated by the position of the continents. R. Detrick (SIO) assisted in locating the center of the Ridge, by rotation of earthquake epicenters. "Late Cretaceous": well after Cenomanian (note position of Site 137). 

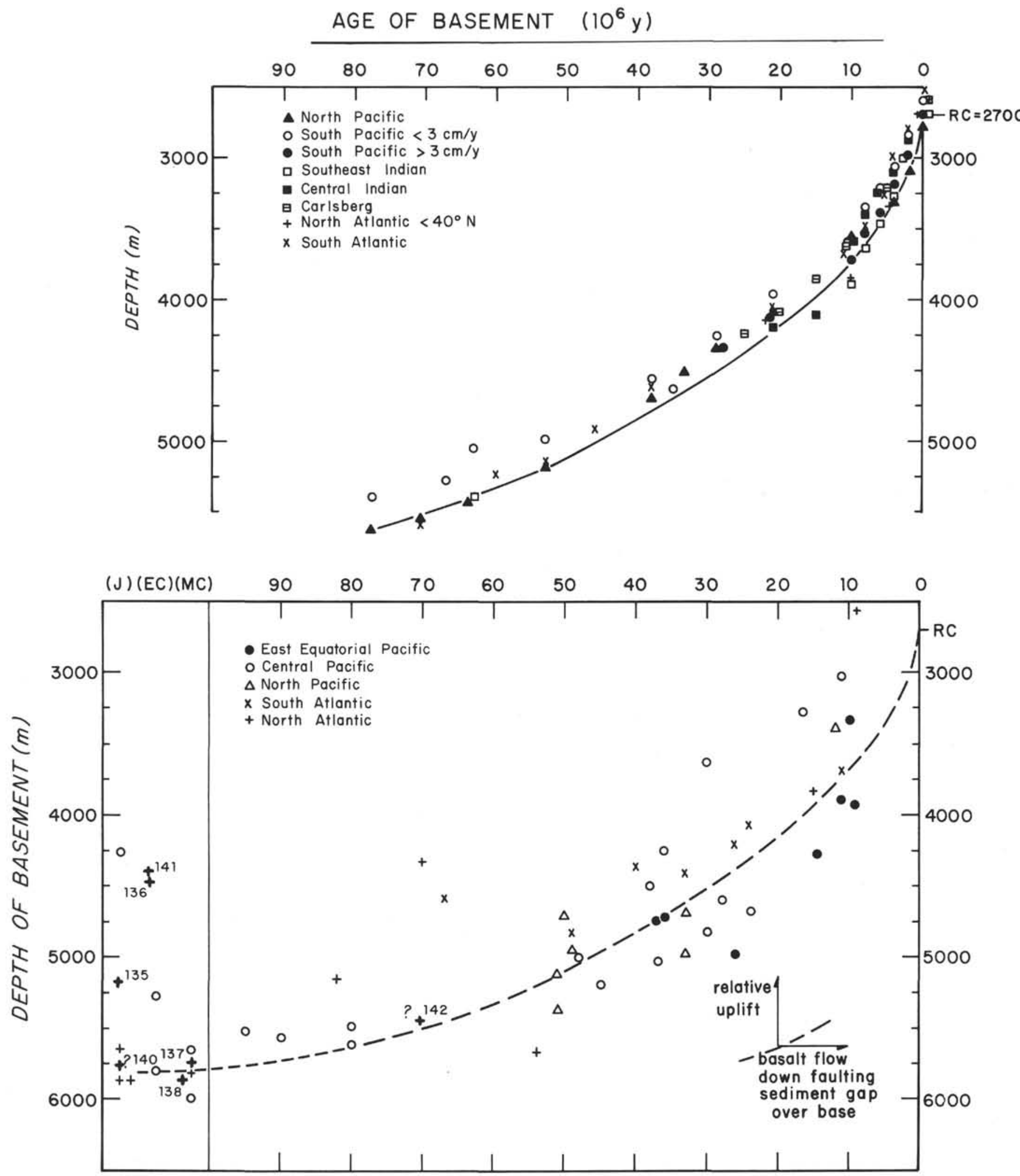

Figure 55. Depth of present sea floor as a function of its age. Upper: Age based on magnetic anomalies (from Berger, 1972; data from Sclater et al., 1971; fit by eye; favoring North Pacific data because of thin sediment cover). RC, ridge crest; J, Jurassic; LC, lower Cretaceous; MC, mid-Cretaceous. Lower: Age based on fossils overlying basalt (after Berger, 1972; data from JOIDES drilling results) Leg 14 sites indicated as bold crosses (ages assumed, in part). Curve is that of upper diagram, extrapolated. Some of the possible factors contributing to the scatter are indicated in the lower right hand corner. Note position of the sites drilled on hills $(135,136,141)$. 


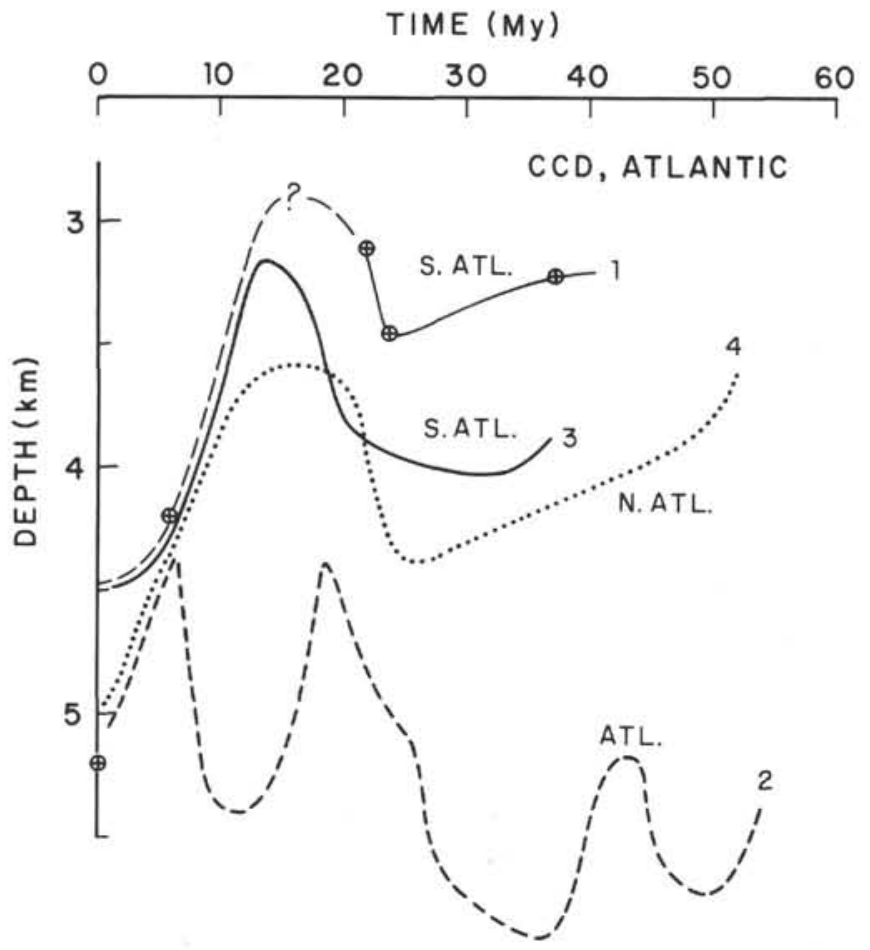

Figure 56. Fluctuation of calcite compensation depth through geologic time.

1 - Points given by Hsu and Andrews (1970) as distance of CCD below Ridge crest in South Atlantic, Leg 3. Connection dashed where based on their discussion. Reinterpretation assuming constant Ridge crest elevation (A-depth reconstruction).

2 - CCD curve of Hay (1970), Sites 4 to 31 (Atlantic). Low value in mid-Miocene based on one core (Site 9, Core 7) which contains both calcareous sediment and pelagic clay. Depths plotted are present depths.

3 - Approximate B-depth at which the sedimentation rate is $2.5 \mathrm{~m} / \mathrm{My}$, South Atlantic, from Berger, 1972, based on Leg 3 data. This level is near the CCD.

4 - Composite CCD level for North Atlantic (B-depths), based on Leg 14 and previous legs. Note parallelity of curves 1 and 4; note offset. quite comparable in shape to Curves 1,3 , and 4 (Figure 56) for Miocene to Recent time.

A composite plot of the CCD in the North Atlantic, based on backtracking and on shallow occurrence of pelagic clay, summarizes Leg 14 data and those of previous legs (Figure 56, Curve 5). The North Atlantic CCD appears deeper than the South Atlantic one, possibly as far back as the Eocene, but the two fluctuate together. A relatively shallow CCD in the Miocene and a very rapid drop at the end of the Miocene by as much as 1500 meters to the present depth appears evident. Also, during the entire Paleogene the CCD apparently stood higher, that is, shallower than now. These inferences become important in reconstructing the paleobathymetry of Sites 135 and 136.

Additional clues to depositional depths come from the presence or absence of terrigenous (and neritic) resediments and of unconformities (Table 11). Terrigenous sand layers presumably indicate a low depositional area, whereas unconformities in a hemipelagic setting suggest erosion or nondeposition on a hill (Sites 135, 136). In a pelagic setting, of course, unconformities may develop rather more independently of topography. They result from the effects of carbonate dissolution and of bottom current action on the resulting highly porous and hence easily erodable clays. For example, at Site 142, situated in an abyssal plain, an unconformity occurs spanning most of the Middle Miocene (peak dissolution time) in a pelagic setting. After the change to a hemipelagic setting sometime in the Late Miocene, no such unconformity would be expected because of the high supply of coarse terrigenous particles.

To find the B-depth track, the age of the basement for each site has to be known. Basalt was reached in several sites $(136,137,138,141)$, but in no case was the overlying sediment cored because of difficulties in predicting the depth of acoustic reflectors. Nevertheless, some estimates can be made. At Site 137, a side-wall core which recovered marl ooze of Albian age, was taken 4 meters above the terminal basalt. Also, Core 16, 15 meters above basalt was placed at the Cenomanian/Albian boundary by P. H. Roth, on the basis of calcareous nannofossils. This boundary is assumed to be 100 million years in age. For an estimated sedimentation rate of $15 \mathrm{~m} / \mathrm{My}$, the basalt would be but 1

TABLE 11

Information Used in Finding Paleo-Depths

\begin{tabular}{|c|c|c|c|c|c|c|c|c|c|}
\hline & Site 135 & Site 136 & Site 137 & Site 138 & Site 139 & Site 140 & Site 141 & Site 142 & Site 144 \\
\hline $\begin{array}{l}\text { Estimated age of } \\
\text { basement }\end{array}$ & $150 \mathrm{My}$ & $121 \mathrm{My}$ & $105 \mathrm{My}$ & $115 \mathrm{My}$ & $164 \mathrm{My}$ & $151 \mathrm{My}$ & $131 \mathrm{My}$ & $70 \mathrm{My}$ & $\mathrm{f}$ ? \\
\hline Basis of estimate & Site 137 & Site 137 & Biostrat. & Site 137 & Site 137 & Site 137 & Site 137 & Francheteau, 1970 & $0-$ \\
\hline $\begin{array}{l}\text { Backtracking (Core } \\
\text { Nos.) }\end{array}$ & 5 to 9 & 5 to 8 & 1 to 17 & 1 to 7 & 1 to 7 & 1 to 8 & 9 & 1 to 9 & - \\
\hline Carbonate (Core Nos.) & $8 \& 9$ & 8 & - & - & - & - & 1 to 7 & - & - \\
\hline $\begin{array}{l}\text { Terrigenous (Core } \\
\text { Nos.) }\end{array}$ & $5 \& 6$ & 4 to 5 & - & - & - & - & 7 & - & - \\
\hline Hiatus (Core Nos.) & SW to 5 & 4 to 5 & - & - & - & - & 6 to 7 & - & - \\
\hline Setting & $\begin{array}{l}\text { Hill in } \\
\text { Abyss. pl. }\end{array}$ & $\begin{array}{l}\text { Shallow } \\
\text { basement }\end{array}$ & $\begin{array}{l}\text { Abyssal } \\
\text { hills }\end{array}$ & $\begin{array}{l}\text { Abyssal } \\
\text { plain }\end{array}$ & $\begin{array}{l}\text { Contl. } \\
\text { slope }\end{array}$ & $\begin{array}{l}\text { Contl. } \\
\text { rise }\end{array}$ & $\begin{array}{l}\text { Diapir } \\
\text { hill }\end{array}$ & $\begin{array}{l}\text { Abyssal } \\
\text { plain }\end{array}$ & $\begin{array}{l}\text { Contl. } \\
\text { margin }\end{array}$ \\
\hline Other & - & - & - & - & - & - & - & - & $\begin{array}{l}\text { Shelf } \\
\text { facies }\end{array}$ \\
\hline
\end{tabular}


million years older, that is, $101 \mathrm{My}$. At the present time, the ridge crest area appears to receive anomalously little sediment (Ewing and Ewing, 1967). The common occurrence of manganese-coated mineral grains and currentwinnowed foraminiferal lutite (Fox and Heezen, 1965), as well as the ponding of sediments on the upper ridge flank (van Andel and Komar, 1969) suggest that sedimentation rates on the crest may be lower than elsewhere. In addition, there is a possibility that crestal sediments have a greater chance of being covered by basalt flowing from the spreading center than do sediments farther from the crest. For these reasons, we estimate an age of $105 \mathrm{My}$ for the basement of Site 137.

The ages of all other sites off NW Africa were computed using this estimate and their distance from the Mid-Atlantic Ridge Crest in terms of the percent of the distance from shelf break to crest, measured parallel to the nearest fracture zones. This percentage was then directly compared to the dated percentage of Site 137. The method assumes that there was, on the whole, no secular trend in spreading rate. Changes in rate such as those proposed by van Andel and Heath (1970) should not markedly influence results (see Table 11). The age of basement at Site 142 was estimated from the palinspastic reconstruction of Francheteau (1970). The age of Site 144 is not known, late Jurassic (or very early Cretaceous) shallow-water calcareous sandstone was dredged below this site from a depth of 4400 meters (Fox et al., 1970).

Our estimates are in reasonable agreement with those of Pitman and Talwani (1972). They propose $167 \mathrm{My}$ for Site $135,140 \mathrm{My}$ for $136,111 \mathrm{My}$ for 137 , and $120 \mathrm{My}$ for 138. Discrepancies in the present estimates (Table 11) may serve as reminder of the range of error that may be associated with these and similar age determinations. ${ }^{15}$

The paleobathymetry of each site can now be constructed, using the basement age estimates (Table 11), the hypothesis of age-depth constancy, and the sedimentologic concepts and assumptions discussed above (Figures 57 and $58)$.

Site 135. A simple B-depth track puts the CCD crossing at just below 3500 meters, in mid-Cretaceous time. During the Aptian, the site was above the CCD, accumulating dark calcareous ooze. During the Cenomanian (?), dark mudstones, chert and limestone accumulated after some subsidence just below the CCD. Both limestones and chert appear to be due to redeposition processes. During Late Cretaceous and Early Tertiary, hemipelagic flysch-like sediments were deposited on an abyssal plain below the $\mathrm{CCD}$. The nature of the hiatus following this sequence is not clear although it may be related to uplift associated with Alpine diastrophism (see Figure 52). The accumulation of calcareous ooze throughout the Neogene would seem to require a shallower depth than that predicted from

\footnotetext{
${ }^{15}$ With regard to Leg 14 results, Table 5 of Pitman and Talwani (1972) (comparison of ages obtained from JOIDES drill holes with ages from proposed isochrons) contains several errors: Site 135, the oldest sediment is Aptian, not Albian; Site 136, ditto; Site 137, the oldest sediment is Albian, not Turonian; Site 138, it is doubtful that basement was reached as stated. The corrections actually improve the fit with their isochrons.
}

backtracking, unless the CCD fluctuations observed elsewhere in the Atlantic (Figure 56) do not apply in this area. The buckling proposed (Figure 57, Site 135) may start considerably earlier than shown, thus removing the site from the sedimentary basin while keeping it below the CCD and consequently preventing all deposition. The postulated buckling seems to have been a reversible event, suggesting compressional uplift not compensated by isostasy. Evidence for mid-to-Late Miocene shallowing was also found at Site 120 (Leg 13), on Gorringe Bank (K. J. Hsu, pers. comm.) Also, compression and intermittent closure of the Gibraltar passage would seem to be required to explain the Late Miocene halites reported from the deep Mediterranean (Geotimes, December 1970).

Site 136. A simple B-depth track puts the CCD (between Cores 7 and 8) near 2500 meters. To bring this crossover in line with that at Site 138, the proposed track is adjusted downward. The volcanogenic sediments accumulating on top of the dark Aptian/Albian marl of Core 8 contain calcite fragments and were not much below the CCD. For the hiatus and the capping Neogene calcareous ooze, considerations are similar to those given for Site 135 . In addition, the great extent of the unconformity may be due to dissolution of carbonate within the volcanogenic material, concomitant increase of porosity and loss of cohesion, and consequent active erosion by bottom currents during the Paleogene.

Sites 135 and 136 are both in a tectonically active zone (Giesel and Seibold, 1968; Krause and Watkins, 1970) and their paleobathymetry, therefore, remains highly speculative.

Site 137. The B-depth track appears to be entirely adequate in describing the paleobathymetry of this site. The CCD is not uniquely defined since noncalcareous sediments are associated with calcareous ones in Cores 7, 8, and 9 . Backtracking puts the CCD zone near 3500 meters, at the end of the Cenomanian. The zone separates marl/chalk ooze facies from pelagic clay facies and consists of an intercalation of various types of sediment (pyritiferous sapropelitic clay, marl ooze, chert, zeolitic clay). The uppermost part of the track may have reached into a deep-reaching oxygen-poor zone, as indicated by greenish colors, presence of sulfides, and organic matter.

Site 138. As in Site 137, simple backtracking appears sufficient for describing the paleobathymetry of this site. Site 138 is farther away from the ridge crest than Site 137; it seems likely, therefore, that it is older. The basalt in Core 7 lacks the expected cover of calcareous ooze and the deposits that overlie it are too young to be basal sediment. We think it probable that the basalt is a companion sill to the one penetrated in Core 6 . The dolomite in Core 6 may be considered sub-CCD carbonate, since it is more resistant to dissolution than calcite. Thus, the B-depth of the CCD should be somewhat above that of the dolomite and this should again put the CCD near 3500 meters, in the Cenomanian.

Site 139. The great age of this site, and the short time span considered, makes the B-depth contribution to paleobathymetry negligible. However, other tectonic movements of an unknown nature (Alpine diastrophism, salt tectonics, faulting etc.) are possible at the continental margin in this 

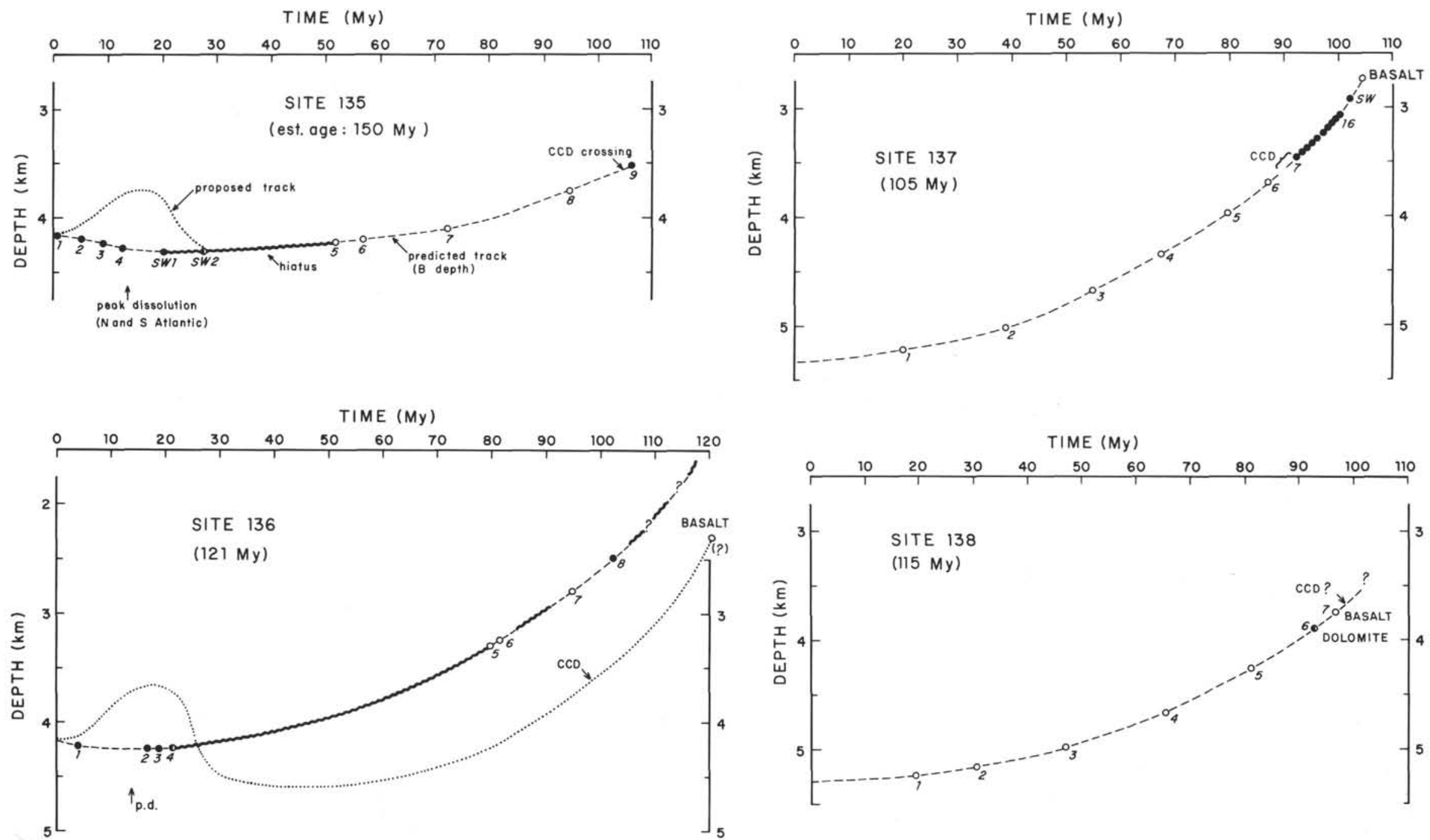

Figure 57. Paleobathymetry for Sites 135 to 138, based on the hypothesis of age-depth constancy (B-depth, broken line) and on sedimentologic clues (Site 135, 136; see text). The stippled line is the proposed "most probable" track. Open circles: non-calcareous sediment. 
TIME (My)

TIME (My)
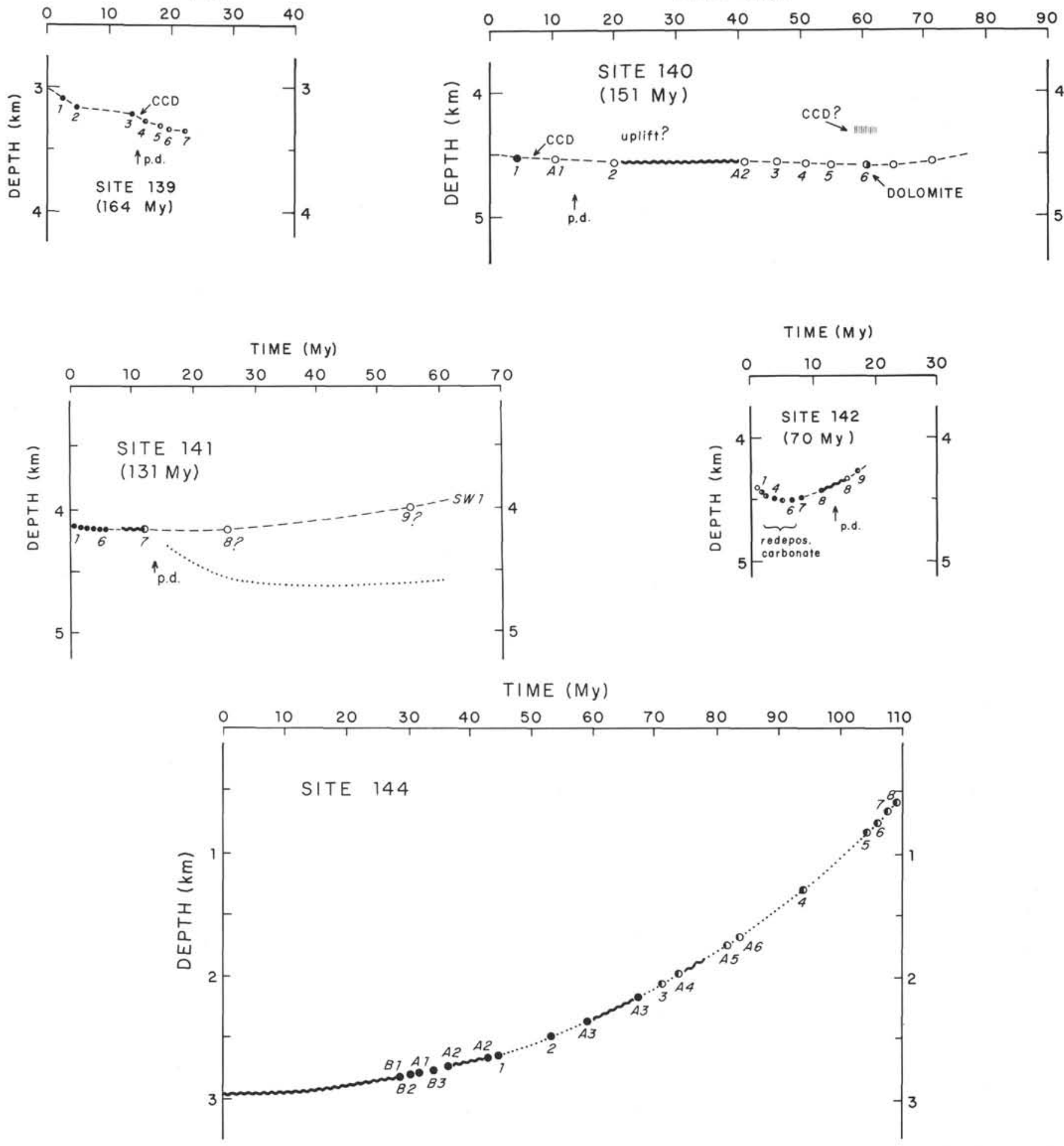

Figure 58. Paleobathymetry for Sites 139 to 144, based on the hypothesis of age-depth constancy (B-depth, broken line) and on sedimentologic clues (Sites 141, 144; see text). The stippled line is the proposed "most probable" track. Open circles: non-calcareous sediment. p.d., peak dissolution time (late mid-Miocene).

area (Rona, 1970). The track shown is based on depth of sediment in the hole, allowing for isostatic adjustment to loading.

Site 140. As in Site 139, the great age of the site makes backtracking a minor contributor to paleodepth reconstruc- tion in the Tertiary. The site may have undergone a more complicated bathymetric history than the one indicated, as suggested by the Oligocene hiatus.

Site 141. The diapir on which this site was drilled appears to be a relatively young feature (see Site Summary 
section) and backtracking would certainly give the wrong paleobathymetric history. The "proposed track" indicates the general trend of the probable path followed.

Site 142. The paleobathymetry of this site is at first dominated by subsidence and later by sediment accumulation. Note the hiatus at peak dissolution time in the Middle to Late Miocene. Much of the Late Neogene carbonate at this site is redeposited and cannot be used for C-depth corrections.

Site 144. The age of this site and its relationship to the spreading Mid-Atlantic Ridge is not known. Two points are available for the reconstruction of the paleobathymetry: the present depth, and the shallow water sediments of Aptian age, in Cores 6, 7, and especially 8. A large part of these sediments may be redeposited (see section on calcareous sediments). We have chosen, somewhat arbitrarily, an area below the shelf edge as a likely place of deposition. Also, we assume that the rate of subsidence decreased since Early Cretaceous, although the two end points could be connected by a straight line, or in more complicated ways (see Heezen, 1968). Unless the paleobathymetry is very different from the one shown, the distribution of sediments suggests an oxygen minimum in the Late Cretaceous reaching down to at least $2 \mathrm{~km}$ (carbonaceous black shale in Cores A5 and A6). The occurrence of low carbonate facies and poorly preserved calcareous fossil assemblages in the interval between latest Cretaceous and earliest Tertiary (A3, 3, A4) suggests increased carbonate dissolution even at relatively shallow depth. The hiatus in Core A3 occurs at the CretaceousTertiary boundary. The rate of subsidence is approximately 20 to 30 meters per million years, in good agreement with that proposed by Fox et al. (1970).

\section{Facies Domains}

The series of cores taken off NW Africa allows a definition of major facies domains through time (Figure 59).

During the Pliocene and at present, pelagic and hemipelagic domains are of comparable width. The CCD stands relatively deep, but the ridge flank also reaches to great depths, so that both calcareous ooze and (oxidized) pelagic clay are represented to a similar extent. Continental slope and abyssal plain belong to the hemipelagic realm, where terrigenous influx of silt increases sedimentation rates (Ericson et al., 1961; Ewing, 1969) and closer proximity to the continent increases fertility. This leads to preservation of some siliceous material and to reducing conditions within the sediment (see Bramlette, 1961). The distribution of domains from the Pliocene on, with calcareous ooze, oxypelite, and hemipelagic clay containing but little admixture of siliceous remains, is typical for the present Atlantic facies regime in a "lagoon" type deep sea circulation (Berger, 1970c).

During the Miocene the ratio of pelagic to hemipelagic sediment domains is not very different from that in the Neogene. The CCD is much shallower, however, severely curtailing the contribution of calcareous ooze to either domain. Also, the CCD zone distinctly rises toward the continent, as do other dissolution levels. This is in accordance with the observation that carbonate dissolution starts at rather shallow depths beneath fertile continentnear areas (Berger, 1970a; 1971; Thiede, 1971), which further decreases the proportion of carbonates during this time. Concomitantly, with the generally greatly increased carbonate dissolution, the contribution from siliceous fossils becomes very significant, suggesting an "estuarine" deep-sea circulation pattern according to the oceanic fractionation model (Berger, 1970c; Seibold, 1970). On the whole, Miocene sedimentation patterns are reminiscent of the present-day North Pacific facies regime with shallow $\mathrm{CCD}$, siliceous deposits, and considerable terrigenous influx, due to orogenesis in the hinterland.

In the Eocene, the ridge flank domain is distinctly narrower than now, so that hemipelagic sedimentation is more widespread than pelagic (Figure 59). Otherwise, facies distributions appear quite comparable to those in the Miocene. The occurrence of calcareous oozes is restricted above a relatively shallow CCD. Sedimentation rates from terrigenous influx are smaller, however, and siliceous remains are less well preserved than in the Miocene.

The Cenomanian sedimentary environment is characterized by hemipelagic sedimentation (black shale and layers of limestone, chert) in a trough that is significantly narrower and shallower than today (Figure 59), although for the most part it is still deeper than 3000 meters. The bottom depth may have been somewhat greater than shown since the sea level apparently stood higher by several hundred meters (see Figure 54, late Cretaceous transgressions). At the time, a significant proportion of the sea floor may have been relatively young, thus increasing the average temperature and hence the average elevation of the oceanic crust (Sclater and Francheteau, 1970), with a consequent transgression of displaced water on to the continents (Menard, 1964, p. 240). The transgressions created shallow shelf seas, which should have trapped coarse terrigenous material while providing shallow-water carbonates for redeposition off the continent.

The oxygen content of bottom waters apparently was quite low (black pyritic shale). Bottom waters cannot be colder than the coldest oceanic surface waters. A generally warm climate (Schwarzbach, 1961; p. 137), therefore, would lead to warm bottom waters (Emiliani, 1961) with relatively low initial oxygen content. This initial oxyty could be further reduced if bottom waters were derived from haline convection rather than from a thermal one (Chamberlin, 1906). For example, abyssal Mediterranean waters $\left(13.2^{\circ} \mathrm{C}, 38.4^{\circ} \%\right.$ ) have an oxyty of about $4.3 \mathrm{ml} / \mathrm{l}$ (Sverdrup et al. 1942, p. 650). In conjunction with an increased residence time of abyssal waters, low oxygen values can then develop. This leads to sapropelitic deposition in the hemipelagic domain while still being able to provide brown pelagic clay in a narrow zone of low sedimentation rate, on the ridge flank below the CCD (Site 137, Cores 7 to 9).

Redeposition processes apparently were active both on the ridge flank and on the continental slope, leading to calcareous layers within non-calcareous sediment in both pelagic and hemipelagic ("flysch") domain. On the ridge flank, the preservation pattern of foraminifera and radiolarians offers clues to this aspect of the depositional environment. It was noted that very well preserved and very 

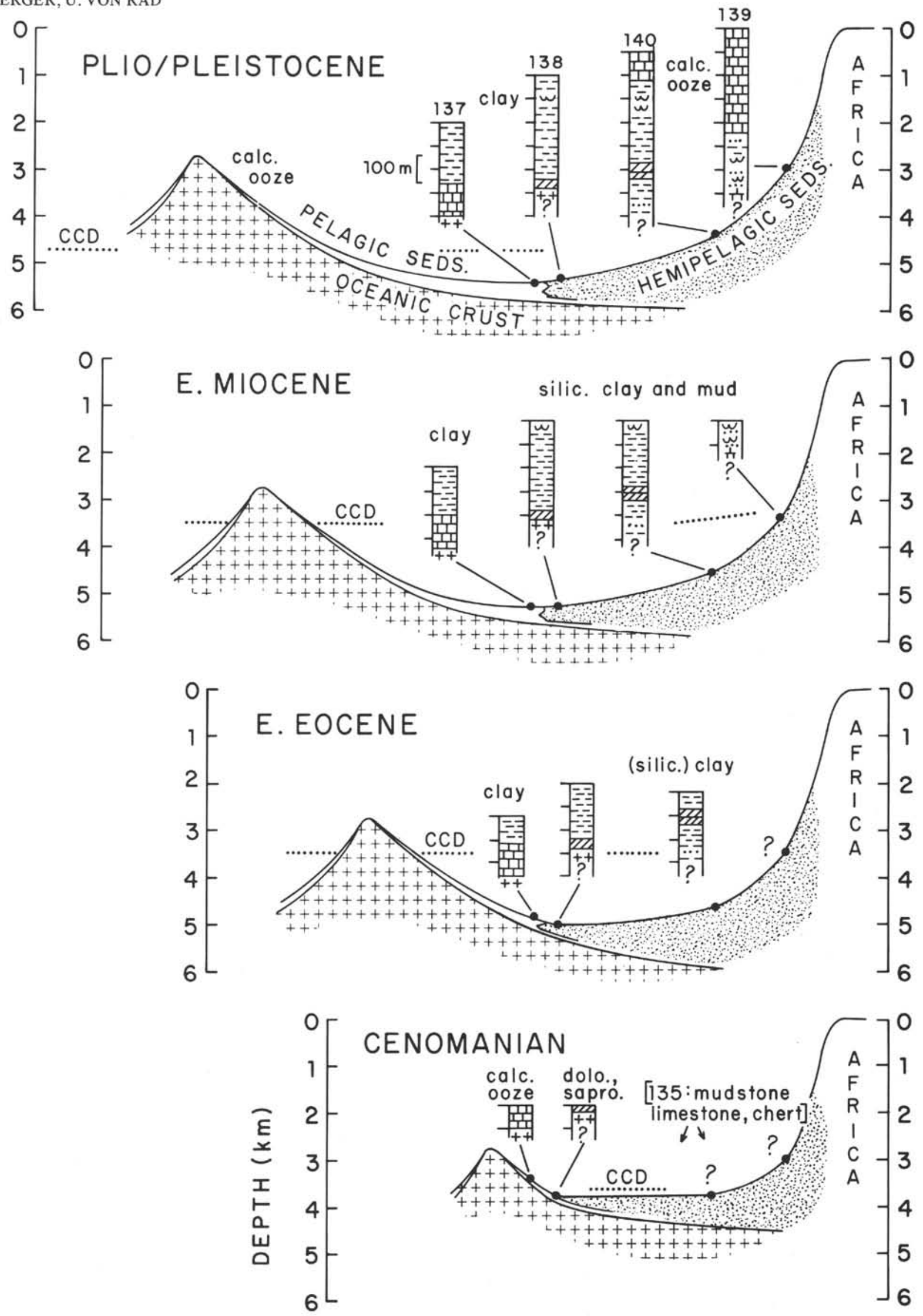

Figure 59. Development of facies domains off NW Africa through geologic time, based on stratigraphic sediment patterns, sea floor spreading, and age-depth constancy. 
poorly preserved foram assemblages are interbedded in Cenomanian sediments on the ridge flank. A hydrographic lysocline (as found by Peterson, 1966, in the Pacific) on the ridge flank would change sedimentation rates considerably, providing for reducing conditions above and oxidizing conditions below a rather narrow zone. The contrast between preservation of foraminifera above and below this level would then be reinforced by sulfate reduction and increase of alkalinity in interstitial waters in the P-zone (see section on foraminifera). Higher sedimentation rates above the lysocline (and higher silica concentrations in a less oxygenated bottom water) would also explain the initial preservation of radiolarians, which were filled with zeolite. Redeposition of these sediments from above the CCD zone to below it could lead to chert or sapropel formation, after dissolution of the carbonate (Site 137, Core 7). At the same time any iron oxide present could be reduced to pyrite. Redeposited pyrite could be concentrated by dissolution of the associated calcareous sediment.

Furthermore, exposure of displaced siliceous fossils in an area of low sedimentation rate to silica-undersaturated bottom waters (derived from saline silica-poor lagoonal shelf waters?) can explain the striking corrosion of radiolarians and of their zeolitic fill seen in Late Cretaceous pelagic sediments $(137$, Cores $4,5,6)$. Also, introduction of reducing sediment from above can account for the presence of rhodochrosite, through reduction of previously precipitated manganese oxide.

Redeposition from the ridge flank could also have contributed to the dolomite-sapropel cycles at 138-6. Alternatively, the sapropelites developed in situ due to relatively high sedimentation rates in a low oxygen environment, at the far end of the hemipelagic domain. In this case, much of the dolomite may have come from the continental slope or even from displaced shallow-water sediment. Alternatives to the redeposition hypothesis, such as hydrothermal activity, do exist of course.

In conclusion, the sedimentary environment of deep-sea deposits changed considerably through geologic time, due to changes in geography, in depth, and in oceanographic conditions. The present attempts to relate the sediment patterns to what is inferred about the paleoenvironment are tentative and should be considered as mnemonic devices and working hypotheses, until better sampling and more thorough study provide greater insight.

\section{REFERENCES}

Bader, R. G., Benson, W. E., Bolli, H. M., Gerard, R. G., Hay, W. W., Riedel, W. R., Rothwell, W. Th. Jr., Ruef, M. H. and Sayles, F. L., 1970. Initial Reports of the Deep Sea Drilling Project, Volume IV. Washington (U. S. Gov. Printing Office).

Bandy, O. L., 1967. Cretaceous planktonic foraminiferal zonation. Micropaleontology. 13 (1), 1.

Bathurst, R. G. C., 1971. Carbonate sediments and their diagenesis. 620 pp. Elsevier, Amsterdam.

Beall, A. O. Jr. and Fischer, A. G., 1969. Sedimentology. In Ewing, M. et al., 1969. Initial Reports of the Deep Sea Drilling Project, Volume 1. Washington (U. S. Gov. Printing Office). 521.

Berger, W. H., 1970a. Planktonic foraminifera: selective solution and the lysocline. Marine Geol. 8, 111. 1970b. Planktonic foraminifera: differential production and expatriation off Baja California. Limnol Oceanogr. 15 (2), 183.

1970c. Biogenous deep-sea sediments: fractionation by deep-sea circulation. Bull. Geol. Soc. Am. 81, 1385 .

1971. Sedimentation of planktonic foraminifera. Marine Geol. 11, 325.

1972. Deep sea carbonates: dissolution facies and age-depth constancy. Nature. 236, 392.

, and Soutar, A., 1970. Preservation of plankton shells in an anaerobic basin off California. Bull. Geol. Soc. Am. 81, 275 .

Berggren, W. A., 1972. A Cenozoic time-scale-some implications for regional geology and paleobiogeography. $J$. Foram. Res. (in press).

Berner, R. A., Scott, M. R. and Thomlinson, C., 1970. Carbonate alkalinity in the pore waters of anoxic marine sediments. Limnol. Oceanogr. 15 (4), 544.

Bonatti, E., 1967. Mechanisms of deep-sea volcanism in the South Pacific. In Researches in Geochemistry, Abelson (Ed.), 2, New York (J.Wiley \& Sons), 453.

Borchert, H., 1965. Formation of marine sedimentary iron ores. In J. P. Riley and G. Skirrow (Eds.). Chemical Oceanography. Academic Press, London. 2, 159.

Boström K., and Peterson, M. N. A., 1969. The origin of aluminum-poor ferromanganoan sediments in areas of high heat flow on the East Pacific Rise. Marine Geol. 7, 427.

Bramlette, M. N., 1946. The Monterey Formation of California and the origin of its siliceous rocks. U. S. Geol. Survey Prof. Paper 212, 1.

1958. Significance of coccolithophorids in calcium-carbonate deposition: Bull. Geol. Soc. Am. 69, 121.

, 1961. Pelagic sediments. In M. Sears (Ed.) Oceanography, Am. Assoc. Adv. Sci. Publ. No. 67, 345.

Brinkmann, 1959. Historische Geologie. Enke, Stuttgart, $360 \mathrm{pp}$.

Bukry, D., 1971. Cenozoic calcareous nannofossils from the Pacific Ocean. San Diego Soc. Nat. Hist., Trans. 16 (14), 303.

Caillère, S. and Hénin, S., 1961a. Sepiolite. In G. Brown (Ed.), The X-ray identification and crystal structures of clay minerals. Mineralogical Society. London, 325. and $1961 \mathrm{~b}$. Palygorskite. Ibid, 353.

Calvert, S. E., 1971. Nature of silica phases in deep sea cherts of the North Atlantic. Nature (Phys. Sci.). 234 (50), 133.

Carozzi, A. V., 1960. Microscopic Sedimentary Petrography, 485 pp. New York (J. Wiley \& Sons).

Chamberlin, T. C., 1906. On a possible reversal of deep-sea circulation and its influence on geologic climates. $J$. Geol. 14, 363.

Chilingar, G. V., Bissel, H. J. and Wolf, K. H., 1967. Diagenesis of carbonate rocks, p. 179-322, In: Diagenesis in sediments. Larsen, G. and Chilingar, G. V. (Eds.), Developments in Sedimentology. 8, Elsevier, Amsterdam.

Choubert, G., and Marcais, J., 1956. Les grands traits de la géologie du Maroc, Lexique Strat. Internat, Afrique. IV.

Cita, M. B., 1971. Biostratigraphy, chronostratigraphy and paleoenvironment of the Pliocene of Cape Verde (North Atlantic). Rev. de Micropaléontologie. 14, no. 5, 17.

Correns, C. W., 1937. Die Sedimente des äquatorialen Atlantischen Ozeans. Wiss. Ergebn. deutsch. Atlant. Exped. Meteor 1925-1927. 3 (3), 298 pp. 
1949. Einführung in die Mineralogie (Kristallographie und Petrologie). Springer, Berlin. 414 pp.

Cronan, D. S., van Andel, T. H., Heath, G. R., Dinkelman, M. G., Bennet, R. H., Bukry, D., Charleston, S., Kaneps, A., Rodolfo, K. S. and Yeats, R. S., 1972. Iron-rich basalt sediments from the Eastern Equatorial Pacific: Leg 16, Deep Sea Drilling Project. Science. 175, 61.

Damuth, J. E., and Fairbridge, R. W., 1970. Equatorial Atlantic deep-sea arkosic sands and ice-age aridity in tropical South America. Bull. Geol. Soc. Am. 81, 189.

Davies, T. A. and Jones, E. J. W., 1971. Sedimentation in the area of Peake and Freen Deeps (Mid-Atlantic Ridge). Deep-Sea Res. 18, 619.

Drever, J. I., 1971. Magnesium-iron replacement in clay minerals in anoxic marine sediments. Science. 172, 1334.

Dunbar, C. O. and Rodgers, T., 1957. Principles of Stratigraphy. Wiley, N. Y., 356 pp.

Eder, F. W., 1971. Riff-nahe detritische Kalke bei Balve im Rheinischen Schiefergebirge. Göttinger Arb. Geol. Palaont. 10, 1.

Edgar, N.T., Ewing, J. I., and Hennion, J., 1971. Seismic refraction and reflection in Caribbean Sea. Bull. Am. Assoc. Petrol. Geol. 55 (6), 833.

Emiliani, C., 1961. The temperature decrease of surface seawater in high latitudes and of abyssal-hadal water in open oceanic basins during the past 75 million years. Deep-Sea Res. 8, 144.

Ericson, D. B., Ewing, M., Wollin, G. and Heezen, B. C., 1961. Atlantic deep-sea sediment cores. Bull. Geol. Soc. Am. 72, 193.

Ernst, W. G. and Calvert, S. E., 1969. An experimental study of the recrystallization of porcelanite and its bearing on the origin of some bedded cherts. J. Am. Science, 267-A 114.

Ewing, J., 1969. Seismic model of the Atlantic Ocean. Am. Geophys. Union, Geophys. Monogr. 13, 220.

and Ewing, M., 1967. Sediment distribution on the mid-ocean ridges with respect to spreading of the sea floor. Science. 156, 1591.

Fell, H. B., 1967. Cretaceous and Tertiary surface currents of the oceans. Oceanogr. Mar. Biol. Ann. Rev. 5, 317-341, London (Allen and Unwin).

Flörke, O. W., 1955. Zur Frage des "Hoch"-Cristobalit in Opalen, Bentoniten und Gläsern: Neues Jahrb. Mineralogie Monatsh. 10, 217.

, 1962. Untersuchungen an amorphem und mikrokristallinem $\mathrm{SIO}_{2}$. Chemie der Erde. 22, 91 .

Folk, R. L., 1968. Petrology of sedimentary rocks. Austin (Tex.), Hemphill. and Weaver, C. E., 1952. A study of the texture and composition of chert. Am. J. Science. 250, 498.

Fox, P. J. and Heezen, B. C., 1965. Sands of the Mid-Atlantic Ridge. Science. 149, 1367.

and Johnson, G. L., 1970. Jurassic sandstone from the tropical Atlantic. Science. 170 , 1402.

Francheteau, J., 1970. Paleomagnetism and plate tectonics. SIO Reference 70-30, $345 \mathrm{pp}$.

Friend, J. K. and Riedel, W. R., 1967. Cenozoic orosphaerid radiolarians from tropical Pacific sediments. Micropaleontology. 13, 217.

Füchtbauer, H. and Müller, G., 1970. Sedimente und Sedimentgesteine. Schweitzerbart, Stuttgart, $726 \mathrm{pp}$.
Giesel, W. and Seibold, E., 1968. Sedimentechogramme vom iberomarokkanischen Kontinentalrand - "Meteor"Forsch. Erg. R., C. 1, 53.

Goldberg, E. D. and Griffin, J. J., 1970. The sediments of the northern Indian Ocean. Deep Sea Res. 17, 513.

Griffin, J. J., Windom, H. L. and Goldberg, E. D., 1968. The distribution of clay minerals in the world ocean. Deep-Sea Res. 15, 433.

Hartmann, M., 1964. Zur Geochemie von Mangan und Eisen in der Ostsee. Meyniana. 14, 3.

Hathaway, J. C., McFarlin, P. F. and Ross, D. A., 1970. Mineralogy and origin of sediments from drill holes on the continental margin off Florida. U. S. Geol. Survey Profess. Paper. 581-E, 26 pp.

Hay, R. L., 1966. Zeolites and zeolitic reactions in sedimentary rocks. GSA Special Paper 85,1 .

Hay, W. W., 1970. Calcium carbonate compensation. In Bader et al., Initial Report of the Deep Sea Drilling Project, Volume 4, Washington (U. S. Government Printing Office), 669.

Heath, G. R. and Moberly, R. Jr., 1971. Cherts from the Western Pacific, Leg 7, Deep Sea Drilling Project. In Winterer, E. L. et al., 1971 Initial Reports of the Deep Sea Drilling Project, Volume VII. Washington (U. S. Government Printing Office). 991.

Hecht, A. D. and Savin, S. M., 1970. Oxygen-18 studies of Recent planktonic foraminifera: comparison of phenotypes and of test parts. Science. 170: 69 .

Heezen, B. C., 1968. The Atlantic Continental Margin. J. Univ. Missouri at Rolla. 1, 5.

Heezen, B. C. and Tharp, Marie, 1961. Physiographic diagram of the South Atlantic Ocean. Publ. by the Geological Society of America. New York.

, 1968. Physiographic diagram of the North Atlantic Ocean. Revised 1968. Publ. by the Geological Society of America, Boulder, Colorado.

Heirtzler, J. R. and Hayes, D. E., 1967. Magnetic boundaries in the North Atlantic Ocean. Science 157, 185 .

Helms, P. B. and Riedel, W. R., 1971. Skeletal debris of fishes. In Winterer, E. L., et al., 1971, Initial Reports of the Deep Sea Drilling Project, Volume VII. Washington (U. S. Govt. Printing Office), 1709.

Hollister, C. D. and Heezen, B. C., 1966. Ocean bottom currents. In: R. W. Fairbridge (Ed.), The Encyclopedia of Oceanography, p. 576. Reinhold Publ. Co., N. Y.

Holmes, A., 1965. Principles of Physical Geology. Ronald Press, N. Y., 1288 pp.

Hsu, K. J. and Andrews, J. E., 1970. History of South Atlantic Basin. In Maxwell, A. E., et al. Initial Reports of the Deep Sea Drilling Project, Volume III. Washington (U. S. Govt. Printing Office), p. 465.

Huckenholz, H. G., 1963. A contribution to the classification of sandstones, Geol. Fören. Stockholm. Förhandl. $85,156$.

Jones, J. B., Sanders, J. V. and Segnit, E. R., 1964. Structure of opal. Nature. 204 (4962), 990.

and Segnit, E. R., 1971. The nature of opal. I. Nomenclature and constituent phases. J. Geol. Soc. A ustralia. 18 (1), 57.

Krause, D. C. and Watkins, N. D., 1970. North Atlantic crustal genesis in the vicinity of the Azores. Geophys. J. R. Astr. Soc. 19 (3), 261.

Landergren, S., 1948. On the geochemistry of Swedish iron ores and associated rocks. A study on iron-ore formation. Sver. Geol. Unders. Ser. C, Avh. och Uppsat., 496, Årsb. 42 , n.5. 
Laughton, A. S., 1971. South Labrador Sea and the evolution of the North Atlantic. Nature. 232 (5313), 612.

Le Pichon, X., 1968. Sea floor spreading and continental drift. J. Geophys. Res. 73, 3661.

Ljunggren, P., 1953. Some data concerning the formation of manganiferous and ferriferous bog ores. Geol. Fören. Förh. 75, 277.

Malfait, B. T. and Dinkelman, M. G., 1972. CircumCaribbean tectonic and igneous activity and the evolution of the Caribbean Plate. Bull. Geol. Soc. Am. $83(2), 251$.

Manheim, F. T., 1965. Manganese-iron accumulation in the shallow marine environment. Sympos. on marine geochemistry. Occas. Pub. 3, Narrang. Marine Lab. Rhode Island, 217.

Marchig, V. and von Rad, U., 1972. Chemistry of interstitial water and sediment samples. Site 137 (Leg 14, Deep Sea Drilling Project) (this volume).

McIntyre, A. and McIntyre, R., 1971. Coccolith concentrations and differential solution in oceanic sediments. In B. M. Funnell and W. R. Riedel, (Eds.), 1971. The Micropaleontology of Oceans. Cambridge University Press, Cambridge, U. K., 253.

McKenzie, D. P. and Parker, R. L., 1967. The North Pacific: an example of tectonics on a sphere. Nature. 216, 1276.

Meischner, K. D., 1964. Allodapische Kalke, Turbidite in riff-nahen Sedimentationsbecken, In A. H. Bouma and A. Brouwer (Eds.), Turbidites (Elsevier, Amsterdam), 156.

Menard, W. H., 1964. Marine Geology of the Pacific. McGraw-Hill, New York, 271 pp.

1969. Elevation and subsidence of oceanic crust. Earth Planet. Sci. Lett. 6, 275.

, 1971. The Late Cenozoic history of the Pacific and Indian Ocean Basins. In The Late Cenozoic glacial ages, K. K. Turekian (Ed.), Yale Univ., New Haven, Conn., 1.

Mizutani, S., 1966. Transformation of silica under hydrothermal conditions. J. Earth Sciences, Nagoya Univ. 14 (1), 56.

Molnar, P. and Sykes, L. R., 1969. Tectonics of the Caribbean and Middle American regions from local mechanism and seismicity. Bull. Geol. Soc. Am. 80 (9), 1639.

Moore, T. C., 1969. Radiolaria: change in skeletal weight and resistance to solution. Bull. Geol. Soc. Am. 80, 2103.

Morgan, W. J., 1968. Rises, trenches, great faults and crustal blocks. J. geophys. Res. 73, 1959.

Mumpton, F. A., 1960. Clinoptilolite redefined. $A m$. Mineralogist. 45, 351.

Nayudu, Y. R., 1962. A new hypothesis for origin of guyots and seamount terraces. Amer. Geophys. Union, Geophys. Monogr. 6, 171.

1964. Palagonite tuffs (hyaloclastites) and the products of post-eruptive processes. Bull. Volcanologique. $27,1$.

Olausson, E., 1960. Description of sediment cores from the central and western Pacific with the adjacent Indonesian Region. Rep. Swed. Deep-Sea Exped. 6 (5), 161. 1961a. Studies of deep-sea cores. Rep. Swed. Deep-Sea Exped. 1947-1948. 8 (4), 337.

1961b. Remarks on some Cenozoic core sequences from the Central Pacific, with a discussion of the role of coccolithophorids and foraminifera in car- bonate deposition. Meddelanden Oceanogr. Inst. Göteborg, 29,5 .

Parker, F. L., 1967. Late Tertiary biostratigraphy (planktonic foraminifera) of tropical Indo-Pacific deep-sea cores. Bull. Am. Paleont. 52 (235), 111.

Pautot, G., Auzende, J. M. and Le Pichon, X., 1970. Continuous deep sea salt layer along North Atlantic margins related to early phase of rifting. Nature 227, 351.

Peterson, M. N. A., 1966. Calcite: rates of dissolution in a vertical profile in the central Pacific. Science. 154, 1542. and Griffin, J. J., 1964. Volcanism and clay minerals in the Southeastern Pacific. J. Marine Res. 22 13.

Edgar, N. T., von der Borch, C. C., and Rex, R. W., 1970. Cruise Leg summary and discussion. In Peterson, M. N. A. et al. 1970. Initial Reports of the Deep Sea Drilling Project, Volume II. Washington (U. S. Government Printing Office). 413.

Pimm, A. C., Garrison, R. E. and Boyce, R. E., 1971. Sedimentology synthesis: lithology, chemistry and physical properties of sediments in the Northwestern Pacific Ocean. In Fischer, A. G. et al. 1971. Initial Reports of the Deep Sea Drilling Project, Volume VI. Washington (U. S. Government Printing Office). 1131.

Pitman, W. C. and Talwani, M., 1972. Sea floor spreading in the North Atlantic. Bull. Geol. Soc. Am. 83, 619.

Price, N. B. and Calvert, S. E., 1970. Compositional variation in Pacific Ocean ferromanganese nodules and its relationship to sediment accumulation rates. Marine Geol. 9, 145 .

Radczewski, O. E., 1937. Die Mineralfazies der Sediments des Kapverden-Beckens, p. 262-277, In C. W. Correns, (Ed.), Die Sedimente des äquatorialen Atlantischen Ozeans. Wiss. Ergebn. Deutsch. Atlant. Exped. "Meteor," 3 (7), Berlin (Gruyter).

Reyre, D. (Ed.), 1966. Sedimentary basins of the African coasts. Pt. 1. Atlantic Coast. Assoc. African Geol. Surv., Paris, 304 pp.

Rona, P. A., 1969. Possible salt domes in the deep Atlantic off northwest Africa. Nature 224 (5215), 141.

1970. Comparison of continental margins of eastern North America at Cape Hatteras and northwestern Africa at Cap Blanc. Bull. Am. Assoc. Petrol. Geol. 54 (1), 129.

Ruddiman, W. F., 1969. Recent planktonic foraminifera: dominance and diversity in North Atlantic surface sediment. Science, 164, 1164.

Scholle, P. A., 1971a. Diagenesis of deep-water carbonate turbidites, Upper Cretaceous Monte Antola Flysch, Northern Apennines, Italy. J. Sed. Petr. 41 (1), 233. 1971b. Sedimentology of fine-grained deepwater carbonate turbidites, Monte Antola Flysch (Upper Cretaceous), Northern Apennines, Italy. Bull. Geol. Soc. Am. 82, 629 .

Schrader, H. J., 1971a. Selektive Auflösung Planktischer Diatomeen im seegebiet zwischen $15-43^{\circ}$ Nördlicher Breite und $8-30^{\circ}$ Westlicher Länge. Proceedings 2nd Plankt. Conf., Roma 1970, Edizioni Tecnoscienza, p. 1139.

1971b. Ursache und Ergebnis der Auflösung von Kieselskeletten in den oberen Sedimentbereichen am Beispiel zweier Kern-profile vor Marokko und Portugal. Proceedings 2nd Plankt. Conf., Roma 1970, Edizioni Tecnoscienza, p. 1149. 1971c. Fecal pellets: role in sedimentation of pelagic diatoms. Science. 174, 55 . 
1972. Kieselsäure-Skelette in Sedimenten des iberomarokkanischen Kontinentalrandes und angrenzender Tiefsee-Ebenen, "Meteor"-Forsch. Ergebnisse, Reihe C, No. 8, p. 10.

Schwarzbach, M., 1961. Das Klima der Vorzeit. Enke, Stuttgart, $275 \mathrm{pp}$.

Sclater, J. G., Anderson, R. N. and Bell, M. L. Elevation of ridges and evolution of the Central Eastern Pacific. $J$. Geophys. Res. 76, 7888 (1971). and Francheteau, J., 1970. The implications of terrestrial heat flow observations on current tectonic and geochemical models of the crust and upper mantle of the earth. Geophys. J. R. Astr. Soc. 20, 509.

Segnit, E. R., Anderson, C. A. and Jones, J. B., 1970. A scanning microscope study of the morphology of opal. Search (Commonwealth. Scient. and Industry Research Organiz.). 1, 349.

Seibold, E., 1969. Zur geologischen Bedeutung ozeanischer Strömungen. Beih. geol. Jb. 80, 207. 1970. Nebenmeere im humiden und ariden Klimabereich. Geol. Rundschau 60 (1), 73.

Sheldon, R. P., 1964. Paleolatitude and paleogeographic distribution of phosphorite. U. S. Geol. Survey, Prof. Paper 501-C, 106.

Smith, A. G., 1971. Alpine deformation and the oceanic areas of the Tethys, Mediterranean, and Atlantic. Bull. Geol. Soc. Am. 82, 2039.

Sverdrup, H. U., Johnson, M. W. and Fleming, R. H., 1942. The Oceans. Prentice-Hall, Englewood Cliffs, N. J., $1087 \mathrm{pp}$.

Thiede, J., 1971. Planktonische Foraminiferen in Sedimenten vom ibero-marokkanischen Kontinentalrand. "Meteor"'Forsch. Ergebnisse, Reihe C. 7, 15.

Turekian, K. K., 1965. Some aspects of the geochemistry of marine sediments. In: J. P. Riley and G. Skirrow
(Eds.), Chemica Oceanography, Vol. 2, Academic Press, London, p. 81 . and Bertine, K., 1971. Deposition of molybdenum and uranium along the major ocean ridge systems. Nature 229, 250.

van Andel, T. H. and Heath, G. R., 1970. Tectonics of the Mid-Atlantic Ridge, $6-8^{\circ}$ South Latitude. Marine Geophys. Res. 1, 5. and Komar, P. D., 1969. Ponded sediments of the Mid-Atlantic Ridge between $22^{\circ}$ and $23^{\circ}$ North Latitude. Bull. Geol. Soc. Am. 80, 1163.

von der Borch, C. C. and Rex, R. W., 1970. Amorphous iron oxide precipitates in sediments cored during Leg 5, Deep Sea Drilling Project. In McManus et al., 1970, Initial Reports of the Deep Sea Drilling Project, Volume $V$. Washington (U. S. Government Printing Office), 541. Nesteroff, W. D. and Galehouse, J. S., 1971. Iron-rich sediments cored during Leg 8 of the Deep Sea Drilling Project. In Tracey, J. I., et al., 1971, Initial Reports of the Deep Sea Drilling Project, Volume VIII. Washington (U. S. Government Printing Office) 829.

von Rad, U., and Rösch, H., 1972. Mineralogy and origin of clay minerals, silica and authigenic silicates, in Leg 14 sediments. In Hayes, D. E., et al., 1972. Initial Reports of the Deep Sea Drilling Project, Volume XIV. Washington (U. S. Government Printing Office).

Wise, S. W., Buie, B. F. and Weaver, F. M., 1972. Chemically precipitated sedimentary cristobalite and the origin of chert. Eclogae geol. Helv. 65 (1), 157. and Hsü, K. J., 1971. Genesis and lithification of a deep sea chalk. Eclogae Geol. Helv. 64 (2), 273.

Wollast, R., McKenzie, F. T. and Bricker, O. P., 1968. Experimental precipitation and genesis of sepiolite at earth-surface conditions. Am. Mineralogist. 53 (9-10), 1645 . 

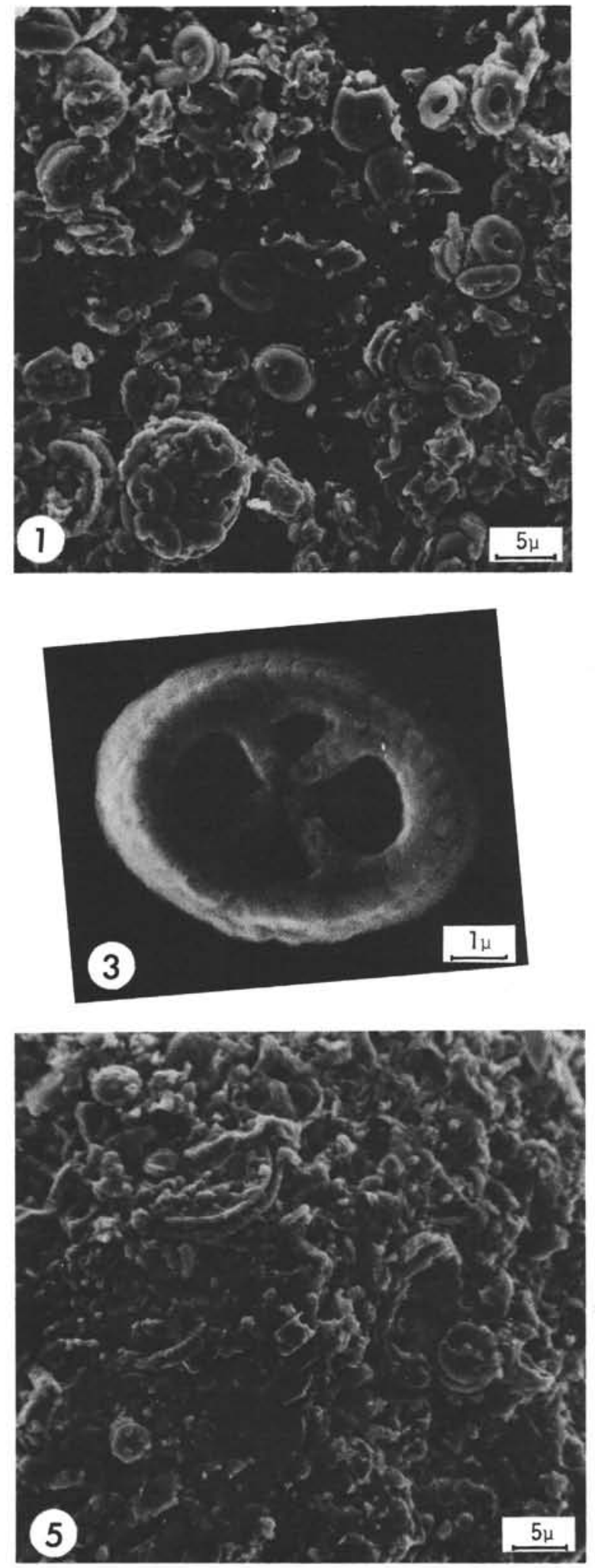
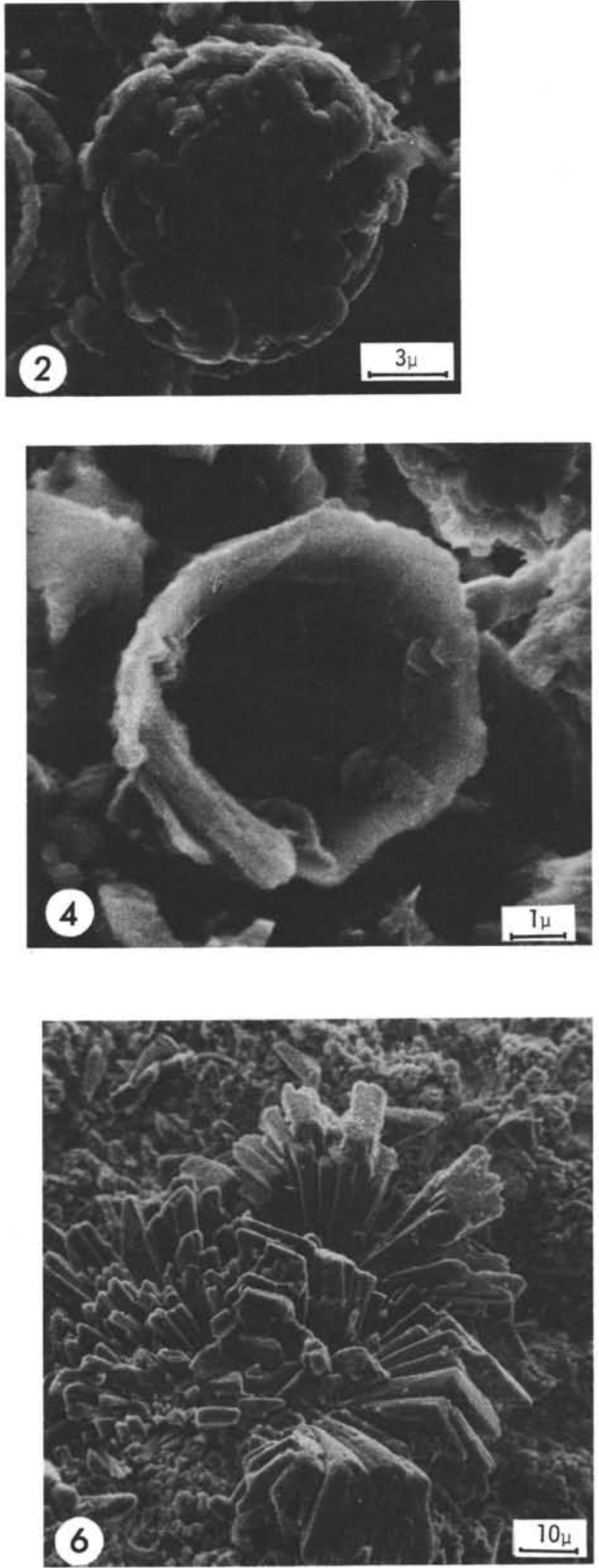

PLATE 1. Preservation of Calcareous Nannofossils. (SEM Kiel, photo W.H.B./Samtleben. Carbon coating, 10 kV). Fig. 1. 136-3-2 (Miocene). Coccolith assemblage enriched in resistant forms, moderate etching, slight overgrowth. (Associated foram assemblage very poorly preserved.). Fig. 2. Same, detail. Coccosphere of placoliths. Fig. 3. 137-10-3 (Cenomanian). Poorly preserved coccolith: incipient destruction of center part. Fig. 4. 144A-5cc (Santonian). Coccolith in laminated marlstone, heavy overgrowth. Fig. 5. 137-12-2 (Cenomanian). Coccolith remains in marlstone fragment. Fig. 6. Same marlstone, Nannoconus (?) fragment. 
PLATE 2. Preservation of Neogene Planktonic Foraminifera. (SEM Kiel, photo W.H.B./Samtleben. Carbon coating, $10 \mathrm{kV}$ ). Note enrichment of non-spined and thick-walled forms, and of specimens with small terminal chambers (kummerforms). Note fragments, benthic forams.

Fig. 1. 135-1cc (Quaternary). Intermediate dissolution $(F S \approx 4)$. Lysocline assemblage.

Fig. 2. 139-1cc (E. Pliocene) Advanced dissolution ( $F S \approx 4$ to 5). Upper R-zone assemblage.

Figs. 3, 4. 135-3cc (Lt. Miocene). Pronounced dissolution (FS $\approx 6)$. Lower R-Zone assemblage.

Fig. 5. 142-7-2. $79 \mathrm{~cm}$ (Lt. Miocene). Advanced dissolution $(\mathrm{FS} \approx 4$ to 5).

Fig. 6. 142-7-5, $119 \mathrm{~cm}$ (Lt. Miocene). Resistant forms of the Globigerinoides sacculifer-Sphaeroidinella spp. group.

Fig. 7. 135-4cc (M/E. Miocene). Globoquadrina venezuelana with thick cortex, from highly dissolved assemblage $(\mathrm{FS} \approx 6$ to 7$)$.

Fig. 8. 136-2-6, $119 \mathrm{~cm}$ (M/E. Miocene). Similar, partially decortified, from FS 7 assemblage. 

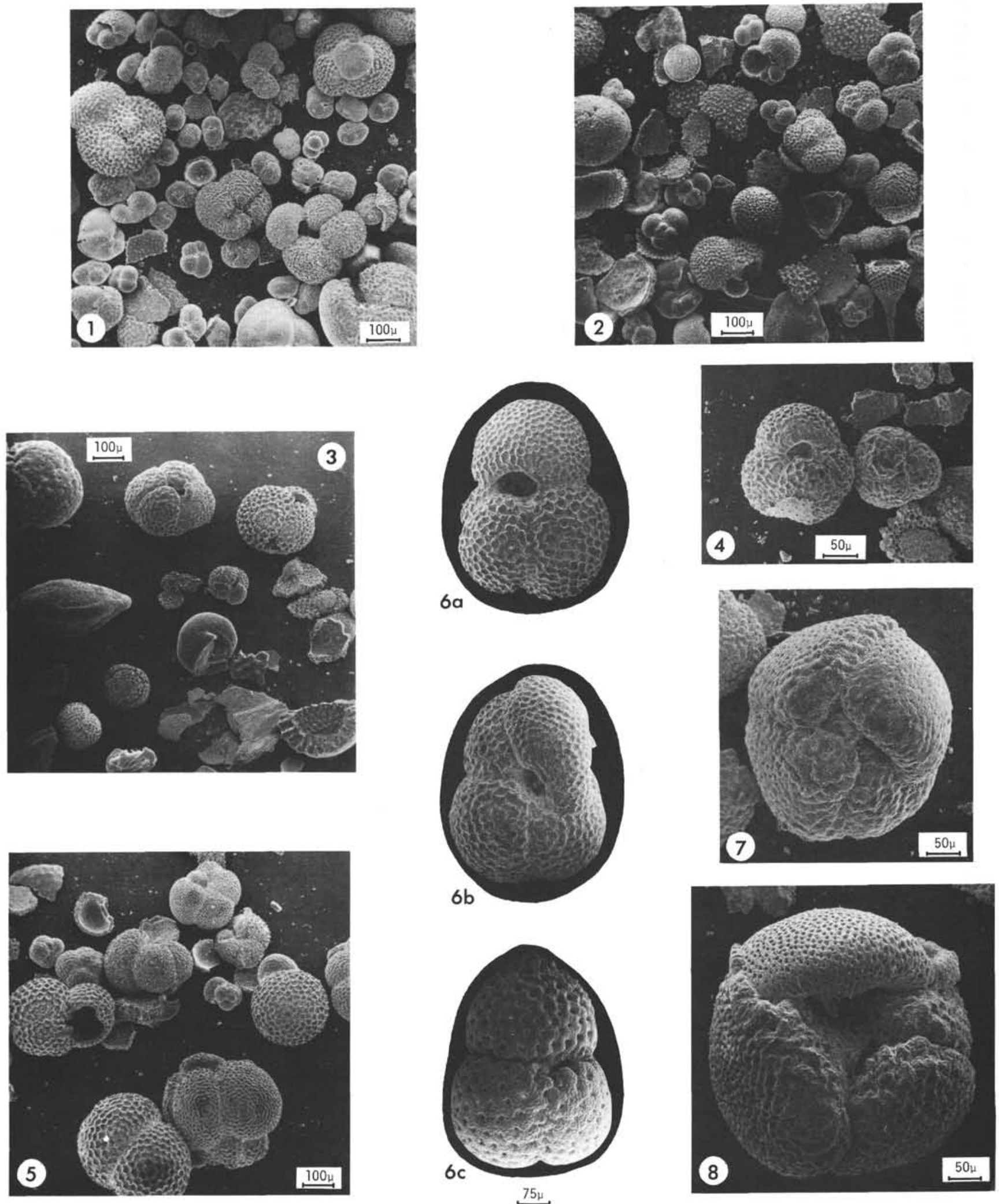

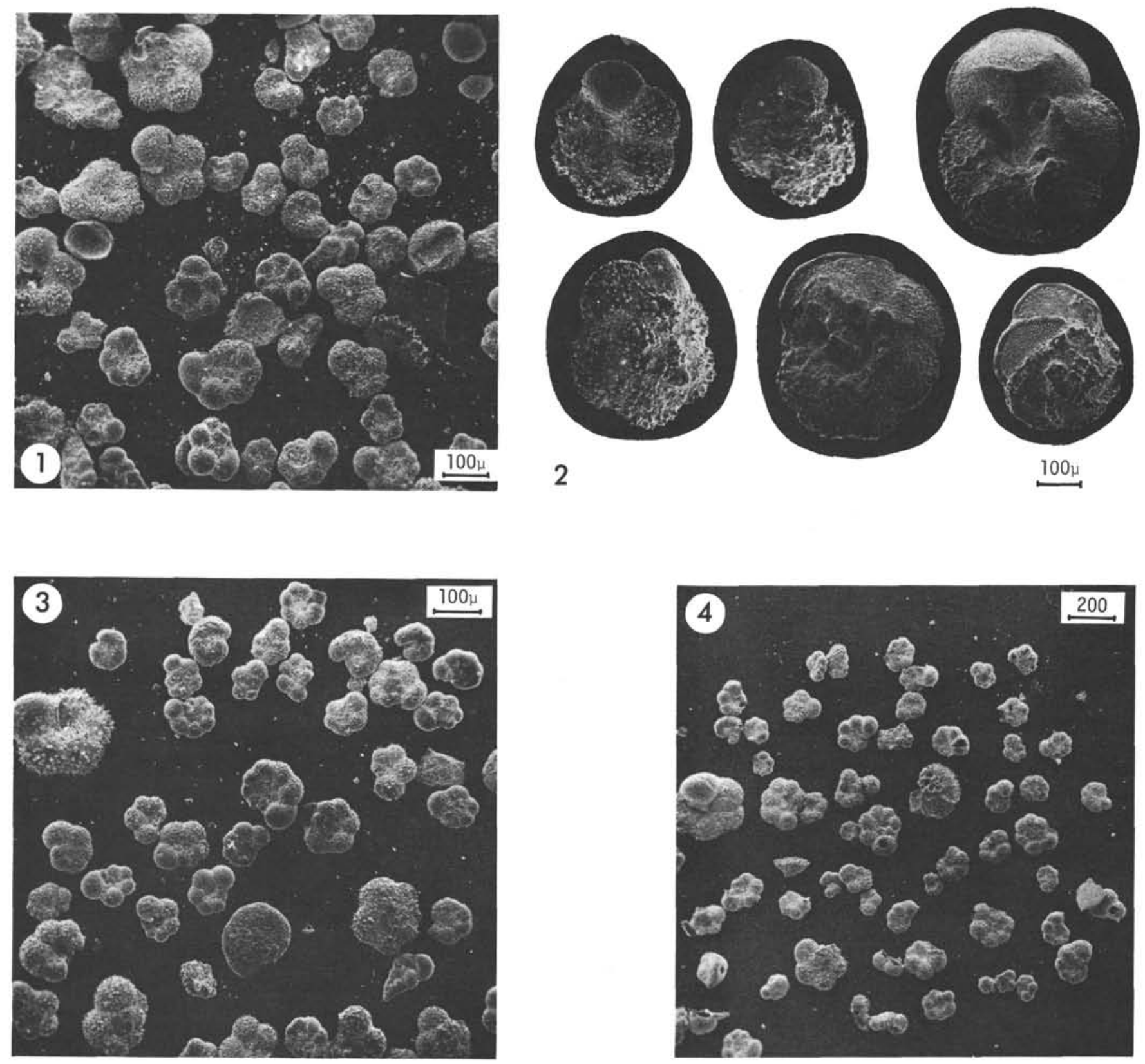

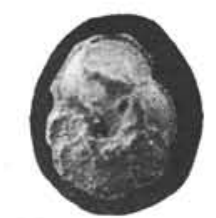

5
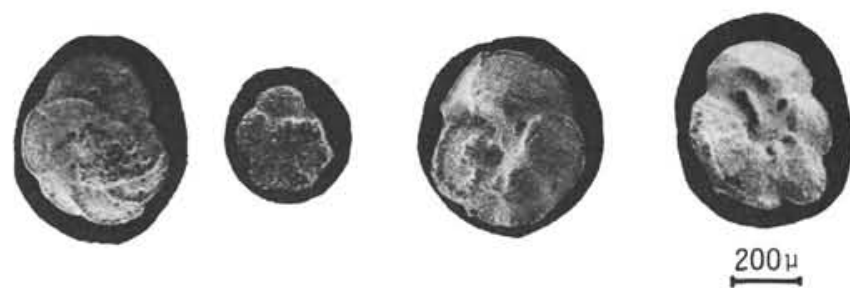

PLATE 3. Preservation of Cenomanian Planktonic Foraminifera. 137-10, 11, and 13. (SEM Kiel, photo W.H.B./Samtleben. Carbon coating, $10 \mathrm{kV}$ ). Note abundant well preserved small spined forms, scarcity of fragments. Figures 1, 2. 10-3, $123 \mathrm{~cm}$. Little dissolution (P-zone assemblage). Small specimens: probably largely Globigerinelloides, Hedbergella, and heterohelicids. Large specimens: Rotalipora and Praeglobotruncana. Note bimodal distribution, Fig. 3. 114, $118 \mathrm{~cm}$. No apparent dissolution (P-zone). Figs. 4, 5. 13-4, $103 \mathrm{~cm}$. Mixed poorly and well preserved assemblage? Composition as in Figs. 1, 2, 3, but somewhat fewer spined forms (?). 

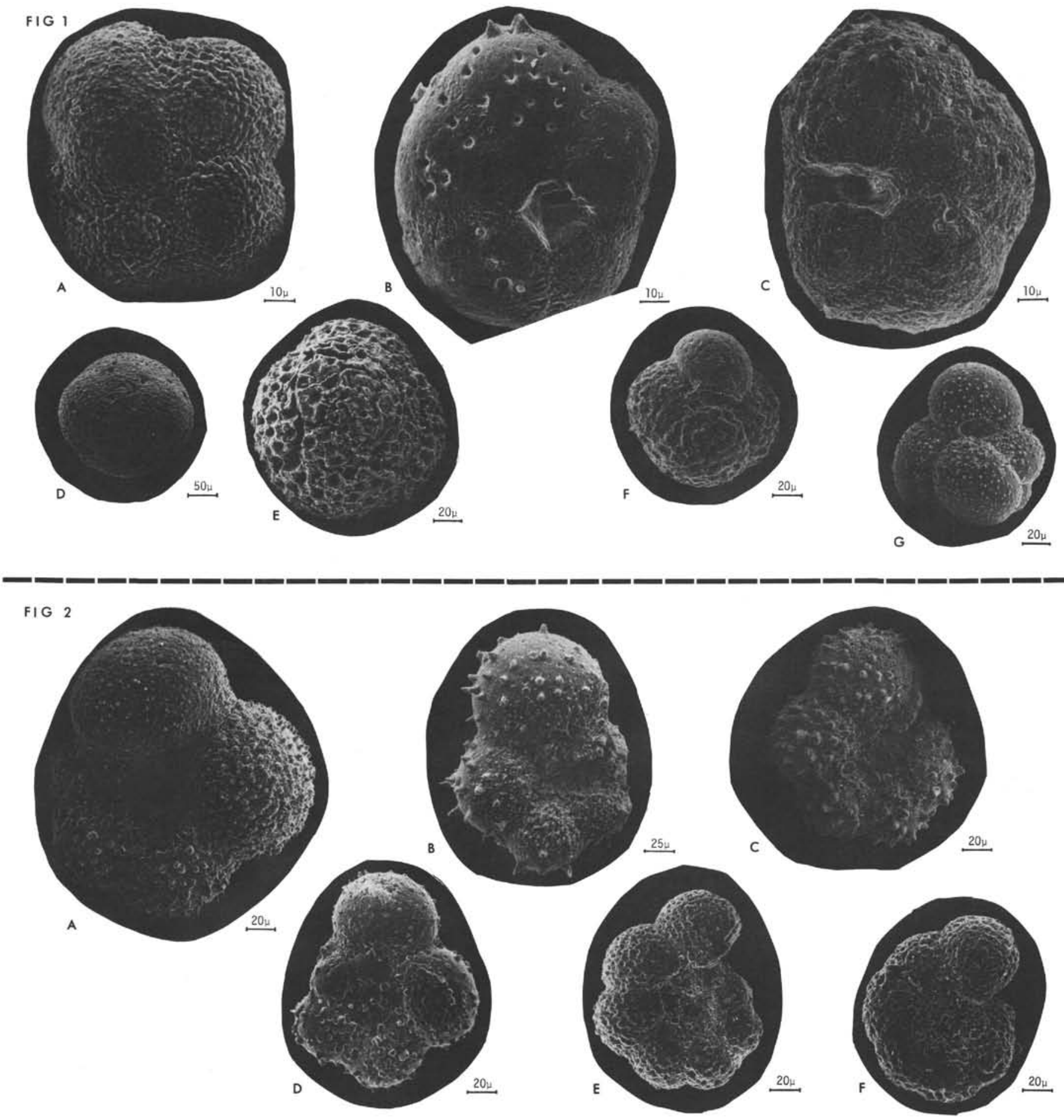

PLATE 4. Kummerform development in small planktonic foraminifera. Comparison of Neogene and Cenomanian fauna. (SEM Kiel, photos W.H.B./Samtleben. Carbon coating, 10 kV). Fig. 1. Neogene small forams, all kummerform. A, B, C., 135-1cc (Quaternary, from moderately well-preserved assemblage). Globigerina cf. quinqueloba, thickly encrusted (pachyform). D. 139-1cc (E. Pliocene). Pachyform "Orbulina" (medium sized specimen. Only occasionally as small as $150 \mu$ ). E. 135-3cc (Lt. Miocene) similar to D. (Globigerinoides?) F. 142-7-2 (M. Miocene). Pachyform Globigerina (G. pachyderma?). G. 139-1cc (E. Pliocene). Slightly kummerform Globigerinita glutinata. Fig. 2. Cenomanian small forams, none kummerform. A. 137-9cc. Spined foram (Hedbergella?) approaching K'form condition ( $q \approx 1)$. B. 137-13-4. $103 \mathrm{~cm}$. Evolute normal form (spined foram) $\mathrm{q}=1.3$ ). C. 137-11-3. $119 \mathrm{~cm}$. Less evolute $(\mathrm{q} \approx 1.2)$ slightly pachyform spined foram (Hedbergella?). D. $137-12-4,93 \mathrm{~cm}$. Slightly encrusted spined foram approaching $\mathrm{K}$ 'form condition $(\mathrm{q} \approx 1)$. E. 137-12-4, $93 \mathrm{~cm}$. Apparently non-spined foram (Globigerinelloides?), slightly pachyform, barely evolute $(\mathrm{q} \approx 1.1)$. F. 137-12-1, $123 \mathrm{~cm}$. Similar, less evolute, more encrusted (note slight reversal of q). 

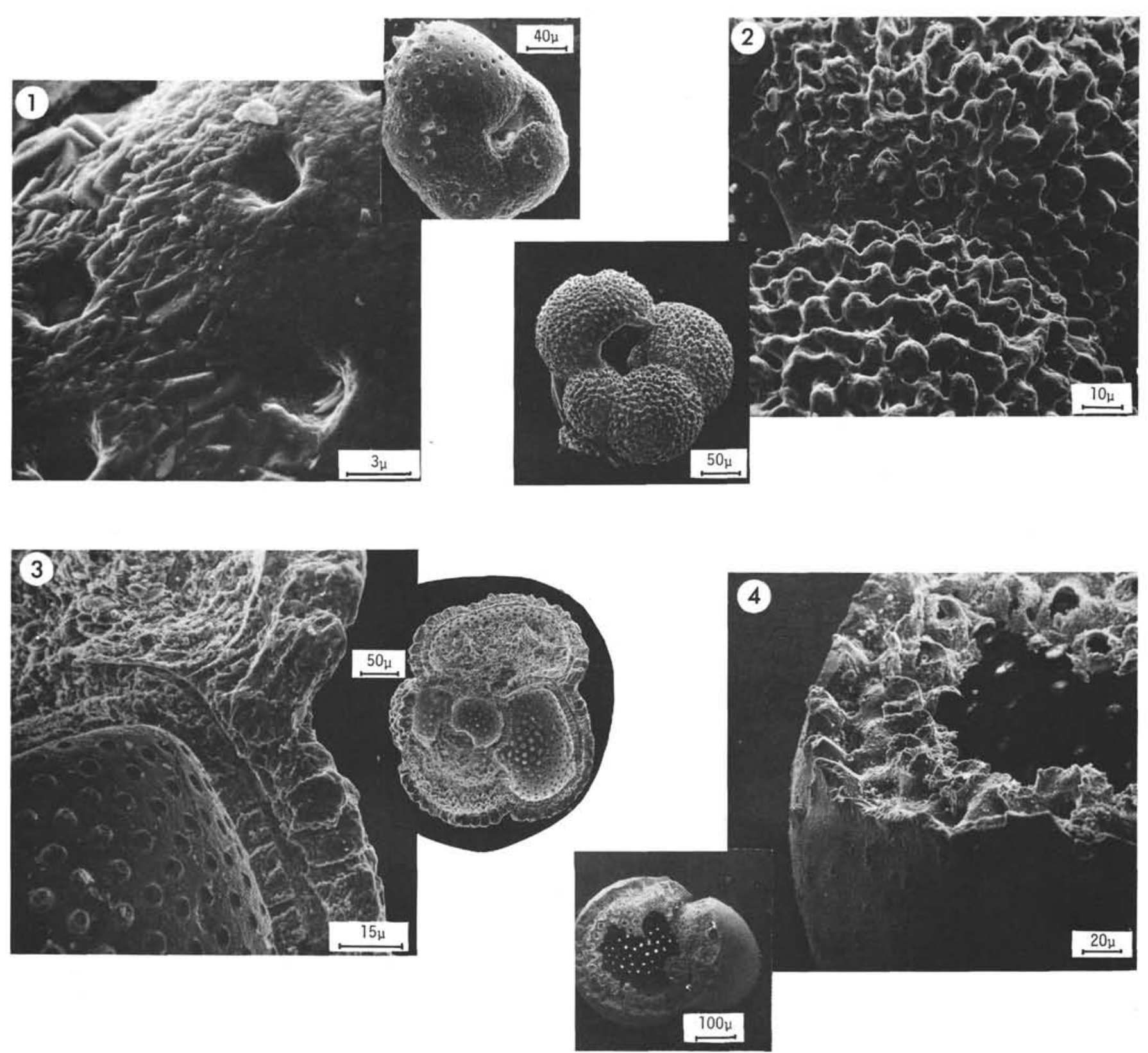

PLATE 5. Shell thickening in Neogene Planktonic Foraminifera. (SEM Kiel, photos W.H.B./Samtleben). Fig. 1. 135-1cc (Quaternary). Typical small foram in moderately dissolved modern assemblage (Globigerina quinqueloba?). Note pronounced cortex formation, enhanced thickening at sutures, leading to smooth undifferentiated pachyform shell. Fig. 2. 139-1cc (E. Pliocene). Medium sized spined foram (Globigerina bulloides) showing shell thickening by increased rugosity, i.e. thickening of spine bases, rather than smoothing. Specimen probably is etched (associated FS = 4.5). Fig. 3. 142-7-2, $119 \mathrm{~cm}$ (Lt. Miocene). Foram fragment, showing devleopment of a secondary wall enclosing the entire test. The cortex appears unrelated to the construction of any particular chamber wall. Fig. 4. 142-7-5, $119 \mathrm{~cm}$ (Lt. Miocene) Fragment of Sphaeroidinella. Note smooth cortex development on originally rugose (spiny) test surface. 

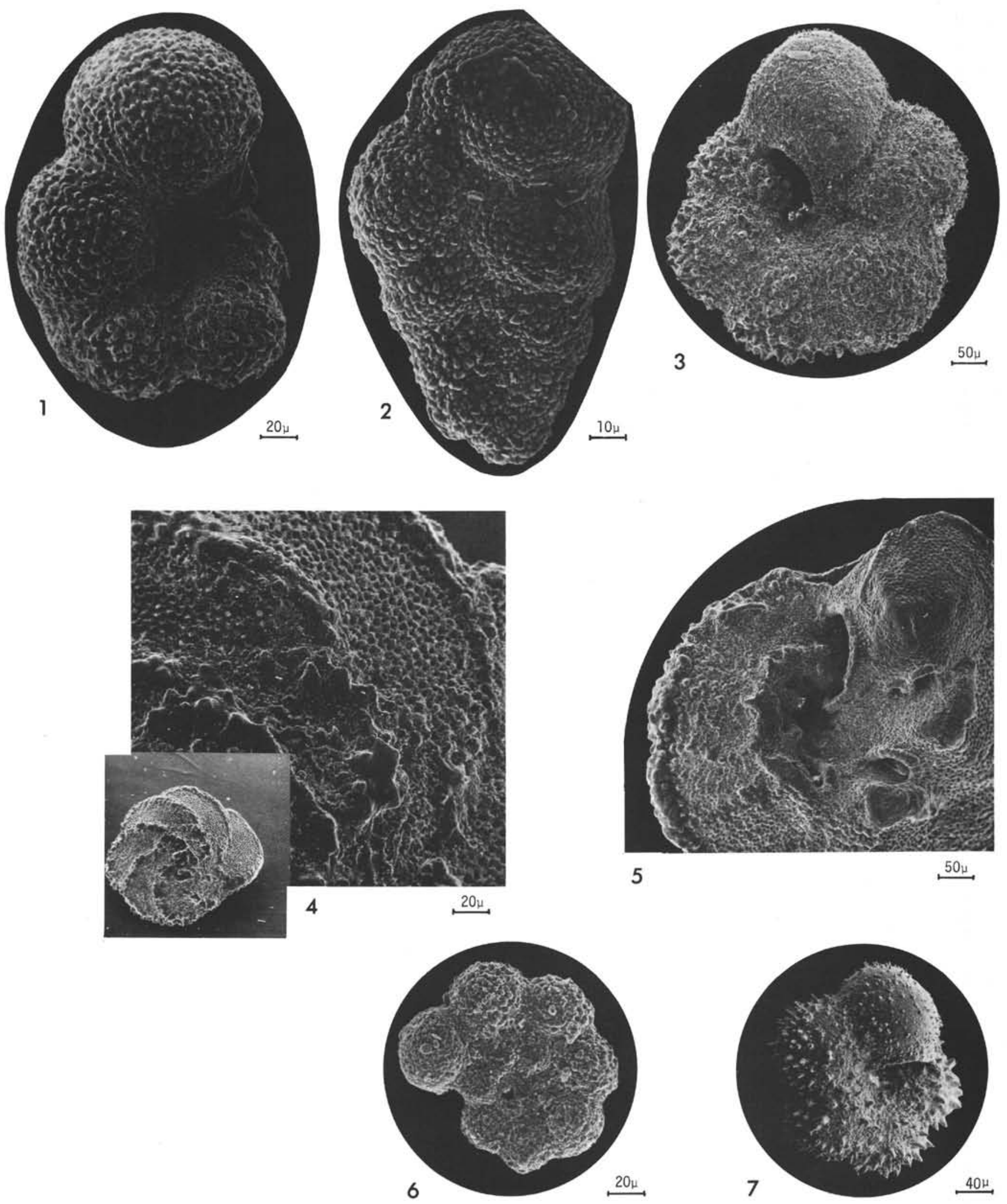

PLATE 6. Shell thickening in Cenomanian planktonic foraminifera. (SEM Kiel, photos W.H.B./Samtleben). Compare with Plate 5. Note absence of cortex formations. Note local thickening of spine-bases and pustules (Figs. 1, 2, 3, 6, 7) and edges (carinae, umbilical chamber edges, Figs. 4, 5). Fig. 1. 144-4cc. Hedbergella. Fig. 2. 137-9cc. Heterohelix. Fig. 3. 137-12-1, $123 \mathrm{~cm}$. Praeglobotruncana (?) Fig. 4. 137-9cc. Rotalipora (?). Fig. 5. 137-12-4, $93 \mathrm{~cm}$. Rotalipora. Fig. 6. 137-12cc. Globigerinelloides (?). Fig. 7. 137-11-4, $118 \mathrm{~cm}$. Spined form (immat. Praeglobotruncana?). 

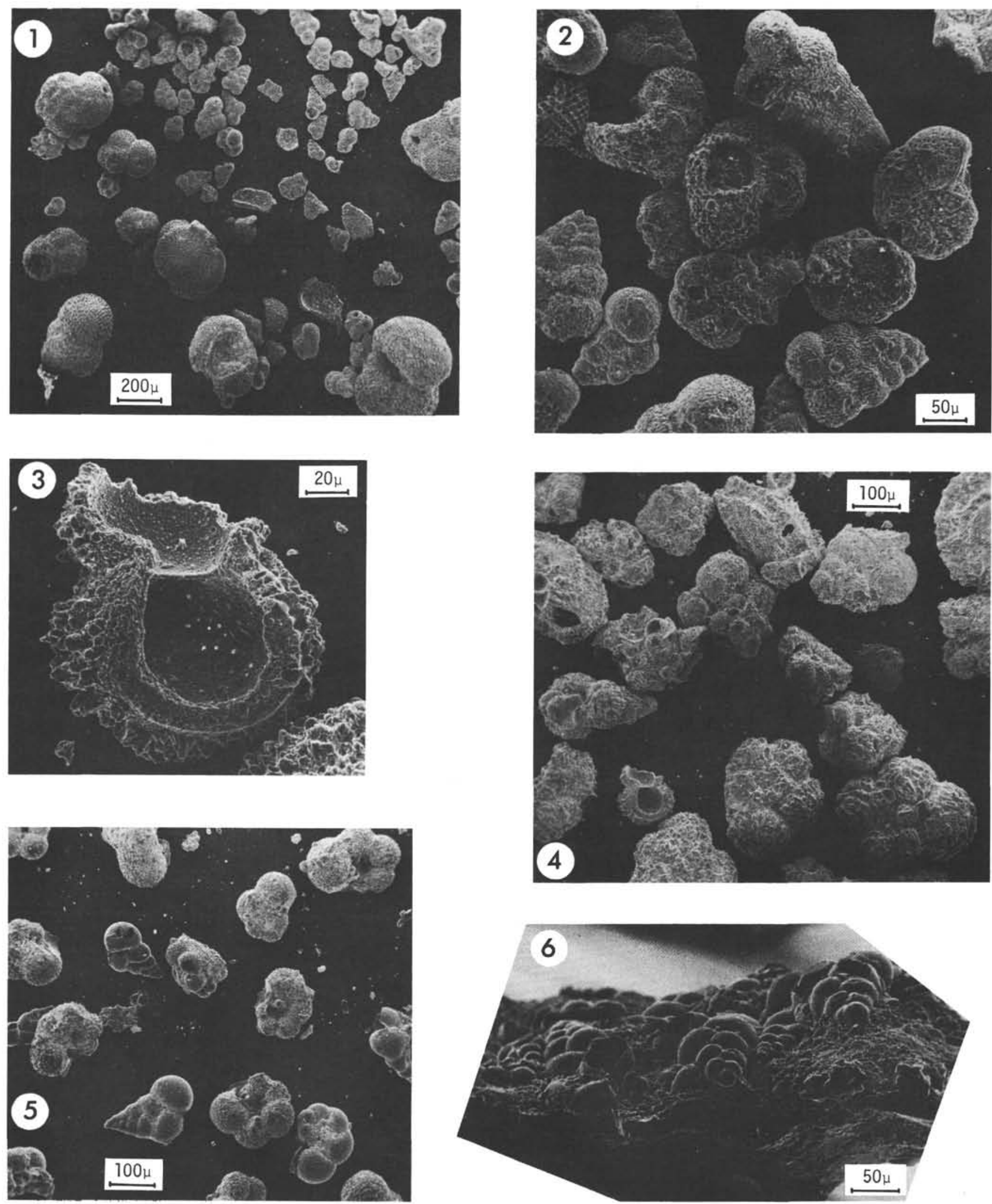

PLATE 7. Foraminiferal assemblages from Demerara Rise. Site 144. (SEM Kiel, photos W.H.B./Samtleben). Note partial lithification, effects on apparent preservation. Figs. 1, 2. A1-2, $119 \mathrm{~cm}$ (Oligocene). Note bimodality, abundance of heterohelicids. Figs. 3, 4. A-3-2, $119 \mathrm{~cm}$ (Lt. Paleocene). Note thickened walls. Figs. 5, 6. 4 cc (Cenomanian). Note absence of keeled forms. Note enrichment of Heterohelix in laminae of finely layered marl (sorting? seasonal effect?). 

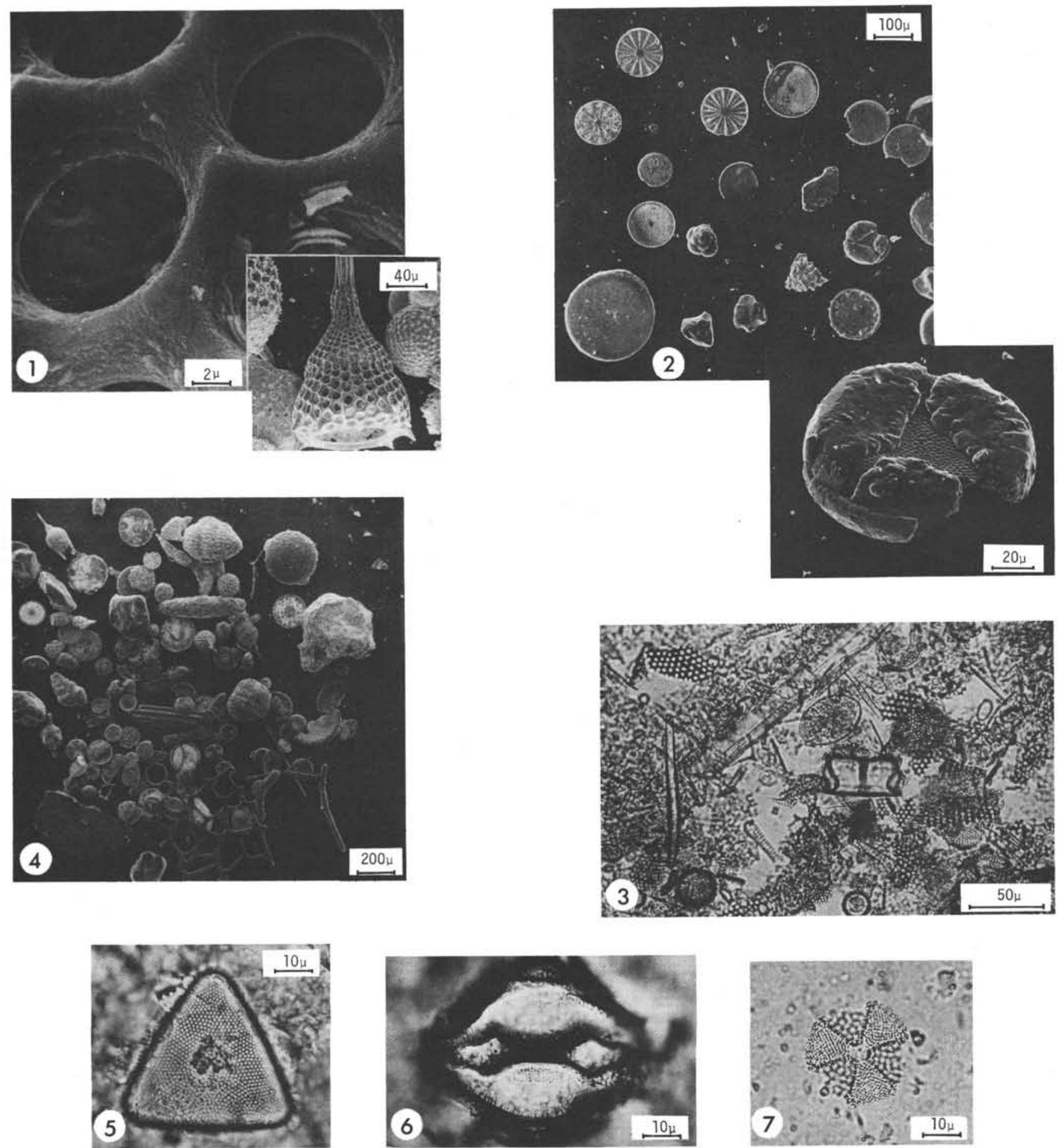

PLATE 8. Preservation of Neogene Siliceous Fossils. Mainly Sites 139, 140 (Continental Slope). (SEM Kiel, photo W.H.B./Samtleben, 10kV, carbon coating. Smear slides: Fig. 3, photo U.v.R.; Figs. 5, 6, 7, photos and identifications H.-J. Schrader) Fig. 1. 139-1cc (E. Pliocene). Heavy-shelled radiolarian (Lamprocyclas) in calcareous ooze. Note etched surface. Fig. 2. 139-3cc (M. Miocene). Well preserved centric diatoms from quartzose (badly dissolved) calcareous ooze. Note pyrite overgrowth (detail). Fig. 3. 139-5-1. $140 \mathrm{~cm}$ (E./M. Miocene). Relatively pure siliceous ooze, clayey and calcareous (coarse fraction: quartz, benthic forams, radiolarians, fish debris). Note maceration. Fig. 4. 140-2-3, $119 \mathrm{~cm}$ (E. Miocene). Mixed well and poorly preserved (?) siliceous assemblages from slightly quartzose and calcareous diatom mud. Some diatoms are partly pyritized. Fig. 5. 139-1 cc (E. Pliocene). Partly corroded centric diatom (Triceratium heterostriches?) Fig. $6.139-5-1,140 \mathrm{~cm}$ (E./M. Miocene). Goniotherium odontella EHR. Fig. 7. 138-1cc (E. Miocene). Actinoptychus undulatus (BAIL.) RALFS, rim dissolved. 

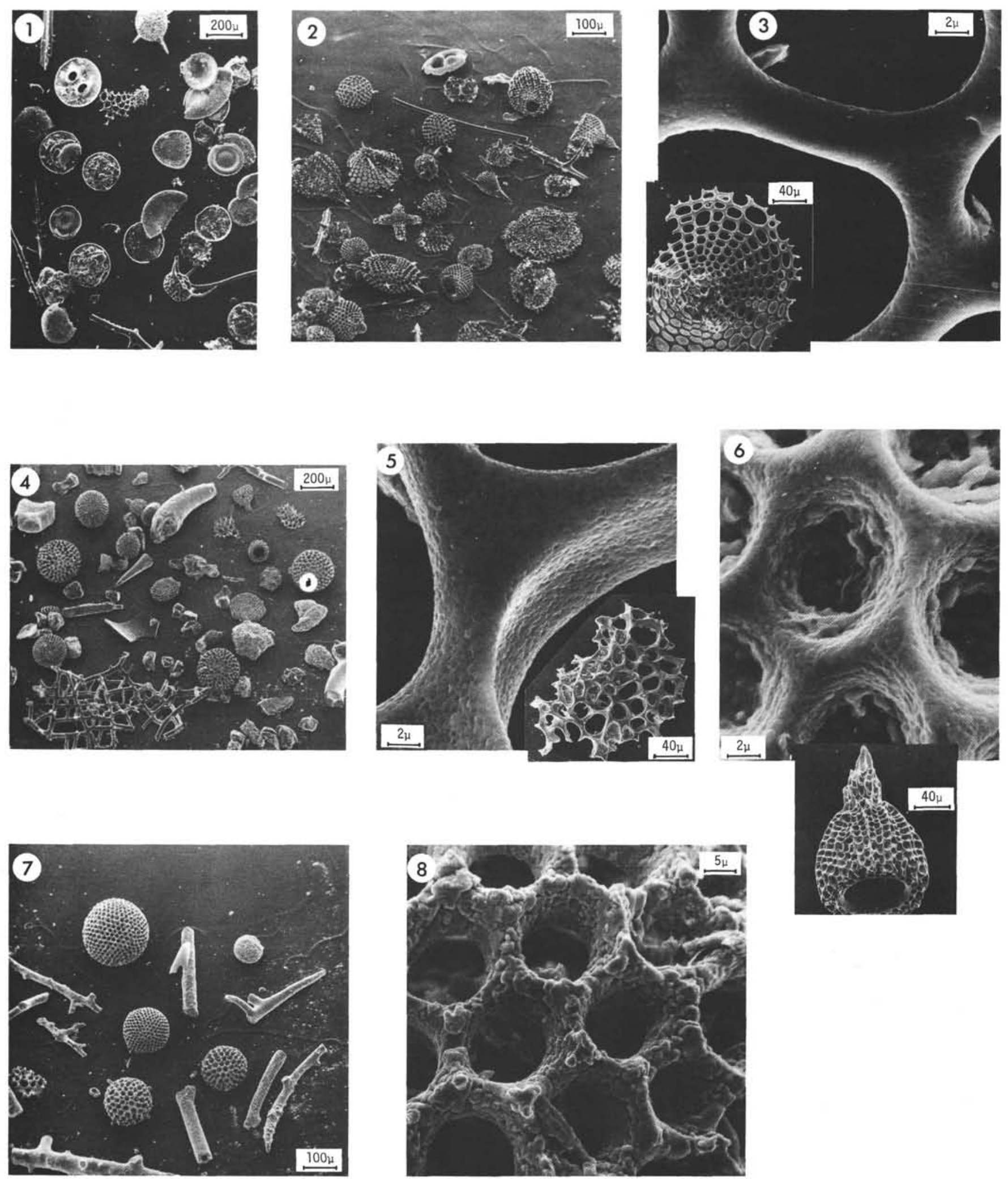

PLATE 9. Preservation of Oligocene Siliceous Fossils. Site 138, Core 2 (continental rise). (SEM Kiel, photos W.H.B./Samtleben, 10kV, carbon coating.) Figs. 1, 2, 3. 2-2, $119 \mathrm{~cm}$. Diatoms and radiolarians from pale green siliceous clay. Sand fraction is purely siliceous. Excellent preservation: delicate radiolarians with smooth surface present. Figs. 4, 5, 6. 2-1, $118 \mathrm{~cm}$. Siliceous assemblage from dark grayish green quartzose clay. Poor preservation: Note heavy tests, sponge spicule, orosphaerid remains, etched (and/or thickened?) surfaces. Figs. 7, 8, 2-6, $118 \mathrm{~cm}$. Poorly preserved siliceous assemblage from greenish gray clay, in part pyritized (see detail). 

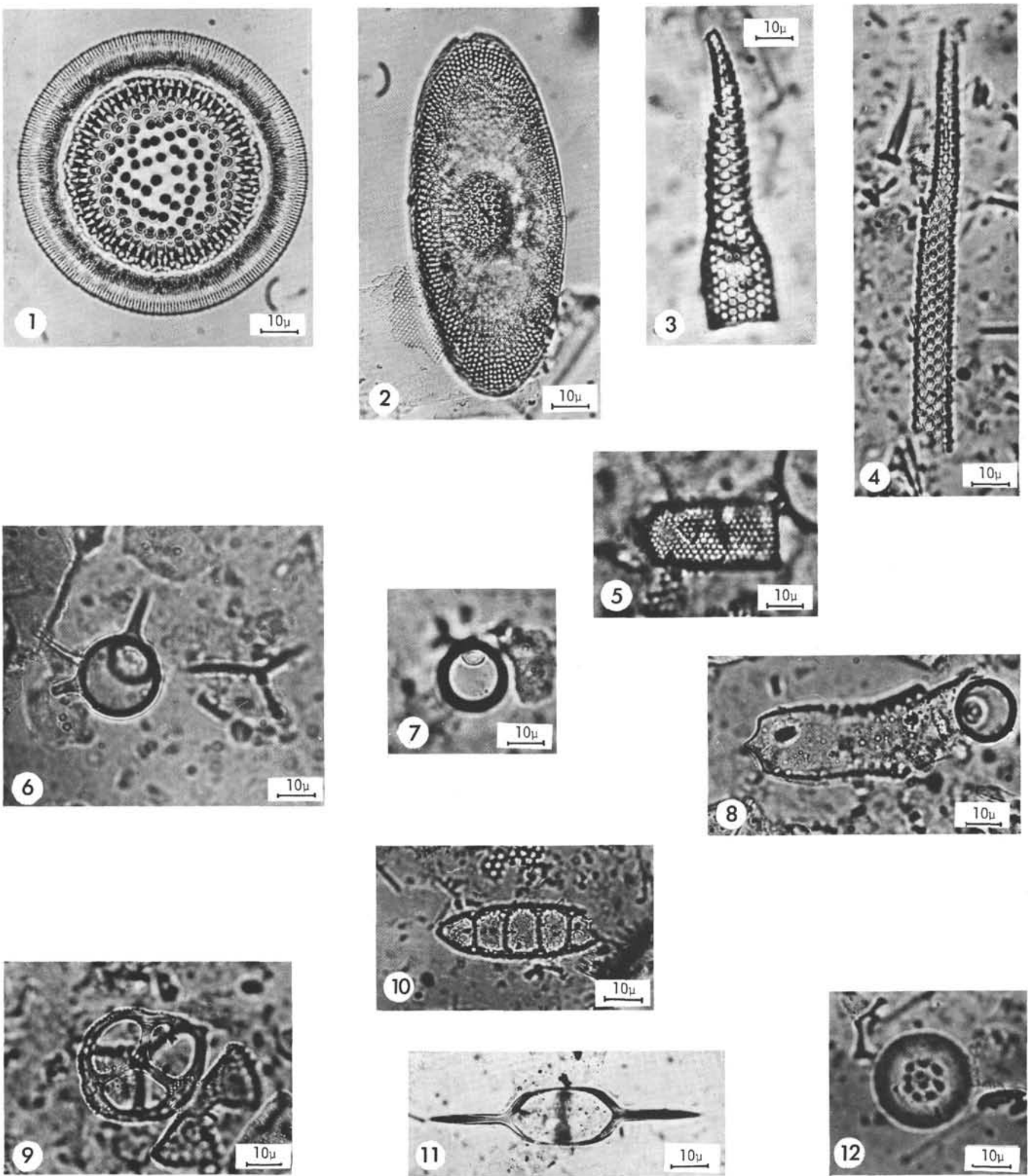

PLATE 10. Oligocene Siliceous Fossils. Site 138-2. (Smear slides, photos and identifications H-J. Schrader.) Fig. 1. 2-1, 30 $\mathrm{cm}$. Coscinodiscus superbus HARDMANN. Fig. 2. Same. C. oblongus GREVILLE. Fig. 3. Same. Pyxilla gracilis TEMP. et FORTI. Fig. 4. 2-1, $100 \mathrm{~cm}$. As in Fig. 3, fragment. Fig. 5. 2-6, $110 \mathrm{~cm}$. Pyxilla sp., fragment. Figs. 6, 7. 2-1, $30 \mathrm{~cm}$. Archaeomonadaceans (cysts of chrysophytes?) Fig. 8. 2-1, $30 \mathrm{~cm}$. Trinacria simulacrum GROVE et STURT var. grossepunctata (?) HUSTEDT. Fig. 9. 2-4, $75 \mathrm{~cm}$. Ebridian skeleton (heterotrophic? pyrrhophytes or chrysophytes). Fig. 10. 2-1, $100 \mathrm{~cm}$. Hemiaulus polycistinorum EHR. (?). Fig. 11. 2-6, $110 \mathrm{~cm}$. Naviculopsis biapiculata (?), silicoflagellate skeleton. Fig. 12. 2-6, $110 \mathrm{~cm}$. Centric diatom (Melosira sp.). 

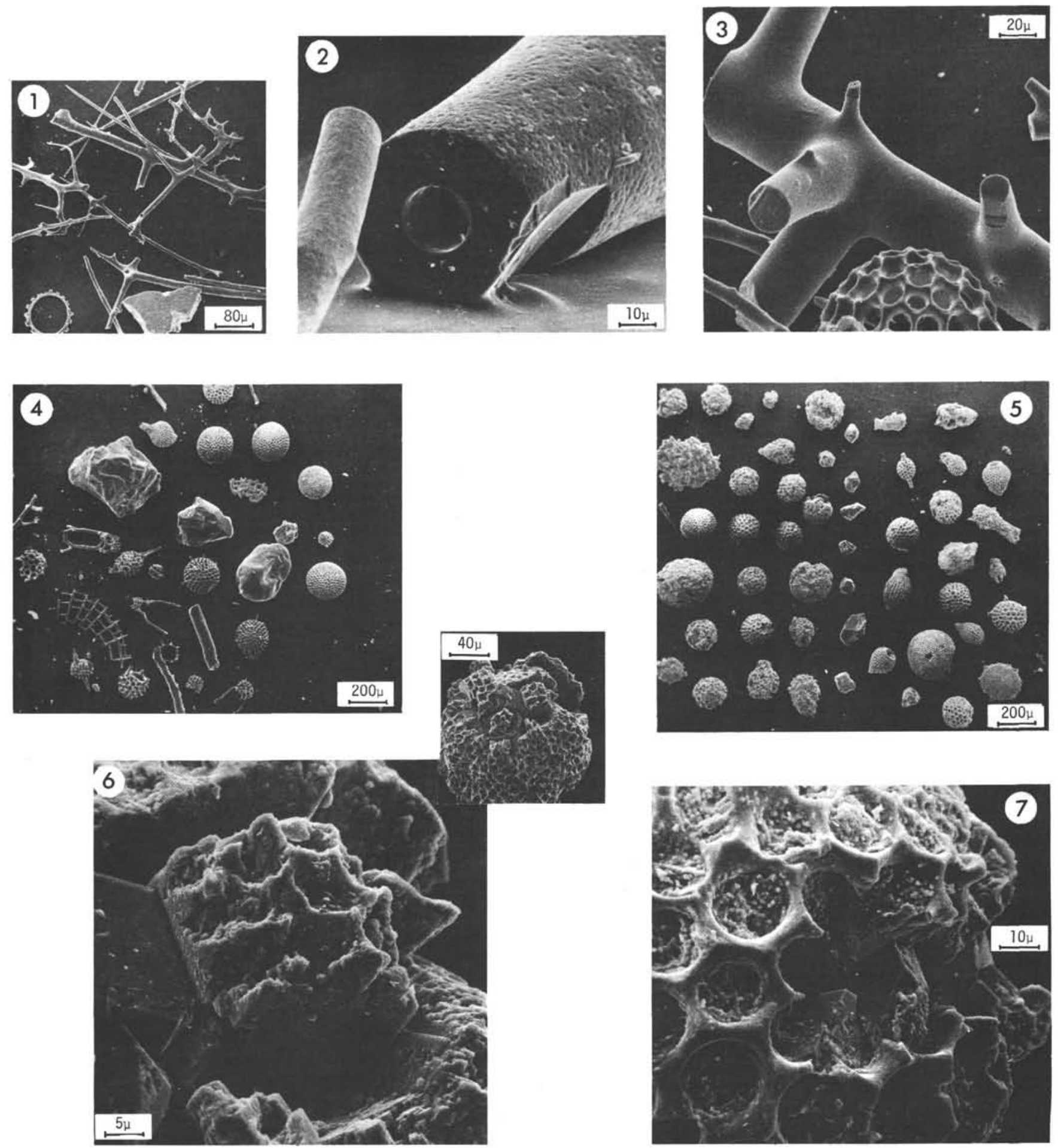

PLATE 11. Preservation of Eocene Siliceous Fossils. Site 140 (continental slope). (SEM Kiel, photos W.H.B./Samtleben, $10 \mathrm{kV}$, carbon coating.) Figs. 1, 2 A2-3, $119 \mathrm{~cm}$ (Lt. Eocene). Extremely dissolved siliceous assemblage (mainly orosphaerid fragments) from brownish to greenish clay. Note fish debris. Note apparent corrosion of sponge spicule. Fig. 3. A2-4, $119 \mathrm{~cm}$ (Lt. Eocene). Orosphaerid fragment from assemblage showing intermediate dissolution (see also Plate 15, Fig. 4). Note relatively smooth surface. Note small central holes in two of the branches. Fig. 4. 140-3-1, $104 \mathrm{~cm}$ (M. Eocene. Note fragments of Podocyrtis goetheana and Eusyringium fistuligerum). Rather poorly preserved assemblage from greenish gray slightly siliceous silty clay, with quartz grains (from nearby sandy layers, by mottling?). Radiolarians contain zeolite and are in part pyritized. Figs. 5, 6, 7. 140-4-3, $141 \mathrm{~cm}$ (E. Eocene). Rather poorly preserved assemblage from greenish gray slightly silty clay (note quartz grains). Radiolarians are zeolite filled, in part pyritized (pyritized, Fig. 6: opaline, Fig. 7). 

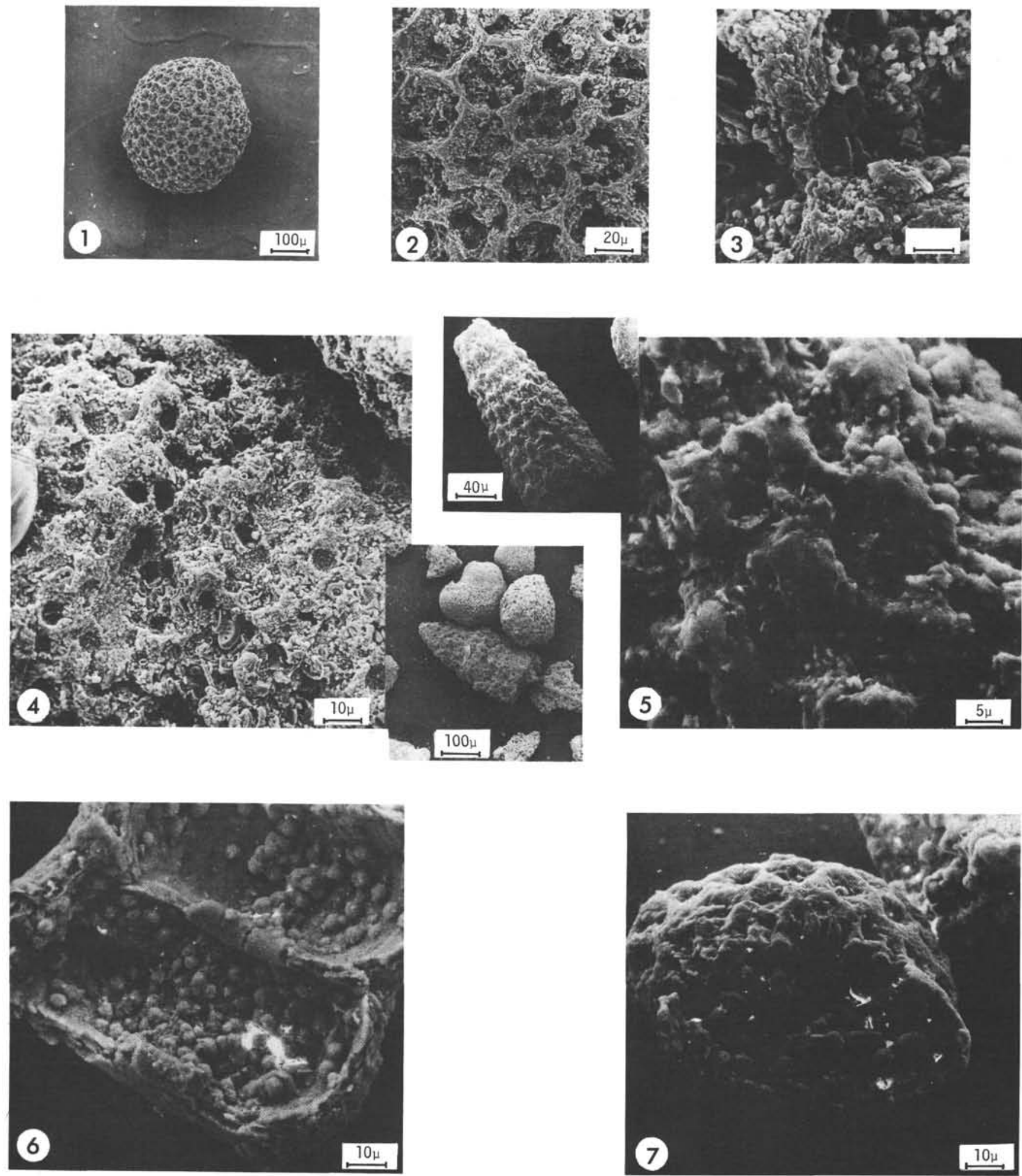

PLATE 12. Preservation of Late Cretaceous Siliceous Fossils. 137-14 (Cenomanian, ridge flank?) and 140-8 (Maestrichtian, continental rise?). (SEM, Kiel, Figs. 1, 2, 3, 4: photos W.H.B./Haake; Figs. 5, 6, 7: W.H.B./Samtleben. 10kV, carbon coating). Figs. 1, 2, 3, 14-4, $140 \mathrm{~cm}$. Spumellarian from poorly preserved assemblage in nanno-foram marl. Note mobilization of silica and incipient lithification through close association with carbonate particles. Fig. 4. Similar, nassellarian. Figs. 5,6,7. $\mathbf{8 - 2}, 105 \mathrm{~cm}$. Poorly preserved radiolarians from carbonate-free greenish gray hemipelagic clay. Note free silica as spherules, silica-rich zeolite (clinoptilolite, Fig. 7). Note shell surface and layering (?), suggesting diagenetic thickening. 

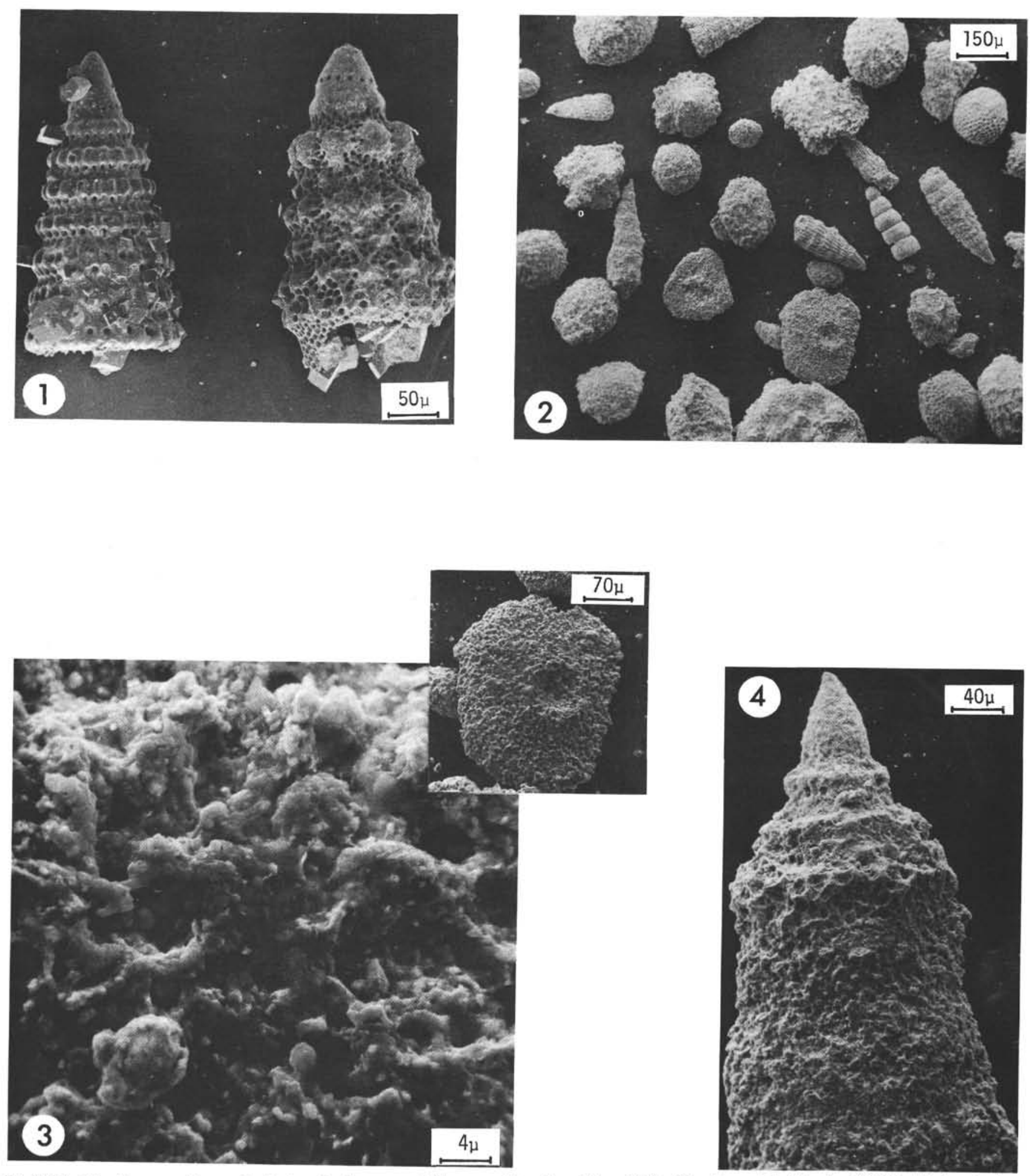

PLATE 13. Preservation of Late Cretaceous Siliceous Fossils. Site 138 (Continental Rise). (SEM Kiel, photos W.H.B./Samtleben, $10 \mathrm{kV}$, carbon coating). Fig. 1.5-1, $117 \mathrm{~cm}$ (Santonian-Campanian). Poorly preserved nassellarians from alternating dark greenish gray and reddish brown pelagic clay. Figs. 2, 3, 4. 6-3, $120 \mathrm{~cm}$ (Cenomanian). Heavily (diagenetically?) corroded specimens from silty layer within a sapropelite layer of the dolomite-sapropelite cycles in 138-6. 

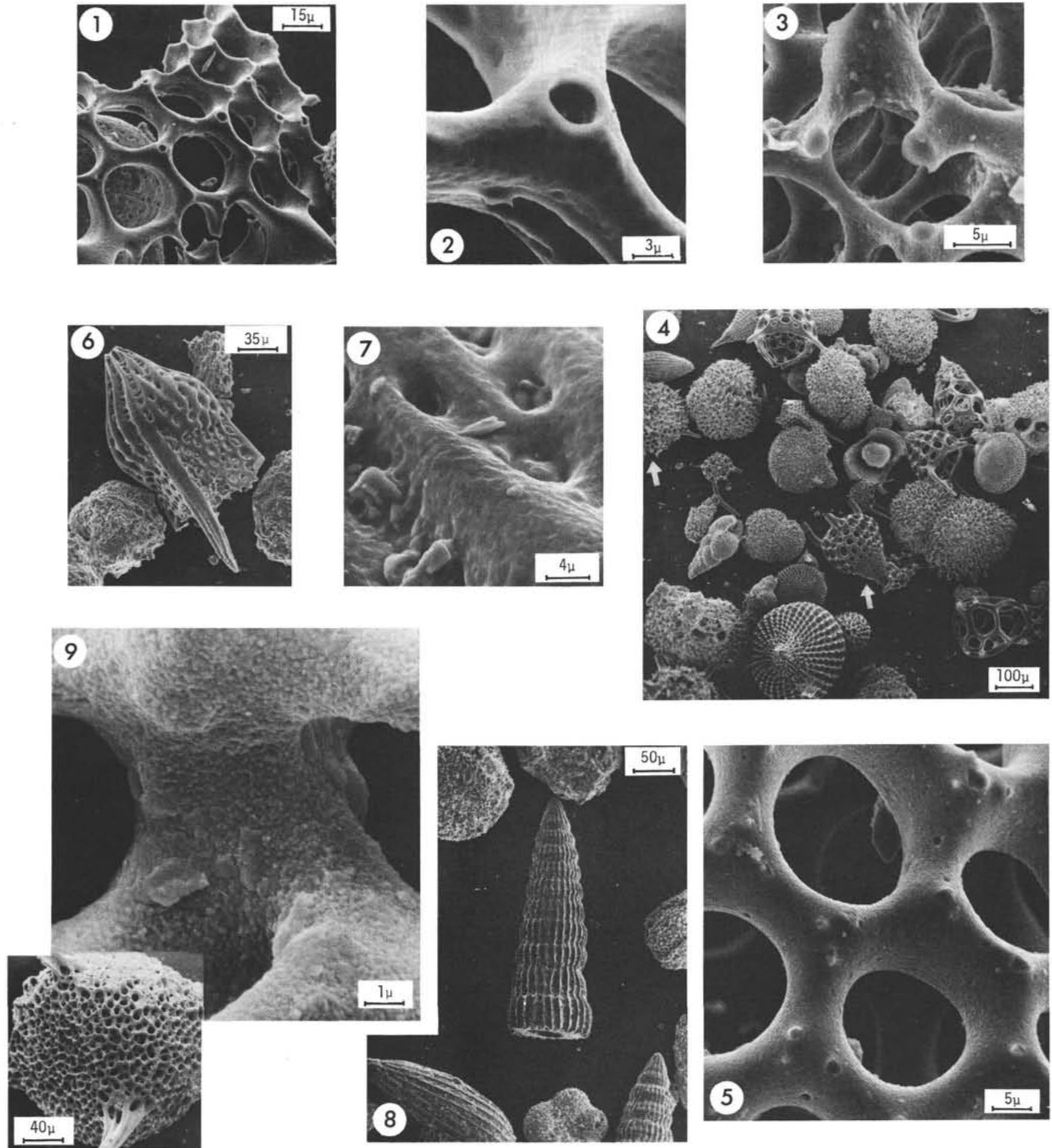

PLATE 14. Preservation of Siliceous Fossils on Demerara Rise. Site 144, various ages. (SEM Kiel, photos W.H.B./Samtleben, $10 \mathrm{kV}$, carbon coating.) Figs. 1, 2. A1-2, $119 \mathrm{~cm}$ (Oligocene). Radiolarian fragment from pale yellowish green foram-nanno chalk ooze. Note relatively smooth surface. Figs. 3, 4, 5. 1-3, $119 \mathrm{~cm}$ (M. Eocene. Note Podocyrtis chalara, P. goetheana, Thyrsocyrtis triacantha). Assemblage of heavy-shelled radiolarians from light greenish gray siliceous marl ooze. Note slightly etched (?) surfaces of spumellarian (Fig. 3, upper arrow in Fig. 4) and a nassellarian (Fig. 4, lower arrow in Fig. 4., T. triacantha). Figs. 6, 7. 2-3, $150 \mathrm{~cm}$ (Lt. Paleocene). Heavy shelled nassellarian from light greenish gray nanno-foram marl ooze. Fig. 8. A4-2, $103 \mathrm{~cm}$ (Campanian/Maestrichtian). Heavy shelled radiolarians (prominent: Dictyomitra) from zeolitic nanno marl ooze. Fig. 9. 5-1, $107 \mathrm{~cm}$ (Aptian). Radiolarian from olive gray laminated marl, showing irregular surface (etching? deposition?). 

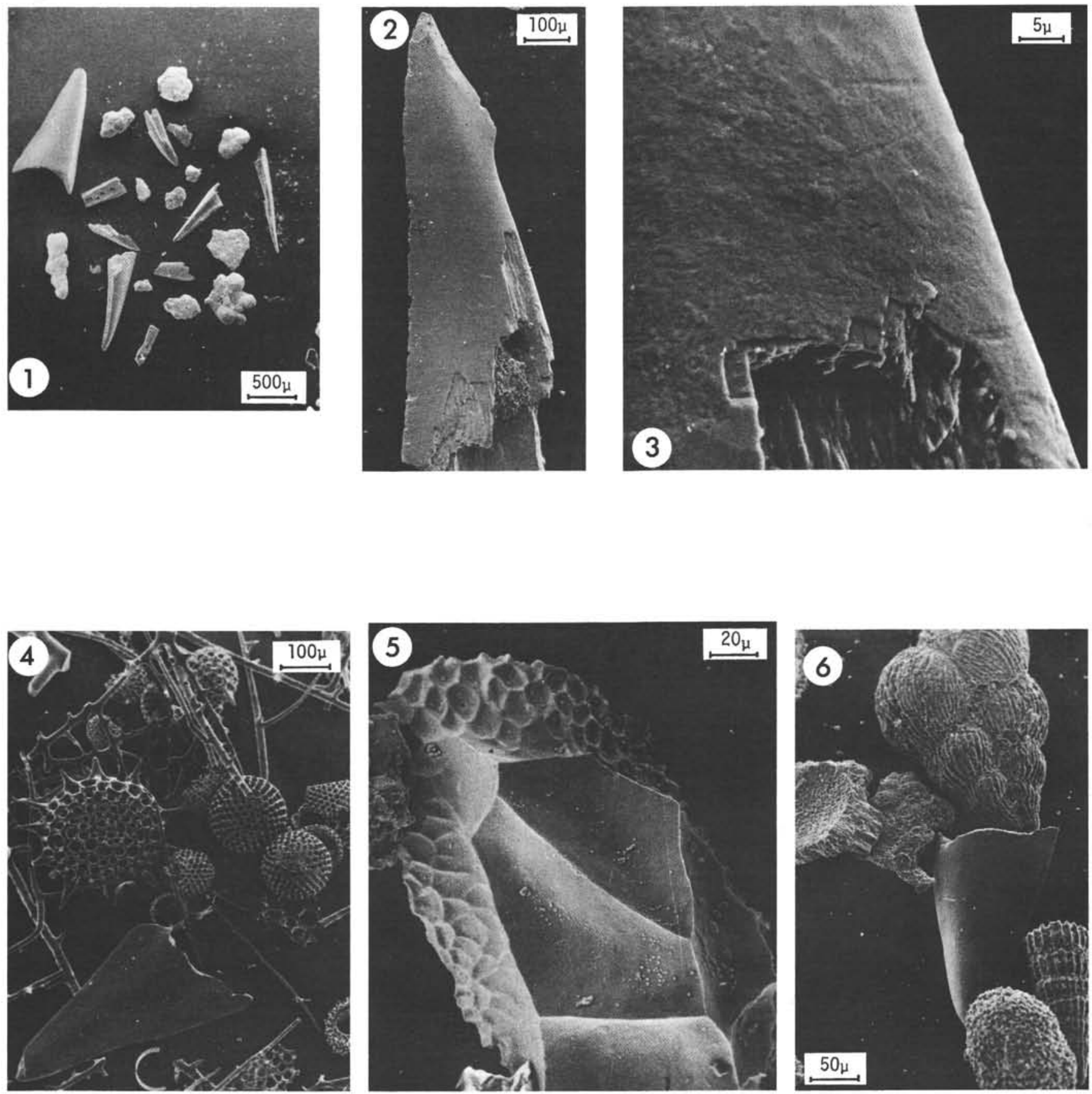

PLATE 15. Preservation of Fish Debris. (SEM Kiel, photos W.H.B/Samtleben, 10kV, carbon coating.) Fig. 1. 136-4-3, 109 $\mathrm{cm}$ (E. Miocene). Typical fossil assemblage from pelagic clay: fish debris and agglutinated forams. Note fragmentation of teeth. Figs. 2, 3. Same, details. Note smooth surface of tooth, despite partial destruction. Fig. 4. 140A-2-4, 119 cm (Lt. Eocene). Well preserved tooth in (rather poorly preserved) radiolarian assemblage. Fig. 5. 141-9-2, 119 cm (?Paleocene). Tooth or bone fragment from pelagic clay. Fig. 6. 144A-42, $103 \mathrm{~cm}$ (E. Maestrichtian). Well preserved, very smooth tooth from mixed calcareous and siliceous assemblage. 

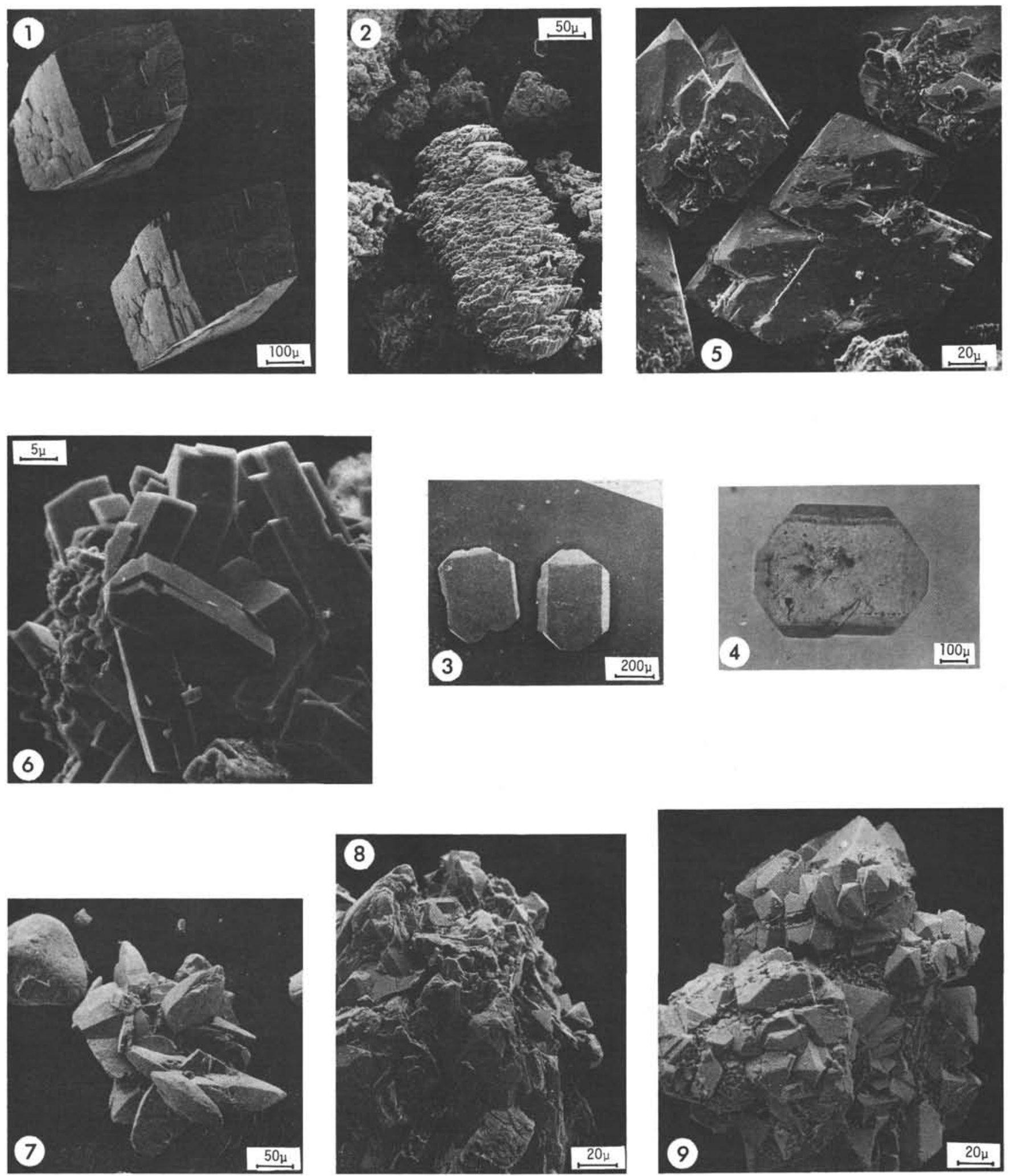

PLATE 16. Authigenic Minerals. (SEM Kiel, 10kV, carbon coating, photos W.H.B./Haake: Figs. 1, 2, 3; W.H.B./Samtleben: Figs. 5-9; balsam mount Fig. 4, photo W.H.B.) Fig. 1. 137-4cc (Maestrichtian). Rhodochrosite. Fig. 2. 137-6-1, 127 cm (Senonian). Rhodochrosite crystal among zeolite aggregates. Figs. 3, 4. Same. Barite crystals. Fig. 5. 144-3cc (Campanian/Maestrichtian). Euhedral calcite (no dolomite recorded in X-ray analysis). Fig. 6. 144A-3-1, 119 cm (Lt. Paleocene). Zeolite aggregate (clinoptilolite). Figs. 7, 8. 140-8-2, $105 \mathrm{~cm}$ (Maestrichtian). Iron sulfide aggregates. Note sub-rounded, polished quartz grain. Fig. $9.138-6-2,25 \mathrm{~cm}$ (Cenomanian). Pyrite aggregate from dolomite sapropelite cycle. 

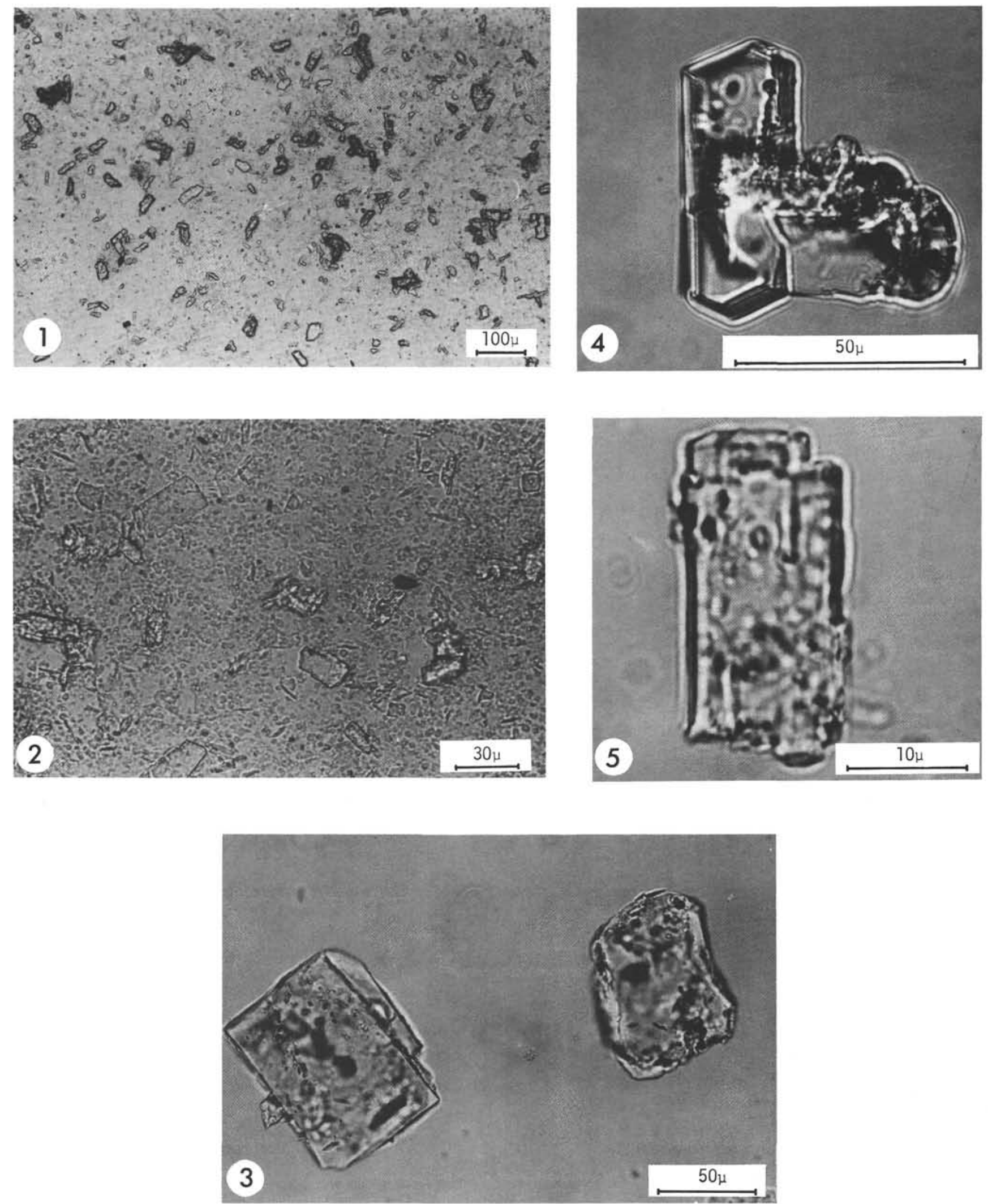

PLATE 17. Zeolites. (Smear slides, plain light, photos U.v.R.). Figs. 1, 2. 137, 6-1, $30 \mathrm{~cm}$ (?Coniacian). Strong negative relief of irregular (corroded?) and euhedral zeolite (clinoptilolite) crystals. Fig. 3. 140-3-3, $105 \mathrm{~cm}$ (M. Eocene). Large rectangular zeolite (clinoptilolite) crystal and rounded quartz. Fig. 4. 137-5-cc. (?Santonian) Euhedral and irregular pseudorhombic

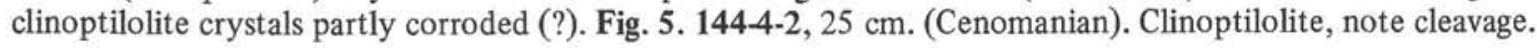



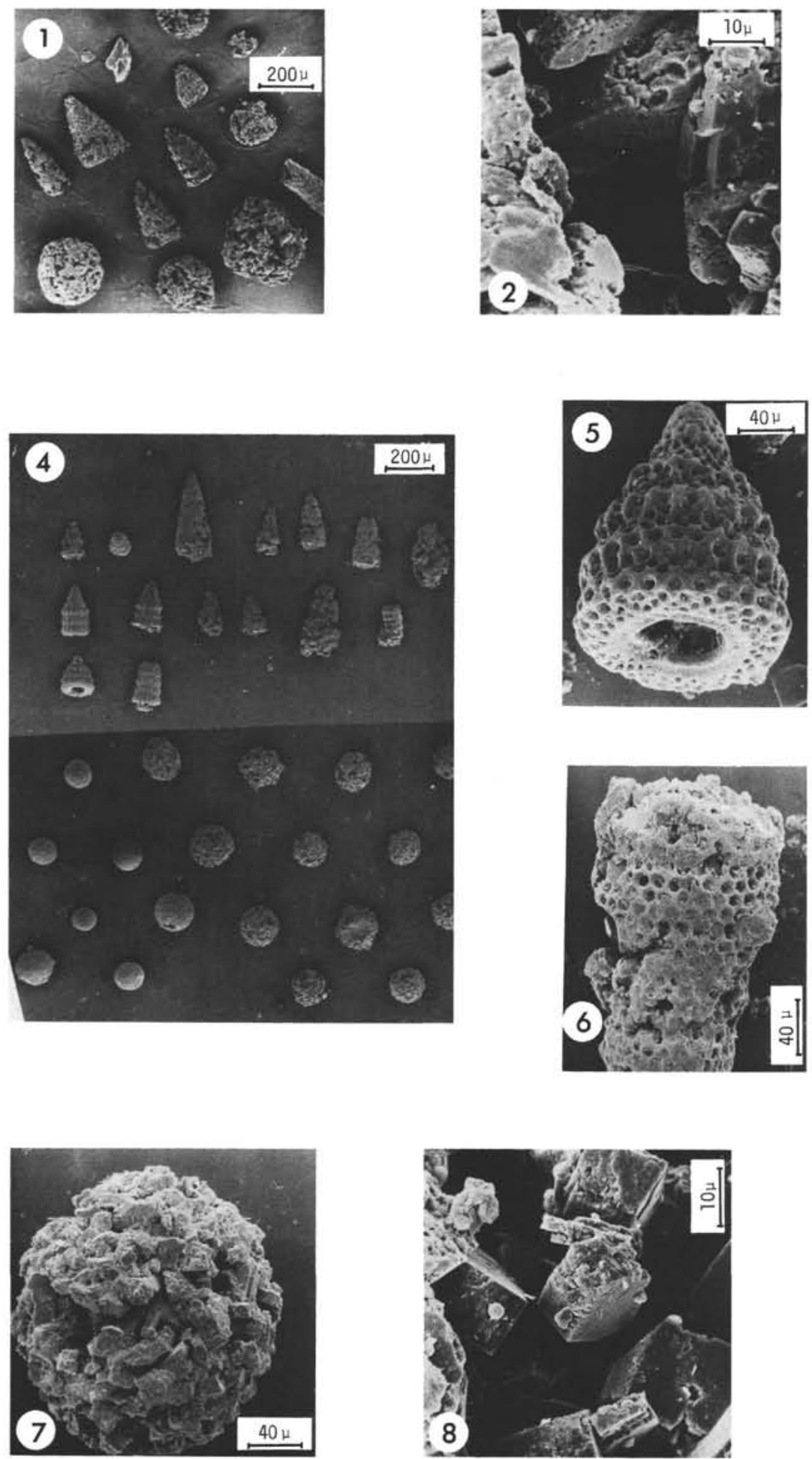
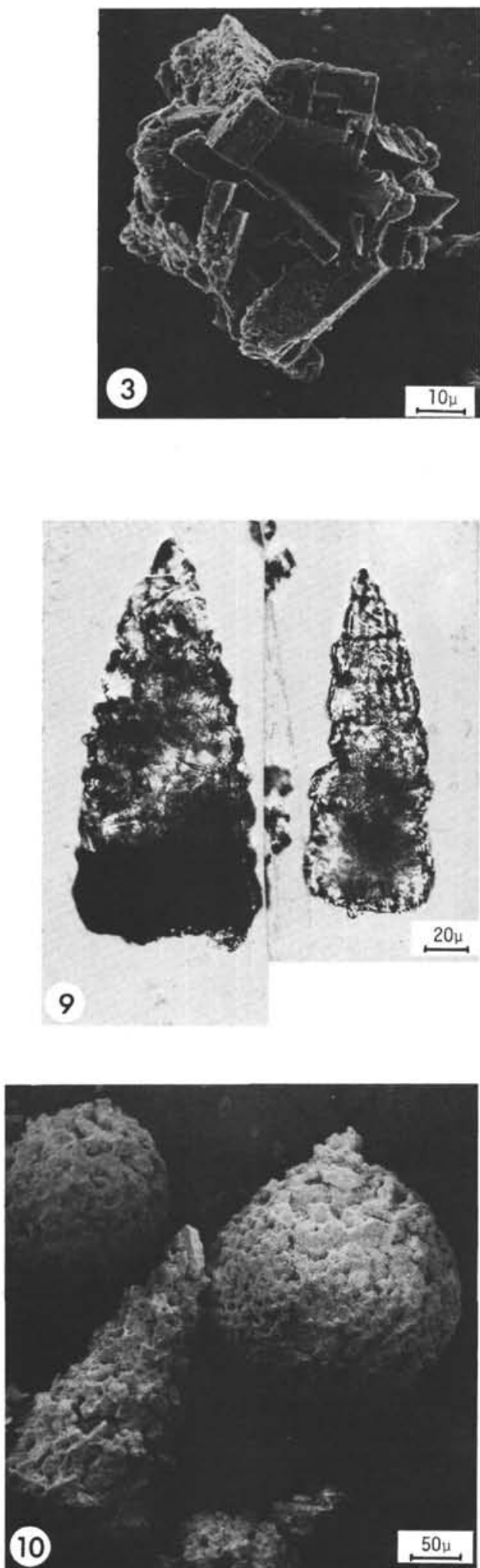

PLATE 18. Late Cretaceous Radiolarian Zeolite Casts. Site 137, transition from fossiliferous ridge flank (?) sequence to barren abyssal clays. (SEM Kiel 10kV, carbon coating, photos W.H.B./Haake: Figs. 1, 2, 3, 4, 5, 6, 7, 8; W.H.B./Samtleben: Fig. 10. Coarse fraction balsam slides: photos Schrader). Figs. 1, 2. 4cc (Maestrichtian). Nassellarian and spumellarian casts, badly corroded. Fig. 3. Same, zeolite aggregate (cast fragment?). Fig. 4, 5cc (?Campanian). Zeolite-filled radiolarians and corroded casts. Fig. 5, 6, 7, 8. Same, details. Note silica spherules in Fig. 8. Fig. 9. Same, plain transmitted light. Fig. 10. 6-1, $127 \mathrm{~cm}$ (?Coniacian/Santonian). Corroded zeolite-filled radiolarians. 


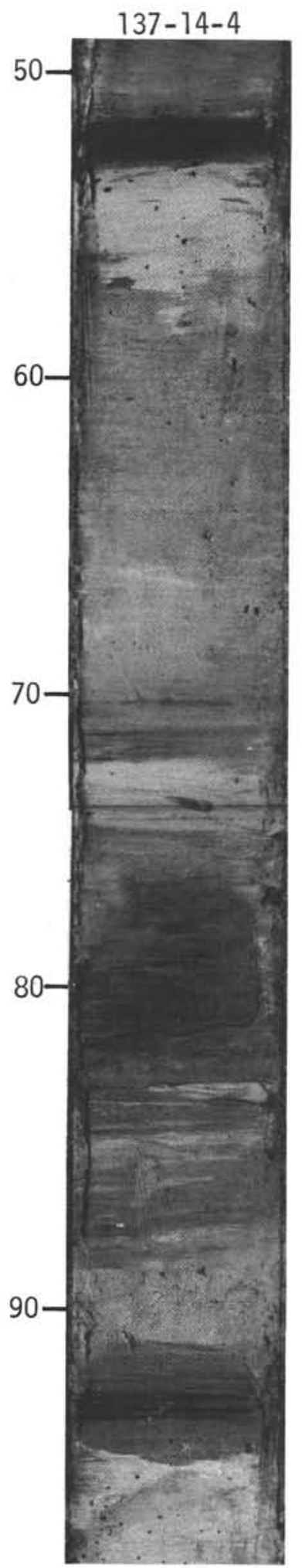

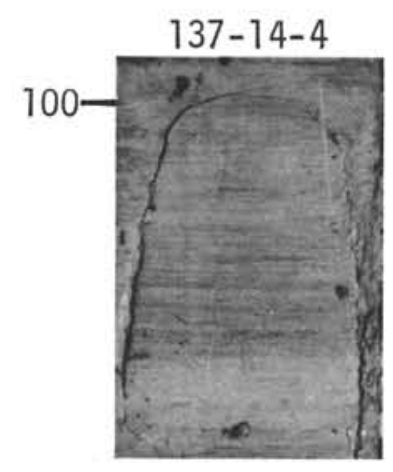

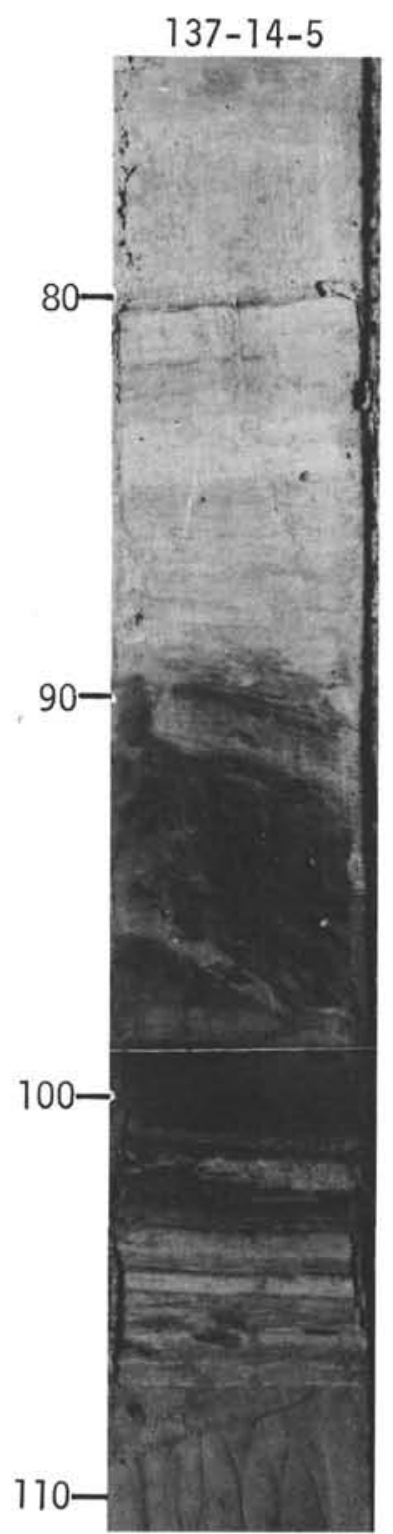

$137-14-5$

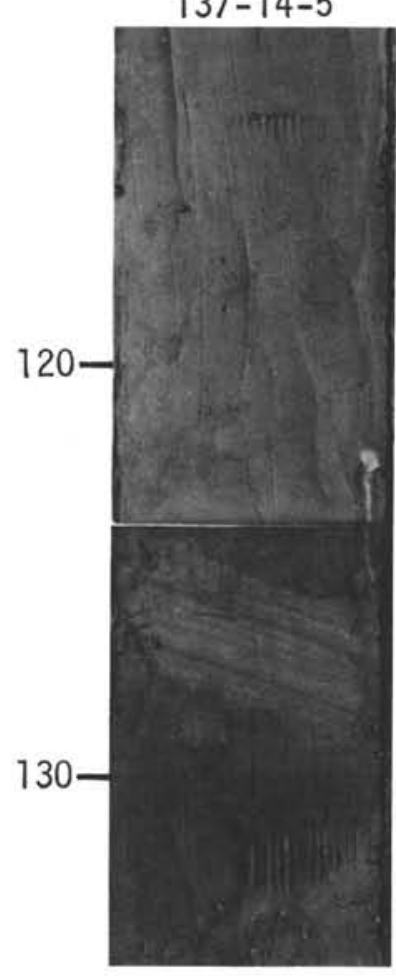

$137-14-6$

$$
137-14-6
$$

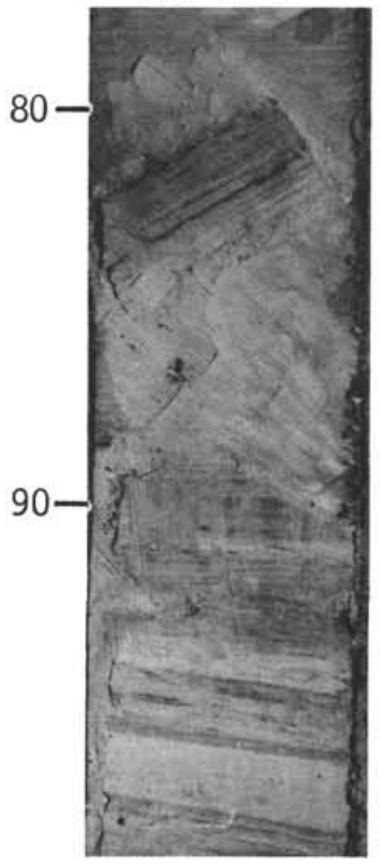

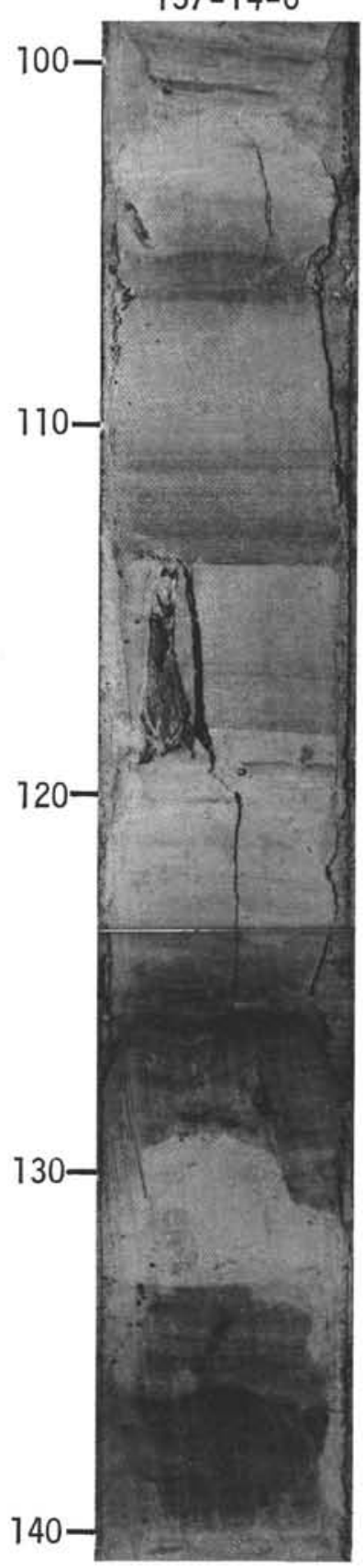

PLATE 19. Sedimentary structures in Cretaceous (ridge flank?) nanno marl ooze. 137-14 (Cenomanian). (Shipboard photos.) Varicolored greenish-gray, brown and gray marl (-chalk) ooze, bedded, and with fine streaky laminations. Colors alternate on a scale of $\mathrm{mm}$ to $\mathrm{cm}$. Note drilling disturbances enhanced by varying degrees of induration. Differential oxidation suggests highly variable sedimentation rates (intermittent redeposition?) in mildly oxidizing environment. Streaky laminations suggest current action and epifaunal activity (?), but little burrowing. 

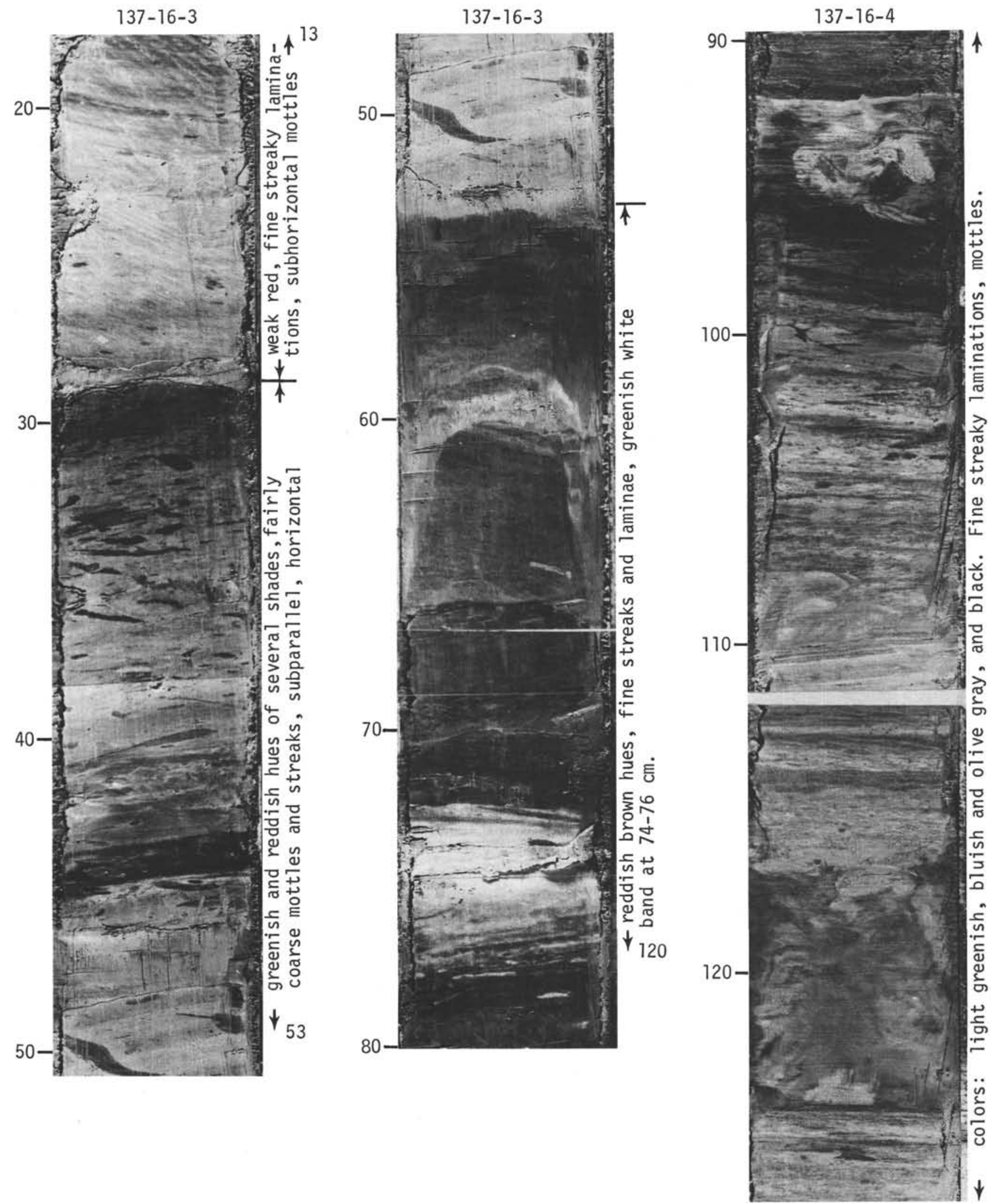

PLATE 20. Sedimentary structures in Cretaceous (ridge crest?) nanno marl ooze, 137-16 (Albian/Cenomanian). (Shipboard photos.) Forams relatively abundant (10-20\% of carbonate). Clay: quartz, mica, feldspar, palygorskite, montmorillonite. Note drilling disturbances enhanced by variations in induration (firm to semi-indurated). Note irregular lensy to subparallel laminations (currents?) not obliterated by bioturbation (low benthic activity?). Note large variations in shade (also hue; intermittent deposition, reworking, relatively low oxidation potential?). 

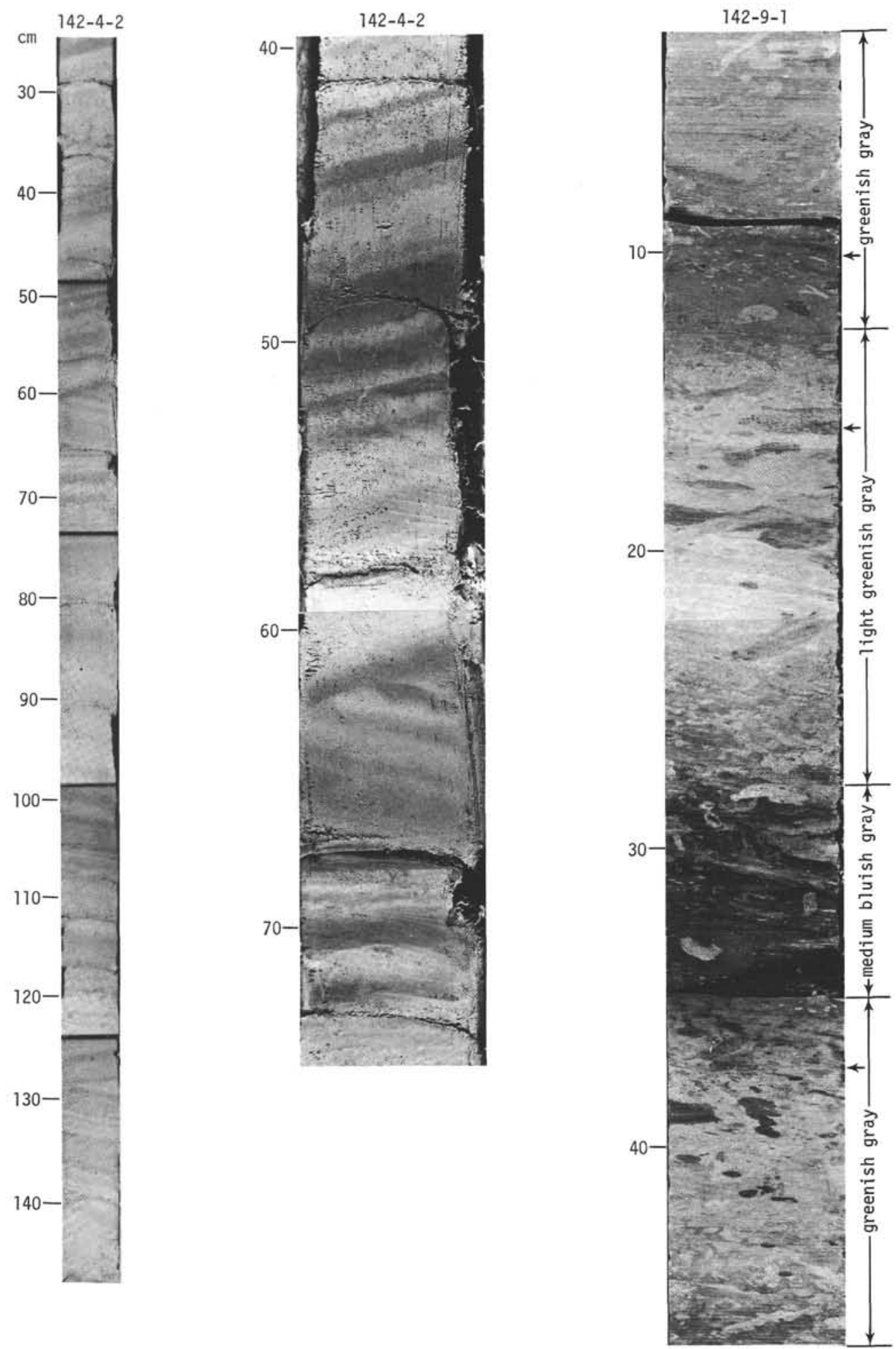

PLATE 21. Sedimentary structures in Neogene calcareous ooze. Site 142. (Shipboard photos.) 142-4-2, 25-150 cm (E. Pliocene) and 40-75 cm (detail). Alternating light brownish gray and light gray bands of sandy (foraminifera) nanno chalk ooze. Color bands are in the order of $\mathrm{cm}$ and in some places apparently originally inclined (?cross-bedding) (e.g. at cm 61). In some cases, apparent angular unconformities are due to rotational torsion of $5-10 \mathrm{~cm}$ long core sections in drilling pipe. 142-9-1, 5-47 cm (E. Miocene). Varicolored, highly mottled pelagic nannofossil marl mud. Note two different burrow types (filled with dark or light-colored material): a) tiny chondrite-type burrows, mostly horizontal, only 1-2 mm in diameter and less than $10 \mathrm{~mm}$ long; b) large 5-12 mm wide burrows, 10-50 mm long, diagonal and horizontal, round cross-sections may appear ellipsoidal due to non-normal sectioning of tubes (some compactional flattening?). Note later generations of burrows crossing earlier ones. 

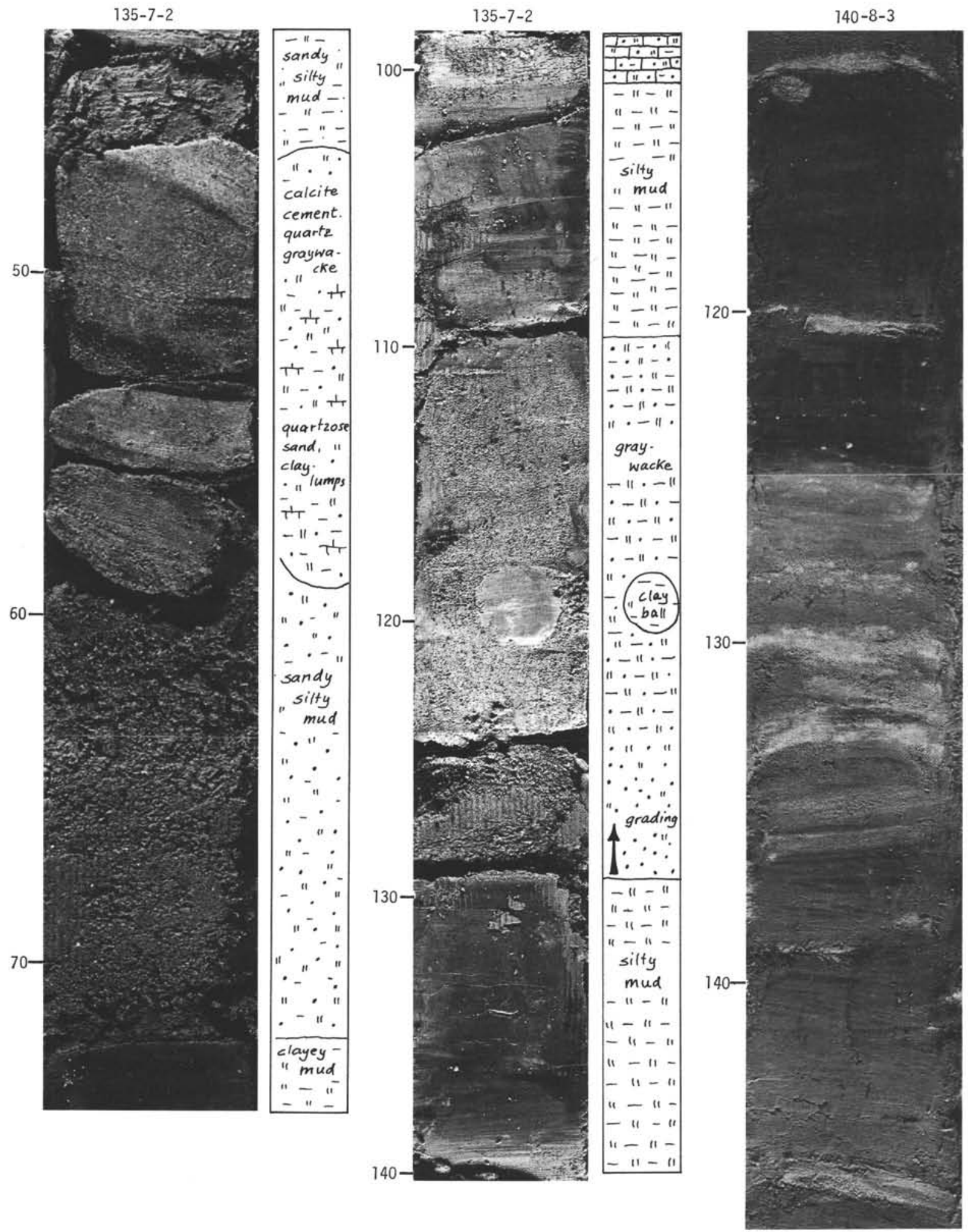

PLATE 22. Flysch-like intercalations of terrigenous silt and sand and hemipelagic mud. (Shipboard photos.) 135-7-2 (Campanian/Maestrichtian). Pelagic clay (where present): brown. Displaced sediment: olive and yellowish green. $75-43 \mathrm{~cm}$ : graded layer, upper part calcite cemented. Silty quartz graywacke (60-70\% quartz, 5-10\% feldspar, rest mainly carbonate, clay lumps, chert and other rock fragments, mica, chlorite, heavies). Near $120 \mathrm{~cm}$ : clay ball within graded layer of fine feldspar-rich graywacke bounded by silty clay. 140-8-3 (Maestrichtian). Pelagic clay: greenish gray. Displaced sediments (clayey and sandy silt): greenish gray. Thin sand layers: (feldspathic) quartz sand, pinkish gray (light layers on photo) (composition, e.g. 80\% quartz, $10 \%$ fsp., rest alterite, biotite, pyrite, heavies). 
$142-5-1$

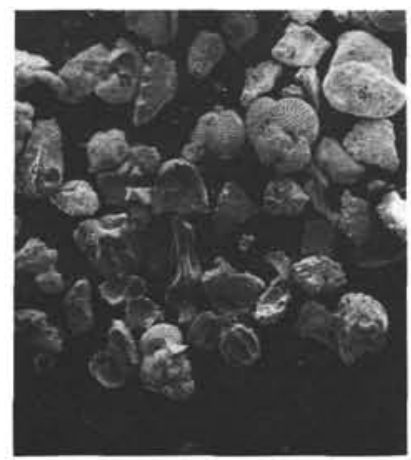

$400 \mu$
PLATE 23. Neogene flysch-like sequence with terrigenous and pelagic allodapic layers. Site 142, 5-1 (left) and 6-2 (right), Early Miocene-Latest Miocene. (Shipboard photos.) Left: lower part, thick terrigenous graded sand layer intercalated into pelagic nanno marl ooze, highly burrowed in part. Lower boundary of sand is erosional. Upper part, mixed foram-shallow water carbonate sand (neriticpelagic turbidite). Right: lower part, graded pelagic (foraminiferal) turbidite within mottled marl ooze. Fine-grained material at top of graded layer consists mainly of broken pieces of discoasters and coccolithophores. Upper part, basal portion of another foraminiferal sand.
142-5-1

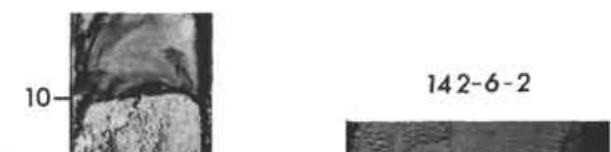

Eํํำ

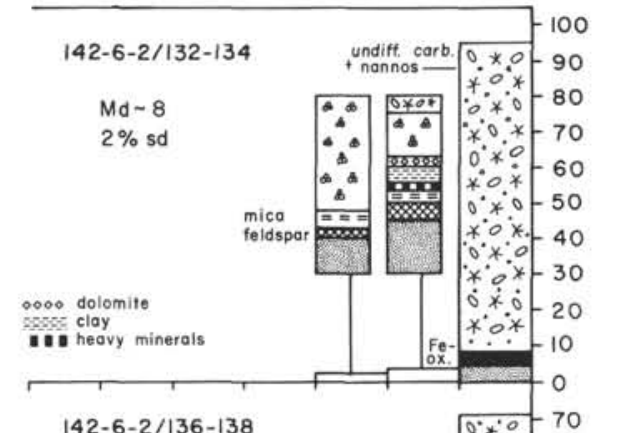

30

100

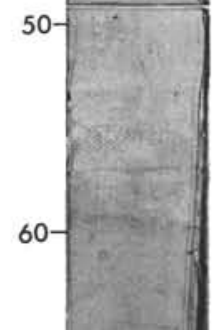

70

\section{0}

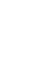

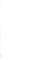

80 80

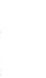

90
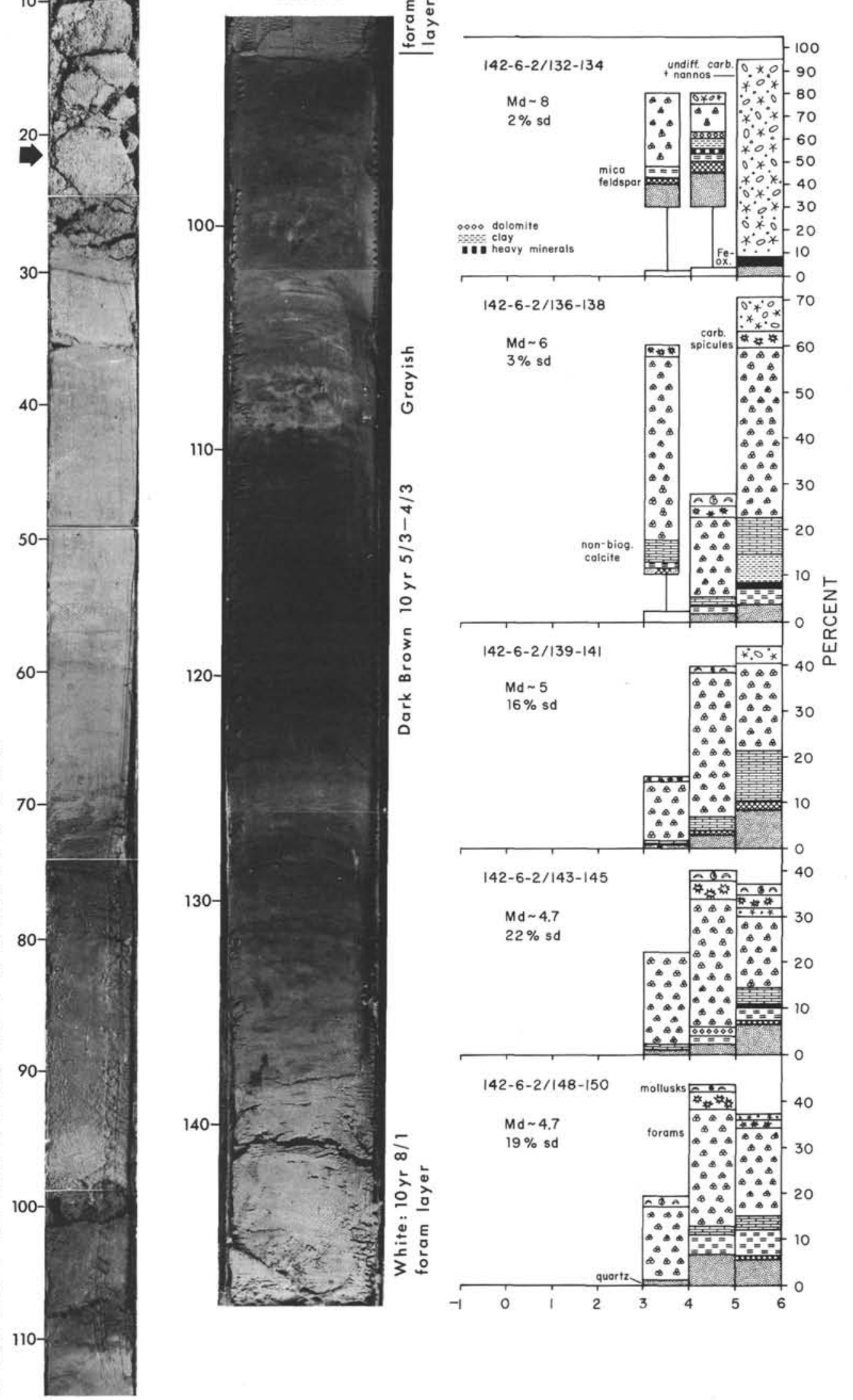

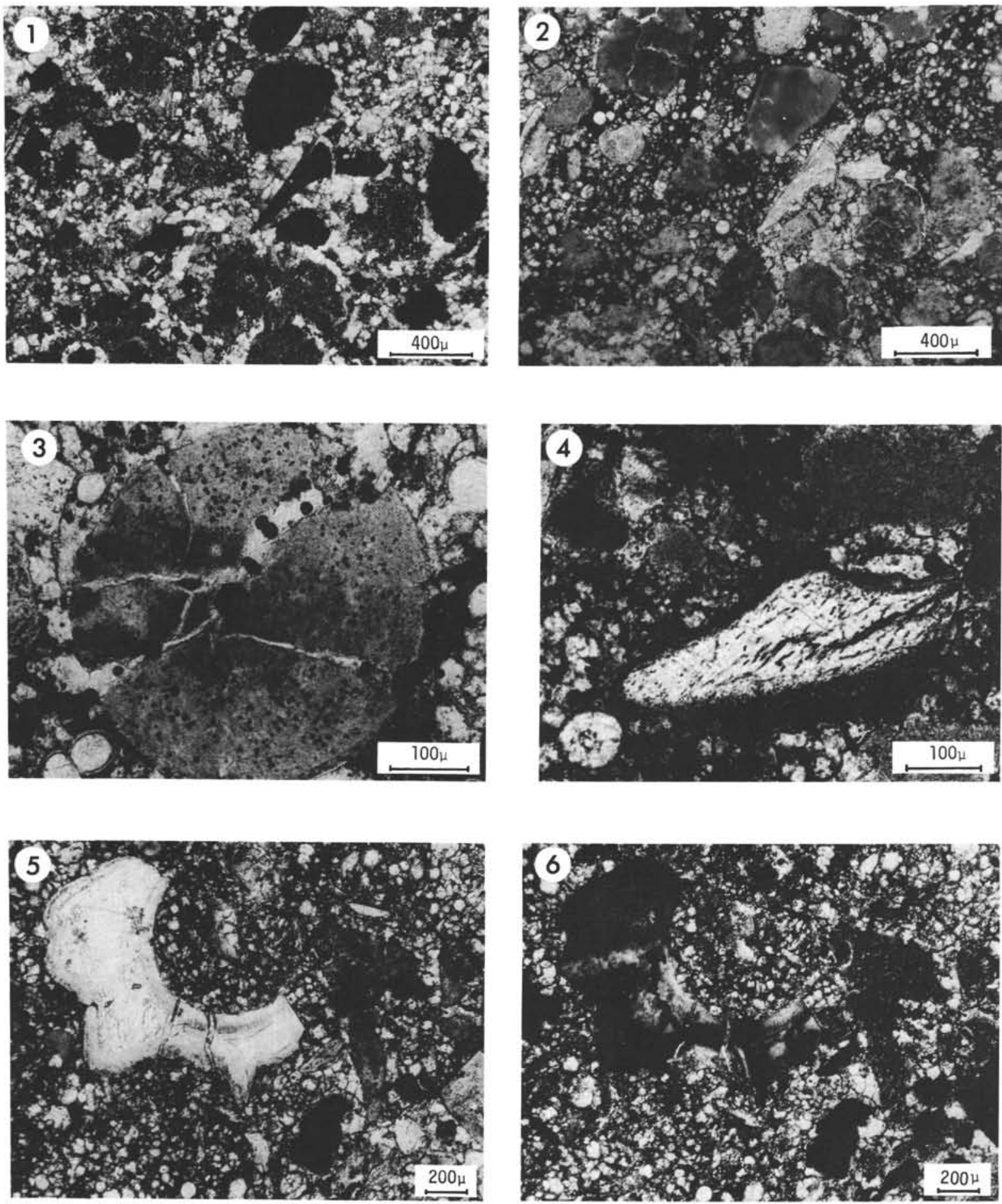

PLATE 24. Glauconitic phosphatic foram biosparite. 144A-5-cc (Santonian). (Thin sections, photos U.v.R.). Composition (point count analysis): $47 \%$ sparitic cement, $12 \%$ foraminifera, 24\% "glauconite", 11\% phosphate, 6\% pyrite. Fig. 1. Crossed nicols. Greenish-gray round and lobate galuconite grains, cryptocrystalline collophane (isotropic under crossed nicols), sharp fish tooth and small pelagic foraminifera (calcite- filled) in a dark brownish, pyrite-rich micro- to macrocrystalline calcite cement. Fig. 2. Same, plain light. Fig. 3. Plain light. Perfectly round fresh glauconite grain with radial desiccation cracks and fissures filled by calcite and framboidal pyrite. Note small pyrite spherules and cubes in glauconite grain. Fig. 4. Plain light. Organic apatite (optically uniaxial negative figure) fish tooth or bone (note tiny Haversian canals.) Grain is surrounded by light-brownish phosphate (upper right corner), glauconite (lower left) and small foraminifera. Most other phosphate grains are optically biaxial. Figs. 5, 6. Plain light and crossed nicols. Fish vertebra (?) consisting of fibrous phosphate material. Note shadowy undulose extinction of concentric layers made by fibrous phosphate laminae. Note broken glauconite grain (center right) and angular collophane (lower right). 

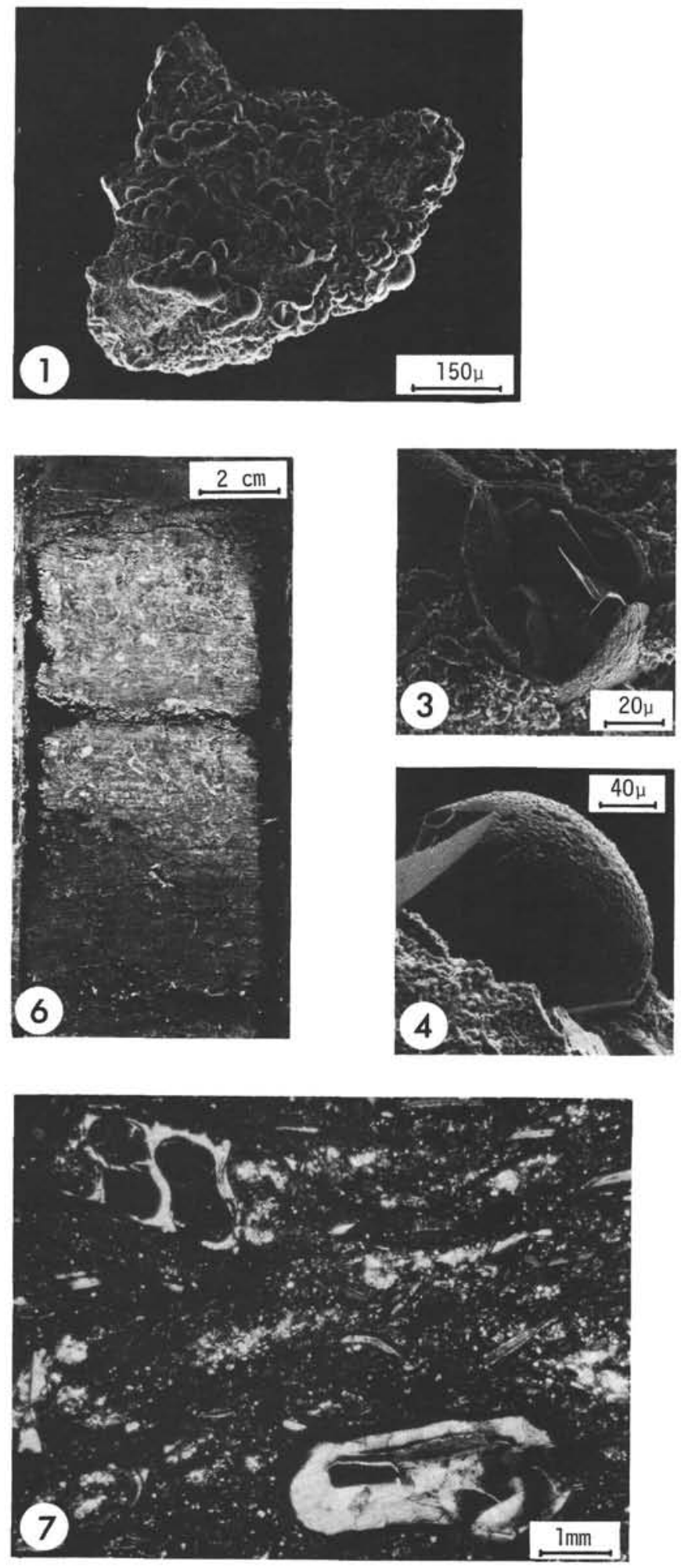
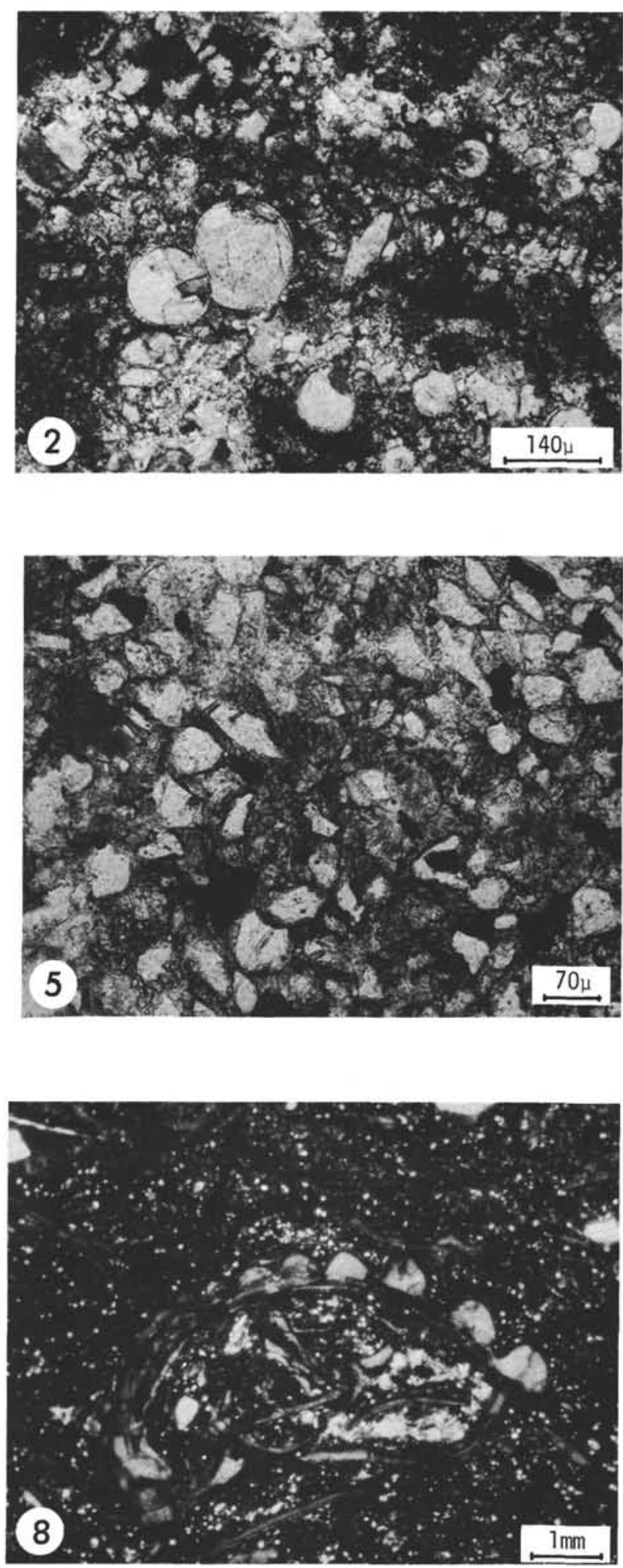

PLATE 25. Cretaceous limestones. 144-4 (Cenomanian), 144-6 and 7 (Aptian). (SEM photos W.H.B./Samtleben, thin section photos U.v.R., core photo shipboard). Fig. 1. 4-3, $119 \mathrm{~cm}$. Laminated foraminiferal marly biosparite layers of heterohelicid planktonic forams alternate with dark carbonaceous laminae. Fig. 2. 4-cc. Similar, section, crossed nicols. Figs. 3, 4. 4-1. Similar, detail of sparry foram fill. Fig. 5. 6-1, 0-8 cm. Quartzose limestone ( $36 \%$ angular quartz, $3 \%$ pyrite, plant debris, heavies, in (50\%) sparitic calcite cement). Fig. $6.7-1,105-120 \mathrm{~cm}$. Coquina limestone bed within carbonaceous clay sequence. Figs. 7, 8, 7-1, 112-117 cm. Same, section, Alizarin stain. Gastropod and pelecypod shells (38\%), clayey (24\%) - micritic calcite (18\%) matrix, Fe oxides (12\%) and quartz (7\%). Probably displaced from outer shelf (?). 

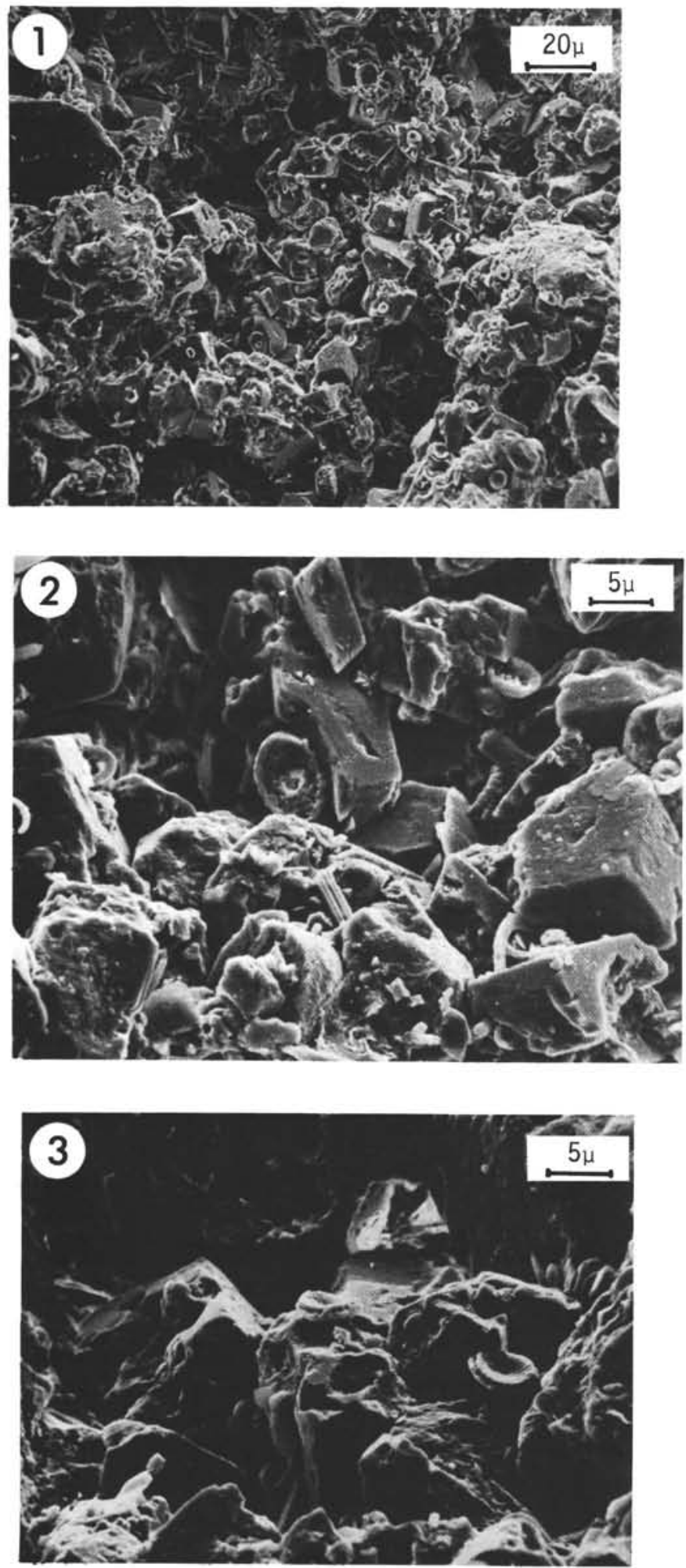
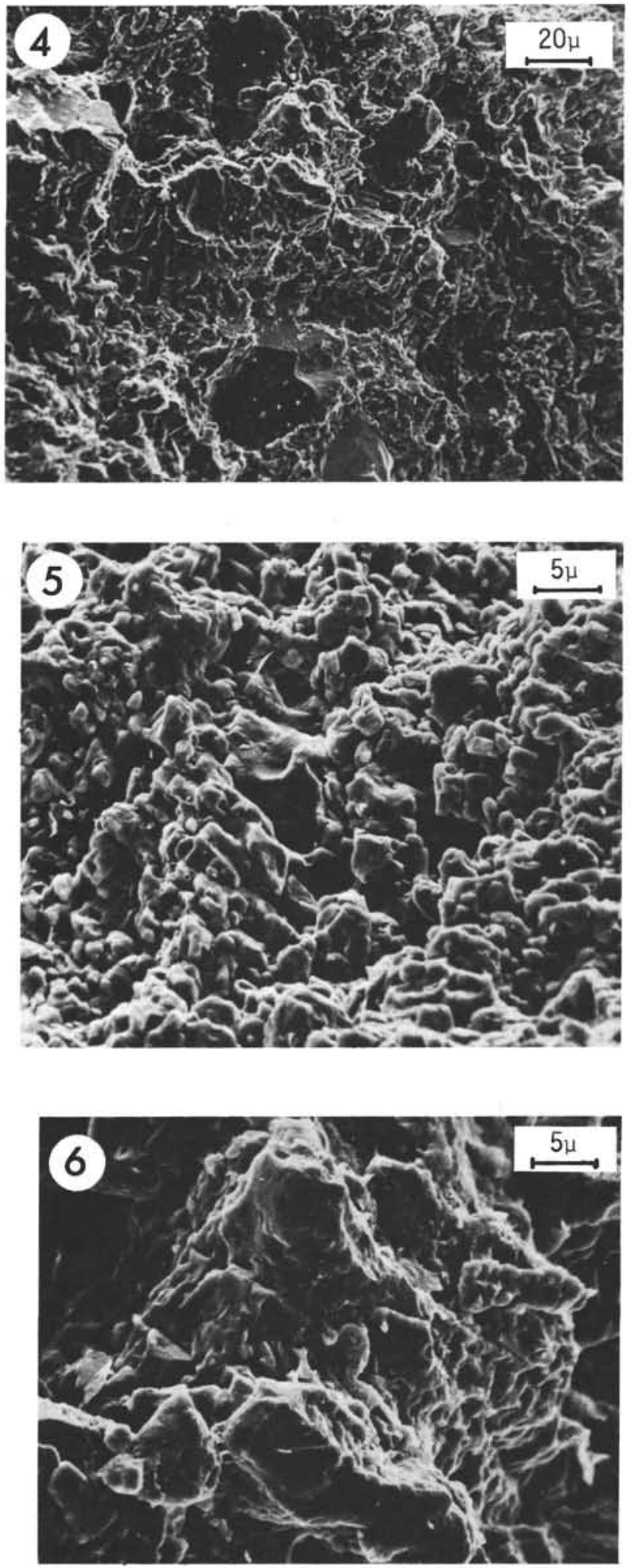

PLATE 26. Cretaceous limestones. 135-9-1, 99-109 cm (Aptian), Figs. 1-3; 135-8-1, 125-129 cm (?Cenomanian), Figs. 4-6. (Broken surfaces, SEM, Hannover). Fig. 1. Quartzose dolomitic nanno-micrite ( $74 \%$ carbonate, $15 \%$ angular quartz, $5 \%$ mica, chlorite). Note intergrowing calcite and dolomite rhombs (X-ray) and pore space. Fig. 2. Same, euhedral carbonate rhombs and partly etched coccoliths (?Watznaueria sp.) well cemented to the rhombs. Note rod-like nannofossils (?rhabdoliths). Fig. 3. Same, well preserved coccoliths (and rhabdoliths) with calcite overgrowth between (?) dolomite rhomboedra cemented by calcite. Fig. 4. Recrystallized (spherulitic) limestone (also see thin sections). Anhedral calcite with large silt-sized quartz grains. Fig. 5. Same, cryptocrystalline calcite; note lack of fossils. Fig. 6. Same, detail of Fig. 4. 

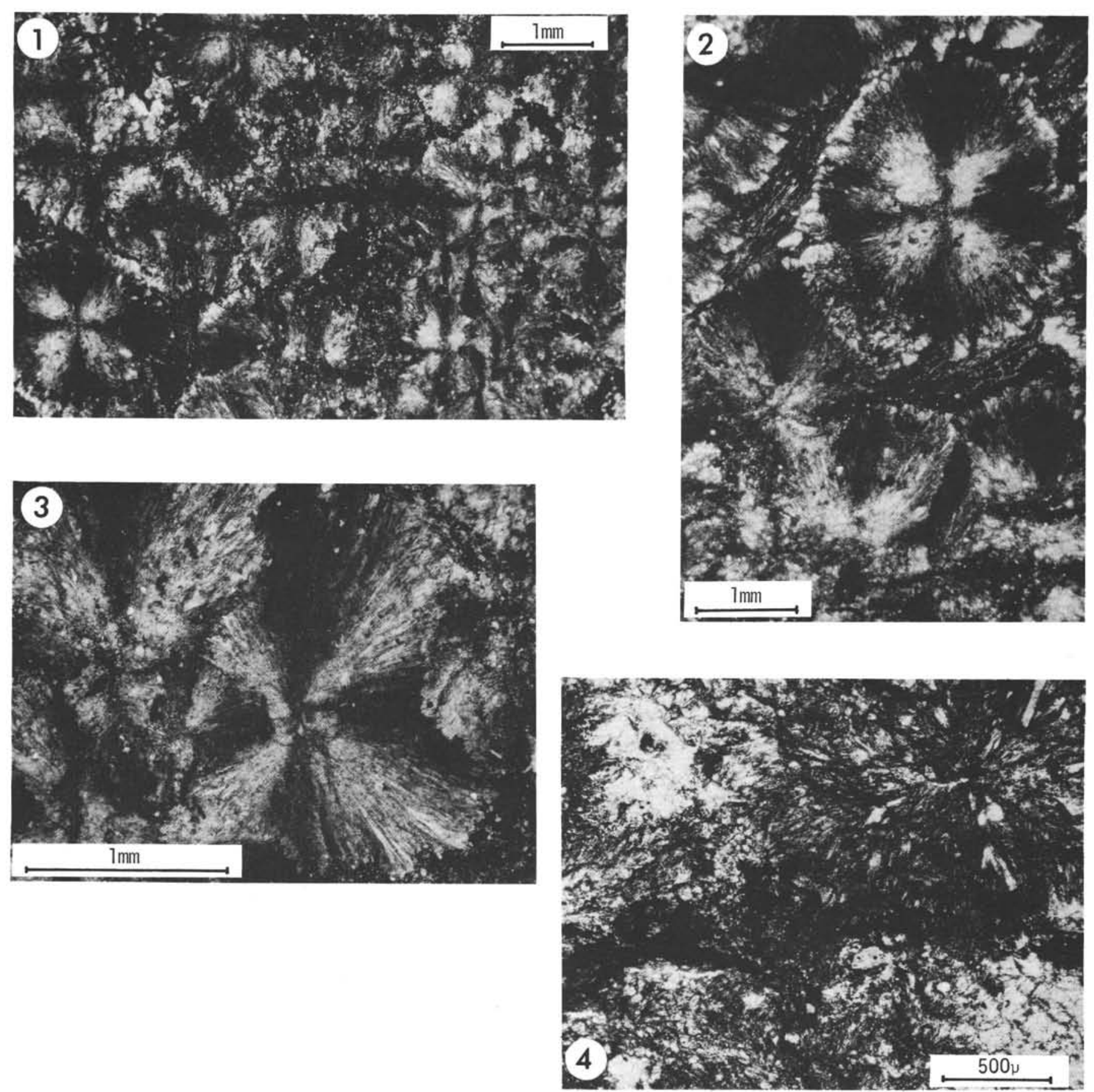

PLATE 27 Recrystallized spherulitic limestone. 135-8-1, 129-133 cm (?Cenomanian). (Thin sections, photos U.v.R.). Fig. 1. Crossed nicols. Fibroradiated spherulites of replacement calcite. Fig. 2. Crossed nicols. Detail. Note concentration of clayey and carbonaceous matter in interstices around large spherule (apparently pushed aside during recrystallization). Fig. 3 . Crossed nicols. Detail. Note intergrowth of individual fibers from neighboring spherulites; pore space is almost completely filled. Note inclusions of (pre-diagenetic) quartz and biotite. Fig. 4. Black horizontal layer rich in pyrite (and ?collophane) crossing and apparently predating the diagenetic fibrous growth of the calcite spherulites. 

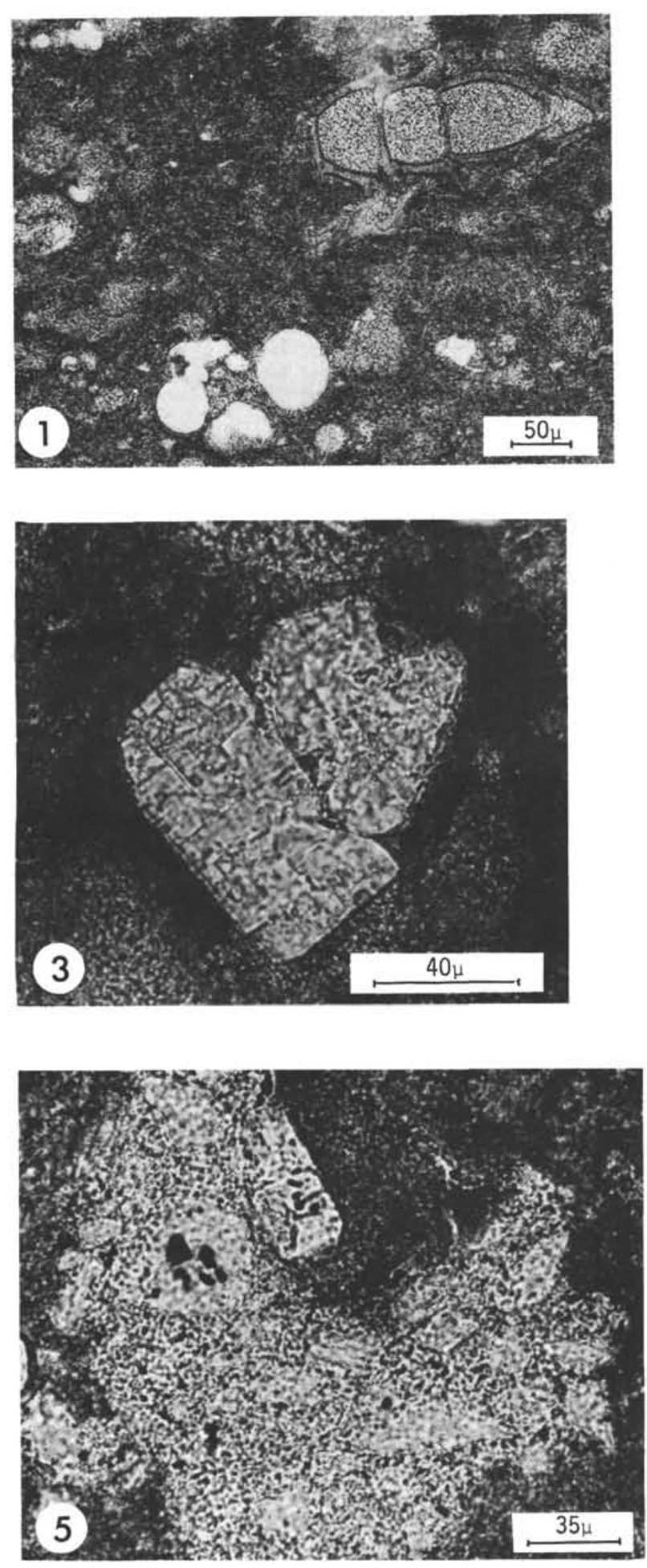
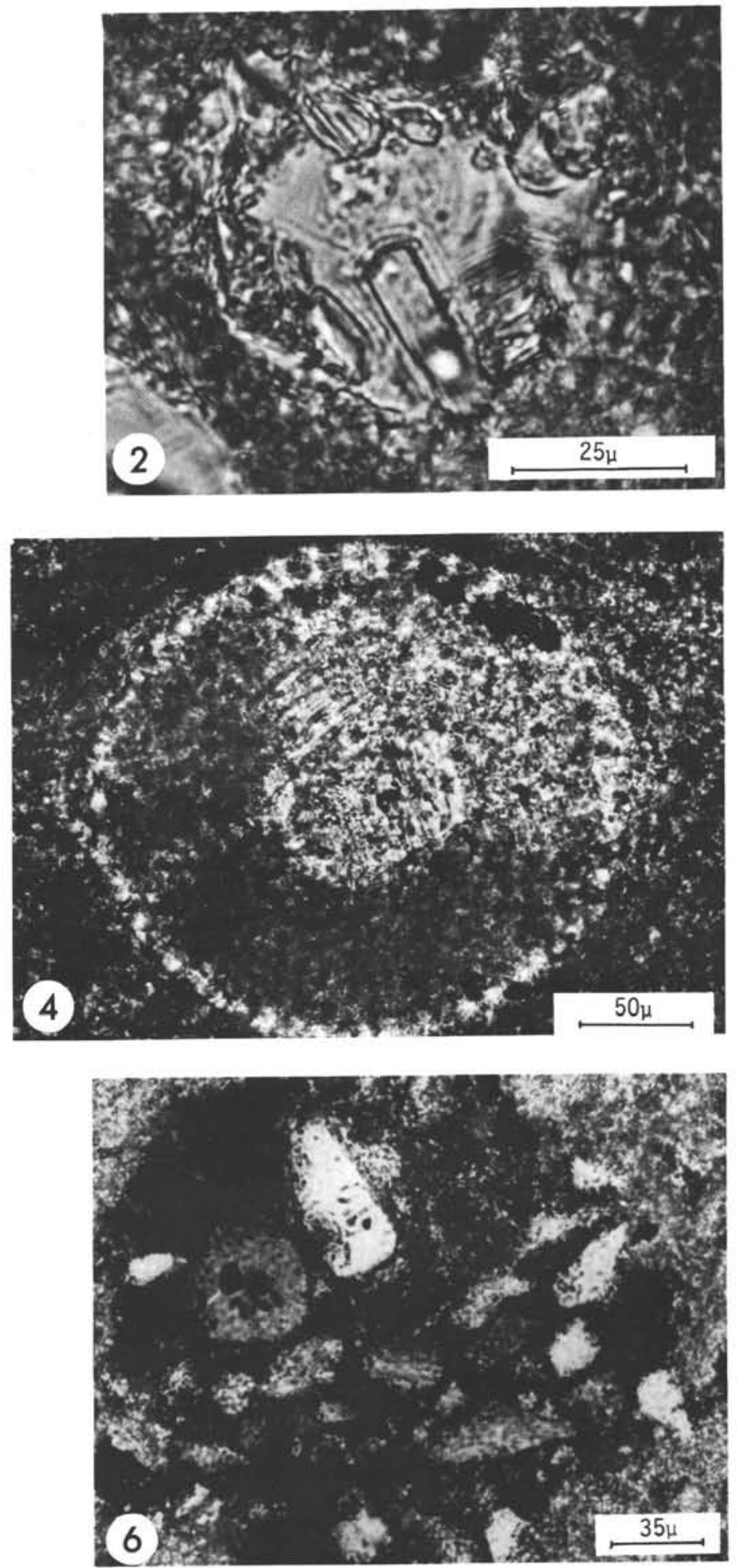

PLATE 28. Foraminiferal and Radiolarian silicified mudstone (Chert type I). 144-3-2, 105-107 cm (Maestrichtian), except Fig. 4. (Thin sections, photos U.v.R.). Fig. 1. Araldite-impregnated specimen, plain light. Benthonic and planktonic foraminifera (partly filled by clay and silica) and "ghosts" of partly dissolved siliceous organisms (?radiolarians) in a very fine grained clay-rich silica matrix (opal, lussatite, and microcrystalline quartz). Fig. 2. Plain light. Small clinoptilolite (?) crystals growing from outer rim of partly dissolved foraminiferal test into the interior pore space (internal apposition fabric). Fig. 3. (Plain light, 160X). Two intergrown large crystals of authigenic barite (?celesto-barite), one of which is euhedral and shows two rectangular cleavage directions. Fig. 4. 139-7-6,47-50, plain light. Opaline radiolarian test with geopetal filling of dense silica-clay matrix. Two zeolite (?clinoptilolite) crystals growing upwards into the open pore space (later filled by silica spherules). Figs. 5 \& 6. Vug or dissolved fossil, filled by aggregates of microgranular barite (and quartz?); traces of pyrite. Matrix is clay-rich silica. 

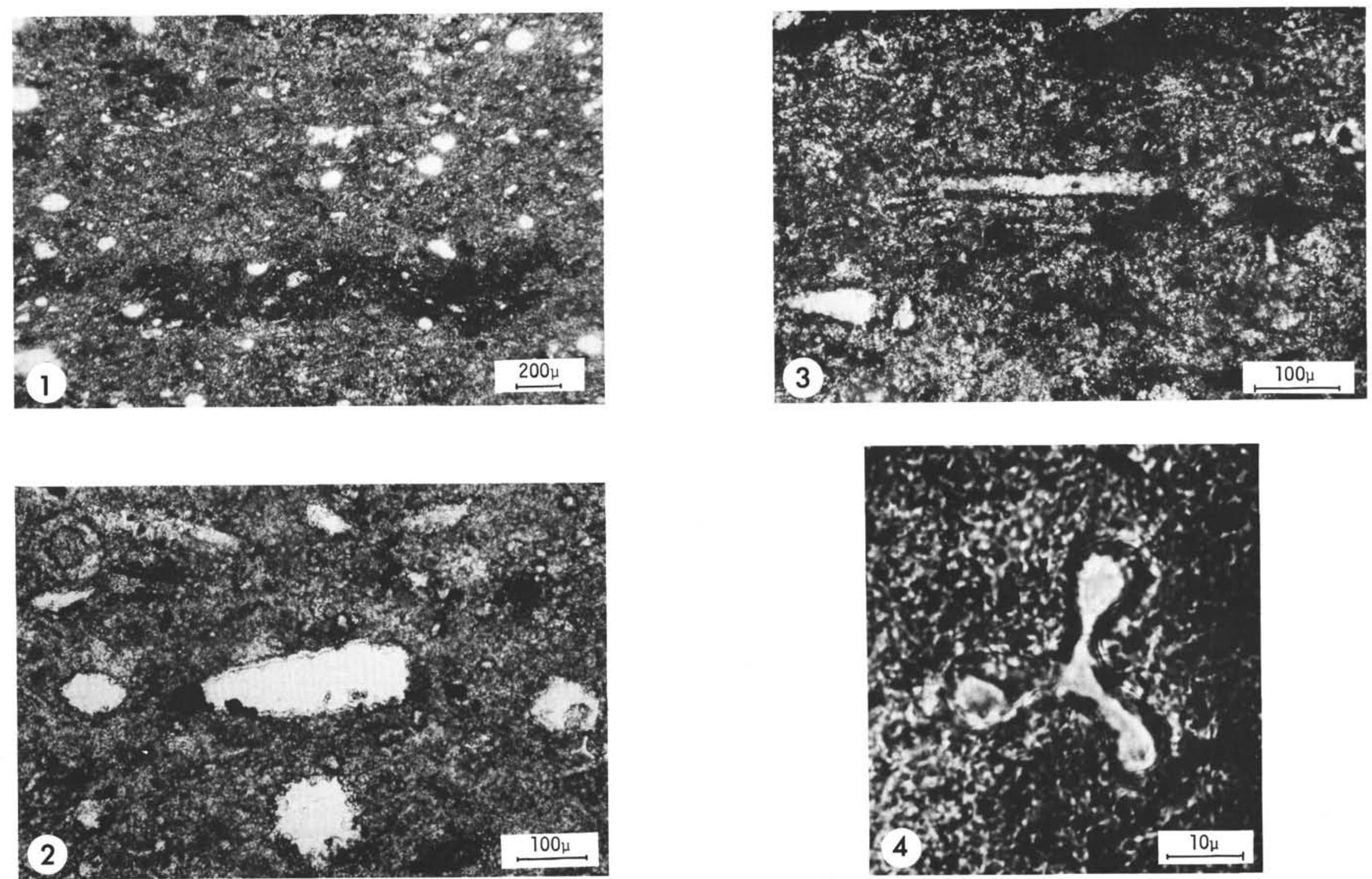

PLATE 29. Dark gray, laminated silicified radiolarian-spiculitic mudstone (Chert type II) 135-8 (Late Cretaceous) (Thin sections, photos U.v.R.). Fig. 1. 135-8-1, $55-58 \mathrm{~cm}$, plain light. Elongate horizontal black organic-rich zone is probably former burrow. Matrix consists of opal-lussatite and microcrystalline quartz, rich in Fe oxides, pyrite, carbonaceous matter and montmorillonitic clay. Abundant recrystallized sponge spicules (20\%) and radiolarians $(5 \%)$. Fig. 2. 8-1, 55-58 cm, plain light. Longitudinal and axial cross-sections of sponge spicules (tests: microcrystalline quartz) and nassellarian radiolarians. Note well-preserved axial canal of sponge spicule in upper left and small triradiate spicule in lower right. Fig. 3. 8-1, 55-58 cm, plain light. Longitudinal and a few axial cross-sections of sponge spicules. Fig. 4. 8-cc, plain light. Triradiate, triaxonic sponge spicule. 

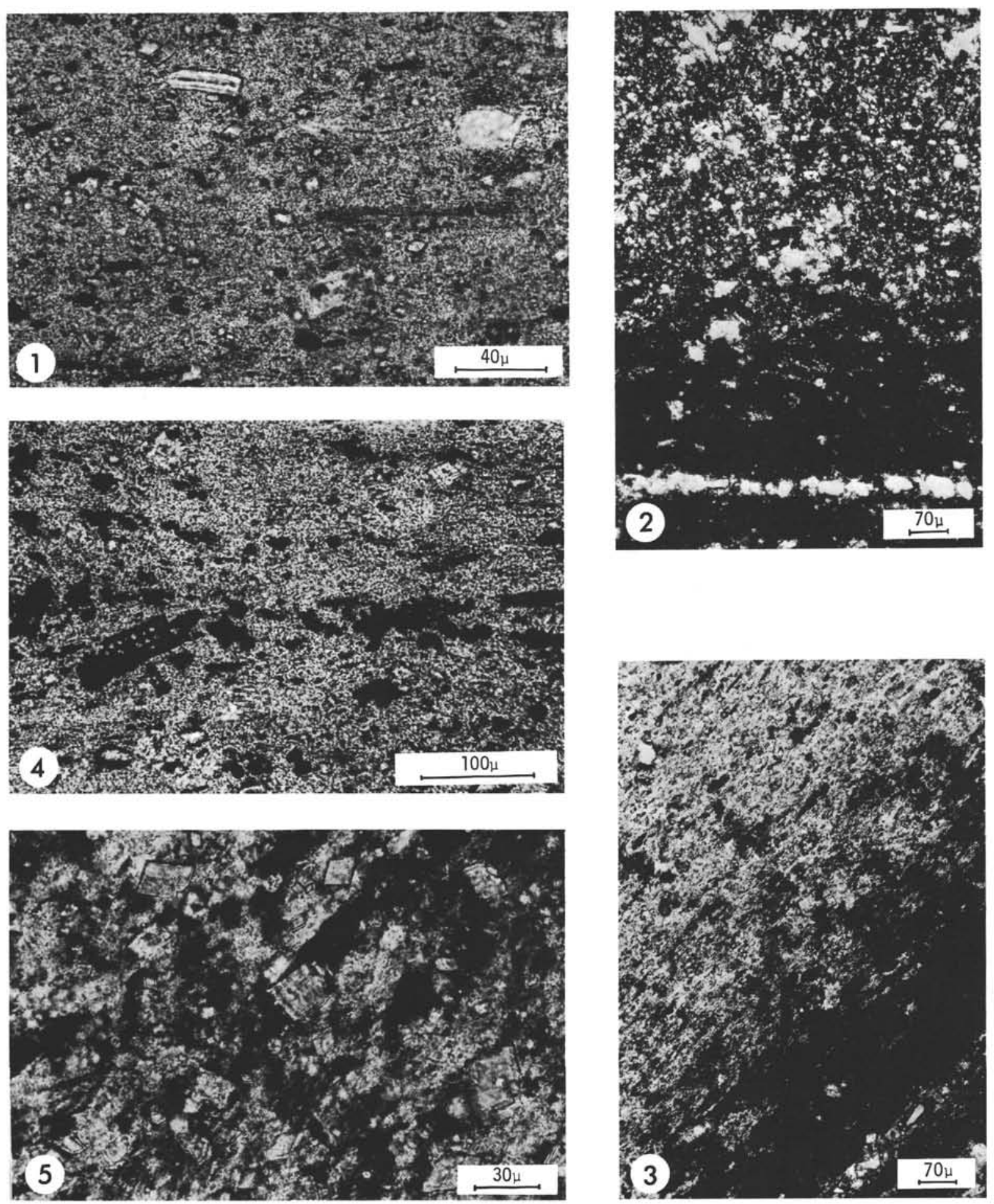

PLATE 30. Faintly bedded, partly homogenized "white" to brown dolomitic and pyritic palygorskite-lussatite chert (type III). 140-6-2, 84.5-91.5 cm., except Fig. 5 (thin sections, photos U.v.R.). Fig.. 1. Plain light. "White" dolomitic palygorskite-lussatite chert. Note rounded terrigenous white quartz (right), dark biotite flakes, well-preserved (?) opaline sponge spicule and many tiny (?relict) dolomite rhombs. Fig. 2. Cross-polarized light. "White" chert with thin terrigenous quartz and carbonate silt layer at base, showing mass extinction of palygorskite clay (and ?silica) parallel to the bedding plane because of mineral parrallelism due to crystallization under directed pressure. Fig. 3. Cross-polarized light. Position $45^{\circ}$ from that of Fig. 2 to show maximum lightening. Note that only terrigenous quartz, opaque matter, and dolomite crystals do not show mass extinction. Fig. 4. Plain light. Layer with a concentration of pyritized radiolarians, traces of dolomite rhombs. Fig. 5. 140-6-2, 95-98 cm, cross-polarized light. Note slightly corroded euhedral dolomite crystals $(10-20 \%$, diameter, 5-30 $\mu$ ) floating as relicts in a palygorskite-rich silica matrix. 

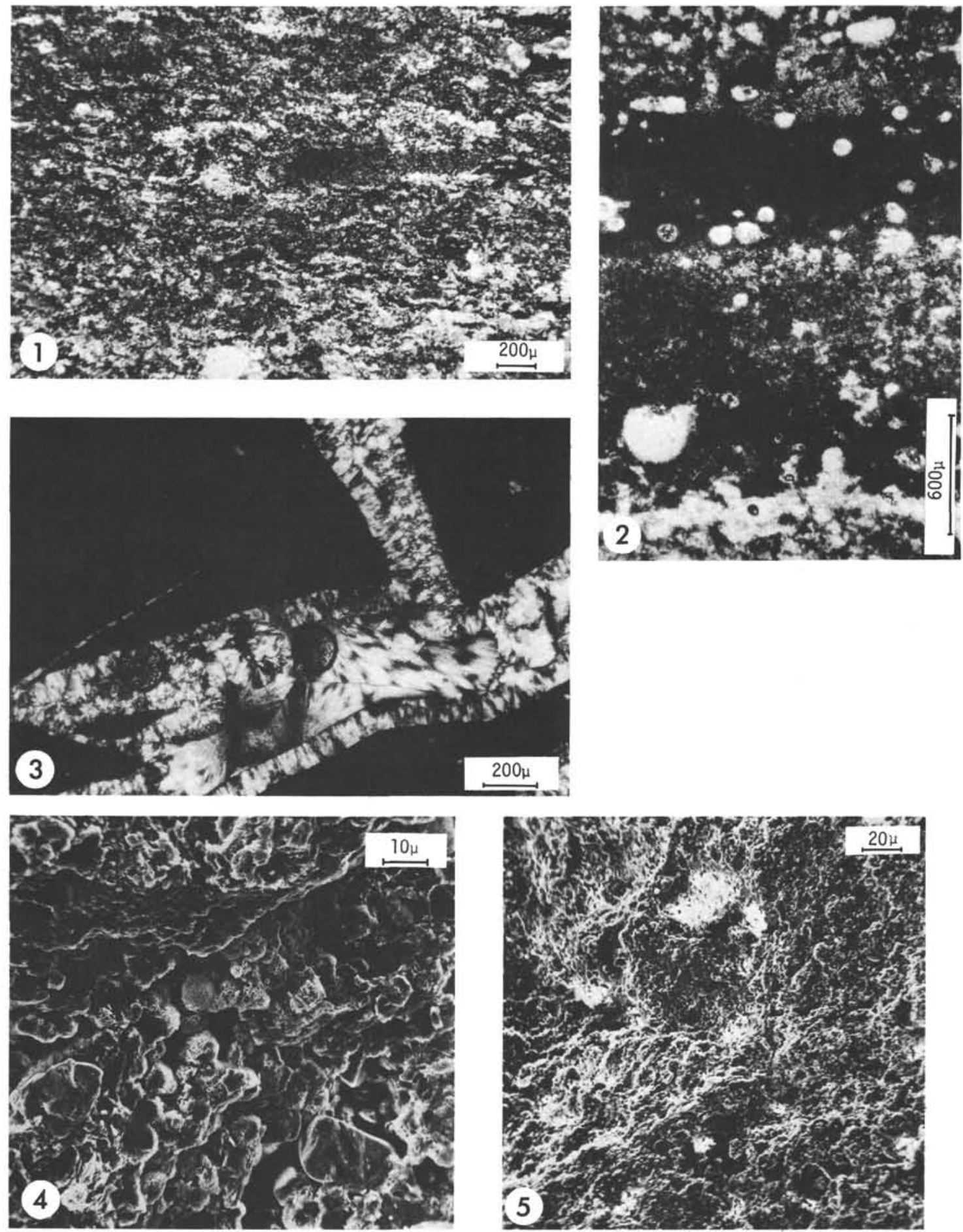

PLATE 31. Mature homogenous, highly recrystallized micro- to cryptocrystalline quartzitic chert (type IV, except Fig. 4). (Thin sections, photos U.v.R.; SEM, Hannover). Fig. 1. 137-7-1, $117 \mathrm{~cm}$, plain light. Note lenticular bedding and traces of bioturbation; poor preservation of fossils (partly "ghosts", party carbonatized), and microquartzitic groundmass with "pin-point extinction" under crossed nicols. Fig. 2. 137-12-2, $116 \mathrm{~cm}$, plain light. Highly recrystallized, distinctly bedded carbonaceous chert. Note $\mathrm{Fe}$ oxide-rich lamina, and diffuse outlines of radiolarians (?) and sponge spicules, filled partly by microcrystalline quartz, partly by chalcedony. Fig. 3. 138-4-cc, cross-polarized light. Brown (ferruginous) microcrystalline chert, cemented by two generations of chalcedony: cement A with radiating fibers of chalcedonic (?) quartz normal to the rims of the joint and cement B with large bundles of radiating chalcedony fibers filling out the remaining pore space. Fig. 4. 135-8-1, 55-58 cm, SEM of broken surface, chert type II, see Plate 29. Note large (silt-size) terrigenous quartz grains (center left) and small $(5 \mu)$ opaline-lussatite gel spheres (center). Fig. 5. 137-12-12, $116 \mathrm{~cm}$, SEM of broken surface, brown, ferruginous chert (see Fig. 2). Note relict coccoliths (silicified nanno marl mud). 

PLATE 32. Various cherts, Transmission EM Micrographs (TEM, Mrs. Scheuermann, Hannover).

Fig. 1. 140-5-cc HF-etched polished section, Triafol-SiO-two stage replica, shadow-casting with $\mathrm{Pt}$ at $30^{\circ}$ and $90^{\circ}$. Clusters of palygorskite needles in "white" opal-lussatite chert.

Fig. 2. 135-8-1, 55-58 cm. Broken surface, two stage replica as in Fig. 1. Cluster of subparallel palygorskite needles of diameter $0.05-0.1 \mu$. Small round objects are possibly axial cross-sections of palygorskite needles.

Fig. 3. Sample 140-6-2, $125 \mathrm{~cm}$. Broken surface, Triafol-SiO-two stage replica, shadowing angle $45^{\circ}$ and $90^{\circ}$. Dark material of lightcolored dolomitic palygorskite-rich chert. Note 2 generations of euhedral and subhedral dolomite rhombohedra (relict?): $1-3 \mu$ and $>10 \mu$. Black spots: opaque sediment material stuck to Triafol foil.

Fig. 4. 140-6-2, $125 \mathrm{~cm}$. HF-etched polished section, two-stage replica as in Fig. 1. Large dolomite rhombohedron, slightly corroded or abraded at left edge. Probably relict crystal predating chertification.

Fig. 5. 140-6-2, $125 \mathrm{~cm}$. Broken surface, two-stage replica as in Fig. 1. Note cobblestone pattern, typical for low cristobalite. Lower right corner: ?terrigenous quartz grain.

Fig. 6. Sample 135-8-1, 55-58 cm. Polished section, two-stage replica as in Fig. 1. Minute silica-spherules and polygonal grains (mostly $0.2-1 \mu$ dia.) in cobblestone pattern, probably low-cristobalite ("opalcristobalite"). (See Footnote 4.) 

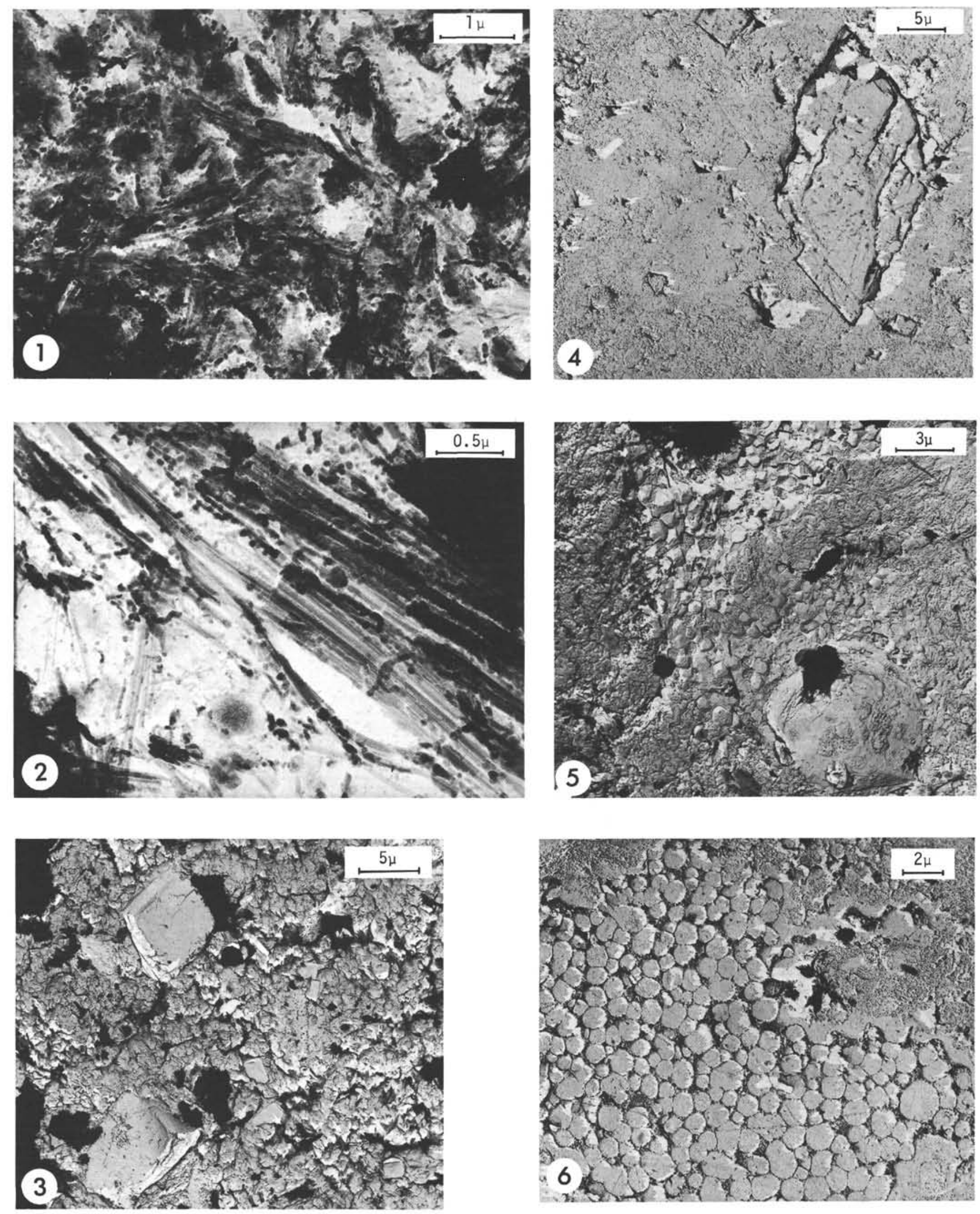
PLATE 33. Mineralogy of Radiolarian tests and casts in cherts. (Thin sections, photos U.v.R.)

Fig. 1. 135-8-1, 55-58 cm. Radiolarian (?) test recrystallized to microcrystalline quartz and calcite lumen filled by carbonate-rich clay.

Fig. 2. 140-3-2, 74-78. Araldite impregnated undisturbed specimen. Siliceous kaolinite montmorillonite-palygorskite mud with abundant opaline tests of sponge spicules, radiolarians and diatom fragments. Brown $\mathrm{Fe}$ oxide bands parallel to bedding. Opaline fossils are partly fragmented and not recrystallized, although palygorskite rich matrix shows mass polarization. OOze is not yet chertified as in Sample 140-6-2 (see chert type III).

Fig. 3. 135-8-1, 55-58 cm, cross-polarized light. Radiolarian (?) cross section. Test recrytallized to microcrystalline quartz. Lumen filled by three coalescing bundles of fibers of chalcedony.

Fig. 4. 135-8-1, 55-58 cm, plain light. Radiolarian (?) cross-section: test consisting of silica spherules $(5-15 \mu \phi)$. Lumen unfilled (open pore space).

Fig. 5. 140-6-2, 84.5-91.5 cm, well-preserved radiolarian (?aged opal), no apparent signs of recrystallization in light-colored Paleogene dolomitic palygorskite-rich "white" chert (type III).

Fig. 6. 138-4-cc, plain light. Mature homogenous "dusty" chert (type IV). Radiolarian cross-section $(140 \mu \phi)$ with test and lumen preserved and filled by micro-to-cryptocrystalline quartz. 

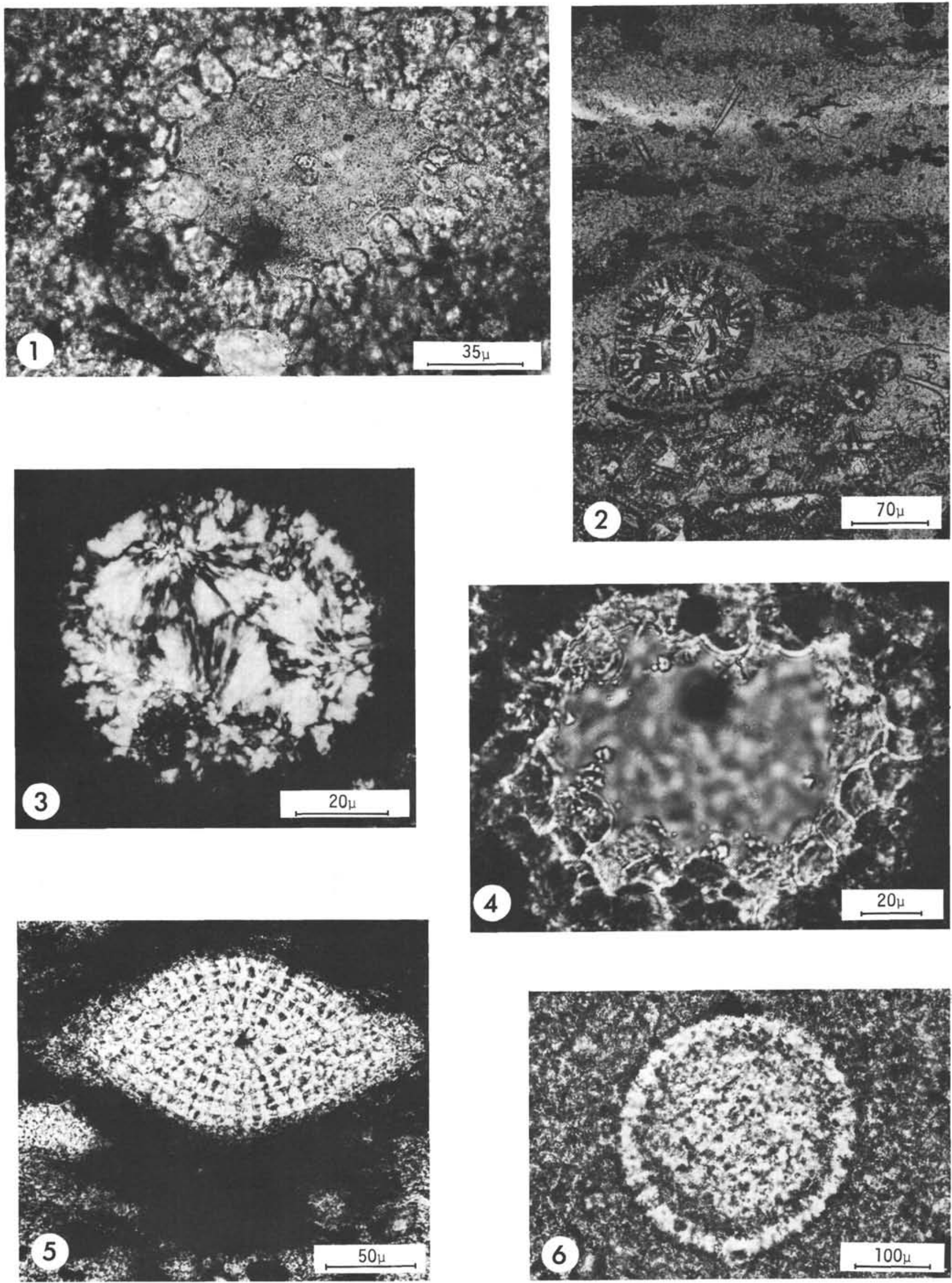

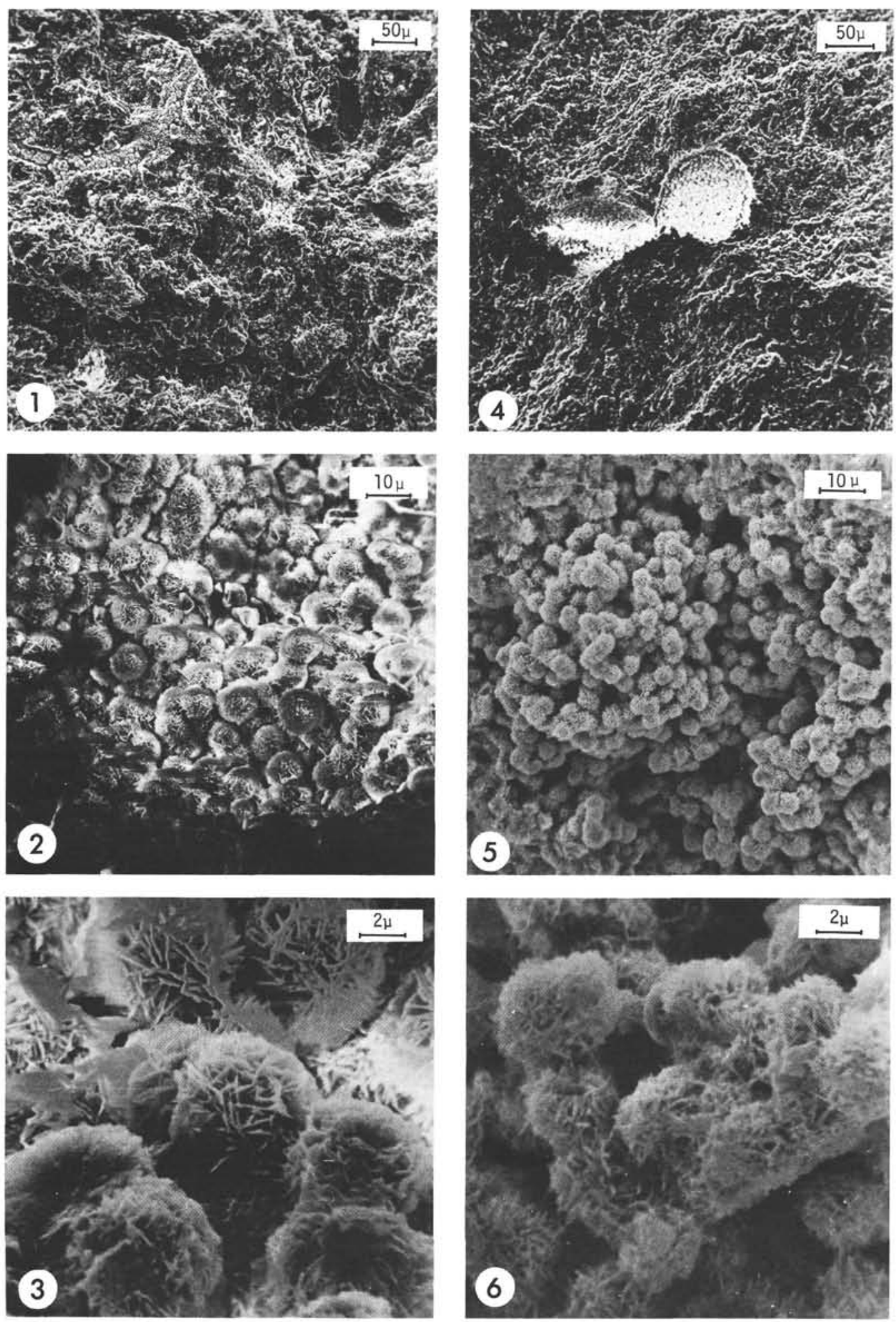

PLATE 34. Opaline-lussatite chert, details. (SEM, 10kV, Hannover). Figs. 1-3. 135-8-1, 55-58 cm. Laminated dark gray radiolarian-spiculitic chert (type II). early Late Cretaceous. Fig. 1. Broken surface. Opaline-lussatite gel spherules, concentrated in vugs and around organic remains. Fig. 2. Detail of Fig. 1, showing cluster of closely packed silica spherules. Fig. 3. Detail of Fig. 2. Silica spherules $(\sim 5 \mu)$ consist of altered and aged opal, almost completely recrystallized to lussatite "needles", a disordered cristobalite-tridymite mixture, in random orientation (O.W. Flörke, pers. comm.). Figs. 4-6. 140-5-cc. Light colored, recrystallized dolomitic palygorskite-rich chert (type III), ? E. Paleogene. Fig. 4. Silica spherules concentrated in two, about 60-80 $\mu$ large fossils (?radiolarians). Fig. 5. Detail of Fig. 4. Individual spherules appear cemented together by bridging crystals of fibrous lussatite. Fig. 6. Detail of Fig. 5. 

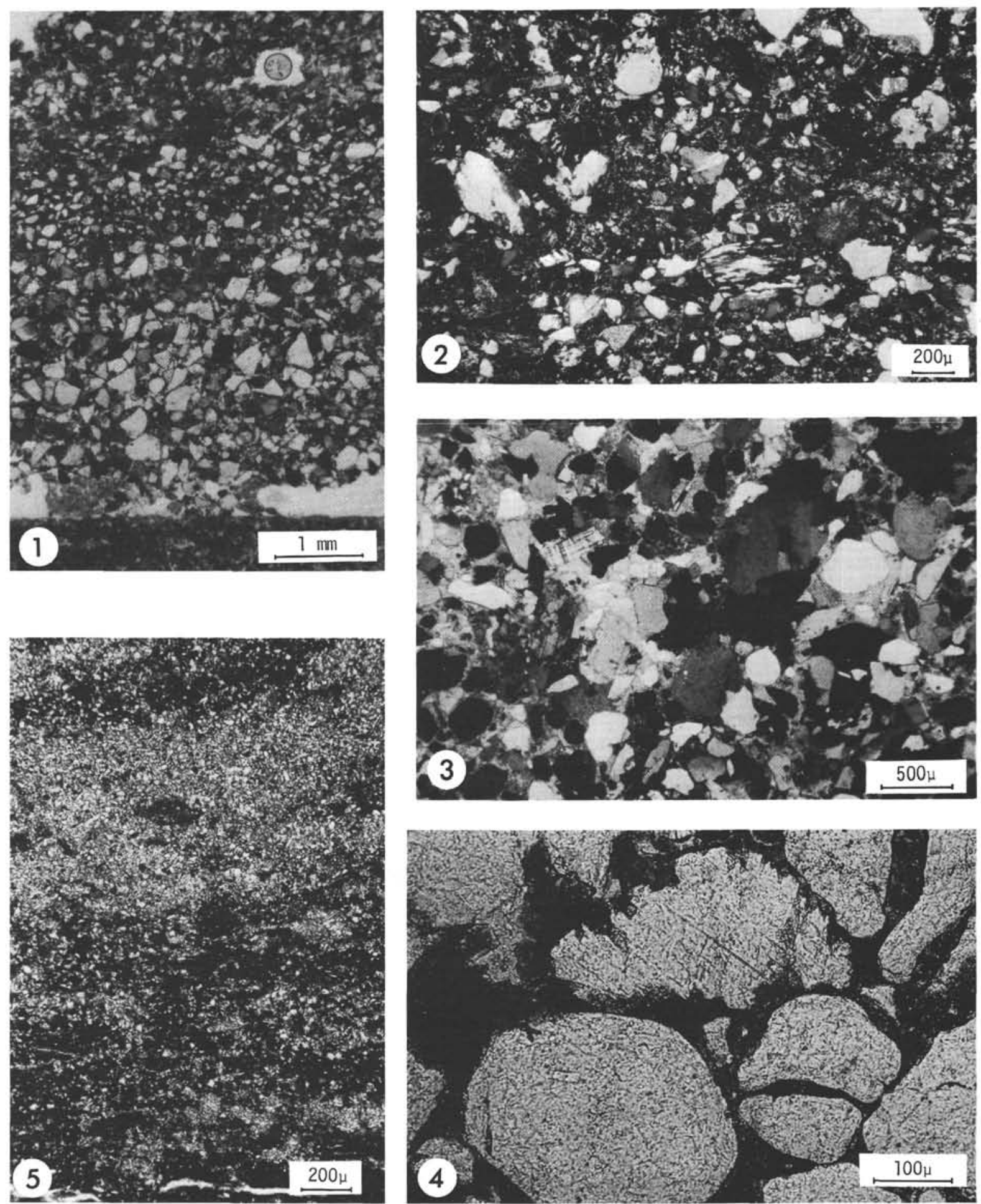

PLATE 35. Terrigenous sediments (sand and silt layers). (Thin sections, photos, U.v.R.). Fig. 1. 135-7-4, $20-23 \mathrm{~cm}$. Araldite-impregnated specimen, plain light. Graded sand layer of graywacke composition. Note angularity of grains and maximum grain size 1-2 mm above base of turbidite. Fig. 2. 135-7-3, 23.5-27 cm. Impregnated specimen, cross-polarized light. Graywacke with metaquartzite fragment (below center), polygranular quartz, reworked coral fragments (center right), foraminifera, quartz, plagioclase, biotite-chlorite, and a carbonate-rich clayey matrix. Fig. 3. 139-6-1, 32-38 cm. Cross-polarized light. Well-rounded mature quartzose sand, approximately $60 \%$ quartz, $3 \%$ feldspar (plagioclase, microcline: left of center), sparry calcite cement. Fig. 4. 139-6-1, 0-7 cm. Plain light. Same rock as in Fig. 3. Note well-rounded character of quartz grains and corroded orthoclase above. Calcite apparently marginally corroding quartz and feldspar. Fig. 5. 140-8-2, $85-92 \mathrm{~cm}$. Impregnated specimen, plain light. Bedded quartz graywacke siltstone. Dark layers rich in clay (in pt. palygorskite) and $\mathrm{Fe}$ oxides, with traces of sponge spicules. 

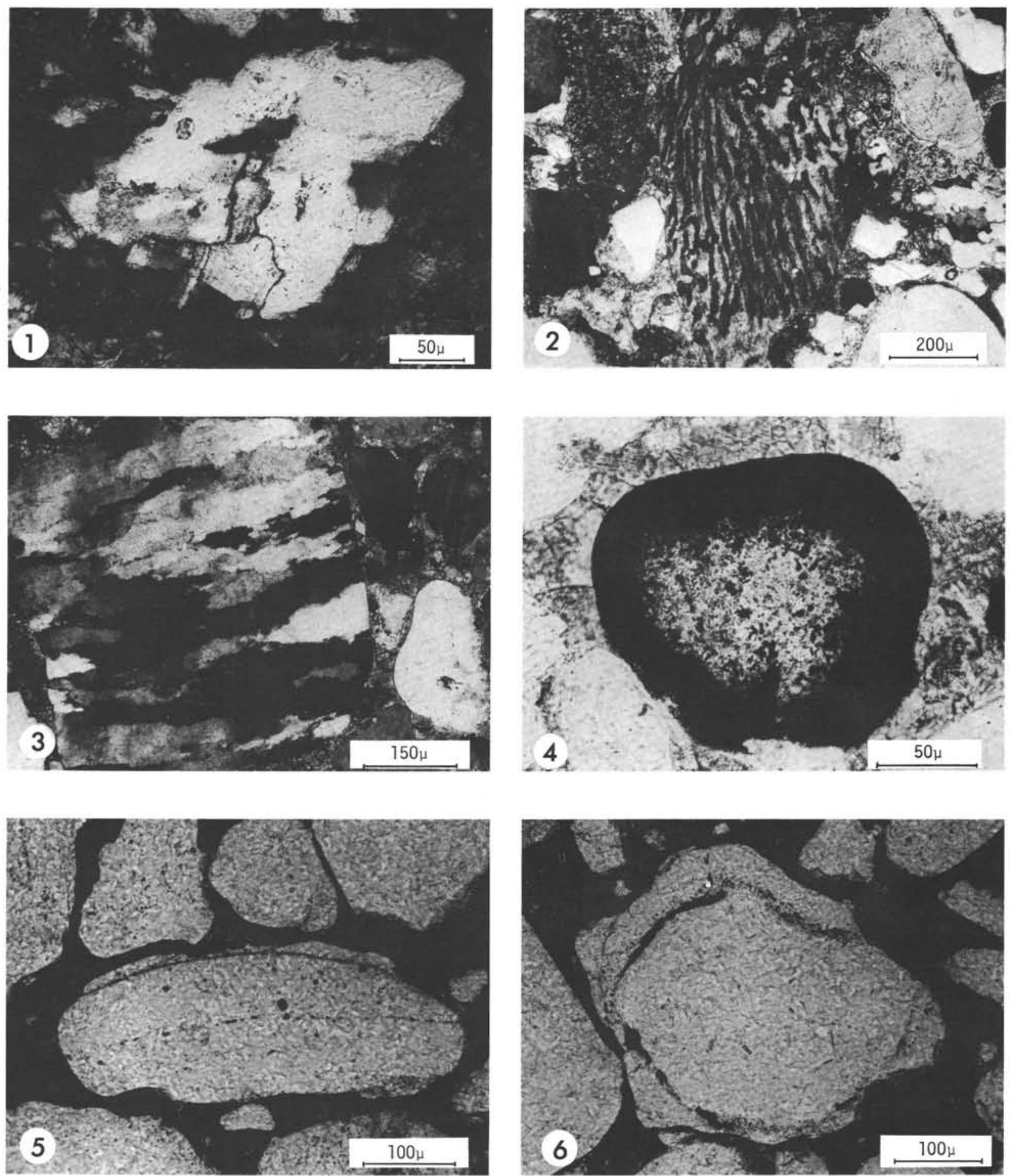

PLATE 36. Minerals and rock fragments in terrigenous sands. 139-6-1 (E. Miocene), except Fig. 1. (Thin sections, photos U.v.R.). Fig. 1. 135-7-3, 23.5-27 cm. (Campanian/Maestrichtian). Cross-polarized light. Plutonic rock fragment (?granite) with quartz-feldspar intergrowth. Fig. 2. 16-19 cm. Cross-polarized light. Myrmekite (quartz "worms" in plagioclase) pointing to a plutonic source. Fig. 3. 0-7 cm. Cross-polarized light. Metaquartzite grain, at right well-rounded quartz and plagioclase. Fig. 4. 0-7 cm. Plain light. Isotropic grain (?organic phosphate or collophane) with thick opaque coating ("ooid"), probably reworked from shallow-water (?shelf). Fig. 5. 0-7 cm. Plain light. Well-rounded elongate quartz grain with secondary silica overgrowth (note dust lines along former boundaries of detrital grain). Fig. 6. 0-7 cm. Plain Light. Quartz overgrowth around subrounded grain in crystalline continuity. 

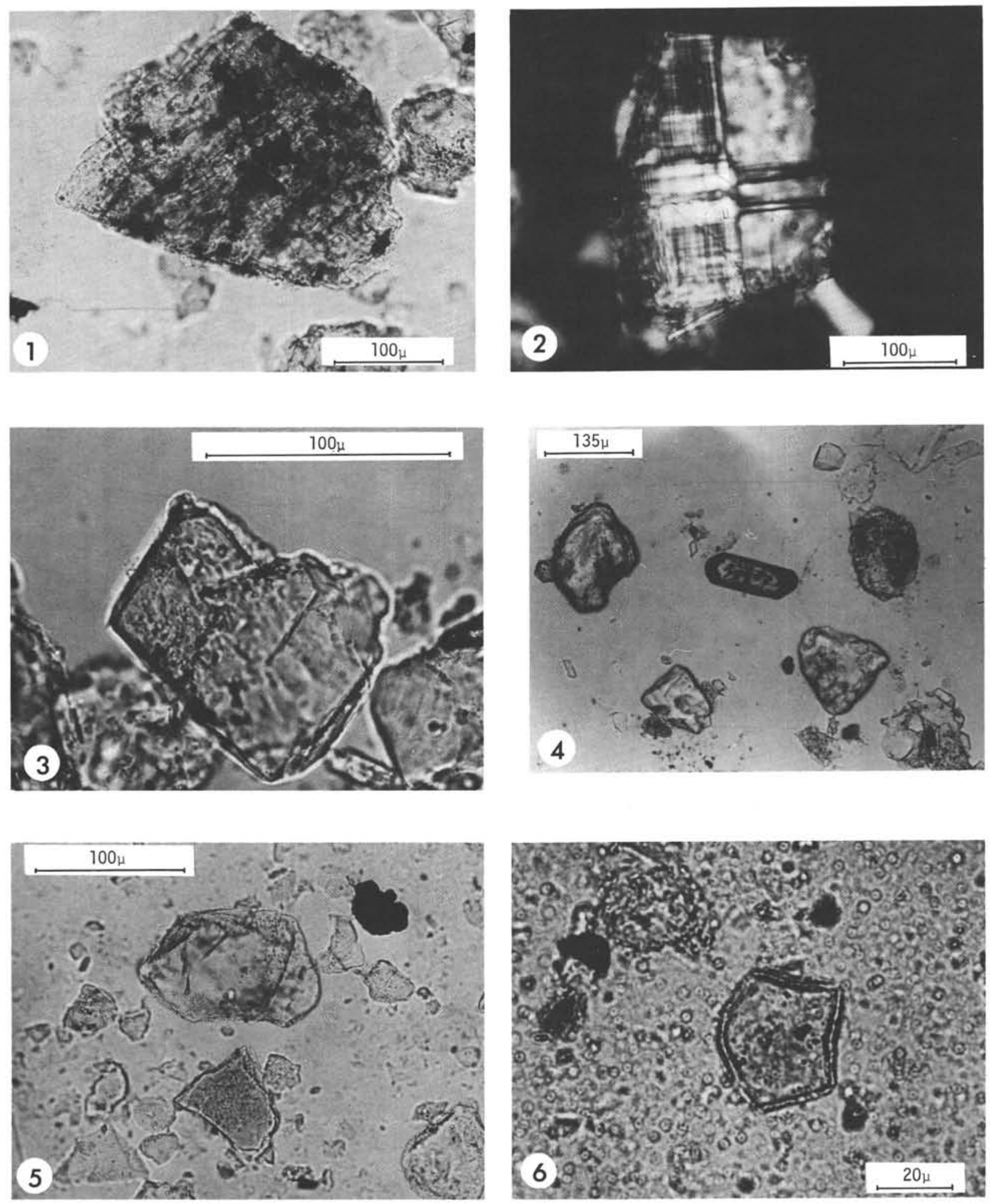

PLATE 37. Minerals in terrigenous sands. 141 sidewall core 1 (?Cret. feldspar-rich quartz graywacke above basalt), except Fig. 6. (Smear slides, photos U.v.R.). Fig. 1. Plain light. Highly altered (chloritized) plagioclase. Fig. 2. Cross-polarized light. Fresh plagioclase crystal with both albite-carlsbad and pericline twinning (probably from plutonic source). Fig. 3. Plain light. Slightly corroded sanidine crystal (probably from volcanic source). Fig. 4. Plain light. Euhedral, slightly rounded zircon, subrounded quartz grains. Fig. 5. Plain light. Rounded quartz with overgrowth, biotite (below), pyrite. Fig. 6. 141-7-4, 75 $\mathrm{cm}$. Plain light. Coated quartz grain ("wüsten quartz"). possibly wind-transported from African desert. Coating mineral is golden-yellow and anisotropic (?Fe oxide). 

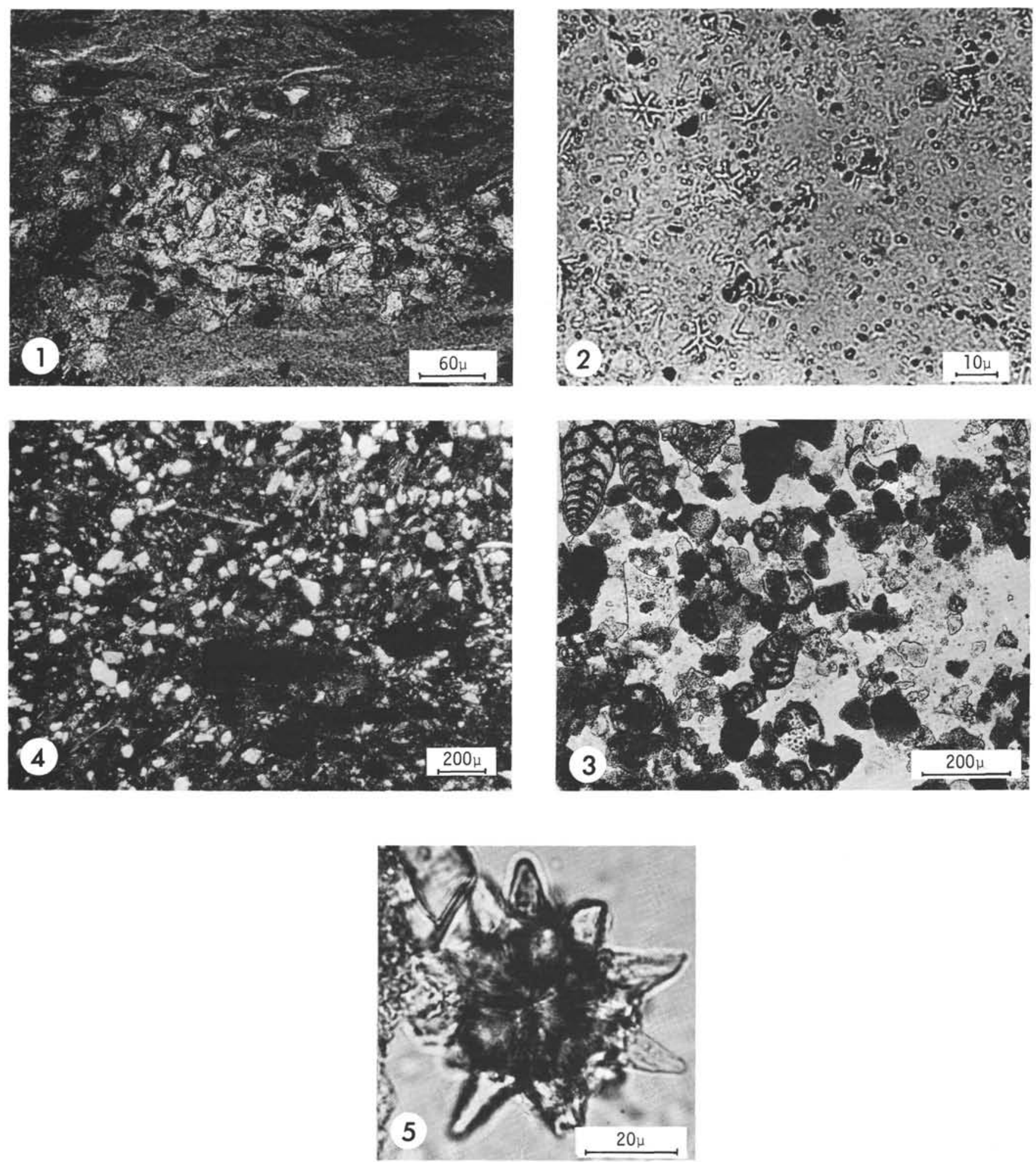

PLATE 38. Terrigenous silty layers and displaced biogenous sediments. (Thin sections: 1, 4; smear slides: 2, 3, 5; photos U.v.R.). Fig. 1. 140-3-2, $74-78 \mathrm{~cm}$. Araldite-impregnated specimen, plain light. Quartz silt lens in montmorillonitepalygorskite clay with mass extinction and pyritized siliceous fossils. Fig. 2. 142-6-1, $35 \mathrm{~cm}$. Reworked coccolith-discoaster ooze in top of (bio-) turbidite. Fig. 3. 142-6-1, $53 \mathrm{~cm}$. Plain light. Mixed terrigenous-foraminiferal sand with quartz, biotite, benthonic foraminifera and nannofossils in matrix. Fig. 4. 144-8-2, $30 \mathrm{~cm}$. Cross-polarized light. Quartzose and micaceous mudstone with plant fragments (graywacke). Fig. 5. 142-6-1, $53 \mathrm{~cm}$. Plain light. Polyaxial spicule, possibly calcareous sponge spicule or didemnid tunicate spicule (see Beall and Fisher, 1969, Plate 8D). 


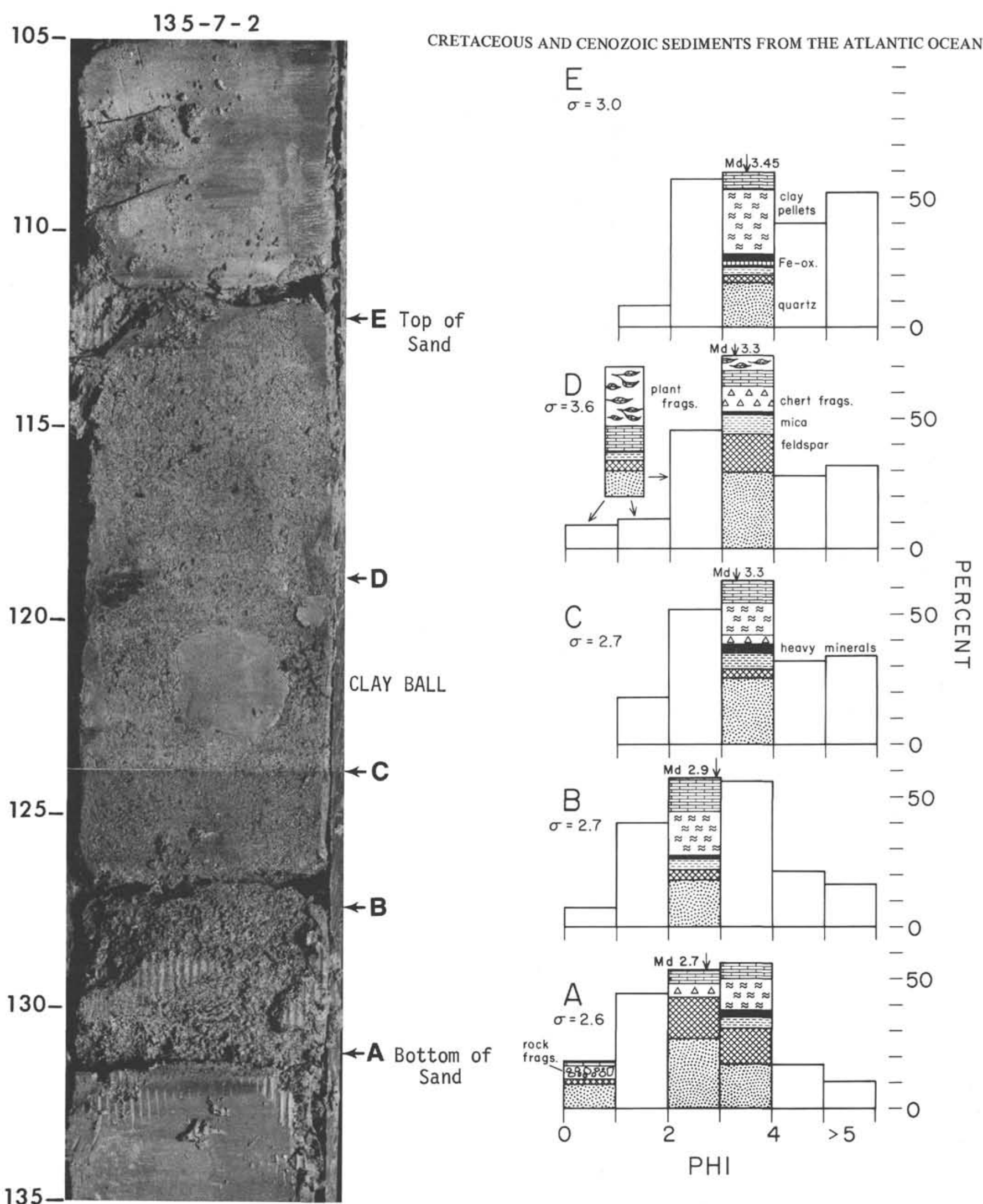

PLATE 39. Graded terrigenous sand layer (graywacke) in Lt. Cretaceous flysch-like sequence. 135-7-2, Campanian/ Maestrichtian. (Shipboard photo) Arrows indicate median. $\sigma=$ phi(84) - phi(16). Degree of sorting, median and maximum grain size decrease regularly from sample A to E; quartz increases slightly from base to top, rock fragments decrease. Carbonate consists almost exclusively of size-sorted planktonic forams. Displaced (in part large, corroded) benthonic foraminifera, bryozoan and coral fragments. echinid spines and ostracods occur especially in samples A to C. Sample D contains up to $60 \%$ carbonized terrestrial plant fragments (see Table 18). 


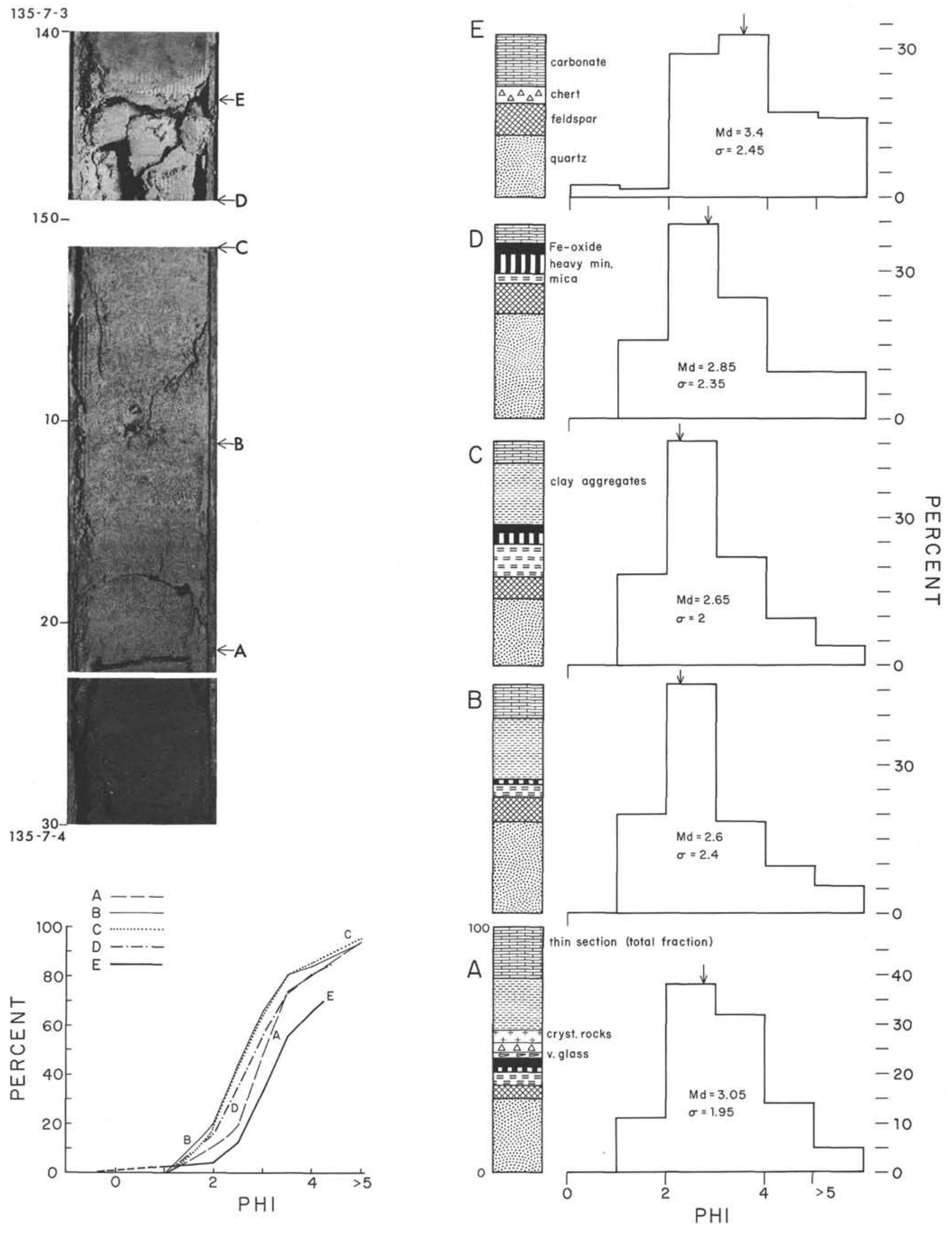

PLATE 40. Graded terrigenous sand layer in Lt. Cretaceous flysch-like sequence. 135-7-3/4, Campanian/Maestrichtian. Composition columns refer to main fraction. Arrows indicate modes; Md. median; $\sigma$, phi(84) - phi(16). A, 135-7-4, 22-23 cm (base of sand). B, 7-4, 11-12 cm. C, 7-4, 0-1 cm. D, 7-3, 149-150 cm. E, 7-3, 143-144 cm. 

PLATE 41. Volcanogenic Sediments. 136-5 and 6. (Campanian). (Thin Sections, Figs. 1, 2, 6, 7; rest smear slides. Plain light. Photos U.v.R.).

Fig. 1. 5-5, 112-121 cm. Freeze dried and araldite-impregn. undisturbed specimen. Parallel- and cross-laminated reworked ash layer. Lower coarse-grained $3 \mathrm{~mm}$ thick layer (10\% glass and palagonite, $60 \%$ limonitic lapilli [?pumice] and altered volcanic rock fragments) has sharp lower contact and appears to grade upwards into fine-grained material (40\% glass and palagonite, $20 \% \mathrm{Fe}$ oxides, $10 \%$ hyalobasalt fragments, rest reworked carbonate crystals and clay).

Fig. 2. Same, brown volcanogenic clay above reworked ash layer with larger carbonate (?dolomite) crystals ( \pm corroded euhedral rhombs, prisms, and "spindles"), volcanic glass altered to brown limonitic aggregates, and a few palagonite grains; all sand grains are probably displaced and reworked together with montmorillonitic clay.

Fig. 3. 5-5, $101-102.5 \mathrm{~cm}$. Fraction $32-63 \mu$. Silt fraction: $80 \%$ corroded carbonate (dolomite and calcite) "spindles" (transition from prisms to rhombs) and tiny carbonate rhombs.

Fig. 4. Same. Detail of carbonate spindle.

Fig. 5. 5-5, $94 \mathrm{~cm}$. Corroded pyroxene (?aegirine-augite) with "coxcomb" fracturing. (Ashes are mostly vitreous with very few crystals.)

Fig. 6. 5-cc. Carbonate-cemented marly tuff with Fe oxide impregnated calcite-clay matrix and volcanic rock and sideromelane fragments. Note pseudorhombic calcite crystals (?paramorphic after pyroxene?).

Fig. 7. 5-cc. Calcite-cemented tuffaceous sandstone (tuff) with $55 \%$ volcanic glass (yellow sideromelane), $9 \%$ golden-yellow palagonite, $15 \%$ sparitic calcite cement and opaque $\mathrm{Fe}$ oxides, altered grains, and hyalobasalt fragments (point count). Note sharp-edged glass shard (center top), fibropalagonitic rims around sideromelane (upper right) and limonitic lapilli and basaltic rock fragments.

Fig. 8. 6-2, $46 \mathrm{~cm}$. Slightly corroded euhedral monoclinic hightemperature sanidine (X-ray analysed, see v.RAd \& Rösch, this volume). 

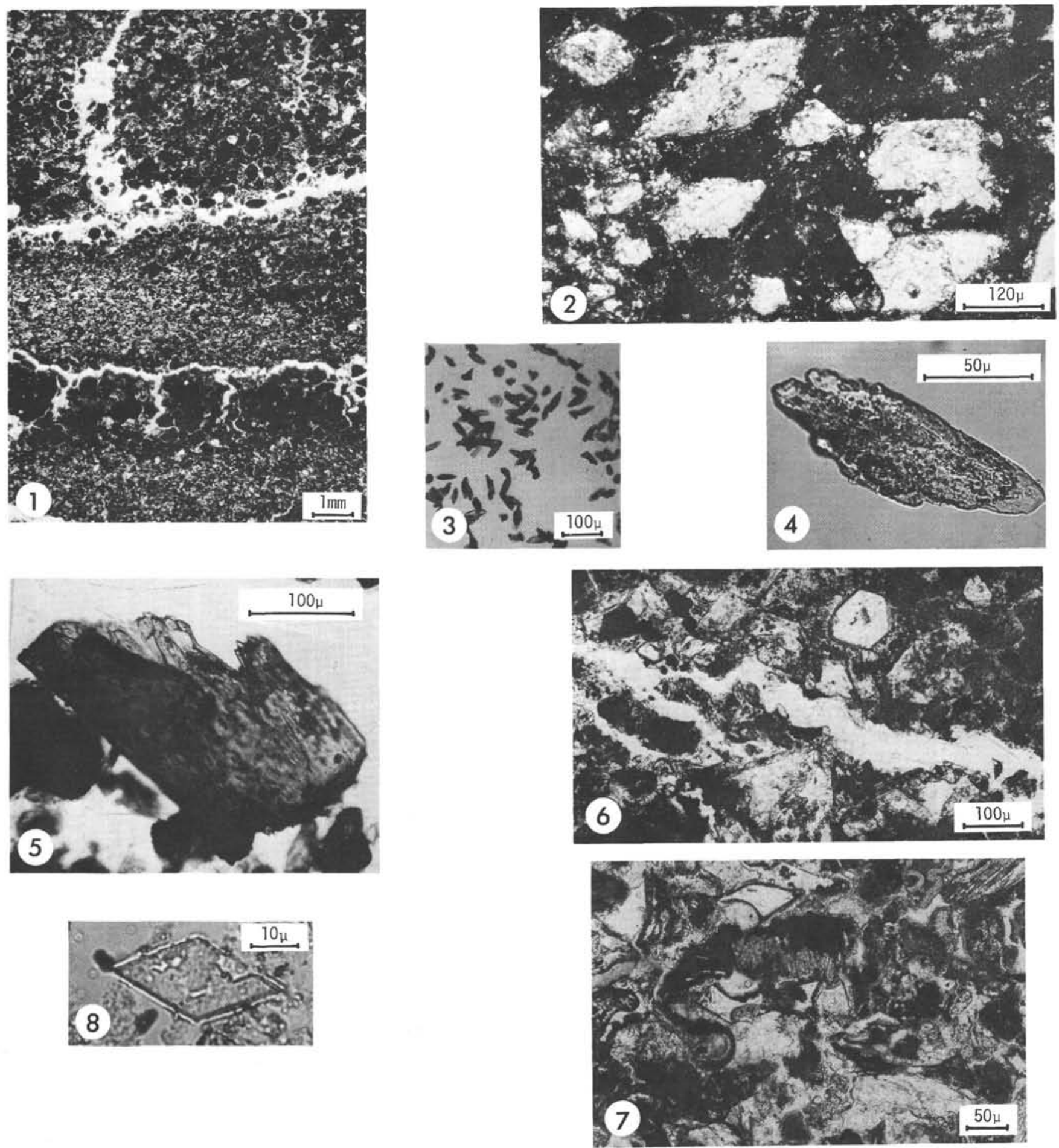

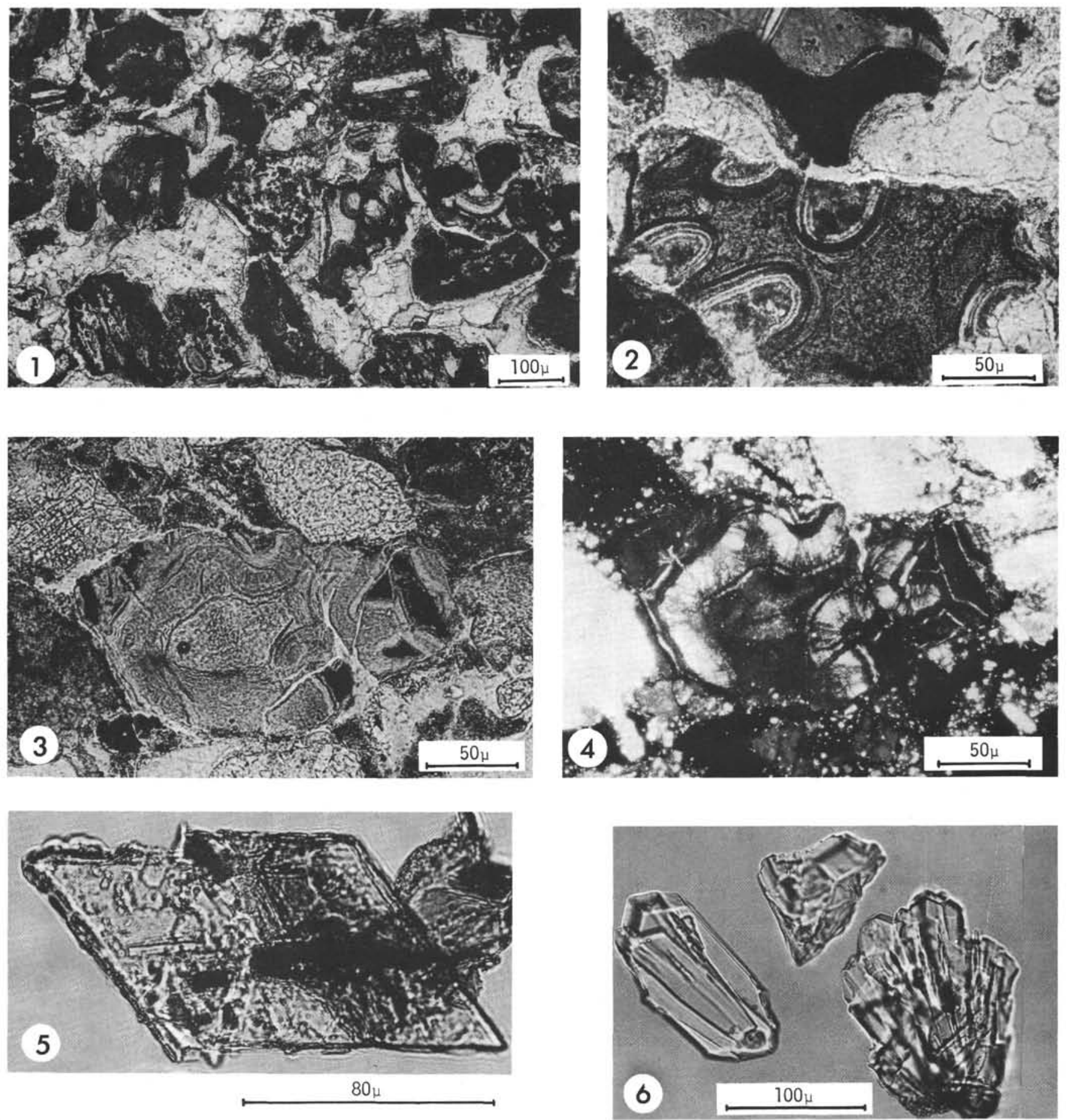

PLATE 42. Volcanogenic sediments (Campanian). (Thin sections, Figs. 14; smear slides, Figs. 5, 6. Photos U.v.R.). Fig. 1. 136-5-cc. Stained with Alizarin-S, plain light. Calcite-cemented vitreous tuff. Volcanic glass (sideromelane) fragments are colorless, golden-yellow, reddish and greenish, sometimes surrounded by palagonite. Some glass shards have perlitic structure. Note abundance of hyaline (ferruginous) basalt fragments with plagioclase laths. Fig. 2. Same, detail. Basaltic glass (sideromelane) fragment with large palagonite-lined ellipsoidal vesicles. Glass fragment at top is surrounded by thick coat of Fe ore. Note two generations of calcite cement: A, surrounding sideromelane and B, filling remaining pore space. Figs. 3, 4 . 135-7-4, 20-23 cm. Plain light and crossed nicols. Reworked light-greenish gray sideromelane grain with thick concentric rims and bands of anisotropic fibrous palagonite. Fe oxide concentrations in outermost part of palagonite. Fig. 5. 136-6-2, 94-95 $\mathrm{cm}$. High temperature sanidine (note monoclinic cleavage), according to X-ray analysis and written communication by Dr. J. C. Hathaway. Fig. 6. 136-6-2, $46 \mathrm{~cm}$. Bundles of unknown twinned mineral: possibly also high-sanidine or (?) authigenic K-feldspar formed during devitrification of pyroclastic material. 

PLATE 43. Structures in Cretaceous volcanogenic sediments. Site 136. (Shipboard photos.)

136-5-5, 125-150 cm. Thick, parallel and cross laminated, reworked altered ash layer and volcanogenic clays (thin-section photo, see Plate 41). Intraformational fault.

136-6-1, 136-145 cm. White alteration rims around brown ferruginous volcanic fragments (? pumice, ? altered glass).

136-8-1, 110-150 cm.

(a) elongate broken (? reworked) fragments of dark-colored semiconsolidated lamina;

(b) slumped portion of ? cross-laminated ash layer;

(c) parallel (-inclined) laminated ash layer;

(d) inclined (cross) lamination of top of erosional surface;

(e) mud flow deposit with reworked white palygorskite clay fragments from bed below (one of it showing lamination);

(f) white palygorskite clay (?altered ash) layer. Note sharp lower contact.

136-8-2, 0-37 cm. Mineralized (?) zone of multicolored clays;

(a) pale reddish-brown and olive-yellow, pale olive clay;

(b) moderate orange pink to mod. reddish orange montmorillonite-rich clay;

(c) green phyllo-silicate sand layer montmor-mixed layer min. (?pumice spherules);

(d) pale olive and light olive brown clay;

(e) yellow silty clay; (montmorillonite-palygorskite-sepiolite-rich);

(f) olive and olive-yellow mica-montmorillonite clay;

(g) very dark gray clay with $10 \%$ nannofossils;

(h) transition (gray) to

(i) light gray nannofossil marl ooze;

(k) very dark grayish brown nannofossil marl ooze (see also color photo in frontispiece of this volume). 

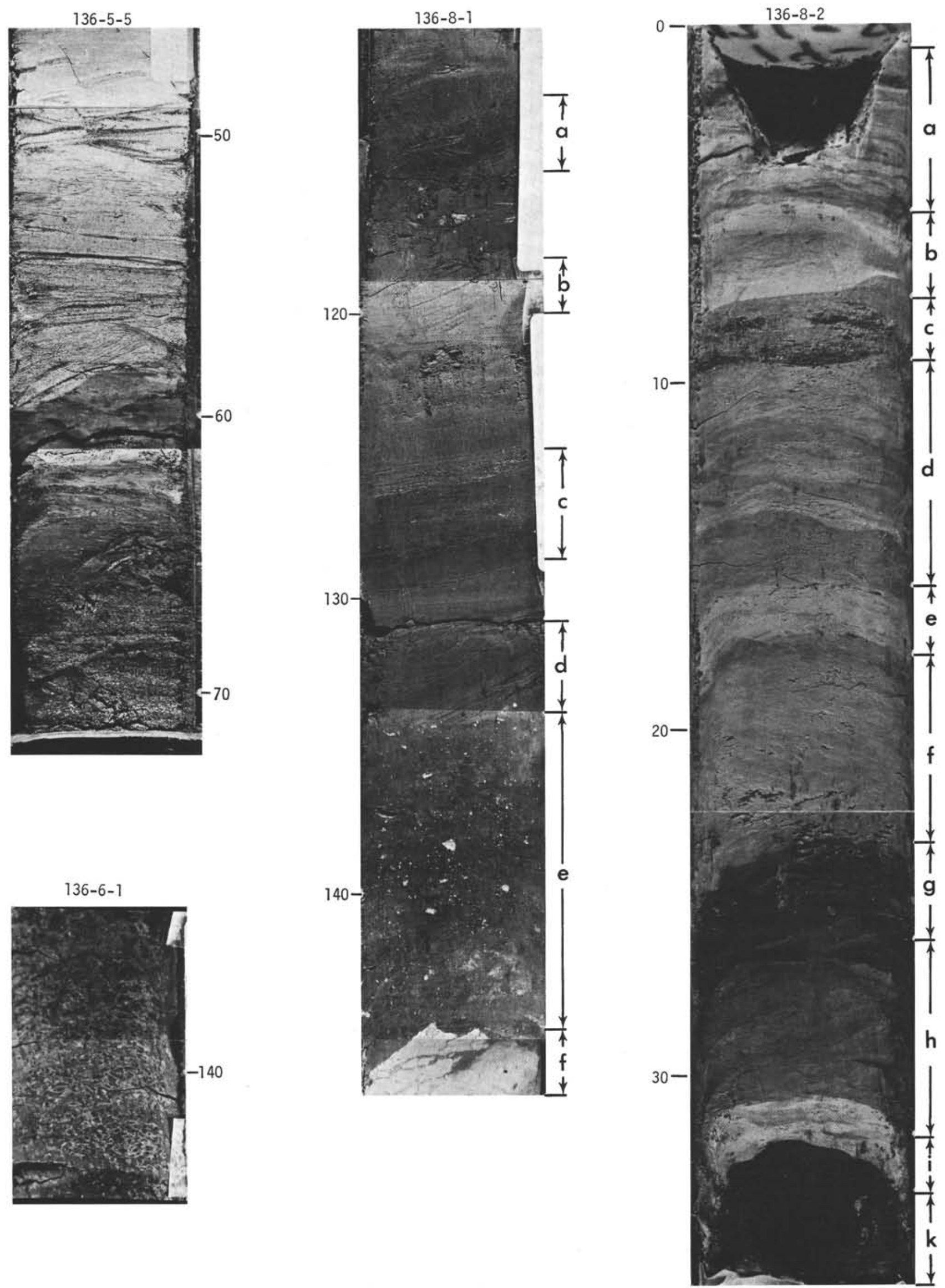
PLATE 44. Dark carbonaceous sediments and associated facies. (Shipboard photos.)

135-8-1 (?Cenomanian). Olive-black zeolitic and pyritic shale and mudstone with intercalated greenish white spherulitic recrystallized limestone, in part slightly silicified. Other sediment layers in this sequence (not shown) include greenish gray soft claystone, dark brown laminated chert. Contacts are all well defined.

137-7-1 (Lt. Cenomanian). Brown-black carbonaceous clay $(15 \mathrm{~cm}, 65$ $\mathrm{cm}$ ), laminated chert layers and large pyrite nodule within sequence of olive gray and greenish gray nannofossil marl and chalk ooze.

137-8-1 (Cenomanian). Greenish gray and very dark gray nannofossil marl ooze with carbonate-poor silty clay layers (slightly dolomitic), brown-black carbonaceous nanno ooze $(30 \mathrm{~cm})$, pyrite nodule $(47 \mathrm{~cm})$, chert fragments $(50 \mathrm{~cm})$, and calcareous laminated mudstone $(58 \mathrm{~cm})$.

140-3-2 (M. Eocene). Greenish gray slightly siliceous silty palygorskitemontmorillonite clay with dark olive gray clay layers having but few siliceous fossils. Pyritization of siliceous fossils common. Note sharp boundaries of dark layers (especially lower). Note mottling. Compare with silicified (palygorskite) clay-dolomite alternations of 140-6, Plate 47. 


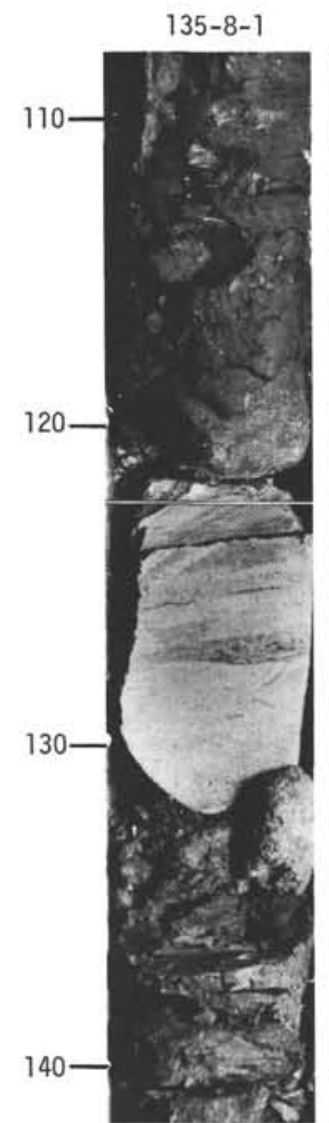

$137-8-1$

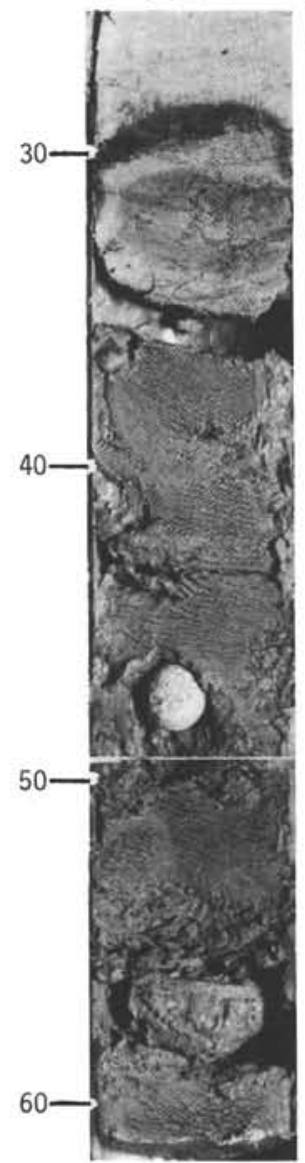

$137-7-1$

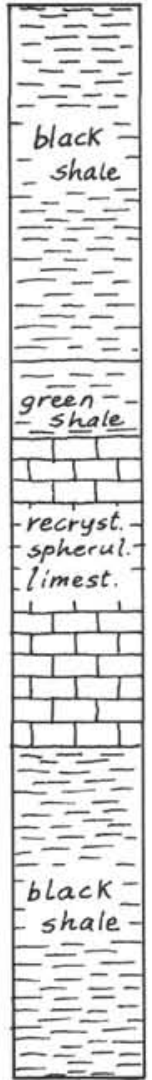

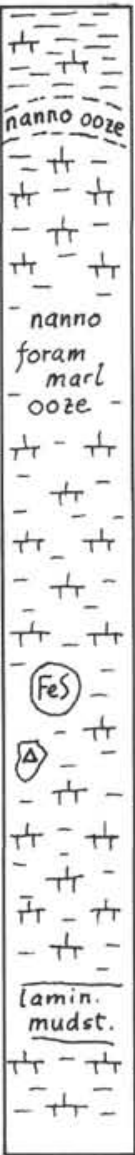
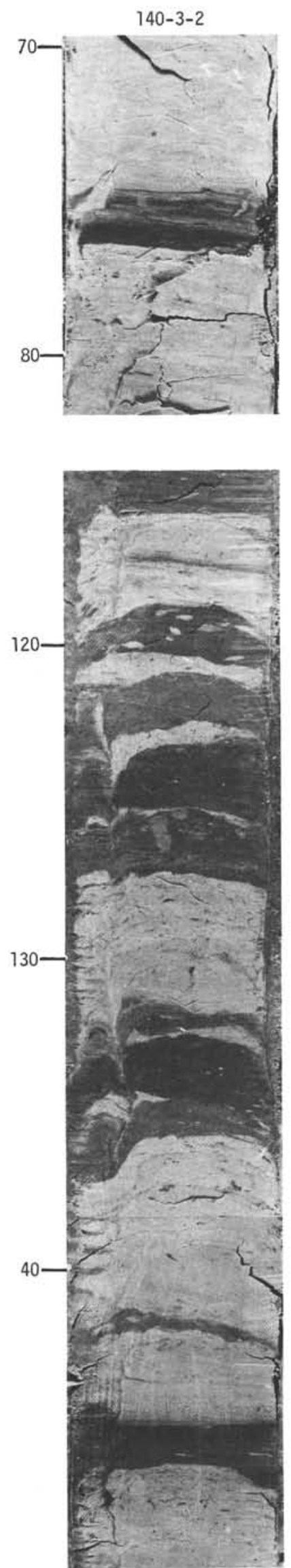

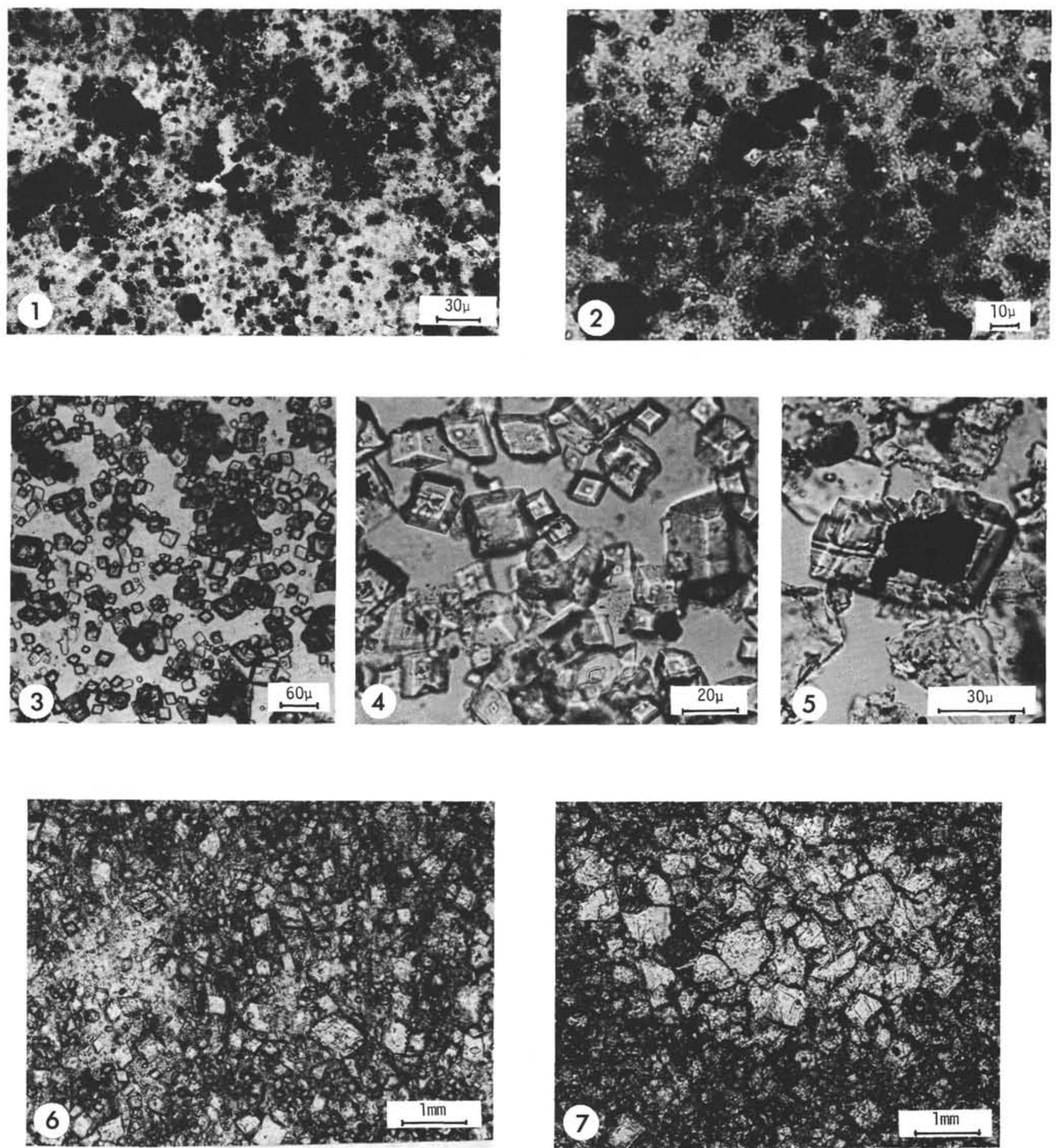

PLATE 45. Sapropelites, dolomites, ankerites. 138-6-3 (Cenomanian), except Figs. 2, 5. (Smear slides, Figs. 1-4; thin sections, Figs. 5, 6, 7; plain light, photos U.v.R.) Fig. 1, $51 \mathrm{~cm}$. Carbonaceous spherules (5-20 $\mu$ diam. and larger aggregates), dolomite rhombs, framboidal pyrite, quartz, biotite, and clay (palygorskite). Fig. 2. 144-4-2, $25 \mathrm{~cm}$. Sapropelitic mud and montmorillonite with $25 \%$ euhedral clinoptilolite laths, montmorillonitic clay, carbonaceous matter $\left(6 \% \mathrm{C}_{\mathrm{org}}\right.$ : oil bitumen, vitrinite), quartz, pyrite, siderite. Fig. 3. 12- cm. 50-80\% silt sized dolomite, quartz, pyrite. Rest: montmorillonite. Fig. 4. Same detail. Note internal smaller rhombs in some of the large ones. Note unusual crystal habit (C-axis often oriented normal to plane of photo). Fig. 5. 140-6-2, $54 \mathrm{~cm}$. (Paleocene). Corroded or abraded subhedral dolomite crystal with carbonaceous (?pyritized) nucleus. Note step-like "grooves" along apical rhomb edges. Fig. 6. $142 \mathrm{~cm}$. Euhedral ankerite crystals $(15-50 \mu)$ floating in a micritic carbonate ground mass, with anhedral to subhedral carbonate crystals $(<5 \mu)$. Fig. 7. Same. Primary (?fossil) vug filled with coarse-crystalline drusy ankerite (70-80\% ankerite, $5-10 \%$ framboidal pyrite, rest montmorillonite, quartz and mica.) 

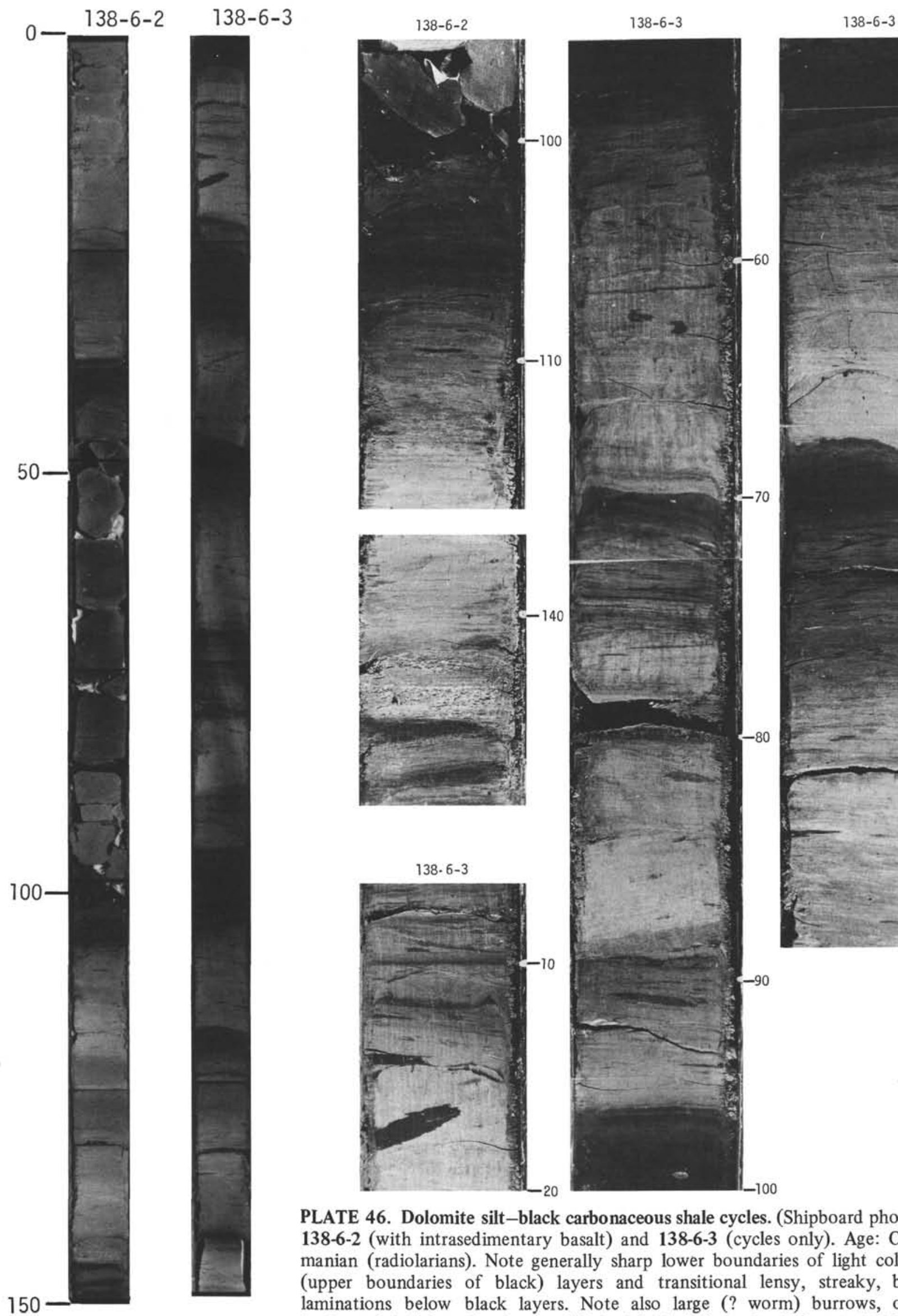

$138 \cdot 6-3$
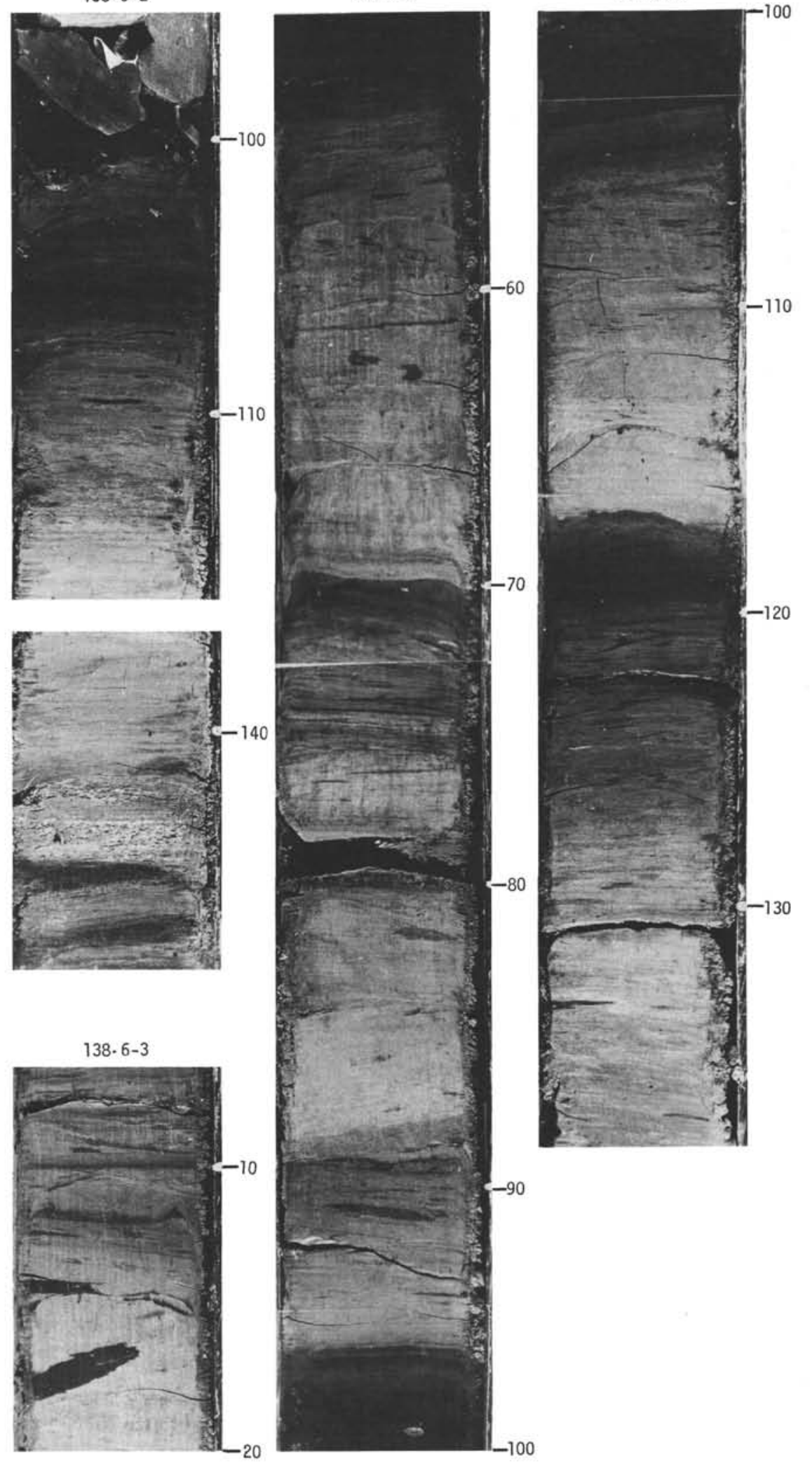

PLATE 46. Dolomite silt-black carbonaceous shale cycles. (Shipboard photos.) 138-6-2 (with intrasedimentary basalt) and 138-6-3 (cycles only). Age: Cenomanian (radiolarians). Note generally sharp lower boundaries of light colored (upper boundaries of black) layers and transitional lensy, streaky, black laminations below black layers. Note also large (? worm) burrows, often horizontal in light-colored zone, filled with black (organic-rich) material. Black layers have sandy lenses full of dark stained radiolarians. Note altered ash layer at $138-6-2,144 \mathrm{~cm}$. 

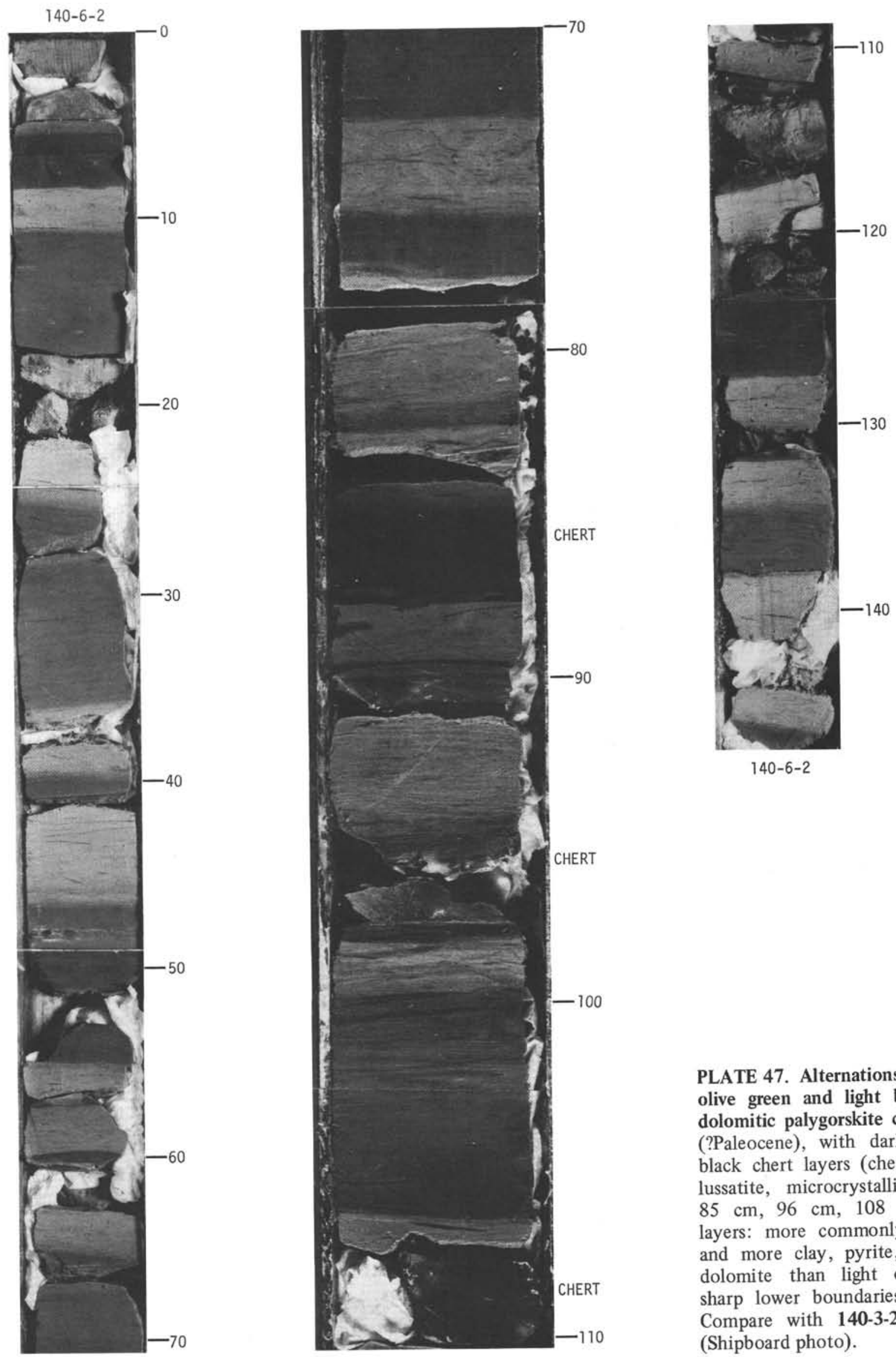

PLATE 47. Alternations of dusky olive green and light bluish gray dolomitic palygorskite clay, 140-6. (?Paleocene), with dark olive to black chert layers (chert type III, lussatite, microcrystalline quartz; $85 \mathrm{~cm}, 96 \mathrm{~cm}, 108 \mathrm{~cm})$. Dark layers: more commonly silicified, and more clay, pyrite, mica, less dolomite than light ones. Note sharp lower boundaries, mottling. Compare with 140-3-2, Plate 44 (Shipboard photo). 


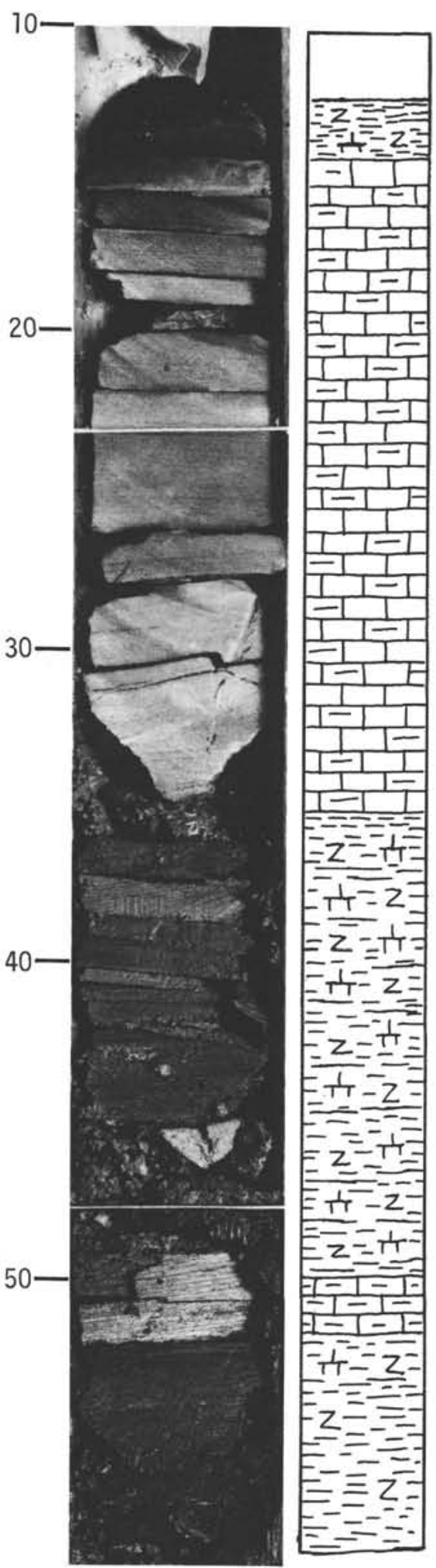

$144 A-5-1$
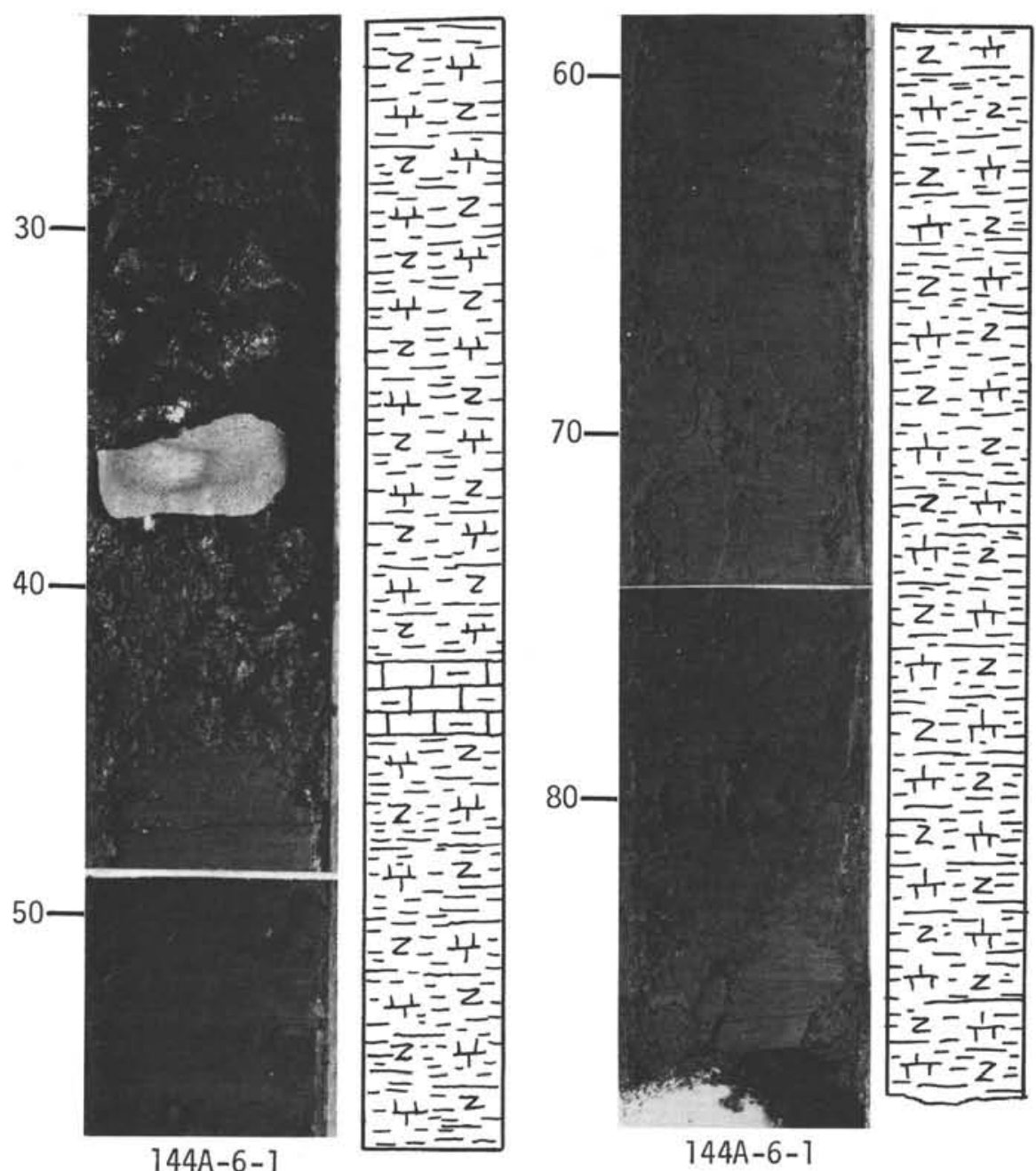

$144 A-6-1$

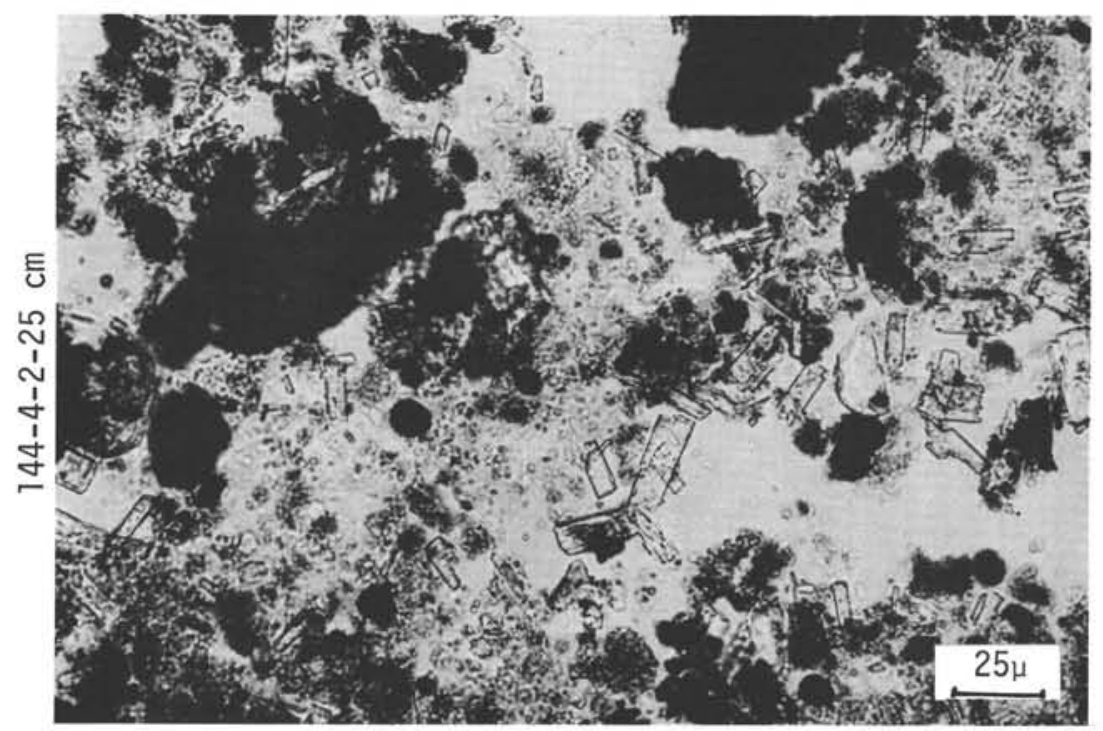

PLATE 48. Cretaceous sapropelite. 144A-5 (Santonian), 144A-6 (Coniacian), 144-4 (Cenomanian), (Cores: shipboard photos. Smear slide: photo U.v.R.). Olive black organic, calcareous, zeolitic shale with intercalations of (probably displaced) calcareous layers. Shale laminae $\sim 0.1 \mathrm{~mm}$ (varves?). Smear slide: Sapropelite with $25 \%$ euhedral zeolite (clinoptilolite), montmorillonitic clay, carbonaceous matter $\left(11 \% \mathrm{C}_{\text {org }}\right.$ : bitumen and vitrinite, see Table 18$)$, and traces of quartz, pyrite and siderite. 


\section{APPENDIX I. CLASSIFICATION OF DEEP SEA SEDIMENTS USED IN THIS REPORT}

I. (Eu-) pelagic deposits (oozes and clays)

$<25 \%$ of fraction $>5 \mu 1$ is of terrigenous, volcanogenic, and or neritic origin. Median grain size $<5 \mu$ (excepting authigenic minerals and pelagic organisms).

A. Pelagic clays. $\mathrm{CaCO}_{3}$ and siliceous fossils $<30 \%$.

1) $\mathrm{CaCO}_{3} 1-10 \%$. (Slightly) calcareous clay.

2) $\mathrm{CaCO}_{3} 10-30 \%$. Very calcareous (or marl) clay.

3) Siliceous fossils 1-10\%. (Slightly) siliceous clay.

4) Siliceous fossils $10-30 \%$. Very siliceous clay.

B. Oozes. $\mathrm{CaCO}_{3}$ or siliceous fossils $>30 \%$.

1) $\mathrm{CaCO}_{3}>30 \%$. <2/3 $\mathrm{CaCO}_{3}:$ marl ooze. $>2 / 3$ $\mathrm{CaCO}_{3}$ : chalk ooze.

2) $\mathrm{CaCO}_{3}<30 \%$. $>30 \%$ siliceous fossils: diatom or radiolarian ooze.

3) Indurated: Pelagic limestone, pelagic chert (radiolarite, diatomite).

II. Hemipelagic deposits (muds)

$>25 \%$ of fraction $>5 \mu$ is of terrigenic, volcanogenic, and/or neritic origin. Median grain size $>5 \mu$ (excepting authigenic minerals and pelagic organisms).

A. Calcareous muds. $\mathrm{CaCO}_{3}>30 \%$.

1) $<2 / 3 \mathrm{CaCO}_{3}$ : marl mud. $>2 / 3 \mathrm{CaCO}_{3}$ : chalk mud.

2) Skeletal $\mathrm{CaCO}_{3}>30 \%$ : foram , nanno , coquina

3) Indurated: marlstones, limestones (in part siliceous).

B. Siliceous muds. $\mathrm{CaCO}_{3}<30 \%$. Siliceous fossils dominant. Prefixes: diatom, radiolarian, spiculitic. Indurated: Siliceous mudstone or shale; muddy chert.

C. Terrigenous muds. $\mathrm{CaCO}_{3}<30 \%$. Quartz, feldspar, mica dominant. Prefixes: quartzose, arkosic, micaceous.

D. Volcanogenic muds. $\mathrm{CaCO}_{3}<30 \%$. Ash, glass, palagonite, etc. common.

III. Pelagic and/or Hemipelagic deposits.

A. Black (carbonaceous) clay and mud: sapropelites.

B. Dolomite - pelite cycles

C. Silicified claystones and mudstones: chert.

1 " $5 \mu$ " stands for an approximate limit of grains identifiable by petrographic microscopy.

\section{APPENDIX II. SUMMARY OF SITE RESULTS}

WD, water depth; TP, total penetration; Pen., penetration in $\mathrm{m}$; Rec., recovery in m; Age: Cenozoic, Q, P, M, O, E, Pa; Cretaceous, $\mathrm{Ma}, \mathrm{Ca}, \mathrm{Sa}, \mathrm{Co}, \mathrm{Tu}, \mathrm{Ce}, \mathrm{Alb}$, Apt.; Lt., Late; M., Middle; E., Early; Ages are based on fossils (see Figure 3). Lithology as in smear slide summary. Totals: Cored of penetrated, recovered of cored.

Site 135

$35^{\circ} 20.8^{\prime} \mathrm{N} ; 10^{\circ} 25.5^{\prime} \mathrm{W} ; 4162 \mathrm{~m} \mathrm{WD} ; 689 \mathrm{~m}$ TP

$750 \mathrm{~m}$ Hill, S.E. edge of Horseshoe A. P.

\begin{tabular}{|c|c|c|c|c|}
\hline Core & Pen. & Rec. & Age & Lithology \\
\hline 1 & $0-4$ & 4.0 & Q & \multirow{6}{*}{$\begin{array}{l}\mathrm{N} \text { chk, it gray, }<5 \% \mathrm{~F} \text {, ex- } \\
\text { cept Core } 1 . \\
\text { Much terrig at base }\end{array}$} \\
\hline 2 & $80-89$ & 8.5 & $\mathrm{P} / \mathrm{M}$ & \\
\hline 3 & $173-182$ & 2.5 & Lt. M & \\
\hline 4 & $259-268$ & 2.1 & M. M & \\
\hline SW1 & 315 & & E. M & \\
\hline SW2 & 325 & & E. M & \\
\hline 5 & $335-341$ & 0.8 & E. E & \multirow{3}{*}{$\begin{array}{l}\text { Mud, clay, sand layers, olv, } \\
\text { gry, brn, grn }\end{array}$} \\
\hline 6 & $341-350$ & 0.1 & $\mathrm{Ma}$ & \\
\hline 7 & $431-435$ & 3.8 & $\mathrm{Ma} / \mathrm{Ca}$ & \\
\hline $\begin{array}{l}8 \\
0\end{array}$ & $564-569$ & 1.0 & Cret & \multirow{2}{*}{$\begin{array}{l}\text { Mudst, black, grn, ls, cht } \\
\mathrm{N} \mathrm{ml,} \mathrm{blk,} \mathrm{ls}\end{array}$} \\
\hline 9 & $685-687$ & 1.8 & Apt & \\
\hline Totals & $8.3 \%$ & $43 \%$ & & \\
\hline Remarl & \multicolumn{4}{|c|}{$135 \mathrm{~A}, 59 \mathrm{~m} \mathrm{TP}$, no recovery. } \\
\hline
\end{tabular}

Site 136

$34^{\circ} 10.1^{\prime} \mathrm{N} ; 16^{\circ} 18.2^{\prime} \mathrm{W} ; 4169 \mathrm{~m} \mathrm{WD} ; 313 \mathrm{~m} \mathrm{TP}$ Abyssal hills, $\mathrm{N}$ of Madeira

\begin{tabular}{cccll}
\hline Core & Pen. & Rec. & \multicolumn{1}{c}{ Age } & \multicolumn{1}{c}{ Lithology } \\
\hline 1 & $130-139$ & 9 & E. P & ) N chk v pale brn no F low \\
2 & $216-225$ & 9 & E.M/M.M & N half; ml, clay at base \\
3 & $235-244$ & 4.7 & E. M & \\
4 & $244-253$ & 3.9 & O/M & \}Clay, terrig silt, pale brn \\
5 & $253-262$ & 1.8 & & Ca \\
6 & $262-271$ & 3.0 & Ca & Clay, ash, red brn \\
7 & $271-280$ & 0.4 & Ce? & N ml, olv gray \\
8 & $280-289$ & 2.5 & Apt & Basalt \\
9 & $308-313$ & 0.2 & $?$ & \\
\hline \multicolumn{5}{l}{ Totals } \\
\hline \multicolumn{5}{l}{ Remarks: Basalt is Aptian or older, unless it is a sill. } \\
\hline
\end{tabular}

Site 137

$25^{\circ} 55.5^{\prime} \mathrm{N} ; 27^{\circ} 03.6^{\prime} \mathrm{W} ; 5361 \mathrm{~m} \mathrm{WD} ; 401 \mathrm{~m}$ TP

Abyss. hills, betw. ridge flank and cont'l rise.

\begin{tabular}{|c|c|c|c|c|}
\hline Core & Pen. & Rec. & Age & Lithology \\
\hline 1 & $52-61$ & 7.0 & $?$ & \multirow{3}{*}{ Clay, brn, barren } \\
\hline 2 & $99-101$ & 0.5 & $?$ & \\
\hline 3 & $135-144$ & 8.8 & $?$ & \\
\hline 4 & $165-173$ & 2.2 & $\mathrm{Ma}$ ? & \multirow{3}{*}{ Clay, brn, zeolitic } \\
\hline 5 & $209-218$ & 0.2 & $\mathrm{Ca}$ ? & \\
\hline 6 & $218-225$ & 1.4 & $\mathrm{Ca}$ ? & \\
\hline 7 & $256-265$ & 0.8 & $\mathrm{Ce}$ & \multirow{2}{*}{ Nanno ml, clay, chert } \\
\hline 8 & $265-274$ & 2.2 & $\mathrm{Ce}$ & \\
\hline 9 & $274-283$ & 3.9 & $\mathrm{Ce}$ & \multirow{10}{*}{$\begin{array}{l}\mathrm{N} \text { ml-chk, red \& grn, occa- } \\
\text { sional silty clay layers }\end{array}$} \\
\hline 10 & 283-292 & 3.6 & $\mathrm{Ce}$ & \\
\hline 11 & $292-301$ & 8.4 & $\mathrm{Ce}$ & \\
\hline 12 & $301-310$ & 8.1 & $\mathrm{Ce}$ & \\
\hline 13 & $320-329$ & 4.8 & $\mathrm{Ce}$ & \\
\hline 14 & $339-348$ & 8.2 & $\mathrm{Ce}$ & \\
\hline 15 & $348-357$ & 2.0 & $\mathrm{Ce}$ & \\
\hline 16 & $375-382$ & 4.7 & $\mathrm{Ce} / \mathrm{Alb}$ & \\
\hline SW1 & 393 & 0.3 & Alb & \\
\hline 17 & $397-401$ & 1.4 & $?$ & \\
\hline Totals & $34 \%$ & $50 \%$ & & \\
\hline
\end{tabular}

Site 138

$25^{\circ} 55.4^{\prime} \mathrm{N} ; 25^{\circ} 33.8^{\prime} \mathrm{W} ; 5288 \mathrm{~m}$ WD; $442 \mathrm{~m} \mathrm{TP}$

E. of 137 , foot of cont'l rise

\begin{tabular}{cccll}
\hline Core & Pen. & Rec. & Age & \multicolumn{1}{c}{ Lithology } \\
\hline 1 & $52-61$ & 8.8 & E. M & Clay, pale grn, sd layers \\
2 & $110-119$ & 9.0 & O & dto, with radiolarians \\
3 & $183-190$ & 0.3 & $?$ & Clay, blu gry \& brn \\
4 & $255-264$ & 0.7 & Cr/T & Mudst, shale, chert \\
5 & $332-341$ & 0.5 & Lt. Cr & Clay, grn gry \& brn, zeo \\
6 & $425-431$ & 3.2 & Ce & Dolo-sapro cycles \\
7 & $437-442$ & 1.0 & $?$ & Basalt \\
\hline Totals & $12 \%$ & $44 \%$ & \\
\hline Remarks: A basalt sill was cored in Core 6. Core 7 basalt also may \\
be a sill.
\end{tabular}


Site 139

$23^{\circ} 31.1^{\prime} \mathrm{N} ; 18^{\circ} 42.3^{\prime} \mathrm{W} ; 3047 \mathrm{~m} \mathrm{WD} ; 665 \mathrm{~m}$ TP

Cont'l rise $250 \mathrm{~km}$, W of Cap Blank

\begin{tabular}{|c|c|c|c|c|}
\hline Core & Pen. & Rec. & Age & Lithology \\
\hline 1 & $114-123$ & 2.6 & M. P & \\
\hline 2 & $225-234$ & 5.1 & E. $P$ & $\left\{\begin{array}{l}\mathrm{N} \text { chk-ml, olive gray, } \mathrm{H}_{2} \mathrm{~S} \\
\text { odor. }\end{array}\right.$ \\
\hline 3 & $345-354$ & $\mathrm{cc}$ & M. M & odor. \\
\hline 4 & $455-463$ & cc & M. M & Silty $\mathrm{N} \mathrm{ml} \mathrm{(qtz),} \mathrm{grn} \mathrm{gry}$ \\
\hline 5 & $570-576$ & 0.2 & E. M & Diat ooz, olv brn \\
\hline 6 & $607-612$ & 0.4 & & Sdst, qtz, dk grn gry \\
\hline 7 & $656-665$ & 9.0 & E. M & Qtz sd, diat md, $\mathrm{N} \mathrm{ml}$ \\
\hline Totals & $8 \%$ & $32 \%$ & & \\
\hline
\end{tabular}

Site 140

$21^{\circ} 45.0^{\prime} \mathrm{N} ; 21^{\circ} 47.5^{\prime} \mathrm{W} ; 4483 \mathrm{~m} \mathrm{WD} ; 651 \mathrm{~m} \mathrm{TP}$

Foot of cont'l rise, $W$ of Cap Blanc

\begin{tabular}{cccll}
\hline Core & Pen. & Rec. & Age & \multicolumn{1}{c}{ Lithology } \\
\hline 1 & $89-98$ & 9.0 & Lt. P & NF chk-ml white \\
A1 & $150-159$ & 0.8 & M.M & Clay, brn, grn gry \\
2 & $201-210$ & 8.1 & E.M & Diat mud, olive \\
A2 & $235-244$ & 8.3 & Lt. E & \} \\
3 & $311-318$ & 4.5 & M.E & Clay (silic.) grn gry. \\
4 & $368-374$ & 1.4 & M.E/E.E & Same, less silic \\
5 & $427-432$ & cc & $?$ & Clay, pale grn \\
6 & $510-519$ & 1.7 & $?$ & Dolo clay, silt, cht \\
7 & $585-587$ & 0.1 & $?$ & Blk shale, chert \\
8 & $645-651$ & 4.1 & Ma? & Clay, silt, sd, cht, grn gry \\
\hline Totals & $11 \%$ & $54 \%$ & & \\
\hline
\end{tabular}

Site 141

$19^{\circ} 25.2^{\prime} \mathrm{N} ; 23^{\circ} 59.9^{\prime} \mathrm{W} ; 4148 \mathrm{~m}$ WD; $298 \mathrm{~m}$ TP

Diapir, $\mathrm{N}$ of Cape Verde Isl., area of low relief

\begin{tabular}{|c|c|c|c|c|}
\hline Core & Pen. & Rec. & Age & Lithology \\
\hline 1 & $5-14$ & 8.0 & Q & \\
\hline 2 & $14-23$ & 8.7 & Lt. P & \\
\hline 3 & $23-32$ & 9.0 & Lt. $P$ & Foram Nanno chk, pale brn \\
\hline 4 & $32-41$ & 9.0 & Lt. P & \\
\hline 5 & $41-50$ & 9.0 & E. $P$ & \\
\hline 6 & $59-68$ & 9.0 & E. P & F N marl, pale yel \\
\hline 7 & $79-88$ & 9.0 & M.M & Calc. clay, brn \\
\hline 8 & $117-123$ & 2.5 & $?$ & Clay brn \\
\hline 9 & $191-200$ & 7.2 & ? & \\
\hline SW1 & 287 & & ? & Sand, subark, grn gry \\
\hline 10 & $295-298$ & 1.1 & $?$ & Basalt \\
\hline Total & $27 \%$ & $89 \%$ & & \\
\hline
\end{tabular}

Site 142

$03^{\circ} 22.2^{\prime} \mathrm{N} ; 42^{\circ} 23.5^{\prime} \mathrm{W} ; 4372 \mathrm{~m}$ WD $; 626 \mathrm{~m}$ TP

Ceara Abyss. Plain, $650 \mathrm{~km}$ NE of Amazon

\begin{tabular}{|c|c|c|c|c|}
\hline Core & Pen. & Rec. & Age & Lithology \\
\hline 1 & 98-106 & 8.0 & Q & Terr fn sand and calcareous \\
\hline 2 & $200-209$ & 4.8 & Q & $\begin{array}{l}\text { clay-marl, olive gray } \\
\text { f }\end{array}$ \\
\hline 3 & 293-301 & 0.9 & Q & \\
\hline 4 & $367-376$ & 7.2 & M.P & f $\mathrm{F}$ chalk-ml, clay \& sd lay- \\
\hline 5 & $423-429$ & 1.5 & M.P & ers, varicolored \\
\hline 6 & $451-457$ & 2.8 & $\mathrm{P} / \mathrm{M}$ & $\mathrm{N}$ marl \& $\mathrm{F}$ sands, pale brn \\
\hline 7 & $479-487$ & 8.4 & L.M & gry \\
\hline 8 & $529-538$ & 2.8 & M./L.M & Clay \& N marl, blu gry, grn \\
\hline 9 & $575-581$ & 4.5 & E./M.M & gry, silic at $609 \mathrm{~m}$ (bit) \\
\hline Total & $11 \%$ & $59 \%$ & & \\
\hline
\end{tabular}

Site 144

$09^{\circ} 27.2^{\prime} \mathrm{N} ; 54^{\circ} 20.5^{\prime} \mathrm{W} ; 2957 \mathrm{~m}$ WD: $327 \mathrm{~m}$ TP

Demerara Rise, between plateau \& steep flank

\begin{tabular}{|c|c|c|c|c|}
\hline Core & Pen. & Rec. & Age & Lithology \\
\hline B1 & $0-9$ & 9.3 & M.O & \multirow{7}{*}{$\begin{array}{l}\text { Foram Nanno chk, pale yel } \\
\text { grn }\end{array}$} \\
\hline B2 & $10-19$ & 9.1 & M.O & \\
\hline A1 & $20-29$ & 7.4 & E.O & \\
\hline B3 & $27-36$ & 8.6 & E.O & \\
\hline A2 & $38-47$ & 9.3 & $\mathrm{O} / \mathrm{E}$ & \\
\hline 1 & $57-65$ & 8.0 & M.E & \\
\hline 2 & $104-112$ & 8.0 & Lt.Pa & \\
\hline A3 & $140-149$ & 9.0 & \multirow{5}{*}{$\begin{array}{l}\mathrm{Lt} . \mathrm{Pa} / \mathrm{Ma} \\
\mathrm{Ma} / \mathrm{Ca} \\
\mathrm{Ma} / \mathrm{Ca} \\
\mathrm{Sa} \\
\mathrm{Co}\end{array}$} & \multirow{3}{*}{$\begin{array}{l}\text { Zeo N F marl (trit. calc. } \\
\text { debris + clay) }\end{array}$} \\
\hline 3 & $162-166$ & 2.3 & & \\
\hline A4 & $171-180$ & 1.9 & & \\
\hline A5 & $180-189$ & 0.6 & & \multirow[t]{2}{*}{ Zeo calcar carbonac blk shl } \\
\hline A6 & $189-197$ & 0.7 & & \\
\hline 4 & $213-219$ & 3.3 & $\mathrm{Ce}$ & Calc carb clay, olv \\
\hline 5 & $264-270$ & 1.6 & \multirow{4}{*}{\multicolumn{2}{|c|}{$\left.\begin{array}{l}\text { Alb/Apt } \text { Marl (trit. calc. debris) } \\
\text { Apt } \\
\text { Apt } \\
\text { Apt }\end{array}\right\}$ Shelly 1s, quartzose marl, }} \\
\hline 6 & $295-298$ & 1.0 & & \\
\hline 7 & $298-300$ & 0.5 & & \\
\hline 8 & $324-327$ & 3.2 & & \\
\hline Totals & $37 \%$ & $70 \%$ & & \\
\hline
\end{tabular}




\section{APPENDIX III. SUMMARY OF SMEAR SLIDE ANALYSIS}

Compiled and averaged for each major facies in each core from shipboard and post-cruise determinations (see Appendix V), and shipboard core descriptions (compilation by W.H.B.). Lab. carbonate samples generally are not exactly from the same place as smear slides.

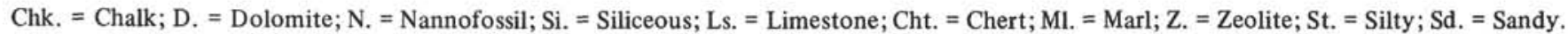

\begin{tabular}{|c|c|c|c|c|c|c|c|c|c|c|c|c|c|c|c|c|c|c|c|c|}
\hline 总 & ப் & 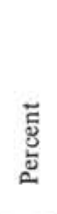 & 竎 & 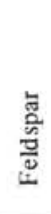 & $\frac{\tilde{J}}{2}$ & 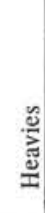 & $\frac{\mathscr{g}}{\tilde{g}}$ & $\frac{\tilde{3}}{\frac{\tilde{y}}{0}}$ & $\begin{array}{l}\text { 苛 } \\
\text { N }\end{array}$ & t: & $\begin{array}{l}\text { 号 } \\
\text { 总 }\end{array}$ & 彄 & 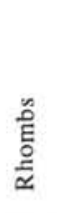 & 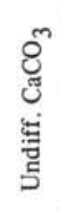 & 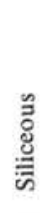 & 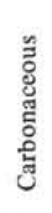 & 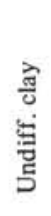 & 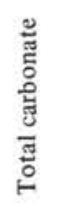 & 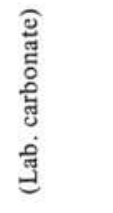 & Facies \\
\hline 135 & $\begin{array}{l}1 \\
2 \\
3 \\
4 \\
5 \\
\\
6 \\
7\end{array}$ & $\begin{array}{r}100 \\
100 \\
100 \\
100 \\
90 \\
10 \\
100 \\
48 \\
32 \\
16 \\
4 \\
39 \\
39 \\
11 \\
11 \\
84 \\
10 \\
6\end{array}$ & $\begin{array}{r}1 \\
12 \\
25 \\
60 \\
37 \\
44 \\
47 \\
35 \\
20 \\
10 \\
10 \\
4 \\
10 \\
30 \\
16\end{array}$ & $\begin{array}{r}1 \\
6 \\
3 \\
7 \\
40\end{array}$ & $\begin{array}{r}4 \\
23 \\
1 \\
5 \\
9 \\
5 \\
5\end{array}$ & $\begin{array}{l}3 \\
1 \\
1 \\
1 \\
1 \\
5\end{array}$ & $\begin{array}{r}1 \\
2 \\
19 \\
1 \\
2 \\
1\end{array}$ & & $\begin{array}{l}20 \\
10\end{array}$ & $\begin{array}{r}1 \\
50 \\
79 \\
9\end{array}$ & $\begin{array}{r}87 \\
96 \\
98 \\
92 \\
1\end{array}$ & $\begin{array}{l}8 \\
3 \\
1 \\
3\end{array}$ & $\begin{array}{r}15 \\
7 \\
18 \\
5 \\
2 \\
\\
5\end{array}$ & $\begin{array}{r}5 \\
\\
12 \\
38 \\
19 \\
15 \\
\\
\\
70 \\
5 \\
15 \\
69\end{array}$ & & & $\begin{array}{r}5 \\
1 \\
1 \\
3 \\
66 \\
20 \\
20 \\
30 \\
1 \\
18 \\
1 \\
30 \\
68 \\
1 \\
9 \\
22 \\
33 \\
4 \\
\end{array}$ & $\left.\begin{array}{l}95 \\
99 \\
99 \\
95 \\
16 \\
12 \\
18 \\
19 \\
43 \\
20 \\
20\end{array}\right\}$ & $\begin{array}{l}(50) \\
(73) \\
(70) \\
(85) \\
(8)\end{array}$ & $\begin{array}{l}\text { N. Chk. } \\
\text { N. Chk. } \\
\text { N. Chk. } \\
\text { N. Chk. } \\
\text { D. Clay } \\
\text { St. Mud } \\
\text { St. Mud } \\
\text { St. Mud } \\
\text { Sd. Mud } \\
\text { Sd. Mud } \\
\text { St. Mud } \\
\text { Si. Mud } \\
\text { Z. Clay } \\
\text { Cht. } \\
\text { Ls. } \\
\text { N. Ml. } \\
\text { St. Mud } \\
\text { Ls. }\end{array}$ \\
\hline 136 & $\begin{array}{l}4 \\
5 \\
6\end{array}$ & $\begin{array}{r}100 \\
100 \\
67 \\
17 \\
16 \\
55 \\
45 \\
50 \\
50 \\
45 \\
40 \\
15 \\
100 \\
50 \\
24 \\
13 \\
10 \\
3 \\
\end{array}$ & $\begin{array}{r}1 \\
1 \\
1 \\
3 \\
15 \\
5 \\
15 \\
6 \\
1\end{array}$ & $\begin{array}{l}5 \\
1 \\
1 \\
1\end{array}$ & $\begin{array}{l}1 \\
3 \\
3 \\
3 \\
2 \\
2 \\
5 \\
1 \\
1 \\
1 \\
1\end{array}$ & $\begin{array}{l}1 \\
1\end{array}$ & $\begin{array}{r}2 \\
2 \\
2 \\
12 \\
5 \\
15 \\
20 \\
5 \\
5 \\
25\end{array}$ & $\begin{array}{r}30 \\
1 \\
5 \\
\\
29 \\
3 \\
\\
25\end{array}$ & $\begin{array}{r}1 \\
5 \\
5 \\
5 \\
10 \\
8\end{array}$ & 2 & $\begin{array}{r}96 \\
97 \\
96 \\
70 \\
2 \\
\\
18 \\
1\end{array}$ & $\begin{array}{l}2 \\
2\end{array}$ & $\begin{array}{r}2 \\
2 \\
10 \\
2 \\
5 \\
1 \\
5 \\
1 \\
1 \\
1 \\
4 \\
\end{array}$ & $\begin{array}{r}13 \\
\\
5 \\
5 \\
1 \\
70 \\
3 \\
27 \\
1 \\
20\end{array}$ & & & $\begin{array}{r}1 \\
1 \\
1 \\
25 \\
57 \\
89 \\
53 \\
83 \\
53 \\
85 \\
68 \\
25 \\
24 \\
60 \\
90 \\
60 \\
60 \\
73 \\
\end{array}$ & $\left.\begin{array}{r}98 \\
99 \\
98 \\
72 \\
25 \\
\hdashline \\
20 \\
6 \\
6 \\
10 \\
2 \\
75 \\
4 \\
28 \\
5 \\
7 \\
40 \\
1\end{array}\right\}$ & $\begin{array}{l}(86) \\
(33-81) \\
(40) \\
(0-1.4) \\
(5) \\
(5)\end{array}$ & $\begin{array}{l}\text { N. Chk. } \\
\text { N. Chk. } \\
\text { N. Chk. } \\
\text { N. Chk. - Ml. } \\
\text { Calc. Clay } \\
\text { St. Clay } \\
\text { Calc. Clay } \\
\text { St. Clay } \\
\text { St. Clay } \\
\text { Clay } \\
\text { St. Clay } \\
\text { Ml. Mud } \\
\text { M. Mud } \\
\text { Ml. Mud } \\
\text { Clay } \\
\text { Ash } \\
\text { N. Ml. } \\
\text { Clay }\end{array}$ \\
\hline 137 & $\begin{array}{l}4 \\
5 \\
6 \\
7\end{array}$ & $\begin{array}{r}100 \\
100 \\
50 \\
50 \\
100 \\
100 \\
100 \\
70 \\
10 \\
10 \\
10 \\
45 \\
40 \\
10 \\
5 \\
50 \\
40 \\
10 \\
70 \\
30 \\
100\end{array}$ & $\begin{array}{l}1 \\
1 \\
1 \\
1\end{array}$ & $\begin{array}{l}1 \\
2\end{array}$ & $\begin{array}{l}2 \\
2 \\
2 \\
\\
2 \\
1 \\
1 \\
1 \\
2\end{array}$ & $\begin{array}{l}1 \\
1\end{array}$ & \begin{tabular}{|r}
1 \\
5 \\
1 \\
7 \\
1 \\
2 \\
2 \\
\\
20 \\
99 \\
5 \\
2 \\
2 \\
7 \\
3 \\
1
\end{tabular} & & $\begin{array}{r}5 \\
10 \\
12 \\
10 \\
20 \\
\\
1\end{array}$ & 45 & $\begin{array}{l}42 \\
65 \\
40 \\
21 \\
44 \\
15 \\
82 \\
60 \\
37 \\
65\end{array}$ & $\begin{array}{l}5 \\
1 \\
4 \\
6 \\
\\
5\end{array}$ & $\begin{array}{l}7 \\
1 \\
1 \\
5\end{array}$ & $\begin{array}{r}10 \\
4\end{array}$ & 3 & $\begin{array}{r}19 \\
5 \\
15\end{array}$ & $\begin{array}{l}86 \\
90 \\
86 \\
82 \\
83 \\
86 \\
75 \\
38 \\
89 \\
10 \\
1 \\
45 \\
28 \\
55 \\
30 \\
46 \\
78 \\
10 \\
40 \\
60 \\
30\end{array}$ & $\left.\begin{array}{l}\cdots \\
\cdots \\
\cdots \\
\cdots \\
\cdots \\
\cdots \\
\cdots \\
40 \\
3 \\
7 \\
\\
49 \\
70 \\
41 \\
23 \\
48 \\
20 \\
88 \\
60 \\
37 \\
70\end{array}\right\}$ & $\begin{array}{l}(\leqslant .3) \\
(.5) \\
(\leqslant 3) \\
(.6) \\
(.1) \\
(64)\end{array}$ & $\begin{array}{l}\text { St. Clay } \\
\text { Clay } \\
\text { Clay } \\
\text { Z. Clay } \\
\text { Z. Clay } \\
\text { Z. Clay } \\
\text { Z. Clay } \\
\text { N. M. } \\
\text { Clay } \\
\text { Cht. } \\
\text { Pyrite } \\
\text { N. Ml. } \\
\text { N. Chk. - Ml. } \\
\text { N. MI. } \\
\text { Sapropel } \\
\text { N. Ml. } \\
\text { Clay } \\
\text { N. Chk. } \\
\text { N. MI. } \\
\text { N. MI. } \\
\text { N. Ml. }\end{array}$ \\
\hline
\end{tabular}


APPENDIX III (Continued)

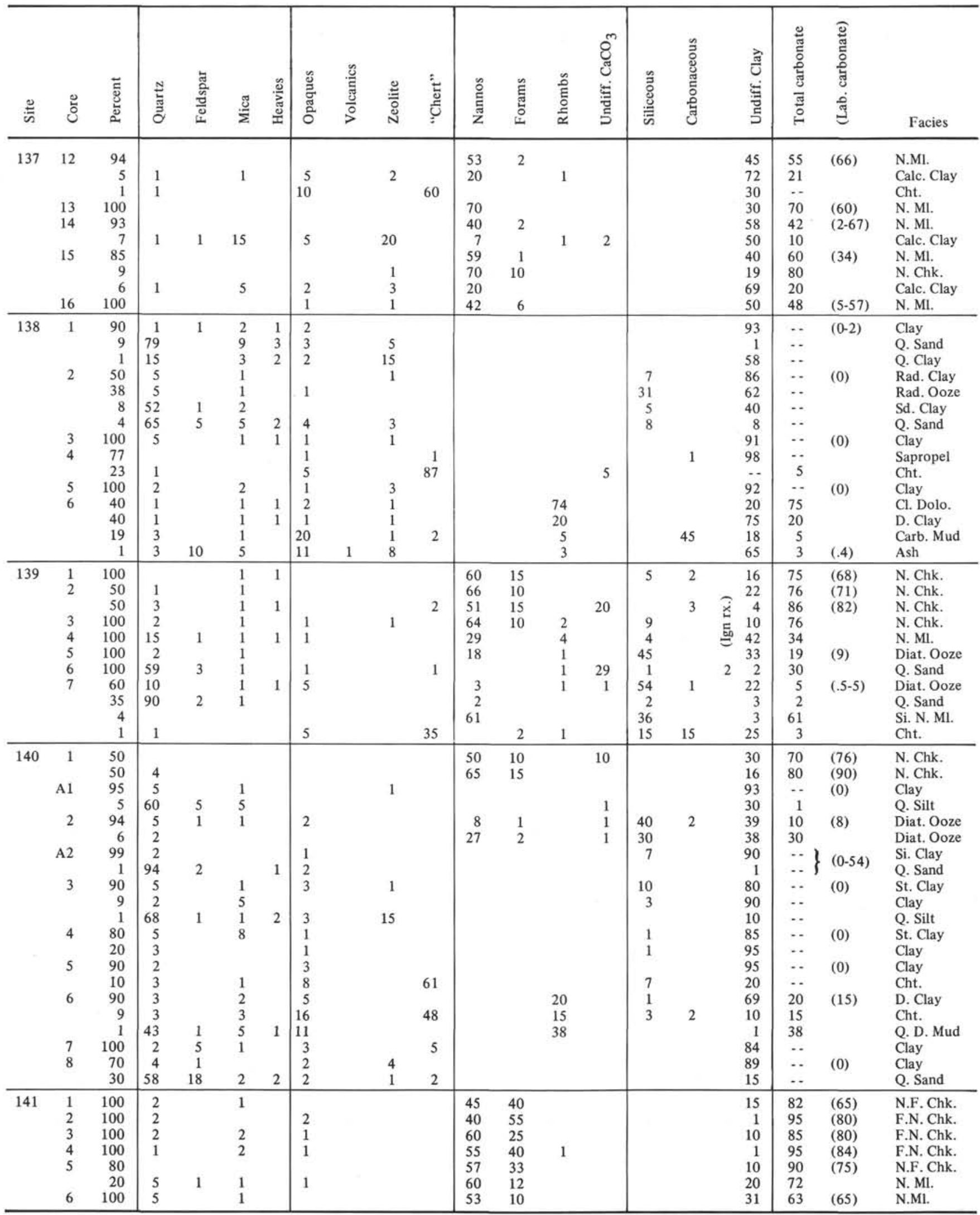


APPENDIX III (Continued)

\begin{tabular}{|c|c|c|c|c|c|c|c|c|c|c|c|c|c|c|c|c|c|c|c|c|}
\hline 总 & ¿ั & 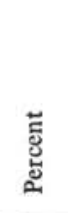 & 总 & $\begin{array}{l}\text { 을 } \\
\text { 음 }\end{array}$ & $\stackrel{5}{2}$ & 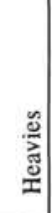 & 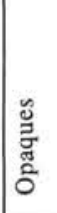 & $\begin{array}{l}\stackrel{0}{\tilde{E}} \\
\frac{\tilde{d}}{0} \\
>\end{array}$ & 芩 & & 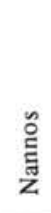 & 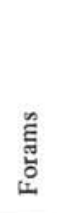 & $\begin{array}{l}\hat{\tilde{\Xi}} \\
\frac{0}{\alpha}\end{array}$ & 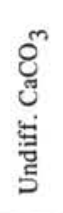 & 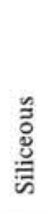 & 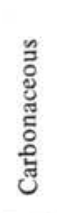 & 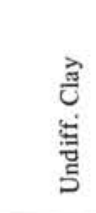 & 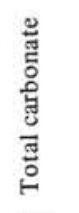 & 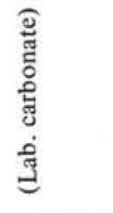 & Facies \\
\hline & $\begin{array}{c}8 \\
9 \\
\text { SW }\end{array}$ & $\begin{array}{r}50 \\
33 \\
17 \\
95 \\
5 \\
98 \\
2 \\
100 \\
\end{array}$ & $\begin{array}{r}4 \\
30 \\
7 \\
30 \\
10 \\
\\
5 \\
44\end{array}$ & 14 & $\begin{array}{l}4 \\
5 \\
2 \\
5 \\
5\end{array}$ & $\begin{array}{l}2 \\
1 \\
1\end{array}$ & $\begin{array}{r}4 \\
11 \\
7 \\
5 \\
4 \\
4 \\
15 \\
1 \\
\end{array}$ & $\begin{array}{l}1 \\
1\end{array}$ & $\begin{array}{r}4 \\
1 \\
3 \\
10 \\
2\end{array}$ & & $\begin{array}{l}56 \\
14\end{array}$ & & 2 & 5 & & 1 & $\begin{array}{l}25 \\
47 \\
70 \\
59 \\
75 \\
86 \\
52 \\
34 \\
\end{array}$ & $\begin{array}{l}63 \\
\cdots \\
14 \\
\ldots \\
\cdots \\
\cdots \\
\cdots \\
\cdots\end{array}$ & $\begin{array}{l}(17) \\
(1.4) \\
(0) \\
(0)\end{array}$ & $\begin{array}{l}\text { N. M1. } \\
\text { Q. Clay } \\
\text { N. Clay } \\
\text { Q. Clay } \\
\text { St. Clay } \\
\text { Z. Clay } \\
\text { Calc. Clay } \\
\text { Ark. Sand }\end{array}$ \\
\hline 142 & $\begin{array}{l}6 \\
7 \\
8 \\
9 \\
9\end{array}$ & $\begin{array}{r}67 \\
23 \\
10 \\
37 \\
37 \\
26 \\
90 \\
10 \\
100 \\
57 \\
33 \\
10 \\
67 \\
22 \\
11 \\
100 \\
75 \\
25 \\
100 \\
\end{array}$ & $\begin{array}{r}40 \\
2 \\
\\
10 \\
50 \\
12 \\
20 \\
2 \\
5 \\
30 \\
3 \\
5 \\
5 \\
2 \\
1 \\
2 \\
3 \\
5 \\
\end{array}$ & $\begin{array}{l}8 \\
1 \\
1 \\
1\end{array}$ & $\begin{array}{r}5 \\
10 \\
10 \\
1 \\
5 \\
1 \\
2 \\
1 \\
1 \\
2 \\
\end{array}$ & $\begin{array}{l}3 \\
2 \\
4 \\
4 \\
2\end{array}$ & $\begin{array}{l}3 \\
2 \\
2 \\
2 \\
3 \\
3 \\
2 \\
2 \\
5 \\
5 \\
4 \\
5 \\
1 \\
1 \\
2 \\
5 \\
1 \\
1 \\
\end{array}$ & & $\begin{array}{l}1 \\
3 \\
1 \\
\end{array}$ & 1 & $\begin{array}{r}13 \\
10 \\
20 \\
5 \\
30 \\
20 \\
44 \\
13 \\
5 \\
20 \\
48 \\
20 \\
72 \\
35 \\
60 \\
1 \\
45 \\
\end{array}$ & $\begin{array}{r}15 \\
20 \\
5 \\
3 \\
30 \\
30 \\
10 \\
35 \\
1 \\
40 \\
3 \\
27 \\
5\end{array}$ & 13 & $\begin{array}{r}20 \\
7 \\
7 \\
10 \\
25 \\
3 \\
18\end{array}$ & 3 & 7 & $\begin{array}{r}20 \\
92 \\
45 \\
35 \\
35 \\
17 \\
40 \\
3 \\
20 \\
65 \\
20 \\
10 \\
38 \\
10 \\
20 \\
28 \\
25 \\
92 \\
33 \\
\end{array}$ & $\begin{array}{l}10 \\
3 \\
39 \\
50 \\
40 \\
10 \\
33 \\
70 \\
74 \\
20 \\
25 \\
80 \\
53 \\
78 \\
75 \\
66 \\
65 \\
2 \\
55 \\
55\end{array}$ & $\begin{array}{l}(.4-4) \\
(32) \\
(2-27) \\
(4.3) \\
(58-97) \\
(17) \\
(14-52) \\
(70) \\
(11-49) \\
(45) \\
\end{array}$ & $\begin{array}{l}\text { Q. Sand } \\
\text { Clay } \\
\text { Calc. Clay } \\
\text { Ml. Mud } \\
\text { N.F. Ml. } \\
\text { Q. Sand } \\
\text { N. Ml. } \\
\text { St. Sand } \\
\text { N.F. Chk. } \\
\text { Calc. Clay } \\
\text { Q. Sand } \\
\text { F. Sand } \\
\text { N. Ml. } \\
\text { F.N. Chk. } \\
\text { N. Chk. } \\
\text { N.F. Ml. } \\
\text { N. Ml. } \\
\text { Clay } \\
\text { N.F. Ml. } \\
\end{array}$ \\
\hline 144 & $\begin{array}{r}\mathrm{B} 3 \\
\mathrm{~A} 2 \\
1 \\
2 \\
23 \\
\mathrm{~A} 3 \\
\\
\\
3 \\
\\
\mathrm{~A} 4\end{array}$ & $\begin{array}{r}100 \\
100 \\
98 \\
1 \\
1 \\
100 \\
100 \\
100 \\
100 \\
75 \\
25 \\
66 \\
34 \\
75 \\
20 \\
5 \\
60 \\
37 \\
3 \\
90 \\
10 \\
40 \\
40 \\
10 \\
10 \\
67 \\
33 \\
50 \\
50 \\
90 \\
10 \\
100\end{array}$ & $\begin{array}{r}1 \\
7 \\
5 \\
29 \\
30 \\
15 \\
10 \\
28\end{array}$ & $\begin{array}{l}1 \\
5\end{array}$ & $\begin{array}{r}2 \\
1 \\
5 \\
5 \\
10 \\
2 \\
1 \\
8\end{array}$ & 1 & $\begin{array}{r}2 \\
1 \\
7 \\
3 \\
3 \\
1 \\
15 \\
15 \\
13 \\
3\end{array}$ & & $\begin{array}{r}15 \\
20 \\
10 \\
1 \\
25 \\
5 \\
1\end{array}$ & 2 & $\begin{array}{r}33 \\
32 \\
41 \\
30 \\
15 \\
9 \\
33 \\
5 \\
5 \\
24 \\
10 \\
1 \\
5 \\
1 \\
6 \\
15 \\
1 \\
7 \\
5 \\
\\
3 \\
3 \\
5\end{array}$ & $\begin{array}{r}10 \\
43 \\
40 \\
39 \\
15 \\
6 \\
32 \\
1 \\
5 \\
8 \\
2\end{array}$ & $\begin{array}{l}1 \\
1 \\
1\end{array}$ & $\begin{array}{r}40 \\
40 \\
20 \\
16 \\
49 \\
9 \\
3 \\
3 \\
10 \\
74 \\
30 \\
5 \\
79 \\
10 \\
60 \\
61\end{array}$ & $\begin{array}{r}5 \\
10 \\
5 \\
1 \\
1 \\
6 \\
4 \\
30 \\
3 \\
1 \\
2 \\
2\end{array}$ & $\begin{array}{r}30 \\
5 \\
\\
39 \\
5 \\
20 \\
10 \\
15 \\
50 \\
\\
1\end{array}$ & 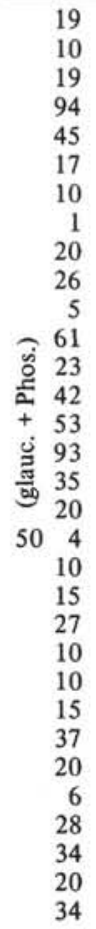 & $\begin{array}{r}73 \\
80 \\
70 \\
-33 \\
53 \\
75 \\
81 \\
69 \\
70 \\
55 \\
85 \\
22 \\
59 \\
41 \\
15 \\
4 \\
25 \\
75 \\
40 \\
30 \\
80 \\
33 \\
70 \\
71 \\
6 \\
43 \\
68 \\
50 \\
30 \\
13 \\
56 \\
22\end{array}$ & $\begin{array}{l}(70) \\
(70) \\
(70) \\
\\
(63) \\
(66) \\
(70) \\
(41) \\
(50) \\
(53) \\
(30)\end{array}$ & $\begin{array}{l}\text { F.N. Chk. } \\
\text { F.N. Chk. } \\
\text { F.N. Chk. } \\
\text { Clay } \\
\text { N.F. Ml. } \\
\text { F.N. Chk. } \\
\text { N.F. Chk. } \\
\text { F.N. Chk. } \\
\text { Chk.-Ml. Mud } \\
\text { Ml. Mud } \\
\text { N.F. Ml. } \\
\text { Ml. Mud } \\
\text { Z. Ml. Mud } \\
\text { N. Ml. } \\
\text { Si. Ml. Clay } \\
\text { Clay } \\
\text { Z. Calc. Sapro. } \\
\text { Marly Ls. } \\
\text { Glauc. Phosph. Ls. } \\
\text { Z. Calc. Sapro. } \\
\text { Ls. } \\
\text { Z. Calc. Sapro } \\
\text { Z. Ml. Mud } \\
\text { F. Ml. Mud } \\
\text { Z. Sapro } \\
\text { Ml. Mud } \\
\text { Ml. Mud } \\
\text { Shelly Ls. } \\
\text { Q. Ml. Mud } \\
\text { Q. Carb. Mud } \\
\text { Shelly Ls. } \\
\text { Q. Calc. Mud }\end{array}$ \\
\hline
\end{tabular}


D, dominant; A, abundant; P, present; $\mathrm{r}$, rare; $\cdot$, very rare. Approximate percentage ranges: $>40 \%, 10-40 \%, 2-15 \%, 1-2 \%,<1 \%$. Small subscripts: O, ostracods; B, bryozoans; M, molluscs; Z, zeolite; D, dolomite; C, calcitt; R, rhodochrosite; M, manganese; F, iron; B, barite; G, glauconite; $\mathrm{F}$, feldspar; $\mathrm{M}$, mica; $\mathrm{H}$, hydrocarbon on fracture surface; averaged where only one facies present in core. (Binocular microscope analysis, W.H.B.)

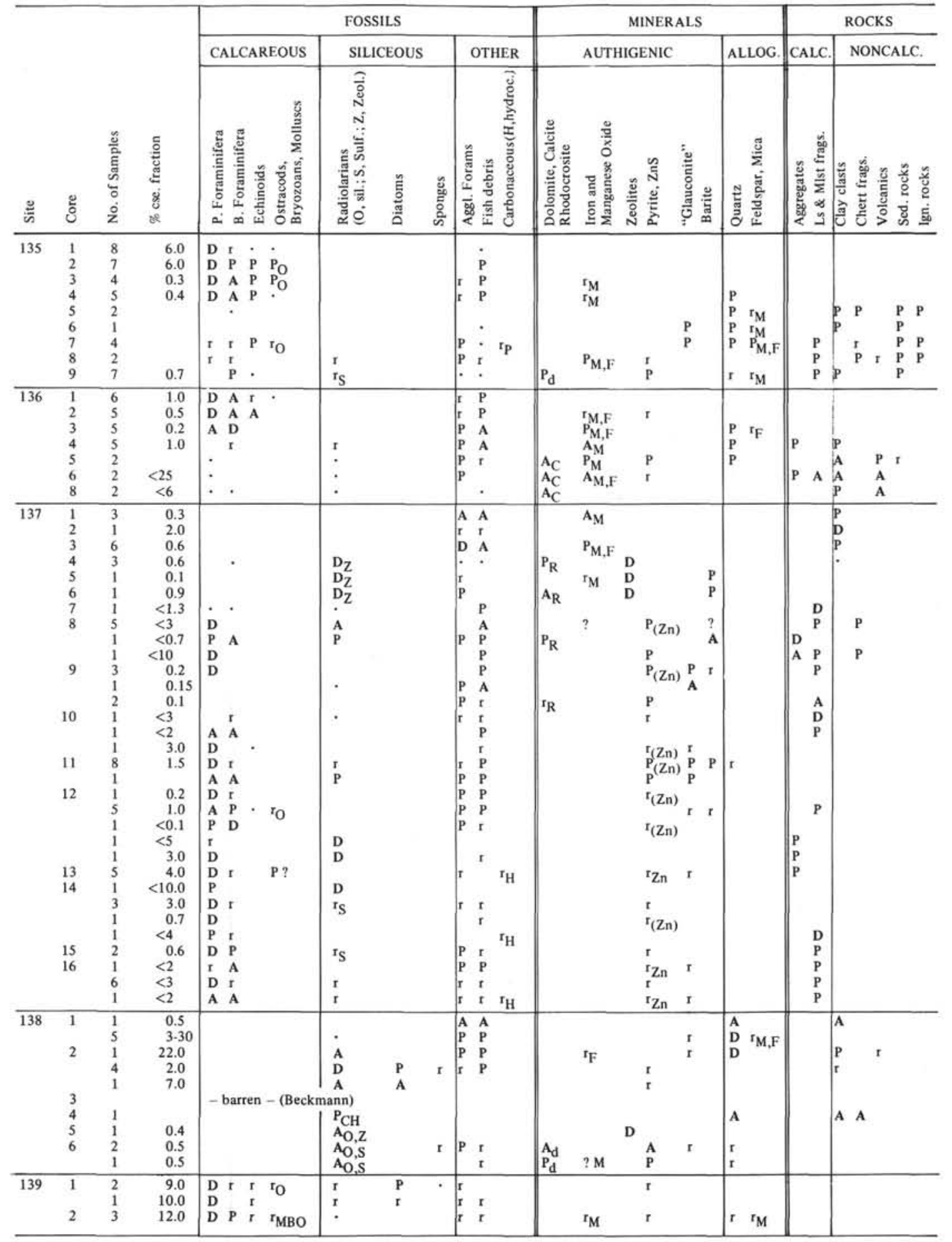


APPENDIX IV (Continued)

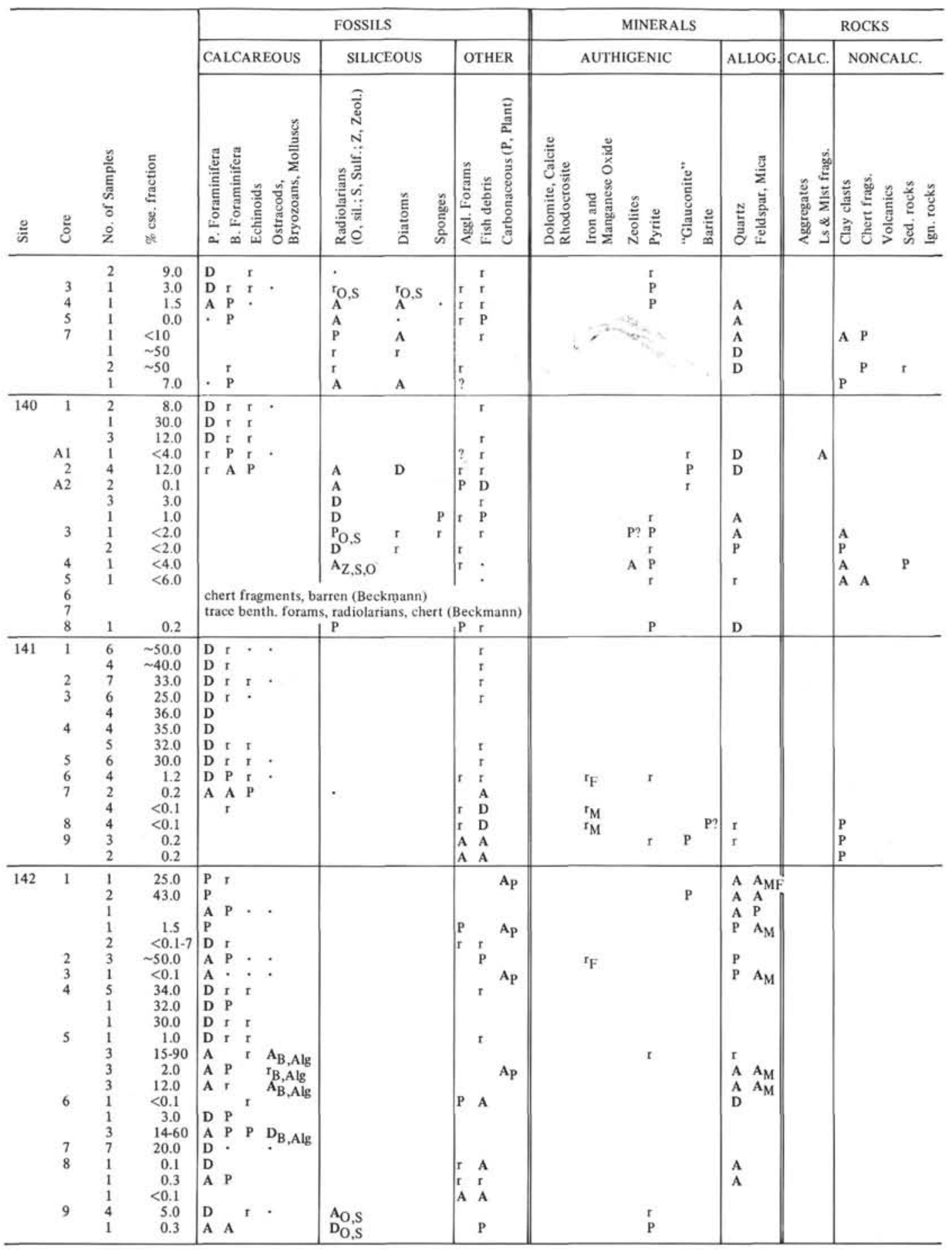


APPENDIX IV (Continued)

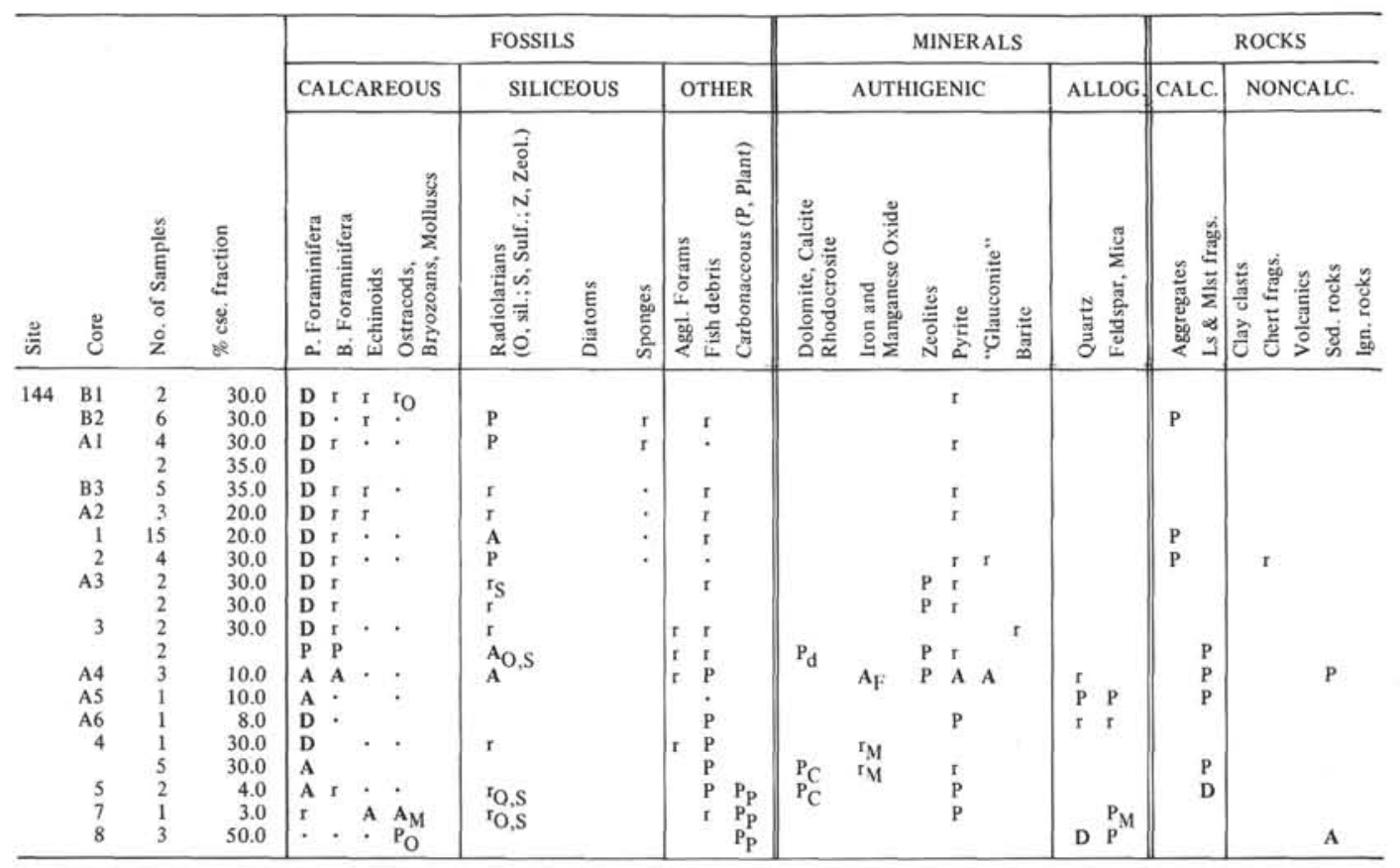


APPENDIX v. COMPOSITION OF SELECTED SAMPLES (OPTICAL ANALYSIS, U. v. R.) /COnt)

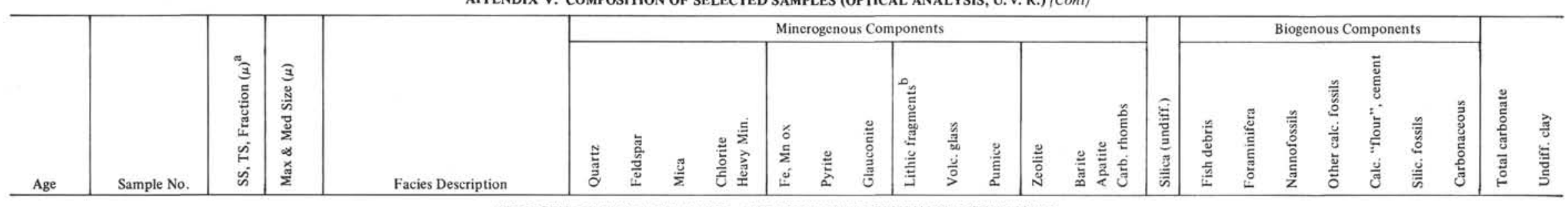

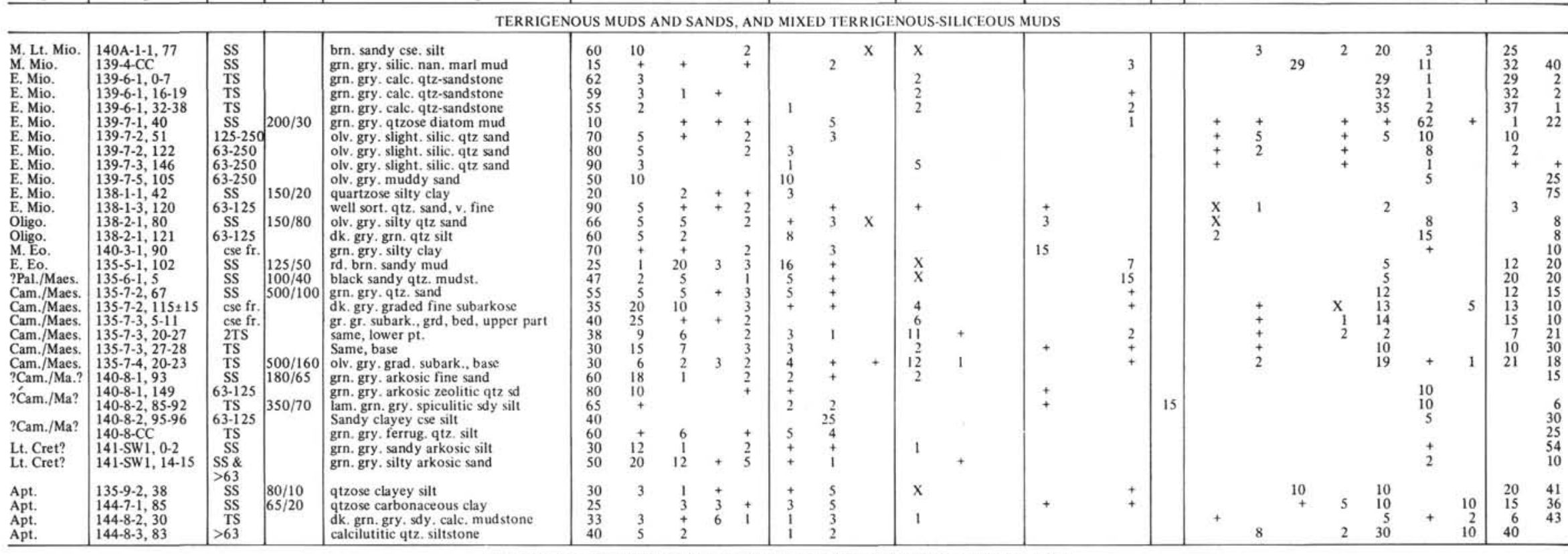

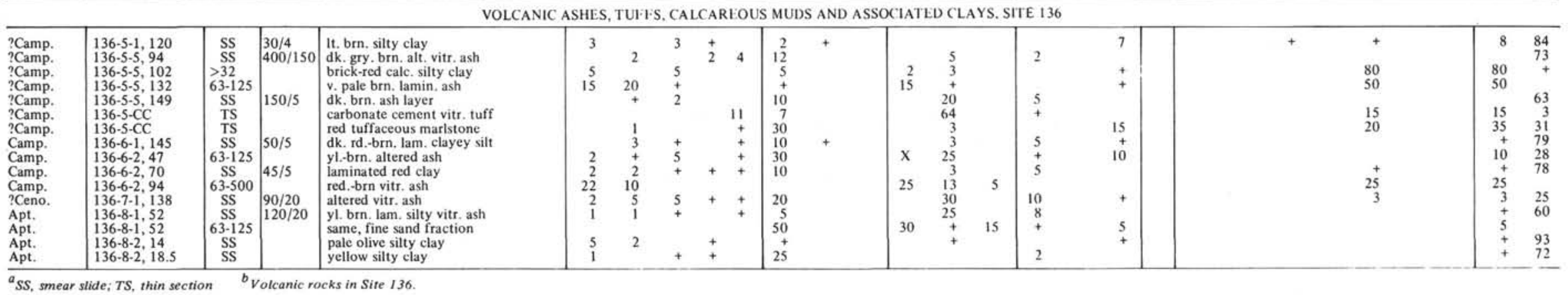




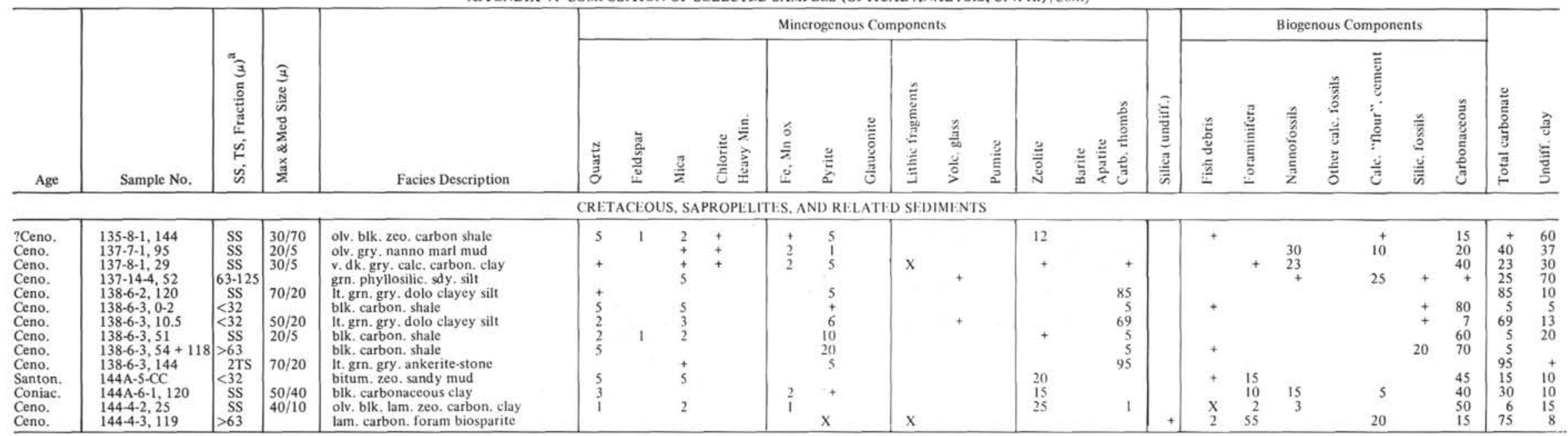

${ }^{a} S S$, smear slide; TS, thin section 